UNIVERSIDADE DE SÃO PAULO

INSTITUTO DE GEOCIÊNCIAS

\title{
SISTEMAS DEPOSICIONAIS EÓLICOS NO QUATERNÁRIO COSTEIRO DO BRASIL
}

Paulo César Fonseca Giannini

TESE DE LIVRE-DOCÊNCIA 


\section{UNIVERSIDADE DE SÃO PAULO \\ INSTITUTO DE GEOCIÊNCIAS}

\section{SISTEMAS DEPOSICIONAIS EÓLICOS NO QUATERNÁRIO COSTEIRO DO BRASIL}

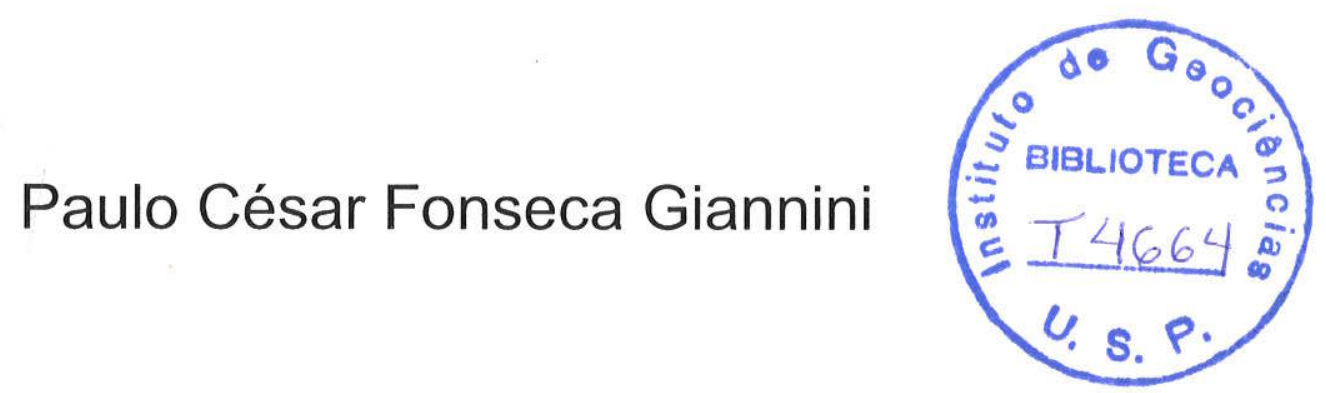

TESE DE LIVRE-DOCÊNCIA

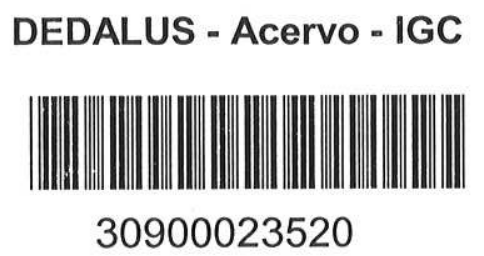

$$
\begin{aligned}
& \text { SÃO PAULO } \\
& 2007
\end{aligned}
$$


"Mas a chama, que a vida em nós criou (...) A mão do vento pode erguê-la ainda"

Fernando Pessoa, "Prece" (In "Mensagem"), 1921/1922 
A Armando Márcio Coimbra e Rody Ávila Medeiros, Mestres que me ensinaram

A Kátia Ruth Carneiro e Márcio José da Silva

Alunos com quem aprendi

In memoriam 


\section{Agradecimentos}

Antes e durante a preparação deste trabalho, perguntei-me muitas vezes: mas o que é e para que serve, afinal, uma Tese de Livre-Docência? Continuo sem saber a resposta, mas tentei, aos poucos, construir meus próprios significados.

Meu primeiro significadó é etimológico. Uma Tese de Livre-Docência deve fazer jus à alusão que o nome faz para docência, ensino. Na realidade fria da carreira universitária, esse nome parece um daqueles fadados a perder completamente o sentido original. Dedicação ao ensino é o que na prática menos conta para a obtenção do título de livredocente. Na universidade, como na nossa sociedade em geral, ser professor de fato é cada vez mais um sacerdócio, a escolha do sacrifício, do caminho mais difícil. Com isso, a palavra professor, tomando o rumo contrário do termo livre-docência, retorna ironicamente para seu significado original: aquele que professa. Ser professor, portanto, tornou-se ser fazedor de uma profissão de fé. Não surpreende que professores de verdade sejam espécies em extinção. Fala-se no prejuizo social que isto representa, mas o problema vai mais além: empobrece-nos como indivíduos. Algumas das melhores emoções intelectuais da minha vida, e a única razão digna de haver entusiasmo acadêmico para fazer uma terceira tese, são imagens raras de professores exercendo brilhantemente sua profissão. Recordo uma aula de literatura no colégio, em que o professor entrou na sala de aula sem dizer uma palavra, pôs-se a recitar de cor, pausadamente, e a representar, os versos de "Tabacaria", de Álvaro de Campos, e em seguida saiu, de novo sem dizer uma palavra. Esta cena inesquecivel e emocionante tornou-se para mim símbolo minimalista do mestre que abdica de si mesmo em troca do conteúdo que ele professa.

Agradeço e reverencio, portanto, a todos os meus professores que, como aquele, honraram sua profissão de fé. Mas destaco aqui os que tiveram influência mais direta sobre a existência desta Tese ou sobre o fato de ela ser como é. Os primeiros serão meus pais. Ao Prof. Nicola Giannini (in memoriam), devo as melhores lições de gramática que já tive, inclusive por nunca terem parecido lições, mas devo também minha decisão precoce pela geologia. À Profa. Ida de Souza Fonseca Giannini, devo a perseverança no estudo, indispensável para a construção deste trabalho. Seguem-se três pessoas que conheci na Universidade. Ao Prof. Kenitiro Suguio, devo o caminho da praia. Quaternário costeiro será sempre, para mim, sinônimo de Kenitiro. Ao Prof. Armando Márcio Coimbra (in memoriam), devo o caminho do ensino de geologia, que através dele se tornou fascinante. Ao Prof. Setembrino Petri, a segurança de poder possuir um ídolo geo-acadêmico.

Mas volto a meus significados. Em segundo lugar, uma Tese de Livre-Docência é o produto de um trabalho solitário. Faz falta a figura do orientador. Ao mesmo tempo, é um trabalho mais coletivo do que todos os outros, porque a essa altura já é possivel ter aprendido não apenas com mestres, mas, pelo menos no meu caso, com inúmeros colegas, com milhares de alunos, com mais de uma centena de orientados. É assim que uma multidão de co-autores permeia cada página deste trabalho. Sou grato a todos, ainda que seja impossível citá-los um a um. Não deixarei, porém, de mencionar os professores Luiz Carlos Ruiz Pessenda, Maria Judite Garcia e Paulo Eduardo de Oliveira (o "Paulo Inólogo") que me municiaram com informações e referências bibliográficas durante a elaboração dos itens sobre clima e paleoclima; nem o Prof. Renato Paes de Almeida que me ajudou entusiasmadamente na bibliografia sobre margens passivas assimétricas. Lembro também que várias passagens desta Tese são transcritas ou retrabalhadas de capítulos sobre sistemas eólicos pertencentes a dois livros, o "Quaternário do Brasil", editado pela Abequa em 2005, e o "Ambientes de Sedimentação...", cuja publicação, pela Petrobrás, é prevista para este ano. Nesses capítulos, tive o apoio inestimável de um verdadeiro time de coautores, de diferentes partes do Brasil. Recito a escalação: Alcina Magnólia Franca Barreto, 
Alexandre Medeiros Carvalho, André Oliveira Sawakuchi, Caroline Thais Martinho, Jean Pierre Peulvast, Liana Barbosa, Luís Parente Maia, Luiz José Tomazelli, Mario Luiz Assine e Vanda Claudino-Salles. Uma seleção, sem dúvida. Sem eles (e sem uma dose de atrevimento meu), eu não teria subsidios para escrever sobre campos de dunas que não conheço pessoalmente. Ao Assine, co-autor nos dois capítulos mencionados, cabem também os créditos pela idéia que gerou o segundo parágrafo destes agradecimentos. Ainda no conhecimento de "outras dunas", foram proveitosos e memoráveis os trabalhos de campo no Rio Grande do Sul e em Santa Catarina com Tomazelli, Lauro Calliari, Patrick Hesp e Sérgio Rabello Dillenburg. No campo do apoio psicológico, os professores Joel Barbujiani Sígolo e Jorge Kazuo Yamamoto fizeram-me a cobrança salutar e necessária para que a Tese saísse neste século. Já os nomes dos professores Ana Maria Góes, Daniel Atencio, Giorgio Basilici, Luiz Alberto "Lurds" Fernandes, Mário Sérgio de Melo, Paulo César Boggiani, Paulo "Paulé" Deblasis e Rodolfo José Angulo pertencem ao terreno da amizade essencial e do constante incentivo.

Seguem-se meus orientados e orientandos de pós-graduação: Ana Lúcia Desenzi Gesicki, Prof. André Oliveira Sawakuchi (de novo), Carlos Conforti Ferreira Guedes, Caroline Thaís "Brau" Martinho (outra vez), Daniel Rodrigues do Nascimento Jr., Deise Bentz, Profa. Eliane de Siqueira, Leandro Menezes Donatti, Milene Fornari, Paula "Pi" Garcia Carvalho do Amaral, Paola Olivina Pellizzari e Priscila "Xiwawa" Mello Leal. Há contribuição dos resultados obtidos por cada um deles nesta Tese, nas entrelinhas e, inúmeras vezes, nas linhas. Mas há, sobretudo, a grata sensação de possuir uma penca, não direi de filhos, mas de verdadeiros irmãos acadêmicos, com quem se pode contar solidariamente a qualquer momento. Nos três últimos anos, houve incondicional compreensão para com o orientador ora ausente, ora estressado. Parafraseando Sawakuchi (2006), quando eu começava a me afogar, sempre vinha algum deles para não me deixar morrer na praia (ou seria no sistema praia-duna?). Não menos relevante foi a colaboração dos orientados de Iniciação Científica que em diferentes épocas trabalharam em temas correlatos ao desta Tese: Ana Cláudia "Medusa" Ferreira Machado, Ana Paula "Treme" Burgoa Tanaka, Carlos Henrique Grohmann de Carvalho, Eva Kaiser Mori, Fabricio Barreto, Jaqueline Silveira Kogut, Jefferson Acioli Machado, Renata Augusta Rocha de Oliveira, Ricardo Avelar Brandão e Vinicius Ribau Mendes.

Que ajuda me deram os bolsistas de Capacitação Técnica FAPESP dos laboratórios de Sedimentologia e Petrografia Sedimentar! Adriano José de Souza, Rebeca Santos Cardoso, Rodolfo Marinho, Simone Campos Carrera e Vítor Ângelo Paulino de Aguiar, sob a regência da maestra Ana Maria Góes e a direção artística do incansável Eng. Isaac Jamil Sayeg, participaram de modo heróico na execução do $13^{\circ}$. Trabalho de Hércules, a luta contra o gigante Memorialis burocrataurus. Sem jamais perder a ternura e o bom humor.

Marco Antônio Chamadoira executou parte dos desenhos em CorelDraw com a qualidade que é sua marca registrada; a técnica e amiga Elaine Aparecida da Silva Sinfrónio deu o apoio necessário no Laboratório de Sedimentologia. Sou grato a eles e a todos demais funcionários, alunos e docentes-pesquisadores do Instituto de Geociências da USP, pela prestatividade e companheirismo.

Mas não posso me esquecer também dos ex-colegas e ex-alunos da UFPR, de onde guardo as melhores recordações. Definitivamente, não haverá frio e cinza na minha memória de Curitiba. Lá conheci Elizabete do Rocio Santos, que se tornou Giannini, e que por isso paga o preço de ter que suportar minha desmedida dedicação ao binômio docência-geologia. Por causa desta Tese, perdemos muitas viagens de férias e muitos fins de semana. François Truffaut e John Neshling devem ter sentido nossa falta. Juntamente com a Betti e com meus pais, estão meus irmãos Idani Maria e José Antônio, Rogério e Roseli, meus sobrinhos Paula, Flaviano, Rodrigo, Guilherme, Lais, Mariana e Pedro Henrique. Eles formam o núcleo, a base e a inspiração. 
Mas uma Tese não é feita só de gana, mas de grana. Resultados apresentados e utilizados aqui só puderam ser alcançados graças ao financiamento de vários projetos FAPESP (Fundação de Amparo à Pesquisa do Estado de São Paulo), com destaque para os Auxílios à Pesquisa 98/00181-0, 01/01732-0, 03/08911-0 e 05/51034-0, e para o Temático 04/11038-0.

Encerro esta página com um terceiro significado para a Livre-Docência, conseqüência natural dos dois significados anteriores: ela deve ser fruto de emoção intelectual, requisito básico da ciência e da vida acadêmica e que se assimila por contágio. Neste caso, a emoção foi reforçada pelas circunstâncias em que a Tese foi preparada. Fui literalmente levado a mudar meu modo de ver as coisas durante sua elaboração. E o que me impus como desafio de pouco mais de seis meses, levou cerca de três anos. Acho, porém, que a Tese não teria tanto sentido sem estes contratempos. Agradeço às dificuldades, porque deram um sabor especial e um significado inesperado a esta minha minúscula enorme conquista de ter terminado. "O esforço é grande e o homem é pequeno". Especialmente eu. 


\section{Sistemas deposicionais eólicos no Quaternário costeiro do Brasil Paulo César Fonseca Giannini}

\section{Índice analítico}

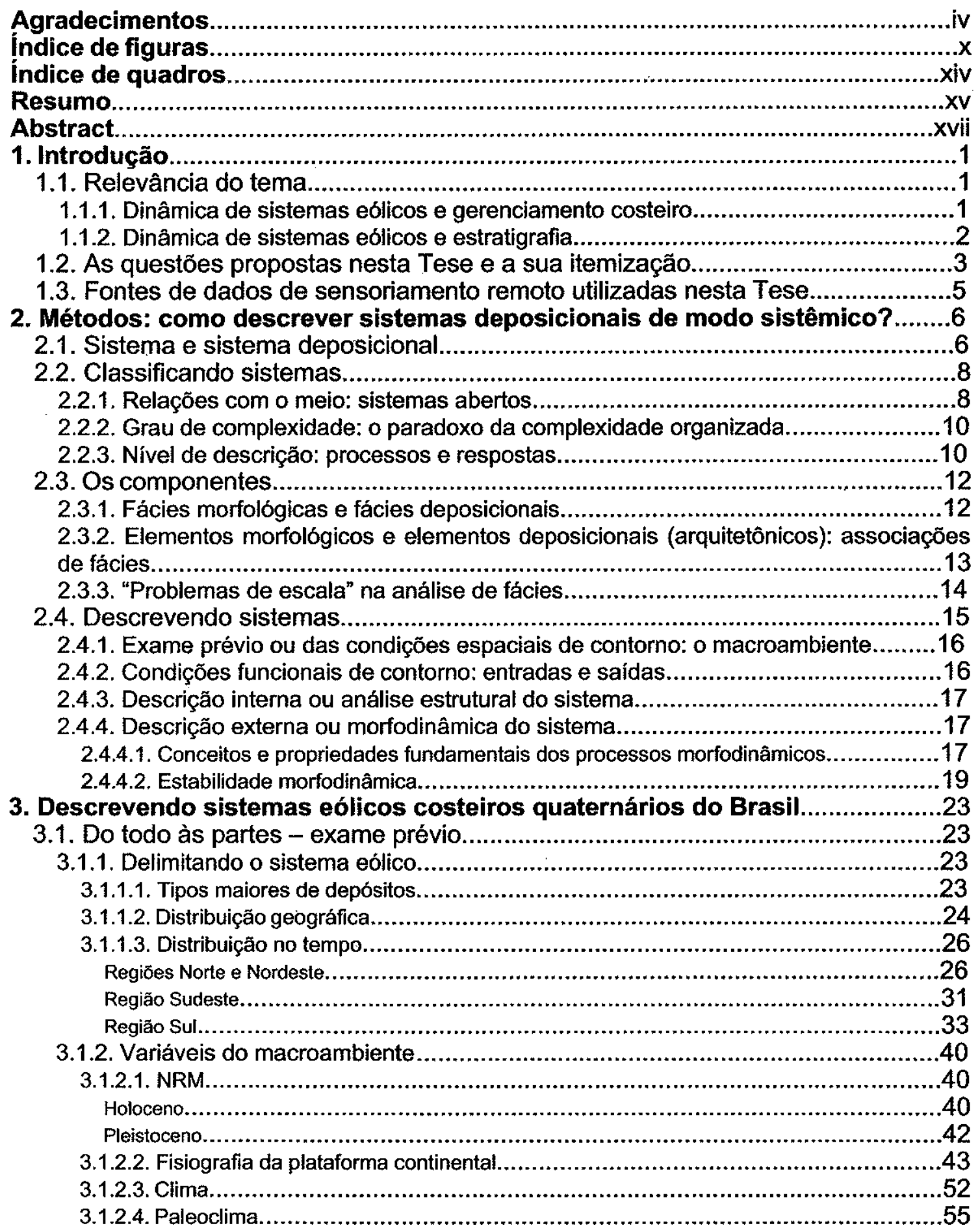


3.2. Descrição externa: relações sistema-meio......................................................63

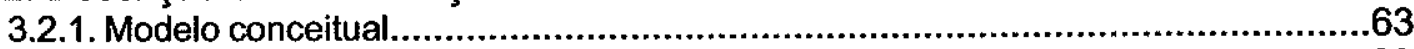

3.2.1.1. Entradas, saídas e espaço de estocagem...................................................63

3.2.1.2. Controle por variáveis do macroambiente..................................................68

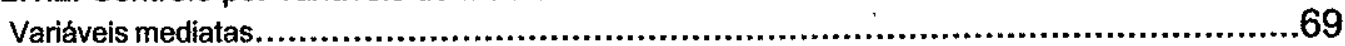

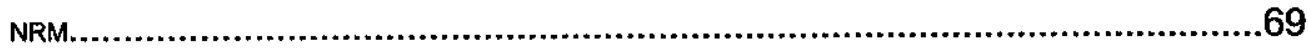

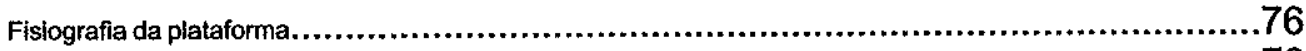

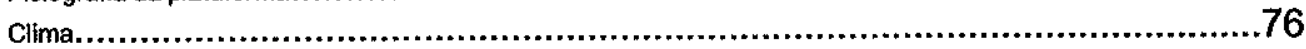

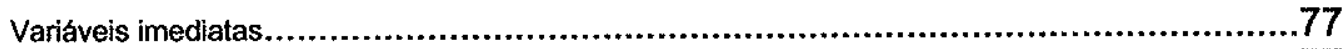

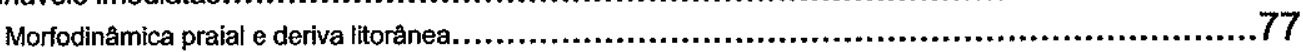

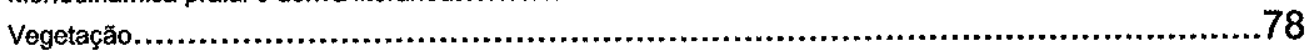

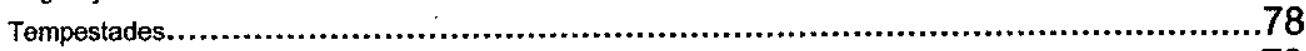

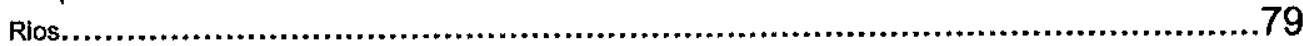

3.2.2. Avaliação da operação do sistema eólico na costa brasileira.............................80

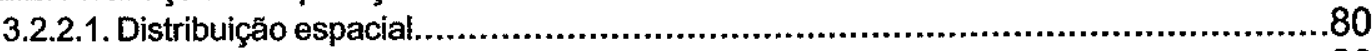

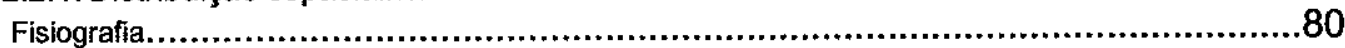

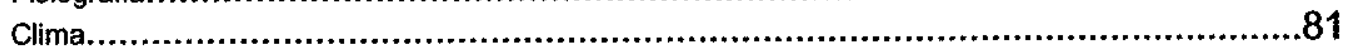

Refração de onda, deriva litorânea e desembocaduras....................................................8

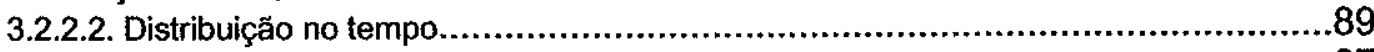

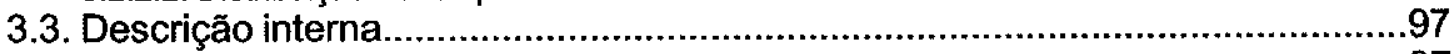

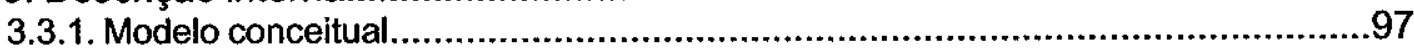

3.3.2. Elementos morfológicos eólicos na costa brasileira.....................................101

3.3.2.1. Elementos morfológicos com vegetação......................................................101

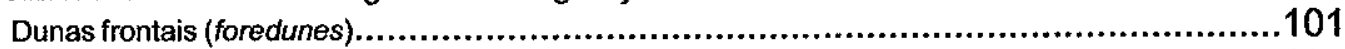

Rupturas de deflaçăo (blowouts) ................................................................. 105

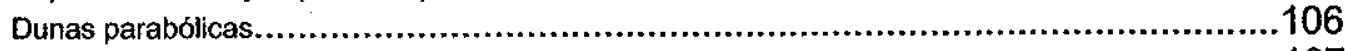

Rastros lineares residuais (trailing ridges) ..........................................................107

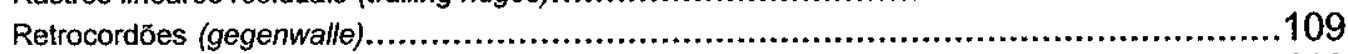

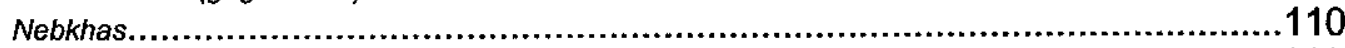

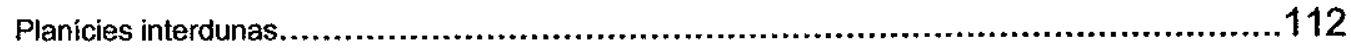

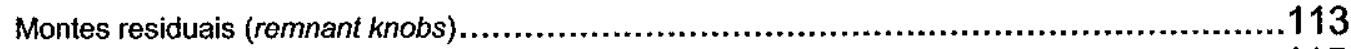

Cordōes de precipitação (precipitation ridges) ......................................................115

3.3.2.2. Elementos morfológicos sem vegetação....................................................116

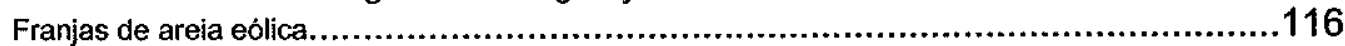

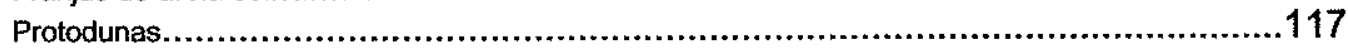

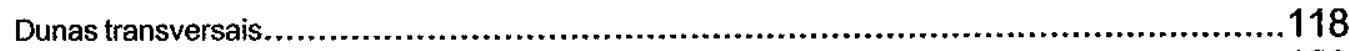

Cadeias barcanóides (barchanoid chains)..........................................................120

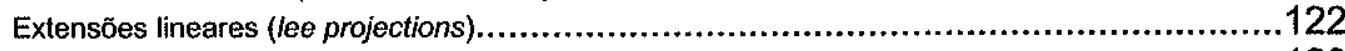

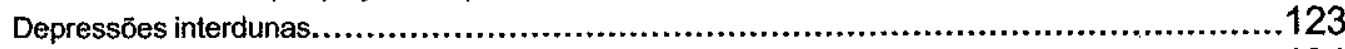

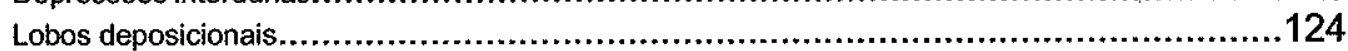

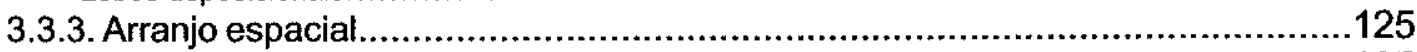

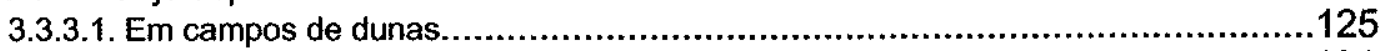

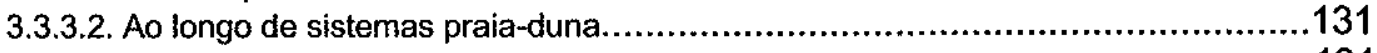

Em setores costeiros dominados por campos de dunas livres........................................131

Em setores costeiros dominados por dunas frontais..............................................135

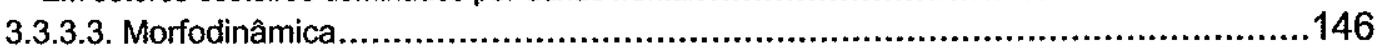


4. Modelo genético para o sistema eólico costeiro do Brasil............................148

4.1. Funções de elementos.............................................................................148

4.1.1. Elementos de suprimento inicial..............................................................148

4.1.2. Elementos de deflação.............................................................................149

4.1.3. Elementos de superposição e cavalgamento e elementos de avanço...............150

4.2. Associações de elementos e suas combinações internas possíveis..............152

4.3. Combinações entre associações de elementos: os tipos de sistema..............153

4.4. Exemplos brasileiros de tipos de sistema........................................................156

4.5. Influxo/efluxo vs. espaço de acumulação........................................................164

4.6. Análise de estabilidade do sistema...........................................................166

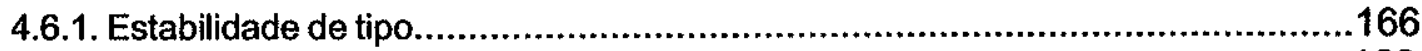

4.6.2. Estabilidade de posição e a arquitetura deposicional.......................................168

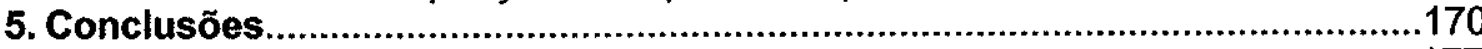

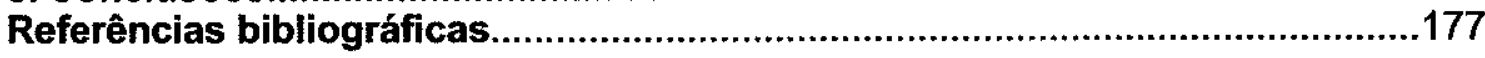




\section{Índice de figuras}

Figura 2.1. Exemplos de sistemas nas ciências biomédicas e nas geociências.

Figura 2.2. Exemplos de relações processo-resposta em escala de duna eólica, destacando sua influência na distribuição de processos mais básicos (em escala de grão ou ôndula).

Figura 2.3. Possibilidade de desdobramento tripartite do conceito de fácies no estudo de depósitos sedimentares recentes.

Figura 2.4. Representação esquemática das quatro fases de análise de um sistema deposicional: 1. Exame prévio ou delimitação sistema-meio. 2. Descrição externa das relações sistema-meio. 3. Descrição interna ou estrutural do sistema. 4. Descrição externa ou funcional do sistema.

Figura 2.5. Representação dos tipos de estabilidade de sistemas, por analogia com a mecânica clássica (segundo Hugget 1985), e seus respectivos exemplos geológicos.

Figura 2.6. Os seis estágios ou tipos de morfodinâmica praial segundo Wright et al.(1979).

Figura 2.7. Representações "cúspide-catástrofe" da combinação não linear entre variáveis.

Figura 3.1. Distribuição dos principais campos de dunas transgressivos ativos e campos de dunas interiores estabilizados do Brasil.

Figura 3.2. Distribuição e morfologia das gerações de dunas D1 (mais nova) a D5 (mais antiga) na célula sedimentar eólica Barrinha / Jericoacoara / Guriú, CE.

Figura 3.3. Distribuição de idades TL obtidas por Barreto et al. (2001) em dunas e paleodunas eólicas da costa do Rio Grande do Norte.

Figura 3.4. Paleodunas Qe3, ao interior, e dunas Qe4, junto à linha de costa, a NE da foz do rio São Francisco, AL.

Figura 3.5. Distribuição de idades TL obtidas por Watanabe et al. (2003) em areias do terraço alto de Itanhaém, SP.

Figura 3.6. Distribuição de idades TL obtidas em paleodunas eólicas (frontais e rupturas de deflação) na faixa externa da liha Comprida, SP (A) e em falésias ao longo da praia da Juréia, Iguape-Peruibe, SP (B).

Figura 3.7. Gerações de depósitos eólicos em Ibiraqüera (Imbituba), SC. A. Fotografia aérea vertical de Cruzeiro do Sul Serviços Aéreos (1979-1981). B. Mapa, simplificado de Giannini (1993).

Figura 3.8. Gerações de depósitos eólicos em Garopaba do Sul (Jaguaruna), SC. A. Fotografia aérea vertical de Cruzeiro do Sul Serviços Aéreos (1979-1981). B. Mapa, simplificado de Giannini (1993).

Figura 3.9. Distribuição das idades TL e LOE obtidas por Giannini et al. (2007c) em paleodunas eólicas da costa de Santa Catarina entre Imbituba e Jaguaruna.

Figura 3.10. Histogramas de distribuição de freqüências de idade para gerações eólicas 1 (A) e 2/3 (B), 2 (C) e 3 (D), segundo Giannini et al. (2007c).

Figura 3.11. Planicie adjacente à enseada da Pinheira, Palhoça, SC, onde cordões de paleodunas frontais se intercalam com cordões de paleodunas parabólicas.

Figura 3.12. Intercalação entre cordões sinuosos e lineares, característica da planície costeira sul-rio-grandense entre Cassino e Albardão.

Figura 3.13. Posições do nivel relativo do mar (NRM) na costa brasileira nos últimos 6 mil anos (idade ${ }^{14} \mathrm{C}$ convencional) inferidas a partir de datação e nivelamento de tubos de vermetídeos.

Figura 3.14. Cenário geológico da margem continental sudeste do Brasil.

13

15

Figura 3.15. Modelo de arquitetura de uma margem passiva do tipo atlântico.

Figura 3.16. Zonas climáticas do Brasil pela classificação de Koppen.

Figura 3.17. Modelo liga-desliga (on-off) de circulação termo-halina entre hemisférios controlada por ciclos sub-Milankovitch, com suas possiveis implicações na assimetria climática entre o Norte-Nordeste e o Sul-Sudeste do Brasil.

Figura 3.18. Registros de $\delta^{18} \mathrm{O}$ residual para espécies de foraminiferos planctônicos e 
bentônicos em sedimentos da margem continental brasileira, conforme Arz et al. (1999).

Figura 3.19. Gráfico de dispersão entre valores de $\delta^{18} \mathrm{O}$ e idades ${ }^{14} \mathrm{C}$ calibradas para 23 amostras de vermetídeos coletadas in situ no litoral de Santa Catarina, entre Imbituba e Laguna.

Figura 3.20. Descrição do sistema deposicional eólico, e comparação com o sistema marinho, a partir dos fluxos de entrada (Qi) e saída (Qe) de sedimentos, ou influxo e efluxo respectivamente, e do espaço disponivel para preenchimento sedimentar.

Figura 3.21. Configuração da acumulação eólica em diferentes tipos de sistema eólico.

Figura 3.22. Desenvolvimento de sistemas eólicos costeiros durante ou logo após queda (A) ou subida de NRM (B).

Figura 3.23. Princípio de Bruun original e sua versão ampliada para explicar formação de campos de dunas em contexto de elevação do NRM.

Figura 3.24. Modelo de desenvolvimento de sistemas eólicos costeiros integrado ao modelo geral da estratigrafia de seqüências.

Figura 3.25. Parte centro-leste da Restinga de Massambaba (Arraial do Cabo) e praia do Foguete (Cabo Frio), RJ, onde campos de dunas transgressivos a partir de áreas fontes lagunar e marinha apresentam rumos de migração opostos.

Figura 3.26. Lobos deposicionais e dunas parabólicas reversos (para NE) na margem interna do campo de dunas da praia Grande do Sul (Jaguaruna), SC.

Figura 3.27. Exemplos de campos de dunas com desenvolvimento assimétrico em costas do Sul do Brasil (Santa Catarina) com deriva litorânea residual para norte: praia do Sol, Laguna ( $A$ e B) e praia do Campeche (dunas da Joaquina), Florianópolis.

Figura 3.28. Exemplos de sistemas eólicos assimétricos em costas do Nordeste do Brasil com deriva litorânea longitudinal residual para norte (linha de costa NW a NS) e para sul (linha de costa NE).

Figura 3.29. Mega-sistema eólico formado pelos campos de dunas de Ponta das Gaivotas, Pequenos Lençóis e Lençóis Maranhenses, MA.

Figura 3.30. Diagrama cronoestratigráfico de Wheeler construído com base na seção tipo das gerações eólicas da costa centro-sul catarinense.

Figura 3.31. Distribuição das idades TL e LOE de paleodunas eólicas costeira do Rio Grande do Norte, quanto a "domínio morfológico" e comportamento do NRM.

Figura 3.32. Tipos básicos de dunas eólicas (McKee 1979).

Figura 3.33. Diferentes tipos de dunas lançados em diagrama de dispersão aporte sedimentar $x$ complexidade do regime eólico.

Figura 3.34. Exemplos dos três tipos de morfologia de dunas frontais incipientes nas praias do Una (Peruibe) e liha Comprida, no litoral sul paulista.

Figura 3.35. Classificação morfológica de dunas frontais estabelecidas, baseada no caso do sudeste da Austrália (Hesp 1988).

Figura 3.36. Exemplos de rupturas de deflação na porção meio-sudoeste da praia de itha Comprida, SP.

Figura 3.37. Exemplos de dunas parabólicas ativas junto a campos de dunas da Região SulSudeste.

Figura 3.38. Campos de dunas com desenvolvimento de planície de deflação formada por rastros lineares residuais, longitudinais ao vento efetivo, e retrocordões, transversais.

Figura 3.39. Elemento morfológico de rastro linear associado ao campo de dunas de Ibiraqüera (Imbituba), SC.

Figura 3.40. Fotografia (A) e reconstituição (B) das estruturas sedimentares expostas em parede de trincheira, corte transversal, aberta na parte proximal de rastro linear associado ao campo de dunas de lbiraqüera (Imbituba), SC.

Figura 3.41. Elemento morfológico retrocordão, em Ibiraqüera (Imbituba), SC.

Figura 3.42. Fotomontagem e reconstituição das estruturas sedimentares encontradas em 110 retrocordão, em lbiraqüera (Imbituba), SC. 
Figura 3.43. Dois modos de ocorrência de nebkhas junto ao campo de dunas da praia Grande do Sul, próximo à vila de Garopaba do Sul (Jaguaruna), SC.

Figura 3.44. Morfologia e registro deposicional de nebkhas da planicie interdunas, no campo de dunas da praia Grande do Sul, Garopaba do Sul (Jaguaruna), SC.

Figura 3.45. Planície interdunas úmida (A) e alagada (B). Campo de dunas livres da praia Grande do Sul (Jaguaruna), SC.

Figura 3.46. Aspectos morfológicos e deposicionais do elemento planície interdunas, na praia Grande do Sul (Jaguaruna), SC.

Figura 3.47. Morfologia e estruturação geral do elemento monte residual em Ibiraqüera 114 (Imbituba), SC.

Figura 3.48. Detalhe de truncamentos sucessivos, em padrão entrelaçado, em corte natural no lado barlavento de monte residual em Ibiraqüera (Imbituba), SC.

Figura 3.49. Elemento cordão de precipitação, sinuoso (A, B: Arroio Corrente, Jaguaruna, SC) e 116 retilíneo (C, D, E, F: Ibiraqüera, Imbituba, SC).

Figura 3.50. Elemento franja eólica em praias dissipativa $(A, B)$ e reflexiva $(C)$.

Figura 3.51. Protodunas transversais de comprimento de onda sub-métrico associadas a 118 processo de carpete de tração eólico.

Figura 3.52. Formas $(A, B)$ e estruturas internas $(C)$ de dunas transversais junto à praia Grande do Sul (Jaguaruna), SC.

Figura 3.53. Dunas transversais alcançadas pelas ondas, na praia Grande do Sul (Jaguaruna), SC.

Figura 3.54. Aspecto geral (A) e trincheira (B) em cadeia barcanóide estudada no campo de dunas de Ibiraqüera (Imbituba), SC.

Figura 3.55. Fotomontagem (A) e reconstituição (B) das estruturas sedimentares encontradas em trincheira escavada em cadeia barcanóide, no campo de dunas de lbiraqüera (Imbitiuba), SC.

Figura 3.56. Elemento morfológico extensão linear, adjacente a parte central e mais alta da concavidade de cadeia barcanóide em Ibiraqüera (Imbituba), SC.

Figura 3.57. Fotografia (A) e reconstituição de afloramento natural (B) em extensão linear em Arroio Corrente (Jaguaruna), SC.

Figura 3.58. Morfologia (A) e depósitos (B,C) de depressão interdunas em Ibiraqüera (Imbituba), SC.

Figura 3.59. Fotomosaico das estruturas expostas em trincheira no flanco de lobo deposicional em Ibiraqüera (Imbituba), SC.

Figura 3.60. Fotografia (A) e reconstituição (B) das estruturas sedimentares, expostas em trincheira, na base do flanco esquerdo de lobo deposicional, em lbiraqüera (Imbituba), SC.

Figura 3.61. Fotografia (A) e reconstituição (B) das estruturas sedimentares expostas em trincheira na frente de lobo deposicional estudado em Ibiraqüera (Imbituba), SC.

Figura 3.62. Dois exemplos de morfologias resultantes da interação entre dinâmica eólica e água na costa oeste cearense, segundo Claudino Sales (2002) e Claudino Sales \& Peulvast (2002).

Figura 3.63. Exemplos de campos de dunas livres da Região Nordeste, formados por barcanas e/ou barcanóides.

Figura 3.64. Campos de dunas costeiros junto à desembocadura do rio São Francisco, AL/SE.

Figura 3.65. Mapa esquemático com os dois tipos de "associações de fácies" na costa centrosul de Santa Catarina (modificado de Giannini 2002).

Figura 3.66. Perfil transversal esquemático da planície costeira do Rio Grande do Sul (segundo Tomazelli 1994).

Figura 3.67. Variação da altura das dunas transversais em função da distância ao longo da 132 praia Grande do Sul (Jaguaruna), SC, segundo dados de Martinho (2004).

Figura 3.68. Variação de elementos morfológicos eólicos ao longo da praia do Ji, município de 
Laguna, SC.

Figura 3.69. Campo de protodunas transversais e barcanóides, próximo à terminação nordeste 134 da praia do Ji (Laguna), SC.

Figura 3.70. Variação de largura e morfodinâmica praial (A) e de altura e tipo de duna frontal (B) 135 ao longo da praia do Una (Peruibe), SP, de NE para SW.

Figura 3.71. Variação de largura e morfodinâmica da praia $(A)$ e da altura e elemento 136 morfológico eólico (B), ao longo da praia da Juréia (Iguape), SP.

Figura 3.72. Tipos de feições eólicas ativas na praia de ilha Comprida, SP.

Figura 3.73. Variação da largura da praia (A) e da altura das dunas frontais incipientes (B) em 138 função da distância ao longo da praia de litha Comprida, SP, de NE para SW.

Figura 3.74. Elementos morfológicos eólicos de estocagem sedimentar imediata em sistemas 140 praia-duna com estocagem sedimentar mediata flutuante.

Figura 3.75. Elementos morfológicos eólicos de estocagem sedimentar imediata em sistemas praia-duna com estocagem sedimentar mediata aproximadamente constante.

Figura 3.76. Elementos morfológicos eólicos de estocagem sedimentar imediata em sistemas 142 praia-duna com estocagem sedimentar mediata anterior nula.

Figura 3.77. Elementos morfológicos eólicos de estocagem sedimentar imediata reiniciada. 143

Figura 3.78. Elementos morfológicos eólicos de estocagem sedimentar imediata interrompida. $\quad 144$

Figura 3.79. Elementos morfológicos eólicos em sistemas sem estocagem sedimentar imediata. 145

Figura 4.1. Modelo para evolução e replicação de campo de dunas adjacente a linha de costa 151 estável.

Figura 4.2. Tipos de sistemas eólicos costeiros do Brasil, sob condição de vento efetivo 154 transversal à linha de costa.

Figura 4.3. Tipos de sistemas eólicos costeiros do Brasil, sob condição de vento efetivo sub- 155 paralelo à linha de costa.

Figura 4.4. Exemplos de sistemas eólicos costeiros do tipo 2 ou A-BI.

Figura 4.5. Exemplos de sistemas eólicos costeiros do tipo 3 ou A-BII.

Figura 4.6. Exemplos de sistemas eólicos costeiros do tipo 4 ou A-BIII.

Figura 4.7. Exemplos de sistemas eólicos costeiros do tipo 5 ou A-B-Cl. 160

Figura 4.8. Exemplos de sistemas eólicos costeiros do tipo 6 ou A-B-Cll. 161

Figura 4.9. Exemplos de sistemas eólicos costeiros do tipo 7 ou A-B-Clll. 162

Figura 4.10. Exemplos de sistemas eólicos costeiros do tipo 8 ou A-C.

Figura 4.11. Evidências de formação ou crescimento preferencial de campos de dunas livres 165

onde a pista do vento encontra lagunas, lagos ou estuários.

Figura 4.12. Arquiteturas deposicionais do sistema eólico costeiro. 


\section{Índice de quadros}

Quadro 2.1. "Aspectos fundamentais da teoria de sistemas", melhor designados principios de abordagem sistêmica.

Quadro 2.2. Enunciados das leis sistêmicas de "produção" interna $\left(\mathrm{d}_{i} \mathrm{~S}\right)$ e "entrada" externa de entropia $\left(d_{e} S\right)$, com suas respectivas condições de validade e mecanismos de manutenção.

Quadro 2.3. Questōes de escala na análise de fácies e algumas de suas possíveis implicações no estudo de sistemas eólicos costeiros no Quaternário.

Quadro 3.1. Setores fisiográficos da costa brasileira e principais elementos geomorfológicos, tectono-estruturais e magmáticos associados nas áreas emersa e submersa adjacentes.

Quadro 3.2. Principais critérios geotectônicos, estruturais e geomorfológicos para o reconhecimento de tipos de segmentos de placas e zonas de transferência em margens passivas do tipo attântico.

Quadro 3.3. Proposta de correlação entre gerações de campos de dunas de diferentes regiões costeiras do Brasil. 


\section{Resumo}

Os sistemas deposicionais eólicos ativos da costa brasileira incluem campos de dunas livres e depósitos vegetados. Os campos de dunas livres encontram-se em quatro áreas principais: 1. no trecho que vai dos Lençóis Maranhenses ao extremo sul do Rio Grande do Norte; 2. nas vizinhanças da desembocadura do rio São Francisco, SE/AL; 3. na região de Cabo Frio, RJ; e 4. entre a itha de Santa Catarina, SC, e o extremo sul do Rio Grande do Sul. Os depósitos vegetados, principalmente dunas frontais, nebkhas e lobos de ruptura de deflação (blowouts), predominam nas demais áreas costeiras do país.

Os elementos morfológicos identificados nestes sistemas eólicos podem ser divididos, quanto à sua função, em quatro grupos. O primeiro grupo, ou de estoque inicial, é o único de ocorrência universal. Nele podem estar presentes dunas frontais, franjas de areia, protodunas e dunas sem vegetação de orientação transversal ao vento. O segundo grupo, ou de deflação, possui a função de separar duas acumulações principais (estoque inicial e estoque final) segundo uma distância de equilibrio. Inclui rupturas de deflação, rastros lineares residuais, retrocordões e dunas parabólicas. O terceiro grupo, de superposição ou cavalgamento, inclui dunas barcanas e, mais tipicamente, cadeias barcanóides. Seu papel é o de elevar a acumulação até uma altura de equilibrio, através da superposição sobre megaforma de hierarquia maior, representada pelo campo de dunas livre, e, ao mesmo tempo, através do cavalgamento das formas de leito de mesma hierarquia. O quarto grupo, dos elementos de avanço, compreende cordões de precipitação e lobos deposicionais e possui a função de estender o campo de dunas, lateral e longitudinalmente, até sua distância de equilíbrio. Sob condição de desbalanço construtivo (influxo maior que efluxo) em dado grupo funcional de elementos, o excesso de areia tende a ser consumido na formação e alimentação de outros grupos mais interiores. Os grupos funcionais constituem domínios do espaço interligados dentro do sistema e, por extensão, verdadeiras associações de fácies: os elementos de estoque inicial compõem a associação praia-duna (A); os elementos de deflação reúnem-se na associação planície deflacionar (B); e os elementos de cavalgamento e de avanço, isolados ou associados, definem a associação campo de dunas livres (C). As relações entre as associações faciológicas podem ser desdobradas em quatro categorias conforme o equilíbrio entre matéria e energia (e entre influxo e efluxo) seja atingido na associação praia-duna $(A)$, na relação entre associação praia-duna e a associação planície de deflação (A-B) ou na relação entre as associações praia-duna, planície de deflação e campo de dunas livres (A-B-C). Relação direta entre as associações praia-duna e campo de dunas livres $(A-C)$ representa equilibrio entre influxo e efluxo seguramente ainda não atingido. Destas relações saem oito estágios morfodinâmicos de sistemas eólicos, numerados de 1 a 8 em grau crescente de relação saldo eólico / espaço de acumulação.

Uma vez alcançada a distância e a altura de equilíbrio, a evolução do sistema varia conforme o saldo influxo-efluxo como todo torne-se nulo ou mantenha-se positivo. Com saldo eólico nulo, o sistema mantém-se em equilíbrio dinâmico de estado estacionário. Fácies de deflação e/ou avanço, caso presentes, passam simplesmente a migrar. Esta migração leva ao distanciamento entre campo de dunas e área fonte além da distância de equilíbrio e, a médio prazo, à estabilização do sistema. Ao mesmo tempo, porém, um novo sistema tende a surgir junto à praia. Se o balanço influxo-efluxo no sistema como todo permanece positivo, o sistema mantém-se através de retroalimentação negativa, com a subdivisão em duas porções, separadas por planície de deflação, de modo que a porção mais proximal passe a atuar como fonte para a distal. Ocorre assim a "duplicação" de campos de dunas ativos.

Se a relação entre o saldo eólico influxo-efluxo e o espaço de acumulação cai bruscamente, o sistema desloca-se em retroalimentação positiva para outro estágio morfodinâmico, em que a retenção de areia seja menor. Inversamente, se o saldo relativo aumenta de modo abrupto, o sistema desloca-se para estágio morfodinâmico de retenção 
maior de areia eólica. Por exemplo, em costa com comportamento transgressivo, a erosão e recolocação em circulação de depósitos subaquosos preexistentes elevam a probabilidade de alimentação do sistema eólico, ao mesmo tempo em que reduzem o espaço de acumulação. A retroalimentação positiva do sistema atua no sentido de aumentar a saturação de areias eólicas e, portanto, a distância e a altura de equilíbrio.

Sob comportamento regressivo persistente, a sucessão de regimes de saldo eólico cada vez menor pode conduzir, por exemplo, à transformação de campos de dunas livres em feixes de cordões dunares. Já sob comportamentos transgressivos, cordões de dunas frontais podem sofrer deflação crescente e permitir o estabelecimento gradual de campos de dunas livres. Este é o tipo de processo aqui evocado para explicar a formação das duas seqüências de depósitos eólicos, deduzidas em Santa Catarina, mas extensível a grande parte dos setores costeiros brasileiros com vocação atual ou recente para formação de campos de dunas livres. A seqüência eólica $A$, mais antiga, relaciona-se ao NRM alto do último interglacial, enquanto a seqüência $B$, mais nova, associa-se ao NRM alto do Holoceno. Os depósitos representativos de três gerações eólicas mais novas $(2,3$ e 4$)$, integrantes da seqüência $B$, teriam se diferenciado no contexto de retroalimentações negativas posteriores à máxima inundação marinhomlagunar do Holocêno. 


\begin{abstract}
In Brazilian coast it is possible to recognize two types of active coastal systems: dunefields and vegetated dunes. The dunefields occur in four main areas: 1. between Lençóis Maranhenses (State of Maranhão) and the southern Rio Grande do Norte; 2. in the São Francisco river mouth (Sergipe/Alagoas); 3. in the Cabo Frio region (Rio de Janeiro); and 4. between Santa Catarina Island and the southernmost Rio Grande do Sul coast. In other coastal sections of Brazil, the dominant type of aeolian deposits corresponds to the vegetated ones, mainly foredunes, nebkhas and blowout depositional lobes.

The morphologic elements recognized in these aeolian systems may be classified, as for their functions, in four groups. The first one, or the initial stock group, is the only with universal occurrence. It comprises foredunes, sand fringes, protodunes and transverse dunes. The second, or the deflation group, has the function of to separate two main accumulations (initial and final stock) according to a equilibrium distance or saturation strength. It includes blowouts, residual trailing ridges, gegenwalle and parabolic dunes. The third group, of climbing or overlapping elements, comprises barchans and, more typically, barchanoid chains. Its role is to elevate the aeolian accumulation until a equilibrium height, by the overlapping of a major megaform (the dunefield), and, in the same time, by the climbing of aeolian bedforms of same hierarchy. The fourth, or advance group, comprises precipitation ridges and depositional lobes. This group play the role of to extend the dunefield until its equilibrium distance. Under constructive unbalance (influx higher than outflux) in a certain functional group of morphologic elements, the sand excess trends to be consumed in the formation and growth of other groups landward. The functional groups occupy determined spatial positions inside the system, being therefore true facies associations: the initial stock elements constitute the beach-dune facies association $(A)$; the deflation elements are grouped in the deflation plain association (B); and the climbing and advance groups, isolated or linked, define the dunefield association (C). The relationships among facies associations can be classified in four types, depending if the equilibrium between matter and energy (and between influx and outflux) is reached in the beach-dune association (type $A$ ), in the link between beach-dune and deflation plain associations (A-B) or in the link among beach-dune, deflation plain and dunefield associations (A-B-C). The direct flow from beach-dune to dunefield $(A-C)$ represents surely non achieved equilibrium between influx and outflux. From these relationships of facies association, eight morphodynamic stages are derived. They are designated 1 to 8 in order of increasing aeolian supply / accumulation space rate.

Once achieved the equilibrium height and distance, the evolution of the aeolian system varies according to the influx-outflux balance, if null or positive. With null sedimentary balance, the system remains in dynamic equilibrium of steady state. The deflation or advance facies eventually present begin simply to migrate. This migration conducts the system to the distancing between dunefield and source area, beyond the equilibrium distance, and, in a medium term, to the system stabilization. In the same time, however, a new system begins to develop beside the beach. If the balance influx-outflux in the system remains positive, the system divides itself into two portions separated by a deflation plain, and its proximal portion begins to act as source to the distal one. Through this mechanism of negative feedback, the duplication of the dunefield occurs.

When the relation between the aeolian balance influx-outflux and the accumulation space decreases abruptly, the system changes by positive feedback to another morphodynamic stage in which the sand retention is lower. In counterpart, when the same relation increases in a abrupt way, the system changes to morphodynamic stage in which the sand retention is higher. For example, in a transgressive barrier, the erosion and restoring in circulation of the pre-existent subaqueous deposits elevates the probability of to nourish the
\end{abstract}


aeolian system in the same time that they reduce the accumulation space. Thus, the positive feedback act to increase the aeolian sand saturation and the equilibrium distance and height.

Under persistent regression, the succession of morphodynamic stages of decreasing aeolian balance may lead the dunefield to transform into foredune ridges. Under transgression, foredune ridges can be submitted to intense deflation permitting the progressive development of dunefields. This is the kind of process here evocated to explain the formation of the two aeolian sequences deduced in Santa Catarina coast, and extensible to great part of the Brazilian coastal sectors with present or recent vocation to forming dunefields. The older aeolian sequence, $\mathrm{A}$, is related to the last interglacial highstand, while the newer sequence, is associated to the Holocene highstand. The three aeolian generations $(2,3$ e 4$)$ which integrates the sequence $B$ would be gathered in the context of negative feedback processes occurred after the Holocene maxim flooding. 


\section{Introdução}

\subsection{Relevância do tema}

Pelo menos dois aspectos justificam a realização de um estudo de síntese, e sob perspectiva sistêmica, acerca dos depósitos eólicos no Quaternário costeiro do Brasil. O primeiro é a necessidade de compreender a dinâmica desses depósitos, como requisito teórico básico para o gerenciamento costeiro. O segundo aspecto é o interesse acadêmico em fazer convergir os métodos e objetos de estudo da geologia do Quaternário, que tradicionalmente enfatizam formas e processos, e da estratigrafia moderna praticada por exemplo na geologia do petróleo, onde os conceitos de sistemas deposicionais e tratos de sistemas desempenham papel fundamental. Esta questão reveste-se de especial significado quando se considera que os depósitos eólicos perfazem parte relevante do registro sedimentar e incluem-se entre os melhores reservatórios tanto de hidrocarbonetos, como de água subterrânea (Giannini et al. 2007c).

\subsubsection{Dinâmica de sistemas eólicos e gerenciamento costeiro}

A erosão de praias induzida pela destruição de dunas costeiras pelo homem e o efeito de construções urbanas e outras intervenções antrópicas sobre a sedimentação eólica são fenômenos relatados em diferentes regiões do Brasil (Angulo 1993b,c, Tabajara et al. 2000, Esteves et al. 2001), a exemplo de outros países (Draga 1983, Nordstrom \& McCkuskey 1985, Moreira 1988, Carter \& Chance 1997, van der Wal 2004). O descaso ou subestimação do papel das dunas eólicas no equilíbrio sedimentar, inclusive no âmbito de políticas públicas de ocupação e gerenciamento costeiro, pode ser ainda considerado um problema mundial. No Brasil, observa-se com freqüência uma inversão de valores: a construção de muros e avenidas beira-mar de asfalto e concreto, na faixa que a natureza reservara às dunas, é geralmente considerada sinônimo de boa administração. Soluções urbanísticas elegantes, que incluem jardins e ciclovias, não levam em consideração a preservação das dunas ativas e da vegetação original responsável por sua manutenção. Trata-se de uma espécie de administração de aparências que reflete, de modo imediato, a falta de informação sobre a dinâmica das dunas eólicas e, de modo mediato, o conhecimento técnico-cientifico talvez ainda incipiente sobre esta questão. A escala do problema, aqui, é mais uma vez mundial: o tema da função das dunas no equilibrio costeiro só começou a se tornar recorrente no meio acadêmico a partir da década de 1980 (por exemplo: Hesp 1981, 1983, 1988, 1989, 1999, 2000, Psuty 1988, Sarre 1989, Carter 1990, Carter et al. 1990, Kroon \& Hoekstra 1990, Arens \& Wiersma 1994, Hesp \& Short 1999). No Brasil, os estudos sobre morfodinâmica praial atravessam fase de florescimento promissor desde a década de 90 , evidenciado pela multiplicação no número de especialistas e publicações, mas só agora começam a ser acompanhados por pesquisas sobre dunas costeiras.

O fato é que excluir os depósitos eólicos da análise da morfodinâmica praial equivale a examinar um paciente com problema respiratório, apenas pelo pulmão. Assim como nas ciências biomédicas, o uso da perspectiva sistêmica possui, mais que interesse teórico, uma funcionalidade prática irresistível. Praias e dunas eólicas ativas mantêm entre si interações de energia e matéria típicas de um sistema natural em equilibrio dinâmico, para não dizer orgânico. A modificação de qualquer parte deste sistema pelo homem implica a alteração do sistema todo em direção a novos estados de equilíbrio, cujo funcionamento pode ser indesejável e de difícil controle (Giannini et al. 2005). Casos de erosão costeira induzida pela destruição de dunas eólicas são ilustrações de sistemas naturais colocados fora de controle (ou em estados muito distantes do equilíbrio). 
No caso específico de campos de dunas livres, a mobilidade da areia introduz um fator complicante no planejamento da ocupação: a necessidade de ponderar-se a influência da dinâmica dunar, através de previsões a médio prazo. Durante o processo de migração que lhes é inerente, estes campos de dunas transgridem os terrenos adjacentes. Desse modo, contribuem para o assoreamento de banhados e corpos lacustres ou lagunares, interrompem estradas $e$, nas regiões urbanizadas, avançam sobre ruas, casas e outras edificações (Giannini et al. 2005). Além disso, cada um desses campos de dunas, na costa brasileira, possui com freqüência dezenas a centenas de quilômetros quadrados, às vezes milhares, caso do notável exemplo dos Lençóis Maranhenses. Muitos deles sucedem-se ao longo de uma mesma praia, como no Rio Grande do Sul, ou de praias vizinhas, como no Ceará, por centenas de quilômetros seguidos. Mantê-los inteiramente intactos parece, à primeira vista, incompativel com o adensamento populacional e o crescimento da economia turistica do país. Assim, os conflitos entre a atividade antrópica e a dinâmica dos campos de dunas transgressivos constituem uma das mais complexas e importantes questões ambientais e econômicas do litoral brasileiro.

Mesmo nas áreas de paleodunas, o uso do solo não pode ser feito sem um planejamento embasado em sólido conhecimento geológico, pois o adensamento da ocupação e as atividades agropecuárias via de regra exacerbam ou reiniciam processos geológicos, principalmente de transporte sedimentar (Giannini et al. 2005). A grande suscetibilidade dos sedimentos arenosos incoesos à erosão pela água ou à reativação pelo vento faz com que o uso do solo conduza ora à desfiguração geomorfológica completa das paleodunas, com reflexos irreversíveis na paisagem, na hidrologia e na biodiversidades faunística e floristica, ora à produção de novos campos dunares, que passam a afetar áreas até então favoráveis à ocupação antrópica. Desse modo, a proteção e reconstituição de campos de dunas não pode prescindir de planejamento cuidadoso na ocupação das áreas de paleodunas. A criação do "Parque das Dunas", em Natal, RN, área de preservação ambiental abarcando os principais campos de dunas e paleodunas ameaçados pelo adensamento urbano local, apresenta-se como um exemplo positivo para a manutenção dos sistemas praia-duna brasileiros (Giannini et al. 2005). Mas que dificilmente resistirá à pressão imobiliária, se não for implantada uma educação sobre o papel das dunas no equilíbrio sedimentar, embasada em conhecimento científico sobre a dinâmica de sistemas eólicos.

\subsubsection{Dinâmica de sistemas eólicos e estratigrafia}

A dificuldade de construção de um modelo de fácies eólicas é reconhecida desde os trabalhos pioneiros da moderna análise de fácies (Walker \& Middleton 1977). Impressionado pela aparente monotonia de processos, estruturas e texturas eólicas, Fisher (1983), um dos fundadores da teoria de sistemas deposicionais (Fisher \& McGowen 1967; Fisher \& Brown 1972), chegou a aventar a possibilidade de tratar os depósitos eólicos como sistemas simples (aqueles em que as respostas a alterações controladas de aporte e energia são previsiveis com base em conceitos de física clássica). Esta visão agora parece ingênua, mas modelos de fácies eólicas costeiras, calcados em exemplos quaternários, continuam relativamente escassos na literatura.

Historicamente, a monotonia faciológica aparente dos depósitos eólicos conduziu à adoção de uma perspectiva estratigráfica que permitisse ver não apenas o registro deposicional em si, mas as superfícies de descontinuidade física que resultam da migração das dunas e/ou das interrupções e mudanças bruscas na deposição. Estas descontinuidades delimitam o que recentemente convencionou-se chamar de elementos arquitetônicos (Miall 1996, 1999; item 2.3.2). Compreendem superfícies de truncamento (bounding surfaces) de diferentes hierarquias e supersuperfícies (Stokes 1968; Brookfield 1977; Kocurek 1981, 
1988; Talbot 1985), cujo estudo tem auxiliado a revelar a complexidade dos sistemas eólicos. No aspecto aplicado, estas superficies, em suas diversas escalas, possuem implicações importantes na distribuição das heterogeneidades de porosidade e permeabilidade que controlam o fluxo de fluidos em reservatórios de água e hidrocarbonetos (Miall \& Tyler 1991).

A ênfase às descontinuidades físicas aproxima a análise de sistemas eólicos da estratigrafia de seqüências, modelo de abordagem surgido na geologia sedimentar durante as três últimas décadas, cujo paradigma é a influência do nível relativo do mar (NRM) na origem e evolução de sistemas deposicionais e no preenchimento de bacias. No modelo da estratigrafia de seqüências, os depósitos sedimentares são divididos em unidades estratigráficas (seqüências deposicionais), separadas por "inconformidades" regionais (limites de seqüências), e suas conformidades correlativas, geradas por queda de NRM (Vail et al. 1977). O caráter cíclico e regional das variações de NRM fornece a este modelo capacidade elevada de correlação e predição. Os padrões de empilhamento de fácies variam de acordo com o tipo de sistema deposicional. Para a caracterização desses padrões em um sistema deposicional específico, é necessário portanto conhecer o modo como as diferentes fácies desse sistema se relacionam com as mudanças de NRM. Esta relação é relativamente bem conhecida para alguns sistemas deposicionais, principalmente os marinhos, e ainda pouco compreendida para outros, como é o caso dos sistemas é́licos em geral.

No que se refere aos campos de dunas e paleodunas costeiros quaternários, a abordagem voltada para os aspectos da teoria de sistemas deposicionais e da estratigrafia de seqüências oferece ainda vasto campo por explorar. Considerando que a variação de NRM no Quaternário é ou pode ser conhecida com detalhe relativamente maior que em outros periodos geológicos, os depósitos eólicos quaternários constituem excelentes modelos para a compreensão da morfodinâmica dunar e de seu efeito na produção $e$ preservação de superfícies, bem como para testar o uso dos conceitos de estratigrafia de seqüências. A adaptação da estratigrafia de seqüências ao estudo de depósitos eólicos quaternários envolve porém desafios adicionais, impostos por pelo menos três traços peculiares destes depósitos: em primeiro lugar, os afloramentos restritos, em que se sobressaem heterogeneidades de mesoescala, dificilmente rastreáveis por prospecção geofísica e testemunhagem; em segundo lugar, a menor escala de tempo e espaço envolvida não só na deposição mas na preservação; em terceiro lugar, e conseqüência dos dois fatores anteriores, o fato de o registro sedimentar refletir flutuações de variáveis não necessariamente ligadas ao NRM, incluindo mecanismos autocíclicos de estocagem sedimentar. Interessa, portanto, menos o paradigma teórico da estratigrafia de seqüências, cuja ênfase no NRM deve ser evitada a priori, e mais o tipo de procedimento metodológico de que a estratigrafia de seqüências se serve, isto é, a construção de modelos sobre estrutura e dinâmica de sistemas deposicionais. Interessa investigar como os sistemas eólicos costeiros respondem morfologicamente às variáveis macroambientais, como migram e se empilham e como isso se reflete no seu registro deposicional. É no contexto destes desafios que esta Tese se insere. A meta ou proposta geral de abordar os depósitos eólicos quaternários da costa brasileira como sistemas deposicionais tem como propósito identificar os fatores e mecanismos controladores da sedimentação e acumulação eólica, e correlacioná-los a alterações nas taxas de deposição e no espaço disponível, à duração e dinâmica dos sistemas deposicionais e à conseqüente produção de arranjos de fácies e elementos arquitetônicos.

\subsection{As questões propostas nesta Tese e a sua itemização}

O ponto de partida para a meta geral estabelecida no item anterior é a existência atual de pelo menos dois grandes tipos de depósitos eólicos costeiros: as dunas frontais e os 
campos de dunas. A partir desse ponto, algumas questões fundamentais conduzem a pesquisa. Em primeiro lugar, qual é e como se explica a distribuição destes tipos ao longo da costa brasileira? Em segundo lugar, porque estes dois tipos maiores de depósitos não são iguais, nos diferentes trechos de costa em que ocorrem, em termos de morfologia, dimensões, dinâmica e orientação? Em terceiro lugar: como se distribuíram estes depósitos no decorrer do tempo, especialmente nas últimas centenas de milhares de anos, e que fatores determinaram esta distribuição? $\mathrm{E}$, ainda, uma quarta grande questão: o que estes sistemas têm em comum, isto é, qual a dinâmica geral de funcionamento de um sistema eólico costeiro que está por trás da existência destes ou de outros tipos de depósitos que possam ser reconhecidos?

Estas questões, que compõem metas específicas desta Tese, conduzem naturalmente a um amplo leque de variáveis capazes de influenciar o desenvolvimento de dunas eólicas costeiras, como aporte sedimentar, energia do vento, pluviosidade, cobertura vegetal, fisiografia da costa, regime de ondas e marés, morfodinâmica da praia, nivel do mar etc. São variáveis que interagem em diferentes escalas de tempo e espaço, de modo tão complexo, que sua descrição e discussão exige um tratamento não causalista e não determinista. Dentre os vários enfoques que permitem este tipo de tratamento, a escolha nesta Tese do enfoque sistêmico deu-se por algumas razões principais. Primeiro, porque o uso de conceitos como sistema eólico e sistema praia-duna torna-se cada vez mais corriqueiro na literatura de geologia costeira. Segundo, porque a estratigrafia moderna deve uma parte substancial de seu arrazoado teórico ao conceito de sistema deposicional, surgido na geologia do petróleo, sob influência da teoria geral de sistemas fundada por Ludwig von Bertalanffy. E terceiro, porque as questões estabelecidas como metas da Tese traduzem-se facilmente em termos de "como se organiza e funciona um sistema", no caso o sistema deposicional eólico costeiro. Quer dizer, trata-se de questões que se adaptam bem às diretrizes da abordagem sistêmica, segundo seu teorizador (item 2.1).

Dentro desta proposta geral de abordar os depósitos eólicos costeiros do Brasil de modo sistêmico, estabeleceu-se a ordenação dos tópicos que se seguem. $O$ capítulo metodológico (2) é dedicado à uma questão de coerência: como descrever sistemas de modo efetivamente sistêmico? Esta questão implica uma sucessão de etapas: inicialmente, estabelecer definições de sistema e sistema deposicional, que sejam harmoniosas entre si, e ao mesmo tempo fiéis às concepções originais dos dois termos (item 2.1); em seguida, compreender a natureza dos sistemas deposicionais dentro da tipologia de sistemas (2.2), estabelecer os componentes menores do sistema deposicional (2.3), no caso as fácies deposicionais, e, finalmente, traduzir para o contexto geológico as fases de descrição de sistemas propostas por Bertalanffy (2.4). O capítulo seguinte (3) é dedicado à descrição geral dos sistemas eólicos no Quaternário costeiro do Brasil, de acordo com o método estabelecido no capítulo anterior. Ele começa pelo exame prévio (3.1), cuja finalidade fundamental é a delimitação dos sistemas e seus tipos no espaço e no tempo (3.1.1), seguida da caracterização e discussão de seu entorno ou macroambiente (3.1.2), com destaque para NRM, fisiografia e clima. Segue-se a descrição externa (3.2), que trata das relações do sistema com o meio e portanto da interação exercida, através de entradas e saidas, com o macroambiente. Aqui discute-se a influência das variáveis do macroambiente na mudança de características dos depósitos eólicos, primeiro através da elaboração de um modelo conceitual geral (3.2.1) e, em seguida, através da aplicação deste modelo ao longo da costa brasileira (3.2.2). Só então o sistema é descrito internamente, quanto a seus elementos morfológicos constituintes (3.3.1 e 3.3.2), vários deles subdivididos em fácies morfológicas e deposicionais, e quanto aos arranjos de elementos (3.3.3). Um modelo de funcionamento do sistema, voltado à explicação e previsão da variação das associações de elementos morfológicos e fácies no espaço e no tempo, é o tema do capítulo de síntese final (4). 
Cabe um esclarecimento antecipado sobre o porquê das frases de autoria do cardeal e pensador místico Nicholas de Cusa (1401-1464), apresentadas ao longo do capítulo 2. Bertalanffy considerava Cusa como precursor do pensamento sistêmico (Bertalanffy 1972b, Laszlo 1974), a ponto de ter-lhe dedicado um ensaio intitulado "O Legado de Cusa" (Bertalanffy 1928). Este ensaio traz implícita certa admiração e até alguma inspiração pela obra e vida do cardeal, mas não esclarece, de modo objetivo, qual fol sua influência na concepção da teoria de sistemas. É, portanto, uma experiência surpreendente ler os versos escritos por Cusa e descobrir que muitas das idéias fundamentais do enfoque sistêmico de fato já estavam lá! É para compartilhar esta descoberta com o leitor da Tese que alguns destes versos (a partir de tradução de Yockey 1993) são transcritos no decorrer do capítulo 2.

\subsection{Fontes de dados de sensoriamento remoto utilizadas nesta Tese}

Para a avaliação qualitativa da distribuição geográfica e de aspectos geométricos maiores dos campos de dunas ao longo da costa brasileira, consultarammse preliminarmente as imagens de satélite fornecidas pelo Instituto Nacional de Pesquisas Espaciais (INPE) ao Guia Quatro Rodas Praias $(1997,2000)$. Este guia serviu de base também para as toponimias de praias, vilas e municipios empregadas neste trabalho.

Para detalhamento, foram consultados os mosaicos de imagens do satélite Landsat-7 obtidas entre os anos de 1990 e 2003, disponibilizados para uso público na rede eletrônica internacional, através do programa GeoCover (NASA 2007). As imagens de satélite reproduzidas na Tese são da cobertura do ano 2000, exceto onde indicado. Fotografias áreas de setores costeiros das regiões sul e sudeste pertencem ao levantamento aerofotogramétrico executado pela Cruzeiro do Sul Serviços Aéreos, nos anos de 1952 a 1980 , escala nominal 1:25.000.

Nas imagens de satélite e fotografias aéreas onde não houver indicação gráfica, o norte geográfico aponta na vertical para o topo da página. 


\title{
2. Métodos: como descrever sistemas deposicionais de modo sistêmico?
}

\author{
"Com que grandeza brilha a força da sabedoria: nas partes do corpo, sua disposição, a vitalidade \\ inspirada, a harmonia e o movimento dos vários órgãos..." (Nicholas de Cusa)
}

\subsection{Sistema e sistema deposicional}

A noção de sistema é no mínimo tão antiga quanto a filosofia grega. O dictum aristotélico "o todo é mais que a soma das partes" é uma definição do problema sistêmico fundamental (Bertalanffy 1972a). Analogamente, a observação de Hipócrates de Cós (460377 a.C.), segundo a qual "o corpo é um todo harmonioso, cujas partes se mantêm em dependência mútua e cujos atos são solidários uns com ou outros" parece um gérmen das idéias que ganhariam status científico no século $X X$, justamente nas ciências biomédicas. É nessa área que o conceito de sistema, tal como hoje se conhece, tem suas origens, durante a década de 1920, através do surgimento da idéia de "reação sistêmica" de Weiss (1925 apud Delattre 1981) e da "teoria organísmica" de Bertalanffy (Bertalanffy 1926 apud Delattre 1981, Bertalanffy 1937). Ambas representavam o organismo vivo através de um conjunto de componentes (o sistema) em interação mútua e dinâmica.

Nas décadas seguintes, Bertalanffy $(1950,1968,1972 a)$ idealizou a aplicação do mesmo conceito a outras áreas da ciência e estabeleceu como meta do que ele chamou de "teoria geral de sistemas" a integração de conhecimentos, a ser perseguida dos níveis mais particulares para os níveis mais abrangentes. Apesar disso, o que hoje se conhece como "teoria geral de sistemas" apresenta-se antes como programa de objetivos metodológicos de que como resultado adquirido (Delattre 1981). O uso do termo "teoria" não é adequado a rigor, dai encontrar-se grafado entre aspas nesta Tese, e os "aspectos fundamentais da teoria de sistemas" (Quadro 2.1), relacionados por Bertalanffy $(1968,1972 a)$, devem ser encarados apenas como principios de abordagem.

O princípio de abordagem essencial pode ser enunciado do seguinte modo: "as propriedades e ações dos níveis superiores não podem ser explicados pela soma das propriedades e ações de cada um de seus componentes considerados isoladamente; apesar disto, é possível chegar aos niveis mais elevados partindo dos componentes menores, quando se conhece o conjunto de componentes e suas inter-relações" (Bertalanffy 1952 apud Bertalanffy 1972a). Desse modo, qualquer sistema só pode ser definido por sua coesão ou conexão, isto é, pela interação entre os elementos componentes (Bertalanffy 1972a).

Quadro 2.1. "Aspectos fundamentais da teoria de sistemas", melhor designados principios de abordagem sistêmica, compilados de Bertallanfy $(1968,1972 a)$.

\begin{tabular}{|c|c|}
\hline & Principio de abordagem \\
\hline 1 & Ênfase à interação entre as partes componentes \\
\hline 2 & Uso e descoberta de leis sistêmicas \\
\hline 3 & Uso de modelos \\
\hline 4 & Perspectivismo \\
\hline 5 & Exploração de isomorfismos \\
\hline 6 & Descrição interna (estrutural) e externa (dinâmica) \\
\hline
\end{tabular}

Entre outros princípios mais específicos que podem ser abstraídos dos trabalhos de Bertalanffy (1968, 1972a), destacam-se (Quadro 2.1): 1. o uso e a descoberta de leis sistêmicas, isto é, "analogias ou homologias lógicas entre relações que, embora pertencendo a fenômenos distintos, são formalmente idênticas entre si"; a "teoria dos sistemas abertos" (Quadro 2.2) seria, segundo esse autor, o exemplo mais geral de lei sistêmica. 2. a utilização 
de modelos, "enunciados analógicos" (ou "correlatos concentuais de traços universais") de objetos observados, cujo caráter de "explicações em princípio" confere-lhes poder preditivo e capacidade de teste e auto-falseamento (Delattre 1981, Fichter 1988); 3. o perspectivismo, isto é, o reconhecimento da multiplicidade infinita de modelos para um mesmo objeto e da importância do ponto de vista, do referencial e do "espaço de estado" (variáveis escolhidas para descrever o sistema) na construção do modelo; 4 . a exploração de isomorfismos comuns a todos os tipos de sistemas, o que permite o emprego de conceitos ou parâmetros universais na sua descrição (por exemplo, "fluxo" e "retroalimentação"); e 5. a subdivisão da descrição de sistemas em interna ou estrutural e externa ou funcional.

Quadro 2.2. Enunciados das leis sistêmicas de "produção" interna (d; $S$ ) e "entrada" externa de entropia $\left(d_{e} S\right)$, com suas respectivas condições de validade e mecanismos de manutenção. dS representa o saldo de entropia na relação do sistema com seu meio. Compilado de Bertalanffy (1950, 1960, 1972a), Hugget (1986) e Prigogine \& Stengers (1988).

\begin{tabular}{|c|c|c|c|c|}
\hline Enunciado & Equação & Lei & Validade & Manutenção \\
\hline 1 & $\begin{array}{c}\mathrm{de}_{\mathrm{e}} \mathrm{S}=0 \\
\mathrm{~d} S=\mathrm{d}_{\mathrm{i}} \mathrm{S}>0\end{array}$ & $\begin{array}{l}\text { Lei da produção } \\
\text { máxima de entropia } \\
\text { (Clausius 1865) }\end{array}$ & $\begin{array}{c}\text { Sistemas } \\
\text { fechados, } \\
\text { irreversiveis }\end{array}$ & $\begin{array}{c}\text { Ausência de trocas com } \\
\text { o meio (estado de } \\
\text { equilíbrio) }\end{array}$ \\
\hline 2 & $d S=d_{\theta} S+d_{j} S \sim 0$ & $\begin{array}{l}\text { Lei da produção } \\
\text { minima de entropia } \\
\text { (Prigogine 1947) }\end{array}$ & $\begin{array}{l}\text { Sistemas } \\
\text { abertos, com } \\
\text { desequilibrios } \\
\text { próximos do } \\
\text { equilibrio }\end{array}$ & $\begin{array}{l}\text { Retroalimentação } \\
\text { negativa ou "auto- } \\
\text { regulação" (estado } \\
\text { estacionário ou de } \\
\text { equilibrio dinâmico) }\end{array}$ \\
\hline 3 & $\begin{array}{c}d S=d_{e} S+d_{S} S<0 \\
d_{e} S \ll<00 \\
d_{i} S \gg>0\end{array}$ & $\begin{array}{l}\text { Principio da baixa } \\
\text { entropia em } \\
\text { sistemas } \\
\text { dissipativos } \\
\text { (Prigogine 1947) }\end{array}$ & $\begin{array}{c}\text { Sistemas } \\
\text { abertos, com } \\
\text { desequilibrios } \\
\text { distantes do } \\
\text { equilibrio }\end{array}$ & $\begin{array}{l}\text { Retroalimentação } \\
\text { positiva ou "auto- } \\
\text { organização" ("evolução } \\
\text { espontânea") }\end{array}$ \\
\hline 4 & $\begin{array}{c}d S=d_{e} S+d_{i} S \\
d_{e} S<=0 \\
d_{j} S>0\end{array}$ & $\begin{array}{l}\text { Lei geral dos } \\
\text { sistemas }\end{array}$ & Geral & \\
\hline
\end{tabular}

Nos métodos de abordagem da geologia sedimentar, a influência da "teoria de sistemas" fez-se sentir no conceito de complexo ou sistema deposicional (Figura 2.1), introduzido, sem definição formal, por Boyd \& Dyer (1964) e Hayes \& Scott (1964). A utilização mais elaborada do termo, dentre os trabalhos pioneiros, deve-se a Fisher \& McGowen (1967). A definição formulada por Galloway (1979), a partir deste trabalho, é a de "uma unidade estratigráfica física tridimensional geneticamente definida, consistindo de um conjunto contíguo de fácies sedimentares relacionadas por processos". Galloway (1979) deriva ainda da aplicação original do conceito três corolários: (1) sistemas deposicionais são os equivalentes estratigráficos de unidades fisiogeográficas maiores; (2) sistemas deposicionais formam os tijolos de construção essenciais no preenchimento de uma bacia sedimentar; (3) o conceito aplica-se com maior eficiência onde os limites entre sistemas estejam preservados e possam ser mapeados. De acordo com Chorley \& Kennedy (1971), todo sistema geocientífico caracteriza-se pela "operação conjunta de componentes como um todo complexo, de acordo com algum padrão observado". Na definição operacional de sistema deposicional abstraída de Fisher \& Mc Gowen (1967), este "padrão observado" corresponde a uma distribuição espacial de fácies elou associações de fácies (Giannini 1993). 


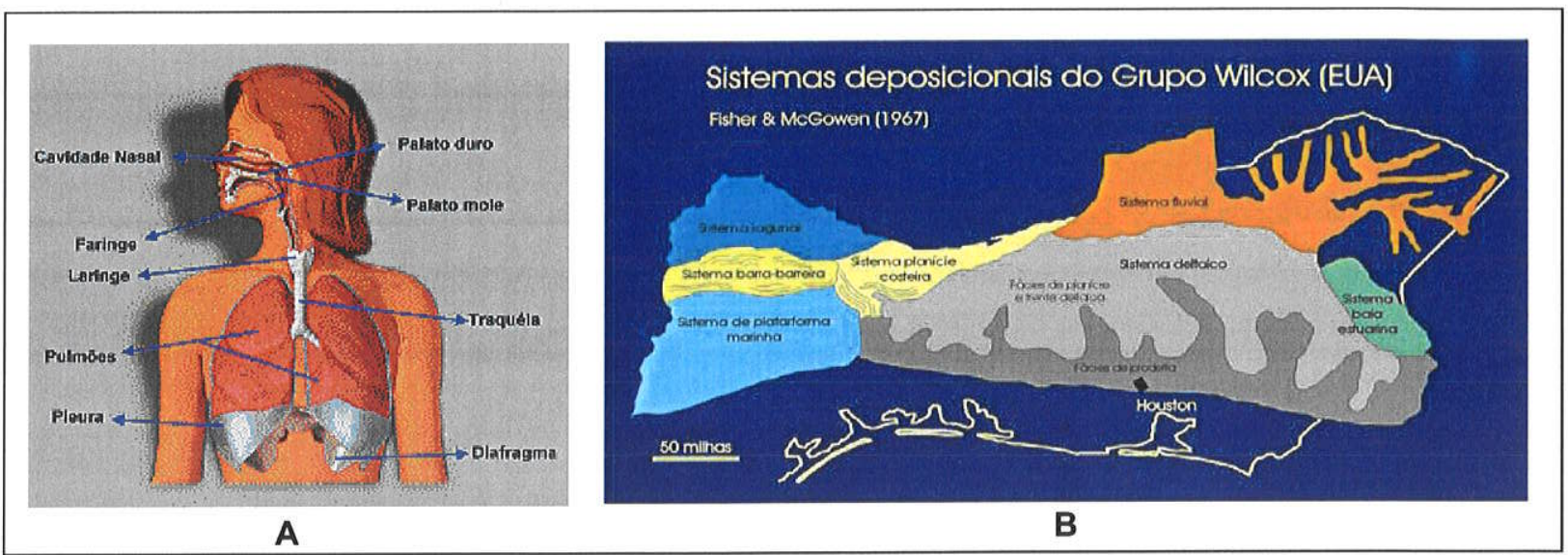

Figura 2.1. Exemplos de sistemas nas ciências biomédicas e nas geociências: A. Sistema respiratório. B. Mapa de sistemas deposicionais terciários do Grupo Wilcox na costa noroeste do golfo do México, apresentado no trabalho pioneiro de Fisher \& McGowen 1967 (desenho de A.O. Sawakuchi). Entre as características comuns aos dois tipos de sistemas ou suas associações, podem-se destacar a interação entre as partes, através de fluxos de matéria e energia, e a morfologia, constituição e posição definida de cada fácies, relacionadas a suas respectivas funções na dinâmica de trocas.

\subsection{Classificando sistemas}

A proposição de um método de descrição de sistemas deposicionais adequado à linguagem e abordagem da "teoria de sistemas" pressupõe saber de que tipo de sistema se trata. São três os critérios consagrados de classificação de sistemas: as relações com o meio, o nível de descrição e o grau de complexidade (Hugget 1985).

\subsubsection{Relações com o meio: sistemas abertos}

A classificação segundo as relações com o meio embasa a subdivisão clássica dos sistemas em abertos, isolados e fechados (Quadro 2.2). Os objetos de estudo das geociências encaixam-se na definição de sistemas abertos (Schumm 1979, 1991; Huggett 1985), isto é, aqueles capazes de manter-se em "estado estacionário" de "produção mínima de entropia", através do fluxo contínuo de energia e matéria com seu meio (Bertalanffy 1932 apud Bertalanffy 1950; Prigogine 1947 apud Huggett 1985). O conceito de "estado estacionário" refere-se a entropia invariável ao longo do tempo na relação sistema-meio (dS 0). A "produção de entropia" mede estritamente o efeito de processos irreversíveis dentro do sistema $\left(d_{i} S\right)$. No estado estacionário, esta produção é compensada pela "entrada de entropia" $\left(d_{e} S\right)$, de sinal negativo, referente às trocas com o meio externo. Em virtude destas trocas, o estado estacionário é também designado "equilíbrio dinâmico" (Prigogine \& Stengers 1988). Neste estado, o sistema consegue manter constância de forma, apesar de processos irreversíveis contínuos (Hugget 1985).

A descrição adequada de sistemas abertos em geociências pressupõe traduzir o conceito de entropia aos seus objetos de estudo. A analogia clássica da entropia com a idéia de desordem não deve ser adotada como regra universal, conforme demonstrado de diferentes modos por Tonnelat (1978), Atlan (1979) e Prigogine \& Stengers (1988). A imprecisão da comparação começa pela subjetividade das noções de ordem e desordem.

O significado exato da entropia depende da definição prévia da escala de análise (menor elemento constituinte) e de seu critério de avaliação (posição espacial, nível energético ou atributo físico ou químico de elemento constituinte). Na escala dos menores elementos constituintes dos depósitos clásticos, os grãos, e no critério físico de tamanho (granulometria) ou no critério químico de mineralogia, pode-se estender a interpretação 
estatística de Boltzmann (1872 apud Prigogine \& Stengers 1988) para a entropia termodinâmica ou atômico-molecular. Nesse sentido, a entropia mediria a incapacidade de as partículas de diferentes tamanhos ou composições migrarem em rumos preferenciais médios e, portanto, sua resistência à realização de trabalho. O estado de máxima entropia seria o de total homogeneidade ou eqüiprobabilidade (Atlan 1979), em que a probabilidade de se encontrar um grão de areia com dado tamanho ou mineralogia fosse a mesma em qualquer parte do depósito sedimentar. $O$ agente transportador de sedimentos, como o vento atuante sobre campos de dunas, exerceria o papel de entrada de entropia, capaz de gerar troca (nula ou negativa) com o depósito. Assim, o arranjo da granulometria segundo padrões de variação geográfica estatisticamente consistentes, em resposta ao transporte sedimentar, como no modelo de McLaren \& Bowles (1986), seria um efeito sobre o sistema de entrada de entropia negativa, na escala íntima de elemento constituinte.

Atlan (1979) defende a analogia formal entre o conceito de entropia e o de complexidade. Esta analogia seria independente de escala e abordagem e poderia portanto ser estendida à observação macroscópica de arranjos espaciais na prática da análise de sistemas deposicionais. Segundo o autor, a medida da complexidade pode ser definida sob três perspectivas distintas: 1. pela "variedade", função direta do número de elementos constitutivos; 2. pela "homogeneidade" destes elementos, no sentido estatístico de Boltzmann; e 3. pela ausência de "restriçōes internas" ("redundâncias" ou "especificidades" e "singularidades"). Restrições internas, neste sentido, seriam índices perceptíveis de nãohomogeneidade. As redundâncias ou especificidades consistem de arranjos repetitivos e regulares de elementos constitutivos, ou suas propriedades qualitativas, capazes de conferir simetria ao sistema (Atlan 1979, Dellatre 1981). As singularidades definem-se como situações relativas particulares de pelo menos uma parte das variáveis no espaço de estado (Tonnelat 1978, Delattre 1981). Estas situações levam a aumento da coerência ou conexão interna, de tal modo que cada elemento constituinte se torna hiper-sensivel a todas os outros (Prigogine \& Stengers 1988). O sistema instabilizado por hiper-sensibilidade conduz-se abruptamente à dissipação de energia livre não inteiramente correspondida por mudança recíproca em seu meio, até a chegada a novo estado estacionário (Bertalanffy 1972a). Esta dissipação de energia justifica a designação "estrutura dissipativa", introduzida por Prigogine (1947 apud Hugget 1985). Fala-se então em desequilíbrios muito distantes do equilíbrio (Quadro 2.2), onde deixa de ser válido o "princípio da mínima produção de entropia". Exemplo é a instabilização repentina da frente de uma duna eólica, com desencadeamento instantâneo de avalancha de areia ou fluxo granular (Giannini 1993), fenômeno que, em física, é tomado como modelo do comportamento denominado "criticalidade autoorganizada" (self-organized criticality: Bak et al. 1987, Bak 1997). Sistemas físicos com este comportamento caracterizam-se pela "complexidade" e pela evolução em pulsos, alternando períodos longos e monótonos com períodos curtos de grandes transformações, os quais se desenvolvem através da superação de estado ou tensão crítica e de processos em cadeia com dissipação concentrada de energia (Sawakuchi \& Giannini 2006).

As singularidades surgem sobretudo através da ação combinada de variáveis internas, inerentes à operação do sistema (Atlan 1979, Delattre 1981), incluindo aspectos constitutivos como granulometria, coesão, empacotamento e saturação em água, e manifestam-se nas variáveis externas, representadas pelas dimensões tempo-espaciais. Essa é a razão pela qual o processo dissipativo é também denominado "evolução espontânea".

No estudo de sistemas deposicionais, as restrições internas podem ser representadas como posições relativas preferenciais de uma fácies em relação a outra (Giannini 1993). Nesse sentido, a formação de arranjos de componentes sistêmicos, tais como padrões de configuração faciológica em um sistema deposicional, requer manutenção de "ordem" pelo sistema (Bertalanffy 1950), através de entrada de entropia negativa que caracteriza o equilibrio de fluxo ou estado estacionário (steady state). Por outro lado, 
mudanças episódicas de arranjo, incluindo aparecimento de novas fácies, podem representar o efeito de singularidades. Analogias conceituais e estudos de simulação têm permitido sugerir a extensão do conceito de criticalidade auto-organizada a sistemas deposicionais (Rothman et al. 1994, Ivanov 1996, Gomez et al. 2002), inclusive eólicos (Sawakuchi 2006).

\subsubsection{Grau de complexidade: o paradoxo da complexidade organizada}

"Tudo que existe existe em virtude da ordem" (Nicholas de Cusa)

O segundo critério de classificação de sistemas, atribuído a Weaver (1958 apud Huggett 1985) também permite reconhecer três tipos: simples, complexos desorganizados e complexos organizados. Esta classificação entretanto esbarra e perde parte de seu sentido na subjetividade do conceito de ordem ou organização. A aceitação mais ou menos consensual dos sistemas naturais abertos como complexos organizados baseia-se na idéia de que os elementos são muitos e suas relações muito fortes para que possam ser estudados isoladamente, mas estas relações possuem natureza supostamente ordenada (Bertalanffy 1972a, Hugget 1985). O problema é que, aceita a equivalência entre complexidade e entropia, estabelecida por Atlan (1979), e as conexões destes dois conceitos com a homogeneidade e a ausência de índices de ordenação, a idéia de complexidade organizada tem algo de paradoxal. Ou, nas palavras de Atlan (1979), passa a significar apenas a "desordem aparente onde haja razões para presumir uma ordem oculta".

A falta de conhecimento sobre esta "ordem oculta" reside exatamente na dificuldade de estudar com detalhe e profundidade as relações entre os componentes individuais, ainda que sua existência possa ser presumida de um arranjo espacial observado em escala mais abrangente. A evolução espontânea de sistemas que atingem singularidades, como no exemplo do conjunto de grãos de areia eólica no fluxo granular, é particularmente sugestiva da existência de ordem oculta, apesar de caos aparente. Esta sensação possui três razões: a primeira é que as singularidades são geradas por combinações de oscilações aleatórias de variáveis (no exemplo do fluxo granular, sutis variações de granulometria, umidade, empacotamento ou solicitações físicas, por exemplo, que se combinam para vencer a tensão crítica intergranular ou atrito interno), o que transmite idéia de caos e complexidade; a segunda razão é que a dissipação de energia durante a evolução espontânea do sistema dáse por mecanismos igualmente aleatórios e pouco conhecidos (no caso, as intensas interações de pressão dispersiva intergranular), o que reforça a noção anterior de caos e complexidade; a terceira é que estes mecanismos materializam-se em construções surpreendentemente estruturadas (línguas de areia com estruturas de gradação inversa, por exemplo; Bagnold 1941, Sallenger 1979, Collinson \& Thompson 1982, Giannini et al. 2007a), de onde se origina a idéia muito freqüente de "ordem a partir do acaso ou da desordem".

\subsubsection{Nível de descrição: processos e respostas}

De acordo com o terceiro critério classificatório, ou do nível de descrição, surgido na geografia física (Chorley \& Kennedy 1971, Terjung 1976, Strahler 1980), um sistema pode ser definido sob três modos diferentes: em termos de formas externas, em termos de processos (fluxos de energia e matéria) e em termos de relações entre processos e formas resultantes. O primeiro tipo, o sistema forma, pode ser exemplificado por uma duna eólica representada por variáveis pertinentes à sua geometria, como crista, face de avalancha (slipface) e flanco de barlavento, e à sua constituição, como propriedades texturais e mineralógicas ou relativas à cobertura vegetal (Giannini 1993). Este tipo de descrição é, na terminologia sistêmica, "estrutural", pois refere-se à distribuição espacial numa fatia de tempo pré-fixada. O segundo tipo, denominado sistema cascata ou sistema fluxo, consiste 
de uma série de linhas de fluxo de matéria e/ou energia unindo diferentes estoques. Os mecanismos de avalancha e de queda de grãos na frente de uma duna podem ser vistos como duas linhas de fluxo que transferem diferentes quantidades e granulações de areia e que dissipam diferentes níveis de energia dos estoques de crista e barlavento para os estoques de sotavento (Giannini 1993). Uma vez que processo implica lapso de tempo e variação, a construção deste tipo de modelo tem caráter mais dinâmico. $\mathrm{O}$ terceiro tipo de sistema recebe o nome de processo-resposta ou processo-forma. Trata-se de sistemas de fluxos de energia considerados em mútua interação com sistemas morfológicos, de tal modo que mudanças no primeiro alteram o segundo e vice-versa (Figura 2.2). Advém da integração entre as descrições interna e externa. O tratamento dos sistemas deposicionais através de modelos processo-resposta tem sido sugerido ou adotado por diversos autores (Krumbein \& Sloss 1963; Galloway 1979; Galloway \& Hobday 1983; Fritz \& Moore 1988), além de ter influenciado Walker (1976) em sua proposta de análise de fácies. É um tratamento "dinâmico-estrutural" ou morfodinâmico.

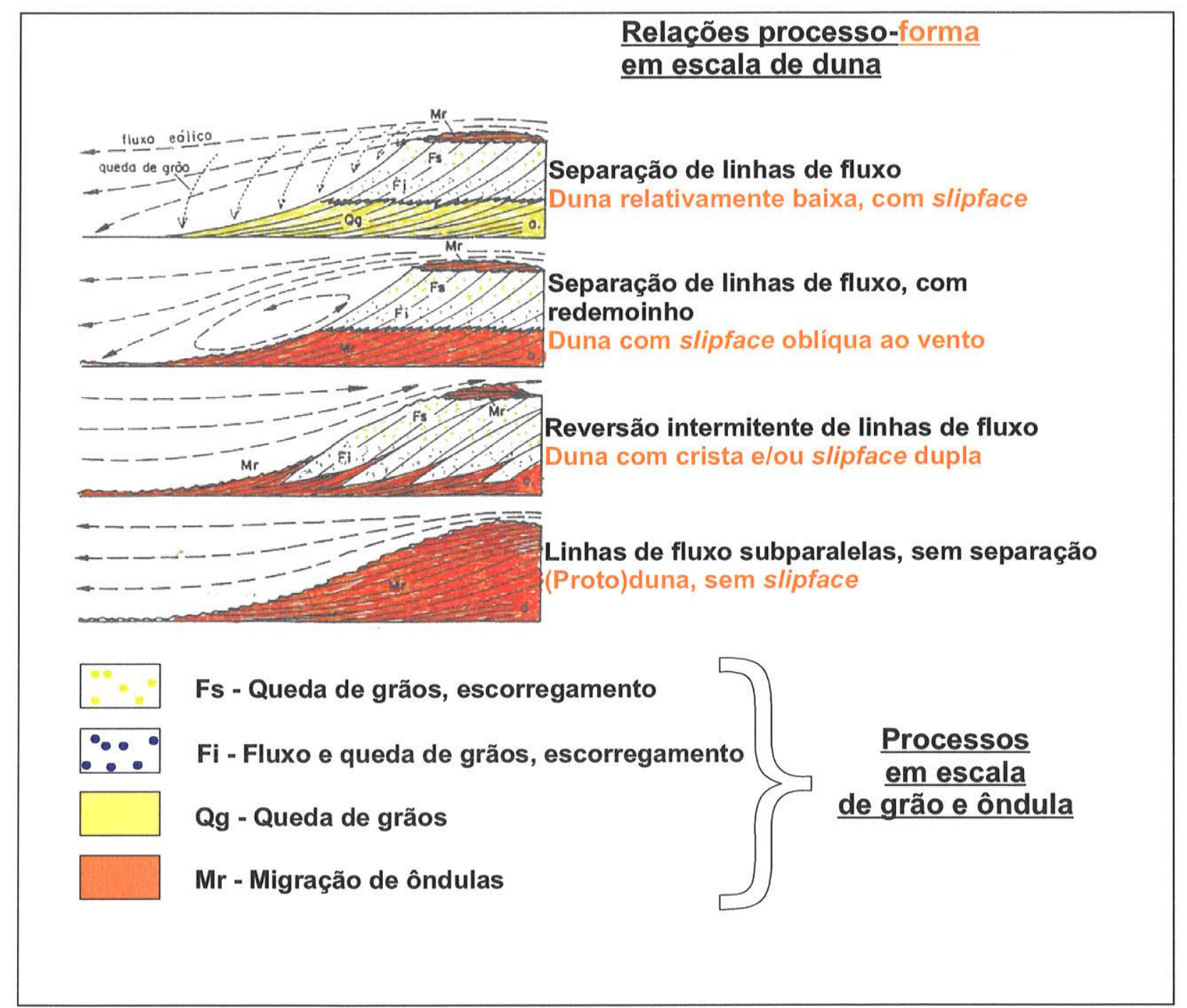

Figura 2.2. Exemplos de relações processo-resposta em escala de duna eólica, destacando sua influência na distribuição de processos mais básicos (em escala de grão ou ôndula). A cada processo em escala de grão corresponde também uma resposta morfológica e constitutiva específica. As respostas, consideradas tridimensionalmente e tanto nos seus aspectos geométricos como constitutivos, são produtos sedimentares ou fácies. Modificado de Hunter (1981) e Caetano-Chang (1997). 


\subsection{Os componentes}

"E como podemos imaginar uma face quando precisamos ir além de todas as faces, transcendendo todas as semelhanças, todas as formas de todas as faces, todos os conceitos de faces, todas as cores, todos os adornos...?" (Nicholas de Cusa)

\subsubsection{Fácies morfológicas e fácies deposicionais}

Na caracterização de sistemas deposicionais, os elementos básicos de descrição são as fácies, unidades sedimentares concretas, porém desconfinadas estratigraficamente (Walker 1976, 1992, Anderton 1985, Giannini 1993), delimitadas por mudanças de propriedades macroscópicas. Embora descritivas, as fácies assim definidas visam, em última análise, a interpretações de processos deposicionais. Pretendem-se portanto fácies deposicionais e não diagenéticas. Deste modo, interessam na sua caracterização sobretudo as propriedades que possam ter-se formado ou existido durante ou logo após a deposição (sindeposicionais e penecontemporâneas, respectivamente). As propriedades sedimentares passiveis de uso na análise de fácies dividem-se quanto ao critério de definição em geométricas, posicionais e de constituição. Entre as propriedades geométricas, incluem-se a geometria externa e a geometria interna (esta engloba petrotrama e estruturas sedimentares sindeposicionais, penecontemporâneas superficiais e eodiagenéticas). Os aspectos posicionais são representados pelas medidas de paleofluxo, tomadas a partir da orientação espacial de tramas e estruturas direcionais e azimutais. Os aspectos constitutivos incluem propriedades de grão, químicas (mineralógicas) e físicas (texturais), e o conteúdo fossilifero do depósito.

As estruturas sedimentares, sobretudo as sindeposicionais, integradas aos aspectos constitutivos, desempenham papel fundamental na interpretação de processos deposicionais. A razão é que estas estruturas resultam da migração e/ou superposição de formas de leito sedimentar, cujos processos e condições deposicionais são supostamente conhecidos a partir de exemplos atuais de campo e laboratório. Isto quer dizer que já se parte de certas relações processo-forma, como premissas. Assim, o procedimento mais usual de análise de fácies divide-se em duas etapas: primeiro, as estruturas sindeposicionais permitem traçar correlações com a morfologia do depósito (leito sedimentar ou frente da duna), ou seja, correlações produto-forma (por exemplo, lâmina lenticular com gradação inversa = língua de areia); em seguida, a partir destas correlações produto-forma e da assunção tácita da validade de correlações processo-forma (língua de areia = fluxo granular), traçam-se correlações produto-processo (lâmina lenticular com gradação inversa = fluxo granular).

Em exemplos quaternários, a morfologia do depósito pode estar ainda preservada e ser assim observada diretamente no campo. Um ingrediente adicional a ser considerado na aplicação do método de análise de fácies ao Quaternário é, portanto, a coexistência de fácies morfológicas, traçados através da observação direta de relações processo-forma, e fácies morfo-deposicionais, baseadas na descrição de elos forma-produto (incluindo atributos como texturas e estruturas sedimentares). Através da integração "em tempo real" destes dois tipos de fácies, é possivel chegar, com segurança relativamente maior que no procedimento usual, às fácies deposicionais clássicas e suas relações processo-produto (Figura 2.3). Desse modo, o raciocínio envolvido na análise de fácies pode ter três, em vez de apenas duas etapas. 


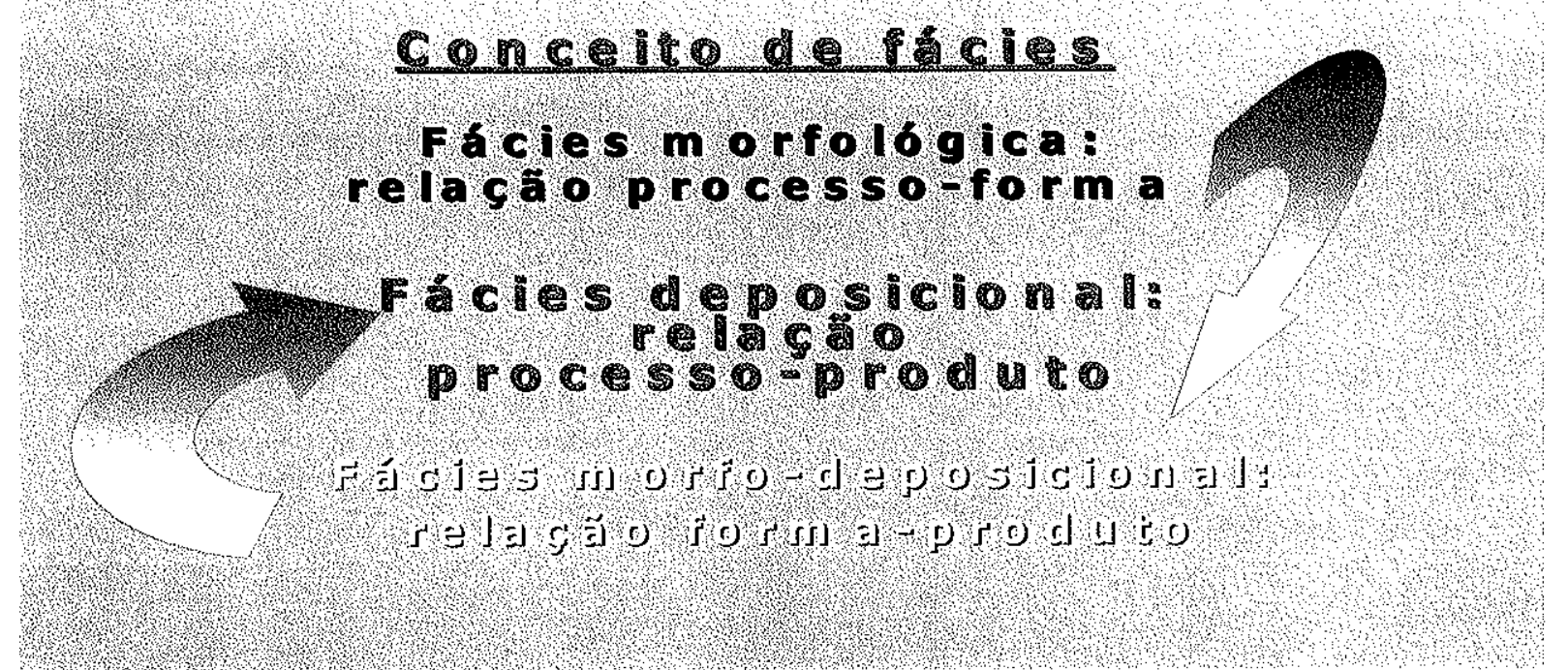

Figura 2.3. Possibilidade de desdobramento tripartite do conceito de fácies no estudo de depósitos sedimentares recentes.

\subsubsection{Elementos morfológicos e elementos deposicionais (arquitetônicos): associações de} fácies

O conceito de fácies é versátil quanto à escala. Suas dimensões, respeitado o requisito de distinção por critérios mesoscópicos, variam de acordo com o grau de detalhamento adotado na análise de fácies. Do ponto de vista genético, as menores fácies possíveis de um depósito sedimentar devem expressar os processos deposicionais mais básicos e específicos da dinâmica e construção do sistema, como são, no caso eólico, a queda de grãos, o fluxo de grãos, a migração de marcas onduladas e o carpete de tração. Uma mesma megaforma de leito sedimentar, como uma duna, pode experimentar intensa e complexa alternância de vários desses processos específicos durante sua atividade. O modo pelo qual estes processos específicos atuam e interagem pode ser característico de cada tipo de megaforma. Assim, diferentes geometrias de dunas podem distinguir-se entre si pela importância relativa e distribuição tempo-espacial de processos ou fácies específicas, que é o que se entende por associações de fácies. Assim como as fácies, as associações de fácies possuem expressão morfológica, a macroforma neste exemplo, e deposicional, o corpo sedimentar tridimensional deixado no registro estratigráfico. Assim como as fácies, as associações de fácies são versáteis na escala, podendo abarcar deste a microforma de leito individual (algumas vezes de uma fácies só) até o sistema deposicional inteiro. O requisito básico é que cada associação possua expressão tempo-espacial em sua escala, seja portanto fisicamente separável das demais por meio de limites físicos. No registro estratigráfico, estes limites têm sido designados "superfícies de separação" (Brookfield 1977, Kocurek 1981, Allen 1983) e o litossoma assim delimitado, "unidade ou elemento arquitetônico" (Allen 1983, Miall 1985, 1988, 1994, 1996, 1999). A cada unidade ou elemento arquitetônico de construção de um depósito sedimentar, registro estratigráfico do sistema, corresponde uma unidade ou elemento morfológico, presente na dinâmica deste sistema quando ativo.

Embora os elementos arquitetônicos possuam uma extensa hierarquia de escalas baseada na abrangência tempo-espacial, a meta final da análise arquitetônica de afloramentos que abranjam mais de uma escala é "o reconhecimento e definição de 
macroformas" (Miall 1999, p.199). Os elementos que podem ser considerados unidades deposicionais fundamentais (storeys) por excelência, são portanto, segundo Miall (1999), os que envolvem o registro de macroformas individuais ou agrupadas (dunas e draas, por exemplo), delimitadas por superfícies de separação de quarta ou quinta ordem na classificação desse autor.

A "definição de uma macroforma", a partir do registro estratigráfico, é um processo em parte interpretativo, especialmente no caso de macroformas cuja dinâmica não é ainda bem conhecida com base em exemplos modernos (Miall 1999). Por outro lado, esta interpretação esbarra em dificuldades relativas a um problema de escala de análise.

\subsection{3. "Problemas de escala" na análise de fácies}

O uso de sistemas deposicionais quaternários como modelos análogos para a interpretação de sistemas deposicionais mais antigos permanece estratégia de trabalho fundamental da sedimentologia e da estratigrafia, desde os primórdios da concepção atualista. Este estudo analógico não pode ser feito, entretanto, sem que se leve em conta o efeito da escala tempo-espacial na análise de fácies deposicionais (Sawakuchi 2006; Sawakuchi \& Giannini 2006). Assim, pelo menos duas questões ou princípios metodológicos devem balizar o uso de modelos análogos baseados em sistemas deposicionais recentes. $O$ primeiro princípio, demonstrado por Sadler (1981), estabelece que a ocorrência de intervalos de não deposição ou erosão, durante a evolução de um depósito ou sistema deposicional, é diretamente proporcional ao intervalo de tempo considerado. A conseqüência mais direta deste efeito é que a taxa de sedimentação aumenta com a diminuição do intervalo de tempo utilizado para calculá-la (Sadler 1981), o que foi apelidado por Korvin (1992) de "paradoxo da taxa de sedimentação". Dada a relação de proporcionalidade entre as escalas de tempo e espaço no registro sedimentar (Giannini 1993), este efeito possui correlações no aspecto da magnitude espacial da deposição. Isto permite enunciar o que seria o segundo princípio metodológico relevante no uso de análogos modernos como modelos de fácies: o registro de eventos deposicionais de grande magnitude é limitado pelo volume de sedimentos disponíveis no sistema e, por extensão, pelas dimensões do próprio sistema. Como diferentes tipos de processos deposicionais, e portanto diferentes fácies, possuem periodicidades e taxas de sedimentação distintas, sistemas do mesmo tipo, porém de tamanhos diversos, podem apresentar diferenças na constituição, representatividade e variabilidade das fácies (Sawakuchi 2006, Sawakuchi \& Giannini 2006). Outro corolário deste princípio é o de que a taxa de sedimentação é um conceito relativo não apenas no tempo como no espaço. Significa que taxas de sedimentação idênticas, atuando no preenchimento de espaços volumetricamente distintos, podem gerar padrões de acumulação também completamente distintos.

Quadro 2.3. Questões de escala na análise de fácies e algumas de suas possiveis implicações no estudo de sistemas eólicos costeiros no Quaternário.

\begin{tabular}{|c|c|c|}
\hline Questão de escala & Enunciado resumido & Exemplos de implicação \\
\hline sedimentação & $\begin{array}{c}\text { A taxa de sedimentação } \\
\text { aumenta com a redução do } \\
\text { intervalo de tempo }\end{array}$ & $\begin{array}{c}\text { Exacerbação da taxa de } \\
\text { acúmulo emigração nas } \\
\text { gerações de dunas mais novas }\end{array}$ \\
\hline Limitação pelo volume & $\begin{array}{c}\text { O registro deposicional depende } \\
\text { do volume sedimentar do } \\
\text { sistema }\end{array}$ & $\begin{array}{c}\text { Diferenças de fácies, ou de seu } \\
\text { arranjo, entre sistemas com } \\
\text { aportes distintos }\end{array}$ \\
\hline Limitação pelo espaço & $\begin{array}{c}\text { O registro deposicional depende } \\
\text { do espaço disponivel para } \\
\text { acumulação }\end{array}$ & $\begin{array}{c}\text { Diferenças de fácies, ou de seu } \\
\text { arranjo, entre sistemas com } \\
\text { espaços disponiveis distintos }\end{array}$ \\
\hline
\end{tabular}




\subsection{Descrevendo sistemas}

"A mente manifesta-se em uma progressão de fluxo natural em quatro vias" (Nicholas de Cusa)

O primeiro requisito para uma descrição sistêmica, em determinado compartimento da ciência, é a padronização de uma linguagem compatível. No aspecto semântico, dispõese de uma linguagem sistêmica potencialmente aplicável a todas as modalidades da ciência, a qual entretanto deve ser submetida a análise conceitual (sintática) cada vez em que for transferida a qualquer uma destas modalidades (Delattre 1981). Dentro deste tipo de análise conceitual, aplicado à geologia sedimentar do Quaternário, um método de descrição de sistemas deposicionais foi previamente proposto (Giannini 1993). Aqui, procura-se aprimorar esse método no sentido de torná-lo mais fiel às etapas da "teoria geral de sistemas" de Bertalanffy (1972a) e, ao mesmo tempo, compatível com os procedimentos de análise de sistemas deposicionais e de fácies que se têm demonstrado mais eficientes (Galloway 1979, Anderton 1985), inclusive no Quaternário costeiro (Cowell \& Thom 1994).

Nesta Tese, propõe-se dividir a análise de sistemas deposicionais em quatro etapas, correspondentes duas a duas a dois ciclos sucessivos de descrição, interna e externa (sensu Bertalanffy 1972a), aplicados em escalas de abrangência decrescente (Figura 2.4). Assim, as duas etapas do primeiro ciclo aplicam-se ao conjunto sistema-meio, enquanto as do segundo visam especificamente ao sistema em foco. Segundo Bertalanffy (1972a), a descrição interna consiste no reconhecimento dos componentes e das variáveis de que o sistema depende, ou variáveis de estado. Ela é, portanto, segundo o autor, essencialmente estrutural. Enquanto isso, a descrição externa descreve a operação do sistema em termos de entradas, saídas e retroalimentações. Possui caráter sobretudo funcional (Bertalanffy 1972a).

Idealmente, a sucessão entre descrição interna e externa não deve ser vista como seqüência estanque de etapas, mas como uma ordenação de comandos em uma rotina de algoritmo, a ser repetida indefinidamente. Este princípio é compatível com o procedimento adotado em análise de fácies, segundo o qual as fácies só devem ser finalmente estabelecidas (formalizadas ou compiladas) após o conhecimento devido de suas associações e interações mútuas (Walker 1976, Anderton 1985, Giannini 1993).

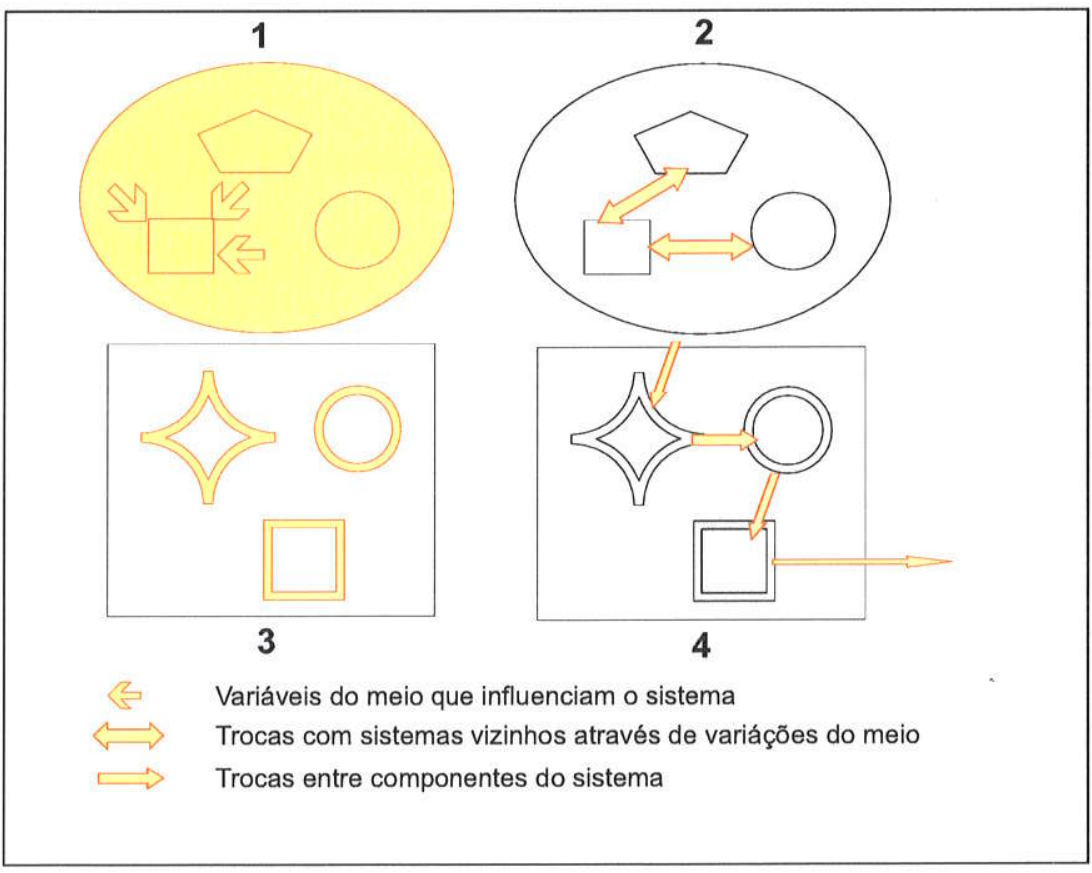

Figura 2.4. Representação esquemática das quatro fases de análise de um sistema deposicional: 1. Exame prévio ou delimitação sistema-meio. 2. Descrição externa das relações sistema-meio. 3. Descrição interna ou estrutural do sistema. 4. Descrição externa ou funcional do sistema. As cores indicam os objetos de interesse principal de cada fase. 


\subsubsection{Exame prévio ou das condições espaciais de contorno: o macroambiente}

"A divindade é o envolvimento e a manifestação de tudo que existe" (Nicholas de Cusa)

O exame prévio visa situar um sistema deposicional de dada escala no seu meio ou macroambiente, isto é, no sistema de hierarquia superior ou espaço que o envolva (Giannini 1993). Ele abrange o reconhecimento preliminar dos sistemas de mesma hierarquia e das variáveis do macroambiente na escala de tempo adotada, e consiste assim numa fase de delimitação de fronteiras espaciais, e mesmo temporais. Nesta etapa, deriva-se do todo em direção às partes, procedimento em essência analítico, onde a escala das partes encontrase pré-determinada na escala do sistema de interesse. Ela pressupõe o estabelecimento de demarcação entre sistemas e meio. O critério básico para esta demarcação é o estético (Dooge 1968), ou de máxima simplificação, cuja condição mais importante é a de que a ação do sistema sobre o meio pode depender tanto de variáveis internas (do sistema) como externas (do meio), mas o sistema não é capaz de modificar os fatores do meio aos quais ele é sensivel (Delattre 1981).

O exame prévio pressupõe saber quais variáveis do macroambiente influenciam significativamente as características do sistema, especialmente suas entradas e saídas, e em que tempo de atuação. Requer portanto a formulação ou adoção implícita de um modelo conceitual de variáveis do macroambiente, ainda que o modo como se dá a influência de cada variável só vá ser abordado na etapa de descrição externa seguinte. Uma vez preparado este modelo, as variáveis macroambientais do sistema específico em questão (neste caso, sistema deposicional) devem ser dimensionadas.

A formulação de um modelo conceitual compõe sempre o primeiro passo de qualquer abordagem sistêmica. Ela está presente, por isso, em todas as etapas de descrição aqui propostas. Aliás, o objetivo desta Tese é, sobretudo, a construção de um modelo conceitual de sistemas eólicos costeiros, com base principalmente em exemplos brasileiros. O modelo conceitual corresponde à imagem mental de determinado fenômeno ou objeto da natureza (Krumbein \& Graybill 1965), em que se procura destacar os traços essenciais e omitir os detalhes supostamente acidentais (Hugget 1985). Como todo primeiro passo, não é trivial, tampouco irrelevante, muito pelo contrário (Cowell \& Thom 1994). GESAMP 1991 (apud Coweel \& Thom 1994) enfatiza que modelos conceituais com pouca ou nenhuma parametrização, porém baseados em conhecimento preestabelecido de processos, podem ser mais úteis que modelos preditivos quantitativos em que os processos tenham recebido pouca atenção.

\subsubsection{Condições funcionais de contorno: entradas e saídas}

"Volto para o divino, com envolvimento e manifestação. Voltando, entro e saio da divindade. Quando a encontro, como o poder que se manifesta, saio. Quando a encontro, como o poder que envolve, entro.

Quando a encontro, como o poder que envolve e se manifesta, entro e saio ao mesmo tempo." (Nicholas de Cusa)

No método da "teoria de sistemas", a descrição externa do sistema deposicional em mútua relação com seus sistemas vizinhos e com o macroambiente deve preceder a descrição interna de cada sistema deposicional. O controle exercido sobre a interação entre os sistemas por variáveis do macroambiente previamente selecionadas deve ser detalhado e integrado. A descrição das condições funcionais de contorno é portanto uma etapa de sintese em escala espacial maior, cujo objetivo principal é determinar o padrão de operação 
do sistema e sua função em relação à operação geral de seu meio (Bertalanffy 1972a), através das relações entre entrada (input) e saída (output) de matéria e energia, denominadas canais de transferência ou comunicação. A comunicação pode ser definida como o intercâmbio de matéria e energia com o meio (Bertalanffy 1972a).

A exemplo do estudo do macroambiente, a descrição externa pressupõe construir ou adotar um modelo conceitual, neste caso um modelo de controle de volume do sistema (entradas e saídas) por variáveis externas.

\subsubsection{Descrição interna ou análise estrutural do sistema}

A descrição interna do sistema em foco pressupõe o conhecimento tão minucioso quanto possível de seus componentes, no caso as fácies eólicas. Assim, o objetivo mais elementar da descrição interna é a determinação dos arranjos espaciais de fácies que caracterizam cada sistema deposicional e que na semântica sistêmica correspondem a "estruturas" ou "padrões" (Bertalanffy 1950, 1972a; Delattre 1981; Gregory 1985). Este caráter "estrutural" da descrição interna torna-a, em primeira instância, uma produção de modelos de formas. Neste contexto, torna-se de essencial importância o conceito de associações de fácies: conjuntos de fácies vizinhas que formem arranjos preferenciais e que tenham posições relativas também preferenciais dentro do sistema.

\subsubsection{Descrição externa ou morfodinâmica do sistema}

De acordo com o princípio geral da "teoria de sistemas", a divisão em partes componentes só tem sentido, ou só se completa, quando estas partes são devidamente situadas dentro da operação do sistema. Deste modo, a descrição interna do sistema, morfológica ou "estrutural", deve passar à externa, de caráter dinâmico e funcional (Bertalanffy 1972a). Na prática da descrição de sistemas deposicionais, é imprescindível a integração mútua entre "estruturas" e a operação do sistema e, portanto, as conjecturas sobre sua evolução no tempo (Gregory 1985), que caracterizam a abordagem como modelo processo-forma ou processo-resposta (Fritz \& Moore 1988, Fichter 1988).

Da interação entre aspectos morfológicos e dinâmicos na descrição interna de sistemas, deriva o conceito de morfodinâmica. Uma definição para morfodinâmica no contexto costeiro pode ser encontrada em Wright \& Thom (1977): "o ajuste mútuo entre topografia e dinâmica de fundo, através do transporte sedimentar". No contexto de sistemas eólicos quaternários, a definição, modificada de Martinho (2004), é a de morfologia e dimensões das feições eólicas (fácies morfológicas) e sua distribuição tempo-espacial em vista do equilíbrio dinâmico do sistema.

\subsubsection{Conceitos e propriedades fundamentais dos processos morfodinâmicos}

Na morfodinâmica de sistemas, são de fundamental importância os conceitos de perturbação e retroalimentação. A perturbação é a flutuação nas variáveis de estado capaz de afastar temporariamente o sistema de seu estado de equilíbrio. A retroalimentação é o mecanismo pelo qual o sistema, uma vez perturbado, retoma seu estado de equilíbrio (retroalimentação sensu stricto ou negativa) ou evolui espontaneamente para novo estado estacionário (retroalimentação positiva). A retroalimentação negativa é o processo de troca controlada de entropia com o meio, pelo qual o sistema se mantém em constante equilíbrio de fluxo. A analogia clássica do princípio de funcionamento deste mecanismo é a do termostato (Bertalanffy 1950, 1965). Trata-se de um controle de função do sistema em relação a seu meio (Bertalanffy 1972a). Bertalanffy (1960) destaca a possibilidade de descoberta de leis de construção-destruição ou de morfologia dinâmica, baseadas na 
premissa de reversibilidade e manutenção do equilíbrio de fluxo. Leis utilizadas para explicar a manutenção de perfis de equilibrio costeiro submetido a variações limitadas do regime de ondas ou do nível do mar, como é o caso do princípio de Dean (1987), poderiam ser aí incluídas (Giannini 1993, Cowell \& Thom 1994).

No contexto da análise da evolução costeira, Cowell \& Thom (1994) listam sete propriedades essenciais dos processos morfodinâmicos: a auto-regulação, a autoorganização, a heterogeneidade, a não-linearidade, a herança markoviana, a nãoestacionaridade e a histerese. Com exceção da heterogeneidade e da histerese, o fenômeno da retroalimentação encontra-se, segundo os autores, na raiz de todas estas propriedades. Auto-regulação e auto-organização são efeitos ou capacidades inerentes à retroalimentação negativa e positiva, respectivamente. Heterogeneidade é a propriedade pela qual os processos se distribuem com intensidade e qualidade variável ao largo do sistema. Nãolinearidade diz respeito à trajetória interrompida que o sistema percorre em seu espaço de estado, quando existem interações fortes entre as variáveis (Bertallanfy 1968). Herança markoviana é a propriedade pela qual o estado estacionário imediatamente anterior, numa evolução morfodinâmica, constitui uma das variáveis a influir no estado estacionário seguinte (Cowell \& Thom 1994). Não-estacionaridade é a propriedade que descreve o sistema como dependente do tempo, isto é, suas mudanças não são totalmente aleatórias, mas cumulativas (Cowell \& Thom 1994). Relacionada a esta dependência, encontra-se a histerese, que é a variação de resposta do sistema a oscilações iniciais, à medida que novas oscilações se superimpõem. A histerese é um efeito de filtragem ligado ao caráter finito do tempo requerido para a resposta morfodinâmica: um atraso irreversível, um obstáculo ao alcance de estados estacionários.

As respostas morfológicas a perturbações são dadas por acréscimos ou retiradas de sedimentos. Admitida como constante a taxa de acréscimo ou retirada, e portanto a taxa de transporte, o tempo necessário para que a resposta morfodinâmica seja completa, e o equilíbrio alcançado, é o quociente entre o volume sedimentar da resposta morfológica e a taxa de transporte. Este tempo recebe o nome de tempo de relaxamento. O tempo de relaxamento é uma grandeza dependente de escala: para dada taxa de transporte, quanto maior o volume envolvido na resposta morfológica, maior é o tempo necessário para a aquisição do equilíbrio. Uma conseqüência disso é que a resposta morfológica é proporcionalmente tão mais demorada quanto maior o volume do depósito sedimentar envolvido. A rigor, o tempo de relaxamento é uma grandeza apenas teórica, pois a taxa de transporte não é constante, mas diminui gradualmente com o tempo, à medida que se aproxima do estado de equilíbrio. Se esta redução for expressa como um decaimento exponencial, então o período para manifestação da resposta morfológica do sistema à perturbação pode ser caracterizado por uma constante de tempo, similar a meia-vida (Cowell \& Thom 1994).

Esta constante de tempo corresponde à razão entre estocagem e dissipação de energia pelo sistema após a perturbação (Bennett \& Chorley 1978 apud Cowell \& Thom 1994) e, portanto, a uma medida direta da capacidade do sistema em filtrar a perturbação (Brunsden \& Thornes 1979 apud Cowell \& Thom 1994). Seu recíproco é a sensitividade, cuja quantificação se pode fazer também através do quociente entre tempo médio de recorrência do evento perturbador e tempo médio de resposta (Brunsden \& Thornes 1979 apud Gregory 1985).

Um dos fatores complicantes na análise do tempo de resposta é a existência do atraso ou defasagem (time lag: Hugget 1985, Cowell \& Thom 1994), efeito pelo qual a resposta morfológica é afetada por novas oscilações nas condições de contorno. $O$ atraso nada mais é que a manifestação da histerese no tempo de resposta.

A dependência do tempo e a histerese tornam a evolução costeira dirigida por uma tensão de desequilíbrio. A conseqüência é que o atraso permite apenas parte da resposta morfológica em direção ao equilíbrio transitivo (Chappell 1983 apud Cowell \& Thom). O 
tempo é maior que o período de manutenção das condições de contorno, o equilíbrio não se desenvolve plenamente, e um "equilíbrio potencial", "estado ótimo" ou "atrator" passa a existir a cada instante (Cowell \& Thom 1994).

\subsubsection{Estabilidade morfodinâmica}

O arcabouço conceitual da análise morfodinâmica de sistemas completa-se com os tipos de estabilidade e a superação de limiares, onde se situa o conceito de retroalimentação positiva ou evolução espontânea. A estabilidade, dada pelo comportamento do sistema diante de perturbações, permite a classificação dinâmica dos sistemas em neutros, estáveis, instáveis e metaestáveis (Figura 2.5).

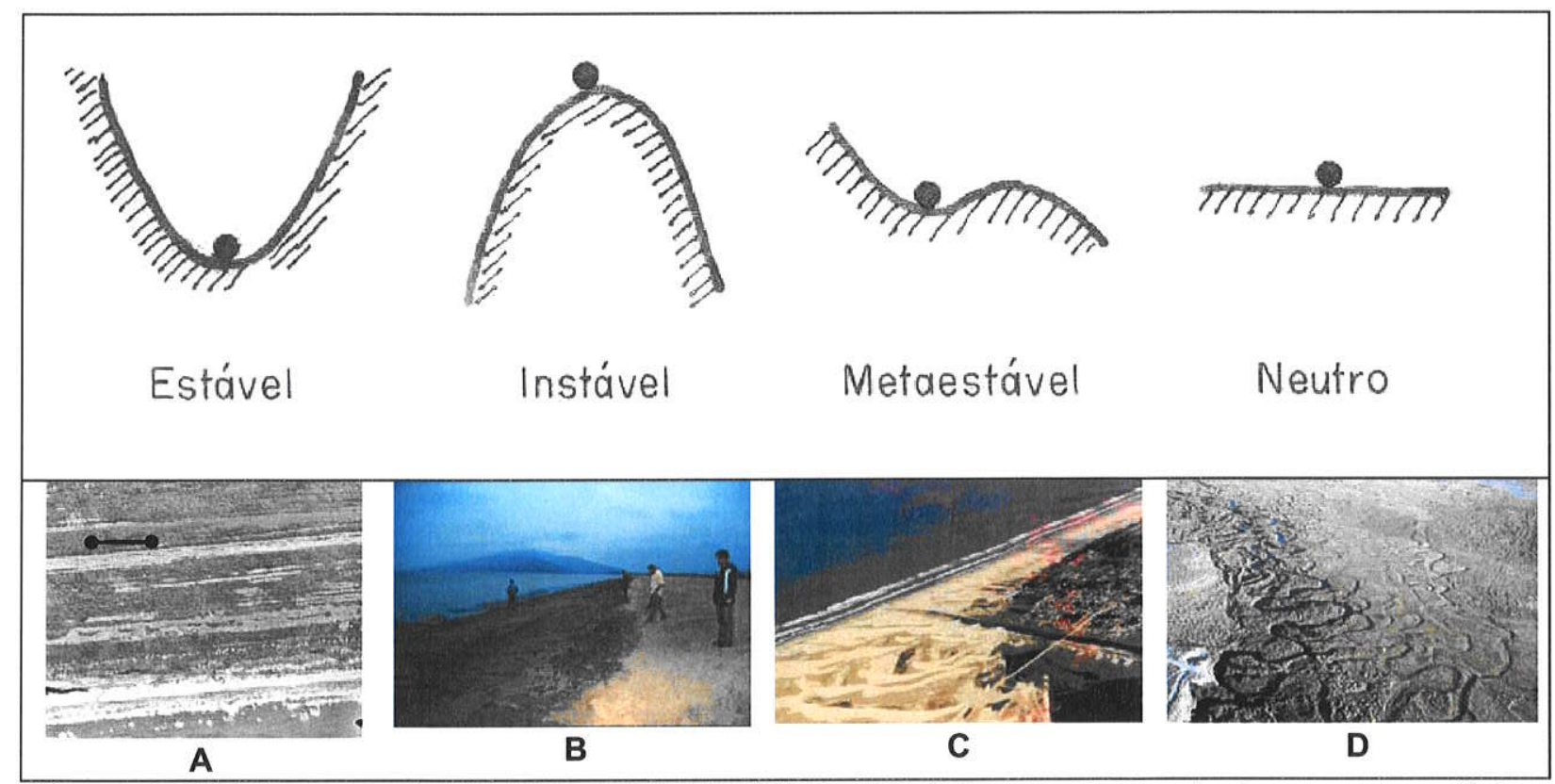

Figura 2.5. Representação dos tipos de estabilidade de sistemas, por analogia com a mecânica clássica (segundo Huggett 1985), e de seus respectivos exemplos geológicos. A. Planície progradante na parte centro-sul da llha Comprida, SP (escala: 100m). B. Chenier com intraclastos de lama na praia de Tijucas, SC. C. Desembocadura lagunar do Camacho, Jaguaruna, SC, que alterna fases de abertura e fechamento (Foto-Bacha, Laguna, 1999). D. Planície fluvial meandrante do rio Owens, Califórnia, EUA (Foto: Alain Glaizner). A classificação depende da escala de observação. Um sistema metastável, dentro de certos limites, pode comportar-se como instável ou estável.

O sistema neutro é aquele em que a perturbação altera apenas sua posição em relação a um referencial externo, mas não sua estrutura (forma, dimensões e posição interna das fácies), como exemplificado pela migração lateral de meandros (Thornes 1983 apud Huggett 1985), em sistemas fluviais cuja energia seja pouco variável. O sistema estável tende a manter suas variáveis restritas a um intervalo de valores médios. É exemplificado por uma planície costeira cujo espaçamento entre alinhamentos de cristas praiais oscile ligeiramente em torno de um valor modal (Huggett 1985). O sistema instável mantém-se enquanto não houver alterações intensas no meio; quando isto acontece, suas próprias variáveis internas assumem valores distintos ao extremo. É um caso raro, representado por sistemas autofágicos (Thornes 1983 apud Huggett 1985), por exemplo, uma planície de maré lamosa em baía protegida, que, ao ser submetida excepcionalmente à ação de ondas, transforma-se em praia cascalhosa de intraclastos de lama. O sistema metaestável mantém- 
se enquanto as flutuações ocorrerem dentro de certos limites; uma vez ultrapassados estes limites, tal sistema passa a dissipar energia de modo irreversível, rumo a estados estacionários geralmente de menor entropia, o que caracteriza a evolução espontânea. Sistemas muito afastados do equilíbrio têm sua sensibilidade aguçada e tornam-se suscetiveis a fatores que, perto do equilíbrio, seriam negligenciáveis (Prigogine \& Stengers 1988).

Existem exemplos de sistemas metaestáveis que podem ser submetidos a sucessivas mudanças de configuração e a sucessivos estados estacionários, cada qual correspondendo a condições relativamente estreitas de variáveis de estado. Tais exemplos são especialmente comuns entre os fenômenos relacionados com fluxo de fluidos e com processos de erosão, transporte e deposição (Hugget 1985). Podem-se citar, entre os primeiros, as séries de formas de leito originadas sob fluxo unidirecional em função de variações no número de Froude e na granulometria (diagrama-modelo de regime de fluxo) e, entre os últimos, a sucessão de padrões morfodinâmicos de praias arenosas (Giannini 1993, Cowell \& Thom 1994), ilustrada na Figura 2.6.

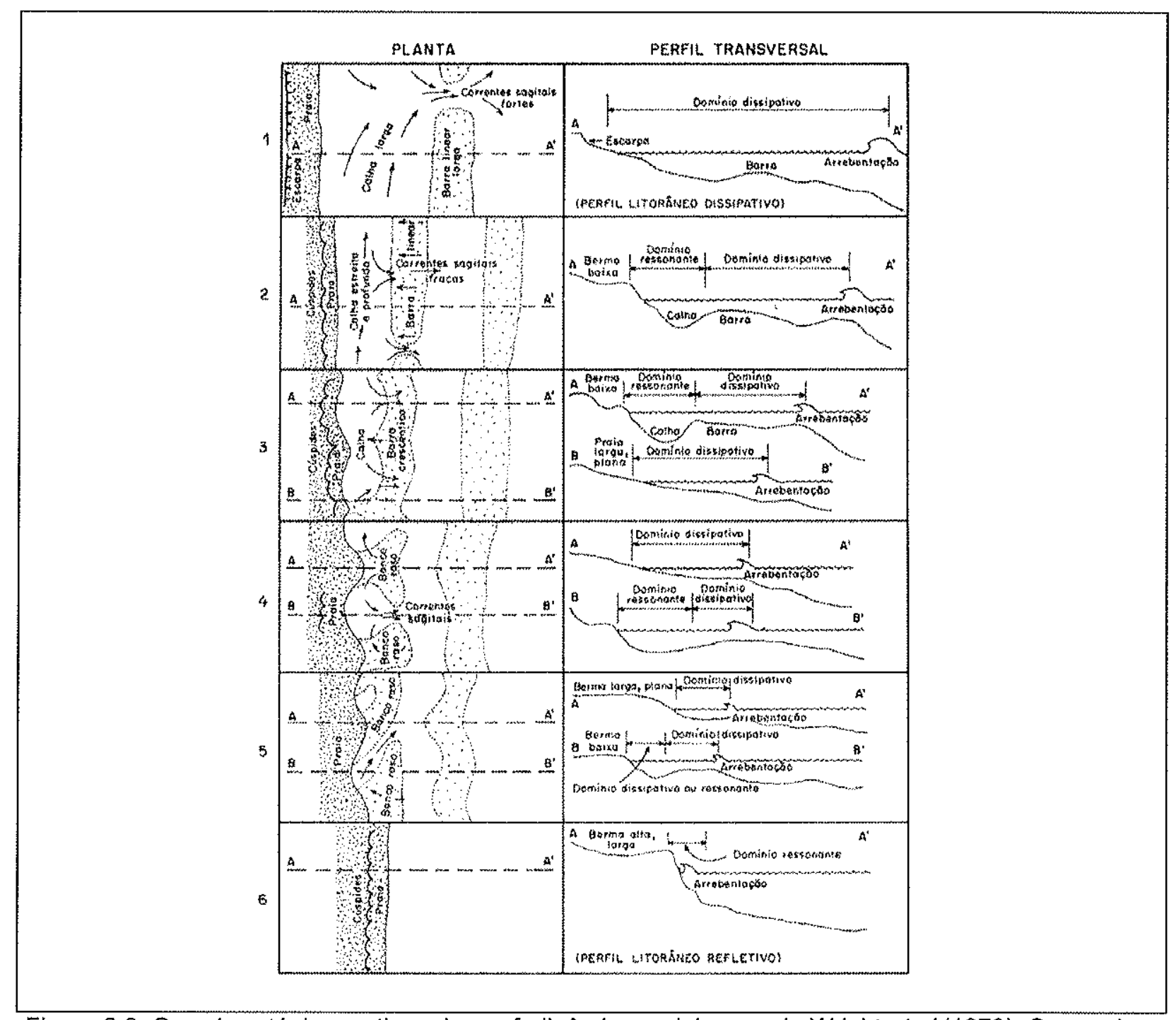

Figura 2.6. Os seis estágios ou tipos de morfodinâmica praial segundo Wright et al.(1979). Os quadros 1 a 6 representam um ciclo de acreção praial completo. 
Nos sistemas metaestáveis, o fenômeno da retroalimentação negativa só é possível dentro de certos limites de oscilação das variáveis de estado. Tais limites, limiares (thresholds) ou singularidades denotam descontinuidades no espaço de estado. Uma vez rompido o limiar, através de oscilação de variáveis, e decorrido certo tempo de atraso, o sistema adquire novo estado estacionário dentro do qual a retroalimentação negativa se torna novamente possivel.

Os estados existentes nos lados opostos de um limiar podem ou não coexistir sob as mesmas condições de contorno. Fala-se então em limiares transitivos e intransitivos, respectivamente (Huggett 1985). Limiares transitivos associam-se a perturbações fortes nas condições de contorno. Já os limiares intransitivos relacionam-se com oscilações em variáveis internas do sistema e ocorrem quando uma ou mais variáveis no espaço de estado são não lineares (Chappell 1983 apud Huggett 1985). Deste modo, correspondem respectivamente aos limiares extrínsecos e intrínsecos de Schumm (1979 apud Gregory 1985).

Exemplo de limiar transitivo ou extrínsico em geologia sedimentar encontra-se na coexistência de depósitos continentais relícticos afogados com depósitos marinhos produzidos após subida rápida de nível relativo do mar.A existência de limiares intransitivos significa que o estado estacionário a ser atingido através da dissipação não é único: o sistema deve "optar" por um dentre dois ou mais novos regimes de equilíbrio. Esta "opção" é - que se chama de bifurcação, e seus princípios teóricos encontram-se na "teoria das catástrofes" de Thom (1972). Num espaço de estado tridimensional, a superfície representativa do limiar pode aparecer, por exemplo, como a parte do meio de uma folha dobrada (Figura 2.7), cada superfície contínua de dobra acima ou abaixo do limiar constituindo um tipo de alternativa. A maioria dos limiares intransitivos e bifurcações estudados em geologia, como os exemplos de Chapell (1978 apud Huggett 1985) e Giannini (1993), aqui reproduzidos, ocorre entre erosão e deposição, com duas variáveis de estado quaisquer combinando-se não linearmente para gerar ou intervir numa terceira variável. No exemplo da figura 2.7A, energia de onda e nível freático combinam-se para criar efeitos episódicos de fluidificação de areia (opção erosiva) ou acreção de barras litorâneas (opção deposicional). Na figura 2.7B, taxa de subida de NRM (ou energia de onda) e granulometria combinam-se para acionar a troca sedimentar episódica entre praia e face litorânea e para tornar a praia abruptamente mais dissipativa (opção erosiva) ou reflexiva (opção deposicional).

Bifurcações diferentes podem suceder-se na evolução de um sistema tanto quanto estados estacionários diferentes. Esta sucessão e o caráter estocástico das condições limiares, somados à não linearidade das variáveis que as determinam e à inclusão do estado estacionário anterior entre estas variáveis, introduz no desenvolvimento do sistema uma dimensão histórica não determinística (Prigogine 1980, Cowell \& Thom 1994). No estudo da evolução morfodinâmica de sistemas costeiros, esta dimensão histórica materializa-se em comportamento "dependente ou sensível a condições iniciais" (Philips 1992) e em "caráter cumulativo, impredizivel e irreversivel", onde saídas morfológicas incluem-se entre as entradas de um novo ciclo (Cowell \& Thom 1994). Este comportamento faz com que a sucessão de estados morfodinâmicos seja influenciada pela herança markoviana da morfologia antecedente: o sistema é dependente de seu próprio passado (Cowell \& Thom 1994). 


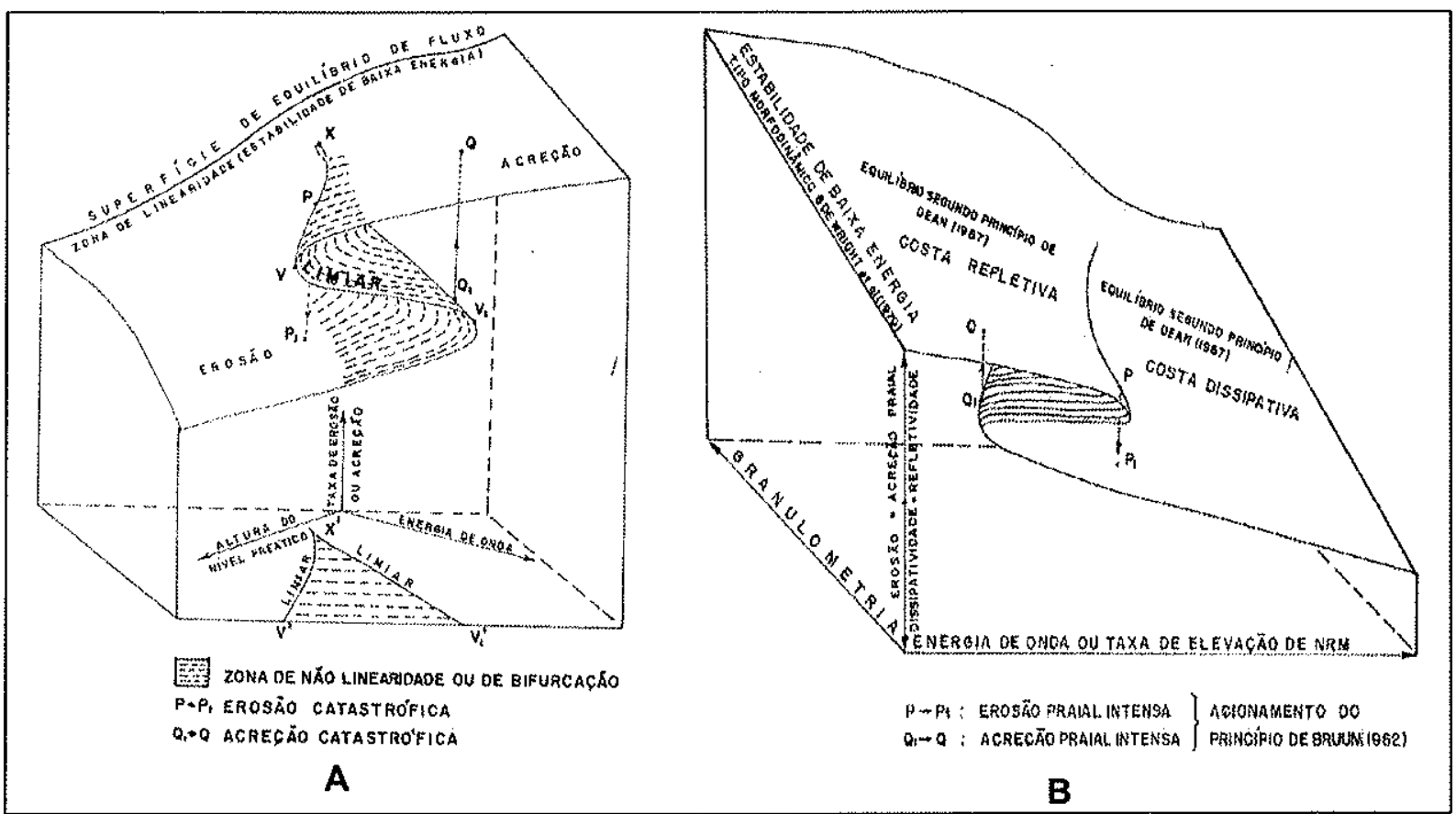

Figura 2.7. Representações "cúspide-catástrofe" da combinação não linear entre variáveis. A. Energia de onda e nível freático controlando a produção de erosão versus acreção praial (segundo Chappell 1978 apud Huggett 1985). B. Granulometria e energia de onda ou taxa de elevação de NRM controlando a produção de morfodinâmicas praiais erosivas versus acrecionares (segundo Giannini 1993). Em B, o mecanismo de Dean representa a simples migração dos estoques em acompanhamento à subida de NRM, com tendência para manutenção da morfodinâmica. 


\section{Descrevendo sistemas eólicos costeiros quaternários do Brasil}

\subsection{Do todo às partes - exame prévio}

\subsubsection{Delimitando o sistema eólico}

\subsubsection{Tipos maiores de depósitos}

Ao examinar-se ao longo da costa brasileira a variação das feições eólicas ativas, o aspecto que mais sobressai como critério de classificação é a influência morfodinâmica direta da cobertura vegetal. Em algumas áreas, como no litoral paulista e paranaense, dominam as feições com influência da vegetação. Em outras, como na maior parte da costa do Ceará e do Rio Grande do Sul, tornam-se dominantes as feições sem cobertura vegetal significativa, mais impressionantes em termos de extensão e volume de areia. A presença ou não de vegetação tem sido de fato freqüentemente adotada como critério maior de classificação de depósitos eólicos no Brasil (Tomazelli 1990, 1994, Claudino Sales 2002, Martinho 2004, Giannini et al. 2005, Martinho et al. 2007).

Entre as feições com vegetação, destacam-se as dunas frontais (foredunes) incipientes e estabelecidas e as rupturas de deflação (blowouts) que, quando alongadas, transformamse em dunas parabólicas com rastros lineares residuais ou trailing ridges (para discussão da definição destes e outros termos relativos a feições eólicas, ver item 3.3.1).

Dentro da categoria dos depósitos eólicos sem vegetação, as feições morfológicas maiores são os campos de dunas livres (dunefields), grandes massas individuais de areias em movimento, constituídas de dunas eólicas simples e/ou compostas, cavalgantes ou coalescentes, em contexto costeiro ou não (Giannini et al. 2005). No caso costeiro, os campos de dunas livres migram via de regra da praia rumo ao interior, recebendo por isso a designação específica de campos de dunas transgressivos (transgressive dunefields), termo introduzido por Gardner (1955) que, cabe ressaltar, não implica necessariamente linha de costa transgressiva (Giannini 1993; Angulo \& Giannini 1994).

Os campos de dunas livres da costa brasileira sempre possuem uma ou mais dentre as seguintes feições: cordões de precipitação (precipitation ridges), dunas de orientação transversal ao vento efetivo, com crista linear (dunas transversais sensu stricto), em meia-lua (barcanas) ou sinuosa (barcanas lateralmente coalescidas ou cadeias barcanóides), e frentes ou lobos deposicionais parabólicos longitudinais ao vento.

Campos de dunas livres são formas de leito eólicas com geometria e dinâmica própria, formadas por superposição e/ou fusão de dunas. Atendem dessa forma à definição de draa (Wilson 1972, Kocurek 1981, 1996, Lancaster 1988) ou macroforma eólica (Jackson 1975). Dependem, como os draas em geral, de condições de suprimento duradouro e espaço disponivel para acumulação dos sedimentos e pressupõem o entulhamento progressivo das superficies interdunas.

Em áreas de relação mais elevada entre energia eólica e suprimento ou de trânsito rápido de sedimentos, lençóis de areia (sand sheets) podem desenvolver-se no lugar de campos de dunas livres. O termo lençóis de areia, já utilizado por Bagnold (1941), refere-se aqui a massas de areia eólica em movimento, com superfície de relevo negligenciável, isto é, sem superimposição de dunas com faces de avalancha (Kocurek \& Nielson 1986). Na costa brasileira, existem exemplos descritos junto à foz do rio São Francisco (Barbosa 1997), na praia de Ibiraqüera, em Santa Catarina (Martinho 2004) e na costa norte do Rio Grande do Sul (Tomazelli 1990). 


\subsubsection{Distribuição geográfica}

Os principais trechos de costa com ocorrência de campos de dunas livres no Brasil são o norte-nordeste, entre o litoral centro-leste do Maranhão (região dos Lençóis Maranhenses) e o sul do Rio Grande do Norte, o de Sergipe-Alagoas nas vizinhanças da desembocadura do rio São Francisco, o do Rio de Janeiro na região de Cabo Frio e a costa meridional, entre a ilha de Santa Catarina e o extremo sudeste do Estado do Rio Grande do Sul (Figura 3.1). Nas demais áreas costeiras do país, o tipo de depósito eólico ativo predominante é o com vegetação, principalmente dunas frontais e lobos de ruptura de deflação (blowouts). É importante ressaltar que a ocorrência de formas eólicas ativas com cobertura vegetal não exclui a possibilidade de dunas livres, e vice-versa. Nos setores costeiros com campos de dunas transgressivos, as feições eólicas com vegetação comumente encontram-se presentes.

Na costa com orientação geral E-W do Nordeste do Brasil, a leste de São Luiz (MA), o trecho entre Formosa (Cruz) e Porto do Barco (Itarema), no Ceará, é a única região com predomínio extensivo de dunas frontais. A sul, as dunas frontais só voltam a destacar-se como principal depósito eólico costeiro nos estados de Pernambuco e Paraíba. Exemplos com diferentes graus de preservação podem ser vistos na praia de Boa Viagem, em Recife, PE, e no litoral sul pernambucano, em Serrambi e Muro Alto (Porto de Galinhas). No litoral sul de Alagoas, entre Pontal do Peba e Ponta do Miaí (Coruripe), as dunas frontais atingem 5 $m$ de altura (Giannini et al. 2005). Em alguns trechos do litoral sergipano, como Pirambu Porto de Sergipe (Pirambu) e Caueira-Saco (Estância), e da costa norte da Bahia, como Mangue Seco (Jandaíra) - Barra do Itapicuru (Sítio do Conde), Porto do Sauípe - Barra do Forte (Praia do Forte) e Arembebe-Salvador (incluindo Itapuã), dunas frontais altas (até $7 \mathrm{~m}$ ) associam-se ao interior a rupturas de deflação e dunas parabólicas. Localmente, a presença de cordões de precipitação permite caracterizar estágio transicional para pequenos campos de dunas transgressivos. No litoral sul baiano, os depósitos tornam-se menos desenvolvidos.

Em São Paulo, a pouca expressão atual de dunas costeiras ativas deve-se a dois fatores: o caráter reflexivo de muitas de suas praias, especialmente no litoral norte, e a intensa urbanização da orla, sobretudo a partir da década de 1960. Por estas razões, os melhores exemplos de dunas costeiras do estado encontram-se atualmente nas praias mais preservadas do litoral sul, com destaque para Una, Juréia e llha Comprida (Bentz 2004). Nestas praias, é comum a presença de dunas frontais com mais de $2 \mathrm{~m}$ de altura. As poucas publicações existentes sobre dunas costeiras em São Paulo anteriores a 1960 deixam pistas sobre a ampla distribuição original destas feições. Assim, Freitas $(1951 a, b)$ descreve "dunas embrionárias" no Guarujá e na Praia Grande e Hueck (1955) faz referência ao mesmo tipo de duna desde Ubatuba até Cananéia, com maior abundância no litoral sul do estado. Ainda segundo Hueck (1955), "dunas móveis" ocorreriam apenas localmente, como resultado de desestabilização pela ocupação antrópica, com destaque para dunas de até $3 \mathrm{~m}$ de altura em Peruibe, hoje inexistentes. O único exemplo de dunas livres hoje conhecido no estado é o do nordeste da ilha Comprida, junto a Icapara, com migração para NNW (Giannini et al. 2003a, 2007b, Guedes 2003, Nascimento et al. 2005). 


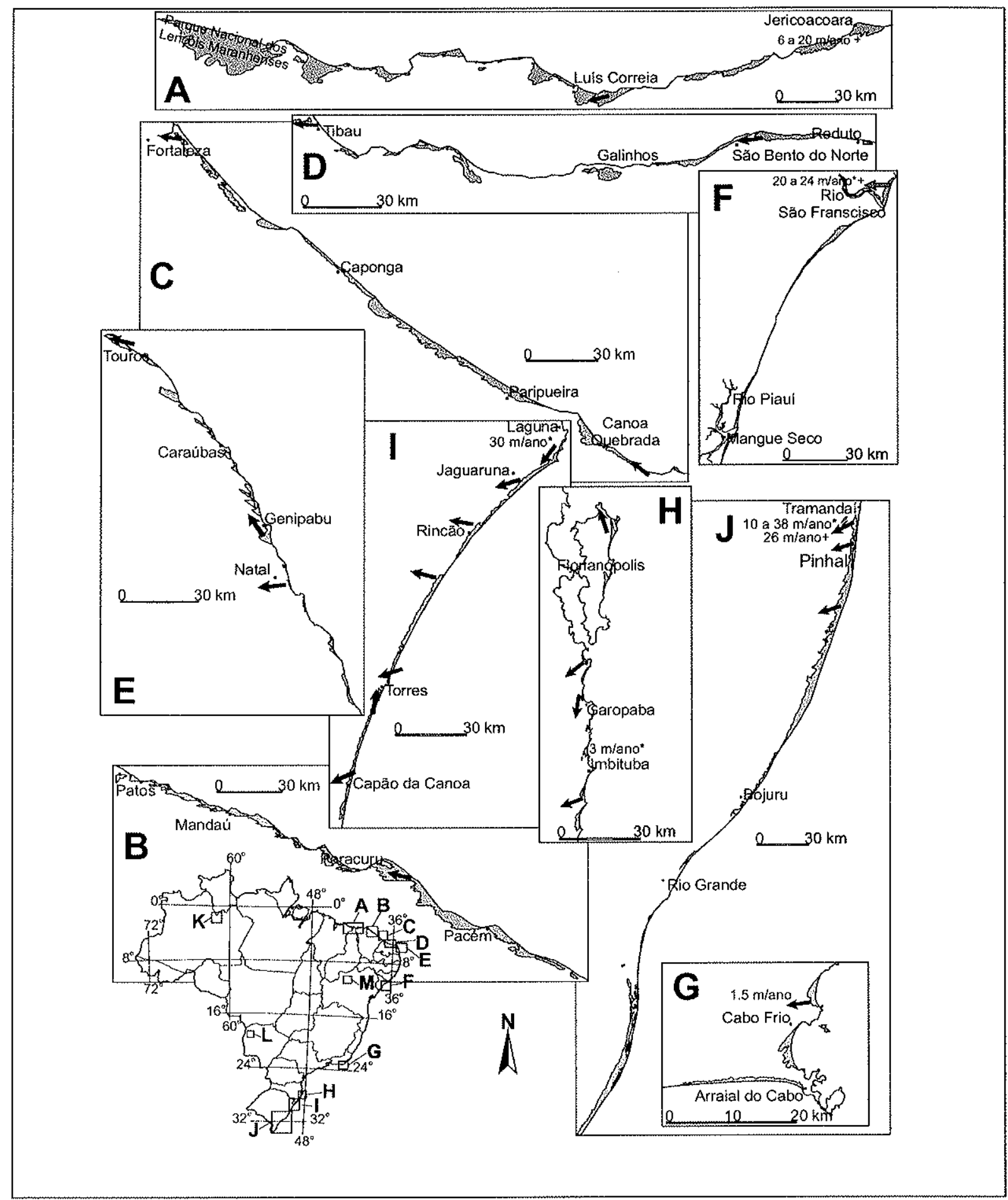

Figura 3.1. Distribuição dos principais campos de dunas transgressivos ativos (em cinza) e campos de dunas interiores estabilizados (áreas K, L e M) do Brasil, segundo Giannini et al. (2005). As setas pretas indicam rumos de migração de dunas, obtidos através de medidas de estratificações cruzadas (Bigarella, 1970/1971). A seta branca (área F) refere-se a rumo observado por Barbosa (1997). Velocidades de migração de dunas baseiam-se em medida direta no terreno $(+)$ ou comparação entre fotografias aéreas (*), realizadas por Maia (1998), Jimenez et al. (1999) e Carvalho (2002), no Ceará, Barbosa (1997), em Sergipe/Bahia, Castro et al. (2002), no Rio de Janeiro, Giannini (1993), em Santa Catarina, e Tomazelli $(1990,1993)$, no Rio Grande do Sul. 
No litoral do Paraná, Bigarella et al. (1969) relataram a existência de cordões de dunas (um a "mais de dois"), muitos já destruídos pelo homem naquela época. No Jardim São Pedro, adjacente à praia do Leste, Bigarella et al. (1969) e McKee \& Bigarella (1972) fizeram menção a um cordão dunar ondulado, de 5 a $10 \mathrm{~m}$ de altura, retido por uma linha de vegetação e por isso designado "duna de retenção". Este cordão foi caracterizado pelos autores como um empilhamento de areia contra a vegetação, normal ao vento. A descontinuidade e sinuosidade das cristas de cordão foram atribuídas a interrupções por rupturas de deflação aproximadamente ortogonais, com "línguas de areia" (lobos deposicionais) à retaguarda. A distribuição de azimutes de mergulho das estratificações cruzadas confirmam a ação de ventos de SE e E, originados, segundo os autores, da migração de celas de anticiclones no avanço de massa de ar Polar, atuantes principalmente no inverno.

\subsubsection{Distribuição no tempo}

Paleodunas, também designadas dunas fixas ou inativas, têm sido referidas em associação à maioria dos campos de dunas transgressivos brasileiros. Estas referências apresentam-se sumariadas a seguir, de norte para sul.

\section{Regiōes Norte e Nordeste}

No Piaui, Lehugeur (1995) descreve um campo de paleodunas próximo à praia, sem vegetação, entre as localidades de Luiz Correia e Coqueiro, cuja fixação é atribuída a capeamento arenoso escuro, de até $50 \mathrm{~cm}$ de espessura, com conchas inteiras e fragmentadas de gastrópodos. Nos Lençóis Maranhenses, Gonçalves et al. (2002) classificam os depósitos eólicos em quatro compartimentos: um de dunas livres atuais (descrito em Gonçalves, 1995), um de "superfícies de truncamento eólico" e dois de dunas fixas transversais e parabólicas.

No Ceará, Claudino Sales (2002) refere-se a "campos de dunas fixas" ao longo de toda a extensão costeira, constituídos de depósitos sem formas definidas, estabilizados por florestas, e de paleodunas parabólicas. Nos setores central e oeste da costa desse estado, parte das paleodunas corresponde a eolianitos, depósitos eólicos cimentados por carbonato de cálcio (Maia 1998). A presença deste tipo de depósito exclusivamente nestes setores associa-se à disponibilidade local de carbonatos na praia e plataforma continental adjacente, provavelmente mobilizados durante episódios transgressivos quaternários (Maia et al. 1999). Na descrição de Carvalho et al. (1994), a deflação atuante sobre os eolianitos cria morfologia ruineforme do tipo yardang (termo introduzido por Hedin 1903-1905 apud Pye \& Tsoar 1990 para referir-se a calhas entre cristas alongadas, paralelas ao vento, esculpidas por deflação em depósito sedimentar consolidado; do turcomano yar, depressão íngreme). Na costa oriental do Ceará, os yardangs cederiam espaço aos rebdous (sensu Guilcher \& Joy 1954 apud Pye \& Tsoar 1990, e Joly 1997), formas de escala métrica criadas em torno de vegetação costeira arbórea de pequeno porte, as quais representam por vezes vestígios de formas longitudinais e dunas parabólicas destruídas pela deflação (Claudino Sales \& Peulvast 2001).

Nos últimos anos, a evolução do conhecimento sobre os depósitos eólicos do Ceará tem permitido várias tentativas de classificação em diferentes gerações de dunas. Dentre outros, Maia (1998) propôs quatro gerações. Posteriormente, Claudino Sales \& Peulvast (2001), Claudino Sales (2002) e Carvalho (2002) identificaram cinco gerações, sendo as duas últimas ainda em atividade (dunas ativas com idades distintas de iniciação). De qualquer modo, a questão das gerações de dunas no Quaternário do Ceará permanece em aberto, dada a escassez de dados de datação absoluta. 
A subdivisão das dunas livres cearenses em duas gerações, denominadas "dunas D1" e "dunas D2" (Claudino Sales 2002), baseia-se na premissa adotada por Maia (1998) e Claudino Sales \& Peulvast (2002), de que a zona de separação física entre estes conjuntos de dunas ativas representa interrupção na iniciação de campos de dunas. A partir da relação entre a velocidade de migração das dunas atuais e sua distância em relação à costa, Claudino Sales (2002) estimou a época desta interrupção como entre 0,3 e 0,4 ka AP, intervalo que compreenderia assim a idade máxima de iniciação das "dunas D1". As "dunas D2", também ainda ativas, com área de ocorrência típica na célula sedimentar BarrinhaJericoacoara-Guriú (Figura 3.2), teriam sido iniciadas entre 0,3/0,4 ka e 1,2 ka. Por raciocínio análogo ao utilizado para D1, a idade máxima da geração D2 foi calculada com base na velocidade de migração destas dunas nesta área (até 10m/ano) e na distância entre Barrinha (área fonte imediata das dunas) e Guriú (local de chegada), da ordem de $12 \mathrm{~km}$, incluindo sua completa passagem através da ponta de Jericoacoara (Claudino Sales 2002). Os campos de dunas ativos mais interiores que se encontram nos demais setores da costa cearense teriam, segundo a autora, a mesma idade D2. As estimativas de idade de D1 e D2 utilizam de modo implícito a premissa de velocidade de migração constante. Desconsideram portanto a proporcionalidade inversa entre velocidade de migração e extensão da duna na direção do vento, sugerida empiricamente por Finkel (1959) e analiticamente, do ponto de vista da física teórica, por Kroy et al. (2002). Levada em conta esta proporcionalidade, bem como o fato de que estas dunas tiveram dimensões menores durante sua iniciação, as idades estimadas por Claudino Sales (2002) podem ser consideradas como valores máximos.

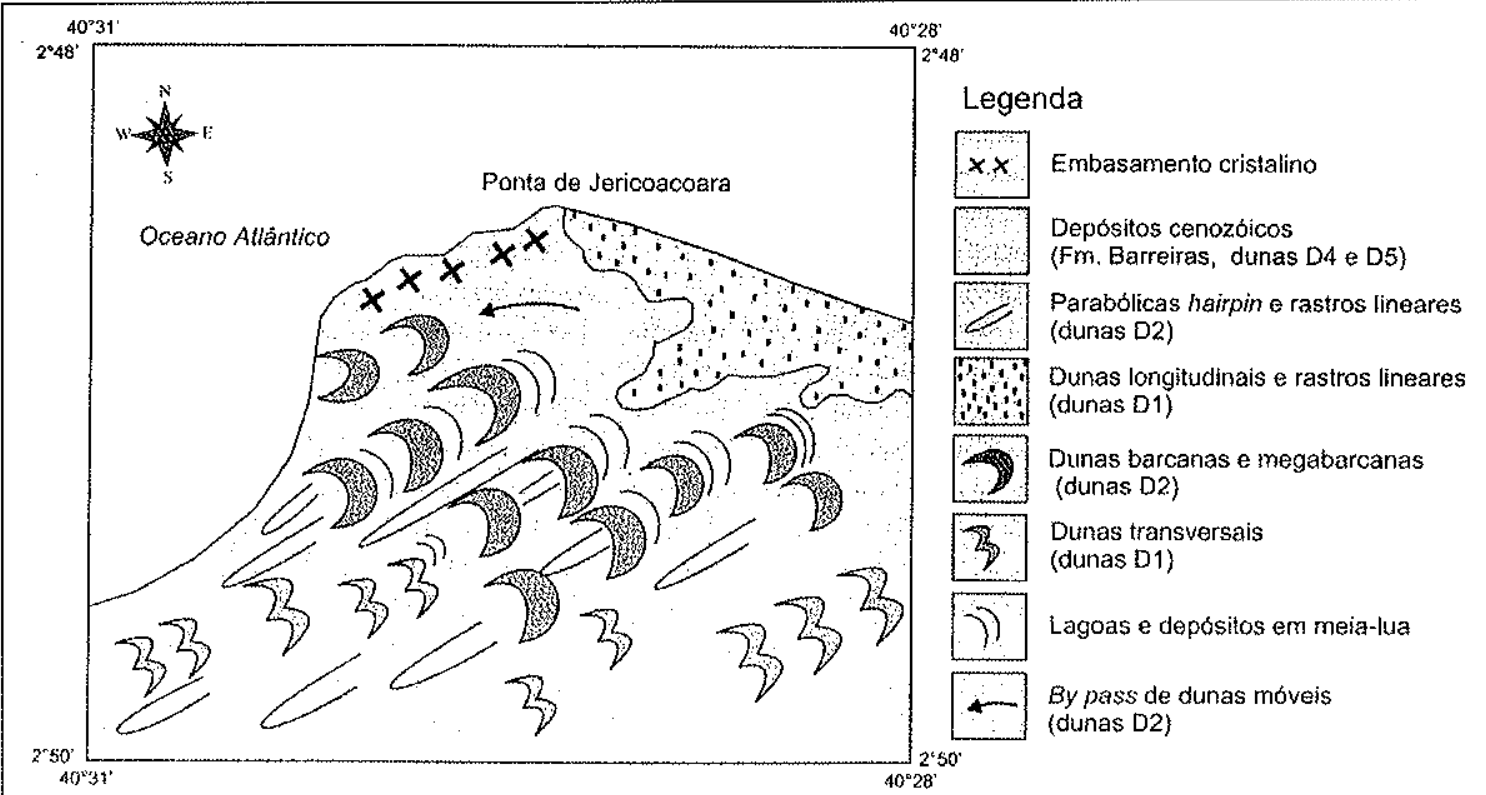

Figura 3.2. Distribuição e morfologia das gerações de dunas D1 (mais nova) a D5 (mais antiga) na célula sedimentar eólica Barrinha / Jericoacoara / Guriú, CE. As dunas D2, ativas de "idade subatual", realizam a passagem através da ponta litorânea, migrando para $S W$ até $12 \mathrm{~km}$ a sotavento, onde já aterraram a laguna e o manguezal de retaguarda de flecha litorânea, antes existente em Guriú. Extraido de Claudino-Sales \& Peulvast (2002).

As gerações de dunas atribuidas à segunda metade do Holoceno, hoje fixadas, foram denominadas "dunas D3" (Claudino Sales 2002). O intervalo temporal desta geração seria entre o Holoceno Médio e 1,2 ka. Deste modo, a autora faz coincidir o limite temporal inferior 
das "dunas D3" com a idade máxima estimada das "dunas D2", assim como com a idade de 1,2 ka obtida por termoluminescência (TL) em paleoduna parabólica (hairpin) situada em Pecém (Maia et al. 1999). Além de formas parabólicas como essa, as "dunas D3" incluiriam os campos de dunas fixos sem formas definidas e os eolianitos.

As dunas formadas durante ou imediatamente após a transgressão holocênica receberam a denominação de "dunas D4". Grande parte dessas dunas acha-se coberta pelas mais recentes. Em outros locais, elas representam campos de dunas descontínuos vegetados, que em Icapuí se estendem até $40 \mathrm{~km}$ ao interior (Claudino Sales \& Peulvast 2001,2002 ). As dunas mais antigas que o inicio da transgressão holocênica, denominadas "dunas D5", representariam todas as acumulações cuja identificação individual ainda não foi feita, e estariam sustentando falésias de abrasão marinha inativas em diversos setores litorâneos.

$\mathrm{Na}$ costa potiguar, as dunas inativas são mais evidentes na faixa que se estende de Touros até o limite com a Paraíba e distribuem-se desde a linha de praia atual (nas regiões de maior erosão) até entre 15 e $20 \mathrm{~km}$ continente adentro no rumo do vento formador. Têm morfologia predominantemente parabólica, composta ou simples. O grau de dissipação da morfologia original, possivel parâmetro de idade relativa crescente avaliado no campo e em imagens de satélite e fotografias aéreas, permitiu a Barreto et al. (2001a,b, 2004) classificar e mapear as dunas inativas da região segundo três "domínios geomorfológicos": das dunas nítidas, tênues e dissipadas. Para a separação destes domínios, os autores utilizaram três tipos de critérios de dissipação crescente: morfológicos, sedimentológicos e biológicos. Os critérios morfológicos incluem a possível redução dos ângulos de inclinação de barlavento e sotavento e da altura da duna, a presença de ravinas e leques de areia, o grau de dissecação e a obliteração das formas deposicionais originais. Os critérios sedimentológicos incluem a intensificação da cor, a presença de silte e argila pedogenéticos e o desvio padrão granulométrico da areia. Os critérios biológicos envolvem principalmente a presença e a densidade de cobertura vegetal, que no Rio Grande do Norte varia de aberta, do tipo restinga (maior parte do Estado), até vegetação densa e fechada de Mata Atlântica (sul do Estado). Superfícies de hiato deposicional entre supostas gerações de depósitos eólicos foram inferidas a partir de observações de campo, como, por exemplo, contatos abruptos marcados por contrastes de textura e coloração. As diferenças de idade entre estes depósitos podem ser avaliadas através dos resultados de datação por TL em 38 amostras apresentados no mesmo trabalho (Figura 3.3). Neste e em outros exemplos de datação por luminescência apresentados neste item, é preciso ter explícitas as limitações inerentes ao método. A dosagem de luminescência não indica necessariamente a idade da deposição, mas sim a última exposição à luz, geralmente relacionada a periodo de estabilização e desenvolvimento de solo ou mesmo de erosão. As idades TL e LOE encontradas devem portanto ser encaradas como idades mínimas de deposição.

A análise gráfica de distribuição das idades obtidas por Barreto et al. $(1999,2004)$ permite reconhecer três intervalos modais principais (Figura 3.3A): de 50 a 10800 anos $(47,4 \%$ dos casos), de 24 a $149 \mathrm{ka}(31,6 \%)$ e de 190 a $270 \mathrm{ka}(15,8 \%)$. Dentro do intervalo modal de idade intermediária (Figura $3.3 \mathrm{C}$ ), as idades TL distribuem-se de modo homogêneo, exceto por leve tendência de concentração na metade final do intervalo. Já no intervalo modal mais recente (Figura 3.3D), identificam-se quatro sub-modas, com destaque para os intervalos correspondentes aos últimos 500 anos ( $15,8 \%$ dos casos) e de 5,6 a 6,5 ka antes do presente (AP) $(10,5 \%)$. Estas sub-modas representam supostamente pulsos no processo de ativação e/ou fixação de dunas eólicas no decorrer do Holoceno. 


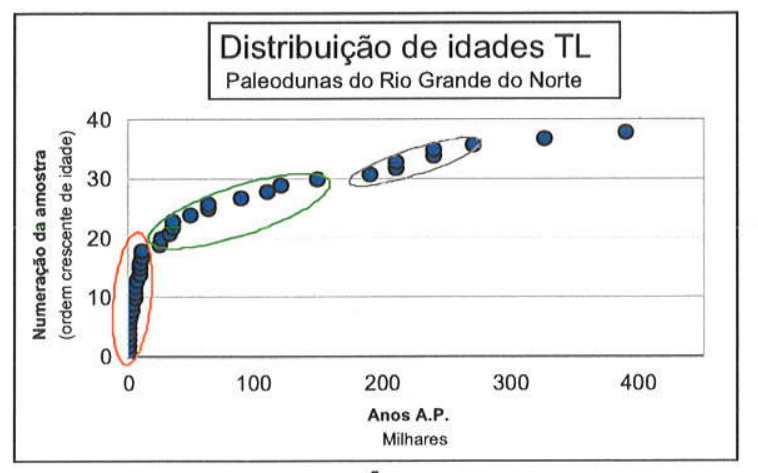

A

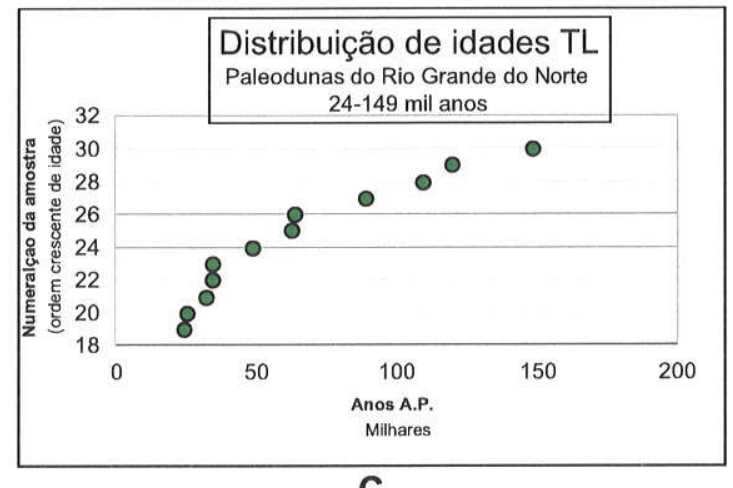

C

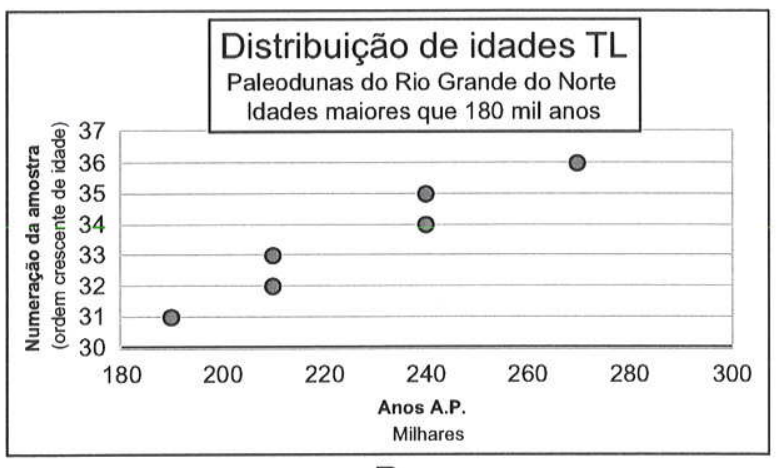

B

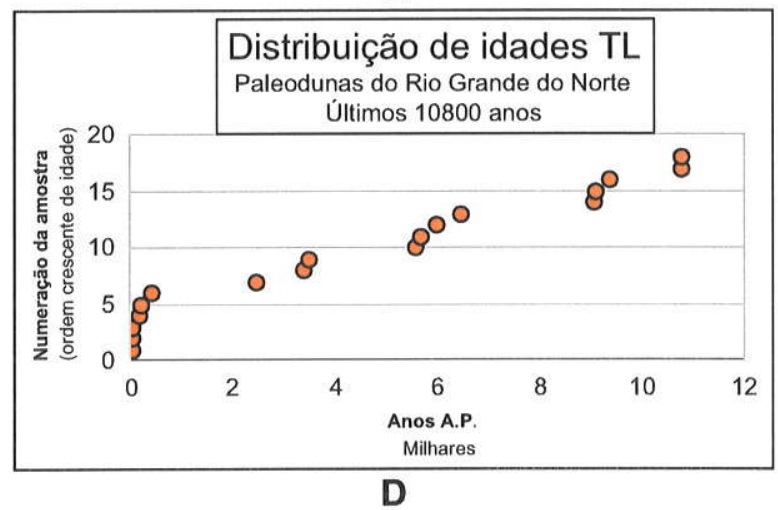

Figura 3.3. Distribuição de idades TL obtidas por Barreto et al. (2004) em dunas e paleodunas eólicas da costa do Rio Grande do Norte. Notar três agrupamentos de idades, destacados com elipses coloridas em A, cujas distribuições encontram-se detalhadas nos gráficos B, C e D.

As dunas inativas do norte da Paraíba, descritas por Barreto et al. (2002b), apresentam alturas de 5 a $30 \mathrm{~m}$ e morfologia parcialmente preservada como parábolas escalonadas voltadas para NW. Consistem provavelmente de rupturas de deflação e dunas parabólicas, modificadas, após a sua fixação, pela ação de águas pluviais e instalação de cobertura vegetal. Datações por TL obtidas por mesmos autores em três localidades (Barra do Camaratuba, praia de Camaratuba e baía da Traição) indicam idades de fixação restritas ao intervalo entre 64,1 e 27,0 ka AP.

$\mathrm{Na}$ Bahia e em Sergipe, duas gerações de dunas pleistocênicas inativas e duas gerações de dunas holocênicas têm sido admitidas (Martin et al. 1980, Bittencourt et al. 1982, Dominguez et al. 1996). Embora as alterações por intervenção humana (estradas, residências, extração de areia etc.) dificultem a definição da morfologia das dunas consideradas pleistocênicas, formas que lembram dunas parabólicas são identificadas pelos autores. A geração mais antiga, ou das "dunas internas" (Qe1), ocupa maior área. É formada por areias finas, dominantemente quartzosas, caracterizadas pelo predomínio $(80 \%)$ de grãos angulosos, granulometricamente bem selecionados, atribuídos a ação eólica sobre sedimentos de origem continental. Segundo Dominguez et al. (1996), esta geração é anterior à formação dos terraços deposicionais relacionados à Penúltima Transgressão (cerca de 120 ka). Esta relação foi inferida pelos autores na região da costa baiana entre Arembepe e a foz do rio Joanes (Lauro de Freitas), onde estes terraços se apoiariam diretamente sobre "dunas Qe1". De maneira semelhante, na costa de Sergipe, Bittencourt et al. (1982) reconheceram a mesma geração sobre os tabuleiros da Formação Barreiras, junto à extremidade sul da zona de progradação associada à foz do rio São Francisco. O fato de não mais haver atualmente nenhuma cobertura arenosa na parte inferior da encosta da Formação Barreiras seria indício, 
segundo aqueles autores, de que os depósitos eólicos de cavalgamento da falésia são anteriores à Penúltima Transgressão, pela qual foram erodidos. Seriam, desse modo, antigas dunas de topo de escarpa (cliff-top dunes sensu Jennings 1967). Todavia, não há informação de idade, baseada em datação absoluta, para testar este modelo.

A geração considerada pleistocênica mais nova, Qe2 ou das "dunas externas", apresenta na costa baiana sedimentos arenosos bem selecionados, com grãos subarredondados. Resultaria da ação eólica sobre os terraços marinhos pleistocênicos formados após a Penúltima Transgressão. A idade pleistocênica destas dunas foi admitida por Dominguez et al. (1996) com base no que se observa no bairro Armação, em Salvador. Nesta região, os terraços holocênicos aparecem em contato lateral com as paleodunas, sem a presença de terraços marinhos pleistocênicos pós - penúltima transgressão, os quais teriam sido destruídos pela transgressão do Holoceno. Há que se considerar, todavia, a possibilidade alternativa de que esta geração eólica corresponda a campos de dunas holocênicos, anteriores à máxima inundação, transgressivos sobre os terraços pleistocênicos. Em Sergipe, a geração Qe2 é melhor evidenciada no trecho entre o rio Vaza Barris e o rio Real/Piauí (Bittencourt et al. 1982, 1983a,b).

As duas gerações de dunas holocênicas do litoral de Bahia e Sergipe encontram-se bem caracterizadas na planície costeira associada à foz do rio São Francisco, na fronteira entre Sergipe e Alagoas (Figura 3.4). Estas duas gerações estão compreendidas nas "dunas litorâneas atuais" (Qe3), relatadas em Martin et al. (1980) e Bittencourt et al. (1982, 1983a,b), e correspondem às dunas inativas e ativas descritas por Barbosa (1997). Portanto, as notações Qe3 e Qe4, respectivamente, utilizadas por Giannini et al. (2005), são redefinição, baseada em Barbosa (1997), da classificação introduzida por Martin et al. (1980). A geração Qe3 atingiria na planície costeira do rio São Francisco a sua máxima extensão. Corresponde, na descrição de Barbosa (1997), a dois tipos de depósitos fixados pela vegetação: dunas parabólicas simples e compostas (nidiformes ou aninhadas e em forma de ancinho), orientadas segundo E-W e SE-NW, e cordões de dunas sem formas bem definidas. Em fotografias aéreas e imagens de satélite, destaca-se a presença de pelo menos três alinhamentos sinuosos sub-paralelos à costa, grosso modo formados pela intercalação entre estes dois tipos de depósitos. Em vista desta distribuição, deve-se considerar a possibilidade de que as formas parabólicas correspondam a frentes de antigos campos de dunas transgressivos, separados entre si e das dunas ativas, junto à praia, por igual número de cordões de dunas frontais relícticas (J.M.L. Dominguez, P. Hesp e S. Dillenburg, comunicação pessoal). Este padrão poderia indicar mudanças rítmicas nas características da sedimentação eólica durante a geração Qe3.

A altitude dos depósitos Qe3 varia de 6 a $13 \mathrm{~m}$. A granulação é areia fina, bem selecionada, sendo os grãos subarredondados. A posição estratigráfica desta geração de dunas, sobre terraços marinhos holocênicos datados de 2,5 ka a 3,7 ka (Barbosa et al. 1986), permite situar sua idade máxima nesse intervalo.

A geração Qe4 compreende cordões dunares frontais e dunas livres que nas adjacências da foz do São Francisco formam campos de dunas de 1 a $3 \mathrm{~km}$ de largura e até $30 \mathrm{~km}$ de extensão ao longo da costa. Seus sedimentos apresentam granulação semelhante à das praias adjacentes. Com base na taxa conhecida de migração de dunas e cordões de precipitação, Barbosa (1997) infere um período de 200 a 400 anos para o seu desenvolvimento. 


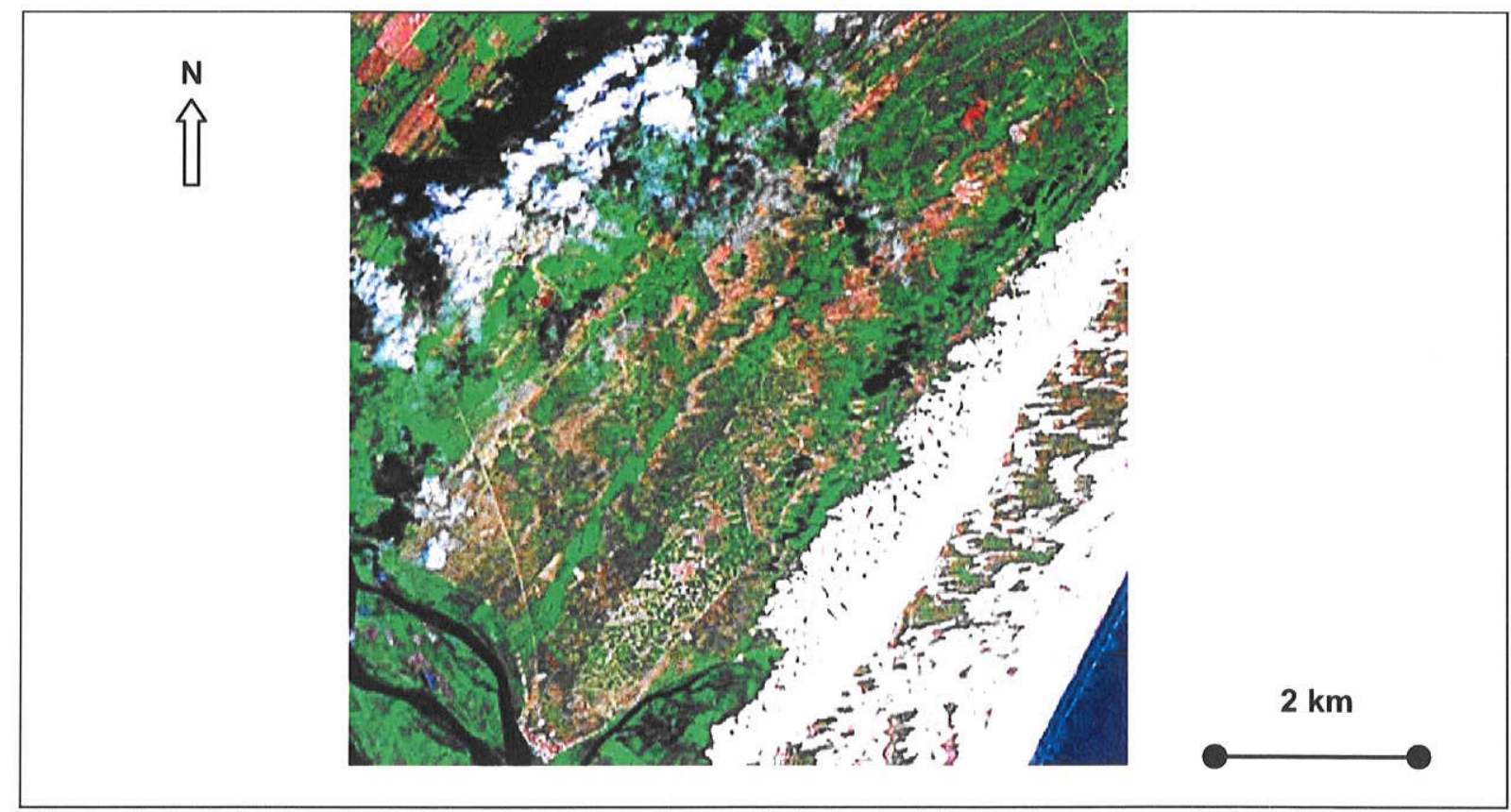

Figura 3.4. Paleodunas Qe3, ao interior, e dunas Qe4, junto à linha de costa, a NE da foz do rio São Francisco, AL. Nas paleodunas, notar alternância entre cordões com e sem formas parabólicas (em rosa e verde, respectivamente), paralelos à costa.

\section{Região Sudeste}

Na região de Cabo Frio, Martin et al. (1997b) fazem referência a "dunas atualmente fixadas pela vegetação e completamente inativas". Segundo os autores, "pode-se dizer que essas dunas sejam holocênicas porque avançaram", quando ativas, "sobre o sistema lagunar", correlacionado ao máximo transgressivo do Holoceno.

$\mathrm{Na}$ planície costeira paulista, há relatos de depósitos arenosos ligeiramente ondulados, repousando sobre areias mais consolidadas do terraço marinho regressivo pleistocênico, nas regiões de Santos-Bertioga (Martin \& Suguio 1976) e Peruíbe-Itanhaém (Martin \& Suguio 1976, Suguio \& Martin 1978; Giannini 1987). O topo destes depósitos atinge cotas de até $14 \mathrm{~m}$, pelo menos $4 \mathrm{~m}$ acima do máximo NRM admitido para o interglacial Riss-Würm (Sangamon) na região. Em vista disso, estes depósitos têm sido interpretados como produtos de retrabalhamento pelo vento, possivelmente na forma de lençóis de areia. Watanabe et al. (2003) dataram por ITL 16 amostras de areia coletadas a profundidades entre 0,5 e 3,6 m no terraço alto de Itanhaém (Figura 3.5). Em 11 dessas amostras, as idades obtidas são compativeis com fase de nível do mar baixo, entre 25 e 90 ka AP. As outras cinco apresentam idades correlacionáveis à época de mar alto do último interglacial. A interpretação dos autores é de que as cinco amostras mais antigas correspondem a terraço marinho, enquanto as onze amostras mais novas provêm de depósitos de retrabalhamento eólico, favorecido por clima supostamente mais seco durante o último glacial. 


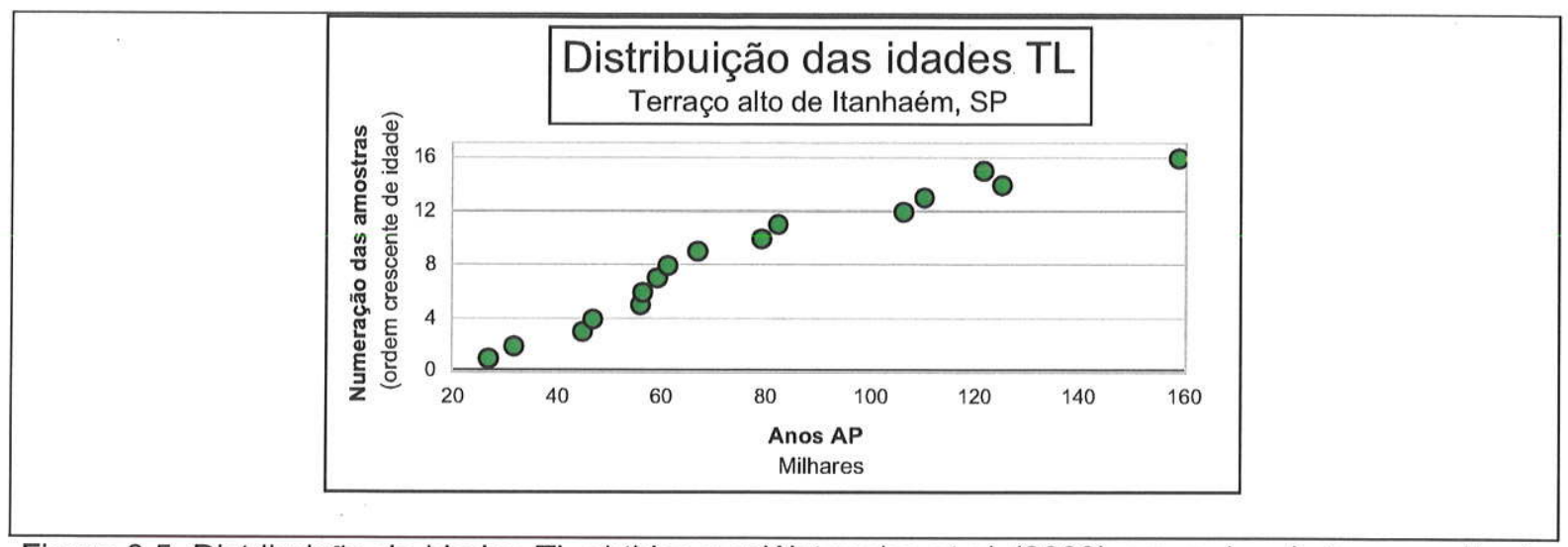

Figura 3.5. Distribuição de idades TL obtidas por Watanabe et al. (2003) em areias do terraço alto de Itanhaém, SP. As onze amostras mais novas corresponderiam, na interpretação dos autores, a depósitos eólicos.

Os maiores cordões dunares do Estado de São Paulo encontram-se na itha Comprida, em cujo terço externo reconhecem-se até quatro alinhamentos descontínuos de dunas com 7 a 8 m de altitude máxima (Petri \& Suguio 1973, Barcelos 1975, Barcelos et al. 1976; Suguio \& Martin 1978). Petri \& Suguio (1973) já reconheciam o caráter de paleoduna dos dois cordões mais internos. Parte dos cordões mais externos é também formada por paleodunas que, na porção centro-sul da ilha, chegam a aflorar junto à praia, na forma de falésias (Giannini et al. 2003a, 2007b; Nascimento 2006). Idades TL obtidas por Suguio et al. $(1999 a, b)$ em cordões dunares a cerca de $10 \mathrm{~km}$ da ponta sudoeste da ilha e a menos de $500 \mathrm{~m}$ da praia atual atingem até $7,4 \pm 1,6 \mathrm{ka}$. Idade mais nova $(5,63 \pm 1,18 \mathrm{ka} A P)$ foi mais tarde obtida por luminescência opticamente estimulada (LOE), no mesmo laboratório, para fácies subaquosas aflorantes na margem lagunar da extremidade sudoeste, porção mais interna e antiga da ilha (Giannini et al. 2003a, 2007b, Guedes 2003). Esta idade foi corroborada por datação ${ }^{14} \mathrm{C}$ de tronco in situ (5308-4877 anos AP cal), posicionado ao longo do mesmo alinhamento de cordão e algumas centenas de metros a NE do ponto de coleta da amostra para LOE. Com base nestas duas idades, e considerando os modelos de evolução progradacional da planície de cordões de ilha Comprida (Martin \& Suguio 1978, Giannini et al. 2003a, 2007b, Guedes 2003), a idade TL de 7,4ka atribuída a paleoduna na porção externa da ilha não é geologicamente compativel e aparenta estar super-estimada. Resultados obtidos por Guedes (2003), comparando datações TL e LOE em amostras de cordões litorâneos da ilha Comprida obtidas nesse laboratório evidenciam tendência sistemática da técnica de TL para aumento de idade em relação às datações ${ }^{14} \mathrm{C}$ e LOE. Resultados inéditos de TL obtidos por A.O.Sawakuchi no Laboratório de Luminescência da Oklahoma State University (Figura 3.6A) indicam para as paleodunas de Ilha Comprida idades inferiores a 2 ka e reforçam o modelo, previamente formulado por Giannini et al. (2007b), de existência de três gerações de dunas nessa ilha.

Poucas dezenas de quilômetros a NE, encontra-se a praia da Juréia (município de Iguape), onde paleodunas de até $7 \mathrm{~m}$ de altura, similares às de Ilha Comprida, ocorrem em erosão na linha de costa atual (Bentz \& Giannini 2003, Ferreira 2003, Bentz 2004). As idades TL em sedimentos seguramente eólicos ao longo desta praia (Figura 3.6B) variaram entre

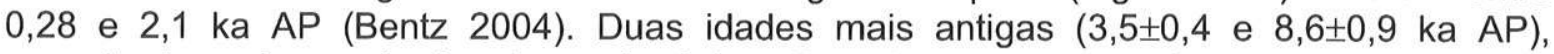
encontradas aí em horizonte pedogênico B sob paleodunas (Bentz 2004), devem corresponder ao substrato marinho dos depósitos eólicos, haja visto que o horizonte $\mathrm{A}$ do paleossolo sobre este substrato confunde-se com a base da paleoduna. Esta hipótese é reforçada pela similaridade destas duas idades com as obtidas por mesma autora em 
trincheiras escavadas em depósitos de espraiamento em outras porções da planície da Juréia, aproximadamente nos mesmos alinhamentos de cordão litorâneo.

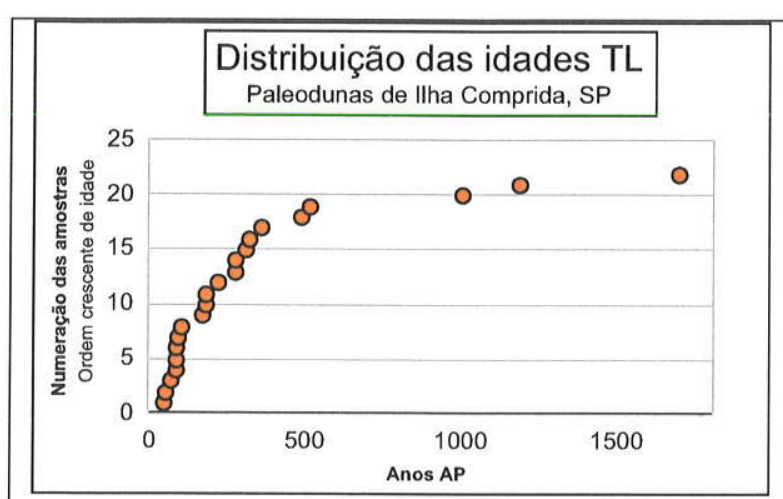

A

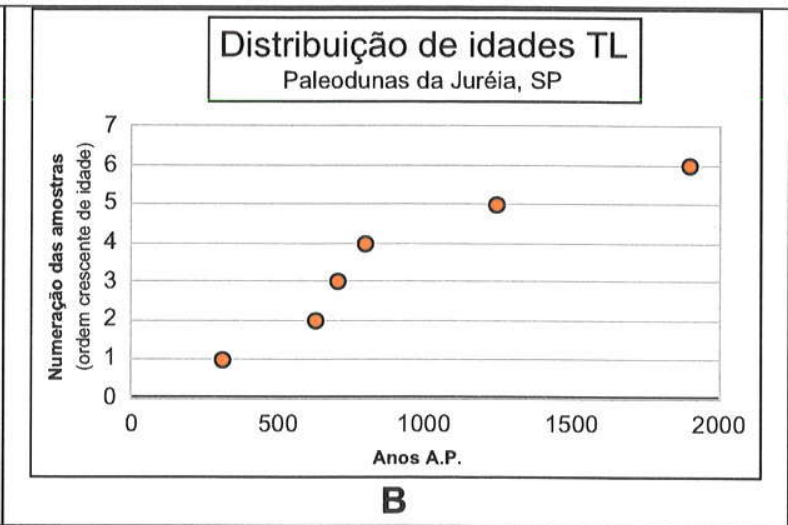

B

Figura 3.6. Distribuição de idades TL obtidas em paleodunas eólicas (frontais e rupturas de deflação) na faixa externa da llha Comprida, SP $(A)$ e em falésias ao longo da praia da Juréia, Iguape-Peruíbe, SP (B). A. Dados inéditos de A.O. Sawakuchi. B. Dados reinterpretados de Bentz (2004).

\section{Região Sul}

$\mathrm{Na}$ costa centro-sul de Santa Catarina, a primeira menção à presença de mais de uma geração de areias eólicas foi feita por Guerra (1950) ao referir-se a "dunas fósseis e vivas" nos arredores de Imbituba. Bigarella (1975) e Bigarella \& Becker (1975a) reconheceram dunas eólicas de idade pleistocênica na praia da Joaquina, em Florianópolis, e na região de Guaiúba, Vila Nova, a sul da cidade de Imbituba, respectivamente.

Martin et al. (1988b) concluíram pela possibilidade de "distinguir pelo menos três gerações de dunas costeiras, principalmente ao sul da ilha de Santa Catarina". A primeira geração, das "dunas antigas", exemplificada pelos depósitos ao interior da praia de Muita Água, em Imbituba, é descrita como areias avermelhadas pedogeneizadas e com densa cobertura vegetal. A segunda geração, das "dunas holocênicas inativas", é composta, segundo eles, por dunas de areias brancas e amareladas, com vegetação, reativáveis pela ação antrópica. A geração mais recente é relatada como "dunas ativas de areias brancas da faixa mais externa da planície litorânea". Para as "dunas antigas", a suposição de idade entre 120 e 7 ka AP baseou-se na observação de que estas dunas encontram-se em erosão hoje na praia de Muita Água (Imbituba). Segundo os autores, tal situação permite "concluir que sua deposição ocorreu quando o nível marinho era muito mais baixo que o atual". Esta conclusão, entretanto, baseia-se na idéia de que a erosão atual das paleodunas deu-se exclusivamente por subida de NRM, premissa contrariada pelo fato de praia de Muito Água situar-se em região com vocação erosiva relacionada à dinâmica local de correntes de deriva litorânea (Giannini 1993).

$\mathrm{Na}$ costa centro-sul de Santa Catarina, o uso combinado de informações sobre empilhamento estratigráfico, grau de dissecação e aspectos mineralógicos e texturais permitiu ampliar para pelo menos quatro o número de gerações reconhecidas de depósitos eólicos (Giannini 1993, 2001, Giannini \& Suguio 1994, Giannini et al. 2001b,c, 2007c, Martinho \& Giannini 2001a,b; Figuras 3.7 e 3.8). 


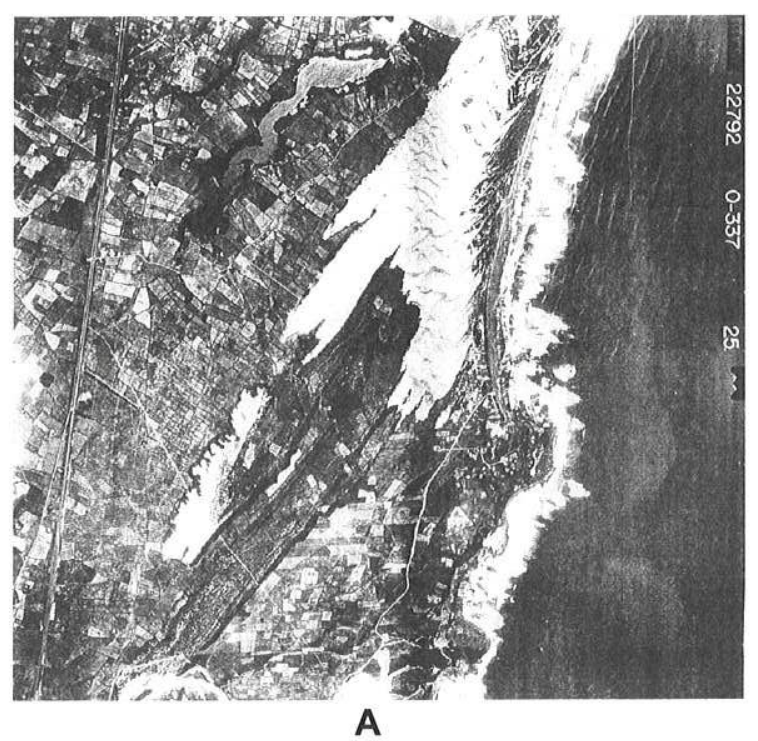

Figura 3.7. Gerações de depósitos eólicos em Ibiraqüera (Imbituba), SC. A. Fotografia aérea vertical de Cruzeiro do Sul Serviços Aéreos (1979-1981). B. Mapa, simplificado de Giannini (1993).

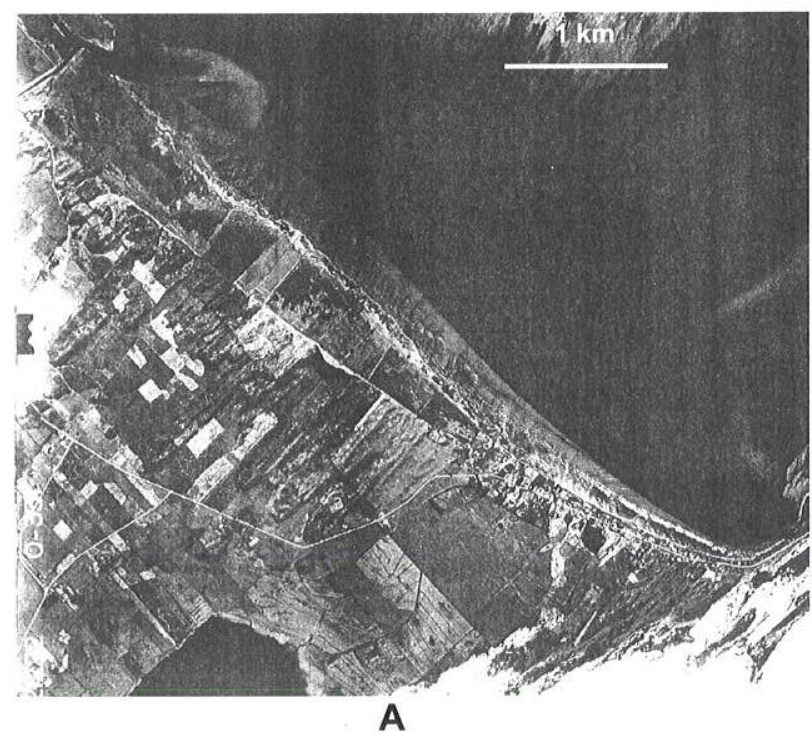

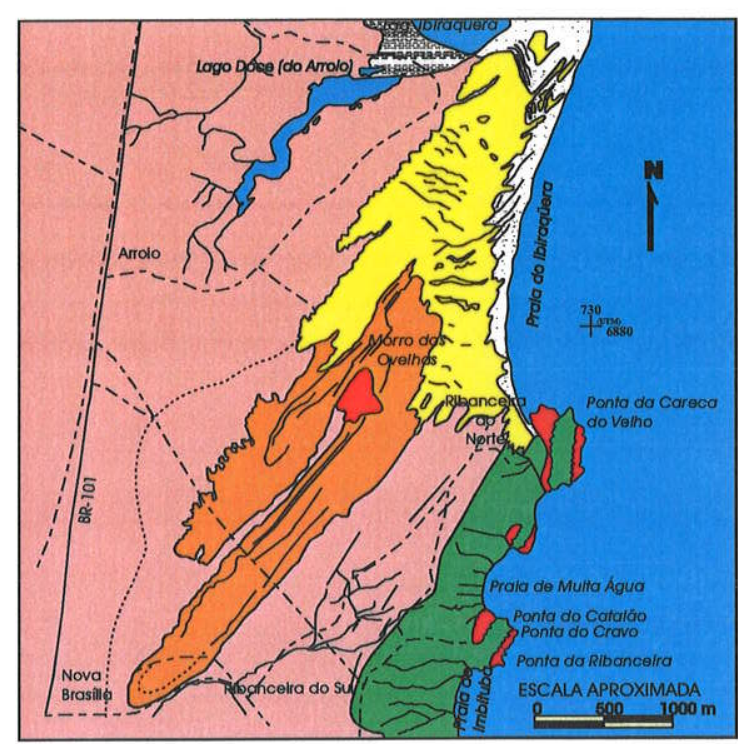

B
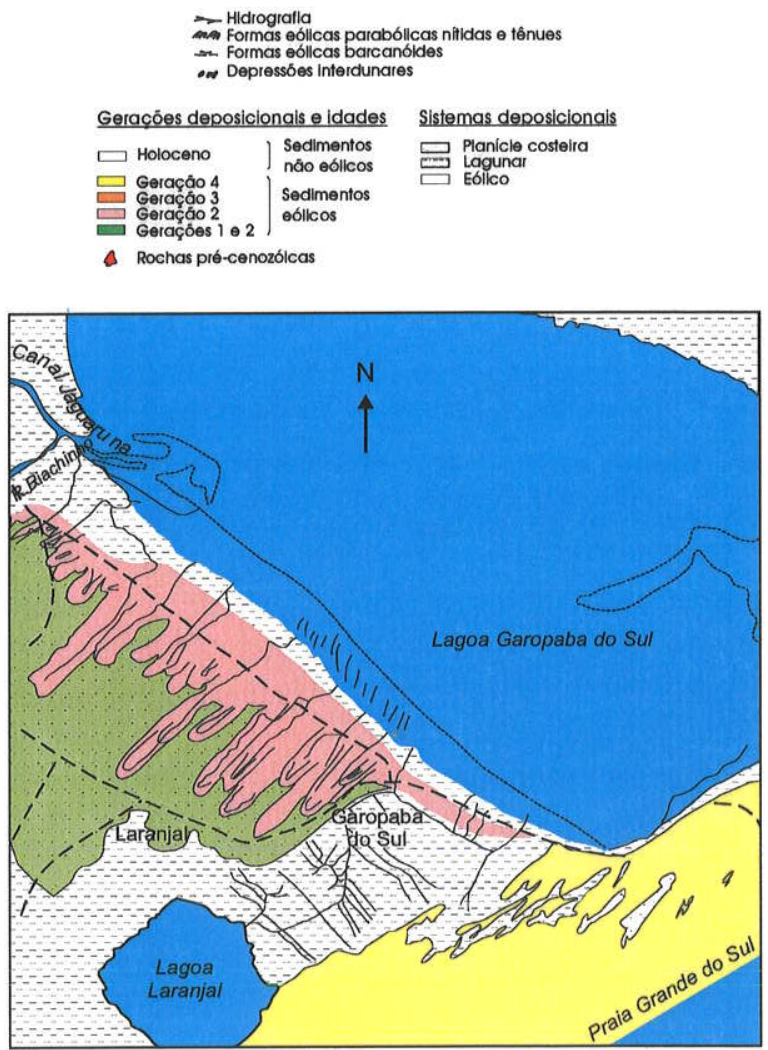

B

Figura 3.8. Gerações de depósitos eólicos em sistemas deposicionals

Garopaba do Sul (Jaguaruna), SC. A. Fotografia $\square$ Eouco aérea vertical de Cruzeiro do Sul Serviços $\rightarrow$ lagunar Aéreos (1979-1981). B. Mapa, simplificado de $\square$ Barra-BarReIra planilie costerira Giannini (1993).

Hidrografia
$\square$ Formas eólicas barcanóides
$\square$ Baixios interdunares úmidos e/ou vegetados
GERAÇŌES DEPOSICIONAIS E IDADES

\begin{tabular}{|c|c|c|}
\hline & HOLOCENO & SEDIMENTOS \\
\hline & PLEISTOCENO & NAO EOLICOS \\
\hline & GERAÇĀO 4 & \\
\hline & GERAÇĀO 2 & $\begin{array}{l}\text { SEDIMENTOS } \\
\text { EÓLICOS }\end{array}$ \\
\hline & GERAÇÃO 1 & \\
\hline
\end{tabular}


Na geração 1, mais antiga, predominam areias de aspecto maciço, com cimentação argilo-limonítica generalizada, e ocorrência freqüente de grânulos e/ou pequenos seixos dispersos. Esta geração não apresenta morfologia dunar preservada. A dissecação é profunda, com ravinas de drenagem em $V$, transversais à costa (Figura 3.7). Seus depósitos são lateralmente descontínuos, com espessura de até dezenas de metros e têm a porção superior caracterizada pela presença de paleossolos e horizontes residuais de grânulos. Em escala de afloramento decamétrica, o contato superior apresenta topografia irregular com vales incisos preenchidos por depósitos da geração 2. A geração 2 consiste de areias maciças ou estratificadas com cimentação argilo-limonitica heterogênea, a qual pode formar manchas e bandas nodulares ou ressaltar estruturas primárias de geometria definida. Sob o aspecto textural, destaca-se a presença freqüente de grânulos e seixos concentrados em paleopavimentos e paleocanais; e sob o aspecto das estruturas pedogenéticas, a presença de ferricretes (veios, crostas sub-horizontais e tubos de rizoconcreções). Seu aspecto geomorfológico mais marcante é a dissecação fluvial controlada por vales entre braços de dunas parabólicas alongadas segundo SW-NE (Figuras 3.7 e 3.8). Localmente, esta unidade apresenta concentrações basais de areia grossa a cascalho terrígeno anguloso ou intraclástico as quais preenchem vales incisos no topo da geração 1. A geração 3 constituise de areias incoesas, colonizadas por vegetação, com sinais extensivos de pedogênese incipiente. Apresenta-se sob a forma de dunas e frentes parabólicas alongadas, imbricadas (Figura 3.7), como cordões de precipitação relícticos ou como rastros lineares residuais de deflação, resultantes de deslocamento de dunas atuais. Seu contato com a geração 2 pode ser abrupto ou gradual. A geração 4 corresponde a dunas ativas. Nas três gerações mais novas, em que as formas deposicionais encontram-se preservadas, o rumo inferido dominante de migração das dunas é o mesmo, de NE para SW (Figuras 3.7 e 3.8).

O contato entre os depósitos das gerações 2,3 e 4 é determinado apenas por mudanças de cor, textura ou coesão entre areias eólicas, a menos da existência localizada de paleossolos, com destaque para ferricretes no topo da geração 2. A passagem entre as gerações 1 e 2, em contraste, caracteriza-se por paleopavimentos granulosos e paleossolos, no porção superior da unidade mais antiga, e por paleocanais com preenchimento intraclástico, na base da mais nova. Desse modo, um hiato deposicional regional entre as gerações 1 e 2 encontra-se evidenciado sob pelo menos três aspectos de campo: 1. a presença ubíqua de paleossolos e/ou depósitos residuais de deflação na parte superior da geração $1 ; 2$. o grau mais elevado de cimentação de seus depósitos; e 3. a presença de intraclastos arenáceos da geração 1 dentro da porção basal da geração 2 (Giannini 1993, Giannini et al. 2007c).

As quatro gerações de areias eólicas de Santa Catarina foram confrontadas quanto a características granulométricas e mineralógicas da fração clástica (Giannini 1993, Giannini \& Suguio 1994, Giannini et al. 1997b, Sawakuchi 2003, Giannini et al. 2007c) e quanto à microscopia petrográfica e textura e quimismo do cimento (Martinho \& Giannini 2001a,b). Na comparação entre os valores granulométricos médios de cada geração, observaram-se, com o decréscimo de idade, tendências para afinamento, melhora de seleção e aumento da assimetria. Este padrão de variação pode ser atribuido ao efeito de afinamento seletivo progressivo através das sucessivas fases de dissecação e atividade eólica. Os sedimentos grossos contidos nas dunas mais antigas teriam sido preferencialmente retidos na drenagem que dissecou estas dunas, enriquecendo em finos a fração transportada pela drenagem em direção à costa, e portanto à área-fonte de dunas mais novas. Diferenças significativas entre as quatro gerações eólicas foram detectadas também no aspecto mineralógico. $O$ índice somatório de minerais ultraestáveis (ZTR de Hubert 1962) diminui da geração 1 para a 4. Índices de minerais metaestáveis e instáveis apresentam o comportamento inverso. Essas 
tendências permitem supor que o efeito de retrabalhamento sucessivo de sedimentos preexistentes, cuja atuação foi admitida com base em resultados granulométricos, não prevalece, no âmbito da mineralogia (i.e., destruição progressiva de minerais instáveis). Com base nelas, o aumento de maturidade mineralógica nas gerações mais antigas pode ser atribuído ao efeito de dois fatores não excludentes: a dissolução pós-deposicional e a seleção aerodinâmica. O primeiro fator refere-se à eliminação preferencial, por dissolução, de minerais instáveis, função direta da idade dos sedimentos (Giannini 1993, Giannini \& Suguio 1994, Giannini et al. 1997a,b). O segundo fator refere-se ao retrabalhamento sucessivo preferencial de minerais pesados de menor densidade, dominados por componentes instáveis.

Quanto aos resultados de análise petrográfica por microscopia óptica e microscopia eletrônica de varredura (MEV) apresentados por Martinho \& Giannini (2001a,b), as diferentes gerações de paleodunas mostram em comum a composição quartzosa, com cimento argiloorgânico-ferruginoso, tendo como filossilicato dominante a caulinita. Observam-se diferenças quanto à textura do cimento e à abundância de componentes líticos, predominantemente intraclásticos. O cimento tende a ser mais abundante, com aspecto de precipitado coloidal e textura em menisco, na unidade 1 , em contraste à aparência particulada nas gerações mais novas. No que se refere ao arcabouço, a presença de fragmentos líticos é pouco mais marcante na unidade 2. A existência de clastos de mineral glauconítico nas duas gerações mais antigas constitui evidência potencial da influência de aporte sedimentar costeiro durante sua deposição. Na comparação entre estas duas gerações, o grau mais elevado de cimentação na geração 1 , associado a maior maturidade mineralógica e menor maturidade textural, refletiria menor duração ou intensidade de transporte seletivo e maior tempo de atuação de dissolução, cimentação e processos pedogenéticos/diagenéticos em geral. $\mathrm{E}$ a maior maturidade textural da geração eólica 2 reforça a tese, levantada em estudos anteriores, de que esta geração seria, em parte, produto de retrabalhamento de gerações eólicas mais antigas.

A idade das gerações 1, 2 e 3 foi inicialmente inferida com base em suas relações com variações de linha de costa, relacionadas a flutuações de NRM de idade conhecida. A ocorrência da geração 1 limita-se a rampas eólicas ancoradas em morros testemunho do embasamento cristalino e a dunas neles empoleiradas, indicio de que se encontraria erodida ou encoberta nas cotas topográficas mais baixas. Numa das ocorrências de rampa eólica, na ponta do Catalão (Figura 3.7), um depósito rudáceo interpretado como paleopraial (Martin et al. 1988), ocorre embutido nos depósitos eólicos, 7 a $8 \mathrm{~m}$ acima de seu depósito homólogo atual. Esta elevação é superior ao máximo NRM holocênico de Santa Catarina $(<3 \mathrm{~m}$, conforme Angulo et al. 1999, 2006), mas coincide com o máximo admitido para o último interglacial no Brasil $(8 \pm 2 \mathrm{~m})$. Estes dados permitem sugerir a erosão ou afogamento das paleodunas da geração 1 , nesse local, pelo máximo transgressivo ligado ao NRM alto de 120 ka AP (Giannini 1993, 2002, Giannini et al. 2001b). A geração 2 guarda relações análogas com a máxima inundação ligada ao alto NRM pós-glacial: nas margens do sistema lagunar, as formas parabólicas da geração eólica 2 encontram-se truncadas discordantemente em algumas áreas (Giannini 1993, Giannini \& Santos 1994) ou afogadas ao longo de planícies interdunas NE-SW, em outras (Giannini et al. 2001b, Giannini 2002). A geração 2 foi portanto afetada pelo sistema lagunar gerado na transgressão holocênica, cujo máximo NRM foi atingido antes de 5587 anos $\left({ }^{14} \mathrm{C}\right.$ cal) AP (Angulo et al. 1999, 2006) e deve ser, pelo menos em parte, mais antiga que essa data. Já a geração 3 ocorre na maioria dos casos sobre a barreira formada supostamente no pico transgressivo ou então sobre planícies holocênicas progradantes, sendo portanto, nesses casos, seguramente posterior à máxima inundação do Holoceno. Dentro desta geração, dois tipos genéticos ou faciológicos devem ser distintos (Giannini 1993). O primeiro corresponde a resíduos de deflação abandonados, os quais não representam um pulso independente de atividade eólica, mas apenas o resultado normal de 
deslocamento de dunas secundárias da geração 4. Estimativa baseada na velocidade de migração das frentes parabólicas ativas associadas a estes depósitos residuais indica idades variáveis entre cerca de 100 e 300 anos. O segundo tipo genético é o das dunas e frentes parabólicas, incluindo as grandes formas atenuadas, que cavalgam o morro das Ovelhas (Figura 3.7) e a zona urbana de Imbituba, e as pequenas formas imbricadas da planície pleistocênica adjacentes às praias de Ji e Sol. Este tipo chega em alguns locais a avançar os limites da planície progradante holocênica e a apresentar passagens transicional tanto para os depósitos sotopostos da geração 2 como para os sobrepostos da geração 4 (Giannini 1993, Giannini et al. 2001b). Pode portanto atingir idades máximas até milhares de anos mais antigas.

Este modelo de distribuição das gerações eólicas no tempo foi testado através de datação por TL e LOE em grãos de feldspato e quartzo em 32 amostras de paleodunas (Figura 3.9) coletadas em oito diferentes localidades: Ribanceira do Sul e Guaiúba, em Imbituba; Barbacena, Bentos, ponta da Ilhota e Santa Marta, em Laguna; e Garopaba do Sul e Campo Bom, em Jaguaruna (Giannini et al. 2007c). Os sítios de amostragem em Ribanceira do Sul, na ponta da llhota e no morro Santa Marta contemplam dunas das três gerações, cavalgantes sobre o embasamento cristalino pré-Cenozoico. As amostras de Guaiúba foram coletadas ao longo de paleoescarpa de abrasão marinha esculpida sobre rampa de areia eólica ancorada em morro-testemunho do embasamento, considerada seção-tipo das gerações 1, 2 e 3 (Giannini et al. 1997b). Em Barbacena, Bentos e Garopaba do Sul, as amostras foram coletadas em dunas parabólicas estabilizadas da geração 2, truncadas pelas margens do sistema lagunar. As amostras foram agrupadas, com base em análise de fácies, quanto ao caráter acumulativo ou deflacionar residual, estas dominantes na porção superior da geração 1.
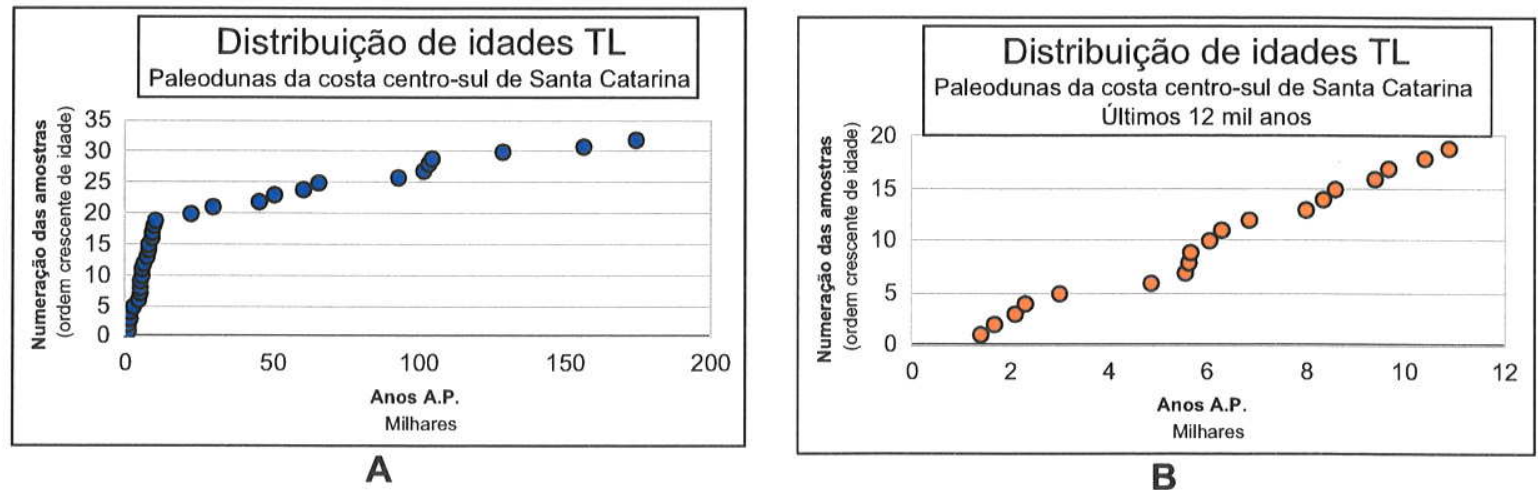

Figura 3.9. Distribuição das idades TL e LOE obtidas por Giannini et al. (2007c) em paleodunas eólicas da costa de Santa Catarina entre Imbituba e Jaguaruna. A distribuição dentro do agrupamento de idades na parte esquerda do gráfico $\mathrm{A}$ pode ser observada com maior detalhe em $\mathrm{B}$.

A distribuição de freqüências das idades TL e LOE, agrupadas por geração deposicional (Figuras 3.10A, C e D), evidencia duas classes modais principais na geração 1, entre 110 e 50 ka AP, e uma classe modal principal na geração 2, em torno de 6 ka AP (Giannini et al. 2007c). A mais antiga das classes modais da geração 1, correspondente a fácies de caráter acumulativo coletadas na base da unidade, ocorre no intervalo cronológico entre 110 e $90 \mathrm{ka}$, coincidente com a idade do último máximo NRM acima do atual no Pleistoceno. A moda mais nova engloba amostras de caráter residual da parte superior da unidade. A geração 2 seria essencialmente anterior ou contemporânea ao máximo NRM do Holoceno na região (alcançado antes de 5,1 ka AP: Angulo et al. 1999, Kneip 2004) enquanto a geração 3 é dominantemente posterior a esta época, com maior parte das idades 
mais novas que 3 ka AP. Esses resultados reforçam o modelo previamente elaborado com base em relações de campo.

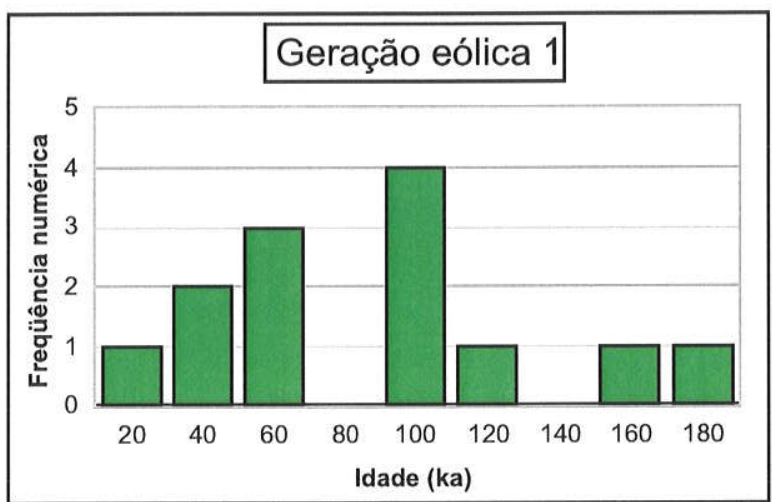

A

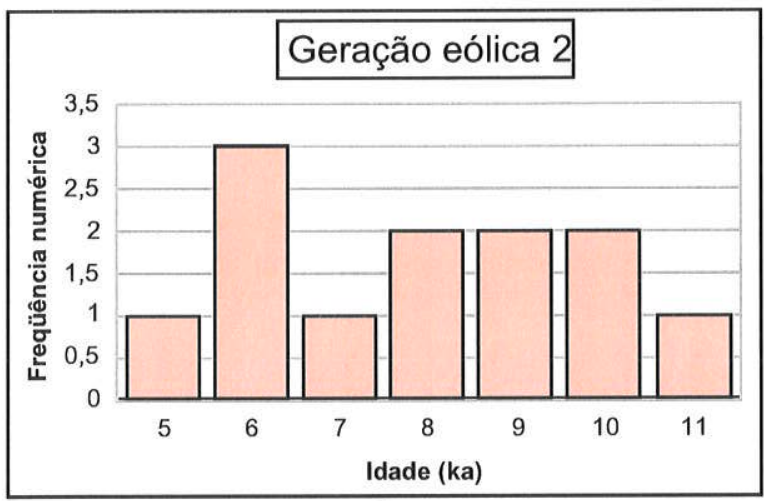

C

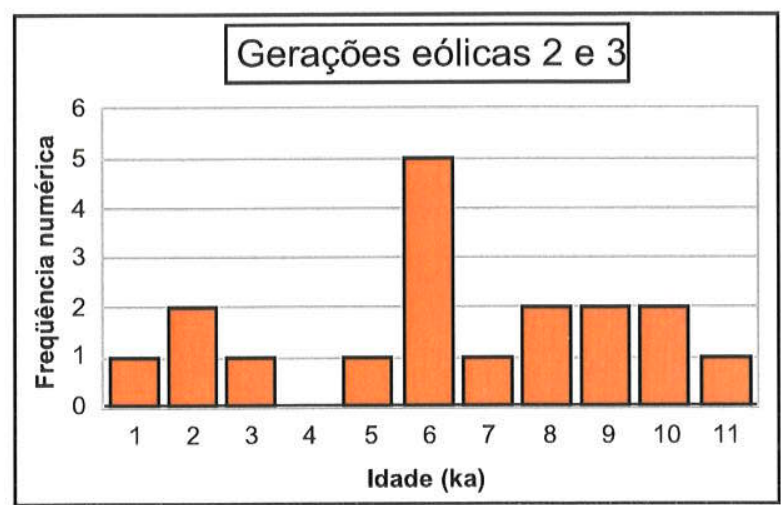

B

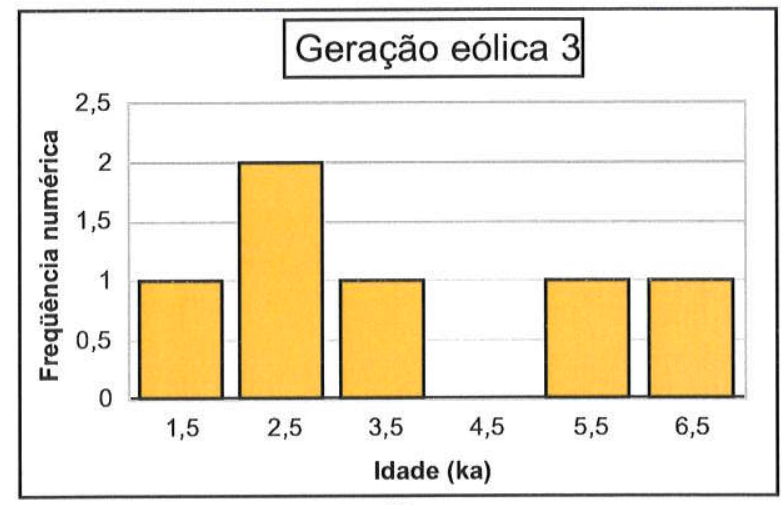

D

Figura 3.10. Histogramas de distribuição de freqüências de idade para gerações eólicas 1 (A) e 2/3 (B), 2 (C) e 3 (D), segundo Giannini et al. (2007c).

Na enseada da Pinheira, imediatamente a sul da ilha de Santa Catarina, três cordões de dunas parabólicas correlatas à geração 3 alternam-se, através da planície progradacional, com relictos de dunas frontais estabilizadas (Figura 3.11), em padrão algo similar ao descrito para os depósitos Qe3 junto à foz do rio São Francisco (AL/SE). 


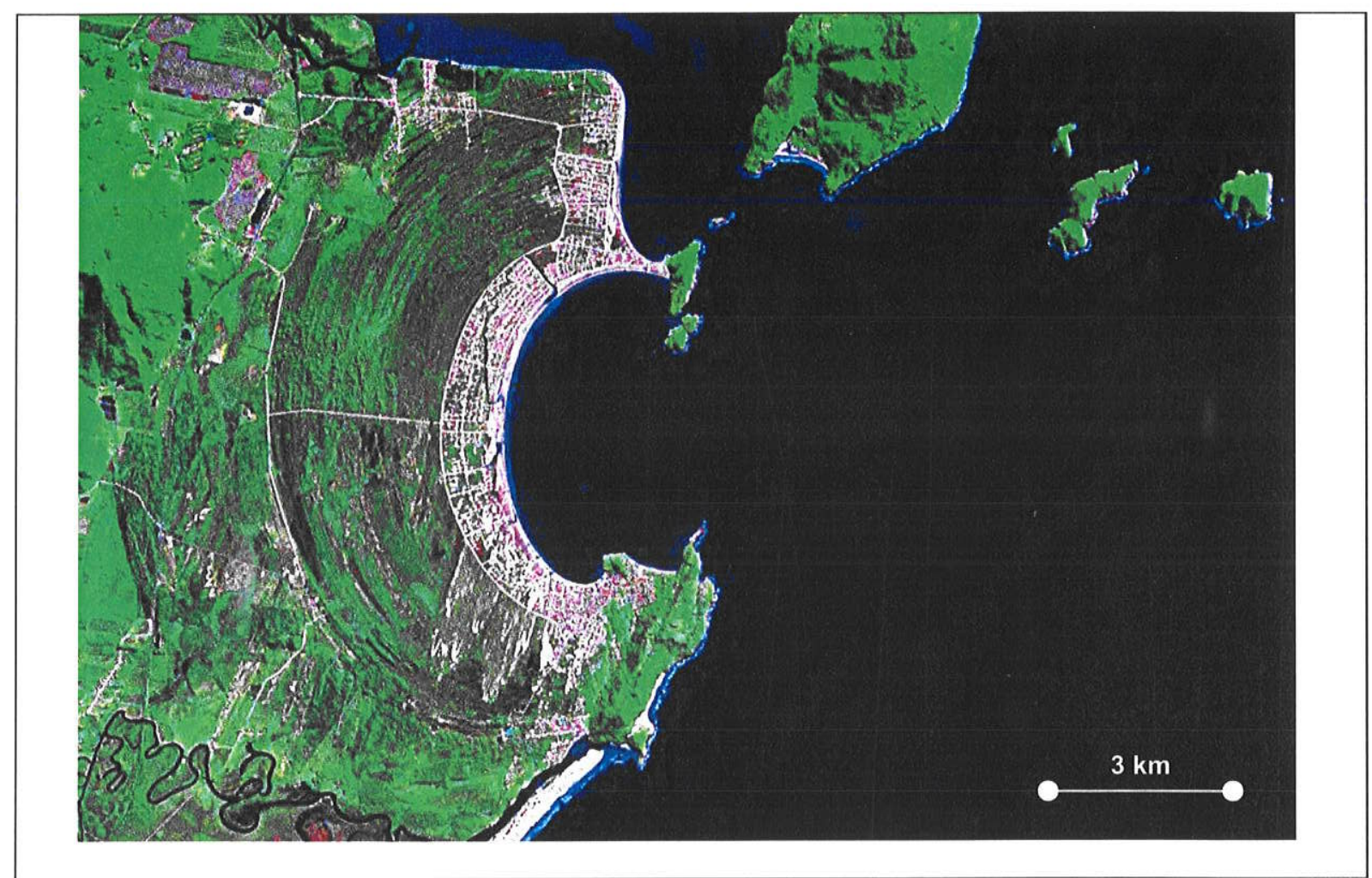

Figura 3.11. Planície adjacente à enseada da Pinheira, Palhoça, SC, onde cordões de paleodunas frontais se intercalam com cordões de paleodunas parabólicas.

Na planície litorânea do Rio Grande do Sul, os deslocamentos laterais da linha de costa resultantes das flutuações glácio-eustáticas do nível do mar durante o Quaternário teriam produzido quatro sistemas do tipo laguna-barreira (Villwock et al. 1986). Cada uma destas barreiras marcaria o limite máximo atingido por um dos eventos transgressivos transcorridos durante o Pleistoceno superior e o Holoceno. Segundo Tomazelli (1990), todas as barreiras caracterizam-se por apresentar expressiva cobertura eólica.

As dunas das barreiras pleistocênicas são formadas por areias quartzo-feldspáticas, finas a médias, de cores amarelo-avermelhadas e que podem apresentar até $15 \%$ de matriz síltico-argilosa, de origem pedogenética. Os processos pedogenéticos teriam sido responsáveis também pela destruição quase total de suas estruturas sedimentares primárias. Crostas e concreções ferruginosas são feições comuns e, em alguns locais, ocorrem horizontes com traços fósseis de raízes.

Paleodunas sobre a Barreira III, correlacionada ao máximo NRM de $120 \mathrm{ka}$, preservam localmente parte de suas formas originais, como barcanas e dunas parabólicas, as quais indicam paleovento dominante de NE, à semelhança das dunas atuais (Tomazelli 1990). Dunas formadas por areias de cor branca ou bege, consideradas holocênicas, possuem granulometria fina a muito fina e composição essencialmente quartzosa, com enriquecimento, em alguns locais, em minerais pesados de alta estabilidade. Correspondem a areias supermaturas, textural e mineralogicamente, e que resultariam, portanto, do retrabalhamento de depósitos sedimentares submetidos a vários ciclos de sedimentação (Tomazelli 1990).

Os depósitos eólicos estabilizados sobre a barreira IV da região entre Querência e Albardão (Figura 3.12) apresentam disposição geométrica similar à observada na foz do rio São Francisco (AL/SE) e na enseada da Pinheira (SC). Observam-se três ou mais cordões sinuosos relativamente elevados, correspondentes a frentes de antigos campos de dunas, 
alternados com complexos de cordões mais lineares e baixos, interpretados como dunas frontais fósseis (P.Hesp e S.Dillenburg, comunicação pessoal), mas que podem também incluir antigos depósitos de deflação, por exemplo, retrocordões.

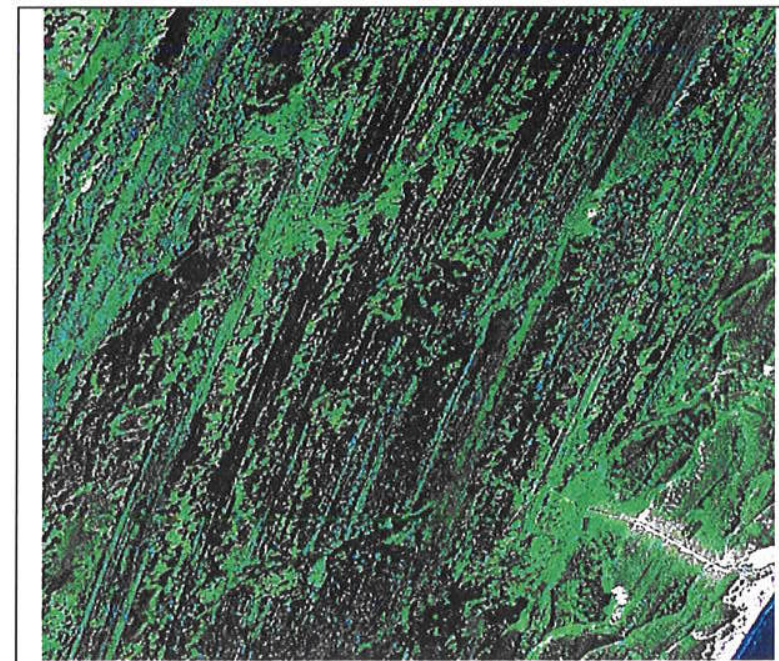

A

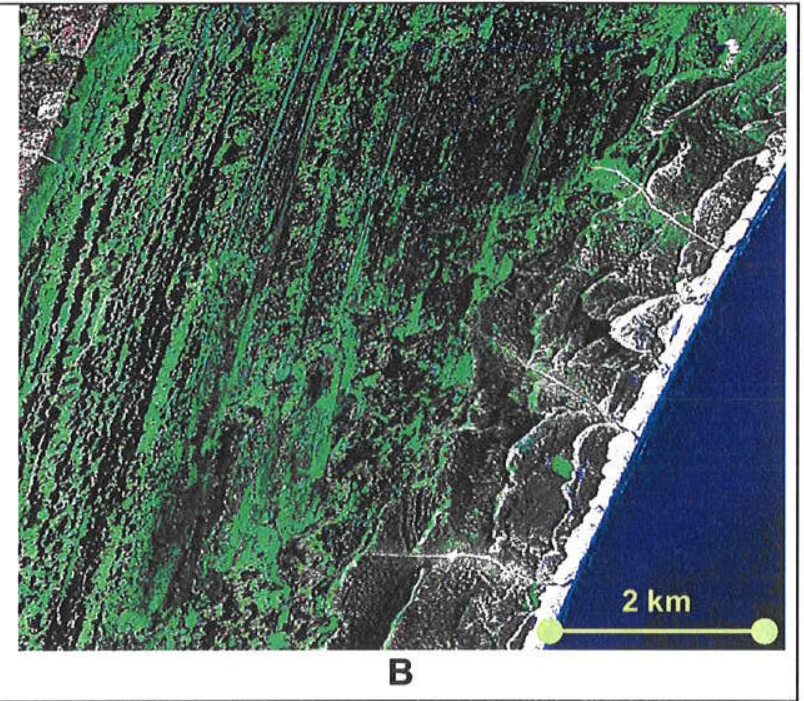

B

Figura 3.12. Intercalação entre cordões sinuosos e lineares, característica da planície costeira sul-riograndense entre Cassino e Albardão. A. Ao norte de Sarita. B. Ao sul de Sarita.

\subsubsection{Variáveis do macroambiente}

\subsubsection{NRM}

\section{Holoceno}

Dispõe-se de mais de 1000 datações de indicadores de paleonivel do mar holocênico na costa leste brasileira (do Rio Grande do Sul ao Rio Grande do Norte), cujos dados se encontram dispersos em mais de uma centena de trabalhos publicados desde meados da década de 1960. Este cômputo impressionante é o resultado do levantamento realizado por Angulo et al. (2006), em revisão crítica abrangente e minuciosa sobre as flutuações de NRM no Holoceno do Brasil. Os indicadores utilizados podem ser subdivididos em seis categorias: bioclastos de concha ou madeira em meio a depósitos de terraços marinhos; concheiros estuarinos ou lagunares; turfeiras e outros depósitos atribuídos a paleomangues; rochas praiais (beach-rocks); sambaquis; e carapaças de animais incrustantes in situ, incluindo ostras, algas calcárias, corais e vermetídeos. Segundo os autores, apenas $30 \%$ dos dados publicados podem ser considerados suficientemente precisos nas escalas de tempo e espaço e na interpretação do paleonível para poderem ser usados de modo confiável como indicadores de NRM. Este sub-conjunto de dados, em que predominam os relativos a vermetídeos (Figura 3.13), evidencia declínio progressivo de NRM, possivelmente a taxa variável, desde o máximo nível do mar holocênico. Diferenças regionais nas curvas de variação de NRM, de Pernambuco ao Paraná, são menores que a margem de erro admitida por esses autores na determinação do paleonível $( \pm 1 \mathrm{~m})$. Já os dados de Santa Catarina são sugestivos de paleoniveis regionais significativamente mais baixos. Outras conclusões alcançadas por Angulo et al. (2006) podem ser assim resumidas:

1. Indicadores atribuídos ao momento em que o NRM, em sua ascensão pós-glacial no Holoceno, igualou a altura zero (nível atual) são, em grande maioria, retrabalhados e do tipo 
complexo (isto é, em que a feição utilizada como indicador de altura não é a mesma utilizada para a datação). Não permitem, portanto, precisão suficiente para confirmar ou rejeitar a hipótese de Martin et al. (1985) e Suguio et al. (1985) que defende a existência de diferenças regionais. Os dados indicam apenas que por volta de 6600 anos AP (6900-7700 anos cal

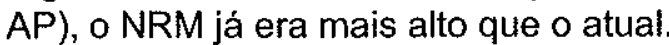

2. A idade do máximo NRM holocênico varia entre $5195 \pm 110$ anos AP (5783-5291 anos cal AP), dado obtido por Martin et al. (1979) na Bahia, e 5410 \pm 80 anos AP (5916-5597 anos cal AP), idade encontrada por Angulo et al. (1999), em Santa Catarina. Ambas as idades referem-se a vermetídeos.

3. O máximo NRM (com precisão de $\pm 1 \mathrm{~m}$ ) teria alcançado 3 a $4 \mathrm{~m}$, no trecho compreendido entre Pernambuco e Paraná, e 2,1 m, em Santa Catarina.

4. No trecho entre Pernambuco e Paraná, o NRM teria permanecido entre 2 e $4 \mathrm{~m}$ acima do atual até cerca de 2000 anos cal AP, caindo em taxa ligeiramente mais rápida a partir de então.

5. Curvas de NRM com padrão distinto do dominante entre Pernambuco e Santa Catarina foram encontradas em diferentes blocos estruturais nos arredores da baía de Todos os Santos (Martin et al. 1984, Carvalho 2000 apud Angulo et al. 2006) e ao longo da costa do Rio Grande do Norte (Bezerra et al. 2003), áreas com reconhecida tectônica diferencial em andamento.

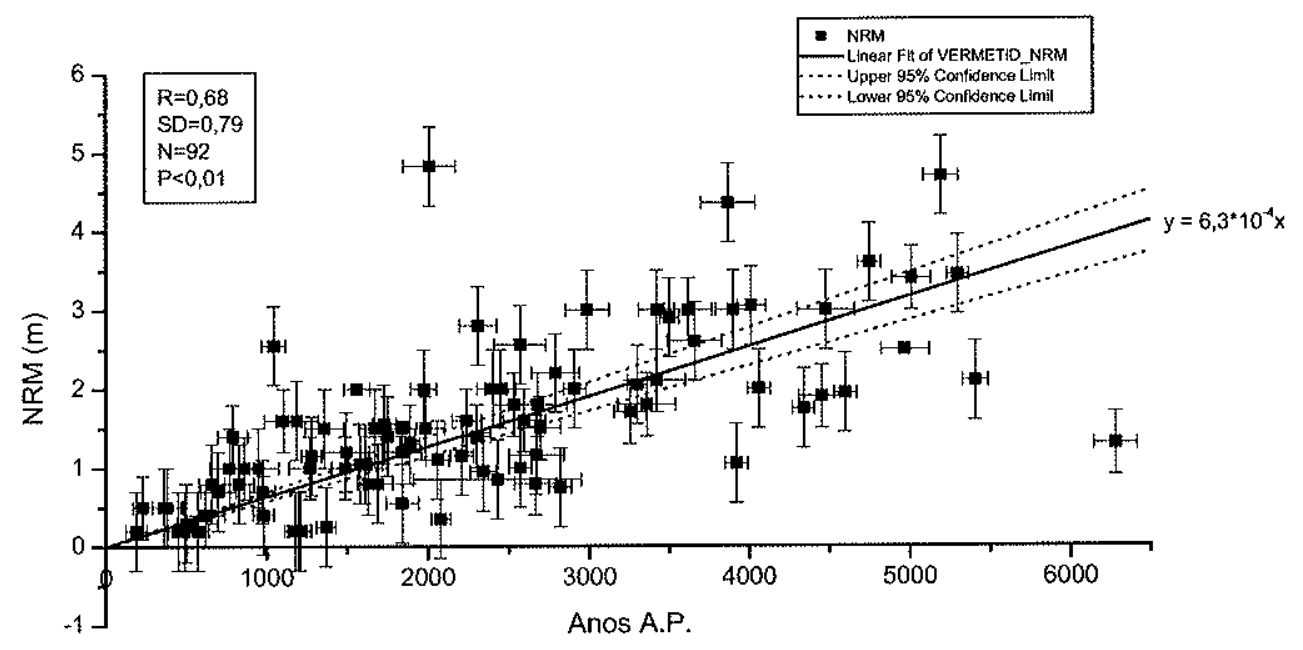

Figura 3.13. Posições do nivel relativo do mar (NRM) na costa brasileira nos últimos 6 mil anos (idade ${ }^{14} \mathrm{C}$ convencional) inferidas a partir de datação e nivelamento de tubos de vermetideos, conforme dados compilados por Angulo \& Lessa (1997) acrescidos dos obtidos por Angulo et al. (1999). O erro da estimativa do paleonivel varia de 0,4 a $0,5 \mathrm{~m}$. $\mathrm{R}=$ coeficiente de correlação, $\mathrm{SD}=$ desvio padrão do ajuste, $N=$ número de pontos e $\mathrm{P}=$ probabilidade de $\mathrm{R}$ ser zero. Extraído de Sawakuchi (2002).

Na costa setentrional do Brasil, onde os dados e modelos de variação de NRM são ainda muito escassos, a planicie macromaré de Bragança, nordeste do Pará (Behling et al. 2001, Cohen et al. 2005 apud Angulo et al. 2006), apresenta-se como única região estudada, no pais, onde se têm indícios de que o NRM mais alto do Holoceno é o atual. 
Evidências de variação de NRM no Pleistoceno têm sido relatadas no Brasil em áreas submersas e emersas. Na plataforma continental externa, a datação de sedimentos supostamente depositados próximo a antigas praias (oóides de calcita magnesiana, no Pará e Amazonas, e cascalhos bioclásticos, no Rio Grande do Sul), permitiu interpretar niveis do mar até $135 \mathrm{~m}$ abaixo do atual entre aproximadamente 19 e 17 ka AP (Milliman \& Barreto 1975, Kowsmann et al. 1977, Kowsmann \& Costa 1979). No Rio Grande do Sul, parte dos materiais datados ocorre associada a sistemas de escarpas e terraços considerados como de abrasão marinha prolongada, o que levou Corrêa (1996) e Corrêa e Toldo Jr. (2001) a admitir niveis do mar estáveis nas cotas -110 a $-100 \mathrm{~m}$, em cerca de $16 \mathrm{ka} A P, \mathrm{e}-70 \mathrm{a}-$ $60 \mathrm{~m}$, por volta de $11 \mathrm{ka} \mathrm{AP}$.

Com relação às evidências emersas, destacam-se os depósitos de praia em terraços com cotas mais elevadas (geralmente superiores a $5 \mathrm{~m}$ ) que aqueles atribuídos ao Holoceno. Os primeiros trabalhos no Brasil a relacionar explicitamente estes depósitos a transgressões pleistocênicas foram os de Suguio \& Martin (1978), nos estados de São Paulo e Rio de Janeiro, e Bittencourt et al. (1979), na costa entre Bahia e Pernambuco. Estes terraços foram atribuídos ao NRM estável da penúltima transgressão (Estágio Isotópico 5), ocorrido mundialmente por volta de $120 \mathrm{ka}$ AP e estimado por mesmos autores em $8 \pm 2 \mathrm{~m}$ acima do atual. A correlação cronológica foi reforçada por restos de corais encontrados na parte basal de terraços marinhos expostos na praia de Olivença, sul da Bahia, datados pelo método U/lo em 123,5 $\pm 5,7$ ka AP (Martin et al. 1982, Bernat et al. 1983). Na região de Touros (RN), Suguio et al. (2001), através de datação por TL, encontraram idade semelhante para terraços arenosos costeiros com $20 \mathrm{~m}$ de altitude. Interpretados como subaquosos, estes depósitos foram correlacionados por Barreto et al. (2002a) ao mesmo NRM alto, o qual estaria alçado, nessa região, por neotectônica.

Villwock et al. (1986) estenderam à planície costeira do Rio Grande do Sul a ocorrência de depósitos sedimentares ligados à penúltima transgressão e à transgressão pós-glacial, mas admitiram a existência adicional de outros dois niveis de terraços construtivos ligados a flutuações glácio-eustáticas mais antigas. A planície costeira foi assim descrita como a justaposição de quatro "sistemas laguna-barreira". Os dois sistemas mais elevados e antigos, denominados laguna-barreira I e II, corresponderiam a registros, até então não reconhecidos no país, de NRM altos glácio-eustáticos correlativos aos estágios isotópicos 9 e 7, respectivamente (Tomazelli \& Villwock 1996, 2000). O sistema lagunabarreira I é representado por areias eólicas muito pedogeneizadas, ancoradas em encostas cristalinas, preservadas em faixa SW-NE, a W da margem interna setentrional da laguna dos Patos. O sistema laguna-barreira II compreende areias eólicas e marinhas preservadas localmente a SW de Tramandaí, na parte interna da barreira geográfica que isola hoje as planícies lagunares de Patos e Mirim. Mais tarde, Martin et al. $(1988 a, b)$ correlacionaram ao sistema laguna-barreira II os terraços altos $(>12 \mathrm{~m})$ existentes em Icapara, município de Iguape, SP, em Itapema, SC, e no morro do Sambaqui, em Matinhos, PR. Os terraços arenocascalhosos de Matinhos e Itapema já haviam sido considerados como indicadores de NRM pretérito superior a $12 \mathrm{~m}$ por Bigarella \& Freire (1960) e Bigarella \& Becker (1975b), respectivamente. Depósitos eólicos de até $20 \mathrm{~m}$ de altitude ocorrem também na itha do $\mathrm{Mel}$ $P R$, entre o morro do Meio e o morro do Miguel.

A existência de terraços marinhos correlatos a NRM altos anteriores ao da penúltima transgressão é não suficientemente documentada, na maioria dos locais do Brasil onde foi sugerida. No estágio atual de conhecimento, o mais prudente é limitar-se a citar argumentos contra e a favor dessa existência. Os argumentos contra referem-se geralmente ao caráter inconclusivo dos dados sobre idade e/ou caráter marinho dos depósitos contidos nesses terraços. Entre eles, podem-se enumerar os seguintes: 
1. Conforme já comentado por Suguio et al. (2005), a inexistência de datações absolutas para os depósitos dos sistemas laguna-barreira I e II no Rio Grande do Sul não permite estabelecer correlações cronológicas seguras.

2. Os depósitos do sistema laguna-barreira I foram originalmente descritos como eólicos e a presença de depósitos eólicos foi admitida também no sistema laguna-barreira II. Em tese, depósitos eólicos podem ter alcançado as porções mais interiores da planície costeira sulrio-grandense durante niveis do mar altos mais recentes.

3. A dificuldade de reconhecimento de terraços altos correlativos aos sistemas lagunabarreira I e II tornam-se acentuadas em áreas costeiras com retrabalhamento eólico generalizado e recorrente, como todo o setor que vai de Garopaba (SC) a Tramandai (RS). Nessa área, as altitudes de topo dos depósitos correspondem freqüentemente ao efeito da ação superimposta do vento e não à deposição marinha. Autores que descreveram a detalhe a cobertura sedimentar de áreas compreendidas por este setor (Horn 1988, Tomazelli 1990, Giannini 1993, 2002, Caruso 1995) não identificaram a presença destes sistemas.

4. O mesmo pode ser aventado em relação ao terraço alto de Icapara (SP), situado numa região favorável ao transporte e acumulação eólica de sedimentos costeiros em excesso (antiga área de mar aberto, em zona de terminação deposicional de deriva litorânea, com face para o vento de SSE, predominante na região, e com anteparo a sotavento). Datações deste terraço por LOE em feldspato (Guedes 2003) indicam idades de 9,5 $\pm 0,9$ ka (LVD798) e 16,1 $\pm 6,0$ ka (LVD799) e são compativeis com a hipótese de retrabalhamento eólico de terraço depositado após a Penúltima Transgressão.

5. Angulo (1992) reinterpreta os terraços de Matinhos como correspondentes a paleonivel do mar 6,5 a 10,5m acima do atual, portanto correlacionável à penúltima transgressão. Segundo o autor, no Paraná, outras "altitudes superiores a $10 \mathrm{~m}$, como as que se verificam na ilha do Mel, estão associadas à ocorrência de dunas eólicas" (p.91).

Entre os indícios ou possiveis evidências da existência no Brasil de terraços costeiros altos mais antigos que os de cerca de $120 \mathrm{ka} \mathrm{AP}$, destacam-se:

1. Barreto et al. (2002a) obtiveram idades TL de $210 \mathrm{ka}$ AP, correlacionável portanto ao Estágio Isotópico 7, para terraços sedimentares ao sul de Natal (RN), interpretados como marinhos.

2. Os depósitos atribuídos aos sistemas lagunambarreira I e II do Rio Grande do Sul distinguem-se de depósitos marinhos e eólicos supostamente mais recentes por seu elevado grau de consolidação. Depósitos arenáceos extremamente consolidados ocorrem por sob paleodunas eólicas da geração 2 em Campo Bom, Jaguaruna, SC, na continuação, para NE, da faixa de ocorrência do sistema laguna-barreira 1 mapeada por Tomazelli \& Villwock (2000).

3. Nessa localidade, a geração eólica 2 apresentou idade TL de $6,1 \pm 0,7 \mathrm{ka}$ (Giannini et al. $2007 \mathrm{c}$ ), enquanto os depósitos consolidados sotopostos foram datados pelo mesmo método em $702 \pm 85$ ka AP (LVD722).

\subsubsection{Fisiografia da plataforma continental}

A costa brasileira, principalmente na Região Sul-Sudeste, alterna trechos retilíneos e contínuos, adjacentes a planícies litorâneas de mais de uma dezena de quilômetros de largura, com trechos irregulares, interrompidos por promontórios do embasamento, junto a planícies mais estreitas. Os principais exemplos do primeiro tipo de costa encontram-se no setor entre Chui (RS) e o cabo de Santa Marta, em Laguna (SC) e no que vai aproximadamente de Matinhos (PR) até Santos-Bertioga (SP). Esta subdivisão é a mais evidente manifestação de uma compartimentação fisiográfica que não se limita à costa e plataforma continental, mas estende-se à distribuição de elementos magmáticos e estruturais 
na hinterlândia e bacias marginais adjacentes (Quadro 3.1). Com base na análise integrada da distribuição desses elementos e das mudanças geomorfológicas da costa, seis setores principais podem ser reconhecidos, de sul para norte (rumo de abertura do atântico Sul):

(1) O setor costeiro quase contínuo a sul de Laguna coincide em extensão com a Bacia de Pelotas, no lado do mar, e com o domínio das grandes lagunas que caracterizam a planície litorânea gaúcha, no lado do continente. Ao longo deste setor, o aumento escalonado, rumo sul, na profundidade e extensão dos três depocentros em que se subdivide a Bacia de Pelotas (Carvalho \& Francisconi 1981) é acompanhado pelo alargamento da plataforma continental e pela ampliação do sistema lagunar. Desse modo, valeria ai a correlação traçada por alguns autores no Rio Grande do Sul (Villwock 1984, Tomazelli 1990), considerando a planície costeira quaternária como extensão aflorante e mais ocidental da Bacia de Pelotas, em solução de continuidade com os sedimentos submersos da plataforma continental. O domínio aflorante da Bacia do Paraná e a serra Geral atingem sua máxima aproximação à costa na região do Sinclinal de Torres, estrutura flexural de orientação NW com atividade principal no Fanerozóico. No cabo de Santa Marta, em Laguna (SC), limite setentrional do setor, observa-se mudança mais ou menos brusca na direção regional da linha de costa, de ENE a NE, ao sul, para NNE a N-S, ao norte.

(2) O setor costeiro de orientação geral NNE que se estende de Imbituba à coordenada aproximada de Itajaí-Joinville é mais escarpado, recortado e de plataforma continental interna mais estreita e íngreme que os setores vizinhos. Ele coincide com a Plataforma de Florianópolis (Giannini 1993, Angulo et al. 1999), paleoalto estrutural do Terciário inferior que separa as bacias de Pelotas e Santos sob a forma de faixa alongada E-W (Macedo 1987). O prolongamento desta faixa ao interior abrange as intrusões alcalinas de Lajes e Anitápolis.

(3) A zona de ocorrência da Bacia de Santos é acompanhada no sopé continental pelo paleoalto do Platô de São Paulo (Carvalho \& Francisconi 1981, Macedo 1987) e no continente pela serra do Mar, que se estende de Joinville a Angra dos Reis (Almeida 1953, 1975). Quanto à geomorfologia costeira, este trecho pode ser subdividido em três segmentos. O segmento sul, equivalente ao litoral meio-norte catarinense, e, principalmente, o norte, entre São Sebastião (SP) e Parati (RJ), são mais recortados e com plataforma mais estreita que o segmento intermediário, da ilha de São Francisco (SC) a Santos-Bertioga (SP), onde se tornam freqüentes as praias de dezenas de quilômetros de extensão, típicas do litoral sul-paulista e paranaense. Ao longo deste segmento central, a direção regional da costa muda gradualmente de N-S para NE, mas a importância das estruturas NE é superada por aquelas direcionadas segundo E-W e NW, tanto na plataforma submersa como na área emersa adjacente. A estruturação NW relaciona-se com os enxames de fraturas e diques, associados ao Arco de Ponta Grossa, que interceptam a costa nessa região. A existência de estruturas com orientação transversal à serra do Mar facilitou a incisão e erosão remontante fluvial o que ajuda a explicar o maior recuo da serra nesse segmento (Almeida 1953, 1964, Giannini 1985, Giannini et al. 2007b), bem como a formação das baías estuarinas de São Francisco, Guaratuba, Paranaguá, Laranjeiras e Trapandé, além do vale do rio Ribeira de Iguape. A divisão tripartite da geomorfologia da costa adjacente à serra do Mar é acompanhada pela segmentação da Bacia de Santos em dois embaiamentos, sul e norte, separados por um paleoalto. O prolongamento para $W$ do segmento central abrange as intrusões alcalinas do Estado do Paraná (de sul para norte: Mato Preto, Ponta Grossa, Sete Quedas, Tunas, Barra do Teixeira, Banhadão, São Jerônimo) e a maior parte das de São Paulo (Cananéia, Jacupiranga, Itapirapuã, Juquiá, Itanhaém, Monte de Trigo), conforme o mapa de Ulbrich \& Gomes (1981). Trata-se de intrusões em sua grande maioria de idade cretácea inferior, pertencentes assim ao primeiro episódio de magmatismo alcalino da costa sudeste brasileira.

(4) O trecho entre Angra dos Reis e Cabo Frio coincide com o Alto de Cabo Frio, limítrofe entre a Bacia de Santos e a de Campos. Distingue-se do setor vizinho a sul pela presença 
intensificada de praias de bolso, pelo estreitamento gradual da plataforma continental e pela maior manifestação de elementos estruturais de direção $\mathrm{E}-\mathrm{W}$, o que determina a própria orientação geral da costa nesse setor. Abrange a maioria das intrusões alcalinas do Estado do Rio de Janeiro, como Mendanha, Canaã, Cabo Frio, Tanguá, Rio Bonito, Serrinha, Morro de São João, Tinguá, Barra do Piraí, Morro Redondo, Itatiaia e Itaúna, além de Campos do Jordão e Passa Quatro, no leste paulista (Ulbrich \& Gomes 1981; Almeida 1991). Todas estes corpos pertencem ao segundo episódio de intrusões alcalinas da costa sudeste, do Cretáceo inferior ao Paleógeno.

(5) A norte de Cabo Frio, já em zona adjacente à Bacia de Campos, a costa readquire orientação preferencial NE a NNE e as praias de bolso deixam de ser dominantes. A partir deste trecho, até a costa oriental do Rio Grande do Norte, a cobertura quase ininterrupta do embasamento pré-cenozóico pelos sedimentos da Formação Barreiras, a relativa monotonia da plataforma continental, sempre ingreme e estreita (predominantemente menor que 50 $\mathrm{km}$ ), e a pouca expressão estrutural ou continuidade lateral aparente dos paleoaltos entre bacias marginais dificultam o reconhecimento de compartimentos fisiográfico-estruturais ao longo da costa. O mergulho regional para $E$ da superficie que aplaina o topo da Formação Barreiras (King 1956) e a ausência de sistemas lagunares ativos com papel de armadilhas de sedimentos terrígenos comparáveis ao da Região Sul possibilita a chegada de grandes rios à costa. A relação da distribuição geográfica destes rios com os elementos tectônicoestruturais evidentes nas bacias marginais e na plataforma, incluindo numerosos cânions (França 1979), é uma possibilidade ainda por investigar. Por exemplo, a desembocadura do rio Paraiba do Sul (RJ) e a grande saliência a ela associada na margem de plataforma ocorram, conforme Carvalho \& Francisconi (1981), adjacentes a um dos depocentros semiisolados da Bacia de Campos.

6) A partir da costa noroeste do Rio Grande do Norte, a plataforma continental passa a alargar-se gradualmente rumo $W$, até alcançar cerca de $300 \mathrm{~km}$ na região do cone do Amazonas. Este alargamento reflete provavelmente a influência da abertura gradual do Rift do Atlântico Norte, desde a Bacia da Foz do Amazonas, a W, até a Bacia Potiguar, a $E$ (Brandão \& Feijó 1994). As rias estuarinas tornam-se mais pronunciadas a $W$ da baía de São José (região de São Luís, MA), situada na extensão costeira do paleoalto que separa as bacias marginais de Barreirinhas, a E, e Pará-Maranhão, a W. 
Quadro 3.1. Setores fisiográficos da costa brasileira e principais elementos geomorfológicos, tectono-estruturais e magmáticos associados nas áreas emersa e submersa adjacentes. Dados da margem continental baseados em Zembruskci (1979), França (1979) e Palma (1979).

\begin{tabular}{|c|c|c|c|c|c|c|c|}
\hline \multirow[t]{2}{*}{ Setor } & \multicolumn{2}{|c|}{ Elementos continentais } & \multicolumn{3}{|c|}{ Características predominantes da costa } & \multicolumn{2}{|c|}{ Elementos oceânicos } \\
\hline & De relevo & \begin{tabular}{|c|}
$\begin{array}{c}\text { Tectono- } \\
\text { estruturais e } \\
\text { magmáticos }\end{array}$ \\
\end{tabular} & Orientação & Morfologia praial & $\begin{array}{c}\text { Sistemas } \\
\text { deposicionais } \\
\text { principais }\end{array}$ & $\begin{array}{c}\text { Fisiográficos (e declive } \\
\text { da plataforma) }\end{array}$ & $\begin{array}{c}\text { Tectono-estruturais e } \\
\text { magmáticos }\end{array}$ \\
\hline $\begin{array}{l}\text { 1. Chuí (RS) - } \\
\text { Laguna (SC) }\end{array}$ & $\begin{array}{l}\text { Serra Geral (substrato } \\
\text { mesozóico) }\end{array}$ & $\begin{array}{c}\text { Arco do Rio } \\
\text { Grande (NW), } \\
\text { Sinclinal de Torres } \\
\text { (NW) }\end{array}$ & ENE a NE & $\begin{array}{l}\text { Praias muito extensas } \\
\text { (dezenas a centenas } \\
\text { de } \mathrm{km} \text { ) }\end{array}$ & $\begin{array}{l}\text { Lagunas e barreiras } \\
\text { transgressivas, com } \\
\text { evolução progradante }\end{array}$ & $\begin{array}{c}\text { Escarpas e cone do Rio } \\
\text { Grande }\left(0,03 \text { a } 0,05^{\circ} ;\right. \\
0,02 \text { a } 0,09^{\circ} \mathrm{na} \\
\text { plataforma interna) }\end{array}$ & $\begin{array}{c}\text { Bacia de Pelotas } \\
\text { (intensa sedimentaçăo } \\
\text { pós-rift) }\end{array}$ \\
\hline $\begin{array}{l}\text { 2. Laguna - } \\
\text { Joinville (SC) }\end{array}$ & $\begin{array}{l}\text { Serra do Taboleiro } \\
\text { (substrato pré- } \\
\text { cambriano) }\end{array}$ & $\begin{array}{l}\text { Intrusões alcalinas } \\
\text { de Lajes e } \\
\text { Anitápolis }\end{array}$ & NNE & $\begin{array}{l}\text { Praias restritas }(<12 \\
\mathrm{km} \text {, na maioria) }\end{array}$ & $\begin{array}{c}\text { Planicies de cordōes } \\
\text { e vales incisos } \\
\text { afogados (baías e } \\
\text { lagunas) } \\
\end{array}$ & $\begin{array}{l}\text { Vales de Santa Marta, } \\
\text { canal de itajaí ( } 0,06 \text { a } \\
0,05^{\circ} ; 0,26 \text { a } 0,07^{\circ} \text { na } \\
\text { plataforma interna) }\end{array}$ & $\begin{array}{l}\text { Paleoalto (Zona de } \\
\text { Cisalhamento) de } \\
\text { Florianópolis }\end{array}$ \\
\hline $\begin{array}{l}\text { 3. Joinville - } \\
\text { Angra dos } \\
\text { Reis (RJ) }\end{array}$ & \multirow{4}{*}{$\begin{array}{l}\text { Serra do Mar } \\
\text { (substrato pré- } \\
\text { cambriano), Superficie } \\
\text { Sul-Americana } \\
\text { mergulhando para W }\end{array}$} & & & & & & Bacia de Santos \\
\hline $\begin{array}{l}\text { 3A. Joinville- } \\
\text { São Francisco } \\
\text { do Sul (SC) }\end{array}$ & & & NNW a NS & $\begin{array}{l}\text { Praias restritas }(<12 \\
\mathrm{km} \text {, na maioria })\end{array}$ & Planícies de cordões & $\begin{array}{c}\left(0,04 \text { a } 0,03^{\circ} \text {; em torno }\right. \\
\text { de } 0,07^{\circ} \text { na plataforma } \\
\text { interna) }\end{array}$ & $\begin{array}{l}\text { Bacia de Santos: } \\
\text { embaiamento sul }\end{array}$ \\
\hline $\begin{array}{c}\text { 3B. São } \\
\text { Francisco do } \\
\text { Sul - Boracéia } \\
\text { (SP) }\end{array}$ & & $\begin{array}{c}\text { Arco de Ponta } \\
\text { Grossa, Bacia de } \\
\text { Curitiba, intrusões } \\
\text { do } 1^{\circ} \text { episódio de } \\
\text { magmatismo } \\
\text { alcalino } \\
\end{array}$ & $\mathrm{NE}$ & $\begin{array}{l}\text { Praias extensas ( }>12 \\
\mathrm{~km}, \text { na maioria) }\end{array}$ & $\begin{array}{l}\text { Planicies de cordōes } \\
\text { e vales incisos } \\
\text { afogados e (baias } \\
\text { estuarinas) }\end{array}$ & $\begin{array}{c}\text { Canais Cananéia e } \\
\text { Queimada }\left(0,03 \text { a } 0,02^{\circ}\right. \\
0,05 \text { a } 0,03^{\circ} \text { na } \\
\text { plataforma interna })\end{array}$ & $\begin{array}{c}\text { Bacia de Santos: } \\
\text { Paleoalto central, Zona } \\
\text { de Cisalhamento de } \\
\text { Curitiba }\end{array}$ \\
\hline $\begin{array}{l}\text { 3C. Boracéia - } \\
\text { Angra dos } \\
\text { Reis (RJ) }\end{array}$ & & & $\begin{array}{c}\text { Muito variável: NS a } \\
\text { EW }\end{array}$ & $\begin{array}{l}\text { Praias de boiso }(<5 \\
\text { km, na maioria) }\end{array}$ & Praias ancoradas & $\begin{array}{c}\text { Canais S. Sebastiāo, } \\
\text { Búzios e llha Grande } \\
\left(0,05 \text { a } 0,04^{\circ} ; 0,05 \text { a }\right. \\
0,51^{\circ} \text { na plataforma } \\
\text { interna) }\end{array}$ & $\begin{array}{l}\text { Bacia de Santos: } \\
\text { embaiamento norte }\end{array}$ \\
\hline $\begin{array}{l}\text { 4. Angra dos } \\
\text { Reis - Cabo } \\
\text { Frio (RJ) }\end{array}$ & $\begin{array}{l}\text { Inversão de mergulho } \\
\text { da Superficie Sul- } \\
\text { Americana, para } W \text {, a } \\
\text { sul, e para } E \text {, a norte }\end{array}$ & $\begin{array}{l}\text { Bacias de São } \\
\text { Paulo, Taubaté e } \\
\text { Resende, } \\
\text { intrusões do } 2^{\circ} \\
\text { episódio de } \\
\text { magmatismo } \\
\text { alcalino }\end{array}$ & EW a NE & $\begin{array}{c}\text { Praias extensas }(>12 \\
\mathrm{km}) \text { nas flechas } \\
\text { arenosas }\end{array}$ & $\begin{array}{c}\text { Flechas arenosas e } \\
\text { lagunas }\end{array}$ & $\begin{array}{c}\text { Canais Rio de Janeiro e } \\
\text { Cabo Frio (em torno de } \\
0,04^{\circ} ; 0,07 \text { a } 0,51^{\circ} \text { na } \\
\text { plataforma interna) }\end{array}$ & $\begin{array}{l}\text { Alinhamento de Cabo } \\
\text { Frio, Zona de } \\
\text { Cisalhamento do Rio } \\
\text { de Janeiro }\end{array}$ \\
\hline $\begin{array}{l}\text { 5. Cabo Frio } \\
\text { - Touros } \\
\text { (RN) }\end{array}$ & $\begin{array}{c}\text { Superficie Sul- } \\
\text { Americana } \\
\text { mergulhando para E }\end{array}$ & $\begin{array}{c}\text { Formaçāo } \\
\text { Barreiras, grandes } \\
\text { desembocaduras } \\
\text { fluviais }\end{array}$ & NS a NE & $\begin{array}{c}\text { Praias extensas }(>12 \\
\mathrm{km}) \text { e praias restritas } \\
\text { de falésias }\end{array}$ & $\begin{array}{l}\text { Vales incisos } \\
\text { afogados e } \\
\text { assoreados e } \\
\text { planícies de cordōes; } \\
\text { estuários a } \mathrm{N} \text { do } \\
\text { Recôncavo }\end{array}$ & $\begin{array}{c}\text { Banco de Abrolhos, } \\
\text { cânions Belmonte, } \\
\text { Camamu, Salvador, } \\
\text { Itaparica, Real, Vaza } \\
\text { Barris, Japaratuba, } \\
\text { Sapucaia, } S \text {. Francisco e } \\
\text { Natal }\left(0,03 \text { a } 0,14^{\circ} ; 0,03\right. \\
\text { a } 0,60^{\circ} \text { na plataforma } \\
\text { intema) } \\
\end{array}$ & $\begin{array}{l}\text { Bacias marginais } \\
\text { orientais (Campos a } \\
\text { Pernambuco-Paraiba) }\end{array}$ \\
\hline $\begin{array}{l}\text { 6. Touros - } \\
\text { Oiapoque } \\
\text { (AP) }\end{array}$ & & $\begin{array}{c}\text { Formação } \\
\text { Barreiras }\end{array}$ & EW a WNW & $\begin{array}{l}\text { Praias extensas }(>12 \\
\mathrm{km})\end{array}$ & Rias estuarinas & $\begin{array}{c}\text { Cone do Amazonas. } \\
\left(0,05 \text { a } 0,03^{\circ} ; 0,05 \text { a }\right. \\
0,01^{\circ} \text { na plataforma } \\
\text { interna) }\end{array}$ & $\begin{array}{c}\text { Bacias marginais } \\
\text { setentrionais (Potiguar } \\
\text { a Foz) }\end{array}$ \\
\hline
\end{tabular}


A idéia de existência de grandes alinhamentos continentais-oceânicos transversais à costa brasileira já está presente em trabalhos clássicos, merecendo menção o "eixo de compartimentação tectônica passando por Lages e Anitápolis", de Paiva (1933) e a "linha tectônica Torres-Posadas", de Leinz (1949). Fúlfaro et al. (1974) interpretaram as mudanças de geomorfologia ao longo da costa paulista dentro de um modelo de compartimentação da região segundo três linhas estruturais transversais à costa, incluindo dentre elas o prolongamento oriental do alinhamento de Paranapanema, no flanco nordeste do Arco de Ponta Grossa. A idéia de existência destes grandes alinhamentos voltou à tona com os resultados do projeto Remac (Reconhecimento da Margem Continental Brasileira), a partir dos quais vários trabalhos tentaram explicar a variação de fisiografia ao longo da margem continental brasileira em termos de zonas de fratura e lineamentos oceânicos, com extensões no continente (Asmus 1978, 1981, 1983, Asmus \& Carvalho 1978, Carvalho \& Francisconi 1981, Guazelli \& Carvalho 1981). As faixas latitudinais aqui enumeradas 2, de Laguna a Joinville, e 4, de Angra dos Reis a Cabo Frio, coincidem de modo aproximado com dois dos "sistemas lineamentos submarinos - alinhamentos continentais" interpretados por Asmus (1981), o Florianópolis Rio Uruguai e o Paranapanema - Rio de Janeiro, respectivamente. Macedo (1987), Pereira \& Macedo (1990) e Macedo et al. (1991) caracterizam aquelas duas faixas latitudinais, bem como a faixa adjacente ao paleoalto entre os embaiamentos sul e norte da Bacia de Santos, como zonas de falhas de transferência (de Florianópolis, Curitiba e Rio de Janeiro, respectivamente), ligadas a acomodação relativa de segmentos crustais vizinhos com contrastes de taxas de estiramento (Figura 3.14). Admitem, por exemplo, ao longo da Plataforma de Florianópolis, uma zona de cisalhamento que separaria e deslocaria em rejeito dextrogiro o bloco de crosta continental estirada do Platô de São Paulo, a norte, em relação ao bloco de crosta oceânica adjacente a Elevação do Rio Grande, a sul.

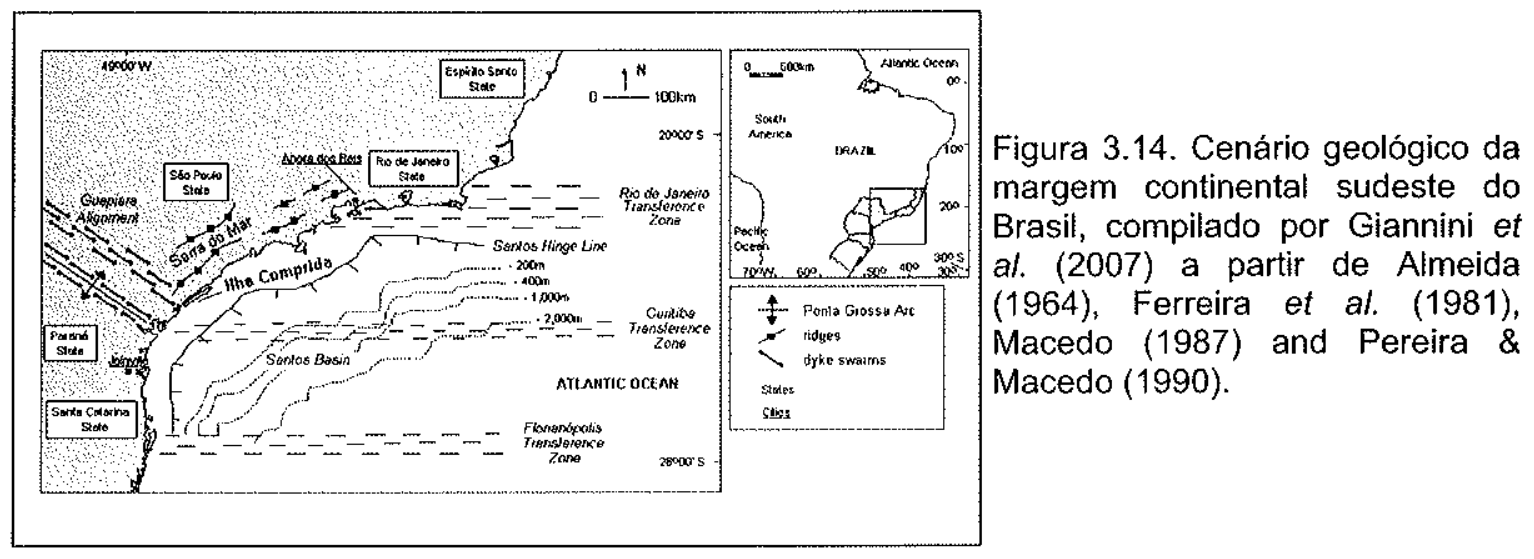

Estas zonas de transferência teriam prolongamento continente adentro, guardando sob este aspecto correspondência com os sistemas alinhamento-lineamento propostos por Asmus (1981). Seriam faixas preferenciais de recorrência de processos tectônicos, incluindo implantação de hemi-grábens encaixados nas falhas $\mathrm{NE}$, daí a coincidência latitudinal da zona de transferência de Curitiba com a Bacia de Curitiba e da zona de transferência do Rio de Janeiro com as bacias de São Paulo, Taubaté e Resende (Pereira \& Macedo 1990). Apesar desses indícios, a expressão e continuidade estrutural em superficie de tais feições continentais-oceânicas é antes inferida que observada (Giannini 1993). Se for possivel generalizar a conclusão que Almeida (1991) obteve em relação ao 
Alinhamento de Cabo Frio, a característica que melhor expressa este tipo de feição é a de alinhamento magmático, cuja disposição não seria a de linhas $E W$, e sim, na forma de arcos, relacionados aos circulos mínimos de rotação das placas continentais ao decorrer de seu afastamento. Durante o esforço distensional na separação das placas, o manto sofreria fusão parcial e o magma resultante seria alojado preferencialmente ao longo de falhas subcrustais associadas a zonas de transferência (Almeida 1991). Com isto, tornase possível supor (Giannini 1993) que intrusões magmáticas alinhem-se ao longo de um só arco de círculo de expressão regional, conforme Almeida (1991), e ao mesmo tempo, ao longo de diferentes falhas contidas em zonas de transferência $\mathrm{EW}$, tais como as inferidas por Macedo et al. (1991).

De acordo com o modelo de extensão litosférica assimétrica (Wernicke 1981, 1985, Lister et al. 1986), zonas de transferência podem separar segmentos de placas litosféricas de diferentes posições em relação a falhas de descolamento (detachment faults) e com arquiteturas estruturais contrastantes (Figura 3.15): de um lado, margens de placa situadas na zona onde a falha de descolamento é rasa e de baixa inclinação, caracterizadas por intenso falhamento rift subparalelo à costa, de mergulho variável; de outro, margens de placa sobre a porção profunda e íngreme da falha de descolamento, caracterizadas por estruturação mais simples à base de falhas normais pouco rotacionais, relacionadas a reativação por abaulamento flexural de direções preexistentes. Esta flexura estaria ligada à intumescência termal por alojamento infra-placa de magma máfico resultante de fusão do manto (Etheridge et al. 1990, Lister et al. 1991). Estes dois tipos de margens têm sido denominados respectivamente de proximal e distal (Wernicke 1985, Wernicke \& Tilke 1989), adotado critério de proximidade da falha de descolamento em relação à superfície, ou de inferior e superior (Lister et al. 1986, 1991, Etheridge et al. 1990, Hansen et al. 1993), adotado critério de posição vertical da placa em relação à mesma falha. Inúmeras diferenças estruturais têm sido apontadas não somente entre os dois tipos de margens de placa, mas também entre eles e as zonas de transferência (Quadro 3.2), as quais podem tanto separar margens contrastantes (sendo então chamadas de zonas de reversão) como simplesmente atravessar um mesmo tipo de margem. Se este modelo geral é admitido, a suposição das zonas de transferência de Florianópolis, Curitiba e Rio de Janeiro (Figura 3.14) explica a individualidade fisiográfica das faixas latitudinais correspondentes, bem como a semelhança entre elas no que se refere a dois aspectos previstos no modelo: a incidência de magmatismo de fonte profunda (Etheridge et al. 1990, Lister et al. 1991) que ai encontraria conduto (Almeida 1991) e a coincidência, grosso modo, com inflexões no mapa de linha de charneira (Wernicke \& Tilke 1989). 


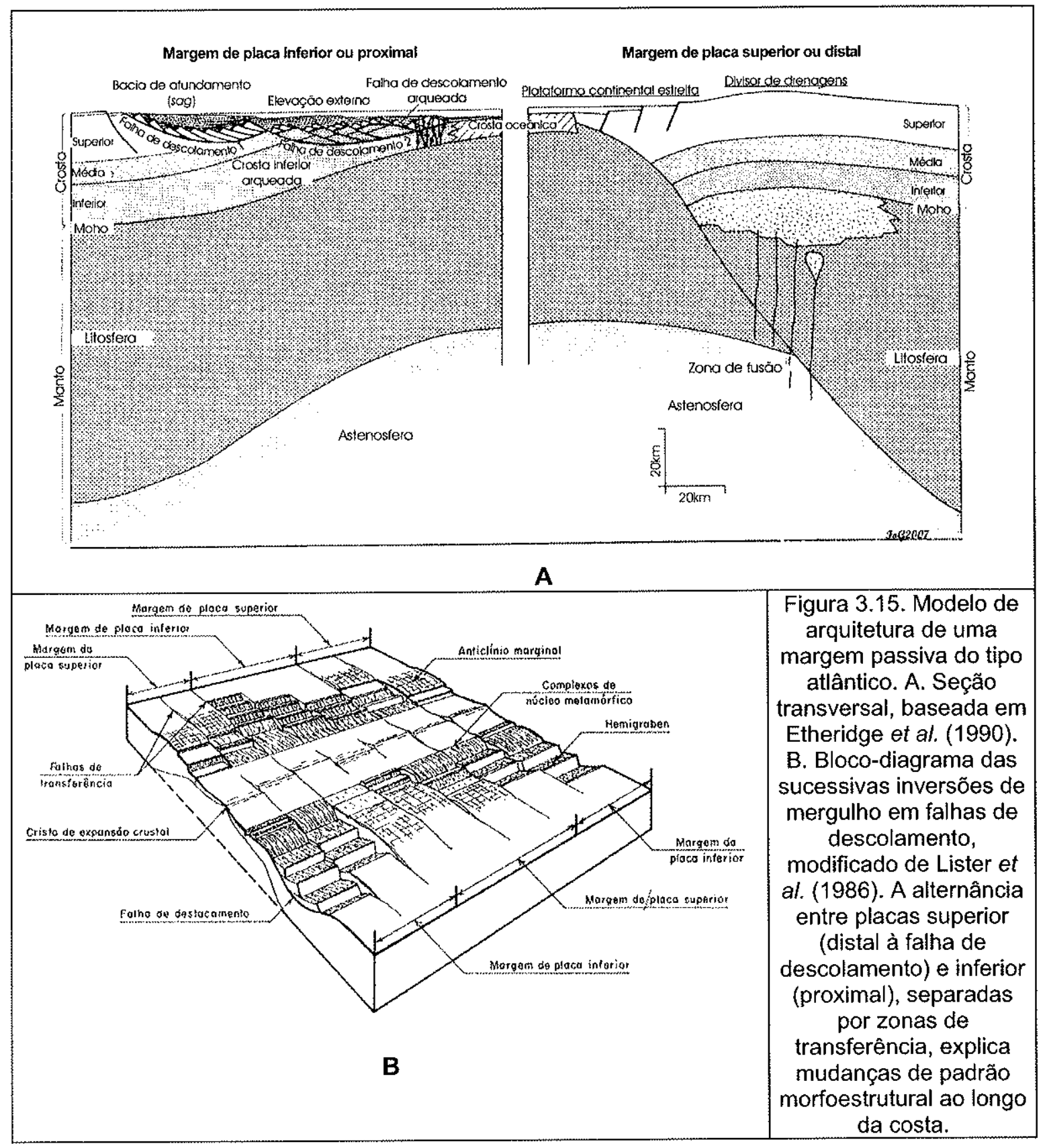


Quadro 3.2. Principais critérios geotectônicos, estruturais e geomorfológicos para o reconhecimento de tipos de segmentos de placas e zonas de transferência em margens passivas do tipo atlântico.

\begin{tabular}{|c|c|c|c|c|}
\hline Critério & $\begin{array}{l}\text { Placa inferior ou } \\
\text { proximal }\end{array}$ & $\begin{array}{c}\text { Placa superior } \\
\text { ou distal }\end{array}$ & $\begin{array}{c}\text { Zona de } \\
\text { transferência }\end{array}$ & $\begin{array}{l}\text { Referências } \\
\text { bibliográficas }\end{array}$ \\
\hline $\begin{array}{l}\text { Afinamento e estiramento da } \\
\text { litosfera }\end{array}$ & $\begin{array}{l}\text { Discreto, } \\
\text { concentrado na } \\
\text { parte superior, } \\
\text { crustal }\end{array}$ & $\begin{array}{l}\text { Acentuado, } \\
\text { concentrado na } \\
\text { parte inferior }\end{array}$ & $\begin{array}{l}\text { Acomodação } \\
\text { de } \\
\text { estiramentos } \\
\text { contrastantes }\end{array}$ & $\begin{array}{l}\text { Wernicke \& Tilke } \\
\text { (1989), Lister et al. } \\
\text { (1991) }\end{array}$ \\
\hline $\begin{array}{l}\text { Aproximação da astenosfera e } \\
\text { adição de calor à crosta }\end{array}$ & & & & $\begin{array}{c}\text { Wernicke \& Tilke } \\
\text { (1989), Etheridge et } \\
\text { al. (1990), Lister et al. } \\
\text { (1991) }\end{array}$ \\
\hline $\begin{array}{l}\text { Adensamento da litosfera, com } \\
\text { tendência a afundamento }\end{array}$ & & & & Hansen et al. (1993) \\
\hline $\begin{array}{l}\text { Soerguimento e espessamento } \\
\text { crustal, com formação de } \\
\text { escarpas costeiras }\end{array}$ & & & & $\begin{array}{c}\text { Wernicke \& Tilke } \\
\text { (1989), Etheridge et } \\
\text { al. (1990), Lister et al. } \\
\text { (1991), Hansen et al. } \\
\text { (1993) }\end{array}$ \\
\hline Tectônica sin-rift & $\begin{array}{l}\text { Subsidência } \\
\text { intensa }\end{array}$ & $\begin{array}{l}\text { Possibilidade de } \\
\text { soerguimento }\end{array}$ & & $\begin{array}{c}\text { Etheridge et al. } \\
(1990)\end{array}$ \\
\hline $\begin{array}{l}\text { Extensão oblíqua } \\
\text { (transtensão) }\end{array}$ & & & & $\begin{array}{l}\text { Etheridge et al. } \\
\quad(1990)\end{array}$ \\
\hline Falha de descolamento & Rasa $(<10 \mathrm{~km})$ & Profunda & & $\begin{array}{c}\text { Wernicke \& Tilke } \\
\text { (1989), Lister et al. } \\
\text { (1991) }\end{array}$ \\
\hline Estilo estrutural & $\begin{array}{l}\text { Falhas rotacionais } \\
\text { complexas }\end{array}$ & $\begin{array}{l}\text { Abaulamento } \\
\text { flexural }\end{array}$ & $\begin{array}{c}\text { Falhas } \\
\text { transcorrentes } \\
\text { profundas }\end{array}$ & $\begin{array}{c}\text { Wernicke \& Tilke } \\
\text { (1989), Lister et al. } \\
\text { (1991), Hansen et al. } \\
\text { (1993) }\end{array}$ \\
\hline Grandes bacias rift & & $\begin{array}{c}\text { Escassas a } \\
\text { ausentes }\end{array}$ & & $\begin{array}{c}\text { Etheridge et al. } \\
(1990)\end{array}$ \\
\hline $\begin{array}{l}\text { Tectônica continental } \\
\text { recorrente: hemi-grábens }\end{array}$ & & & & $\begin{array}{c}\text { Macedo (1987), } \\
\text { Pereira \& Macedo } \\
\text { (1990), Macedo et al. } \\
\text { (1991) }\end{array}$ \\
\hline $\begin{array}{l}\text { Limites de hemi-grábens } \\
\text { (falhas extensionais de grande } \\
\text { rejeito) e mergulho do topo dos } \\
\text { blocos basculados }\end{array}$ & $\begin{array}{l}\text { Para o lado do } \\
\text { continente }\end{array}$ & Para o lado do mar & $\begin{array}{l}\text { Falhas normais } \\
\text { difusas, com } \\
\text { inversão de } \\
\text { mergulho }\end{array}$ & $\begin{array}{c}\text { Wernicke \& Tilke } \\
\text { (1989), Etheridge et } \\
\text { al. (1990), Lister et al. } \\
\text { (1991) }\end{array}$ \\
\hline $\begin{array}{l}\text { Núcleo de complexo } \\
\text { metamórfico tectonicamente } \\
\text { positivo }\end{array}$ & & & & Lister et al. (1991) \\
\hline $\begin{array}{l}\text { Tendência para exposição de } \\
\text { embasamento de crosta } \\
\text { inferior }\end{array}$ & & & & Hansen et al. (1993) \\
\hline $\begin{array}{l}\text { Geometria da linha de } \\
\text { charneira }\end{array}$ & $\begin{array}{l}\text { Côncava para o } \\
\text { mar, com baías de } \\
\text { afogamento por } \\
\text { subsidência rápida }\end{array}$ & Saliente para o mar & Inflexionada & $\begin{array}{l}\text { Wernicke \& Tilke } \\
\text { (1989), Hansen et al. } \\
\text { (1993) }\end{array}$ \\
\hline $\begin{array}{l}\text { Largura da plataforma } \\
\text { continental }\end{array}$ & $\begin{array}{c}\text { Grande (centena de } \\
\text { km) }\end{array}$ & $\begin{array}{l}\text { Pequena (poucas } \\
\text { dezenas de } \mathrm{km} \text { ) }\end{array}$ & Variável & $\begin{array}{c}\text { Etheridge et al. } \\
\text { (1990), Hansen et al. } \\
(1993)\end{array}$ \\
\hline $\begin{array}{l}\text { Intumescência termal por } \\
\text { magmatismo basáltico infra- } \\
\text { placa }\end{array}$ & & & & Lister et al. (1991) \\
\hline $\begin{array}{l}\text { Magmatismo pós-rift de fonte } \\
\text { infra-placa na hinterlândia, por } \\
\text { fusão parcial do manto }\end{array}$ & & & & $\begin{array}{l}\text { Etheridge et al. } \\
\text { (1990), Almeida } \\
\text { (1991) }\end{array}$ \\
\hline Sedimentação sin e pós-rift & $\begin{array}{l}\text { Espessa (vários } \\
\text { milhares de } \mathrm{m} \text { ) }\end{array}$ & $\begin{array}{l}\text { Delgada (poucos } \\
\text { milhares de } \mathrm{m} \text { ) }\end{array}$ & & $\begin{array}{c}\text { Wernicke \& Tilke } \\
\text { (1989) }\end{array}$ \\
\hline
\end{tabular}


Ainda de acordo com o modelo das margens de placa assimétricas, as faixas latitudinais compreendidas entre as três supostas zonas de transferência podem pertencer tanto ao tipo proximal ou inferior quanto ao distal ou superior. Comparando as margens complementares de África e América do Sul, Etheridge et al. (1990) e Lister et al. (1991) admitem uma inversão no tipo de margem na "zona de transferência Walvis - Rio Grande", a qual interceptaria a costa atlântica sul-americana na faixa de latitudes entre $28^{\circ} \mathrm{S}$ e $30^{\circ} \mathrm{S}$, equivalente ao setor Florianópolis - Porto Alegre. A sul desta faixa, a margem de placa proximal seria evidenciada pela maior largura da plataforma e pela cobertura por bacias rift espessas. A norte, as evidências de margem distal seriam a presença de escarpas proeminentes no limite interno da planície litorânea e, segundo Etheridge et al. (1990), o "vulcanismo máfico intraplaca" pós-rift, cretáceo a terciário, que representaria o "resultado atrasado" da fusão e ascensão de magma através de "litosfera anomalamente quente e/ou espessa". Estes autores citam também o estilo estrutural da Bacia de Campos, a despeito de sua espessura expressiva, e a largura reduzida da plataforma continental adjacente, como evidências adicionais de margem distal no setor correspondente à costa sudeste e nordeste do Brasil.

As interpretações de Etheridge et al. (1990) e Lister et al. (1991) são baseadas em evidências excessivamente vagas quanto ao posicionamento geográfico e o contexto geológico das feições geomorfológicas, estruturais e magmáticas mencionadas (parte delas destacada neste texto por aspas). Omitem, por exemplo, a existência de plataforma continental com largura relativamente grande a norte da latitude aproximada de Florianópolis, indício contrário à interpretação de margem distal para toda essa área, e não fazem referências diretas às bacias marginais de Pelotas e Santos. Frente às escassas informações disponíveis, o que se pode destacar como hipóteses mais plausiveis a partir das interpretações daqueles autores são: 1. A área a sul do paleoalto de Florianópolis é margem de placa inferior ou proximal. A evidência, além das mencionadas por Etheridge et al. (1990) e Lister et al. (1991) para o setor a sul da zona de fratura Walvis - Rio Grande, é a vocação subsidente da Bacia de Pelotas, evidenciada pela grande espessura de sedimentos pós-rift, a maior dentre as bacias marginais brasileiras (Carvalho \& Francisconi 1981, Asmus 1983). 2. A área a norte do alinhamento de Cabo Frio, com extensão por toda a costa oriental brasileira, é margem de placa distal, como sugerem a plataforma continental estreita e os depocentros comparativamente pouco espessos nas bacias marginais, principalmente a norte da Bacia do Espírito Santo. 3. A margem do tipo proximal reapareceria na costa setentrional ou equatorial, a julgar pelo aumento pronunciado de largura da plataforma continental para $W$, com comportamento inverso na plataforma da margem complementar da África, a oeste da região da fossa do Benuê e delta do rio Niger. Evidência adicional é a notável espessura de sedimentos pós-aptianos na área defronte ao Cone do Amazonas, indicativa da vocação para subsidência que caracteriza as margens proximais.

A área de mais dificil identificação quanto ao tipo de margem de placa é a compreendida entre as zonas de transferência de Florianópolis e Cabo Frio. Algumas caracteristicas, como a grande largura da plataforma junto à costa paulista, a plataforma estreita na margem oposta complementar da África, corresponde à costa sul de Angola, a espessura de mais de $7 \mathrm{~km}$ na Bacia de Santos e a geometria ligeiramente embaiada da linha de charneira nos depocentros sul e norte desta bacia (Pereira \& Macedo 1990) incluem-se entre aspectos apontados nos modelos de extensão litosférica assimétrica como diagnósticos de margem proximal; outros, como a presença das escarpas costeiras (no caso, da serra do Mar) e o registro de magmatismo na área continental adjacente constituem argumentos utilizados por Etheridge et al. (1990) e Lister et al. (1991) para incluir esta área dentro de uma extensa margem de placa distal; acrescente-se a eles a 
geometria ligeiramente saliente para o mar da linha de charneira diante da costa centrosul paulista (Pereira \& Macedo 1990), feição que, no modelo de Wernicke \& Tilke (1989), também seria indicativa de margem distal.

\subsubsection{Clima}

O regime climático depende da interação entre fatores dinâmicos, representados pela migração de massas de ar, e estáticos, com destaque para o relevo (Nimer 1966, 1979). As massas de ar atuantes na zona costeira brasileira provêm de centros de alta pressão, posicionados predominantemente sobre áreas oceânicas, aos quais se associa circulação divergente em célula anti-horária ou anticiclone. Ao atingirem o continente, podem ser influenciadas pelo relevo de dois modos (Giannini et al. 2005). O primeiro tipo de influência, importante em escala regional, materializa-se no efeito de ascensão e condensação na presença de encostas abruptas, com formação de chuvas orográficas. Este fenômeno é bem caracterizado ao longo das escarpas das serras Geral e do Mar, nas regiões Sul e Sudeste do país. A pequena distância entre a escarpa da serra do Mar e a linha de costa contribui para a concentração dos maiores indices pluviométricos do território brasileiro entre a costa sul-fluminense e a norte catarinense (média anuais de até $4500 \mathrm{~mm}$ na região de São Sebastião, SP, segundo Nimer 1979). Mesmo fenômeno tem influência perceptível também na costa nordestina a sul de Touros (RN), onde se concentram as isoietas mais elevadas da região (acima de $1250 \mathrm{~mm}$ anuais, conforme Nimer 1979). A segunda influência do relevo, mais evidente em escala local, é a deflexão das massas de ar em movimento por feições topográficas marcantes. Com isto, a direção de vento mais efetiva na formação de dunas eólicas costeiras apresenta não apenas variações graduais, ligadas a mudanças regionais nos fatores dinâmicos (por exemplo, mudança de orientação relativa dos ramos de anticiclone), como também abruptas, relacionadas à interação entre fatores dinâmicos e feições locais de relevo (como possivelmente exemplificado na região de Torres, RS). De comum em termos azimutais, os ventos formadores de dunas possuem a origem nas áreas oceânicas.

De norte para sul, os centros de alta pressão influentes na costa brasileira correspondem aos núcleos de dois anticiclones semipermanentes, o do Atlântico Norte (Açores) e o do Atlântico Sul, e de um anticiclone móvel, o Polar. A costa norte-nordeste é influenciada por três massas de ar principais, associadas aos dois anticiciones semipermanentes. A Massa Equatorial Norte associa-se à zona de alísios de NE do Anticiclone do Atlântico Norte, ali mais atuante no periodo compreendido pelo verão e outono austrais (entre dezembro e abril). A Massa Equatorial Atlântica associa-se à zona dos intensos alísios de SE do Anticiclone do Atlântico Sul, ali mais atuante no inverno e na primavera austrais (segundo semestre). A Massa Tropical Atlântica forma-se nas áreas marítimas aquecidas do Atlântico Sul, de onde atinge a fachada litorânea leste-nordeste do Brasil, sobretudo no primeiro semestre do ano, produzindo instabilidades e ação de alísios de $E$ a NE (Nimer 1979). No encontro dos dois anticiclones semipermanentes, a ascensão das massas de ar forma uma zona latitudinal de baixa pressão, a Zona de Convergência Intertropical ( $\mathrm{ZCl}$ ) ou doldrum (do inglês, calmaria), cuja posição determina o Equador Térmico e a faixa de alta pluviosidade associada (Nimer 1979). A posição média da $\mathrm{ZCl}$ varia ao longo do ano entre o oeste do Maranhão, no verão austral, e as Guianas, no inverno. Ao deslocar-se para o Hemisfério Sul, no período equivalente entre o verão e o outono austrais, a $\mathrm{ZCl}$ determina a estação chuvosa na costa norte-nordeste do Brasil entre o Rio Grande do Norte e o Amapá; e ao migrar para o Norte (Guianas e América Central), entre o inverno e a primavera, afasta-se da costa norte-nordeste, assim determinando o periodo de estiagem nessa região. Desse modo, a precipitação sobre a 
parte norte do continente sul-americano seria amplamente controlada pelos movimentos sazonais da ZCl (Martin et al. 1997a). Sua influência reflete-se nos mapas de pluviosidade e duração de estiagem (Nimer 1979), em que se pode observar que a região mais seca da costa nordestina, entre Lençóis Maranhenses (MA) e Touros (RN) está compreendida na área além do alcance médio da $\mathrm{ZCl}$ para sul.

Rumo sul, a Massa Tropical Atlântica mantém sua importância, mas a influência das massas equatoriais é gradualmente substituída pela ação das massas de ar frio procedentes do Anticiclone Polar, o qual se desloca de SW com trajetória predominantemente marítima, no verão, e continental no inverno (Nimer 1979, Orselli 1986, Martin et al. 1988b). A separação transicional entre as áreas de influência das massas de ar Equatorial e Tropical, ao norte, e Polar e Tropical, ao sul, define uma faixa semi-permanente NW-SE de condensação e nebulosidade, que intercepta a costa na Região Sudeste (Monteiro 1973, Satyamurti et al. 1998). Esta faixa, relacionada à Zona de Convergência do Atlântico Sul (ZCAS), define aproximadamente o máximo alcance médio das frentes frias, zonas de baixa pressão e instabilidade formadas no encontro das massas Polar e Tropical Attântica. Devido à trajetória mais oceânica e ao aquecimento mais rápido da massa polar, a faixa de nebulosidade é mais atuante no verão, quando passa a separar duas zonas de pluviosidades contrastadas: chuvosa a sul e seca a norte (Nogués-Paegle \& Mo 1997). A distribuição de chuvas ao longo do ano também é afetada pela posição da faixa de nebulosidade, resultando mais uniforme (menos sazonal) a sul que a norte (Nimer 1979). No inverno, a ZCAS desloca-se para o norte; as frentes frias avançam mais, podendo atingir o Espírito Santo e a Bahia, porém, mais secas, geram menos instabilidade. No verão, a ZCAS posiciona-se mais a sul, as frentes frias enfrentam mais resistência para penetrar, adquirindo caráter estacionário, mas associam-se com maior freqüencia a aumento de pluviosidade. A faixa de nebulosidade tem então sua máxima manifestação no litoral centro-norte de São Paulo (Monteiro 1973). Somada ao efeito das precipitações orográficas da serra do Mar, determina a zona de verão mais ameno da costa sul-sudeste do país, entre as latitudes de Joinville, SC, e São Sebastião, SP (Figura 3.16). Esta zona coincide grosso modo com a área de maior expansão ao interior do dominio da Floresta Atlântica.

A posição da ZCAS parece exercer influência sobre o fracionamento isotópico do oxigênio na água de chuva, questão fundamental para estudos de paleoclima baseados em espeleotemas (Cruz 2003; item 3.2.1.4). Assim, a correlação inversa entre quantidade de chuva e $\delta^{18} \mathrm{O}$, observada a norte do Rio de Janeiro, desaparece na ZCAS, e chega a inverter-se no Rio Grande do Sul. Uma interpretação é que o enriquecimento médio das águas de chuva em ${ }^{18} \mathrm{O}$ a sul do Rio de Janeiro esteja ligado à maior influência de massas de ar úmido polares, carregadas no isótopo pesado, atuantes especialmente no inverno. Desse modo, a variação de $\delta^{18} \mathrm{O}$ ao longo do tempo, num mesmo espeleotema, seria antes função da proporção entre chuvas de inverno ( $\delta^{18} \mathrm{O}$ mais positivo) e de verão $\left(\delta^{18} \mathrm{O}\right.$ mais negativo) que da taxa de precipitação global (F.W.Cruz Jr., comunicação pessoal). 


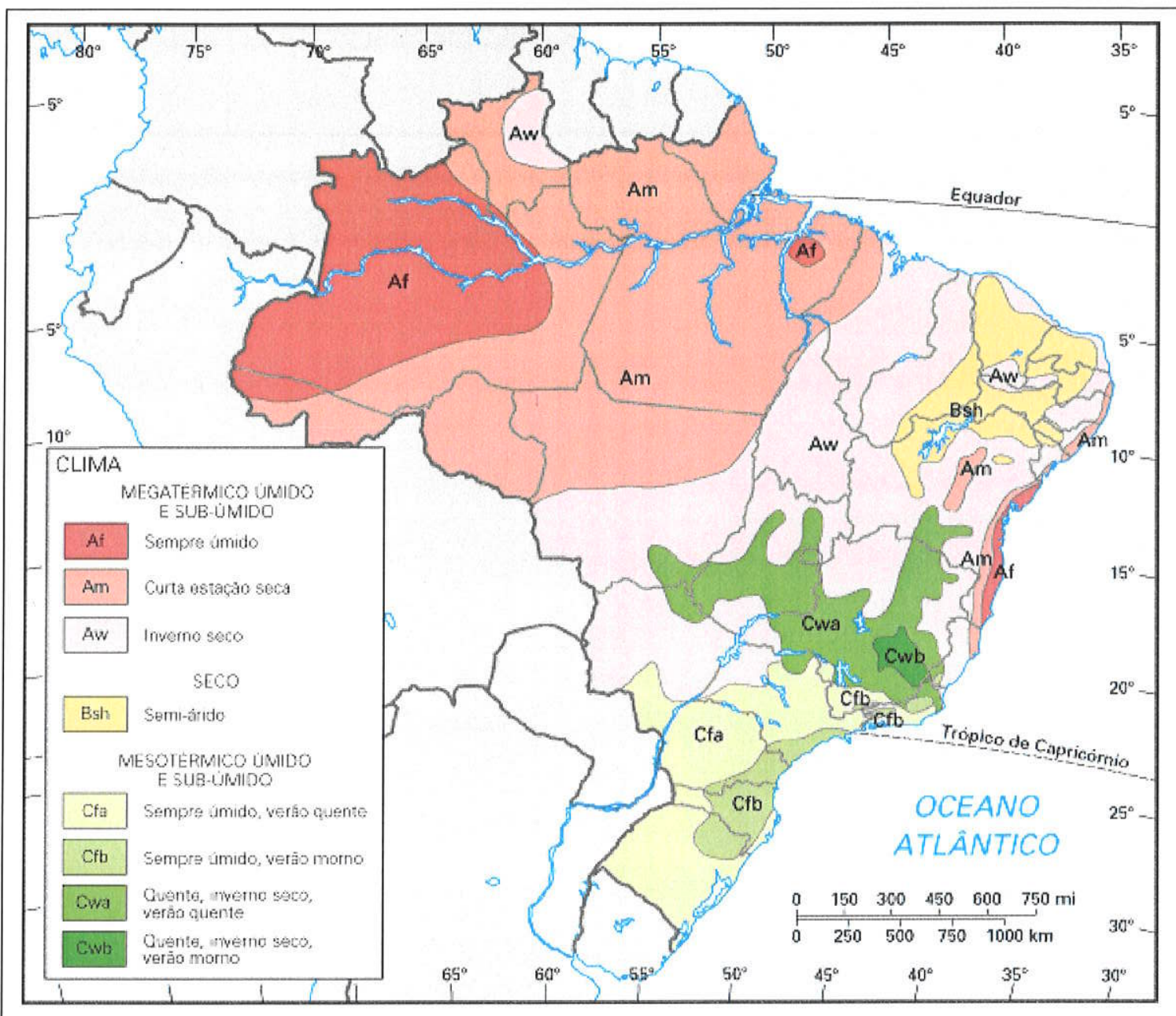

Figura 3.16. Zonas climáticas do Brasil pela classificação de Koppen. Extraído de Guia Internet Brazil (1999).

O Anticiclone Tropical do Atlântico Sul age na costa das regiões Sul e Sudeste através de ventos de NE a NW, enquanto o Anticiclone Polar possui ventos de $\mathrm{W}$ a NW que se modificam para S a SE, à medida que se aproximam do trópico (Nimer 1966, 1979). Importante mudança neste padrão de ventos é acarretada pelas frentes frias às quais se associam instabilidade, com intensos ventos ciclônicos oriundos dos quadrantes de sul (Nimer 1966, 1979, Monteiro 1973).

A dinâmica climática da costa brasileira pode ser melhor entendida através de sua interação com a circulação oceânica. A energia de atuação da Massa Equatorial Atlântica e dos alísios de SE determina a intensidade da Corrente Oceânica Sul-Equatorial e de suas ramificações na margem da plataforma continental nordestina, a Corrente do Brasil, rumo SW, e a Corrente do Brasil Setentrional, rumo NW (Richardson \& Walsh, 1986). A Corrente do Brasil Setentrional é mais intensa em profundidade que em superfície, com transporte máximo associado à máxima intensidade dos ventos de SE, no inverno austral. $\mathrm{Na}$ margem leste-sudeste, área de atuação da Corrente do Brasil, a sazonalidade é menos acentuada e a estrutura termo-halina das águas melhor definida. Águas Tropicais, mais salinas na base $(>3,7 \%)$, ocorrem na plataforma e talude superior, passando oceano 
afora a Águas do Attântico Sul Central, sobre Águas Intermediárias Antárticas com fluxo para norte, estas caracterizadas por menor sainidade $(3,4 \%)$ e maior teor de oxigênio (Arz et al. 1999). No Sul-Sudeste, os ventos de NE, especialmente no verão, promovem circulação transversal à margem da plataforma caracterizada por transporte costa afora na superfície e ressurgência das Águas do Atlântico Sul Central. As mudanças de orientação da margem da plataforma, como as que ocorrem em Cabo Frio, RJ, e no Cabo de Santa Marta (Laguna), SC, induzem um padrão meandrante na Corrente do Brasil e favorecem, desse modo, a formação preferencial de redemoinhos frontais intensos os quais podem intensificar o efeito da ressurgência por sobre a plataforma continental (Castelão et al., 2004). Este fenômeno ajuda a explicar a baixa precipitação na região de Cabo Frio (Nimer 1979).

A intensidade relativa da Corrente do Brasil Setentrional e da Corrente do Brasil possuem papel relevante na dinâmica climática global (Arz et al. 1999). O fortalecimento dos ventos de SW e da Corrente do Brasil setentrional, às expensas da Corrente do Brasil, intensifica a circulação termo-halina entre os hemisférios sul e norte. Inversamente, o enfraquecimento dos ventos de SE aumenta o fluxo da Corrente do Brasil e desfavorece a circulação entre hemisférios. Nessa situação, os gradientes termo-halinos entre o NorteNordeste e o Sul-Sudeste do Brasil são reduzidos.

\subsubsection{Paleoclima}

Interpretações sobre mudanças paleoclimáticas do Quaternário superior no território brasileiro provêm principalmente de tentativas de reconstituição paleovegetacional. No entanto, conforme alertado por Amaral et al. (2006), são raros os estudos paleoclimáticos em que informações interpretadas como ligadas de modo direto à paleovegetação (comumente, informações palinológicas), apresentam-se integradas a outros tipos de dados micropaleontológicos, sedimentológicos e isotópicos. Este problema metodológico manifesta-se em escalas tanto local como regional. $\mathrm{Na}$ escala local, uma conseqüência do problema é que parte das variações atribuídas à mudança de paleoflora e, por extensão, de paleoclima, em diferentes áreas de estudo, pode estar muito mais ligada, a rigor, a alterações de fácies e dinâmica sedimentar, capazes de determinar a distribuição e preservação do registro micropaleontológico nas dimensões de espaço e tempo. Já na escala regional, de território brasileiro, o problema manifesta-se na escassez de tentativas de correlação entre interpretações paleoclimáticas de diferentes bases de dados. É a esta lacuna em escala regional que se volta neste subitem. Desse modo, as discussões que se apresentarão em seguida devem ser encaradas apenas como um esforço preliminar de integração de dados, voltado à compreensão dos mecanismos controladores das mudanças climáticas mais consensuais.

Interpretações de reconstituição paleovegetacional do Quaternário superior no Brasil baseiam-se em quatro tipos principais de dados: 1. palinologia de sedimentos lacustres e lagunares, incluindo turfeiras (De Oliveira 1992, Ferraz-Vicentini 1993, Ledru 1993, Roth \& Lorscheitter 1993, Behling 1995a, 1997a, Lorscheitter \& Mattozo 1995, Neves \& Lorscheitter 1995, Colinvaux et al. 1996, Ledru et al. 1996, 1998, 2001, FerrazVicentini \& Salgado-Labouriau 1996, De Oliveira et al. 1999, Barberi et al. 2000, Melo et al. 2003, Garcia et al. 2004); 2. isótopos de carbono contidos na matéria orgânica do solo ou sedimento (Desjardins et al. 1996; Pessenda et al. 1996a, 1996b, 1998a, 1998b, 1998c, 2001b, Freitas et al. 2001, Scheel-Ybert et al. 2003, Ybert et al. 2003) ou em fragmentos de carvão (Soubiès 1979/80, Sanford et al. 1985, Desjardins et al. 1996, Pessenda et al. 1996a, Gouveia et al. 1999, Santos et al. 2000); 3. antracologia (Schell- 
Ybert 2000, Schell-Ybert et al. 2003); e 4. registros isotópicos, geoquimicos e de taxa de crescimento em espeleotemas e tufas calcárias (Cruz 2003, Auler et al. 2004, Wang et al. 2004, Cristalli 2006).

A planície costeira quaternária e as morrarias adjacentes têm sido pouco contempladas nesses estudos (Neves \& Lorscheitter 1995, Behling \& Negrelle 2001, Ledru et al. 2001, Pessenda et al. 2001b, Ybert et al. 2003, Cruz 2003, Amaral et al. 2006). Não existem todavia evidências de que as mudanças climáticas possam ter sido substancialmente diferenciadas entre planícies litorâneas e zonas interiores. O que há são apenas indícios de que a sensibilidade dos tipos de vegetação às mudanças climáticas variou de acordo com o domínio geográfico. Assim, as florestas teriam perdurado por mais tempo nas baixadas litorâneas que no planalto, durante períodos frios, enquanto os campos resistiriam por tempo maior no planalto que junto ao litoral, no "ótimo climático" do Holoceno (Behling 1998, 2002, Cruz 2003).

Da compilação dos dados disponíveis, e baseando-se também em trabalhos de síntese sobre paleovegetação e paleoclima no Quaternário tardio do Brasil, os capitulos mais consensuais sobre a história da vegetação no território brasileiro podem ser assim enumerados: 1. predomínio de temperaturas mais baixas que o atual durante o Último Máximo Glacial; 2. oscilações abruptas e acentuadas durante o Tardiglacial, aproximadamente entre 17 e $11 \mathrm{ka} \mathrm{AP}$, intervalo caracterizado também por aumento (Ledru et al. 2002) ou manutenção da umidade; 3. elevação da pluviosidade efetiva no Holoceno, evidenciada por expansão da floresta, com suspeitas de episódio mais seco no meio do período, principalmente dentro do intervalo entre 8 e 3 ka AP (Sifeddine et al. 1991, Ledru et al. 1996, 2001, Barreto 1996, Gouveia et al. 1997; Pessenda et al. 1998a, 1998b, 1998c, 2001a,b, De Oliveira et al. 1999, Freitas et al. 2001, Garcia et al. 2004). No campo das controvérsias, cabe destacar a existência de duas correntes opostas de interpretação para as condições de umidade durante o Último Máximo Glacial: mais úmidas, segundo alguns (Colinvaux et al. 1966, 1999, De Oliveira 1992, Colinvaux 1993, Haberle 1997, Colinvaux et al. 1999, 2000, Barberi 2001, Bush et al. 2001, Auler et al. 2004), versus mais secas, segundo outros (Ledru et al. 1998, Behling 1998, Behling \& Negrelle 2001, Cruz 2003).

Os dados escasseiam à medida que se afasta do alcance do método ${ }^{14} \mathrm{C}$. As informações sobre o Estágio Isotópico 5 (120 a 75 ka AP), que abrange o periodo de NRM alto correspondente ao último interglacial, restringem-se às análises em espeleotemas de Santa Catarina e São Paulo, apresentadas por Cruz (2003). De acordo com este autor, tomando como referência as condições climáticas atuais, o período teria sido marcado por alternâncias, mais acentuadas em São Paulo, entre clima mais quente e menos úmido versus mais frio e chuvoso.

Ainda que a falta de precisão geocronológica dos dados dificulte sua correlação ao largo de todo território brasileiro, os três capítulos consensuais maiores ao longo dos últimos 20 mil anos coincidem e podem ser explicados no âmbito de mudanças climáticas globais reconhecidas principalmente através da comparação entre dados de foraminíferos planctônicos dos sedimentos de fundo oceânico e de testemunhos de gelo (Mclntire \& Molfino 1997, Arz et al. 1998, 1999, Flenley 1998). Curvas de variação de $\delta^{18} \mathrm{O}$ em foraminiferos da margem continental brasileira e nos espeleotemas de São Paulo e Santa Catarina (Cruz 2003) apresentam todas a mesma configuração geral: variação rápida entre aproximadamente 20 e 5 ka AP, seguida de estabilização ou mesmo de variação lenta em sentido inverso, desde então. Por outro lado, cabe destacar que, à medida que se refina a análise da história isotópica e paleovegetacional, a resposta a mudanças paleoclimáticas globais pode variar de região para região do pais, na dependência da posição relativa de elementos climáticos como a ZCl e a ZCAS. 
Um primeiro exemplo disso é que a umidificação do clima a partir de aproximadamente 4 a $3 \mathrm{ka} \mathrm{AP}$ nas costas norte (Ledru et al. 2001) e maranhense (Pessenda et al. 2001b), com extensão até parte da América Central (Bush et al. 1992, Curtis \& Hodell 1993, Hodell et al. 1991, 1995), pode não guardar correspondência estreita a sul da $\mathrm{ZCl}$. Estudos palinológicos apontam para diminuição de umidade a partir de 5 a 4 ka AP no noroeste da Bahia (Barreto 1996, De Oliveira et al. 1999) e norte de São Paulo (De Oliveira 1992, Ledru 1993, Garcia et al. 2004).

Um segundo exemplo de possivel compartimentação ou assimetria norte-sul do clima no território brasileiro encontra-se na transição Pleistoceno-Holoceno, entre cerca de 11 ka AP e 8 ka AP: enquanto nas regiões Centro-Oeste, Sul e Sudeste, haveria o predominio de gramineas, interpretado como indicativo de clima relativamente seco (Ferraz-Vicentini 1993; Ledru 1993; Roth \& Lorscheitter 1993; Stevaux 1994, 2000; Behling 1995a,b 1997a,b; Lorscheitter \& Mattozo 1995; Neves \& Lorscheitter 1995; Ferraz-Vicentini \& Salgado-Labouriau 1996; Ledru et al. 1996, 1998b; Pessenda et al. 1996a, 1996b, 1998a; Behling 1999; Barberi et al. 2000; Gouveia 2001), em regiões do Norte-Nordeste e no sul da Amazônia predominariam as florestas, provavelmente associadas a clima mais úmido (Barreto 1996, De Oliveira et al. 1999, Ledru et al. 2001, Pessenda et al. 2001b). A partir de aproximadamente 9 a 7 ka AP, o clima seco teria se instalado também no Norte-Nordeste, onde perdura por dois a três milênios. A hipótese da existência deste contraste climático sul versus norte, na transição Pleistoceno-Holoceno, deve porém ser vista com extrema cautela, pois baseia-se fortemente na discutivel associação direta entre aumento de gramíneas e redução de umidade.

Uma possível compartimentação ou assimetria climática no território brasileiro pode ser explicada e testada segundo pelo menos dois modelos, não excludentes. O primeiro deles baseia-se na sazonalidade da dinâmica climática atual, em que a distribuição de umidade na metade setentrional do continente sul-americano é determinada pela posição da ZCl (Martin et al. 1997, De Oliveira et al. 1999). Assim, como no mapa climático atual, haveria acentuada assimetria entre alta umidade, da faixa de varredura da $\mathrm{ZCI}$ para norte, e baixa umidade, a sul dessa faixa. Dentro deste modelo, os periodos mais úmidos no Norte brasileiro estariam relacionados à posição mais ao norte desta zona de convergência, sendo acompanhadas na Região Nordeste de redução de umidade e ampliação do alcance dos alísios de SE. Em tese, estes períodos devem corresponder também a fases de aquecimento no Hemisfério Norte, devido à aproximação (deslocamento para $N$ ) do Equador térmico. Ressalvas que podem ser feitas a este modelo é que ele é apenas descritivo, não explica o mecanismo de migração da $\mathrm{ZCl}$, e parte da premissa de um estado de equilibrio climático único, similar ao atual.

O segundo modelo para explicar a compartimentação do paleoclima no território brasileiro explicaria os mecanismos de migração da $\mathrm{ZCl}$. Baseia-se numa situação de desequilibrio na dinâmica climática, desencadeado pelo aquecimento abrupto das águas superficiais em baixas latitudes, próximas à $\mathrm{ZCl}$, incluindo a costa nordeste do país (Arz et al. 1998, 1999). De acordo com este modelo, o aumento, além da situação de equitíbrio, da temperatura das águas superficiais, elevaria bruscamente a evaporação e a umidade na costa nordestina, e, por decorrência, os ventos alisios de $E$ e SE, com conseqüente intensificação e ampliação do alcance para o Hemisfério Norte da Corrente do Brasil Setentrional, em detrimento da Corrente do Brasil rumo oposto (Figura 3.17, lado rosa). Este processo acentuaria, portanto, a diferença de temperatura das águas oceânicas superficiais, entre as costas nordeste e sul-sudeste do país. 


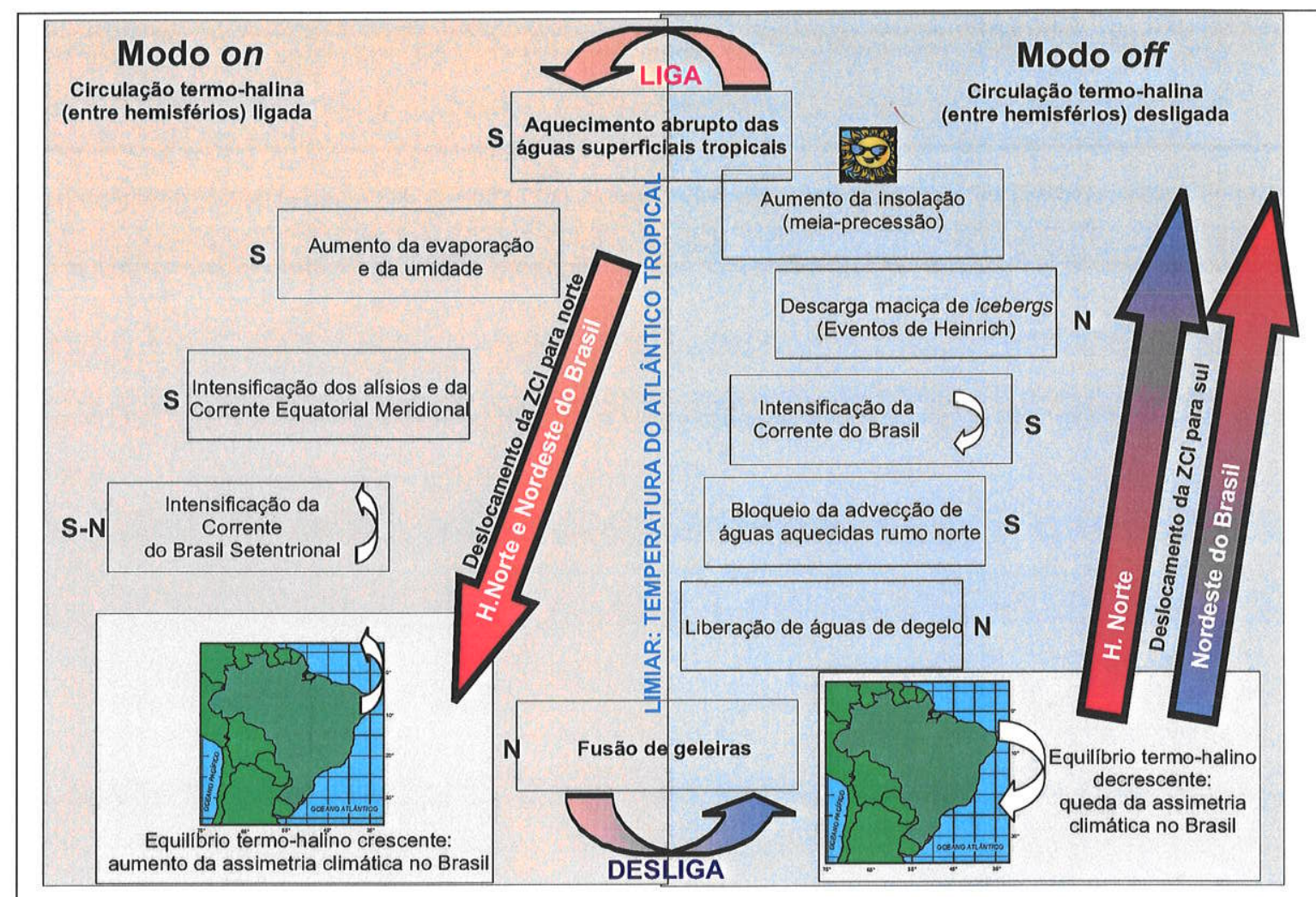

Figura 3.17. Modelo liga-desliga (on-off) de circulação termo-halina entre hemisférios controlada por ciclos sub-Milankovitch (baseado em Arz et al. 1998, 1999), com suas possíveis implicações na assimetria climática entre o Norte-Nordeste e o Sul-Sudeste do Brasil. As cores de preenchimento das setas grandes representam as tendências de aquecimento (vermelho) ou resfriamento (azul) das águas oceânicas superficiais. Os símbolos S e $\mathrm{N}$ referem-se aos hemisférios.

Arz et al. (1998) admitem o aquecimento das águas tropicais de baixa latitude como sendo a resposta não linear mais imediata do sistema climático à ação dos ciclos astronômicos de insolação de meia-precessão ou sub-Milankovitch (com periodicidade média de 9500 a 12000 anos) evocados por McIntire \& Molfino (1997). Os picos de insolação ligados a estes ciclos afetariam primeiramente, de modo positivo, a evaporação, a temperatura das águas superficiais e a umidade costeira nas latitudes baixas, com reflexos posteriores no clima global (Short et al. 1991, Arz et al. 1998). Nas altas latitudes boreais, o reflexo da intensificação das correntes quentes superficiais rumo norte é a fusão parcial de geleiras e o estabelecimento de período de resfriamento gradual das mares e continentes (Oldest Dryas, Older Dyas e Young Dryas, por exemplo), que pode culminar com um episódio de descarga maciça de icebergs, o denominado evento de Heinrich. Ao mesmo tempo, no Atlântico Sul, o enfraquecimento gradual da Corrente do Brasil Setentrional devido ao bloqueio pelas águas de degelo do Hemisfério Norte permite a retomada das trocas de calor entre as costas norte e sul brasileiras, via Corrente do Brasil (Figura 3.17, lado azul). Desse modo, a circulação oceânica retorna ao seu estado de equilíbrio anterior, até o desencadeamento de novo pico de aquecimento subMilankovitch, e assim sucessivamente. Neste modelo, o aquecimento rápido do oceano tropical provocaria o aumento de umidade do Nordeste brasileiro, e este aumento de umidade seria o gatilho para fases de aquecimento nas latitudes altas do Hemisfério 
Norte. Enquanto isso, nas áreas de média latitude do Atlântico Sul, o enfraquecimento da Corrente do Brasil implicaria possivel aumento na influência das massas de ar e correntes oceânicas subantárticas (mais frias, menos salinas e empobrecidas em ${ }^{18} \mathrm{O}$ ), com abaixamento na temperatura das águas costeiras. Isto contribuiria para manter a evaporação e a umidade relativamente baixas na Região Sul-Sudeste e para acentuar a assimetria climática entre o sul e o norte do país.

Resultados de medidas isotópicas de $\mathrm{O}$ em foraminíferos planctônicos, referentes a testemunhos na margem continental sudeste (Espirito Santo e Rio de Janeiro) e extremo nordeste brasileiro (Pernambuco a Ceará), obtidos por Arz et al. (1998, 1999), permitem testar este modelo. Redução do $\delta^{18} \mathrm{O}$ de testas de organismos planctônicos, ao longo do tempo, pode ser atribuída a dois fatores: o primeiro, de caráter local a regional, é a queda da salinidade da água superficial, ligada a incremento no aporte de água doce do continente ou aumento na intensidade relativa de correntes oceânicas menos salinas; o segundo, de caráter global, é a queda no volume de gelo (Shackleton 1987, Wefer \& Berger 1991, Arz et al. 1998). Os picos negativos de $\delta^{18} \mathrm{O}$ podem assim ser correlacionados a picos de aporte fluvial e pluviosidade, fortalecimento de correntes de baixa salinidade relativa e/ou "máximos deglaciais" globais. De acordo com Arz et al. (1998), os máximos de umidade continental relacionados a baixos valores de $\delta^{18} \mathrm{O} \mathrm{em}$ foraminíferos planctônicos marinhos da margem nordeste do Brasil coincidem com elevações relativas no aporte terrígeno à margem continental (aferido através das relaçôes $\mathrm{Fe} / \mathrm{Ca}$ e $\mathrm{Ti} / \mathrm{Ca}$ ), o que evidencia a existência de aumento de aporte fluvial, ligado a incremento de precipitações no continente. Além disso, o início das fases de aumento de umidade assim detectadas coincide com o final de eventos de Heinrich ( $\mathrm{H} 1$ a $\mathrm{H} 6$ ), datados no Hemisfério Norte.

Partindo dessas observações, Arz et al. (1999) construíram gráficos de variação nos últimos 22 mil anos do $\delta^{18} \mathrm{O}$ residual (isto é, do valor remanescente após subtraída a parcela de $\delta^{18} \mathrm{O}$ negativo devida ao efeito deglacial global) em foraminiferos das margens nordeste e sudeste do Brasil (Figura 3.18). Segundo estes gráficos, o primeiro pico negativo de $\delta^{18} \mathrm{O}$ residual nos últimos 22 mil anos de registro sedimentar ocorre entre $17 \mathrm{e}$ $13 \mathrm{ka} \mathrm{AP}$, tanto na margem nordeste como na sudeste. Este período corresponde a um dos mais importantes picos de aporte terrígeno na margem nordeste do Brasil detectados por Arz et al. (1998). E é também o momento em que as diferenças de $\delta^{18} \mathrm{O}$ entre as margens nordeste e sudeste atinge seu menor valor, próximo de zero (Arz et al. 1999), indicativo de intensa circulação e homogeneização das águas superficiais da costa brasileira, condição que, no modelo, seria típica de aquecimento pós-Heinrich de águas tropicais. Este dado é ainda compativel com a idade atribuída com base em testemunhos de gelo ao evento de Heinrich $\mathrm{H} 1$ (17 a $15 \mathrm{ka} \mathrm{AP}$ ). Leva a crer em um aquecimento das águas superficiais do Oceano Atlântico tropical, que atingiu tanto a porção nordeste como a sudeste da margem continental brasileira, resultando em provável aumento de umidade em ambas as regiões. Após esse período, a diferença de $\delta^{18} \mathrm{O}$ entre as margens nordeste e sudeste aumenta rapidamente, permanecendo elevada (maior que $0,4 \%$ ) até o final do registro sedimentar. Os maiores picos negativos de $\delta^{18} \mathrm{O}$ durante os últimos 13000 anos de registro, na margem sudeste, encontram-se entre $6 \mathrm{ka}$ anos AP (Globorotalia sacullifer) e $3 \mathrm{ka}$ anos AP (Globorotalia ruber). Já as amostras da margem continental nordestina apresentam tendência mais persistente de declínio de $\delta^{18} \mathrm{O}$ residual desde $13 \mathrm{ka} A P, \mathrm{com}$ pico negativo no topo da coluna sedimentar amostrada (idade ${ }^{14} \mathrm{C}$ calendário inferior a $1 \mathrm{ka}$ AP). Desse modo, a manutenção de umidade na segunda metade do Holoceno no extremo nordeste não é acompanhada na costa sudeste, o que parece concordar com as análises de palinomorfos e isotópos em sedimentos continentais obtidos por De Oliveira (1992), De Oliveira et al. (1999), Ledru et al. (2001) e Pessenda et al. (2001b). Nesse 
contexto, podem ser incluidos os dados de espeleotemas de São Paulo e Santa Catarina (Cruz 2003), em que a segunda metade do Holoceno é marcada por ligeira redução de $\delta^{18} \mathrm{O}$, interpretada como aumento da influência das massas de ar polar, provavelmente associadas a um enfraquecimento relativo da Corrente do Brasil e da Massa Tropical Atlântica.
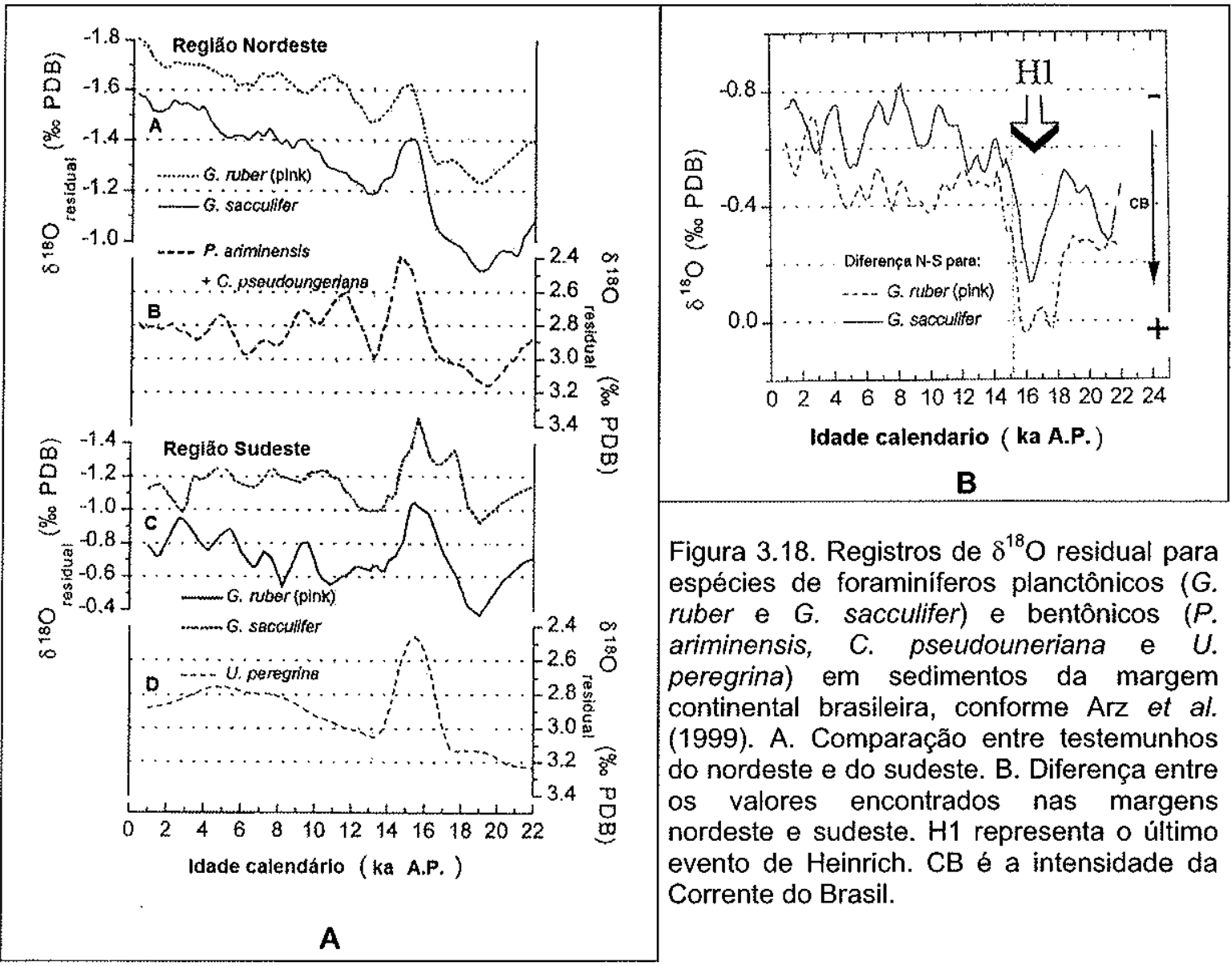

Figura 3.18. Registros de $\delta^{18} \mathrm{O}$ residual para espécies de foraminiferos planctônicos ( $G$. ruber e G. sacculifer) e bentônicos ( $P$. ariminensis, C. pseudouneriana e $U$. peregrina) em sedimentos da margem continental brasileira, conforme Arz et al. (1999). A. Comparação entre testemunhos do nordeste e do sudeste. B. Diferença entre os valores encontrados nas margens nordeste e sudeste. $\mathrm{H} 1$ representa o último evento de Heinrich. $\mathrm{CB}$ é a intensidade da Corrente do Brasil.

Quanto à transição Pleistoceno/Holoceno, não há diferenças marcantes de comportamento do $\delta^{18} \mathrm{O}$ de foraminiferos planctônicos, entre as margens nordeste e sudeste. O último máximo de terrígenos na coluna sedimentar holocênica da margem nordeste ocorre por volta de $10 \mathrm{ka}$ AP e corresponde a um pico negativo pouco pronunciado de $\delta^{18} \mathrm{O}$ entre $11 \mathrm{ka}$ e $9 \mathrm{ka}$. Na correlação com o Hemisfério Norte, esta época não foi imediatamente antecedida de evento de Heinrich, e, de fato, o máximo de terrigenos e o mínimo de $\delta^{18} \mathrm{O}$ possuem magnitudes menores que as registradas logo após eventos de Heinrich considerados inequívocos (16ka, $25 \mathrm{ka}, 32 \mathrm{ka}, 40 \mathrm{ka}$ e $47 \mathrm{ka}$ AP). Mas foi precedida por resfriamento continental, o Young Dryas, que estaria supostamente ligado ao suprimento à costa de águas frias deglaciais, à semelhança do que ocorre nos eventos de Heinrich e nas fases Dryas anteriores (Arz et al. 1999). Existe, portanto, possibilidade de assimetria climática entre sul e norte do país nesse período, ainda que os dados de $\delta^{18} \mathrm{O}$ nas margens nordeste e sudeste não reflitam diferenças marcantes entre estas duas regiões. 
De fundamental importância para testar a eficiência do modelo de Arz et al. (1998, 1999) na explicação da assimetria climática do Brasil oriental seria a obtenção de dados de $\delta^{18} \mathrm{O}$ referentes a testemunhos de sedimentos marinhos no Sul do país. Para essa região, além das medidas isotópicas de espeleotemas do norte de Santa Catarina obtidos por Cruz (2003), sugestivas de mudança nos últimos 4 a 5 mil anos, dispõe-se dos resultados de $\delta^{18} \mathrm{O}$ de carapaças aragoníticas de vermetídeos (Petaloconchus) utilizados por Angulo et al. (1999) como indicadores de paleonível do mar na região entre Imbituba e Laguna, costa centro-sul do estado. Estes dados são particularmente interessantes uma vez que este gênero de gastrópodos se encontra atualmente "extinto" a sul de Cabo Frio (RJ), devido supostamente a sua inadaptação a águas frias (Laborel $1979,1986)$. O resfriamento das águas costeiras explicaria também o desaparecimento do mangue a sul de Laguna, SC. Vestígios antracológicos de mangue, datados de cerca de 5 ka A.P, são relatados em meio ao sambaqui Encantadas IV, em Jaguaruna, SC (DeBlasis et al. 2007). Espera-se, portanto, encontrar nos dados de $\delta^{18} \mathrm{O}$ de vermetídeos um padrão de $\delta^{18} \mathrm{O}$ capaz de explicar o declínio de temperatura das águas, a partir de algum momento do Holoceno, necessário para estas mudanças de fauna e flora.

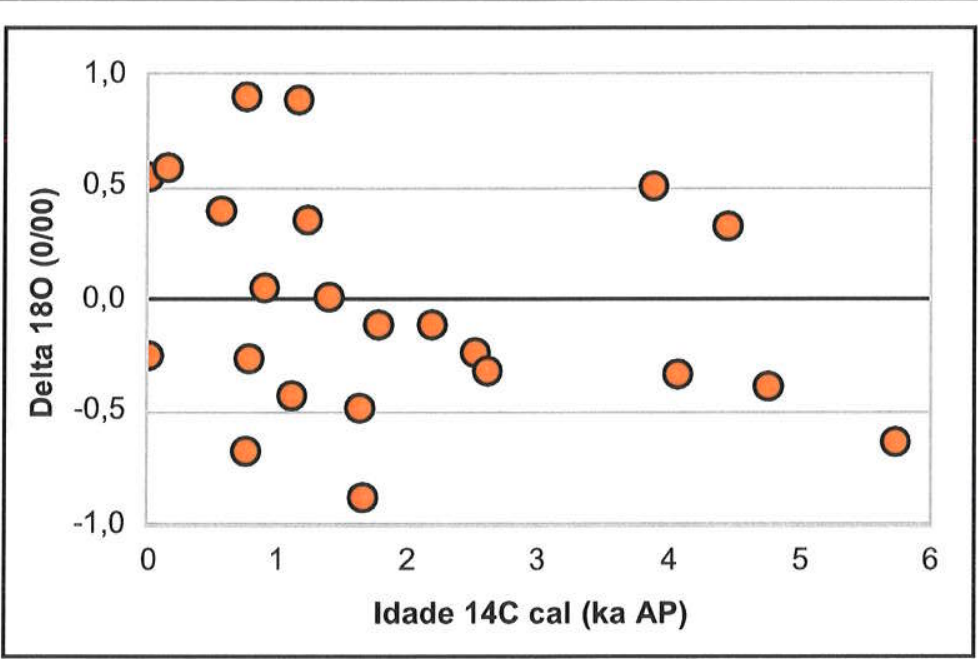

Figura 3.19. Gráfico de dispersão entre valores de $\delta^{18} \mathrm{O}$ e idades ${ }^{14} \mathrm{C}$ calibradas (ponto mediano do intervalo) para 23 amostras de vermetídeos coletadas in situ no litoral de Santa Catarina, entre Imbituba e Laguna. Base de dados extraída de Angulo et al. (1999, 2006). Correlação linear inversa $(R=0,289)$, aceitável a nível de significância $\alpha$ (erro I) de 0,1 .

A análise dos de $\delta^{18} \mathrm{O}$ de vermetídeos (Figura 3.19) permite notar duas particularidades: em primeiro lugar, os vermetídeos viveram na região pelo menos até 190 \pm 65 anos AP (equivalente a 0 ano cal), indício de que o patamar de resfriamento das águas, suficiente para seu desaparecimento, só foi atingido em tempo histórico; em segundo lugar, uma tendência de $\delta^{18} \mathrm{O}$ crescente com a redução de idade abarca todo o intervalo de tempo amostrado, correspondente aos últimos 5 mil anos. Interpretada em termos globais, esta tendência implicaria enriquecimento residual das águas na zona costeira em ${ }^{18} \mathrm{O}$ devido ao aumento do volume de gelo no período. Esta interpretação, entretanto, é incompatível com os modelos mais aceitos de deglaciação no Holoceno. Parece provável, portanto, que maior parte do aumento gradual de $\delta^{18} \mathrm{O}$ deva-se ao fator local a regional, isto é, intensificação do aporte de águas menos salinas (e mais frias) pela Corrente das Malvinas, o que, por implicar menor taxa de evaporação da água do mar, 
pode envolver também redução de umidade na costa. Alternativamente, pode-se evocar redução do aporte de água doce e relativamente quente, empobrecida $\mathrm{em}^{18} \mathrm{O}$, o que estaria relacionado à queda de pluviosidade e umidade na zona continental adjacente. $A$ primeira hipótese explica de modo mais direto o desaparecimento dos vermetídeos a sul de Cabo Frio e do mangue a sul de Laguna. Desse modo, os resultados de Angulo et al. (1999) mais os dados antracológicos de sambaquis constituiriam indício adicional de que mudanças climáticas ligadas a alteração na circulação oceânica, dentro dos últimos 5000 anos, teriam afetado pelo menos parte das regióes Sul e Sudeste do país.

No mesmo intervalo de tempo, observa-se aumento de $\delta^{18} \mathrm{O}$ residual em espécimes de foraminifero bentônico (Uvigerina peregrina) encontrados no testemunho da margem continental sudeste, em contraste à redução ou manutenção do $\delta^{18} \mathrm{O}$ em outras espécies de foraminífero bentônico (Planulina Ariminensis e Cibicicoides pseudoungeriana) encontradas na margem nordeste (Arz et al. 1999, Figura 3.18). Estes dados reforçam a hipótese de compartimentação climática, com aumento relativo de umidade no Norte-Nordeste, não acompanhado no Sul-Sudeste do pais durante a segunda metade do Holoceno. A verificação segura de hipóteses deste tipo requer, entretanto, o adensamento e a integração de informações de palinologia, sedimentologia e isótopos estáveis no Holoceno do Brasil. 


\subsection{Descrição externa: relações sistema-meio}

\subsubsection{Modelo conceitual}

$\mathrm{Na}$ descrição externa clássica, o sistema é abordado como uma "caixa" (Figura 2.4), isto é, um dominio do espaço, cujo volume e geometria são controlados por entradas e saídas e pelas variáveis do meio que o envolve capazes de exercer controle seja sobre o sistema seja sobre estas entradas e saídas (Bertalanffy 1972a). A descrição externa pode ser subdividida em dois passos. O primeiro é a descrição do domínio espacial e dos processos de entrada e saida que controlam o saldo sedimentar e, portanto, o volume ocupado pelo sistema. Esta descrição faz naturalmente ressaltar as variáveis do macroambiente mais significativas no controle das entradas e saídas (em contraposição às variáveis internas do sistema, mais ligadas à auto-organização) e conduz, desse modo, ao segundo passo, que consiste na caracterização do modo de ação destas variáveis.

\subsubsection{Entradas, saídas e espaço de estocagem}

As questões do saldo sedimentar e de espaço para estocagem deste saldo encontram-se contempladas na tentativa de Kocurek \& Havholm (1993) de modelar sistemas deposicionais eólicos de acordo com o arcabouço conceitual da estratigrafia de seqüências. Nesse modelo, o saldo sedimentar eólico refere-se à diferença entre entradas e saídas, representadas por volumes de sedimentos, e o espaço de estocagem é determinado pela posição do nivel freático relativa à superfície deposicional, controlada basicamente pelo clima, pela taxa de subsidência e, nos casos costeiros, pelo nível relativo do mar (NRM).

Em relação à questão do saldo de volumes sedimentares (Figura 3.20), aqueles autores denominam o fluxo de entrada (Qi) como influxo (influx) e o fluxo de saida (Qe), como efluxo (outflux). O influxo seria função da disponibilidade de sedimentos na fonte externa e da capacidade e competência de transporte eólico a partir desta fonte, que podem portanto ser consideradas variáveis ou parâmetros de entrada. O efluxo dependeria do espaço disponível para o armazenamento de sedimentos e da capacidade e competência de transporte eólico no sistema, os parâmetros de saída. $\mathrm{Na}$ linguagem mais comumente utilizada no estudo de regimes de ventos e dunas recentes, o influxo equivale à deriva eólica efetiva, ou DEE (Fryberger 1979), que resulta da coexistência de deriva eólica potencial (DEP) com estoque sedimentar (Giannini et al. 2005, 2007a). A DEP, em dado azimute e intervalo de tempo, é diretamente proporcional à freqüência e à velocidade do vento, esta elevada ao cubo (Langsberg 1956 apud Goldsmith 1978, Lettau \& Lettau 1975 apud Fryberger 1979, White 1979). Sarre (1988) comparou várias fórmulas de fluxo eólico existentes na literatura e concluiu que, para exemplos específicos em que a área fonte se encontra na zona intermarés, a que dá resposta mais realística em comparação com medidas de campo é a de White (1979), reproduzida na equação 1:

$q=2.61 V_{*}^{3}\left(1-V_{* i} / V_{*}\right)\left(1+V_{* i}^{2} / V_{*}^{2}\right) \rho / g$

onde $q$ é a taxa de transporte de sedimentos $\left(\mathrm{kgm}^{-1} \mathrm{~s}^{-1}\right), V_{*}$ é a velocidade de arrasto, $\rho$ é a densidade do ar, $g$ é a aceleração da gravidade e $V_{t t}$ é a velocidade de arrasto critica para determinado diâmetro de grão (acima da qual se inicia seu movimento).

A DEE difere da DEP por depender de uma série de fatores, além do fator vento, cuja ausência pode inibir na prática a formação de dunas. Destacam-se, dentre estes fatores, a existência de estoque, na área fonte imediata, com propriedades sedimentológicas e incoesão adequadas e o rumo de incidência dos ventos relativo ao mesmo estoque. 
Propriedades texturais como diâmetro médio e seleção são essenciais na formação do campo de dunas. Um tipo básico de seleção granulométrica, correspondente à eliminação ou separação de lama e cascalho, é imprescindivel para a saturação de fluxo eólico necessária à formação de dunas. A eliminação de lama e cascalho e a concentração de areia em granulação suficientemente fina para ser carreada pelo vento é controlada por fatores externos e internos ao sistema. Entre os fatores externos, destacam-se a constituição da rocha mãe e a sua distância ao sistema deposicional costeiro, variáveis influenciadas pelo contexto fisiográfico-tectônico. $\dot{E}$ como decorrência destes fatores que grandes campos de dunas costeiros são mais comuns junto a margens passivas do que em ativas. Entre os fatores internos de separação granulométrica, destaca-se a dinâmica do sistema deposicional costeiro e a competência seletiva de seus agentes deposicionais. Através destes fatores internos, dois dos contextos típicos de desenvolvimento de sistemas eólicos são o de costas dominadas por ondas e o de costas dominadas por marés com energia de onda expressiva a ponto de formar planícies intermarés essencialmente arenosas. Propriedades mineralógicas e morfométricas também influem na formação de campos de dunas, uma vez que, a exemplo do tamanho de grão, afetam diretamente a velocidade limiar de transporte eólico.

A incoesão da areia é controlada não somente pela ausência de lama associada, mas pela umidade do substrato durante a atuação dos diferentes rumos de vento. A umidade depende da pluviosidade e da evaporação (ligada à insolação), variáveis amarradas ao clima e portanto macroambientais, e da permo-porosidade e saturação aquosa da areia, variáveis essencialmente internas. $\mathrm{Na}$ área fonte aluvial ou costeira, a umidade depende ainda do regime de inundações fluvial ou por marés, respectivamente, variáveis que podem também ser consideradas internas.

Em sistemas eólicos costeiros, a influência exercida sobre a deriva eólica pelo rumo de incidência do vento em relação à área-fonte foi sintetizada por Goldsmith (1979) no seguinte princípio: quanto mais reto (próximo de $90^{\circ}$ ) o ângulo entre vento e linha de costa, maior o "potencial de formação de dunas". Idéia semelhante foi utilizada por Carvalho (2002) para explicar a orientação dos campos de dunas cearenses. Este autor chega a expressar matematicamente o potencial de formação de dunas pela equação 2

$P_{t}=q_{t} \cdot \operatorname{sen} \alpha$

onde $q_{t}$ é a DEP e $P_{t}$, é seu valor corrigido em função do ângulo $\alpha$ entre vento e linha de costa. Uma das razões para esta relação é que quanto mais perpendicular à costa for o transporte eólico, mais rapidamente os seus depósitos se afastam da zona intermarés e, portanto, do risco de erosão subaquosa. Além disso, menor é a distância que o sedimento eólico percorre antes de ser freado ou desviado (Giannini et al. 2005) por obstáculo exercido seja por escarpas ou outras formas de elevação topográfica, seja pela vegetação. A proximidade entre fonte e desaceleração inicial significa perda rápida de efluxo e portanto acúmulo rápido. Com isso, o sistema eólico transversal à costa pode transpor mais rapidamente o obstáculo, através de processos de cavalgamento de elevações ou de precipitação ou avanço das areias sobre a vegetação. Sob esse ponto de vista, um sistema eólico paralelo à linha de costa seria mais sujeito a reciclagem de sedimentos eólicos pelas ondas e marés e a transporte eólico prolongado com pouca desaceleração, o que favorece inclusive o trânsito para arco praial vizinho e a restrição, por distância prolongada, à uma faixa estreita adjacente ao mar. Desse modo, a influência negativa da orientação do vento paralela à linha de costa na formação de dunas, admitida nos modelos de Goldsmith (1979), parte de duas premissas implícitas: o efluxo alto (para o sistema subaquoso e para os sistemas eólicos de praias vizinhas) e o extenso espaço disponível, ao longo da costa, para a acumulação eólica. O modelo pode falhar na mesma medida em que estas premissas 
falharem. Não leva em consideração o efeito de entulhamento por areia eólica e formação de dunas que pode ser propiciado, num sistema eólico paralelo à costa, pela redução de efluxo para o interior e pela diminuição de espaço no rumo do continente.

Desemboca-se assim no segundo aspecto da descrição externa de sistemas eólicos, o do espaço de estocagem dos saldos sedimentares. O conceito estratigráfico clássico que mais se aproxima é o de espaço de acomodação: espaço disponível para preenchimento sedimentar numa bacia (essencialmente marinha), controlado pelo efeito combinado de nível do mar e tectônica (Posamentier \& James 1993). No caso eólico, torna-se necessário lançar mão de conceitos adicionais ou pouco usuais na estratigrafia seqüencial de sistemas marinhos, entre os quais se incluem a acumulação, o espaço de acumulação, a altura de equilíbrio, a preservação e o espaço de preservação (Figura 3.20). As definições dadas a seguir para este conceitos baseiam-se na análise, apresentada por Giannini et al. (2007a), do uso destes conceitos por Kocurek \& Havholm (1993).

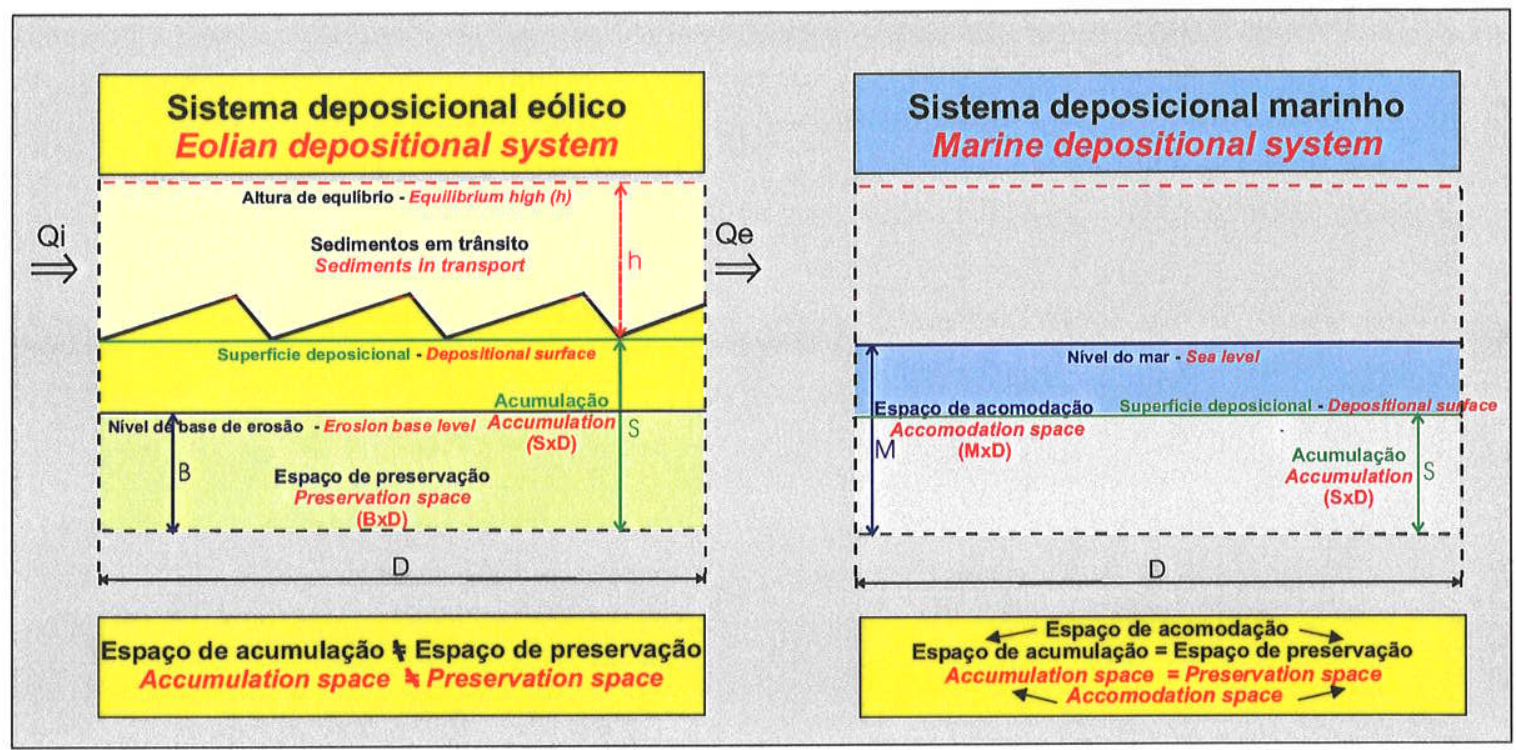

Figura 3.20. Descrição do sistema deposicional eólico, e comparação com o sistema marinho, a partir dos fluxos de entrada (Qi) e saída $(Q e)$ de sedimentos, ou influxo e efluxo respectivamente, e do espaço disponivel para preenchimento sedimentar. Adaptado de Kocurek \& Havholm (1993) por Giannini et al. (2007a).

A acumulação é o mecanismo pelo qual os sedimentos depositados ao longo do tempo constituem um corpo tridimensional de estratos. O espaço de acumulação corresponde à parcela do espaço de acomodação que é preenchida por depósitos sedimentares. Seu limite superior é a altura de equilíbrio, a qual pode ser definida como a altura, acima da superfície deposicional, até a qual é possível haver aprisionamento de sedimentos no sistema. Nos sistemas marinhos, esta altura coincide com o nível do mar. Nos eólicos, ela encontra-se no nível acima do qual a velocidade do vento é suficientemente alta para carrear todo sedimento e, portanto, para que o saldo sedimentar no sistema seja nulo, isto é, com influxo igual a efluxo (Qi=Qe; Figura 3.20). Esta condição é também conhecida como limiar de saturação. No modelo de Kocurek \& Havholm (1993), a variação do espaço de acumulação resume-se à variação da altura de equilíbrio. No entanto, a altura de equilíbrio é apenas a componente vertical desse espaço. Sua componente horizontal, a área da acumulação eólica, é função da extensão transversal ao vento das fácies arenáceas dos sistemas deposicionais, aluviais ou costeiros, que the atuam como fonte imediata e da 
máxima distância do depósito eólico a essa fonte, ao longo do rumo do vento. Desse modo, o conceito de espaço de acumulação pode ser estendido a aspectos geográficos. Nesse sentido, é possivel falar também em distância de equilibrio. Nos sistemas eólicos costeiros, a distância de equilibrio é aqui definida como a distância, ao interior da praia, e no rumo do vento, até a qual é possivel haver contínuo saldo positivo ou saturado de sedimentos (Qi>Qe) no sistema. Esta distância guarda estreita relação com o conceito físico de comprimento de saturação (saturation length), definido por Sauermann et al. (2001) na escala de duna e protoduna (heap) eólica. A tradução geológica deste conceito é a alternância entre saturação sedimentar positiva e negativa através de dunas e interdunas, respectivamente, como já fora descrito por Kocurek \& Havholm (1993). Desse modo, a relação entre Qi e Qe oscila através do sistema eólico, na escala de campo de dunas, segundo uma distância que lhe é caracteristica e que se torna fixa quando atingida a condição de equilibrio estacionário. Conceito similar, numa hierarquia acima de complexidade, supõe-se existir na escala maior de análise do sistema eólico e aplicar-se assim ao espaçamento entre draas ou campos de dunas. A distância de equilíbrio representaria portanto um atrator no desenvolvimento do sistema na direção do equilibrio estacionário. Por outro lado, o alcance da distância de equilíbrio num sistema eólico em formação não significa necessariamente que o saldo sedimentar (Qi-Qe) no sistema tenha sido anulado, mas apenas que esse sistema atingiu uma forma de equilíbrio entre taxa de aporte e energia.

A preservação é a incorporação da acumulação ao registro estratigráfico. $O$ espaço de preservação é a parcela do espaço de acumulação que se incorpora neste registro. Seu limite superior é o nivel de base de erosão. Nos sistemas marinhos, o nivel de base de erosão coincide com o nivel do mar e, portanto, o espaço de preservação equivale ao espaço de acumulação. Nos sistemas eólicos, o nivel de base é determinado, numa primeira aproximação, pelo nivel freático, e portanto só coincide com o nível do mar em casos especificos. A idéia de um espaço de acomodação sensu stricto, onde o sedimento se acumula e se preserva, não se aplica ao caso eólico.

Apesar de geralmente não coincidirem, nivel do mar (nivel de base de erosão em sistemas costeiros) e nível freático (ligado ao nível de base em sistemas eólicos) possuem dinâmicas diretamente relacionadas entre si. Esta relação é tão mais evidente e imediata quanto mais próximo da costa estiver o sistema eólico (Kocurek \& Havholm 1993). No entanto, o nivel freático não desempenha em relação ao sistema eólico exatamente a mesma função que o nível do mar em relação aos sistemas marinhos ou costeiros. Enquanto o nivel do mar pode ser considerado nivel de base destes sistemas, por materializar a superfície acima da qual a erosão predomina francamente sobre a deposição, o nível freático define apenas o limite inferior potencial da erosão nos sistemas eólicos (Giannini et al. 2007a). A possibilidade de acumulação de centenas de metros de areia eólica acima do lençol freático em desertos interiores demonstra que a adoção do nível freático como nível de base de erosão, na escala de tempo do Quaternário, constitui aproximação grosseira. Desse modo, o nível freático configura-se mais como nivel de estabilização do sistema eólico de que como nivel de base. Estabilização pode ser definida ai como indisponibilidade do substrato arenoso ao transporte eólico. A proximidade entre lençol freático e superfície deposicional determina os processos ou fatores de estabilização de sistemas eólicos, os quais têm importância central na definição dos limites tempo-espaciais e na classificação destes sistemas, segundo Kocurek \& Havholm (1993).

Kocurek \& Havholm (1993) classificam os sistemas eólicos, segundo os fatores que provocam sua estabilização. Entre estes fatores, o mais atuante é a posição do nível freático e sua franja de capilaridade em relação à superfície deposicional. Disso resulta a subdivisão dos sistemas eólicos em secos, úmidos e estabilizados (Figura 3.21). 


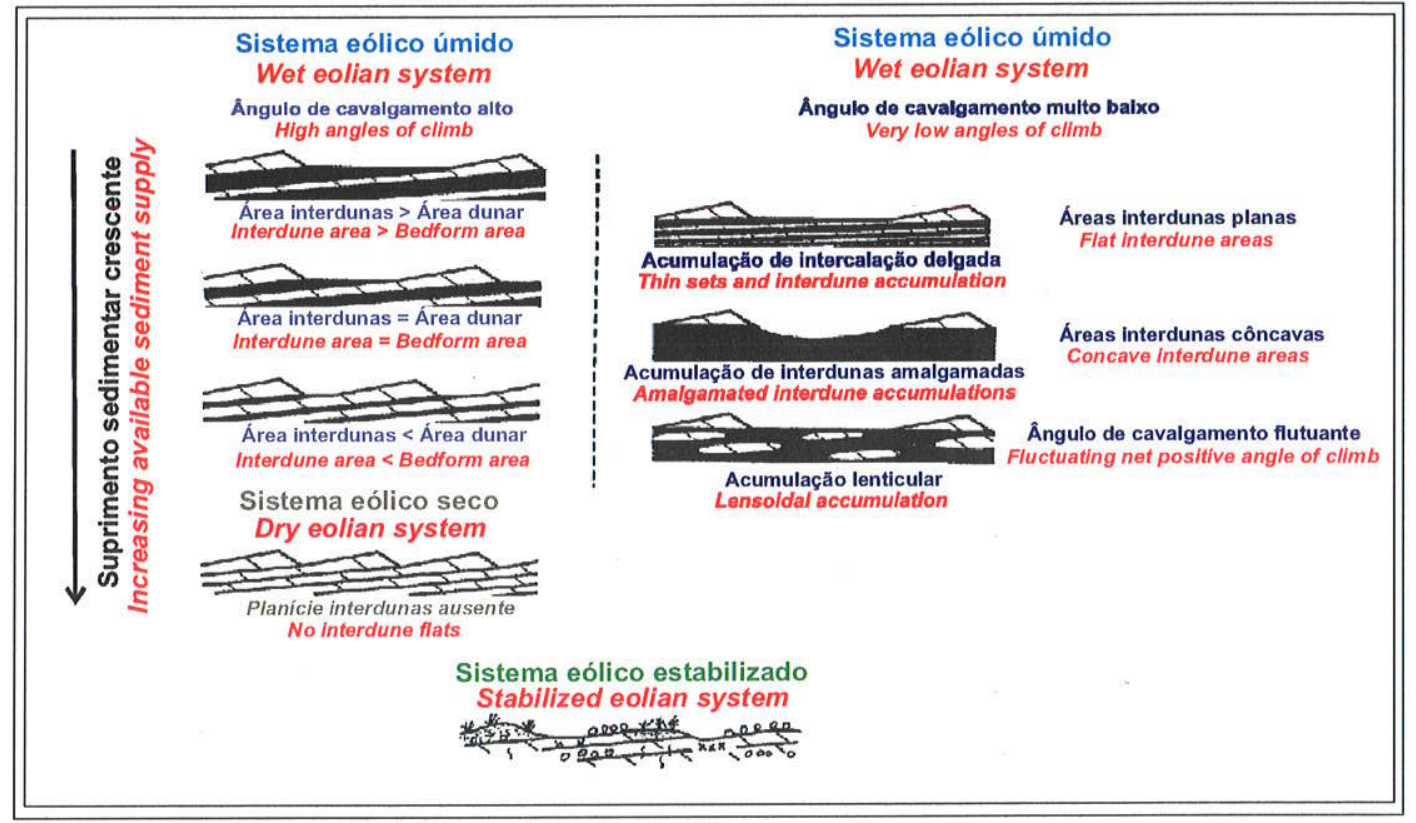

Figura 3.21. Configuração da acumulação eólica em diferentes tipos de sistema eólico. A parte direita da figura representa depósitos de sistema eólico úmido formados em baixo ângulo de cavalgamento das formas de leito. Baseado em Kocurek \& Havholm (1993).

Sistemas eólicos secos caracterizam-se por nível freático e franja de capilaridade abaixo da superfície deposicional, com constante disponibilidade de areia incoesa para o transporte pelo vento. Os processos de erosão e estabilização do sistema seriam dependentes de fatores aerodinâmicos e do aporte sedimentar. Entre duas situações extremas de aporte, do baixo ao elevado, os sistemas eólicos secos podem variar desde dunas isoladas que migram sobre um substrato deflacionar até mares de areia dominados por campos de dunas. No primeiro caso, ocorrem planícies interdunas. No segundo caso, a escassez de água favorece a incoesão dos sedimentos, inclusive nas planícies interdunas, e torna-as áreas favoráveis à erosão e redeposição pelo vento. As planícies interdunas, assim assoreadas por areia eólica, transformam-se em depressões interdunas (cavas entre dunas sucessivas).

A transformação das planícies interdunas em depressões interdunas é condição necessária à acumulação neste tipo de sistema eólico, uma vez que o processo de acumulação só se inicia quando houver cavalgamento (climbing), em ângulo positivo, entre sucessivas formas de leito. Assim, cada duna é soterrada pela duna subseqüente rapidamente, sem erosão completa de seus depósitos. Como conseqüência disto, é rara a presença no registro estratigráfico de depósitos de planícies interdunas em meio a sistemas eólicos secos.

O término da acumulação nos sistemas eólicos secos pode ocorrer por queda do aporte ou quando o depósito atingir altura tal que não haja mais condição para desaceleração do vento (perda de efluxo). O limite espacial máximo superior para a acumulação (altura de equilíbrio) neste tipo de sistema é determinado, portanto, por fatores essencialmente aerodinâmicos (Kucurek \& Havholm 1993). O mesmo pode ser estendido ao limite em extensão no rumo do vento e à distância de equilíbrio.

Nos sistemas eólicos úmidos, o nível freático e sua franja de capilaridade encontramse aflorantes ou próximos (até poucos metros) da superfície deposicional. A presença de água diminui o potencial erosivo e a quantidade de sedimentos que podem ser transportados 
pelo vento (DEE). Desse modo, os mecanismos responsáveis pela dinâmica das formas de leito e estabilização do sistema não são controlados unicamente por fatores aerodinâmicos. A redução do potencial erosivo devido à presença de água na superfície explica a preservação de depósitos interdunas nestes sistemas ou mesmo o aparecimento de sabkhas e outras associações de fácies subaquosas (Kocurek \& Havholm 1993). Outra decorrência da menor quantidade de sedimentos incoesos, potencialmente transportados pelo vento, é o menor tamanho das dunas.

A relação entre os tipos de sistema, seco ou úmido, e o clima não é de unicidade. Segundo Kocurek \& Havholm (1993), a transição de um sistema subaquoso do tipo sabhka para um sistema eólico úmido e deste para um sistema eólico seco poderia ser descrita em termos do suprimento de sedimentos, este controlado pela tectônica. Equivale a dizer que a presença de água próxima à superficie, regida pelo comportamento do nível freático, é controlada não somente pelo clima, mas pela taxa de subsidência e, em sistemas eólicos costeiros, pelo nível do mar. Desse modo, é teoricamente possivel existir sistemas eólicos secos, sob clima úmido, desde que o aporte se torne muito elevado. E, no caso costeiro, é possivel haver sistema eólico úmido, sob clima seco.

O terceiro tipo de sistema eólico, na classificação de Kocurek \& Havholm (1993), é chamado sistema eólico estabilizado (Figura 3.21). Sua característica diagnóstica é a ação de fatores estabilizadores que atuam simultaneamente ao transporte, deposição e acumulação de sedimentos, sem afetar o sistema como todo. Estes fatores possuem assim caráter tipicamente local. Incluem vegetação, cimentação, filmes de lama, depósitos residuais de cascalho e derrames de lava. O critério usado pelos autores na individualização deste tipo de sistema é diferente do critério de proximidade do lençol freático utilizado na distinção entre sistemas eólicos secos e úmidos, ainda que o freático possa influir em parte dos fatores estabilizadores arrolados. Trata-se, portanto, a rigor, de classificações complementares, pois os sistemas eólicos estabilizados também podem ser classificados, ao mesmo tempo, como úmidos ou secos, na dependência da natureza dos fatores estabilizadores (Giannini et al. 2007a). É como se desenvolvessem super-superfícies úmidas ou secas, porém de extensão restrita. Além disso, para que estes fatores prevaleçam sobre a deposição, deve haver queda do aporte eólico. Desse modo, sistemas eólicos estabilizados parecem representar mais um estágio de desenvolvimento do que propriamente uma classe independente de sistema eólico (Giannini et al. 2007a).

Pode-se considerar, portanto, que existe ampla gama de fatores estabilizadores, entre os quais o lençol freático elevado se destaca pela capacidade de agir por toda a extensão do sistema eólico. Seja qual for o fator estabilizador, sua prevalência sobre a deposição depende de que haja queda do aporte eólico. Assim, a existência de fatores estabilizadores não constitui condição suficiente para o encerramento do sistema.

\subsubsection{Controle por variáveis do macroambiente}

A questão que se coloca aqui é quais os fatores do macroambiente relevantes para o controle de volume e forma do sistema eólico costeiro e como eles atuam. A falta de estabelecimento prévio de perspectiva e escala de abordagem faz com que esta questão seja tratada muitas vezes de modo pouco rigoroso na literatura sobre dunas costeiras. Por exemplo, para Hesp \& Thom (1990), os três fatores principais na formação de campos de dunas seriam o aumento do aporte sedimentar, as mudanças de NRM e a instabilização de dunas frontais. Sob o ponto de vista do modelo conceitual sistêmico exposto no item anterior, esta afirmativa mistura um fator essencialmente macroambiental, o NRM, com uma variável de entrada, o aporte, o qual por sua vez, depende do NRM e de outras variáveis macroambientais não mencionadas. Considerando que a principal importância das variações de NRM reside na disposição do próprio estoque sedimentar ao transporte eólico, e que 
vários fatores além do NRM podem determinar esta disposição, não parece interessante tratar as duas variáveis, aporte e NRM, na mesma hierarquia. Campos de dunas e dunas frontais são apenas dois dos reservatórios de areia do sistema eólico costeiro, passiveis de coexistência, e cuja ocorrência, morfologia e dimensões são controlados pelo estoque na fonte (aporte primário), por sua vez determinado, dentre muitas outras variáveis, pelo comportamento do NRM.

O estoque sedimentar primário é controlado pelo saldo de sedimentos na porção constante ou intermitentemente emersa do sistema deposicional costeiro que atua, em escala de tempo imediata e mediata, como fonte para o vento. Em escala mediata, no decorrer do Quaternário, a extensão e distribuição dos sistemas deposicionais ao longo da costa depende da disponibilidade de espaço de acomodação sedimentar, controlada pelas variações de NRM e pela fisiografia costeira. Face à amplitude das variações de NRM no decorrer do Quaternário (mais de uma centena de metros), falar em fisiografia costeira aqui implica falar em fisiografia da plataforma continental (Howell \& Thom 1994). Assim, dentre as variáveis mediatas que controlam o aporte sedimentar eólico regional, destacam-se as mudanças do NRM, e variações associadas do lençol freático, a fisiografia da plataforma continental e o clima (Short 1988a,b, Giannini 1993, Giannini \& Santos 1994, Dillenburg et al. 2000, Giannini et al. 2001b,c).

As mais importantes variáveis macroambientais seriam portanto o estoque sedimentar primário, como caráter de variável passiva, e clima, nivel do mar e contexto tectono-estrutural, como variáveis ativas. Em suma, a formação, a morfologia e as dimensões dos depósitos eólicos costeiros são determinados pela ação ou influência, sobre o estoque de sedimentos disponiveis para o transporte eólico, do contexto climático (principalmente regime de ventos), do NRM e das características tectono-estruturais e fisiográficas da bacia.

Caracteristicas mais locais ou imediatas da costa, fortemente ligadas a ação isolada ou combinada das variáveis macroambientais, também influenciam o estoque. Dentre as variáveis imediatas, são freqüentemente lembradas a energia das ondas, e conseqüentemente, o grau de dissipatividade morfodinâmica da praia (Short 1988a,b, Carter 1990, Giannini 1993, Giannini \& Santos 1994), a ocorrência de tempestades (Christiansen et al. 1990; Giannini \& Santos 1994; Giannini et al. 2007c), o rumo residual das correntes de deriva litorânea (Giannini \& Santos 1994), o suprimento por rios (Hesp \& Thom 1990) e a redução da cobertura vegetal (Hesp \& Thom 1990).

Variáveis mediatas

NRM

O comportamento do NRM é talvez o mais polêmico dentre os fatores controladores da sedimentação eólica, dando lugar a dois modelos opostos, conforme se associa a iniciação de campos de dunas a NRM baixo e/ou em queda ou a NRM alto e/ou em elevação (Figura 3.22).

Sistemas eólicos e NRM baixo ou em queda

De acordo com este modelo, os campos de dunas costeiros seriam gerados pelo retrabalhamento de sedimentos expostos na plataforma continental durante regressão forçada (Sayeles 1931, Wright 1963, Schofield 1975 apud Pye \& Bowman 1984, Coetzee 1975/1976, Hobday 1977, Ward 1977 apud Pye 1983). A queda do nível do mar implicaria o transporte de sedimentos de zonas mais profundas para zonas mais rasas para restabelecer o perfil de equilibrio da superficie deposicional (Schofield 1975 apud Pye \& Bowman 1984), 
em mecanismo recíproco ao postulado pelo princípio de Bruun para o caso de NRM ascendente. A acrescência praial assim possibilitada disponibilizaria sedimentos para a formação de campos de dunas transgressivos.

A principal crítica que se pode fazer contra este modelo é que os sedimentos expostos acima do nivel médio de maré apresentam elevada probabilidade de serem afetados por processos estabilizadores como colonização por vegetação, cimentação eodiagenética e desenvolvimento de solos (Giannini et al. 2007c). A queda do nivel do mar implica, desse modo, condições desfavoráveis à disposição de sedimentos ao transporte eólico. Além disto, mesmo que se admita sua formação, os depósitos eólicos em contexto de queda do nivel de base seriam submetidos à erosão subaérea acelerada pela formação de vales incisos. Teriam assim drasticamente reduzido o seu potencial de preservação no registro geológico (Giannini et al. 2001b, 2007c). A conclusão é que, apesar da possibilidade de retrabalhamento eólico durante a queda do nível do mar, não se trata de situação favorável à iniciação e preservação de campos de dunas transgressivos. Mais do que este problema teórico, o modelo de formação de sistemas eólicos tem a seu desfavor uma objeção empírica: ele não explica os dados cronoestratigráficos disponíveis para campos de dunas costeiros (Lees 2006).

Alguns trabalhos associam a origem de sistemas eólicos específicos a fases de NRM em queda, porém sem defender explicitamente esta associação como norma (Christiansen \& Bowman 1986, Christiansen et al. 1990, Dominguez et al. 1987, Suguio et al. 2001). Christiansen \& Bowman (1986) e Christiansen et al. (1990) relatam o desenvolvimento de campos de dunas transgressivos na Dinamarca sob condições de NRM em declínio. Segundo estes autores, o abaixamento do NRM favoreceria a disposição de areia ao transporte eólico, neste caso, através de três mecanismos: (1) exposição de extensas áreas da plataforma à atividade do vento; (2) abaixamento do nivel freático, com conseqüente aumento da quantidade de areia na zona insaturada em água; e (3) abaixamento do nível de base de onda, com disponibilização de novo prisma de areias submersas ao transporte pelas ondas, e, posteriormente, pelo vento. Cabe ressalvar que os eventos de abaixamento de NRM e a conseqüente formação de dunas referidos por estes autores possuem duração aproximada de 1000 anos, e situam-se dentro do contexto maior do último período pósglacial. Assim, não contrariam a idéia de que, numa escala de tempo mais duradoura (multimilenar), a formação de campos de dunas costeiros seja desencadeada pela ascensão do NRM.

Dominguez et al. (1987) mencionam que a queda do nivel do mar durante o Holoceno provocou o desenvolvimento de "lençóis de areia eólicos regressivos" sobre sedimentos de cordões litorâneos da costa nordeste brasileira. Esses autores baseiam-se na idéia de que a queda do nivel do mar expõe sedimentos da planície costeira ao retrabalhamento eólico. Hipótese semelhante foi admitida por Suguio et al. (2001) para explicar os antigos "lençóis de areia" existentes na região de Itanhaém, SP, cujas idades TL teriam incidido, predominantemente, no período correlato ao último máximo glacial (item 3.1.1.3). Em relação a estes dois casos, deve-se destacar que, embora faltem descrições mais detalhadas sobre os depósitos eólicos e discussão sobre o significado das datações, certamente não se trata de campos de dunas transgressivos sensu stricto. Parece valer o comentário de Pye \& Bowman (1984) segundo o qual os contextos de NRM baixo não são suficientes senão para a formação de delgados lençóis de areia eólica sobre a planície costeira. 


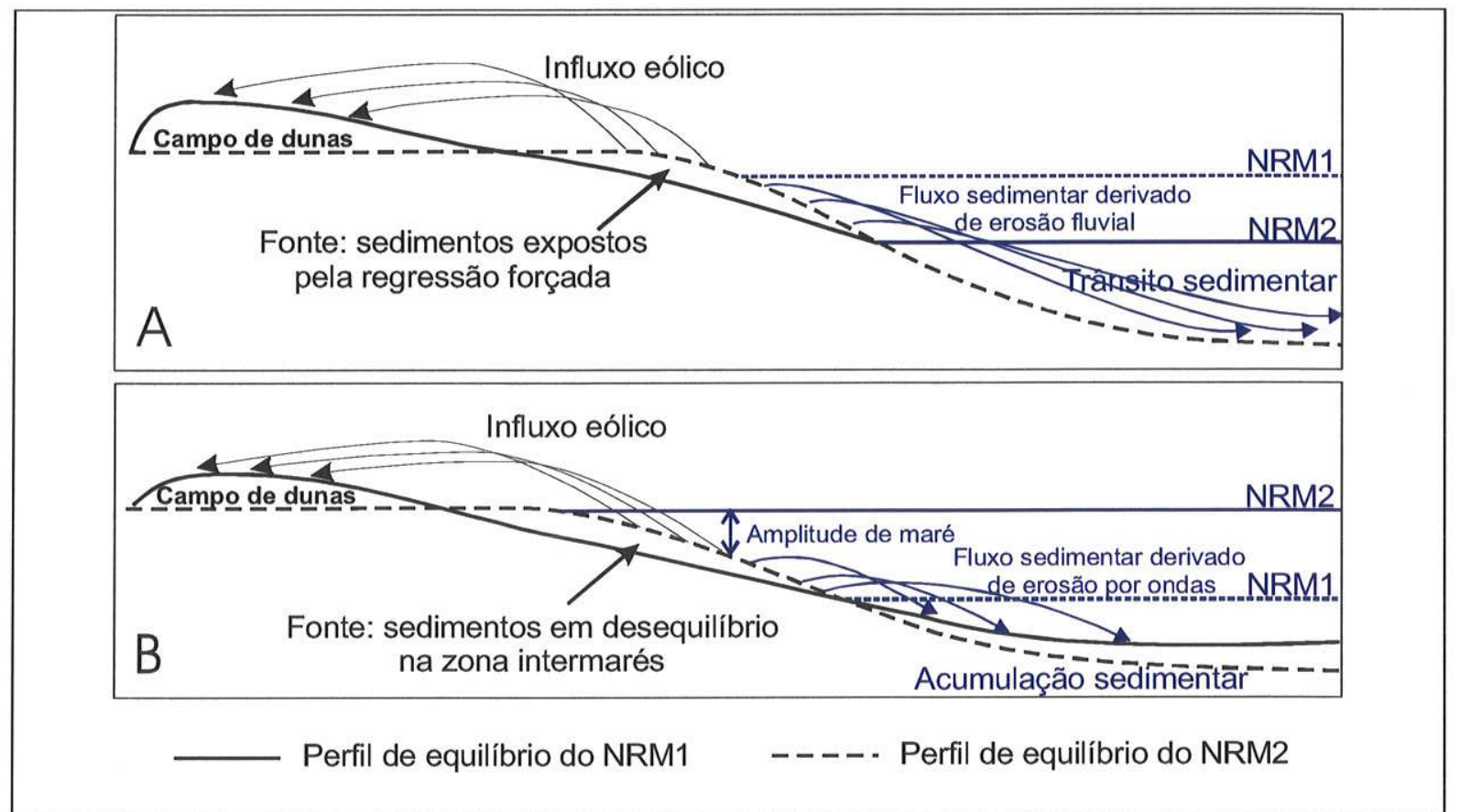

Figura 3.22. Desenvolvimento de sistemas eólicos costeiros durante ou logo após queda (A) ou subida de NRM (B). A manutenção do aporte eólico no caso B é complicada pela alta probabilidade de estabilização de sedimentos acima do nível de preamar, por fatores como cobertura vegetal, formação de solo e cimentação eodiagenética. Os fluxos subaquosos aparecem em azul. Baseado em Sawakuchi (2003).

Sistemas eólicos e NRM alto

No segundo modelo, a formação de sistemas eólicos costeiros é relacionada à elevação de NRM (Cooper 1958, Roy \& Thom 1981, Thom et al. 1981, Pye \& Bowman 1984, Giannini 1993; Giannini \& Santos 1994; Giannini et al. 2001b,c, Sawakuchi 2003, Lees 2006, Giannini et al. 2007c), o que induziria erosão costeira para restabelecer a superfície deposicional do perfil de equilíbrio. Cooper (1958) sugere que o avanço uniforme de campos de dunas transgressivos por ampla área de Oregon (oeste do EUA) é resultado da erosão costeira provocada pela última subida global do nível eustático. Desta forma, eventos similares deveriam ser encontrados em outras partes do mundo. A queda ou estabilização subseqüente do nível do mar na região teria ocasionado a estabilização das dunas através da fixação das areias costeiras pela vegetação. O nível eustático seria assim a principal variável controladora do desenvolvimento de dunas costeiras. Como efeito, a ciclicidade das variações de nível eustático induzida por glaciações e deglaciações ficaria refletida na sucessiva estabilização e ativação de campos de dunas costeiros, respectivamente.

Parte dos defensores do modelo (Roy \& Thom 1981, Giannini 1993, Giannini \& Santos 1994, Giannini et al. 2001b,c) baseia sua argumentação teórica no princípio de Bruun (1962), sobre erosão costeira induzida por NRM ascendente. Os sedimentos arenosos colocados em desequilíbrio na zona intermarés (antepraia e pós-praia não vegetado) pela subida de NRM teriam como que um segundo destino, além da zona submersa prevista por este princípio. Assim, sob regime de ventos adequado, parte destes sedimentos em desequilíbrio seria transportada pelo vento rumo ao continente para produzir dunas eólicas. Com o fim da elevação de NRM e a exaustão da fonte sedimentar eólica, um novo perfil de equilíbrio seria alcançado. De acordo com este modelo, a fonte sedimentar encontra-se na zona intermarés ou antepraia, fora da ação dos processos estabilizadores, e com sedimentos em excesso 
derivados da subida de NRM (Figura 3.23). A mais longo prazo, a subida do nível do mar configuraria situação desfavorável à incisão fluvial e à erosão subaérea e favoreceria assim a preservação dos sedimentos eólicos no registro geológico (Giannini et al. 2001b; Giannini et al. 2007c).

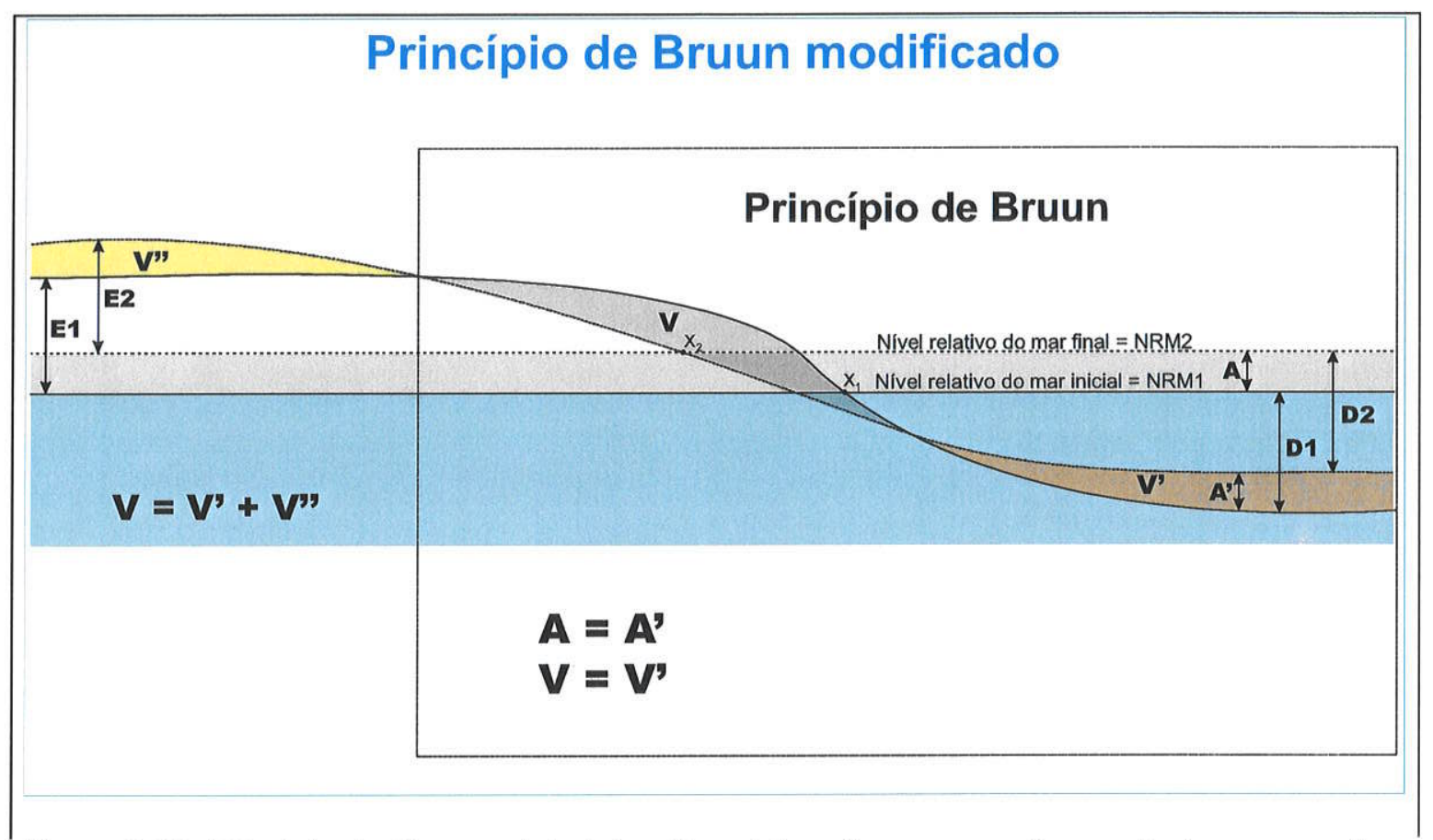

Figura 3.23. Princípio de Bruun original (moldura interna) e sua versão ampliada para explicar formação de campos de dunas em contexto de elevação do NRM (moldura externa, em azul). A: elevação de NRM, A': elevação do fundo sedimentar, D: profundidade, E: altura eólica de equilíbrio, V: volume colocado em desequilíbrio pela elevação de NRM, V': volume de areia deslocado pelas ondas, V': volume de areia deslocado pelo vento. Desenho de A.O. Sawakuchi e P.C.F. Giannini, baseado em Giannini et al. (2001b).

São vários os casos-estudo, além do trabalho pioneiro de Cooper (1958), em que campos de dunas transgressivos específicos são atribuídos a situação de NRM alto, interpretação quase sempre apoiada por resultados de datação.

$\mathrm{Na}$ Austrália e na Nova Zelândia, dunas fósseis distantes da costa atual já eram atribuídas à elevação pós-glacial de NRM, com base em dados de campo, em trabalhos que podem ser considerados clássicos (Brothers 1954 e Bird 1964 apud Goldsmith 1978, Jennings 1957, Davis 1980). Pye (1983b) reforçou esta interpretação, estendendo-a ao último NRM alto do Pleistoceno. Com base em datações e no uso de modelos morfoestratigráficos de acumulação eólica, associou a maioria das dunas pleistocênicas de Queensland, nordeste da Austrália, ao último evento interglacial. Segundo esse autor, a principal geração de campos de dunas holocênicos na área data do intervalo entre 5,7 e 4,4 ka AP, época coincidente com o máximo NRM regional. No Sudeste da Austrália, evento correlacionável manifesta-se entre 8 e 5,5 ka AP, depositando dunas que logo em seguida são parcialmente erodidas pelo máximo transgressivo (Ohmori et al. 1987). No sul da Austrália, Short (1988) situa evento correspondente entre 10 e 6,5 ka AP e associa-o à formação de dunas de topo de escarpa (cliff-top dunes).

$\mathrm{Na}$ costa leste australiana, idades ${ }^{14} \mathrm{C}$ de fragmentos vegetais em paleossolos embutidos em sedimentos eólicos (Pye \& Bowman 1984) evidenciam o desenvolvimento de campos de dunas transgressivos entre 10 e 6 ka AP. Pye \& Bowman (1984) interpretam a 
geração destes campos de dunas como resultado do carreamento pelo vento, para o continente, de parte da areia erodida na praia durante a subida do nivel do mar. No Japão, este evento corresponde à primeira fase de formação das denominadas O/der Dunes, ocorrida entre 7,5 e 6 ka AP (Endo 1986). A descrição das dunas depositadas nesta fase corresponde a de rampas de areia eólica (depósitos eólicos ancorados no lado barlavento de uma elevação topográfica).

Modelo para explicar o desenvolvimento de campos de dunas com base em variações do nível do mar no Quaternário superior foi proposto também para a costa noroeste da Irlanda, por Carter \& Wilson (1993). Propõem-se três fases evolutivas, cada uma delas caracterizada por um tipo de comportamento do nivel do mar. A fase inicial, correspondente ao período de nível do mar baixo (lowstand) provocado pelo último estágio glacial (Glaciação Würm, finalizada em aproximadamente $12 \mathrm{ka}$ AP), seria caracterizada pela deposição de grande volume de sedimentos glaciais sobre a plataforma continental exposta. A fase seguinte teria início com a rápida subida do nível do mar induzida pela deglaciação, quando os sedimentos glaciais previamente depositados seriam retrabalhados por agentes costeiros, sob transgressão rápida. Nesta fase, ocorreria segregação granulométrica dos sedimentos da plataforma e formação de barreiras de cascalho. A última fase começaria com a estabilização seguida por queda suave do nivel do mar (em aproximadamente $5 \mathrm{ka} A P$ ). Durante esta fase haveria progradação, com concentração de sedimentos na fração areia na zona de face litorânea (shoreface) e desenvolvimento de praias dissipativas pela eliminação das barreiras de cascalho. O elevado aporte arenoso onshore favoreceria então a deposição de areias eólicas, cujas idades indicam iniciação dos campos de dunas entre 6 e 5 ka AP.

A importância do NRM e do clima, nos processos de iniciação de campos de dunas costeiras foi recentemente avaliada por Lees (2006), tomando como base o caso australiano. Segundo este autor, o padrão de mudança climática, por si próprio, é insuficiente para explicar os padrões observados de distribuição de campos de dunas costeiros no tempo. Apesar de mudanças climáticas e de NRM serem inseparáveis durante grande parte do Holoceno, todos os eventos de iniciação de dunas costeiras na Austrália são expressas apenas na linha de costa e não como reativação de unidades antigas. O autor chama atenção ainda para períodos de desenvolvimento generalizado de campos de dunas transgressivos. A abrangência continental destes eventos sugere que mudanças interregionais de NRM, mais que mudanças climáticas regionais, teriam sido o gatilho para a iniciação desses campos de dunas.

No Brasil, utilizou-se a hipótese de geração de campos de dunas transgressivos a partir de areias praiais colocadas em desequilíbrio pela subida do NRM (Figura 3.23), para relacionar os depósitos eólicos costeiros do litoral centro-sul catarinense ao máximo nivel do mar do último interglacial e do pós-glacial (Giannini 1993). Haveria duas seqüências deposicionais de depósitos eólicos, separadas entre si por descontinuidade erosiva, relacionada à estabilização do sistema eólico mais antigo durante a queda de NRM do último lacial (Giannini et al. 2001b). Resultados de datação TL e LOE obtidos posteriormente reforçaram (Sawakuchi 2003, Giannini et al. 2007c) este modelo (item 3.1.1.3).

Mais recentemente, as tentativas de correlação entre dunas eólicas costeiras e nivel do corpo de água têm sido estendidas a costas lacustres. Idades LOE (Luminescência Opticamente Estimulada) de sedimentos eólicos quaternários do campo de dunas de Algodones, na borda do paleolago Cahuilla (sudeste da Califórnia, EUA) e idades ${ }^{14} \mathrm{C}$ dos sedimentos lacustres associados levaram Stokes et al. (1997) a subdividir os depósitos eólicos desta área em dois grupos com idades distintas. Os sedimentos eólicos mais antigos são do Pleistoceno (idade LOE mínima de 31 ka AP) e apresentam maior grau de alteração, atribuido a período de estabilidade e pedogênese entre o Pleistoceno tardio e o Holoceno inicial ou médio. Os sedimentos mais recentes possuem idades que variam de 3,1 ka AP até o presente. Com base nesses resultados, os autores admitiram relações entre a elevação de 
aporte eólico responsável por ambas as gerações de dunas com o final de fases de nível do lago alto.

Correlações entre períodos de formação de dunas costeiras lacustres com variações do nivel do lago foram traçadas também, numa escala de tempo mais curta, por Loope \& Arbogast (2000). O método consistiu em comparar as idades ${ }^{14} \mathrm{C}$ de paleossolos soterrados por dunas eólicas com a curva de variação do nível do lago Michigan. A datação de fragmentos vegetais dos paleossolos forneceria a idade de morte dos vegetais por soterramento eólico. As idades obtidas coincidem com fases do nível do lago alto, com periodicidade de 150 anos, levando os autores a concluir que a atividade eólica seria desencadeada pela subida do nível do lago. Esta relação permite interpretar que a estabilização e ativação de campos de dunas costeiros seriam sensiveis a variações de nivel do corpo de água adjacente, mesmo em curto periodo de tempo.

Influência do NRM sobre o aporte édico: uma sIntese sob a perspectiva da estratigrafia de sequências

Em escala de tempo milenar, a disponibilidade de sedimentos para alimentar um campo de dunas costeiro é controlada pelo volume de areia na zona intermarés do sistema deposicional marinho adjacente e pela capacidade deste sistema em renovar este volume. $A$ elevação de NRM gera aumento do espaço de acomodação na margem da bacia. Ao mesmo tempo, cria excesso de sedimentos na zona intermarés devido ao desequilibrio da superfície deposicional induzido pelo aumento da lâmina de água. Sob condições imediatas adequadas (presença de areias incoesivas com granulometria compativel e exposição a ventos onshore regulares e potentes), este estoque de sedimentos pode alimentar campos de dunas costeiro (Giannini \& Santos 1994; Giannini et al. 2001b,c). Entretanto, a formação e preservação de sistemas eólicos costeiros formados nesse contexto depende da taxa de subida do NRM. Durante fases acentuadamente transgressivas, sob taxa alta de elevação de NRM, o estoque sedimentar disponivel ao retrabalhamento eólico pode ser rapidamente submerso, sem tempo suficiente para a formação de campos de dunas. Mesmo que formados, os depósitos eólicos podem ser inundados e erodidos pelas ondas do contexto transgressivo. Assim, os sedimentos eólicos eventualmente depositados durante fases de elevação rápida de NRM possuem baixo potencial de formação e preservação. A fase de desaceleração da transgressão imediatamente anterior à máxima inundação seria mais favorável à formação de campos de dunas (Figura 3.24-I). Os depósitos eólicos formados nesta fase podem ser inundados e erodidos por ondas na parte marginal do sistema, tendo seu potencial de preservação reduzido localmente (Figura 3.24-II). Na fase subseqüente do ciclo de variação eustática, a desaceleração da subida de NRM determina o fim da transgressão (Figura 3.24III e -IV). Esta fase caracteriza-se pelo trato de sistemas deposicionais de mar alto ou highstand (baixa taxa de aumento ou de queda de NRM), com progradação dos sistemas marinhos costeiros devido à taxa elevada de sedimentação terrígena na margem de bacia. Além do grande volume de sedimentos ai depositado ser favorável ao desenvolvimento de sistemas eólicos costeiros, o potencial de preservação destes sistemas vê-se aumentado pelo nível de base relativamente elevado e pelo contexto desfavorável à erosão costeira.

Durante fases de queda de NRM ou de lowstand, a situação é de trânsito (bypass) de sedimentos na margem da bacia por efeito da redução de espaço de acomodação (Figura 3.24.V). Os sedimentos vindos do continente são depositados nas porções distais da bacia. Assim, faltam sedimentos costeiros para alimentar o sistema eólico. Mais que isso, taxas elevadas de queda de NRM levam à erosão, por incisão fluvial, de depósitos eólicos por ventura acumulados. 


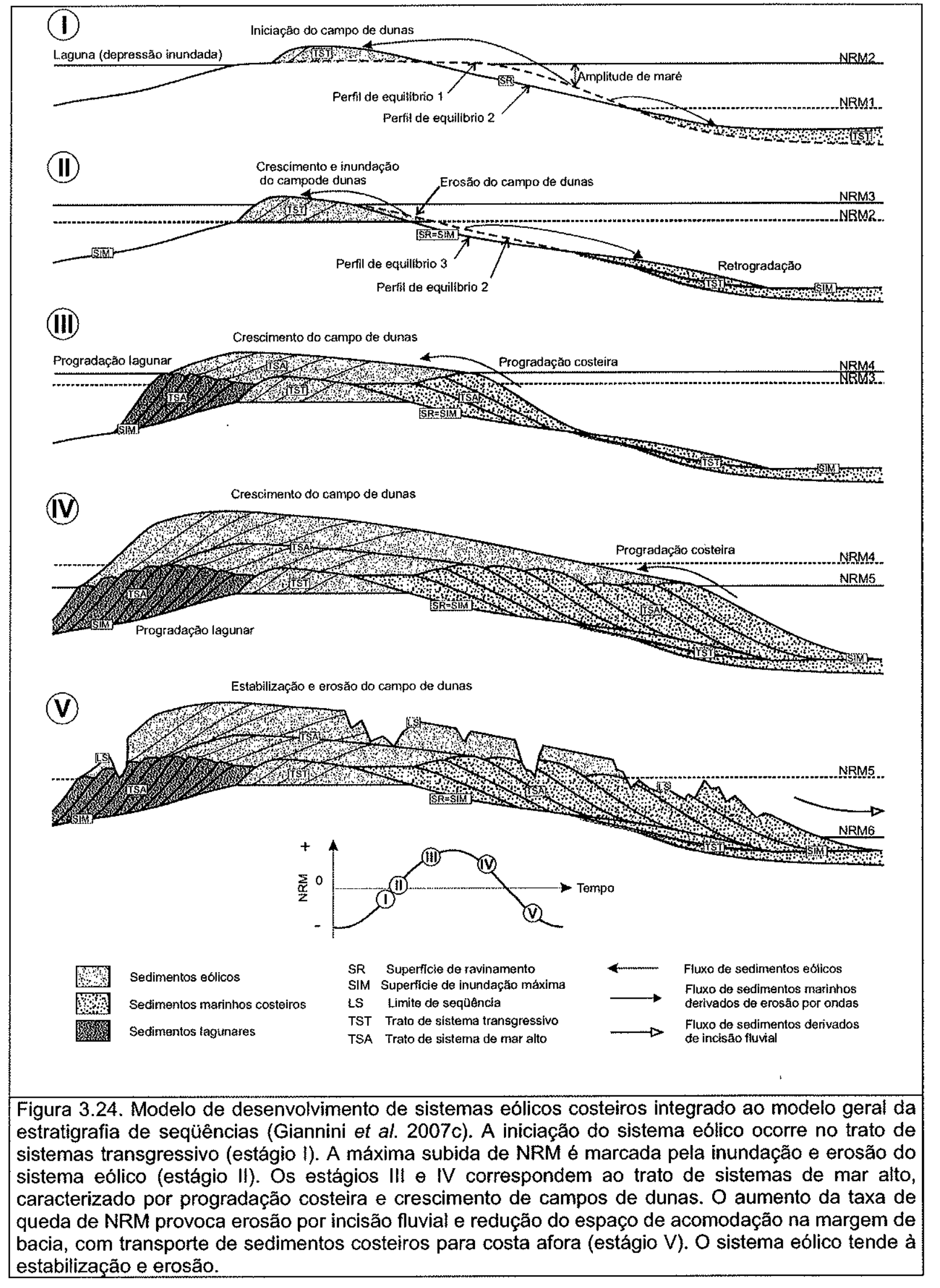


De acordo com o modelo apresentado, a formação de sistema eólicos costeiros estaria associada preferencialmente aos tratos de sistema transgressivo e de mar alto do modelo geral da estratigrafia de seqüências. Os sedimentos do trato de mar alto possuiriam, entretanto, potencial de preservação comparativamente mais alto.

\section{Fisiografia da plataforma}

O estoque sedimentar potencial para o transporte eólico depende de sua disponibilidade por agentes costeiros, principalmente ondas. Desse modo, seu domínio espacial abrange toda a zona da plataforma continental acima do nivel de base de onda, ou o que na escola australiana de geologia costeira tem sido denominado barreira arenosa costeira (coastal sand barrier. Roy et al. 1994). As características morfológicas desta zona da plataforma que favorecerem a manutenção do estoque e/ou sua disponibilidade ao vento, favorecem também, por extensão, o desenvolvimento de sistemas eólicos costeiros. Assim, plataformas internas de declive suave, por apresentarem prisma sedimentar de interação com ondas volumoso, bem como baixa taxa de perda de sedimentos para costa afora, são teoricamente favoráveis ao maior desenvolvimento de sistemas eólicos costeiros.

Esta previsão teórica de aumento do estoque sedimentar costeiro (disponivel para transporte eólico) por efeito da redução do declive da plataforma é em parte reforçada pelos resultados de simulação matemática de barreiras costeiras transgressivas apresentados por Roy et al. (1994). O declive da plataforma figura ai justamente como o parâmetro mais determinante nas características dimensionais e dinâmicas da barreira. Sob taxa constante de subida de NRM, a redução gradual do declive, de 0,8 a $0,1^{\circ}$, induz aumento no volume da barreira costeira e na taxa de reciclagem de seus sedimentos, sem perdas costa afora. Desse modo, reduz-se a liberação de sedimentos pelo mecanismo básico da "regra de Bruun padrão", efeito que só vem confirmar o corolário do próprio princípio de Bruun (1962) segundo o qual a defasagem na resposta erosivo-deposicional do sisterna costeiro à subida de NRM aumenta com a redução do declive. Barreiras com essa ordem de grandeza de declive seriam favoráveis ao deslocamento do excesso de estoque para o interior, por ação do vento. Ainda de acordo com os resultados da simulação, esta retenção de areias na barreira torna-se desprezivel para declives acima de $0,8^{\circ}$, e o funcionamento da regra de Bruun atinge ai sua máxima eficiência. Para ângulos menores que aproximadamente $0,1^{\circ}$, a tendência de aumento de volume da barreira costeira com a diminuição do declive da plataforma desaparece e chega mesmo a inverter-se. A perda de energia das ondas por friç̧ão atinge a partir de então valores tão elevados que o volume de areia disponível para o transporte transversal se torna maior que a capacidade das ondas incidentes. Com isso, a barreira passa a reduzir suas dimensões, deixando na costa afora, na forma de lençol de areia residual (trailing-edge sand sheet), o sedimento não transportado (Roy et al. 1994).

\section{Clima}

Uma vez estabelecido o estoque de areia na área fonte, o transporte eólico depende da incoesão e das características do vento, quanto à velocidade e orientação relativa, características em grande medida controladas pelas condições climáticas. No que se refere à formação de grandes depósitos (campos de dunas livres) em escala de tempo geológica, a satisfação instantânea das condições de transporte (velocidade do vento, granulometria, incoesão) não é suficiente. A variabilidade de cada variável independente ao longo do tempo passa a exercer controle fundamental no fluxo eólico regular necessário ao desenvolvimento do campo de dunas. Nesse sentido, a formação do campo de dunas depende da associação entre duas probabilidades: a não ocorrência de chuva e a atuação de vento, soprando para o continente, com velocidade acima da limiar. Como estes fatores climáticos podem ser 
considerados variáveis ao acaso, o transporte eólico atua como um processo estocástico (Sawakuchi 2006, Giannini et al. 2007c). Apesar disso, não se deve aceitar o clima como fator determinante de sistemas eólicos a priori. A razão é que ainda não se têm bem conhecidas a freqüência e intensidade de chuvas capazes de inibir o transporte eólico e principalmente o fluxo regular necessário para formar campos de dunas. Analogamente, não se tem bem conhecida a influência, sobre esse fluxo, da freqüência de rajadas de vento, tampouco o da taxa de insolação e evaporação. Além das dificuldades de monitoramento destes parâmetros no campo, existe a diferença de escala entre o intervalo de tempo de medição (meses a poucos anos) e o intervalo de tempo envolvido na formação de campos de dunas (séculos a dezenas de milhares de anos).

Um dado relevante para a relativização da importância do clima sobre o aporte é que os campos de dunas livres possuem cobertura vegetal localizada ou mesmo ausente, independentemente de condições climáticas. Esta característica estaria ligada antes à elevada taxa de sedimentação eólica em relação à velocidade de instalação e crescimento de vegetação (Giannini \& Santos 1994) que ao clima. Embora o aumento da energia dos ventos onshore ou o recrudescimento da aridez climática possam ser fatores favoráveis à elevação da taxa de sedimentação eólica, não se trata de condições necessárias à iniciação de campos de dunas transgressivos, pois estes se desenvolvem sob diferentes regimes de ventos e ondas, bem como em condições climáticas variadas, chegando mesmo a ser mais comuns atualmente em costas de clima temperado úmido (Short 1988a,b, Hesp 1989, Hesp et al. 1989, Hesp \& Thom 1990, Trenhaile 1997).

Variáveis imediatas

Morfodinâmica praial e deriva litorânea

A influência das ondas na geração do estoque sedimentar necessário à formação de depósitos eólicos costeiros dá-se sob os aspectos escalar, ou da energia (altura) de onda, e vetorial, ou de sua direção e sentido de propagação. O primeiro aspecto diz respeito à influência da energia da onda na determinação da morfodinâmica praial sensu Wright et al. (1979). A formação preferencial de grandes sistemas eólicos (campos de dunas livres) em praias mais dissipativas ou de mais alta energia vem sendo reconhecida desde Short \& Hesp (1984). Ela pode estar ligada a várias das caracteristicas típicas deste regime morfodinâmico: a faixa mais ampla de movimentação de sedimentos por quebra e espraiamento de onda, associada a maior largura da zona intermarés, aumenta o estoque sedimentar disponível ao vento; a presença de sedimentos arenosos de granulação mais fina eleva a probabilidade de transporte eólico; e a existência de antepraia superior ampla e de baixo mergulho, sem berma, favorece o campo ou pista de atuação (fetch) do vento.

No aspecto vetorial, o estoque de sedimentos costeiros disponiveis ao vento seria favorecido na terminação ou encontro das células de transporte litorâneo determinadas pela refração ou difração das ondas predominantes no tempo geológico. A refração associa-se ao caso clássico de deriva litorânea longitudinal induzida pelo vaivém de frentes de onda obliquas em relação à linha de costa. A terminação da praia onde se tem o maior atraso na chegada de frente de onda, e portanto maior dissipação de energia, coincide com o sotamar da deriva litorânea longitudinal. O pólo deposicional é portanto uma zona de dissipação de energia de onda. A difração é a convergência radial das linhas de propagação de onda em direção a uma área situada em elevaçåo na topografia de fundo. A convergência de linhas de fluxo significa concentração de energia de onda e, ao mesmo tempo, de afluxo sedimentar. Relação energia/afluxo baixa favorece a formação de feições deposicionais salientes na linha de costa junto à elevação (proto-tômbolos), e de embaiamentos ou 
concavidades nos trechos de linha de costa vizinhos. Neste caso, os pólos deposicionais ou saliências são zonas de concentração de energia de onda.

Vegetaçăo

A redução da cobertura vegetal das dunas frontais, com formação de rupturas de deflação (blowouts), faz com que volumes variáveis de areia, antes protegidos, sejam colocados à disposição dos ventos voltados para o interior. O resultado pode ser a instabilização das dunas frontais e a formação de campos de dunas transgressivos (Hesp \& Thom 1990). Os fatores de redução da vegetação podem ser vários, de origem antropogênica ou natural. Os primeiros incluem o impacto de pedestres, animais e veículos automotores (Moreira 1988, Tabajara 2000). Entre os fatores naturais, listam-se o avanço de marés de tempestades, a deflação das partes naturalmente menos cobertas por vegetação da duna frontal durante eventos eólicos de alta energia, o sepultamento e morte da vegetação por areias trazidas nesses eventos e a eliminação de determinadas espécies de plantas pelo aumento da salinidade (Hesp 1983, Carter 1990, Hesp \& Thom 1990, Roy et al. 1994, Giannini \& Santos 1994, Hesp 2000). Em vários destes fatores, o avanço da linha de costa rumo ao continente (transgressão), em diferentes escalas de tempo e espaço, comparece como condição implicita.

Tempestades

A análise da influência das tempestades sobre sistemas eólicos costeiros é um exemplo da impossibilidade de se separar totalmente variáveis imediatas e mediatas. Embora a ocorrência de eventos de tempestade específicos possa ser considerada variável de curto prazo, a freqüência e intensidade das tempestades são controladas por variáveis climáticas de mais longo duração. Além disso, independentemente da escala, tempestades podem desempenhar dupla função em relação ao balanço sedimentar costeiro, com possibilidade de transferir areia tanto para costa afora como em direção ao continente (Roy et al., 1994), na dependência de fatores como declividade da plataforma interna e ação de ventos para o interior. Seja qual for o destino do sedimento, o aumento da frequência e energia das tempestades favorece a exaustão rápida do estoque de areia na zona intermarés.

Numa análise de curto prazo, o aumento da altura das ondas durante períodos de tempestades seria análogo a uma subida instantânea de NRM, com mudança no perfil de equilíbrio da superfície deposicional e colocação do novo prisma praial, incluindo ou não dunas de orla costeira, em condição de desequilibrio (Giannini \& Santos 1994). Nessa escala de análise, a ação das tempestades contra a formação e manutenção de depósitos eólicos costeiros pode dar-se sob pelo menos três aspectos. O primeiro é o aumento da coesão das areias na zona intermarés e nas interdunas inundadas e sua conseqüente indisponibilidade temporária para o transporte eólico. O segundo é a erosão de dunas eólicas de orla, como frontais e transversais, seja formando falésias seja gerando leques de sobrelavagem. $O$ terceiro é a transferência de areia do estoque intermarés para costa afora, o que depende da eficiência de mega-correntes de retorno (megarips). Entretanto, o segundo e o terceiro aspectos, com alguma defasagem no tempo, podem ter efeito inverso e contribuir para a alimentação do campo de dunas. Desde que haja energia eólica suficiente e granulometria adequada, os leques de sobrelavagem ou os sedimentos em desequilíbrio na praia não carreados por correntes de retorno podem ser transportados pelos ventos, continente adentro, rumo a campos de dunas (Giannini \& Santos 1994, Lees 2006). A eficiência das correntes de retorno em exaurir o prisma praial em desequilíbrio remete à fisiografia da plataforma continental interna: declives ingremes são mais favoráveis ao transporte costa 
afora e, conseqüentemente, à rápida exaustão do estoque, que declives suaves (conforme discutido no item 3.2.2.3.1).

Numa análise de mais longo prazo, as tempestades podem ser o fenômeno de curta duração responsável pelo restabelecimento, por efeito cumulativo, do perfil de costa colocado em desequilibrio por subidas de NRM. Constituem assim fator essencial de exaustão do excesso de areia na zona intermarés, com destino potencial tanto para o continente, pelo vento, como para costa afora, por mega-correntes de retorno. A definição do destino preferencial durante certo intervalo de tempo geológico depende não somente da freqüência e intensidade das tempestades e do vento atuante sobre areia seca nesse período, como também, em grande parte, da morfologia da plataforma desde a face litorânea até a linha de costa. Considerando que esta morfologia é essencialmente determinada pela herança fisiográfica, a análise da influência das tempestades, uma variável essencialmente climática, realça a importância, no suprimento costeiro, de duas outras variáveis de mais longo prazo: o NRM e a fisiografia (Giannini et al. 2007c).

Rios

A presença de rios e desembocaduras lagunares pode atuar de modo direto ou indireto no aumento localizado de estoque sedimentar costeiro disponivel ao vento. A influência indireta faz-se através do eventual efeito molhe hidráulico sobre as correntes de deriva litorânea longitudinal, com incremento de estoque a barlamar. Nesse caso, a deriva longitudinal regional é impedida pelo jato fluvial de continuar seu caminho, o que cria um estoque local de areia "marinha" (isto é, não diretamente fornecida pelo rio em questão). Quanto maior a taxa de transporte por deriva longitudinal e quanto mais eficiente o bloqueio hidráulico, maior é a taxa de crescimento de estoque local.

O efeito direto faz-se através da introdução dos sedimentos fluviais na célula de deriva a sotamar. Nesse caso, a eficácia da deriva longitudinal determina o quanto o aumento de estoque por aporte fluvial se dispersa ao longo da praia. Quanto menos intensa a deriva, mais localizado é o aumento de estoque.

Como se vê, o modo de manifestação e a taxa de aumento de estoque costeiro dependem em ambos os casos da taxa de transporte por deriva longitudinal. Analogamente, o modo de manifestação ou não do aumento de estoque costeiro no volume de areia do sistema eólico depende em ambos os casos da relação entre duas taxas que atuam interativamente como fatores limitantes: o aporte adicional devido à presença do rio (seja esse aporte fornecido diretamente ou induzido pelo efeito molhe) e a deriva eólica potencial, a qual determina a capacidade do vento em retrabalhar este aporte.

Se a entrada de sedimentos fornecida ou induzida pelo rio é maior que a capacidade do vento em retrabalhá-los, o resultado é a progradação costeira localmente acelerada. $O$ aumento de volume do sistema eólico, limitado pela baixa deriva eólica potencial, ocorre disperso através da planície progradante, geralmente na forma de dunas (frontais, ou mais raramente, transgressivas) de pouca altura, com geometria de cordões, no caso de a entrada adicional de sedimentos ser flutuante, ou de terraços ou lençóis, no caso desta entrada ser constante. A impossibilidade de acumulação local prolongada, devido ao afastamento rápido da fonte imediata, torna-se fator de estabilização igualmente rápida de dunas (Pye \& Bowman 1984).

No caso de entrada adicional de sedimentos por influência fluvial menor ou igual à capacidade de redeposição pelo vento, a tendência é o aumento localizado de expressão (altura e largura) do sistema eólico (geralmente campos de dunas), sem mudança significativa na taxa de progradação. 
As duas situações podem alternar-se ao longo do tempo, quando houver flutuação relativa entre taxa de estocagem adicional de sedimentos (por variações de deriva litorânea ou de aporte e vazão fluvial) e potencial eólico.

\subsubsection{Avaliação da operação do sistema eólico na costa brasileira}

\subsubsection{Distribuição espacial}

Fisiografia

A análise da distribuição dos tipos de depósitos eólicos ao longo da costa brasileira (item 3.1.1.1), confrontada à subdivisão da costa por critérios tectono-estruturais (item 3.1.2.2), demonstra maior concentração e porte de campos de dunas livres nos setores 1, a sul de Laguna, e 6, do oeste do Rio Grande do Norte ao Maranhão. Coincidem assim com trechos fisiográficos interpretados como de margem de placa inferior ou proximal, cujas características descritivas em comum são a plataforma continental relativamente larga e de baixo mergulho e o predomínio de arcos praiais extensos (mais longos que $12 \mathrm{~km}$ ).

Campos de dunas ocorrem também, de modo mais descontínuo e subordinado, nos setores 2, entre Imbituba e Itajai-Joinville, e 4, entre Angra dos Reis e Cabo Frio, ambos mais recortados, de plataforma continental mais estreita e interpretados como associados a zonas de transferência.

No setor 5 , do leste-nordeste brasileiro, caracterizado pelo máximo estreitamento da plataforma continental e considerado como de margem de placa superior ou distal, os campos de dunas transgressivos tornam-se dominantes apenas a norte de João Pessoa, estando restritos, a sul, a planícies quaternárias progradantes nas proximidades de desembocaduras de grandes rios, com destaque para o São Francisco. O setor 5 contém a principal faixa de afloramentos da Formação Barreiras, cuja distribuição geográfica atual é certamente reflexo da tectônica regional cenozóica. Sob esse aspecto, é relevante destacar que a área de dunas frontais altas, em transição para pequenos campos de dunas transgressivos, que vai de Pirambu, no sul de Sergipe, a Itapoã, no norte da Bahia, encontrase justamente no trecho onde esta formação se apresenta mais dissecada e distante da costa. Esta coincidência pode ser indício de que o fornecimento sedimentar por esta unidade, tipicamente imatura, é fator desfavorável à formação de depósitos eólicos, embora não suficiente para impedir o desenvolvimento de campos de dunas entre o norte da Paraíba e Macau (RN), extremo norte da ocorrência da Formação Barreiras junto à costa nordestina. Pode também ter relação com a diminuição da presença e/ou influência da Formação Barreiras o fato as dimensões dos campos de dunas livres aumentarem a NW dessa área.

O setor 3, de Joinville a Angra dos Reis, é o único em que os campos de dunas livres são praticamente ausentes (i.e., menores que $1 \mathrm{~km}$ de largura). A plataforma continental, neste setor, chega a ser tão ou mais larga que nos setores com máximo desenvolvimento de campos de dunas livres. A característica fisiográfica singular do setor é a presença da serra do Mar. Na parte norte, onde a escarpa desta serra aproxima-se da costa e tem-se o predomínio de praias de bolso reflexivas, a falta de espaço de acumulação e de areia fina podem constituir os fatores de origem fisiográfica responsáveis pelo impedimento à formação de campos de dunas. A escassez deste tipo de depósito mesmo no litoral paranaense e sul paulista, onde as praias são tipicamente mais longas, com areias finas, e as planícies largas, faz supor, entretanto, que algum outro fator, não fisiográfico, ajude a determinar a não formação de campos de dunas livres no setor adjacente à serra do Mar.

Os dados a respeito de declive da plataforma (Quadro 3.1) não permitem confirmar nem rejeitar a hipótese formulada no item 3.2.1.3.1 (subitem "fisiografia da plataforma"), deduzida de Roy et al. (1994), segundo a qual os grandes campos de dunas seriam 
favorecidos pelos declives de plataforma mais baixos, dentro do intervalo aproximado de 0,1 a $0,8^{\circ}$. Maior parte da plataforma brasileira apresenta declives pouco abaixo de $0,1^{\circ}$, valor considerado ideal para o transporte do estoque de areia eólica pelo vento, mas isto inclui áreas com e sem campos de dunas. Por outro lado, os menores ângulos da plataforma brasileira (em torno de 0,02) ocorrem justamente em trechos com pouco ou nenhum desenvolvimento de campos de dunas livres: na latitude de Rio Grande, RS (ver discussão no item 3.2.2.1.3), no litoral paulista e no cone do Amazonas, junto à costa de Amapá e Pará.

\section{Clima}

A comparação entre os mapas do Brasil de distribuição de depósitos eólicos (Figura 3.1) e de zoneamento climático segundo a classificação de Koppen (Figura 3.13) permite observar coincidência entre as áreas costeiras dominadas por diferentes tipos de depósitos eólicos e as zonas climáticas.

$\mathrm{Na}$ costa de clima megatérmico (tipo A), a região de domínio de campos de dunas que se estende do Maranhão à costa norte do Rio Grande do Norte coincide com zona de inverno seco $(\mathrm{Aw})$, a sul do alcance médio da $\mathrm{ZCl}$. Já o trecho da costa nordestina com menor desenvolvimento de campos de dunas livres, que se estende do sudeste do Rio Grande do Norte até a Bahia, corresponde a zonas climáticas sempre úmida (Af) ou de curta estação seca (Am).

A pluviosidade cai abruptamente na região de Búzios a Cabo Frio, onde voltam a ocorrer campos de dunas livres. Influenciado pelo resfriamento de águas costeiras por ressurgência, o clima desta região classifica-se como de inverno seco e verão quente (Cwa), e os índices pluviométricos são inferiores a $1000 \mathrm{~mm} /$ ano. A mesma região representa também a fronteira aproximada entre os climas megatérmicos (tipo $A$ ), a norte, e os mesotérmicos (tipo C), a sul.

A área dominada por dunas frontais que se estende do litoral central do Estado do Rio de Janeiro até o norte catarinense coincide com zona de clima sempre úmido de verão morno (Cfb). Nesta área, encontram-se os maiores indices pluviométricos da costa brasileira (de 1400 a mais de $3000 \mathrm{~mm}$ ). Estes índices são por um lado condicionados por fator geológico-geomorfológico: o efeito de anteparo exercido pela serra do Mar sobre as massas de ar úmido provenientes do Atlântico, responsável pela freqüência elevada de chuvas. A determinação da pluviosidade pelas condições de relevo é patente a ponto de justificar o uso regional do termo "chuvas orográficas". Por outro lado, os índices pluviométricos elevados são influenciados por fator climatológico, o incremento de umidade na ZCAS, zona sob maior influência das frentes frias (item 3.1.2.3).

O setor dominado por campos de dunas livres correspondente à costa meio-sul catarinense e sul-rio-grandense coincide com zona de clima sempre úmido e verão quente (Cfa). A distribuição homogênea das chuvas no decorrer do ano não implica, porém, pluviosidade total muito elevada. Na costa central de Santa Catarina, os indices pluviométricos anuais médios são inferiores a 1600mm (Orselli 1986). No Rio Grande do Sul, eles caem gradualmente de pouco mais de $1800 \mathrm{~mm}$, no extremo norte da faixa costeira, a menos de $1400 \mathrm{~mm}$ na metade sul da mesma faixa (SCP-RS, 2007).

Outro aspecto que manifesta a influência do regime climático é a direção do vento efetivo e sua orientação em relação à linha de costa. Na Região Nordeste, o efeito dominante dos ventos alísios controla a migração dos campos de dunas para quadrantes de oeste, com rumo exato de avanço variável segundo compartimentos (Figura 3.1). As zonas de alteração no rumo de transporte eólico preferencial nesta região do país coincidem com mudanças na orientação da linha de costa, de modo que o transporte efetivo sempre ocorre em direção transversal (normal ou obliqua) a ela (Giannini et al. 2005). Por exemplo, no 
trecho da costa potiguar de orientação NS, o avanço dos campos de dunas é para NW. Com a mudança mais ou menos brusca de orientação da costa para EW, a norte de Touros, os ventos NW passam a soprar costa afora e o rumo de avanço passa a SW. Já nos trechos de orientação geral NW, no Ceará, o rumo de avanço é W. Estes dados parecem sugestivos de que o modelo de Goldsmith (1979) e Carvalho (2002), segundo o qual o potencial de formação de dunas cresce com o aumento do ângulo entre vento e linha de costa, é em grande parte aplicável ao Nordeste do Brasil.

Nos campos de dunas transgressivos de Cabo Frio, RJ, o mais ao norte dentre aquelas sob influência regular da oposição de massas de ar polar, para quadrantes de norte, e tropical, para os de sul, a orientação predominante do vento efetivo é para SW. Nessa região, a Restinga de Massambaba oferece curioso exemplo de campos de dunas com rumos opostos, a partir de fontes distintas, relacionado à sua orientação WNW (Figura 3.25). O vento rumo SW sopra costa afora na área da barreira, o que impossibilita o desenvolvimento de campos de dunas costeiros de mar aberto nesse rumo. Com isso, estes campos de dunas costeiros desenvolvem-se no rumo do vento predominante, NE. Por outro lado, a presença de pontas arenosas de orientação NW na margem externa da laguna de Araruama permite aí a formação de campos de dunas maiores, de fonte lagunar, voltados para SW. O exemplo de Cabo Frio reforça a importância da orientação relativa entre vento e área fonte na determinação do rumo de avanço de campos de dunas, já sugerida para a costa nordestina; aqui, porém, com possibilidade de verdadeiras inversões de rumo.

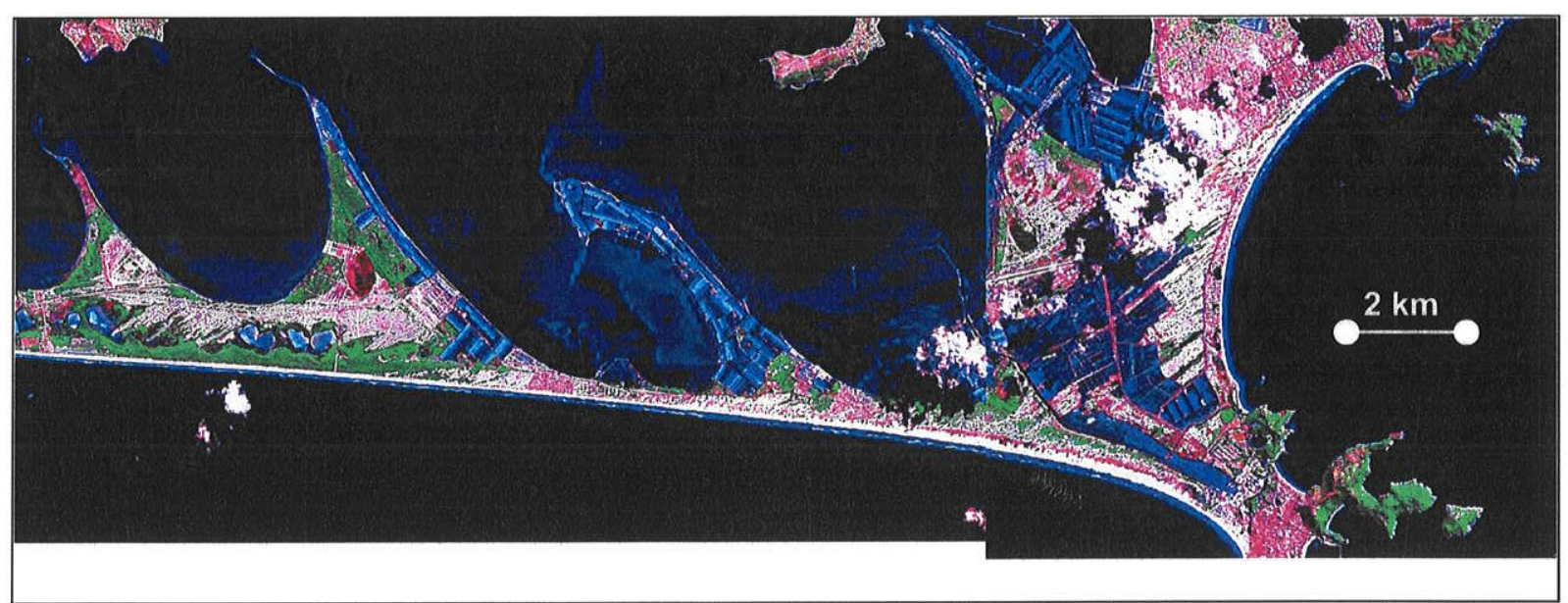

Figura 3.25. Parte centro-leste da Restinga de Massambaba (Arraial do Cabo) e praia do Foguete (Cabo Frio), RJ, onde campos de dunas transgressivos a partir de áreas fontes lagunar e marinha apresentam rumos de migração opostos. Exemplo de dominação do fator aporte sobre o fator clima na determinação do rumo de avanço de sistemas eólicos costeiros.

No Sul do Brasil, impulsionados pelo vento de NE, os campos de dunas livres dirigem-se para SW, quase sempre em ângulos menores que $45^{\circ}$, e algumas vezes paralelos à linha de costa.

Cálculos da DEP para estações meteorológicas em regiões com campos de dunas livres na costa de Santa Catarina (Giannini 1993) e Rio Grande do Sul (Tomazelli 1990) indicam, como regra, regime de ventos bimodal de alta energia na classificação de Fryberger (1979). O vento prevalecente, proveniente de NE, sopra o ano todo, enquanto os ventos predominantes, de $\mathrm{W}, \mathrm{SW}$ e $\mathrm{S}$, tornam-se mais importantes entre o final do verão e o início do inverno. $\mathrm{O}$ incremento da coesão das areias pela umidade ligada à passagem de frentes frias tornaria estas areias indisponíveis ao transporte eólico e seria assim a principal razão do predomínio de migração para sul nos campos de dunas do Sul do país (Giannini 1993). Em Laguna (SC), por exemplo, os ventos de S a SW (53\% da DEP), mais fortes 
(predominantes), revelam coincidência com dias de chuva da ordem de $70 \%$, enquanto os ventos de $\mathrm{N}$ a NE ( $41 \%$ da DEP), mais freqüentes (prevalecentes), são mais atuantes nas épocas menos chuvosas (Giannini 1993). Feições deposicionais de reversão de avanço de campos de dunas são comuns, porém sempre em caráter local e/ou temporário. Exemplos podem ser encontrados nos campos de dunas de Passagem e Gravatá-Teresa (Giannini 1993), bem como na parte interna do campo de dunas da praia Grande do Sul (Jaguaruna) junto à margem sudoeste das lagunas Garopaba do Sul e Laranjal (Figura 3.26). Entre as paleodunas, formas parabólicas com lobo deposicional voltado para NNW ocorrem também na parte nordeste da liha de São Francisco, cerca de $120 \mathrm{~km}$ a norte (Hesp et al. 2007).

A mais notável exceção à tendência, na região Sul, de migração de dunas ativas para sul encontra-se nos campos de dunas da ilha de Santa Catarina, os quais caminham para NNW. A análise de distribuição de freqüências de ventos na estação de Florianópolis (Giannini 1993) faz ressaltar a efetividade de ventos de S e SE ( $86 \%$ da DEP total), ativos particularmente durante os meses de primavera ( $45 \%$ da DEP total). A DEP referente a estes azimutes é relativamente muito grande (mais de dez vezes superior a DEP total de Laguna, por exemplo), o que favorece o efluxo e pode portanto ser explicação para a super-atuação dos processos de deflação nos campos de dunas da ilha (Giannini et al. 2005).

Há duas linhas de interpretação para a inversão de rumo de migração das dunas na Ilha de Santa Catarina em relação a outras regiões da costa catarinense e gaúcha. A primeira atribui esta inversão a uma anomalia local no regime de ventos (Bigarella 1972, 1975) e/ou na posição das áreas fontes de areia eólica (Giannini et al. 2005). A segunda considera que a ilha situa-se imediatamente a norte de uma zona de mudança no padrão regional de ventos costeiros (Hesp et al. 2007).

Para Bigarella (1972, 1975), a migração para NNW dos campos de dunas transgressivos da praia de Campeche-Joaquina ("campo da Lagoa") e Moçambique deve-se ao obstáculo exercido pelos morros da ilha, alinhados segundo N-S. Assim, os ventos de NE seriam defletidos para $\mathrm{N}$ e enfraquecidos, no corredor $\mathrm{N}-\mathrm{S}$ criado entre os morros e os pontões costeiros. Esta hipótese é compatível com os dados de ventos da estação de Florianópolis, em que se nota a maior DEP dos ventos de N, em relação aos de NE. Giannini et al. (2005) chamaram a atenção para o fato de que, devido à deriva litorânea residual para NNE (item 3.2.2.1.3), o suprimento de areia eólica estaria restrito às extremidades norte das praias de Moçambique e Campeche. Como estas extremidades encontram-se protegidas do vento prevalecente, de NE, pela ponta das Aranhas e pela ponta do Retiro, respectivamente, o estoque de areia seria transportado apenas pelos vento predominante, de sul. Esta hipótese adicional é compativel com a localização dos campos de dunas, deslocada, em ambos os casos, para a parte norte da praia, e com a ausência de campo de dunas na praia dos Ingleses (norte da ilha), cujo estoque sedimentar seria desfavorecido por sua posição e orientação, abrigada das ondas de sul (Giannini et al. 2005). Segundo esta hipótese, a inversão no deslocamento de areias eólicas em Florianópolis seria similar, ainda que em escala maior, aos casos mencionados de Laguna e Jaguaruna (Figura 3.26). 


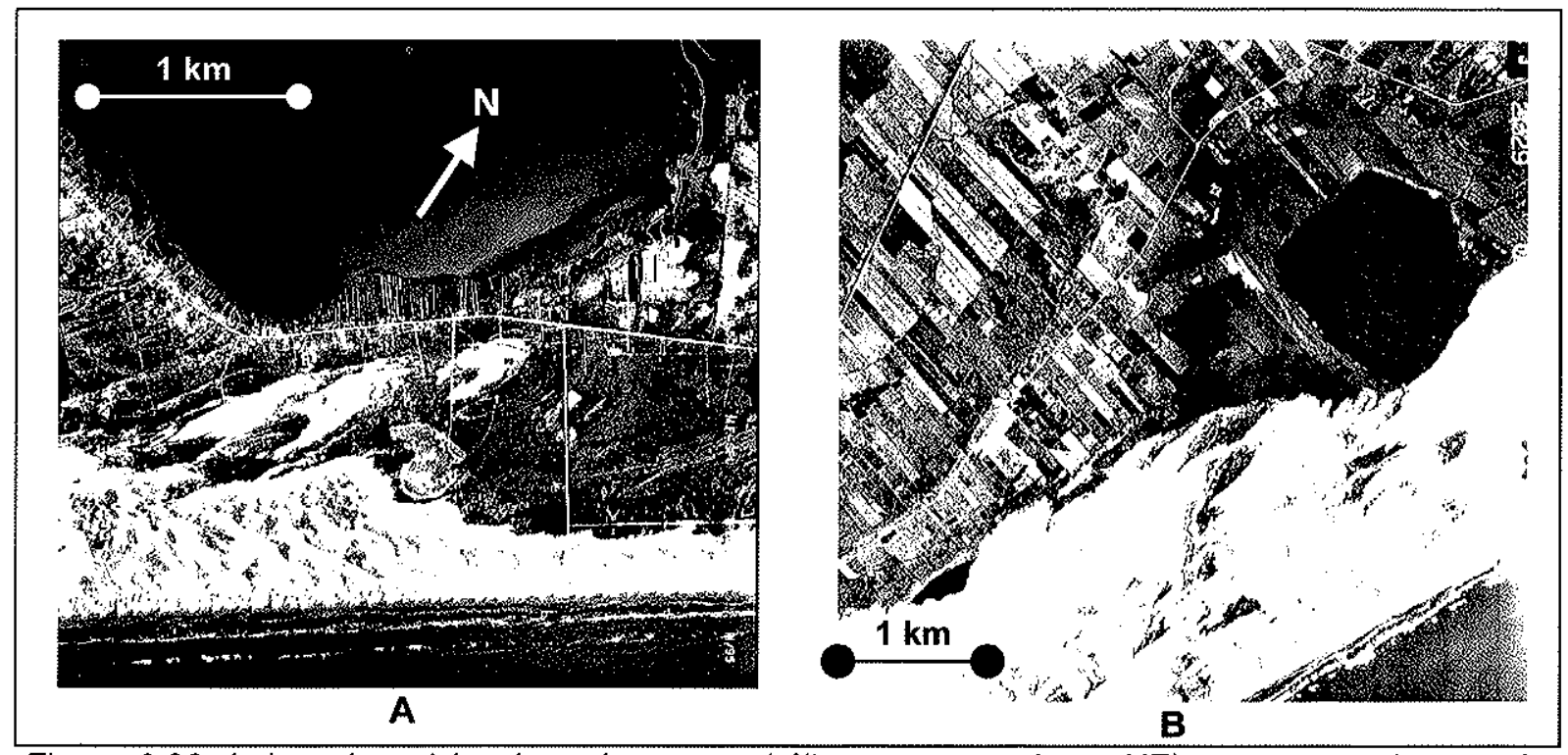

Figura 3.26. Lobos deposicionais e dunas parabólicas reversos (para NE) na margem interna do campo de dunas da praia Grande do Sul (Jaguaruna), SC. A. A margem sudoeste da laguna Garopaba do Sul (vôo 2000, escala nominal 1:12500). B. A margem sudoeste da laguna Laranjal (vôo 1979-1981, escala nominal 1:25000).

A hipótese de Hesp et al. (2007) de inversão no padrão direcional regional de ventos entre Pinheira e litha de Santa Catarina baseia-se em dois argumentos: 1. A presença das paleodunas parabólicas para NNW na litha de São Francisco, situada a norte. 2. Os dados de ventos coletados na liha do Arvoredo, situada em mar aberto $10 \mathrm{~km}$ a NE da liha de Santa Catarina, registrando o mesmo predomínio de ventos para NNW verificado em Florianópolis. Esse conjunto de argumentos parece suficiente para invalidar a hipótese de inversão local por efeito de sombra aerodinâmica, mas não o modelo de inversão por falta de aporte, uma vez que a situação fisiográfica das paleodunas da llha de São Francisco é análoga a das dunas da llha de Santa Catarina. Ele é reforçado também pelo rumo de avanço para NNW encontrado, a norte, nos lobos de blowouts de dunas frontais da praia do Leste, PR (Bigarella et al. 1969; McKee \& Bigarella 1972) e no pequeno campo de dunas de llha Comprida, SP (Guedes 2003, Nascimento 2006, Giannini et al. 2007b).

Em suma, parece bastante provável que uma mudança regional no padrão de ventos costeiros ocorra entre a enseada da Pinheira e a ilha de Santa Catarina, localização que guarda provavelmente relação com o limite sul da zona de maior atuação da ZCAS. Mas a influência da posição relativa da área fonte, à semelhança do inferido, em escala regional, no Nordeste, e em escala local, em Cabo Frio, Laguna e Jaguaruna (Figuras 3.25 e 3.26), não pode ser ainda inteiramente descartada.

\section{Refração de onda, deriva litorânea e desembocaduras}

Em escala regional a local, a distribuição e as dimensões dos depósitos eólicos podem refletir a influência do aporte costeiro controlado pelo padrão de ondas e suas correntes induzidas. Este, por sua vez, resulta da combinação de variáveis climáticas e fisiográficas.

A influência do transporte litorâneo no desenvolvimento de campos de dunas faz-se aparente de dois modos distintos, conforme se esteja a sul ou a norte do cabo de Santa Marta (Laguna), SC. A sul, a linha de costa, ininterrupta exceto pelos promontórios de Torres (RS), Morro dos Conventos (Araranguá, SC) e Costão do llhote (Laguna, SC), apresenta 
direção variável entre NE e N-S. As variações de direção da costa, sempre suaves, definem a alternância de concavidades e convexidades tênues. Dillenburg et al. (2000) basearam-se nesta alternância e nas variações de largura da barreira costeira (no sentido da escola australiana) para dividir a costa gaúcha em cinco setores, de sul para norte: Chuí-Verga, Verga-Estreito, Estreito-Mostardas, Mostardas-Tramandaí e Tramandaí-Torres. A linha de costa nos trechos Verga-Estreito e Tramandaí-Torres caracteriza-se pela geometria ligeiramente côncava para o mar. Sob esse aspecto, o trecho Tramandai-Torres tem continuidade, para norte, até o cabo de Santa Marta. Os demais trechos, todos com linha de costa convexa, destacam-se pelo maior desenvolvimento de campos de dunas transgressivos. Comparando estes setores costeiros com a plataforma interna adjacente, Dillenburg et al. (2000) observaram coincidência entre os trechos correspondentes a projeções da linha de costa e zonas de aumento de declividade na plataforma interna (até isóbata $-50 \mathrm{~m}$ ). Segundo a interpretação dos autores, a barreira teria caráter progradante, evidenciado pela presença de alinhamentos de cordões litorâneos (inclusive dunares), nos trechos côncavos, e caráter "retrogradante" (transgressivo) ou estacionário, nos trechos convexos, com grandes campos de dunas. A tendência supostamente mais erosiva dos trechos convexos é atribuída pelos autores à convergência de linhas de fluxo de ondas, com conseqüente concentração de energia. Esta interpretação é discutivel sob dois aspectos. $O$ primeiro deles é que nem a aparente ausência de cordões litorâneos nem a maior presença de campos de dunas transgressivos podem ser utilizados como evidências de não progradação. A segunda ressalva é que convergência de linhas de fluxo pode representar tanto erosão como deposição, na dependência da ausência ou presença de afluxo sedimentar. A hipótese alternativa aqui defendida para explicar a associação demonstrada por Dillenburg et al. (2000) entre trechos convexos e maior desenvolvimento de campos de dunas livres na costa gaúcha baseia-se no modelo de refração/difração apresentado no item 3.2.1.3.2. Segundo esse modelo, os trechos de linha de costa convexa representam como regra zonas de convergência de energia e de fluxo sedimentar. $O$ caráter convexo ou côncavo da costa estaria relacionado à energia de onda, que por sua vez seria controlada por processos de dissipação e refração da onda ao longo da plataforma interna adjacente. Nas zonas costeiras situadas diante de elevações topográficas da plataforma interna, há convergência de linhas de propagação de onda e de transporte sedimentar. Estas zonas concentram portanto não somente a energia das ondas (Dillenburg et al. 2003), como também o afluxo de sedimentos, dai a morfologia saliente da linha de costa e o maior desenvolvimento de campos de dunas. Enquanto isso, as reentrâncias costeiras, com mais baixa declividade na plataforma adjacente, constituiriam zonas de dissipação de energia e de divergência de sedimentos.

Em suma, a sul de Santa Marta, a quase ausência de rios ou promontórios, por distâncias de dezenas de quilômetros ao longo da costa, e a existência de irregularidades suaves na plataforma continental interna adjacente fazem com que o balanço de sedimentos nos sistemas costeiros fique a mercê das convergências e divergências de refração de ondas criadas pela topografia de fundo. Desse modo, a influência da fisiografia da plataforma continental interna sobre a energia e a trajetória das ondas é realçada (Dillenburg et al. 2003), com concentração de estoque sedimentar e de campos de dunas nas zonas salientes, com convergência de fluxo de ondas e com maior ângulo de declive.

A norte do cabo de Santa Marta, a linha de costa, mais recortada, caracteriza-se pela sucessão de arcos praiais delimitados por promontórios e/ou desembocaduras fluviais e de maré. A refração devida à inclinação entre frentes de onda predominantes em escala regional e linha de costa constitui o principal fator determinante do rumo de deriva litorânea longitudinal em cada arco praial. Assim, para extensos compartimentos costeiros caracterizados por trends direcionais determinados de linha de costa e frente de onda, a deriva litorânea residual em cada arco praial aponta preferencialmente para o mesmo rumo, 
por exemplo, para quadrantes de norte, na região entre a costa centro-sul catarinense e a sul fluminense. Inversões locais nesse padrão devem-se principalmente à difração em pontões do embasamento cristalino e/ou esporões, como exemplificado na praia do Porto, em Imbituba, SC (Giannini 1993) e na praia do Farol, na ilha do Mel, PR (Giannini et al. 1995, 2004a), ou ao efeito molhe exercido por desembocaduras, como ilustrado na terminação sul da praia da Juréia, em Iguape (Bentz \& Giannini 2003), e da praia de ilha Comprida (Nascimento et al. 2005, Nascimento 2006, Giannini et al. 2007b), ambas no litoral sul paulista. De qualquer modo, a distribuição longitudinal do estoque sedimentar é controlada em essência pelas feições que constituem os limites naturais do arco praial.

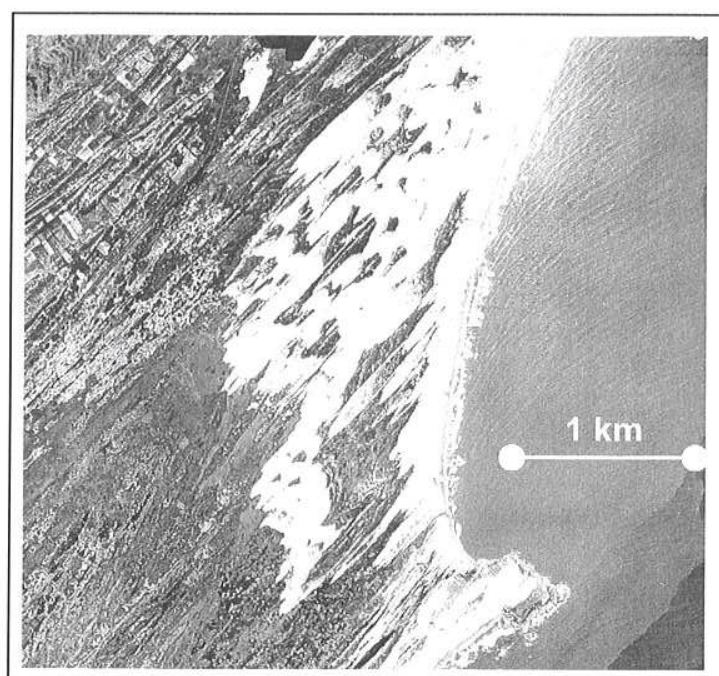

A

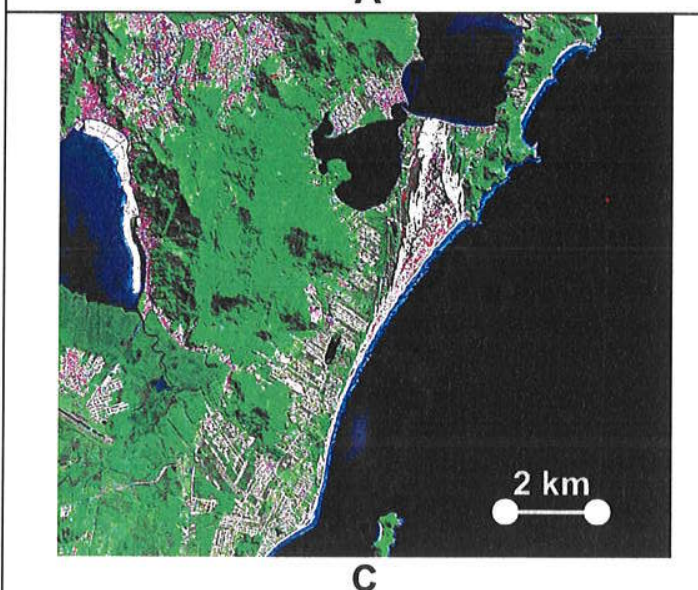

C

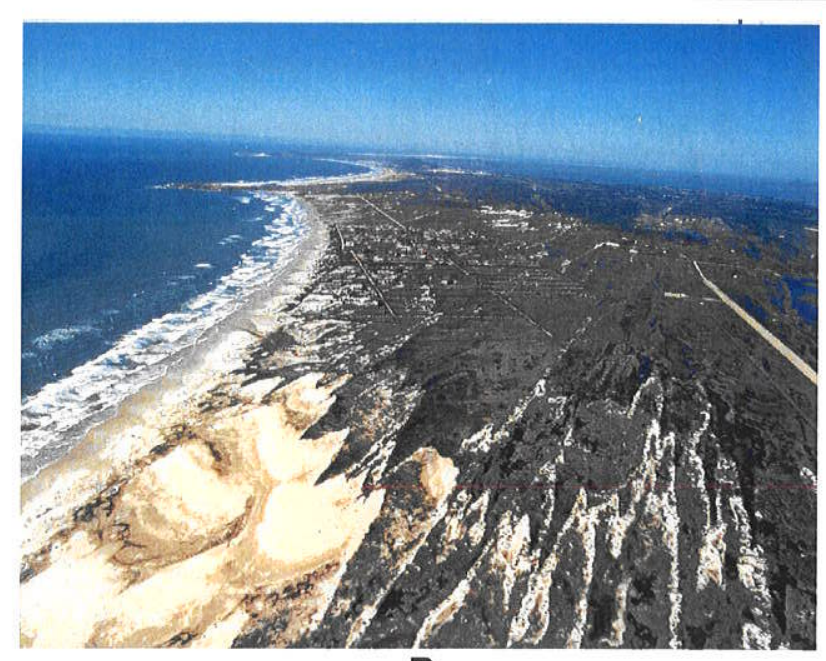

B

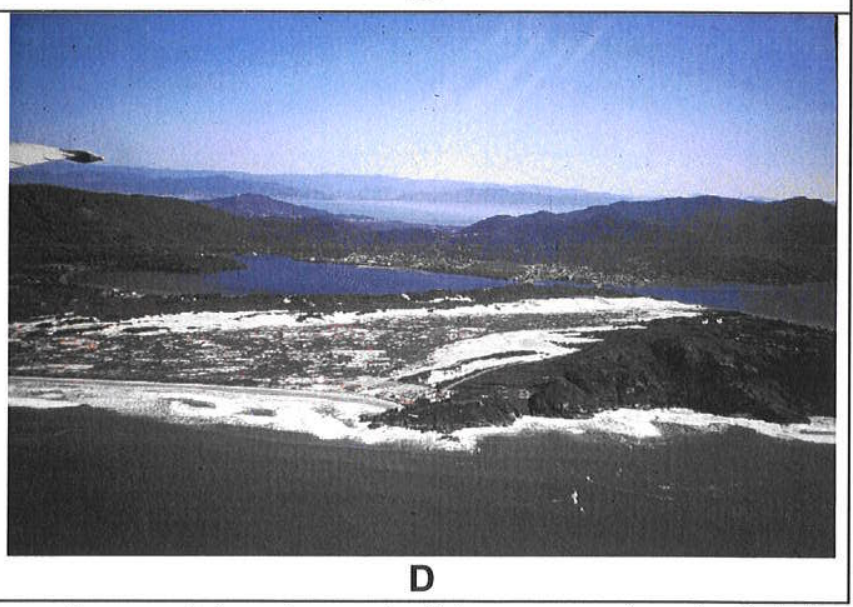

\section{D}

Figura 3.27. Exemplos de campos de dunas com desenvolvimento assimétrico em costas do Sul do Brasil (Santa Catarina) com deriva litorânea residual para norte: praia do Sol, Laguna (A e B) e praia do Campeche (dunas da Joaquina), Florianópolis: A. Fotografia aérea vertical, sobrevôo 1956; B. Fotografia aérea oblíqua, 1999 (Foto Bacha, Laguna); C. Imagem de satélite Landsat, 2000; D. Fotografia aérea oblíqua, 1994.

No que se refere aos trechos de costa com campos de dunas livres, esta determinação do estoque por células de deriva litorânea restritas e, na maioria das vezes, grosso modo equivalentes ao próprio arco praial, deve manifestar-se na assimetria dos campos de dunas ao longo de cada célula, com maior desenvolvimento a sotamar. Este é de fato o padrão na costa sul brasileira, onde, sob predomínio de deriva resídual para norte, muitos campos de dunas livres originam-se da porção norte das praias (Figura 3.27). Quase 
todas as praias adjacentes a campos de dunas na costa sul-sudeste (a norte de Santa Marta) enquadram-se nesta regra, merecendo destaque as praias Grande do Norte, Galheta, Ji, Sol, Itapirubá - Vila Nova e Ibiraqüera, nas região de Laguna e Imbituba, SC (Giannini 1993, Giannini \& Santos 1994, Martinho et al. 2007), Siriú, em Garopaba, SC, Guarda do Embaú e Gamboa, na região de Palhoça e Paulo Lopes, SC, Campeche (Joaquina) e Moçambique, em Florianópolis, SC. Mesmo na extensa praia Grande do Sul, na vizinhança sul do cabo de Santa Marta, também se observa esta regra (Giannini 1993, Martinho \& Giannini 2002, Martinho 2004, Martinho et al. 2007). Nas praias do Porto, em Imbituba, e da Pinheira, em Palhoça, onde os campos de dunas desenvolvem-se na terminação sul, a exceção parece apenas confirmar a regra do controle indireto do aporte eólico pela deriva longitudinal, pois, pelo menos para a praia de Imbituba, existem evidências geomorfológicas e sedimentológicas de inversão local no rumo de deriva litorânea residual (Giannini 1993). Trata-se em ambos casos de praias em enseada assimétricas, com pontão limitrofe sul maior que o norte e com orientação média, NNW, destoante da norma regional (NE a NNE).

$\mathrm{Na}$ Região Sudeste, a deriva litorânea predominante para quadrantes de norte e leste reflete-se na assimetria dos campos de dunas transgressivos da região entre Saquarema e Búzios, RJ. Na praia da Restinga de Massambaba, com mais de $40 \mathrm{~km}$ de extensão, os campos de dunas desenvolvem-se preferencialmente nos últimos $15 \mathrm{~km}$ a ENE (Figura 3.25). Nos três principais arcos praiais vizinhos a norte, Foguete-Dunas-Forte, Peró e Tucuns (Cabo Frio), RJ, todos de orientação média NNE, o comprimento máximo do campo de dunas e a maior concentração de areia eólica encontram-se sempre na metade setentrional da praia (Figura 3.25).

$\mathrm{Na}$ costa leste-nordeste entre o Espírito Santo e Touros, RN, a ação predominante de ventos e ondas de SE a E, associados ao Anticiclone Equatorial do Atlântico Sul e ao Anticiclone Tropical Atlântico (item 3.1.2.3), favorece o predominio de deriva litorânea longitudinal para SW, nos trechos de costa de orientação NE (sul do Espírito Santo, norte da Bahia, Sergipe e Alagoas) e para quadrantes de norte nos trechos de costa com orientação NW a N-S (norte da Paraiba e sul do Rio Grande do Norte). A assimetria no desenvolvimento dos campos de dunas livres segundo o rumo de deriva assim determinado está mais uma vez presente. Na extremidade sul da costa alagoana, o campo de dunas adjacente à praia da Peba, situada imediatamente a norte da foz do rio São Francisco, alarga-se grosso modo para sul, rumo provável de deriva litorânea longitudinal predominante. Já a sul da foz, o campo de dunas é melhor desenvolvido junto à parte meio-norte da praia de Pirambu (SE), de $40 \mathrm{~km}$ de extensão. A assimetria aqui estaria ligada a deriva longitudinal localmente dirigida para NE devido ao efeito molhe hidráulico exercido pelo rio São Francisco. A redução do campo de dunas na extremidade norte da praia, junto à foz do rio, estaria ligada ao aumento da influência de areias, fornecidas por este rio, com granulometria acima da competência do vento (Barbosa 1997). Na porção sul da costa do Rio Grande do Norte, onde a deriva litorânea residual regional é supostamente dirigida para $\mathrm{N}$ a $\mathrm{NW}$, o desenvolvimento preferencial dos campos de dunas na parte norte das praias que the servem como área-fonte é evidente nas praias de Cotovelo, Pium, Barreira d'Água (Figura 3.28A), GenipabuGraçandu, Muriú, Maxaranguape, Caraúbas e Pititinga. Inversões nessa tendência regional de assimetria de campo de dunas' podem ser observadas nas chamadas dunas de Genipabu, cuja área fonte imediata é a praia da Redinha - Santa Rita (Figura 3.28B), e no campo de dunas da praia de Guaraíras, em Nisia Floresta (Figura 3.28C). Nestes dois casos, o campo de dunas é mais desenvolvido na terminação sul da praia. As exceções, entretanto, fazem apenas por confirmar a regra. A praia de Redinha - Santa Rita possui direção NNE, diferente da orientação regional da costa, o que deve favorecer deriva local para sul. Além disso, há que se considerar a influência do rio Potenji, situado no limite sul da praia, como fonte adicional de sedimentos para o sistema eólico. Já na praia de Guaraíras, situada a sotamar de uma desembocadura estuarina, a assimetria invertida para $S$ deve-se 
provavelmente ao aporte adicional por esta desembocadura e/ou ao bloqueio por ela exercido sobre a deriva regional para $\mathrm{N}$.

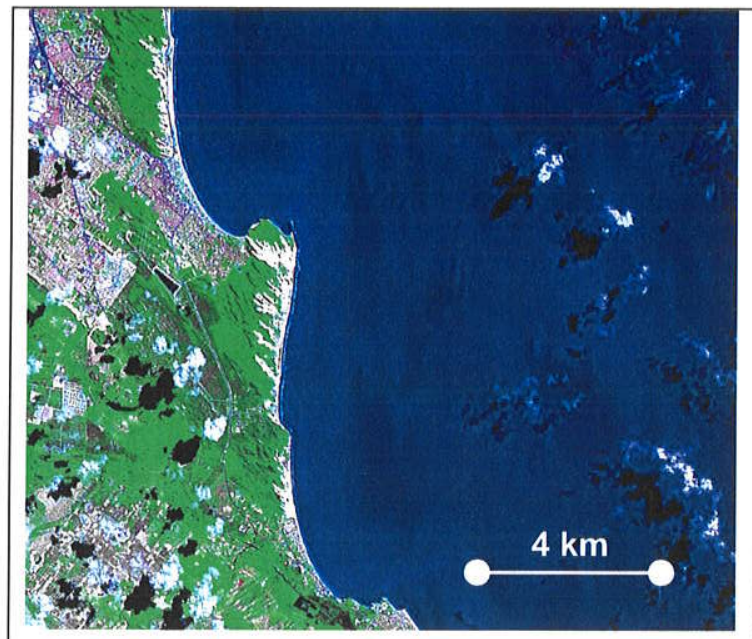

A

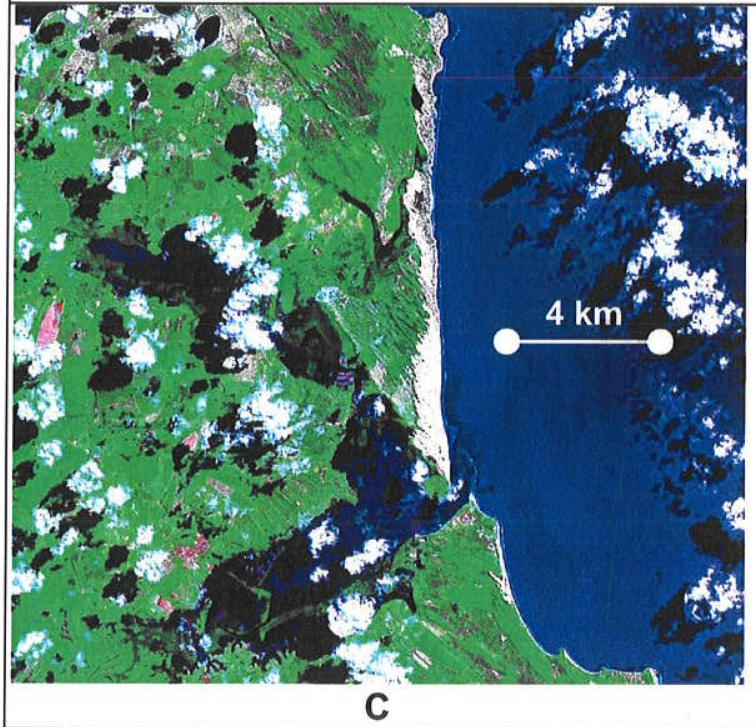

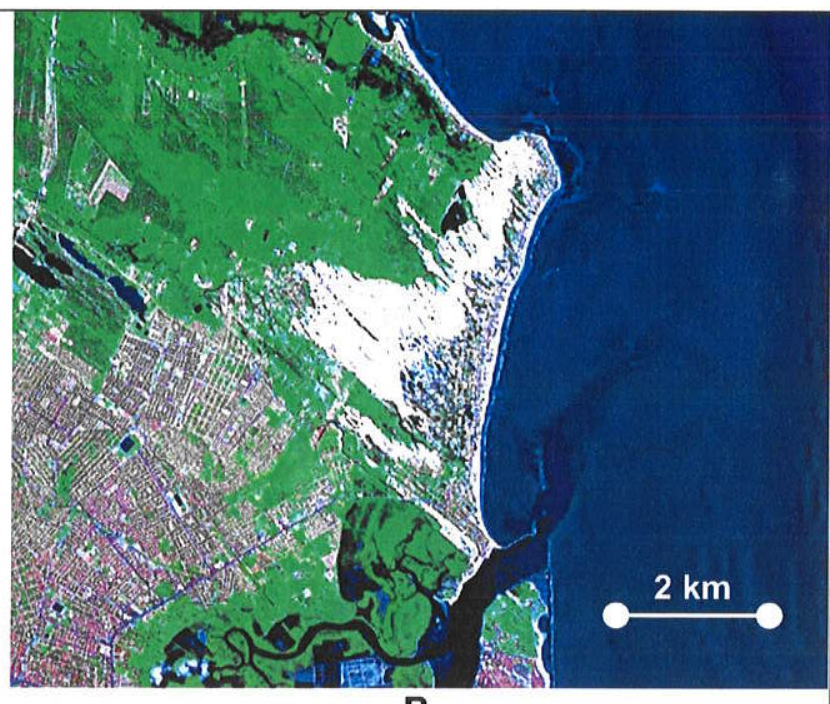

B

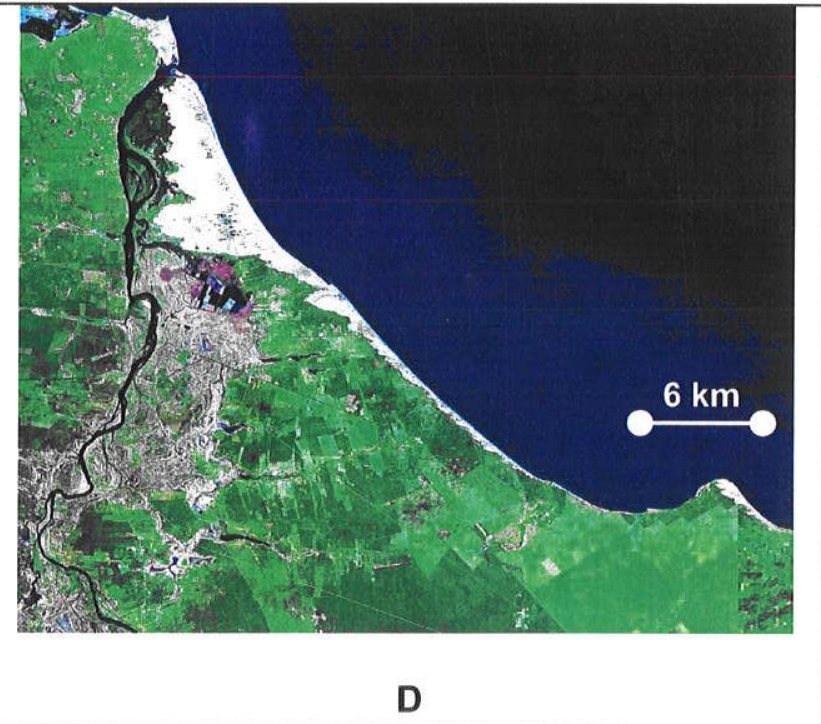

Figura 3.28. Exemplos de sistemas eólicos assimétricos em costas do Nordeste do Brasil com deriva litorânea longitudinal residual para norte (linha de costa NW a NS: A e D) e para sul (linha de costa $\mathrm{NE}$ : B). Em C, a inversão do rumo de deriva regional $(\mathrm{N})$ deve-se provavelmente à presença da desembocadura da lagoa Guaraíras. A. Praias de Cotovelo, Pium (Parnamirim) e Barreira d'Água (Natal), RN. B. Praia de Redinha - Santa Rita (Extremoz), RN. C. Praia de Guaraíras (Nísia Floresta), RN. D. Praias de Peroba-Redondas (Icapuí), Majorlândia e Canoa Quebrada (Aracati), CE.

$\mathrm{Na}$ costa norte-nordeste a NW de Touros, os ventos e ondas de NE, relacionados ao Anticiclone Equatorial Norte, ganham importância. Em virtude da orientação da linha de costa, entre NW e E-W, a deriva regional dirige-se para quadrantes de oeste. Neste trecho, os campos de dunas livres tendem à simetria, provavelmente pelo aumento da amplitude de maré e à intensa compartimentação do setor por pequenas rias (poucos quilômetros de largura). Maior desenvolvimento de campos de dunas em seu lado oeste, a favor da deriva litorânea longitudinal, pode ainda assim ser bem observado nas praias de Canoa Quebrada 
(Figura 3.28D) e Cumbuco, no Ceará e de Tutóia e Ponta das Gaivotas, no Maranhão. Já nos campos de dunas de Pequenos Lençóis e Lençóis Maranhenses, MA (Figura 3.29), o ligeiro desenvolvimento preferencial na parte leste estaria relacionado ao aporte dos rios Novo/Cangatá e Preguiças, situados na terminação oriental dos respectivos arcos praiais (Gonçalves 1995). As desembocaduras destes rios não interrompem a deriva predominante em escala regional com a mesma eficácia que várias outras ao longo da costa nordestina, o que se evidencia no desvio destas desembocaduras rumo oeste e com a formação de flechas arenosas proeminentes (Ponta das Gaivotas e Barra do Preguiça). Estes rios têm em comum também o fato de margear e portanto retrabalhar as areias de frentes de campos de dunas. Por exemplo, as areias da parte leste do campo de dunas dos Lençóis Maranhenses são, em parte, derivadas do retrabalhamento dos lobos deposicionais da porção oeste dos Pequenos Lençóis. Trata-se portanto de rios que levam à costa grande volume de sedimentos, maior que a capacidade de dispersão pela deriva longitudinal para oeste (item 3.2.1.3.2). Esse excesso de sedimentos no pólo de partida da deriva longitudinal torna-se disponível para o vento, resultando no maior desenvolvimento dos campos de dunas de Pequenos Lençóis e Lençóis Maranhenses em sua porção leste.

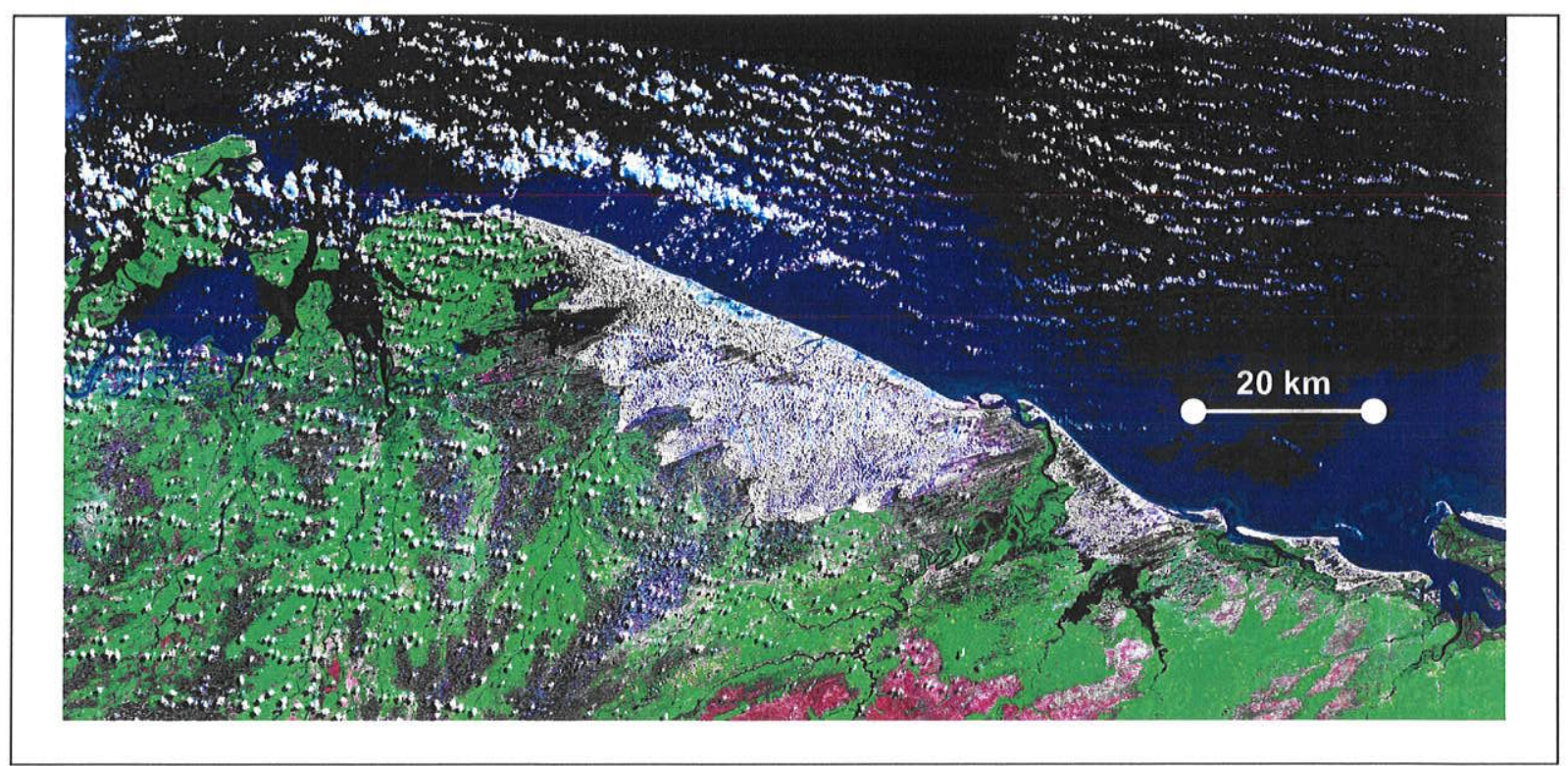

Figura 3.29. Mega-sistema eólico formado pelos campos de dunas de Ponta das Gaivotas, Pequenos Lençóis e Lençóis Maranhenses, MA. Notar maior desenvolvimento, no rumo do vento efetivo, da parte leste de cada campo de dunas, alimentada pela baía de Tutóia e pelos rios Novo-Cangatá e Preguiça, respectivamente. Notar também reciclagem sucessiva de sedimentos eólicos de um campo para outro, de $\mathrm{E}$ para $\mathrm{W}$, via drenagens, o que se reflete no aumento progressivo de tamanho do mega-sistema nesse rumo.

A oeste de Lençóis, onde as pequenas rias de maré dão lugar às baías estuarinas de São José, São Marcos e Cumã e às reentrâncias maranhenses, com dezenas de quilômetros de largura, a ausência de sistemas deposicionais costeiros com segregação de areia incoesa na zona intermarés dificulta a formação de grandes sistemas eólicos.

\subsubsection{Distribuição no tempo}

O uso de critérios estratigráficos e geomorfológicos tem permitido o reconhecimento de quatro gerações de areias eólicas quaternárias em três diferentes áreas costeiras do Brasil com campos de dunas livres: no Ceará, no Sergipe e norte da Bahia e em Santa 
Catarina (item 3.1.1.3). A comparação entre as idades aproximadas inferidas para estas gerações em cada área, relativas a episódios transgressivos e/ou de variação de NRM de extensão inter-regional, permite o traçado de correlações entre seus respectivos sistemas eólicos costeiros (Quadro 3.3). De acordo com estas correlações, a geração de dunas mais antiga (D5 de Claudino Sales 2002, no Ceará, Qe1, de Bittencourt et al. 1982 e Dominguez et al. 1996, nos estados de Sergipe e Bahia, e geração 1, de Giannini 1993, em Santa Catarina) é seguramente anterior ao máximo transgressivo do Holoceno e tida também, pelo menos junto à foz do rio São Francisco (SE) e em Santa Catarina, como anterior ou aproximadamente contemporânea ao máximo NRM de 120 ka AP. A segunda geração (D4, Qe2, geração 2) apresenta-se como anterior ou aproximadamente contemporânea à máxima inundação ligada ao NRM mais alto do Holoceno. A terceira geração (D3, Qe3, de Barbosa 1997, geração 3) corresponde às dunas inativas posteriores a esta máxima inundação. $E$ a última geração (D1, Qe4, geração 4) compreende as dunas ativas, com iniciação estimada em poucos séculos.

Quadro 3.3. Proposta de correlação entre gerações de campos de dunas de diferentes regiões costeiras do Brasil. Para o Rio Grande do Norte, não foram incluidas as idades mais antigas que $150 \mathrm{ka}$ AP

\begin{tabular}{|c|c|c|c|c|c|}
\hline Estado & \multicolumn{5}{|c|}{ Geração eólica e respectiva idade inferida ou medida por TL/LOE* } \\
\hline $\begin{array}{c}\text { Ceará } \\
\text { (Claudino Sales } \\
\text { 2002) }\end{array}$ & $\begin{array}{l}\text { D5: anterior à } \\
\text { transgressão } \\
\text { holocênica }\end{array}$ & $\begin{array}{c}\text { D4: } \\
\text { contemporânea à } \\
\text { transgressão } \\
\text { holocênica }\end{array}$ & $\begin{array}{l}\text { D3: Holoceno } \\
\text { médio a } 1,2^{*} \mathrm{ka} \\
\mathrm{AP}\end{array}$ & $\begin{array}{c}\text { D2: ativa, } \\
\text { iniciadas entre } \\
1,2^{\star} \text { e } 0,3 \mathrm{ka} \mathrm{AP}\end{array}$ & $\begin{array}{c}\text { D1: ativa, iniciada } \\
\text { após } 0,3 \mathrm{ka} \text { AP }\end{array}$ \\
\hline $\begin{array}{c}\text { Rio Grande do } \\
\text { Norte } \\
\text { (Barreto et al. } 2004 \text { ) }\end{array}$ & $\begin{array}{c}\text { Tênues ou } \\
\text { dissipadas: } 63-24^{*} \\
\text { ka AP }\end{array}$ & $\begin{array}{c}\text { Tênues ou nítidas: } \\
10,8-9,1^{*} \text { ka AP } \\
6,5-5,6^{*} \text { ka AP }\end{array}$ & $\begin{array}{c}\text { Nitidas: } 3,5-2,5^{*} \\
\text { ka AP }\end{array}$ & \multicolumn{2}{|c|}{$<0,5^{\star}$ ka AP } \\
\hline $\begin{array}{c}\text { Paraíba } \\
\text { Camaratuba- } \\
\text { Traição } \\
\text { (Barreto et al. } \\
\text { 2002a) }\end{array}$ & $64-27^{*}$ ka AP & & & & \\
\hline $\begin{array}{c}\text { Santa Catarina } \\
\text { Imbituba- } \\
\text { Jaguaruna } \\
\text { (Giannini 1993, } \\
\text { Giannini et al. } \\
\text { 2001b,c, 2007c, } \\
\text { Sawakuchi 2003) }\end{array}$ & $\begin{array}{c}\text { 1: iniciada antes } \\
\text { ou durante a } \\
\text { última } \\
\text { transgressão } \\
\text { pleistocênica } \\
174,8-50,8^{\star} \text { ka AP }\end{array}$ & $\begin{array}{l}2: \text { iniciada antes } \\
\text { ou durante o alto } \\
\text { NRM pós-glacial } \\
10,9-4,9^{*} \text { ka AP }\end{array}$ & $\begin{array}{l}\text { 3: fixada após a } \\
\text { transgressão } \\
\text { holocênica } \\
6,3-1,4^{*} \text { ka AP }\end{array}$ & \multicolumn{2}{|c|}{ 4: ativa } \\
\hline
\end{tabular}

Dois argumentos usados por Lees (2006) na Austrália, para defender que o NRM é mais determinante que o clima na formação de campos de dunas costeiros, parecem válidos também no caso brasileiro (Giannini et al. 2007c). O primeiro argumento é o de que os eventos iniciadores de campos de dunas costeiros são generalizados e inter-regionais, inclusive dentro do Holoceno. O segundo é o de que estes eventos não são acompanhados por reativação de campos de dunas antigos. Haveria assim uma ligação entre variações de NRM e criação de aporte sedimentar costeiro que seria responsável pelo acionamento do gatilho (trigger), referido por Lees (2006), para a iniciação de campos de dunas transgressivos. 
Um ponto adicional a favor desta ligação entre NRM e suprimento eólico é a distância dos campos de dunas ativos e inativos em relação a suas áreas fontes, as linhas costeiras atual e pretéritas, respectivamente (Giannini et al., 2001c). Esta distância, que se relaciona indiretamente com o conceito de distância de equilibrio introduzido no item 3.2.1.1, constitui fator controlador na manutenção em atividade dos campos de dunas atuais, assim como deve têmlo feito em relação a cada uma das gerações de dunas hoje inativas (Giannini et al. 2001b). O argumento é que a estabilidade da linha de costa é condição necessária para a manutenção da atividade do sistema eólico, visto que, se a linha de costa varia rapidamente, - aporte eólico dilui-se através de uma ampla área costeira. Nesse sentido, o avanço da linha de costa rumo ao continente a taxas moderadas teria favorecido a deposição e sucessivo retrabalhamento de dunas costeiras. Já o recuo (regressão) da linha de costa dificultaria este retrabalhamento, devido à diluição de aporte eólico provocada pelo crescente distanciamento entre fonte imediata primária (praia e dunas frontais) e fonte imediata secundária (dunas preexistentes). Assim, cada região costeira, sob dada taxa de suprimento eólico, possui uma distância característica entre linha de costa e campo de dunas, função da distância de equilíbrio. Nas três áreas comparadas, centro-sul de Santa Catarina, BahiaSergipe e Ceará, a distância à linha de costa atual é de até $7 \mathrm{~km}$ para as frentes de campos de dunas ativos e de menos de $10 \mathrm{~km}$ para as frentes de campos de dunas antigos. A distância relativamente pequena entre os campos de dunas fósseis mais interiores $e$ as frentes dos campos de dunas ativos sugere que as gerações eólicas antigas formaram-se quando a posição da linha de costa, e também provavelmente o NRM, eram não muito diferentes do atual. Isto é uma evidência adicional de formação das gerações eólicas em um contexto geral de mar alto, similar ao presente. As gerações mais antigas teriam sido depositadas a partir de áreas fontes costeiras situadas pouco mais ao interior (esta afirmativa pode ser estendida a demais regiões com campos de dunas fósseis da costa brasileira, à grande exceção de Lençóis Maranhenses, onde a mesma distância entre paleodunas e dunas mais interiores atinge dezenas de quilômetros). O fato de depósitos das duas gerações mais antigas terem sido alcançados pelo mar durante as duas últimas máximas inundações da costa brasileira pode ser considerado um indício de que estas gerações se formaram, pelo menos em parte, sob contexto transgressivo. As duas gerações mais novas, atribuidas por definição à regressão que sucedeu à máxima inundação holocênica, teriam sido geradas ainda no mesmo contexto de NRM elevado responsável pela geração anterior, porém sem alcançar a mesma interiorização.

Utilizando raciocínio desse tipo para a costa centro-sul de Santa Catarina e observando a discordância entre as gerações 1 e 2, Giannini et al. (2001b,c, 2007c) e Sawakuchi (2003) interpretaram que, do ponto de vista da estratigrafia de seqüências, os sistemas eólicos costeiros da região fariam parte de duas seqüências deposicionais. A seqüência inferior (denominada seqüência 1 por Sawakuchi 2003 e seqüência A por Giannini et al. 2007c), pleistocênica, corresponderia à fase de NRM alto do último interglacial e integraria um trato de sistema transgressivo. A seqüência superior, pleistocênica-holocênica (seqüência 2 ou B), incluiria um trato de sistemas transgressivo, no qual se enquadraria grande parte da geração 2 , e o atual trato de sistemas de mar alto, com as gerações 3 e 4 . Seria resultante do retrabalhamento élico de sedimentos costeiros acumulados durante o final da transgressão holocênica e a fase subseqüente de NRM alto e relativamente estável, ainda em andamento. $O$ truncamento da seqüência eólica $B$ pelas margens do sistema lagunar holocênico indica que a acumulação eólica se iniciou durante a última transgressão marinha pós-glacial. Assim, o estágio inicial desta seqüência pertenceria a trato de sistema transgressivo, ainda que os depósitos eólicos correspondentes tenham baixo potencial de preservação devido à inundação marinha. A superfície irregular do topo da geração 1 materializaria o limite de seqüências, produzido pela exaustão da fonte de sedimentos 
eólicos e pela incisão fluvial associada à queda de NRM ocorrida durante o último período glacial.

Considerando a ligação existente entre variações de NRM e sedimentação eólica costeira, as seqüências $A$ e B seriam equivalentes a seqüências deposicionais de quarta ordem. Desse modo, dada a similaridade nos padrões de mudanças de NRM (em uma escala de $100 \mathrm{ka}$ ) de diferentes setores da costa brasileira durante o Quaternário superior, estas duas "seqüências deposicionais eólicas" envolveriam depósitos eólicos de outras regiões costeiras do país. Este raciocínio permite usar o diagrama cronoestratigráfico das gerações eólicas de Santa Catarina (Figura 3.30) como guia para a descrição de depósitos eólicos do Quaternário superior em outras regiões costeiras do Brasil com curva de NRM e arcabouço estratigráfico similares (Sawakuchi 2003, Giannini et al. 2007c).

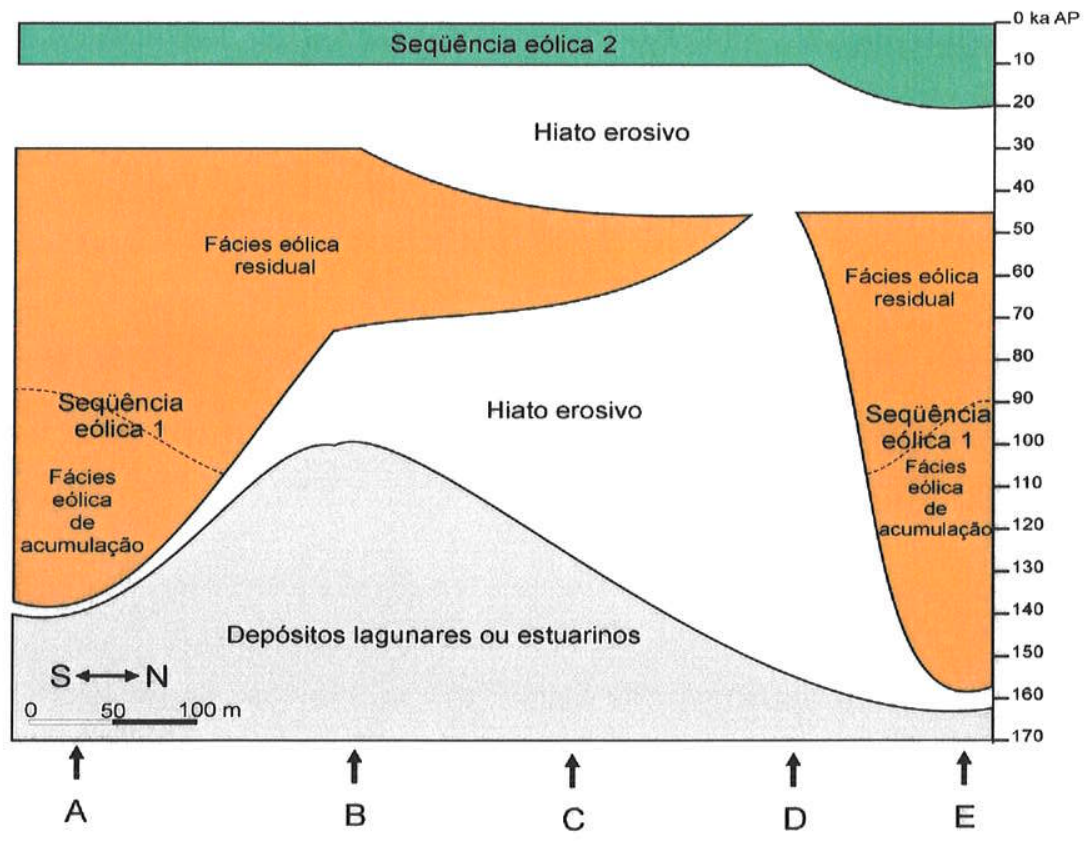

Figura 3.30. Diagrama cronoestratigráfico de Wheeler construido com base na seção tipo das gerações eólicas da costa centro-sul catarinense (seções colunares A, B, C, D e E, ao longo da escarpa de Guaiúba, Imbituba). Modificado de Sawakuchi (2003).

Das três áreas em que as quatro gerações eólicas podem ser correlacionadas, só se dispõe de cronologia absoluta sistemática de paleodunas em Santa Catarina (Sawakuchi 2003, Giannini et al. 2007c). Uma vez que se trata de datações por luminescência, referentes não necessariamente à idade deposicional e sim à idade da última exposição, e considerando que as fácies relacionadas à deflação ou hiato favorecem exposição mais prolongada que as fácies de caráter estritamente acumulativo, as idades obtidas não podem ser analisadas sem antes levar em consideração o contexto faciológico de cada amostra datada. O exame da distribuição de idades em função do caráter acumulativo ou deflacionar dos sedimentos datados demonstram o predomínio de fácies deflacionares na geração 1 , com aumento para o topo da unidade (Giannini et al. 2007c). A tendência ascendente para engrossamento do diâmetro médio, com perda de seleção granulométrica, e para incremento na concentração de minerais pesados, encontrada na mesma unidade por Sawakuchi (2003) 
e Sawakuchi et al. (em preparo), pode ser atribuída a aumento de deflação induzido por diminuição do aporte e/ou aumento da cobertura vegetal. As gerações 2 e 3 , em contraste, exibem tendência ascendente para afinamento com melhora de grau de seleção e decréscimo no teor de pesados (Sawakuchi 2003, Sawakuchi et al. em preparo), indicativa de manutenção com retrabalhamento ou aumento do aporte sedimentar.

Os resultados obtidos nas datações de paleodunas em Santa Catarina reforçam o caráter sincrônico e regional dos episódios de deposição eólica representados pelas seqüências $A$ e $B$, bem como a correlação entre as fases de acumulação eólica e os períodos de NRM alto relacionados ao último interglacial e ao pós-glacial. Os resultados permitem ainda observar hiato de pelo menos algumas dezenas de milhares de anos, entre a última fácies de acumulação da geração 1 (>50ka AP) e o inicio da geração 2 (<10,9 ka AP) (Giannini et al. 2007c).

A seqüência eólica $A$ apresenta grande amplitude de variação nas idades obtidas por luminescência (de 174,8 a 23,0 ka AP em SC, Figura 3.10A). Esta amplitude pode ser atribuída a variações locais não somente no prazo de exaustão do aporte eólico supostamente criado pela flutuação de NRM, mas também no período de estabilização das dunas. O primeiro fator, o estoque de areia disponivel ao transporte pelo vento, depende de variáveis locais como o gradiente da plataforma interna, a freqüência e intensidade das ondas de tempestade e a deriva litorânea residual em cada setor costeiro. Visto que a exaustão da fonte de areia impede a deposição mas não o retrabalhamento eólico, o periodo de estabilização das dunas depende também de outras variáveis locais, controladas pela paleogeografia, como umidade do substrato e taxa de crescimento de vegetação.

Analogamente, a dispersão das idades da seqüência eólica $B$, que confirma a distribuição em três gerações principais $(2,3$ e 4$)$, pode ser relacionada a variações locais no tempo de exaustão do estoque de areia e/ou de estabilização das dunas. As gerações 2 e 3 não são sincrônicas (Figuras 3.10C and 3.10D), mas não existe hiato deposicional regional entre elas: pelo contrário, a passagem dos depósitos da geração 2 para os da 3 , em afloramento, é freqüentemente transicional. A geração 3 possui em parte caráter local, uma vez que uma de suas formas de ocorrência se encontra nas fácies ou posições dos campos de dunas ativos (geração 4) onde o suprimento e retrabalhamento eólicos foram abandonados (antigos rastros lineares residuais e cordões de precipitação). Por outro lado, mesmo que este processo de abandono autocíclico seja admitido como único mecanismo formador da geração 3 , o fato de suas idades concentraram-se no intervalo entre 3 e 2 ka AP é indício de que fatores externos contribuíram para levar o sistema à exaustão ou estabilização sistemática nesse período. Por isso mesmo, considera-se a idéia de existência de três gerações dentro da seqüência $B$ reforçada pelos dados de TL e LOE, ainda que se deva reconhecer a carência de maior número de datações, principalmente para a geração 3 . As gerações eólicas 2,3 e 4 seriam assim partes integrantes do mesmo sistema deposicional eólico e a individualização de cada uma resultaria da exaustão de suprimento sedimentar ou da dinâmica de estabilização da seqüência eólica B (Giannini et al. 2001b,c, Giannini et al. 2007c).

Dispõe-se de datações de dunas costeiras quaternárias também nos estados do Rio Grande do Norte e Paraiba (Barreto et al. 1999, 2001a,b, 2002b, 2004, Giannini et al. 2001a). As idades TL e LOE aí encontradas não contrariam a idéia de correlação entre as duas últimas fases de NRM alto (superior ao atual) e a formação de campos de dunas correspondentes às seqüências eólicas A e B. Das três faixas de idades modais encontradas nas datações TL obtidas por Barreto et al. $(1999,2004)$ para os depósitos costeiros do Rio Grande do Norte (item 3.1.1.3, Figura 3.3), as duas mais recentes e marcantes, de 149 a 24 ka e de 10800 a 50 anos, coincidem aproximadamente com os intervalos cronológicos encontrados para as seqüências A e B de Santa Catarina, respectivamente. Dentro do segundo intervalo, o número e a distribuição de sub-modas são também muito semelhantes 
aos de Santa Catarina, exceto pela presença exclusiva de sub-moda com idades inferiores a 500 anos no Rio Grande do Norte. Esta diferença, entretanto, pode dever-se apenas a uma questão de método de amostragem, uma vez que em Santa Catarina evitou-se deliberadamente datar feições cujo contexto de campo desse indícios de atividade muito recente. A sub-moda de 5,6 a 6,5 ka AP, encontrada nas datações das dunas do Rio Grande do Norte, apresenta forte coincidência com a moda registrada na costa catarinense para a geração 2. Desse modo, é bastante provável que a existência das duas seqüências, e mesmo das quatro gerações, possa ser estendida também à costa potiguar.

De acordo com as idades TL dos depósitos eólicos costeiros do Rio Grande do Norte apresentadas em Barreto et al. (1999, 2004), a fixação de dunas teria ocorrido tanto durante contextos de NRM alto ligados a estádios interglaciais, como nos de NRM baixo associados a estádios glaciais (Giannini et al. 2001a). Quando se analisa a distribuição dos tipos de dunas quanto ao grau de dissipação morfológica (nítidas, tênues e dissipadas), em função das idades de fixação e dos contextos de NRM correspondentes a estas idades (Figura 3.31), nota-se correlação direta do grau de dissipação não apenas com a idade, mas também com os contextos de NRM baixo. Esta correlação permite interpretar intensificação dos processos de dissipação de dunas, antes de sua fixação, nos períodos de NRM mais baixo. Este aumento da dissipação está ligado possivelmente mais à deflação que a incremento das precipitações, pois este último fator deveria acelerar a fixação das dunas por vegetação e favorecer a preservação de formas deposicionais. As dunas com idades compatíveis com contexto de NRM baixo seriam formadas assim a partir do retrabalhamento deflacionar de areias de dunas preexistentes e da planície exposta na regressão forçada.

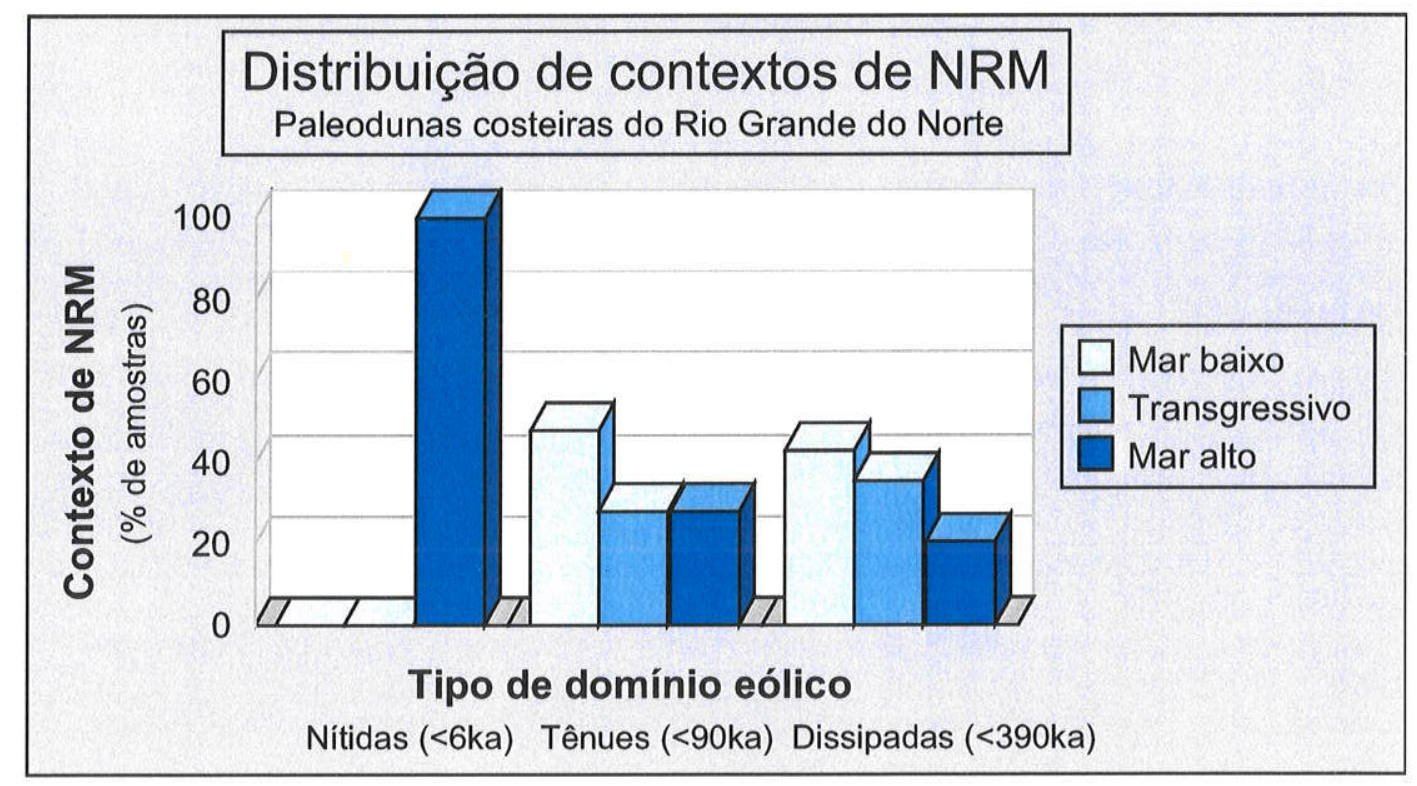

Figura 3.31. Distribuição das idades TL e LOE de paleodunas eólicas costeira do Rio Grande do Norte, quanto a "domínio morfológico" e comportamento do NRM inferido a partir da relação entre as idades obtidas e as curvas de nível do mar de Mesolella et al. (1969), Corrêa (1996) e Angulo \& Lessa (1997). Baseado em Giannini et al. (2001a) e Barreto et al. (1999, 2004).

Com base em resultados granulométricos e de proveniência de minerais pesados, obtidos por Giannini et al. (2001a) para as mesmas amostras submetidas à datação por Barreto et al. (1999, 2004), interpreta-se que os sedimentos eólicos cujas idades de fixação incidem em épocas de mar baixo ou transgressivo teriam sido influenciados pela erosão mais efetiva da Formação Barreiras, o que pode ser atribuído ao rebaixamento do nível de 
base de erosão. A maior importância da Formação Barreiras como rocha-fonte imediata nos períodos de nível do mar mais baixo do que o atual explicaria a presença de dunas de coloração mais vermelha, de granulação mais grossa e com maior concentração de minerais pesados nesses períodos (Giannini et al. 2001a, 2005, Barreto et al. 2004). A esse fator deve ser adicionado o caráter mais deflacionar dos depósitos eólicos fixados sob contexto de mar baixo, o que deve fazer ressaltar, por seleção residual, características texturais e mineralógicas típicas da Formação Barreiras, como a maior presença de areia média e o elevado teor de minerais pesados.

Para a costa norte da Paraiba, as idades TL sugerem que a fixação das dunas se procedeu em momentos de NRM mais baixo que o atual durante o Pleistoceno Superior, entre 64,1 e $27 \mathrm{ka} \mathrm{AP}$ (Barreto et al. 2002b).

$\mathrm{Na}$ costa do Rio Grande do Sul, a associação de depósitos eólicos a quatro sistemas ilha-barreira vinculados aos quatro últimos niveis do mar mais altos que o atual (Villwock et al. 1986, Tomazelli 1990) torna implícita, ainda que de maneira genérica e indireta, a relação entre deposição eólica e flutuações de NRM. Por outro lado, a concentração de rizólitos em distintos níveis recorrentes, indicativa de paleossolos (Tomazelli 1990, 1993), pode ser tomada como indício de sucessivas fases de estabilização e reativação de dunas. Tomazelli (1990, 1993) interpreta estes paleossolos como "registro das variações paleoclimáticas cíclicas que afetaram a região durante o Pleistoceno". Segundo este autor, fases climáticas mais secas favoreceriam a atividade eólica e fases úmidas favoreceriam a estabilização das dunas pela vegetação.

Tomazelli $(1990,1993)$ não foi o único a atribuir diferentes gerações de dunas eólicas à instauração cíclica de fases de clima mais seco durante o Quaternário superior. Na costa do Ceará, Claudino Sales \& Peulvast (2002) e Claudino Sales (2002) consideram a possibilidade de a interrupção do aporte eólico entre as gerações ativas D1 e D2, ocorrida segundo esses autores por volta de 0,3 a 0,4 ka AP estar associada a oscilações climáticas. Em Santa Catarina, Sawakuchi (2003) cogita que o êxito crescente dos processos de deflação, para o topo da unidade 1, pressuponha instauração de fase de clima mais seco, de modo que não houvesse vegetação para impedir o retrabalhamento eólico.

Entre as paleodunas interiores, o fato de a influência do nivel do mar sobre o aporte ser muito menos direta tem tornado mais freqüentes as interpretações de controle paleoclimático na atividade eólica. Na planície quaternária do médio rio São Francisco, por exemplo, hipóteses de intensificação da atividade eólica durante fase de drenagem mais endorréica, ligada a clima mais seco, têm sido cogitadas desde trabalhos regionais pioneiros (Moraes Rego 1926, Domingues 1948). Mais recentemente, datações por TL em amostras de paleodunas coletadas em poços rasos (até $4 \mathrm{~m}$ ), acompanhadas de estudos palinológicos em sedimentos turfáceos associados às, apontaram para diminuição de umidade a partir de 5 a 4 ka AP (Barreto 1996, De Oliveira et al. 1999). A idade TL máxima encontrada, $28 \mathrm{ka}$ AP, permite sugerir que pelo menos desde essa época houve condição para fixação de dunas (Tatumi et al. 1998a,b, Barreto et al. 2002c). O inicio da atividade eólica pode todavia, como enfatizado pelos autores, ter sido muito mais antigo, dado não só o princípio da datação TL mas o fato de a sucessão arenosa apresentar mais de $100 \mathrm{~m}$ de espessura.

Datações por TL e LOE foram realizadas também em 14 amostras de terraços marginais do baixo rio Negro atribuidos a paleodunas eólicas (Santos et al. 1993), coletadas entre 50 e $300 \mathrm{~cm}$ de profundidade (Tatumi et al. 2000, Carneiro Filho et al. 2002). As idades variaram entre 7,8 e 32,6 ka AP. Com base nestes resultados, os autores interpretaram que durante o Pleniglacial e parte do Holoceno, a região noroeste da Amazônia teria sido submetida a condições climáticas mais secas e sazonais que as atuais.

A comparação entre depósitos eólicos costeiros e interiores, balizada por datações e estudos palinológicos, é, sem dúvida estratégica para rastrear a possível influência de oscilações paleoclimáticas na formação de campos de dunas. Os dados disponiveis até o 
momento são, entretanto, escassos e inconclusivos. A correlação de episódios de formação de dunas eólicas costeiras com fases de paleoclima mais seco esbarra em pelo menos três grandes dificuldades: a primeira é a falta de informações de contexto geológico e faciológico de parte das amostras datadas, o que dificulta a reconstituição da estratigrafia e torna prudente questionar, em alguns casos, a própria origem eólica do depósito. A segunda, que afeta também a correlação entre nivel do mar e formação de dunas, é a falta de datações em sedimentos eólicos cujos resultados possam ser atribuídos seguramente a momentos de deposição pelo vento. A terceira é o estágio de compreensão ainda insatisfatório sobre as variações paleoclimáticas quaternárias nas diferentes regiões costeiras do país, em grande parte por falta de integração entre dados geológicos e micropaleontológicos. Com isso, torna-se prematuro avaliar, no momento, as suspeitas de controle climático sobre as gerações de campos de dunas. 


\subsection{Descrição interna}

\subsubsection{Modelo conceitual}

A distinção entre fácies ou associações de fácies eólicas baseia-se na caracterização de tipos morfológicos de dunas e na morfologia e constituição das interdunas (Fisher 1983). Adotando essa perspectiva, Karpeta (1990) subdivide os arenitos eólicos permianos da Formação Bridgnorth (Inglaterra) em fácies de dunas e de interdunas, e atribui cada uma das seis fácies dunares reconhecidas a um tipo diferente de geometria e/ou dimensão de duna eólica. Soares (1992) considera as fácies eólicas neopaleozóicas e mesozóicas da Bacia do Paraná como "registros de entidades morfológicas".

No Quaternário costeiro, uma faciologia fundada em tipos morfológicos, onde diferentes formas de duna correspondem a diferentes fácies, tem auxiliado a descrever a dinâmica do sistema eólico (Giannini 1993, 1998, 2001b; Martinho \& Giannini 2001; Martinho et al. 2007). De acordo com a concepção adotada nesses trabalhos, são os saldos entre entradas e saidas de sedimentos que determinam os tipos morfológicos e as dimensões de dunas e interdunas (fácies), os quais podem interligar-se, superpor-se ou fundir-se, chegando a gerar novas formas em hierarquias superiores de escala (associações de fácies), representadas por campos de dunas e draas (Giannini 1993).

Por outro lado, considerando que as fácies são definidas como registros de processos deposicionais específicos, e que vários processos diferentes (fluxo de grãos, queda de grãos, migração de ôndulas de areia, cordões de grânulos, adesão superficial, carpete de tração etc) podem concorrer para a formação e crescimento de dado tipo de duna, o detalhamento progressivo do sistema eólico leva à promoção das geometrias de duna ao status de elementos ou associações de fácies morfológicos, cujo registro corresponde a elementos arquitetônicos ou associações de fácies deposicionais (capítulo 2).

A entrada e a saída de sedimentos que controlam os elementos morfológicos do sistema eólico possuem correspondência com os conceitos de influxo e efluxo, respectivamente, na acepção de Kocurek \& Havholm (1993). O saldo sedimentar entre influxo e efluxo depende da relação entre disponibilidade de sedimentos no sistema e energia eólica para movê-los. Nos campos dunares de desertos amplos e estabelecidos, a variação de fácies depende estreitamente da diversidade de formas e tamanhos de elementos morfológicos. Já nos sistemas de climas úmidos e nos costeiros, a disponibilidade de areia incoesa pode ser reduzida na proporção direta da participação da água nos processos deposicionais. O transporte subaquoso é aí o principal fator de quebra da exclusividade de ação do agente eólico, principalmente nas fácies interdunas e deflacionares (Giannini 1993). Assim, a proximidade e freqüência da presença de água nas interdunas torna-se, nesse contexto, importante controlador da diversificação faciológica, inclusive na criação de tipos de dunas especificos ou exclusivos da influência da água e da vegetação.

Uma vez que a descrição interna do sistema eólico é aqui baseada na identificação de elementos morfológicos, torna-se importante uma breve introdução sobre a classificação, terminologia e significado genético das principais formas de dunas, com ênfase no contexto costeiro, baseada em Giannini et al. (2007a).

No seu sentido mais amplo, dunas eólicas são formas de leito onduladas, quase sempre assimétricas, produzidas pelo transporte e deposição de particulas pelo vento. A assimetria caracteriza-se por inclinação maior no lado sotavento (lee side ou downwind) que no lado barlavento (stoss side ou upwind). O conceito de duna possui um significado implícito quanto à hierarquia de tamanho de formas de leito eólicas, segundo o qual dunas são maiores e portanto passiveis de superposição por ôndulas (sinônimos: microondulações, marcas onduladas ou simplesmente ondulações; em inglês, ripples), estas com comprimentos de onda predominantemente centimétricos a decimétricos. No sentido mais 
estrito, dunas são as formas onduladas desta hierarquia altas e íngremes o bastante para desenvolver avalanchas de areia no flanco de sotavento. Formam-se assim, na parte superior do lado sotavento, as faces de avalancha (slipfaces). Neste sentido, às formas submétricas a métricas sem face de avalancha pode-se reservar o uso dos termos megaripples (Taira \& Scholle 1979) ou protodunas (Kocurek et al. 1992).

Face à enorme abrangência da definição de duna eólica, existem diversas propostas para sua nomenclatura e classificação, em muitos casos com denominações conflitantes, o que ficou evidenciado na revisão terminológica apresentada por Breed \& Grow (1979). O esquema adotado por McKee (1979), baseado na morfologia observada via sensores remotos (Figura 3.32), é um dos mais usados ainda hoje, embora misture aspectos direcionais (transversal), azimutais (reversa), geométricos (linear, parabólica) e genéticos (blowout). A rigor, tanto o tipo A da Figura 3.32, designado "transversal", como B (barcanóide) e C (barcana), possuem eixo maior transversal ao vento efetivo. $O$ tipo $A$ é tão ou mais linear do que $D$, estando a diferença entre eles na orientação da crista em relação ao vento efetivo. A geometria parabólica também não é exclusiva do tipo assim designado $(G)$, podendo ocorrer, com menor relação comprimento/largura, no tipo $\mathrm{H}$ (blowout). A passagem entre $A$ e $B$ é transicional, sendo os dois tipos referidos em conjunto como cordões crescênticos.

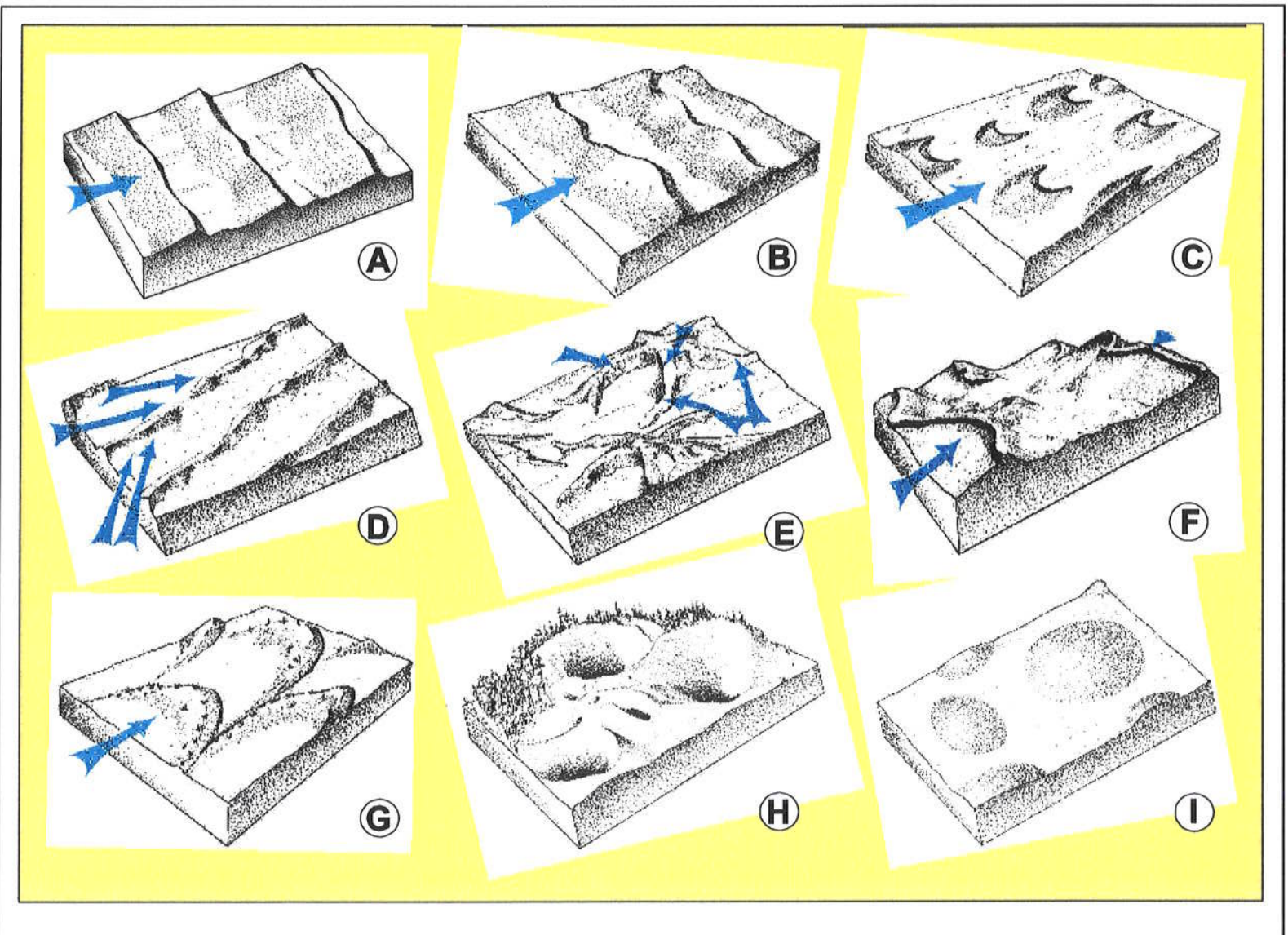

Figura 3.32. Tipos básicos de dunas eólicas (McKee 1979): A. "Transversal". B. Barcanóide. C. Barcana. D. "Linear" ou seif. E. Estrela. F. Reversa. G. Parabólica. H. Ruptura de deflação ou blowout. I. Dômica. Figura extraída de Giannini et al. $\left(2007^{\mathrm{a}}\right)$.

Os tipos de dunas mais universais, isto é, com ocorrência tanto em desertos como em áreas costeiras úmidas, são os de orientação transversal ao sentido de fluxo eólico 
principal: transversais sensu stricto (Figura 3.32A), barcanóides (Figura 3.32B) e barcanas (Figura $3.32 \mathrm{C}$ ). A geometria da crista nestas dunas aumenta de sinuosidade das dunas transversais para as barcanas isoladas ou lateralmente coalescidas (barcanóides). As dunas transversais são megaformas eólicas de crista e perfil de sotavento aproximadamente retilíneos, com orientação, ortogonal ao vento efetivo, pouco variável ao longo de sua extensão. Direções de vento diferentes da modal seriam predominantemente a ela perpendiculares o que contribuiria para manter a linearidade da crista e da face sotavento. Cadeias barcanóides e barcanas são formas de leito eólicas influenciadas por pequenos desvios do vento em relação ao azimute principal. Estes desvios são supostamente os responsáveis pelo desenvolvimento de "projeções de sotavento" (lee projections: Cooper 1958) "elementos longitudinais" (Brookfield 1977) ou "extensões lineares" (Martinho et al. 2007), cúspides que caracterizam a geometria em planta das cadeias barcanóides e que possuem orientação grosso modo coincidente com a dos ventos mais efetivos. Nos grandes mares de areia da África, cadeias barcanóides com desenvolvimento proeminente de extensões lineares são denominadas aklé (Collinson \& Thompson 1982).

Dunas alongadas, com duas direções de faces de avalancha alternadas ao longo de seu comprimento (Figura 3.32D), são designadas seif, "lineares" ou "longitudinais". Embora consagrados, os termos entre aspas guardam imprecisões: esta forma não é rigorosamente linear, porque à alternância de faces de avalancha corresponde certa sinuosidade na crista; nem é meramente longitudinal, uma vez que os dois rumos de vento atuantes na formação das faces de avalancha podem possuir ângulo de mais de $15^{\circ}$ em relação à crista. São exclusivas de ergs, ocorrendo por exemplo nos desertos do Saara, da Arábia e da Namíbia. As formas em estrela (Figura 3.32E) formam-se pela interação de ventos com sentidos de fluxo variados, e as reversas (Figura $3.32 \mathrm{~F}$ ), através da alternância de fluxos eólicos opostos. As dunas parabólicas (em forma de U: Figura 3.32G) e os blowouts (elípticas em planta, com escavação central em forma de prato: Figura $3.32 \mathrm{H}$ ) são controlados por estabilização parcial ligada à existência de vegetação e/ou nível freático alto, daí sua ocorrência quase exclusiva em campos de dunas de áreas úmidas. Também controladas por vegetação e/ou umidade são as dunas dômicas (Figura 3.32l), caracterizadas pela forma circular ou elíptica em planta, sem faces de avalancha evidentes.

Em ergs livres da influência direta da vegetação e da interferência de sistemas deposicionais vizinhos (aluviais ou costeiros, por exemplo), a geometria e as dimensões de formas de leito eólicas estabelecem-se em equilíbrio com variáveis relativas à energia e orientação do vento e ao volume e granulação do aporte sedimentar. Com base nesse princípio, tem-se procurado inferir quais são as formas de dunas ou draas estáveis sob diferentes condições combinadas especificas de volume de sedimentos e complexidade ou variabilidade do regime eólico (McKee 1979, Wasson \& Hyde 1983, Lancaster 1989, 1995, Pye \& Tsoar 1990). O volume, controlado pela relação aporte/energia (ou influxo/efluxo), é medido através da espessura equivalente de areia. A complexidade do regime eólico medese pelo índice de variabilidade direcional do vento, que é a relação entre a magnitude do vetor resultante de deriva eólica potencial $\left(D E P_{R}\right)$ e a soma escalar total da mesma deriva em todas as direções de ação do vento (DEP).

De acordo com os resultados obtidos por aqueles autores (Figura 3.33), dunas de orientação transversal, incluindo barcanas e cordões crescênticos (cadeias barcanóides e dunas lineares transversais), são características de regime eólico pouco complexo, com indice de variabilidade superior a 0,5. Dentro desta categoria de dunas, o aumento gradual de suprimento é capaz de converter barcanas (Figura 3C) em cordões crescênticos simples (Figuras 3A e 3B) e estes em cordões crescênticos superpostos (draas compostos). 


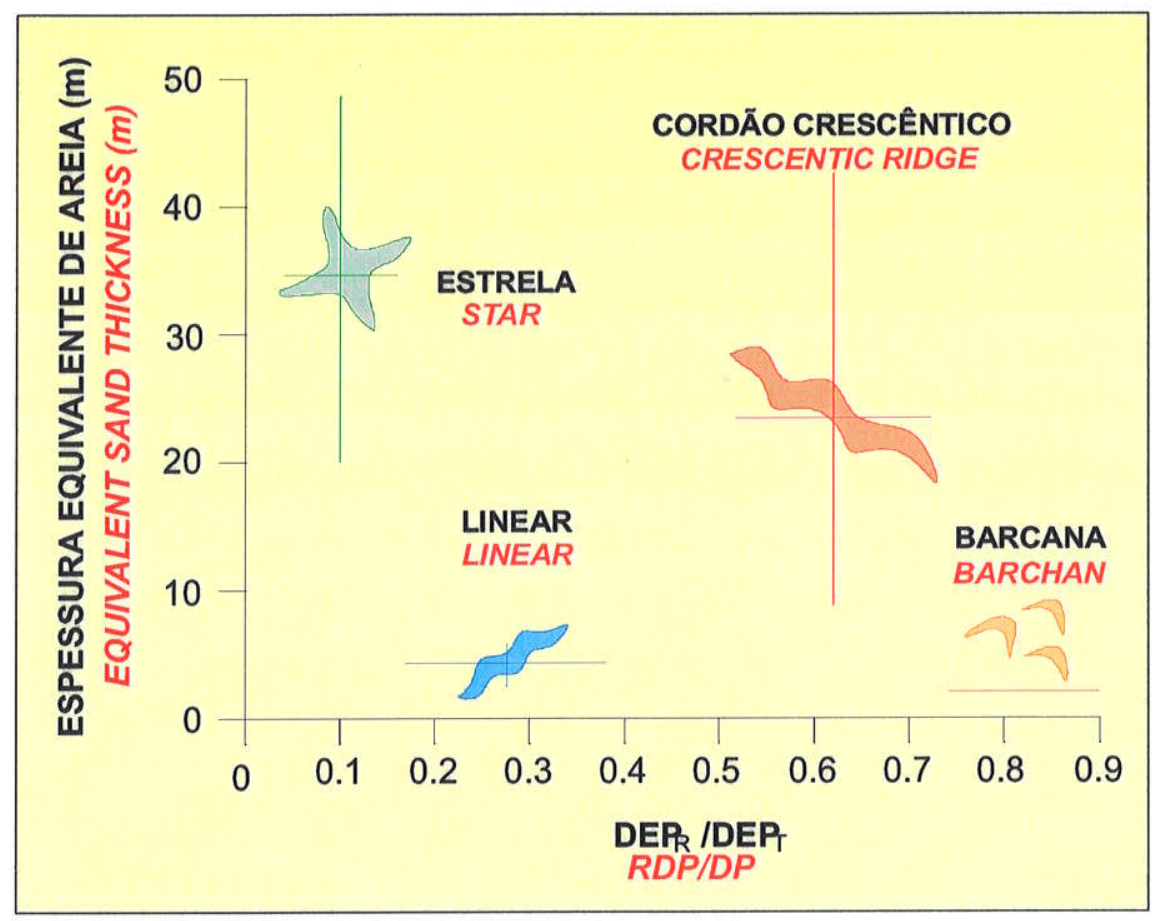

Figura 3.33. Diferentes tipos de dunas lançados em diagrama de dispersão aporte sedimentar $x$ complexidade do regime eólico, representado pela relação entre a magnitude do vetor deriva eólica potencial resultante, ou $\mathrm{DEP}_{\mathrm{R}}$, e a deriva eólica potencial (escalar) total, ou $\mathrm{DEP}_{\mathrm{T}}$. Compilado de Wasson \& Hyde (1983) e Lancaster (1995) por Giannini et al. (2007a).

Cordões crescênticos formam-se a índices de variabilidade direcional mais baixos $(0,5$ a 0,7$)$ que barcanas $(0,75$ a 0,9$)$. Os de baixa sinuosidade, equivalentes às dunas transversais clássicas, seriam favorecidos pela elevação do aporte relativo à energia (McKee 1979, Giannini 1993, Giannini \& Santos 1994).

As dunas seif formam-se em porções do erg com relação suprimento/energia baixa e regime eólico complexo (índice de variabilidade direcional entre 0,15 e 0,4). Este regime caracteriza-se pela alternância de dois ventos dominantes ligeiramente oblíquos à crista, com até $120^{\circ}$ de diferença de azimute, o que se reflete na atitude espacial das faces de avalancha.

Formas de dunas podem ser influenciadas ou determinadas também por vegetação e interferência de sistemas deposicionais vizinhos. No campo de dunas móveis que se estende de Santa Marta a Campo Bom (Laguna e Jaguaruna, SC), a ocorrência exclusiva de dunas transversais junto à praia é questão não somente de proximidade da área fonte, mas também da linearização das interdunas por inundação via ondas de tempestade (Giannini 1993, Giannini \& Santos 1994). Outro exemplo é dado pelos zibars, cuja formação é condicionada pela presença de areia grossa, sob diferentes taxas de aporte eólico. Já entre os depósitos eólicos determinados pela presença de vegetação, encontra-se pelo menos uma dezena de tipos, que incluem dunas frontais, nebkhas, parabólicas, rastros lineares residuais e cordões de precipitação (item 3.3.1.1).

Em função da distribuição azimutal dos ventos dominantes e da relação entre energia eólica e disponibilidade de areia, esta fortemente influenciada pela profundidade do nível freático, os tipos de dunas variam não somente de um campo de dunas para outro, como também dentro de um mesmo campo de dunas, caso da Namíbia. 


\subsubsection{Elementos morfológicos eólicos na costa brasileira}

Os elementos morfológicos eólicos identificados na costa brasileira podem ser subdivididos em dois grupos, conforme exista ou não influência morfodinâmica significativa da vegetação (Giannini et al. 2005). Os elementos com influência da vegetação equivalem às feições eólicas também designadas "semi-fixas" (Claudino Sales 2002). As sem influência da vegetação guardam correspondência com as denominadas dunas livres (Tomazelli 1990). Este subitem é dedicado à descrição e discussão terminológica geral de cada elemento morfológico dentro destes dois grupos, com comentários sobre o elemento sedimentar ou arquitetônico correspondente, onde cabível. A apresentação dos aspectos morfológicos antecede aos sedimentológicos, estes baseados principalmente em resultados obtidos nos campos de dunas transgressivos do centro-sul catarinense (Giannini 1993, Martinho 2004, Martinho et al. 2007) e em dunas com vegetação do litoral sul paulista (Ferreira 2003, Bentz 2004, Nascimento 2006, Giannini et al. 2007b). A proposta terminológica é um detalhamento da introduzida por Giannini et al. (2005).

\subsubsection{Elementos morfológicos com vegetação}

Os elementos com vegetação encontram-se listados a seguir, das porções mais proximais para as mais distais em relação à fonte praial.

\section{Dunas frontais (foredunes)}

Dunas frontais correspondem a acúmulos contínuos de areia em meio à vegetação ao interior da zona de pós-praia (sob morfodinâmica praial intermediária a reflexiva) ou da antepraia superior (sob morfodinâmica dissipativa). Dunas frontais, ou suas variedades morfológicas, têm sido descritas no Brasil sob diversos outros nomes, como antedunas (Bigarella 1946), dunas embrionárias (Huech 1955), pró-dunas (a partir do termo pro-dunes proposto por Bigarella et al. 1969, e Bigarella 1972), dunas de retenção (a partir das retention dunes de McKee 1979), dunas barreira, dunas-cordão e dunas bordejantes. Hesp (1988) lista ainda vários outros sinônimos encontrados na literatura em língua inglesa, como bank dunes, lee-sourtce dunes (Melton 1940), frontal dunes (Guilcher 1958) e beach-ridge dunes (Bigarella et al. 1969). A designação foredune já era utilizada no clássico trabalho de Cooper (1958), mas o termo passou a dominar na comunidade científica mundial principalmente após os trabalhos de Hesp $(1983,1988,2000)$. Na literatura geológica do Brasil, tem predominado desde então o termo duna frontal, tradução literal da proposta de Guilcher (1958).

$\mathrm{Na}$ escala de dezenas de metros ao longo da praia, as dunas frontais podem apresentar a geometria de cristas de relevo ligeiramente sinuosas, paralelas à linha de costa, quando recebem a denominação de dune ridges (Bigarella et al. 1969) ou cordões dunares. Nessa mesma escala, as outras geometrias comuns em dunas frontais, além do cordão, são a rampa e o terraço (Hesp 2000; Figura 3.34). 


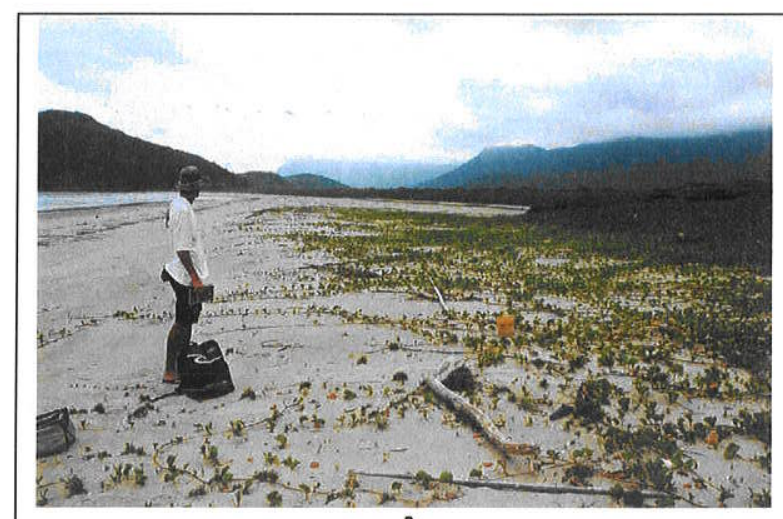

A

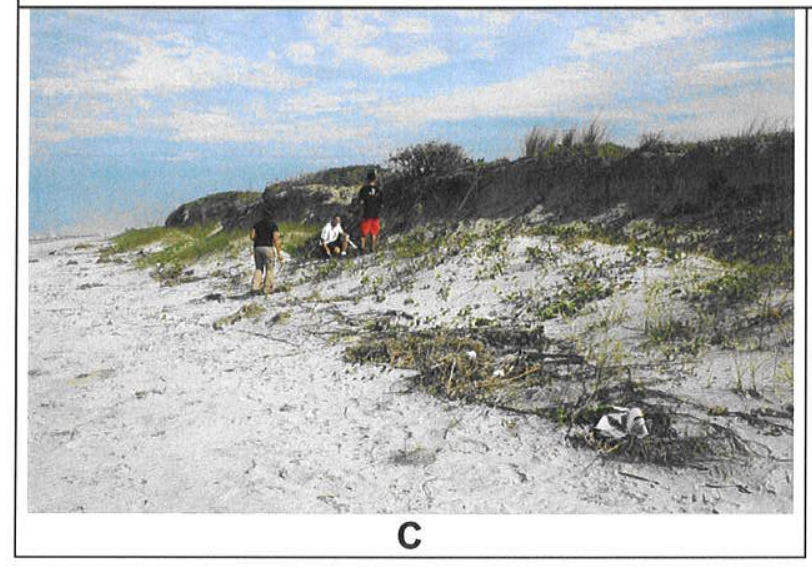

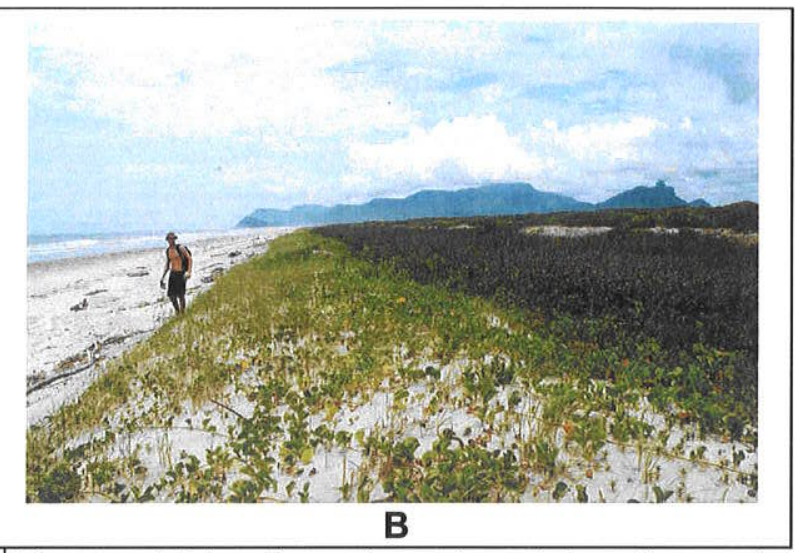

Figura 3.34. Exemplos dos três tipos de morfologia de dunas frontais incipientes nas praias do Una (Peruibe: A, B) e llha Comprida (C), no litoral sul paulista. A. Terraço. B. Cordão. C. Rampa ancorada em falésia de duna estabelecida.

Segundo Hesp $(1983,1988)$, as dunas frontais começam como dunas incipientes ou embrionárias e evoluem, com o aumento da altura, da complexidade morfológica e da diversidade de cobertura vegetal, para dunas estabelecidas. A sub-classificação das dunas frontais em incipientes e estabelecidas é, portanto, de cunho genético e evolutivo, de modo que as fronteiras entre estas duas classes são transicionais e mesmo arbitrárias, a depender dos limites adotados de contrastes de tamanho, idade relativa e complexidade morfoecológica. Nesta Tese, propõe-se designar como incipientes as dunas em que a deposição eólica predomina sobre a deflação e a colonização por vegetais, de tal modo que a flora é extremamente especializada (mais de $95 \%$ da cobertura constituída por no máximo três espécies). Além disso, a geometria da duna frontal incipiente é simples. Mudanças de geometria para o interior, como passagem de rampa a terraço ou descontinuidade entre um cordão e outro certamente representam passagem de duna incipiente para estabelecida.

As dunas frontais estabelecidas, por sua maior complexidade morfológica em relação às incipientes, podem apresentar formas mais variadas na escala de menos de uma dezena de metros, sendo umas das mais comuns a suavemente ondulada ou hummocky. Caracterizadas por taxas de deposição eólica mais baixas que as dunas incipientes, podem ser intensamente remodeladas por processos erosivos, principalmente eólicos. Desse modo, o grau de modificação da morfologia original por estes processos constitui-se em critério de classificação. Utilizando este tipo de critério, Hesp (1988) dividiu as dunas estabelecidas em cinco estágios, 1 a 5 , na ordem de erosão crescente. A morfologia hummocky seria comum no estágio 3 (Figura 3.35). 


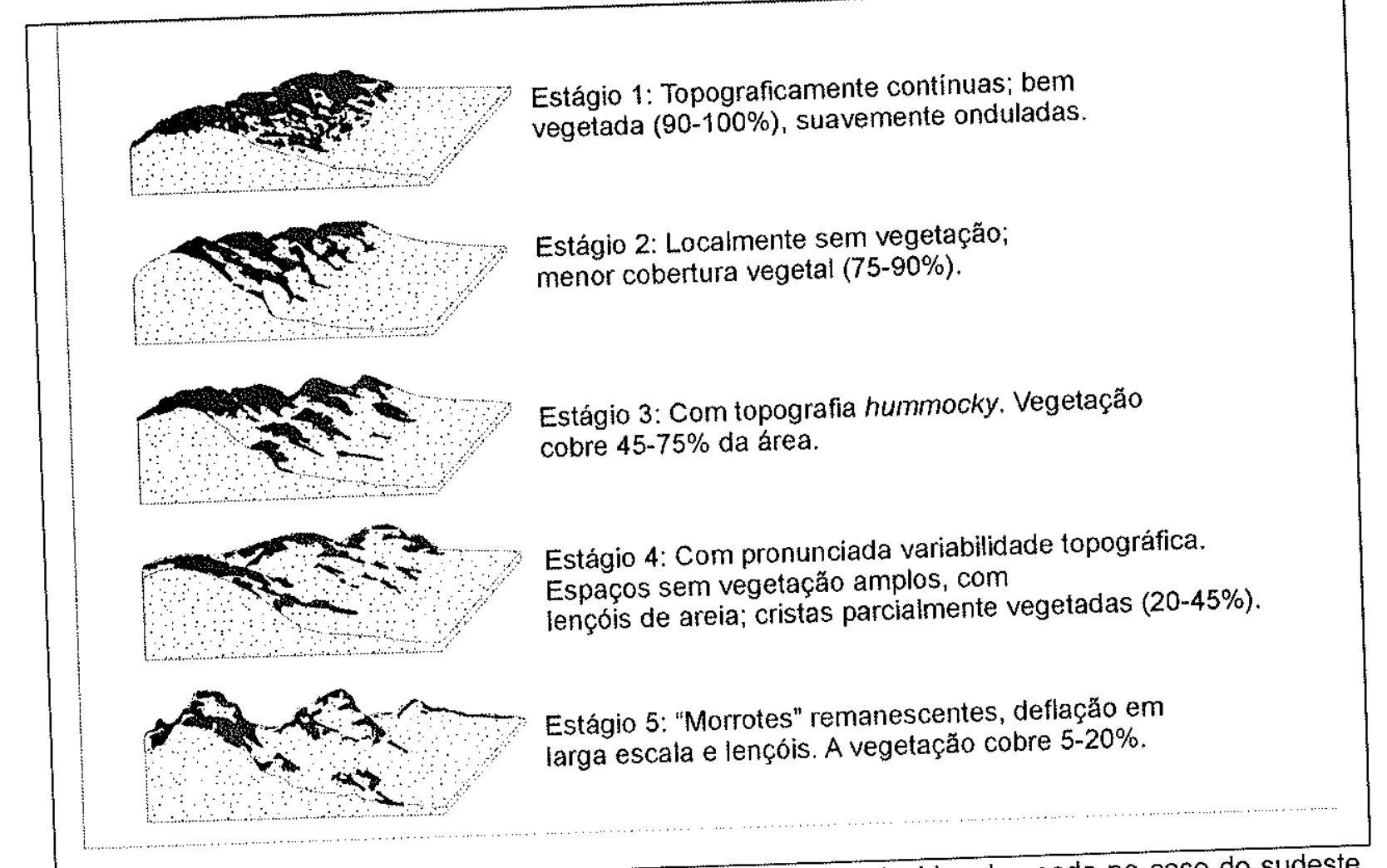

Figura 3.35. Classificação morfológica de dunas frontais estabelecidas, baseada no caso do sudeste da Austrália. Adaptado de Hesp (1988) por Bentz (2004).

Em escala de evolução de linha de costa, as dunas frontais podem formar-se sob dois contextos principais: em costa aproximadamente estável ou sob progradação. No primeiro contexto, a iniciação das dunas frontais dá-se através da colonização vegetal de franja eólica (item 3.3.1.2) em lençol ou em rampa. A morfologia em rampa ancora-se via de regra em falésias mortas sobre dunas mais antigas e representa tipicamente, portanto, processo de reconstrução. A formação da rampa depende de que a elevação instantânea de NRM (por exemplo, através da ação de onda de tempestade), envolvida no esculpimento da falésia sobre a duna preexistente, seja menor que a altura desta duna. Caso contrário, temse a formação de leques de sobrelavagem, muitas vezes submetidos em seguida à deflação eólica, com formação de blowouts. Quando a altura da rampa ultrapassa a altura da falésia, a duna frontal evolui para outras formas, sendo a mais comum a de cordão assimétrico.

No contexto progradacional, predominam as dunas frontais em feixes de cordões e em terraço. A geometria de cordão associa-se à existência de pulsos na razão entre a taxa de progradação e a taxa de aporte eólico. Pode formar-se por exemplo sob aporte eólico constante e estabilizações momentâneas da linha de costa, sendo a cava (swale sensu Hesp 2000) entre dois cordões vizinhos representativa de fase de progradação entre duas estabilizações; ou sob progradação constante e variação do aporte eólico, sendo a cava neste caso registro de uma queda temporária neste aporte. Os cordões tornam-se tão mais largos quanto mais permanente a relação entre taxa de progradação e de suprimento eólico, tendendo à geometria de terraço na condição de máxima constância desta relação. Sob essas condições, a altura da duna frontal em terraço é diretamente proporcional à razão entre suprimento eólico e progradação. 
Em escala mais local e imediata, a formação de dunas frontais está ligada à questão da rugosidade de forma representada principalmente pelas plantas e dos redemoinhos por elas gerados. As linhas de fluxo divergem a barlavento do obstáculo e convergem e reatamse em seguida a sotavento, compondo redemoinhos de geometria elipsoidal. Às zonas de convergência das linhas de fluxo, com vocação deposicional, deve-se a construção da duna. Assim, a extensão em área da zona deposicional é diretamente proporcional ao alcance horizontal dos redemoinhos. Quanto menor este alcance, menor a área de deposição eólica. A deposição de areia em área restrita favorece o aumento da altura da duna. A área de projeção horizontal dos redemoinhos, e, conseqüentemente, da duna, diminuem com a altura, o porte (largura) e a densidade da vegetação e com a velocidade do vento. A altura da duna aumenta com os mesmos fatores (Carter 1988, Hesp 1989, 1999). Isto ajuda a explicar porque as dunas estabelecidas, mais interiores e cobertas por vegetação mais densa e de maior porte quando comparadas com incipientes de mesma região, tendem a ser mais altas.

As características mais distintivas das estruturas internas de dunas frontais são o predominio de estratificações cruzadas de baixo ângulo $\left(<20^{\circ}\right)$, a preservação de estratificações dorsais (backset), com mergulho para o mar, e de topo de duna (topset) e a escassez de feições de avalancha (Bigarella et al. 1969, Goldsmith 1973, 1978, Hesp 1983, 1988). O padrão azimutal das estratificações depende da geometria da duna, pois enquanto rampas podem ser dominadas por mergulhos para o mar e terraços por estratificações subhorizontais, cordões de dunas tendem a caracterizar-se por maior dispersão nos rumos de mergulho. No caso de dunas estabelecidas, a estruturação depende também do estágio erosivo, com aumento de complexidade do estágio 1 para o estágio 5 (Hesp 1988). Nas dunas simples dos estágios 1 e 2 (Figura 3.35), Hesp (1988) descreve laminações monótonas interrompidas apenas por superfícies com geometria típica de reativação ou terceira ordem. Nas dunas de estágios erosivos mais avançados, tornam-se freqüentes, segundo mesmo autor, estratificações cujas superfícies de truncamento, geradas por blowouts, abrasão marinha ou formação e soterramento de solos, não são obedecidas pelos estratos acima. Estas estratificações podem apresentar ângulos de mergulho mais altos. Estratificações cruzadas com ângulos de mergulho para o mar, superiores a $40^{\circ}$, podem formar-se graças à retenção de areia por vegetação pioneira em rampas recém-formadas aos pés de dunas frontais escarpadas (P.A.Hesp, com. pessoal). Estratificações cruzadas ingremes com mergulho para o continente, provavelmente associadas a faces de avalancha de lobos deposicionais, também podem ser encontradas em dunas frontais modificadas por blowouts (próximo subitem).

Medidas de atitude de estratificações cruzadas expostas em cordões de dunas frontais incipientes na parte sudoeste da praia de Itapirubá, municipio de Imbituba, SC, apresentaram dispersão de azimute de mergutho de $180^{\circ}$, entre NE e SW (Giannini 1993), com inclinação máxima de $29^{\circ}$, para NW, e média de $14^{\circ}$. Apesar de os ventos mais importantes na região, os prevalecentes de NE e os predominantes de SW, serem subparalelos à costa, os ventos transversais, de SE, seriam os principais responsáveis pela expansão da areia ao interior através de blowouts e pela produção, desse modo, de estratificações de avalancha, de ângulo mais ingreme (subitem seguinte). Rumo NE, sentido da deriva litorânea longitudinal predominante ao longo da mesma praia, estratificações cruzadas com mergulho para o mar (SE), associadas à parte dorsal das dunas frontais, tornam-se importantes (Giannini 1993). Desse modo, a preservação destas estratificações seria restrita às porções mais deposicionais da praia. 
Rupturas de deflação é o termo proposto por Giannini et al. (2005) como tradução para blowouts, definidas como feições mistas (erosivo-deposicionais), geradas por retirada e redeposição local, pelo vento, de depósitos arenosos preexistentes (Figura 3.36). A ruptura faz-se através da produção de bacia deflacionar (deflation basin), delimitada por paredes subparalelas ("erosional" walls) que se fecham, rumo sotavento, em lobos deposicionais (depositional lobes) em forma de U, com faces de avalancha (Hesp 2000). Traduções em português propostas anteriormente, como "bacia ou cava de deflação" por exemplo (Angulo 1992, Giannini 1993), ressaltam apenas uma parcela (erosiva) da feição. Além disso, cava ou bacia são designações essencialmente morfológicas, enquanto o termo ruptura, assim como blowout, designa ao mesmo tempo um processo e seu produto morfológico. $\mathrm{O}$ propósito da tradução aqui adotada é portanto preservar a abrangência e o caráter processoproduto implícito do termo inglês.

A relação deposição/erosão aumenta gradualmente da bacia para as paredes e das paredes para os lobos. Enquanto a bacia é essencialmente erosiva e o lobo é dominantemente deposicional, as paredes apresentam regime erosivo na parte interna e deposicional na externa. Caracterizam-se assim por séries de estratificações cruzadas planares a ligeiramente tangenciais no topo, cuja atitude é grosso modo coincidente com a superfície externa. Devido a menor altura do depósito e maior ação deflacionar do vento, as paredes são mais sujeitas que o lobo a encharcamento basal, com produção de convoluções por fluidificação, e a concentração residual de minerais pesados e sedimentos relativamente grossos. O lobo caracteriza-se por estratificações cruzadas tangenciais no topo (possivelmente sigmóides) ou truncadas por superfícies de terceira ordem, com rumo de mergulho no sentido do vento principal. Considerando a típica dinâmica das rupturas deflacionares, em que paredes e lobos migram aproximadamente com a mesma velocidade rumo ao interior, os depósitos de lobos tendem a ser sucessivamente destruídos pelos das paredes e só se preservam na fase de estabilização, quanto parte das paredes é coberta pelos lobos. Como resultado, a sucessão vertical mais comumente encontrada em depósitos de blowout estabilizados é de estratificações cruzadas com mergulhos laterais divergentes, atribuíveis às paredes, sob estratificações cruzadas com mergulho frontal, correlacionadas aos lobos. Considerando o decréscimo relativo de processos deflacionares das paredes para os lobos, essa sucessão pode ser caracterizada por tendência ascendente de afinamento e redução na concentração de minerais pesados.

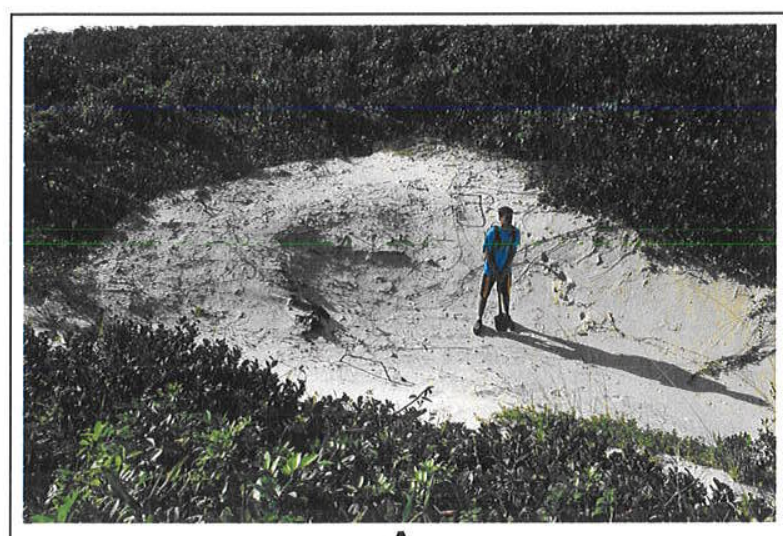

A

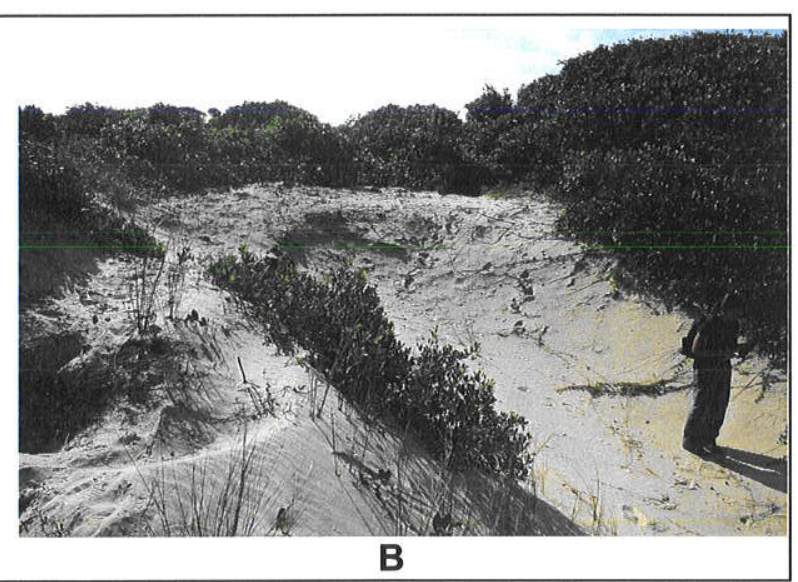

B

Figura 3.36. Exemplos de rupturas de deflação na porção meio-sudoeste da praia de ilha Comprida, SP. Rumo de avanço (NNW) na diagonal superior esquerda das fotos. 
O termo duna parabólica, introduzido por Steenstrüp (1894 apud Howell 1960), refere-se a dunas caracterizadas por geometria plana em $\mathrm{U}$ ou $\mathrm{V}$, com convexidade voltada para sotavento (Jennings 1957; Figura 3.37). Possuem basicamente os mesmos componentes da ruptura de deflação. Na duna parabólica, entretanto, o contraste entre lobo deposicional e paredes, quanto ao grau e porte de cobertura vegetal, é maior que na ruptura de deflação. À medida que a ruptura de deflação evolui para duna parabólica, o lobo torna-se menos vegetado e, como conseqüência disso, passa a migrar mais rapidamente que a bacia deflacionar e as paredes iniciais. Os processos erosivo-deposicionais atuantes na bacia e nas paredes iniciais são gradualmente abandonados, à medida que o lobo, em seu crescente afastamento rumo ao interior, modela novas bacia deposicional e paredes. Do ponto de vista morfológico, a diferença da duna parabólica em relação à ruptura de deflação é portanto o maior alongamento das paredes, individualizadas sob a forma de braços ou rastros lineares residuais (próximo subitem).

As dunas parabólicas podem ter geometria simples ou composta. A geometria parabólica simples equivale à forma também conhecida na literatura como hairpin (termo introduzido por Melton 1940, cuja tradução seria: em grampo de cabelo), longwalled (Pye 1982) ou adelgaçada (attenuated, de Semeniuk et al. 1989). A geometria composta, caracterizada pela coalescência lateral de várias formas parabólicas menores, tem sido designada no Brasil por uma série de sinônimos como imbricada (Giannini 1993), em ancinho (Barbosa 1997), escalonada (Barreto et al. 2002a,c) ou digitada, correspondentes aos termos em inglês imbricate (Tinley 1985 apud Hesp et al. 1989), fretted (Semeniuk et al. 1989) ou digitate (Pye \& Tsoar 1990). Quanto à disposição relativa, algumas dunas parabólicas, tanto simples quanto compostas, apresentam convexidade encaixada na concavidade de dunas parabólicas a sotavento, quando são então designadas aninhadas (Barreto 1996) ou nidiformes (Barbosa 1997), traduções para nested (Melton 1940).

O registro morfológico e deposicional das dunas parabólicas é uma combinação dos registros de rupturas de deflação, na área de estabilização, e rastros lineares residuais, na sua área de passagem a barlavento.

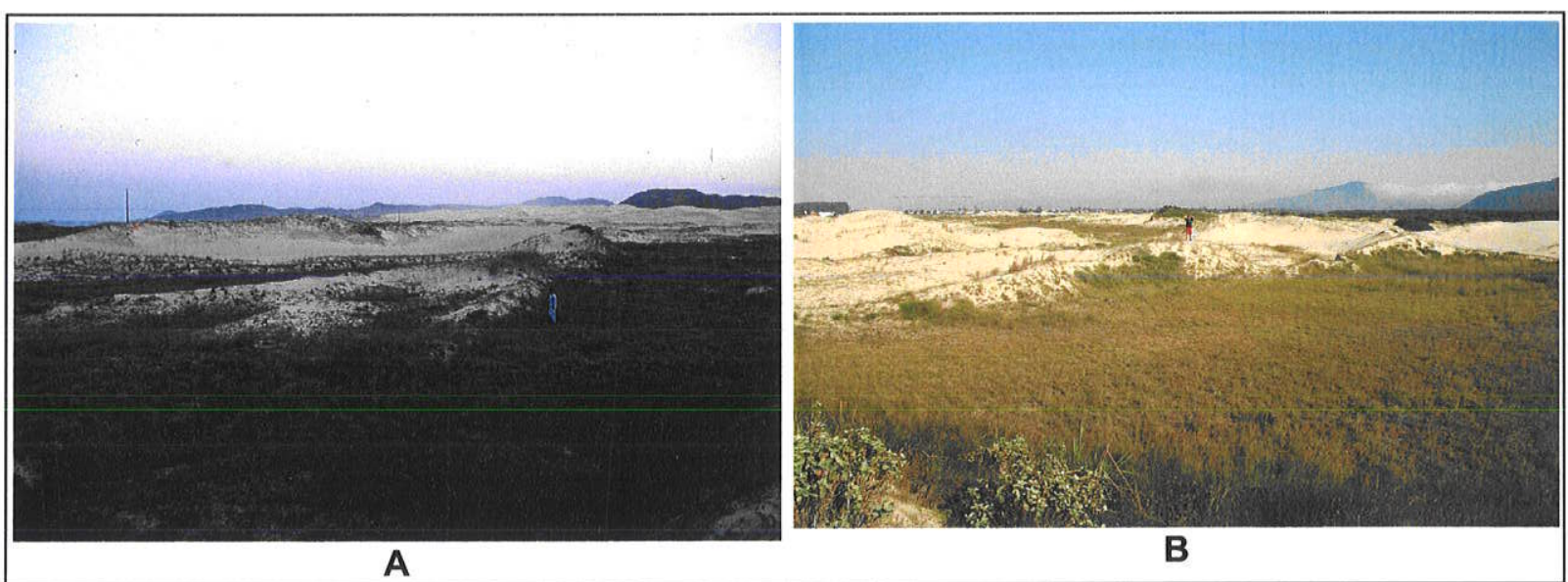

Figura 3.37. Exemplos de dunas parabólicas ativas junto a campos de dunas da Região Sul-Sudeste. A. Ibiraqüera (Imbituba), SC. B. Parte nordeste da ilha Comprida, SP. Em ambas as fotos, o rumo de migração é diagonal, para a direita superior (SW em A, NNW em B). 
Rastros lineares residuais representam os braços alongados de dunas parabólicas ou das terminações de dunas barcanas e cadeias barcanóides parabolizados de campos de dunas móveis, que são deixados para trás, pela fixação da vegetação, à medida que a duna ou campo de dunas migra. Possuem direção longitudinal ao vento efetivo e, enquanto ativos, caracterizam-se por apresentar face externa com vegetação, com caráter deposicional, e face interna sem vegetação, com caráter erosivo. Com a estabilização, tendem a ter o topo aplainado e a ser inteiramente cobertos pela vegetação.

Em campos de dunas móveis, a parabolização na parte terminal de cristas de dunas barcanas ou cadeias barcanóides, responsável pela formação dos rastros lineares, pode ser atribuída à retenção de areia pela vegetação e à escassez de sedimentos na área deflacionar. Exemplos podem ser encontrados nos campos de dunas de Ibiraqüera (Imbituba), SC, Cajueiro da Praia, Luís Correia, Morro da Mariana, PI, e Baía do Caju, MA (Figura 3.38).

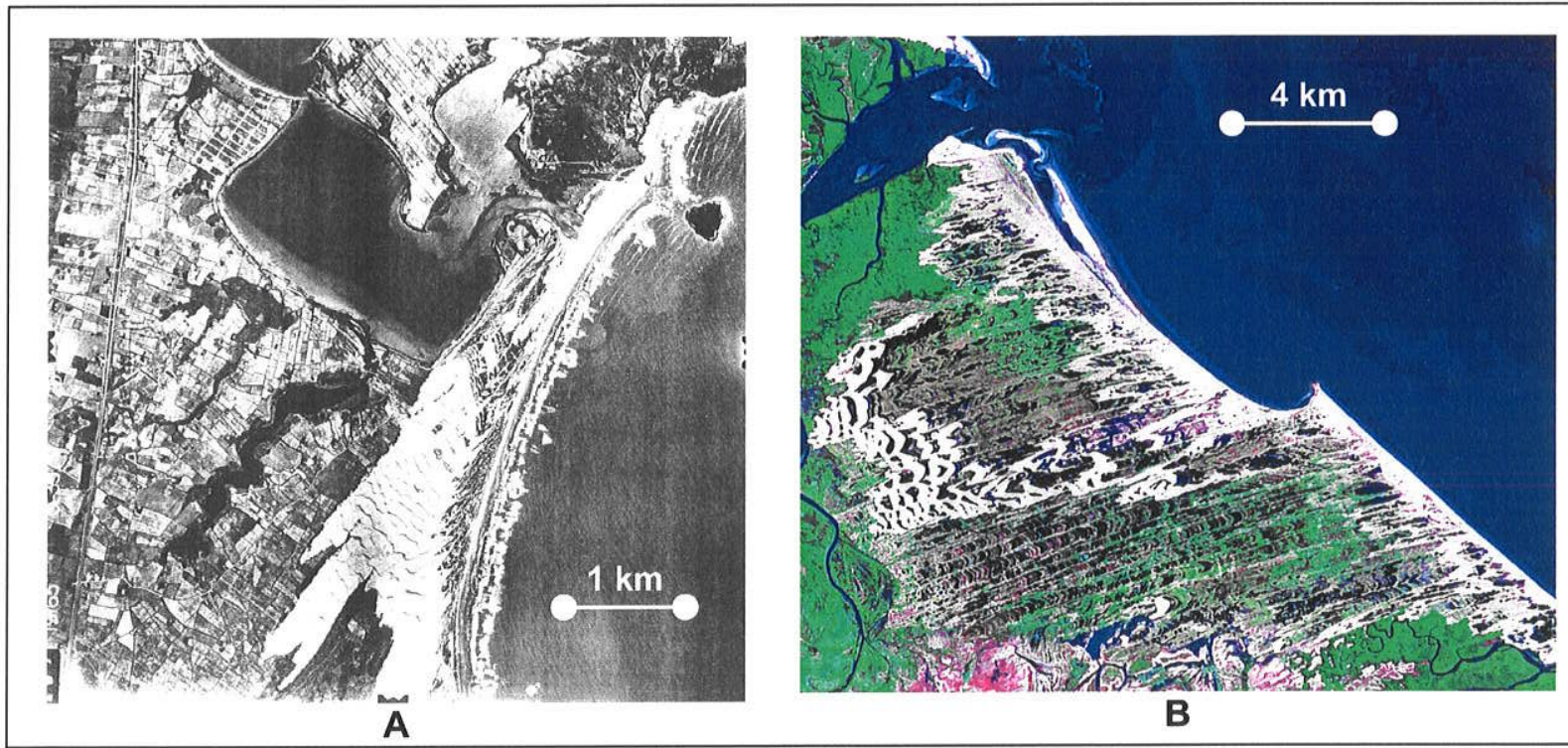

Figura 3.38. Campos de dunas com desenvolvimento de planície de deflação formada por rastros lineares residuais, longitudinais ao vento efetivo, e retrocordões, transversais. A. Praia de Ibiraqüera (Imbituba), SC. B. Praias de Pedra do Sal e Porto dos Tatus (Morro da Mariana), PI.

Em Ibiraqüera, onde o aporte ao longo da praia e o campo de dunas são assimétricos (item 3.2.2), a parabolização e o desenvolvimento de rastros lineares são mais conspícuos nas áreas de menor suprimento, situados na parte sul da praia (Martinho \& Giannini 2002, Martinho et al. 2007). Nesse campo de dunas, trincheiras foram abertas nas porções proximal e distal, em relação à área fonte praial, de um mesmo rastro linear. Em ambas as porções, pôde-se observar duas séries de estratificações cruzadas (Figuras 3.39 e 3.40). A série inferior, formada por estratificações ligeiramente acanaladas, mergulha de modo concordante à face externa do rastro linear, representando portanto depósitos de braço de parábola. A série superior, formada por estratificações planares, com ângulo de mergulho mais tênue, fitoturbadas, representa os depósitos do topo sub-horizontal e vegetado do rastro linear. O empilhamento encontrado é sugestivo do processo de estabilização por vegetação que deve caracterizar a formação de um rastro linear a partir de um braço de duna parabólica. Na parte proximal do rastro linear, o diâmetro médio dos sedimentos é mais grosso (até areia média) e a seleção pior (até 0,75 phi) na série inferior que na superior. $\mathrm{Na}$ 
porção distal, o sedimento torna-se mais fino e bem selecionado e a diferença granulométrica entre as duas séries diminui (Martinho 2004).

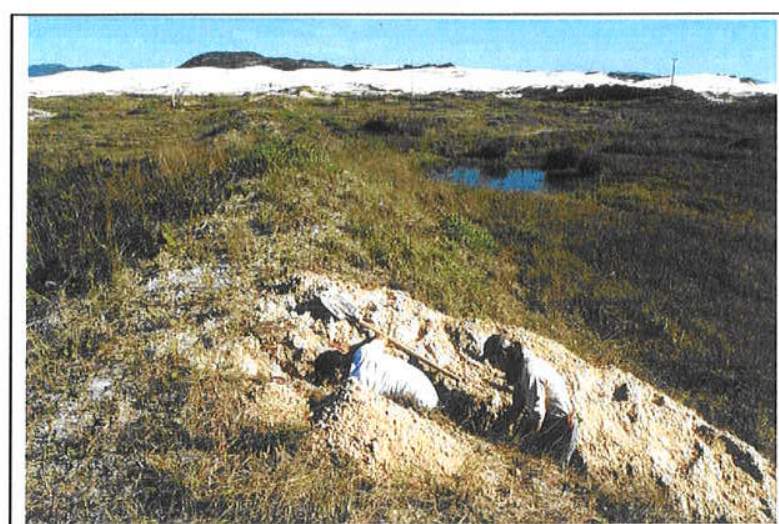

A

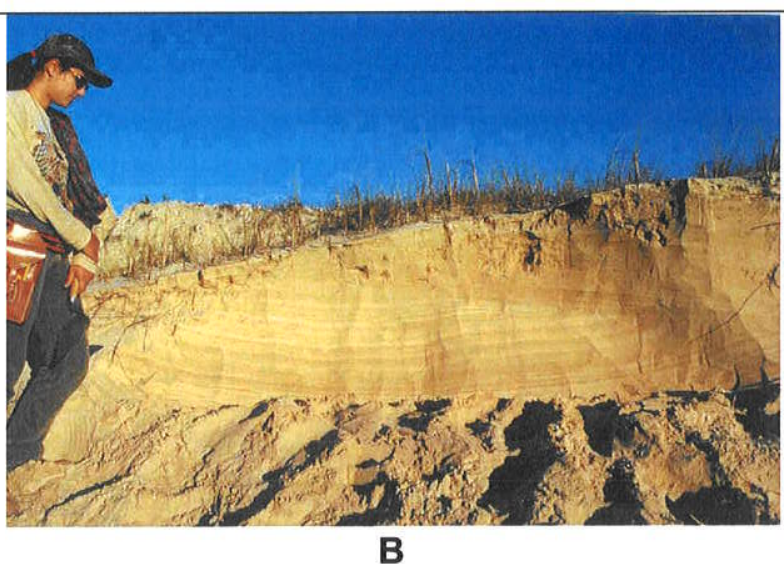

B

Figura 3.39. Elemento morfológico de rastro linear associado ao campo de dunas de Ibiraqüera (Imbituba), SC. A. Aspecto geral, destacando, em primeiro plano, o trabalho de abertura de trincheira na parte proximal. B. Corte longitudinal ao rastro, na sua parte distal. Observar truncamento de série de estratificações cruzadas acanaladas por cruzadas aparentemente planares.

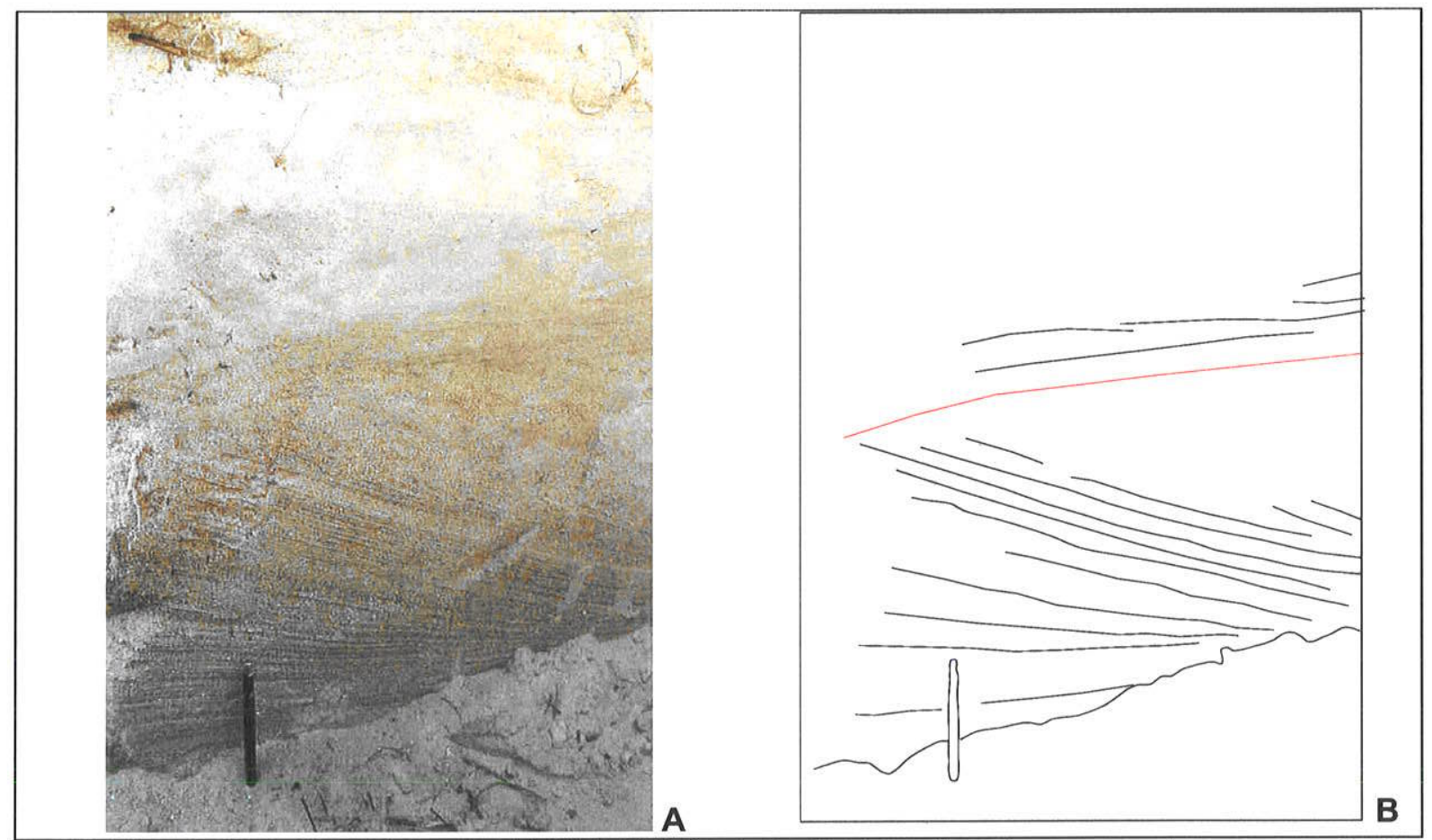

Figura 3.40. Fotografia (A) e reconstituição $(B)$ das estruturas sedimentares expostas em parede de trincheira, corte transversal, aberta na parte proximal de rastro linear associado ao campo de dunas de Ibiraqüera (Imbituba), SC. A fácies inferior é ai mais grossa e pior selecionada que a superior (Martinho 2004). 
O termo retrocordão (Giannini et al. 2005) foi sugerido como equivalente de gegenwalle (em alemão, literalmente, acumulação contrária), introduzido por Paul (1944) para designar cordões de areia depositada por ventos reversos, em meio à vegetação da planície deflacionar, na margem barlavento de campos de dunas móveis (Figuras 3.38A e 3.41). Deixados sucessivamente para trás, à medida que o campo de dunas migra para o interior, exibem geometria em planta subconcordante com o lado barlavento das barcanas e barcanóides que compõem o campo de dunas. Os exemplares mais conspícuos de retrocordões encontram-se em planícies interdunares sazonalmente inundadas, como as dos campos de dunas costeiros do Piauí e do Maranhão, ou a da retaguarda de megabarcanas isoladas em Jericoacoara e Camocim, no Ceará. O melhor desenvolvimento de retrocordões sob condições de inundação recorrente permite sugerir que a ação de ventos reversos seja prescindivel na formação deste elemento morfológico. A umidade associada ao nível freático ligeiramente sobrelevado no lado barlavento da duna, e, num segundo momento, a colonização por vegetação, seriam os fatores essenciais. Sob este aspecto, os retrocordões têm origem e evolução similares a de dunas frontais, podendo apresentar feições de remodelagem como rupturas de deflação e dunas de sombra (Giannini et al. 2005).

Nas trincheiras abertas em retrocordões de planície deflacionar na costa catarinense, os sedimentos específicos desta elemento morfológico restringem-se a fácies deposicional mais superficial, com $0,2 \mathrm{~m}$ de espessura, caracterizada por areias de cor marrom, devida à impregnação por matéria orgânica coloidal (Figura 3.42). A estratificação apresenta mergulhos sub-horizontais e truncamentos suaves ligados a variações de até $160^{\circ}$ no rumo de mergulho (Martinho 2004). A presença de matéria orgânica e a grande variação no azimute de merguho, com preservação tanto de séries frontais (foreset) como de dorsais (backset) de dunas de sombra, são evidências da baixa mobilidade da feição, ligada à influência da vegetação e da umidade. A fácies encontrada abaixo, constituída por areias esbranquiçadas bem selecionadas, ligeiramente menos finas, com séries decimétricas de estratificações cruzadas de alto ângulo $\left(20^{\circ}\right.$ a $\left.30^{\circ}\right)$, é relíctica da passagem de cadeias barcanóides.

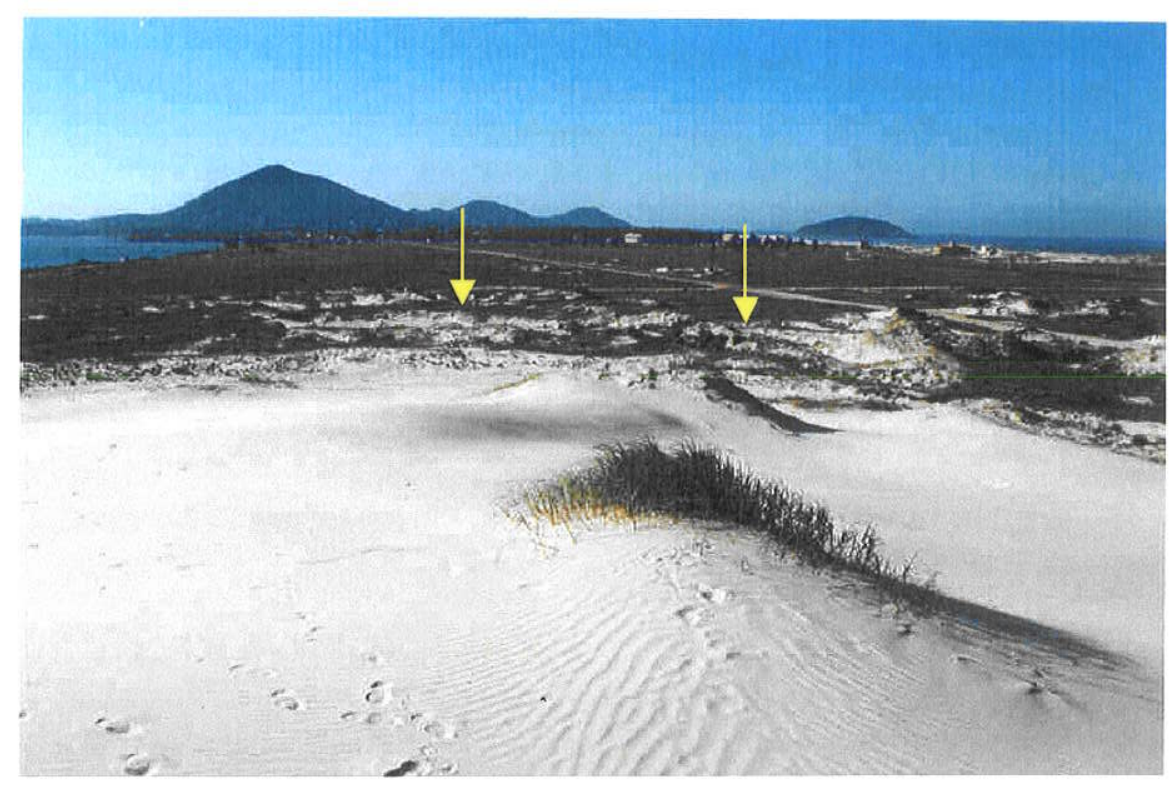

Figura 3.41. Elemento morfológico retrocordão, em Ibiraqüera (Imbituba), SC. 


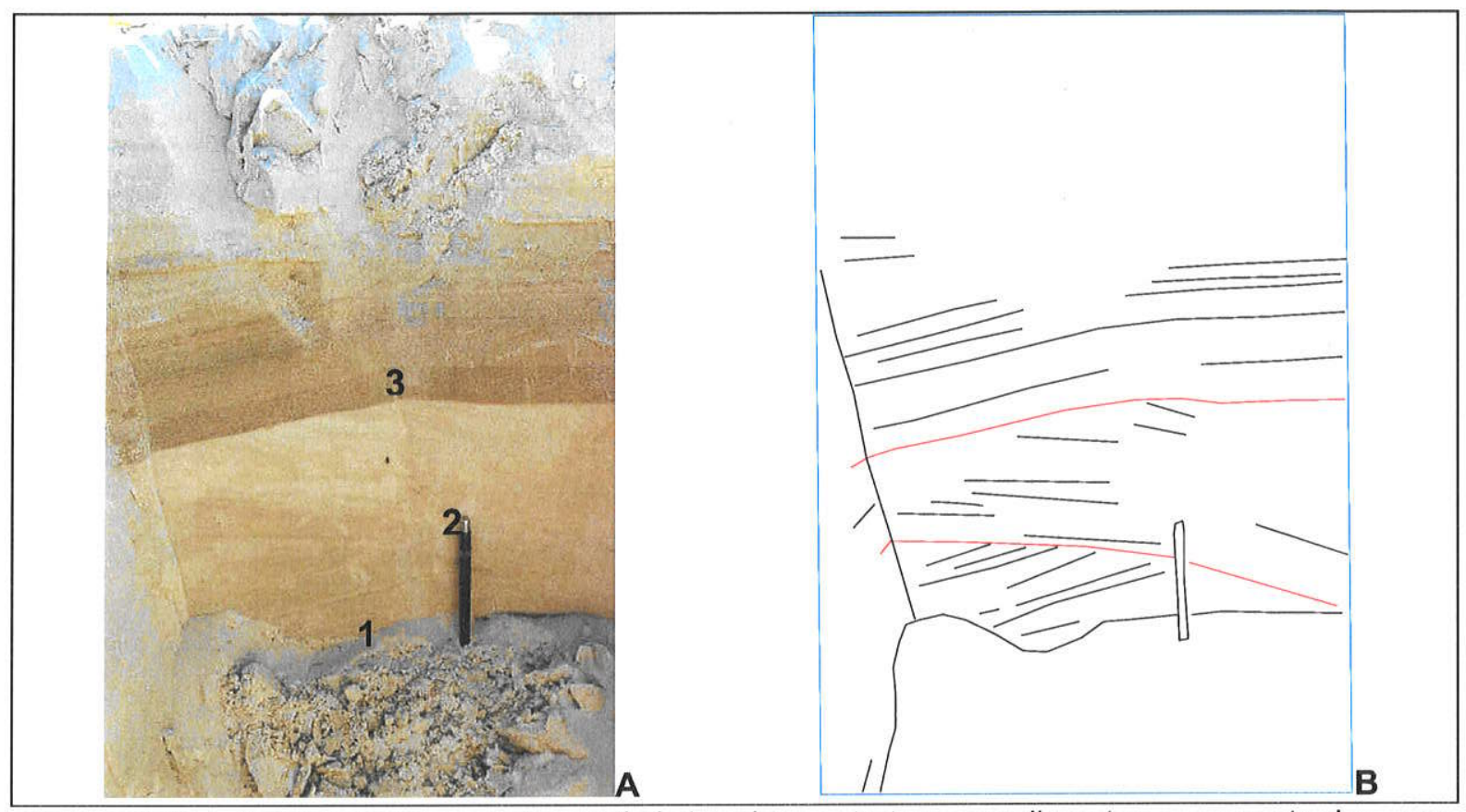

Figura 3.42. Fotomontagem e reconstituição das estruturas sedimentares encontradas em retrocordão, em Ibiraqüera (Imbituba), SC. Três séries de estratificações cruzadas (1, 2 e 3) podem ser observadas. As linhas vermelhas ilustram superfícies de terceira ordem. Apenas a série 3 é fácies deposicional de retrocordão, sendo as séries inferiores atribuídas a cadeias barcanóides.

\section{Nebkhas}

O termo de origem árabe nebkhas foi introduzido por Killian (1945 apud Tenberg 1994), para referir-se a montículos de areia formados por deposição eólica em meio à vegetação. Dunas de sombra (shadow dunes) são variedades de nebkhas com cauda alongada no sentido do vento, induzidas pelo obstáculo exercido pela vegetação (Giannini et al. 2005) e/ou pelo próprio nebkha inicial (Martinho et al. 2007). Os nebkhas maiores e mais complexos podem experimentar variações sazonais no grau de assimetria, de acordo com mudanças na velocidade e orientação do vento. Alternam assim fases de erosão a barlavento e desenvolvimento de dunas de sombra a sotavento, com períodos de reconstrução ou acreção lateral (P.A. Hesp, comunicação pessoal).

Os nebkhas da costa brasileira, com alturas tipicamente submétricas, associam-se a planícies interdunas úmidas ou inundáveis de campos de dunas móveis ou a retrabalhamento eólico de terraços de dunas frontais incipientes, em áreas de relação constante entre taxa de progradação e taxa de suprimento eólico (Figura 3.43).

Nas trincheiras estudadas em campos de dunas móveis em Jaguaruna (Figura 3.44), o elemento deposicional, com espessura decimétrica, é composto por séries delgadas (centimétricas) lenticulares de estratificações cruzadas de baixo ângulo com grande dispersão no azimute de mergulho. Esta geometria é típica de formas de leito eólicas discretas e baixas, fixadas pela vegetação, com preservação tanto de estratos frontais como de dorsais. Este elemento deposicional ocorre sobre camada sub-horizontal encharcada, de coloração mais escura, mosqueada e com estruturas sindeposicionais pouco aparentes, com maior porcentagem de areia média e de pelíticos, interpretada como fácies de inundação da planície interdunas. 


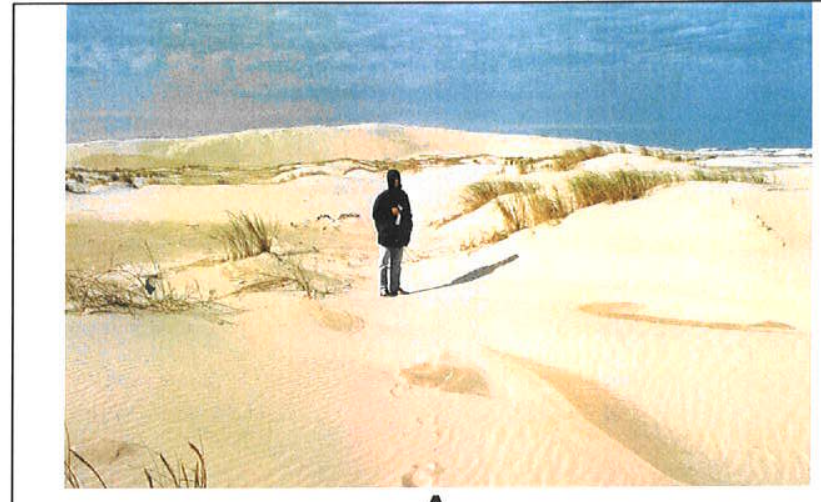

A

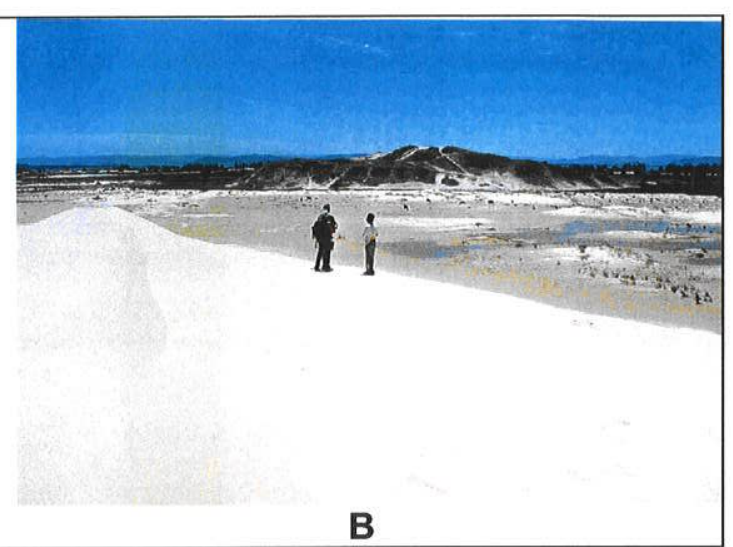

B

Figura 3.43. Dois modos de ocorrência de nebkhas junto ao campo de dunas da praia Grande do Sul, próximo à vila de Garopaba do Sul (Jaguaruna), SC. A. Em planície interdunas. B. Na margem interna, ao interior de dunas transversais (ao fundo, sambaqui de Garopaba do Sul).

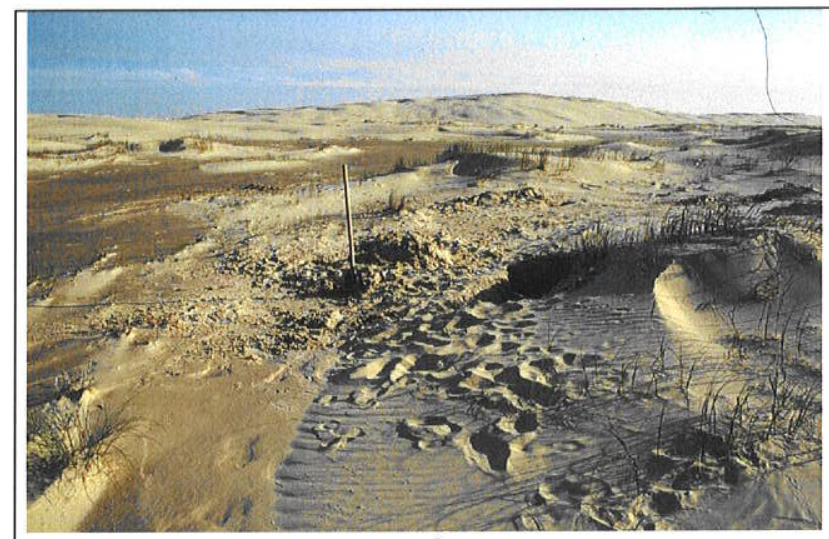

A

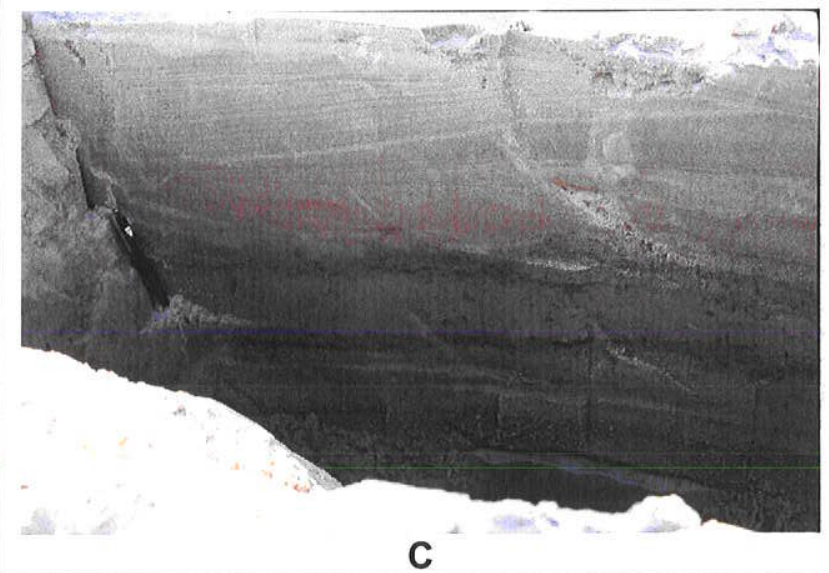

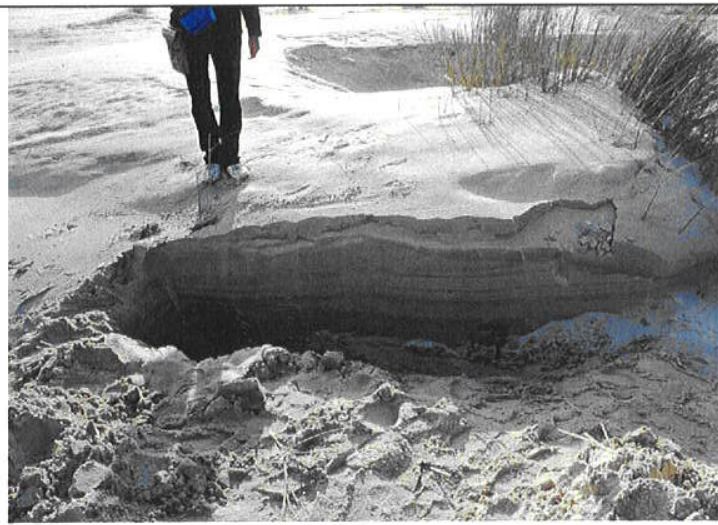

B

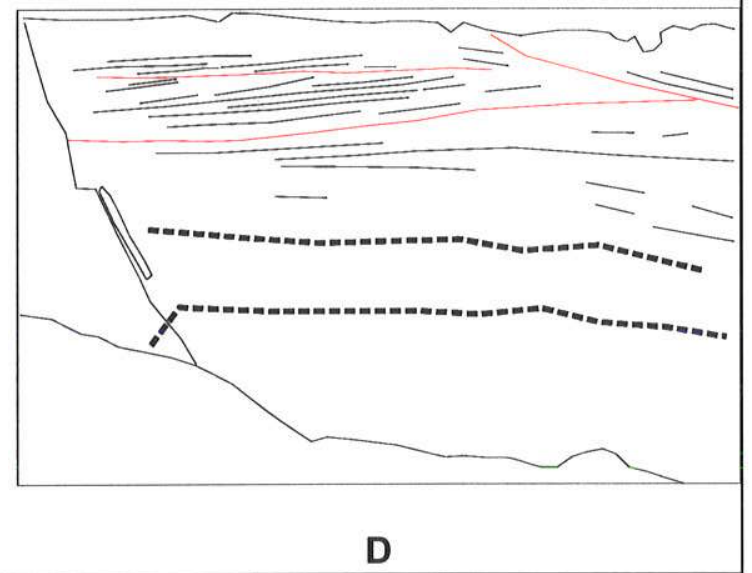

Figura 3.44. Morfologia e registro deposicional de nebkhas da planície interdunas, no campo de dunas da praia Grande do Sul, Garopaba do Sul (Jaguaruna), SC. A, B. Contexto e aspecto geral da trincheira de estudo. C, D. Fotografia e reconstituição das estruturas sedimentares expostas na trincheira. A camada inferior caracteriza-se por estratificação sub-horizontal alternando níveis claros e escuros (destacados com traços pretos no desenho), ambos mosqueados e sem estrutura interna aparente. A camada superior apresenta estratificações cruzadas de ângulo baixo truncadas por superfícies de terceira ordem (linhas em vermelho). Apenas esta camada superior representa depósitos do próprio nebkha. 
Planícies interdunas são áreas aproximadamente planas situadas entre dunas, comumente transversais ou barcanóides, onde a deflação predomina sobre a deposição eólica e onde os processos deposicionais não eólicos são tão ou mais atuantes que os eólicos (Figura 3.45). Caracterizam-se por apresentar areias coesivas durante maior parte do tempo, devido a umidade ou alagamentos periódicos, e vegetação pioneira esparsa. A periodicidade dos alagamentos pode ser sazonal, ligada à elevação do nível freático na estação chuvosa, ou irregular, por influência por marés de tempestade. A deposição eólica dá-se de dois modos possíveis: durante os períodos de incoesão do substrato, através da migração e cavalgamento de ôndulas, sob ação de ventos relativamente fracos; e durante os períodos, dominantes, de substrato coesivo, através de areias incoesas trazidas das dunas, via carpetes de tração, por ventos de alta velocidade. São comuns estruturas de adesão na superfície (Figuras 3.46A) e presença de nebkhas.

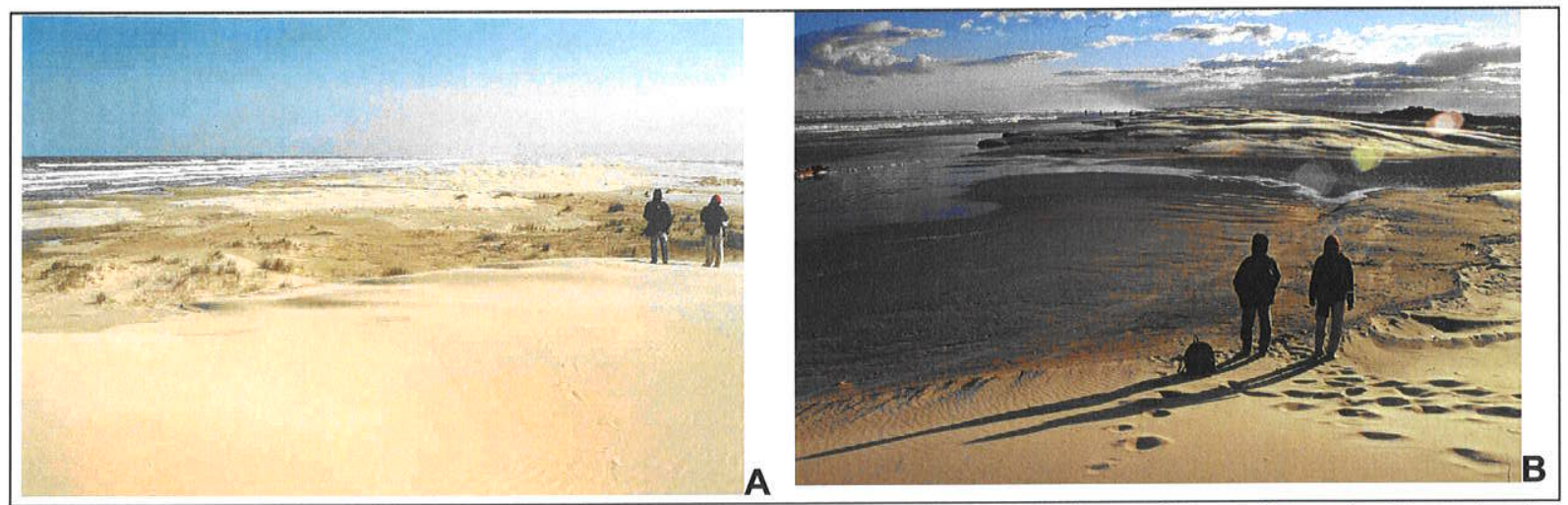

Figura 3.45. Planície interdunas úmida (A) e alagada (B). Campo de dunas livres da praia Grande do Sul (Jaguaruna), SC.

Ao exame via trincheira de exemplos na costa catarinense (Figura 3.46B), observa-se o predomínio de areias finas muito bem selecionadas e estruturas internas monótonas, dominadas por estratificações plano-paralelas sub-horizontais. Localmente, observa-se sobreposição das estratificações plano-paralelas por séries decimétricas de estratificações cruzadas de dunas transversais, por sua vez truncadas pela superfície da planície interdunas atual (Figura $3.46 \mathrm{C}, \mathrm{D})$. 


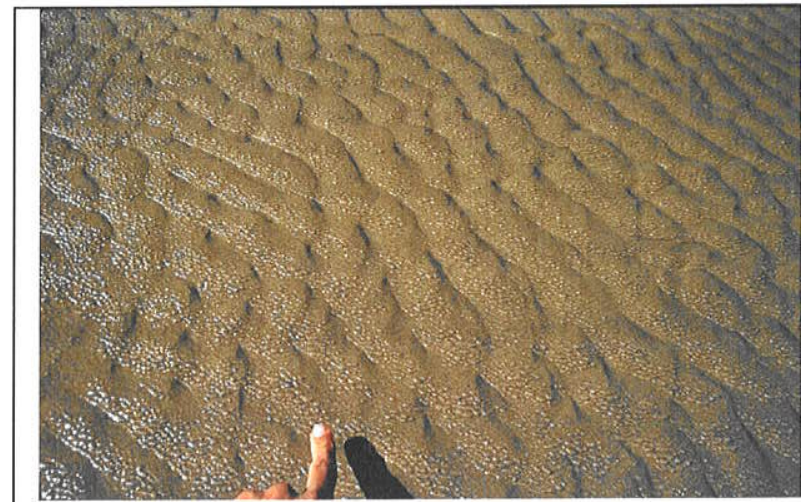

A

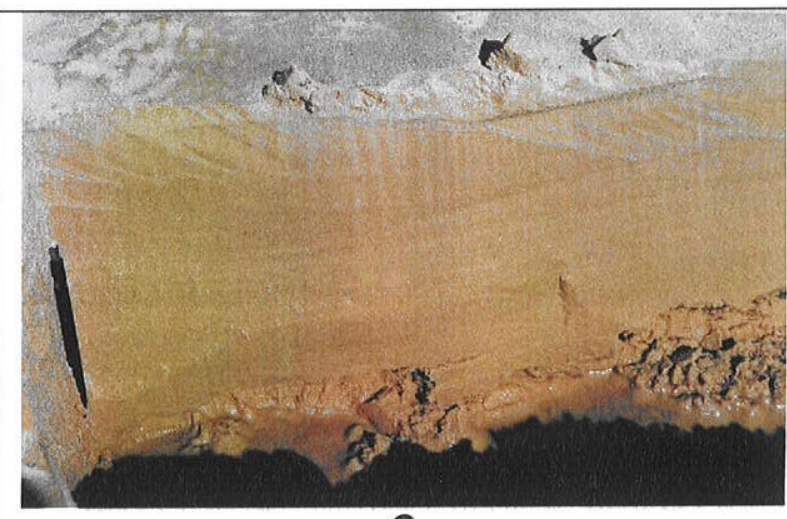

C

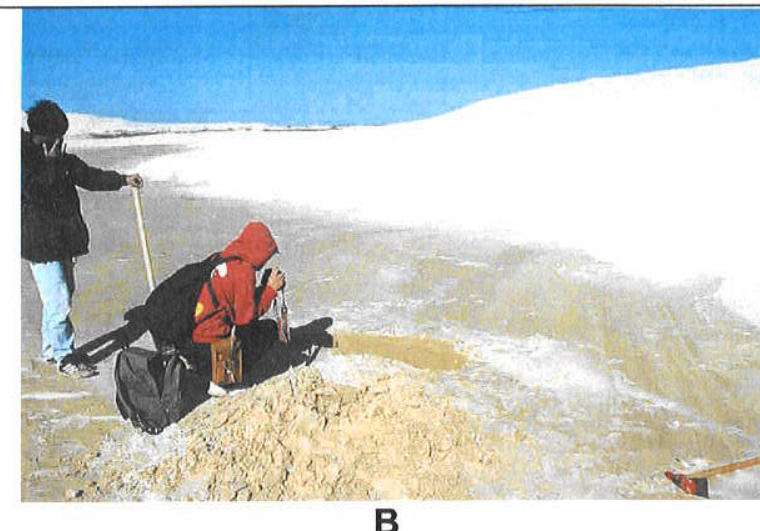

B

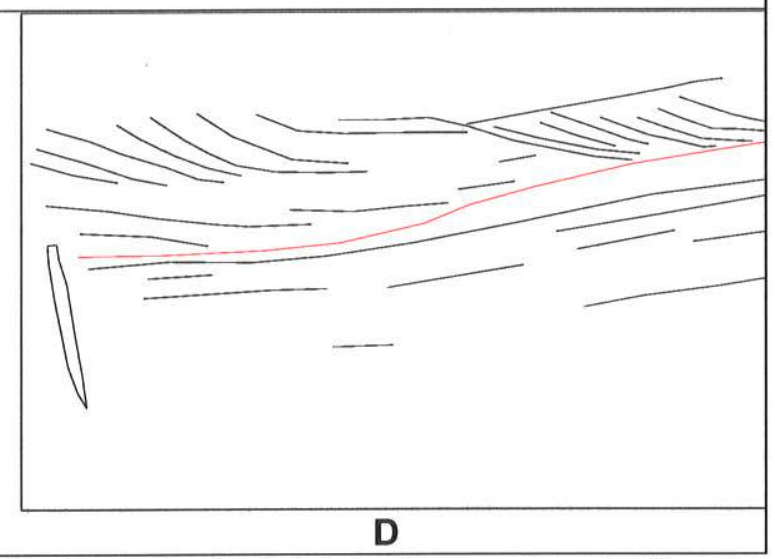

Figura 3.46. Aspectos morfológicos e deposicionais do elemento planície interdunas, na praia Grande do Sul (Jaguaruna), SC. A. Õndulas subaquosas, com superimposição de marcas de adesão. B. Abertura de trincheira de estudo. C e D. Fotografia e reconstituição das estruturas sedimentares expostas na trincheira. Observam-se séries lenticulares de estratificações cruzadas tangenciais na base, atribuídas a pé de dunas transversais, sobre estratificações plano-paralelas ligeiramente onduladas, típicas de deposição em interdunas.

\section{Montes residuais (remnant knobs)}

Montes residuais são morrotes de areia assimétricos, parcialmente vegetados, que ocorrem em meio ao campo de dunas. Representam porções remanescentes de um depósito eólico que sofreu erosão diferencial. Seu flanco sotavento é densamente vegetado, com sinais de deposição de areia em meio à vegetação, enquanto o barlavento tem aspecto predominantemente erosivo. Semeniuk et al. (1989) utilizam o termo de modo abrangente, incluindo as ocorrências em meio a planícies de deflação, para as quais aqui se prefere o termo nebkha.

Observado à distância a partir do lado barlavento, este elemento apresenta predomínio de estratificações cruzadas sub-horizontais (Figuras 3.47 ). Em escala de maior detalhe (centimétrica), encontram-se truncamentos entrelaçados (Figura 3.48 ), associados a laminações cruzadas internas que mergulham contra o vento principal. A grande dispersão (cerca de $180^{\circ}$ ) das medidas de azimute de mergulho das estratificações (Martinho 2004) deve-se a superfícies irregulares e cavas de deflação decimétricas produzidas pelo vento em torno das plantas, bem como à possibilidade de deposição e preservação de estratificações cruzadas dorsais devido à retenção e proteção da areia pela vegetação. 


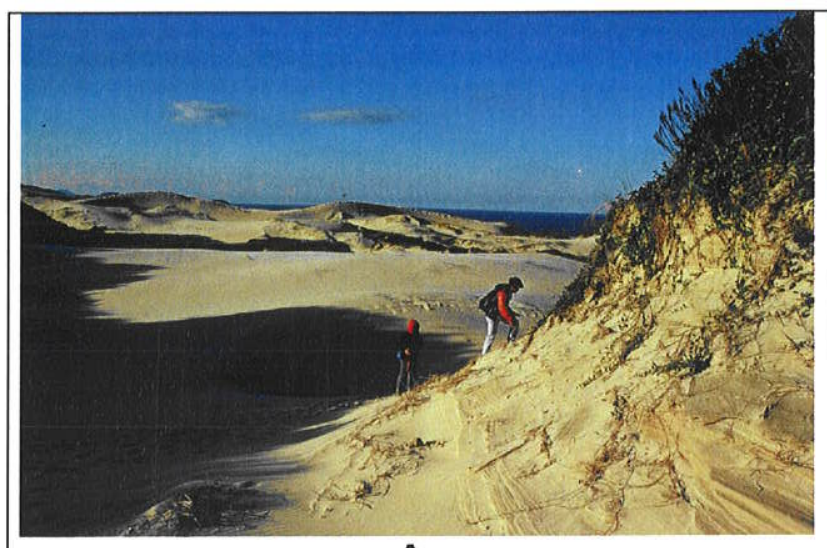

A

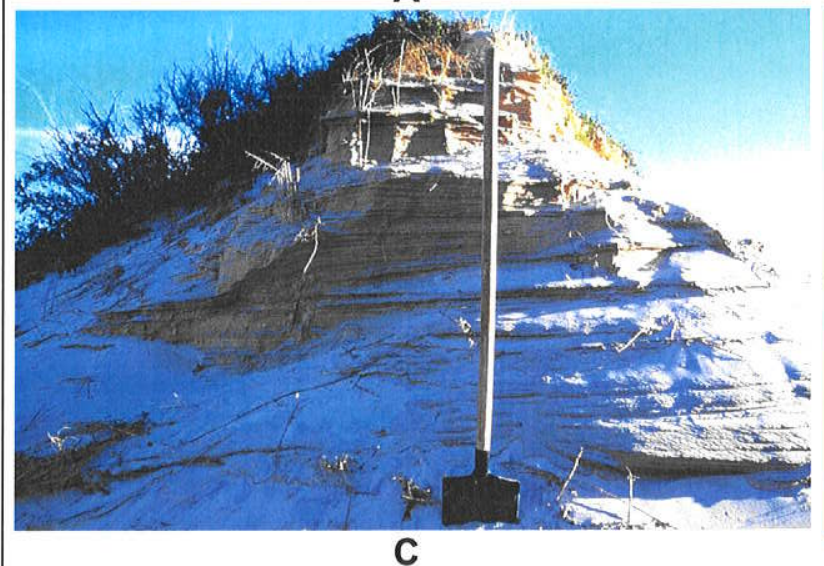

Figura 3.47. Morfologia e estrturação geral do elemento monte residual em Ibiraqüera (Imbituba), SC. A. Contexto de ocorrência: antigo cordão de precipitação sobreposto por cadeias barcanóides (visíveis ao fundo). B. Erosão e exposição de estruturas sedimentares internas no lado barlavento. C, D. Fotografia e reconstituição das estratificações sub-horizontais expostas no flanco barlavento.

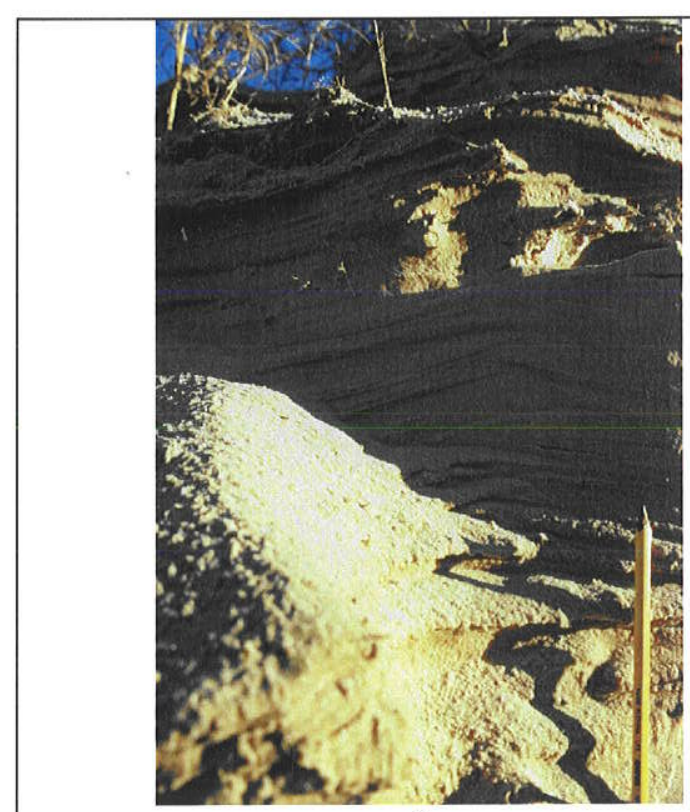

A

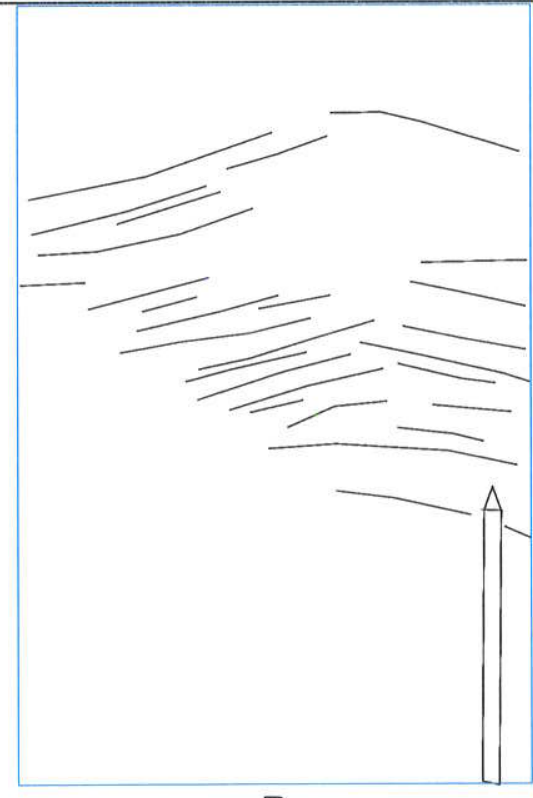

B

Figura 3.48. Detalhe de truncamentos sucessivos, em padrão entrelaçado, em corte natural no lado barlavento de monte residual em Ibiraqüera (Imbituba), SC. 
Cordões de precipitação são pilhas cônicas alongadas (Figura $3.49 \mathrm{~A}$ a D) formadas pela areia que cai (precipita) de vários metros de altura em meio à vegetação, ao longo das margens laterais e, às vezes, frontais, de campos de dunas livres. Estas areias podem provir diretamente de dunas transversais e cadeias barcanóides ou de lobos deposicionais coalescidos de dunas parabólicas. A geometria é tipicamente assimétrica, com mais vegetação e declive mais íngremes na face externa, deposicional, que na face interna, dominantemente erosiva (Hesp \& Thom 1990).

Cordões de precipitação ocorrem ao longo de toda a margem sotavento de campos de dunas, sob baixa taxa de aporte eólico. Com o aumento desta taxa, porém, tendem à interrupção localizada por lobos sem vegetação, curtos e fortemente inclinados a favor do vento, aqui denominados lobos de precipitação. Com aumento ainda maior da taxa de aporte eólico, dão lugar, na parte frontal, a lobos deposicionais sem vegetação alongados, e passam assim a ocorrer preferencial ou exclusivamente nas margens laterais do campo de dunas. Considerando que a presença de vegetação é fator de desaceleração no movimento das areias, os cordões de precipitação laterais desempenham o papel de diques marginais ou ombreiras de contenção na dinâmica de sistemas eólicos costeiros.

Em campos de dunas oblíquos ou paralelos à costa, os cordões de precipitação são assimétricos na distribuição, com maior desenvolvimento na margem mais voltada para o continente, o que pode ser atribuído ao maior porte e capacidade retentora da vegetação e à maior incoesão das areias nas áreas mais afastadas da costa. Nestes casos, o grau de sinuosidade da crista nas margens laterais depende da presença e do porte de frentes secundárias de avanço (Figura $3.49 \mathrm{~A}$ e $\mathrm{B}$ ), orientadas transversalmente ao rumo de migração principal do campo de dunas (Giannini 1993). Estas frentes secindárias correspondem a lobos de precipitação antigos (com vegetação) ou ativos. Durante a migração sucessiva do cordão para o interior, cristas com vegetação podem ser abandonadas no interior do campo de dunas, dando origem a montes residuais (Figura 3.47). Ainda no caso de campo de dunas subparalelo à costa, o cordão de precipitação aumenta de altura com a distância ao longo da direção principal de avanço do campo de dunas. Freqüentemente, como no campo de dunas da praia Grande do Sul (Jaguaruna), SC torna-se feição expressiva apenas a vários quilômetros da praia. Isto permite aventar que o cordão de precipitação, a exemplo de outros depósitos eólicos com face de avalancha (Kroy et al. 2002), possua uma altura mínima de formação.

Os sedimentos da face externa do cordão de precipitação apresentam tendência ascendente para afinamento e piora de seleção (Martinho 2004), o que estaria possivelmente ligado ao aumento da importância de processos de queda de grãos em relação a fluxo de grãos.

A fácies deposicional caracteriza-se por estratificações cruzadas planares monótonas, em séries espessas (métricas, pelo menos). A orientação das estratificações, coincide com a face mais vegetada do cordão. As lâminas possuem irregularidades e corrugações de dimensões até centimétricas, que são atribuídas à deformação ligada à agitação mecânica da vegetação. A possibilidade de acentuação da laminação por concentração de minerais pesados (Figura 3.49E e F) está possivelmenre relacionada ao caráter de contenção deste elemento morfológico, com retenção preferencial de grãos mais densos durante a ação de ventos mais fortes. 


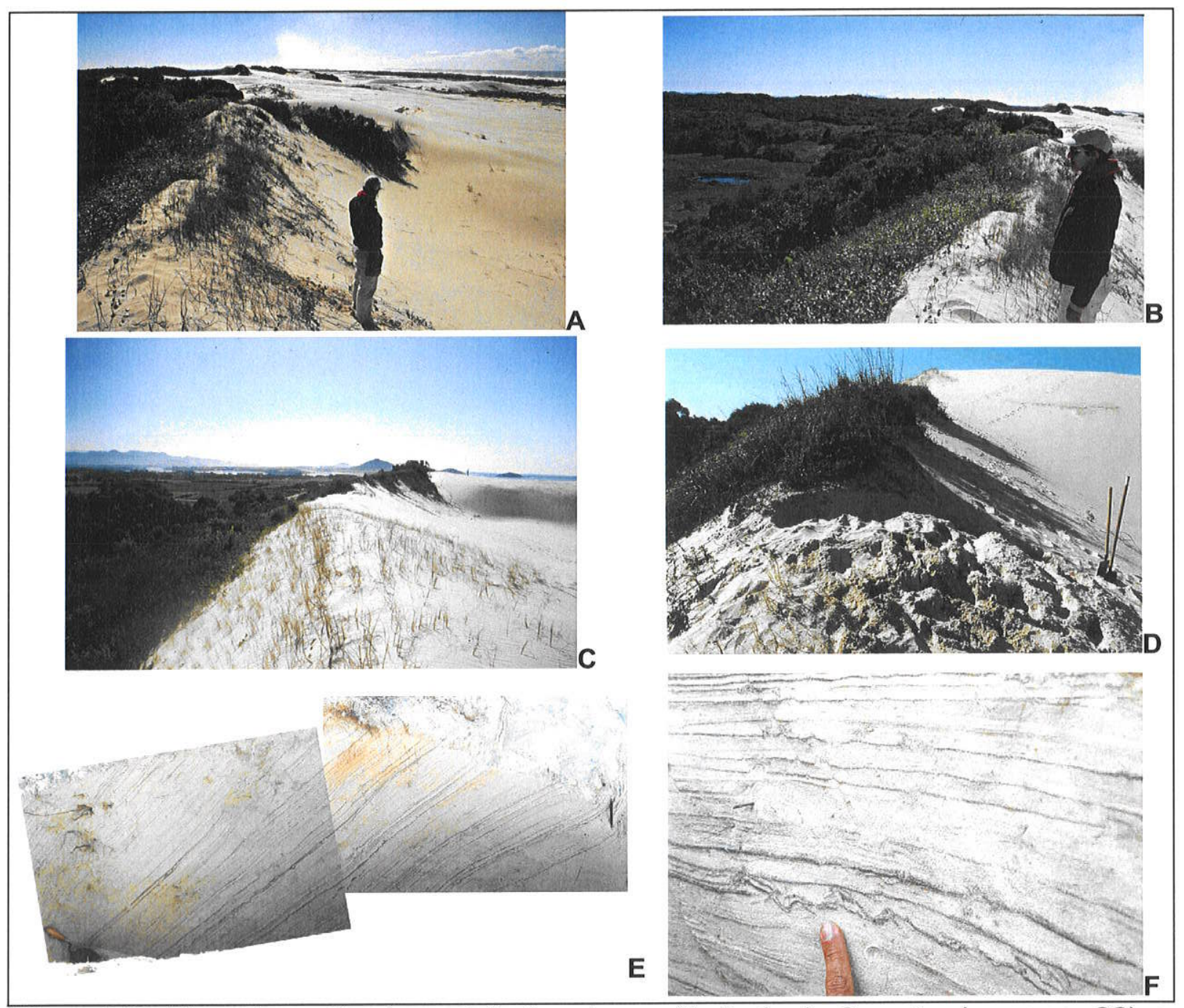

Figura 3.49. Elemento cordão de precipitação, sinuoso (A, B: Arroio Corrente, Jaguaruna, SC) e retilíneo (C, D, E, F: Ibiraqüera, Imbituba, SC). A,B,C. Aspectos gerais. D. Trincheira de estudo. E, F. Estratificações cruzadas de ângulo alto (maior que $20^{\circ}$ ), ressaltadas por minerais pesados escuros, expostas em trincheira. Em F, destacam-se estruturas deformacionais, atribuídas à agitação de plantas pelo vento.

\subsubsection{Elementos morfológicos sem vegetação}

Os elementos sem influência da vegetação incluem sete tipos principais, listados a seguir na ordem proximal-distal.

\section{Franjas de areia eólica}

O termo franja de areia eólica é introduzido nesta Tese para referir-se a sedimentos incoesos, desvegetados, acumulados pelo vento, sob a forma de lençol ou rampa de espessura até decimétrica, aos pés das dunas frontais ou das escarpas costeiras (Figura 3.50). As franjas de areia eólica, uma vez colonizadas por vegetação, dão lugar a dunas frontais incipientes do tipo terraço ou rampa. Sob aporte eólico elevado, podem evoluir para 
protodunas. Por sua posição no sistema deposicional, este é o elemento eólico mais influenciado pela inundação por ondas e marés. A forma em rampa é tipicamente associada ao retrabalhamento, pelo vento, de leques subaquosos de pé de escarpa (Figura 3.50B).

O elemento deposicional é caracterizado por séries decimétricas a centimétricas de estratificações plano-paralelas, com mergulho baixo (tipicamente menor que $5^{\circ}$ ), para o mar ou para o continente, este último caso mais comum sobre bermas de praias intermediáriasreflexivas (Figura 3.50C). Acentuação das laminações por concentrações de minerais pesados escuros e convoluções produzidas por fluidificação são feições comuns. Repousa tipicamente sobre séries cuneiformes de estratificações plano-paralelas, com mergulho baixo (até $15^{\circ}$ ) para o mar, relacionadas a espraiamento de ondas pulsáteis na face de praia.
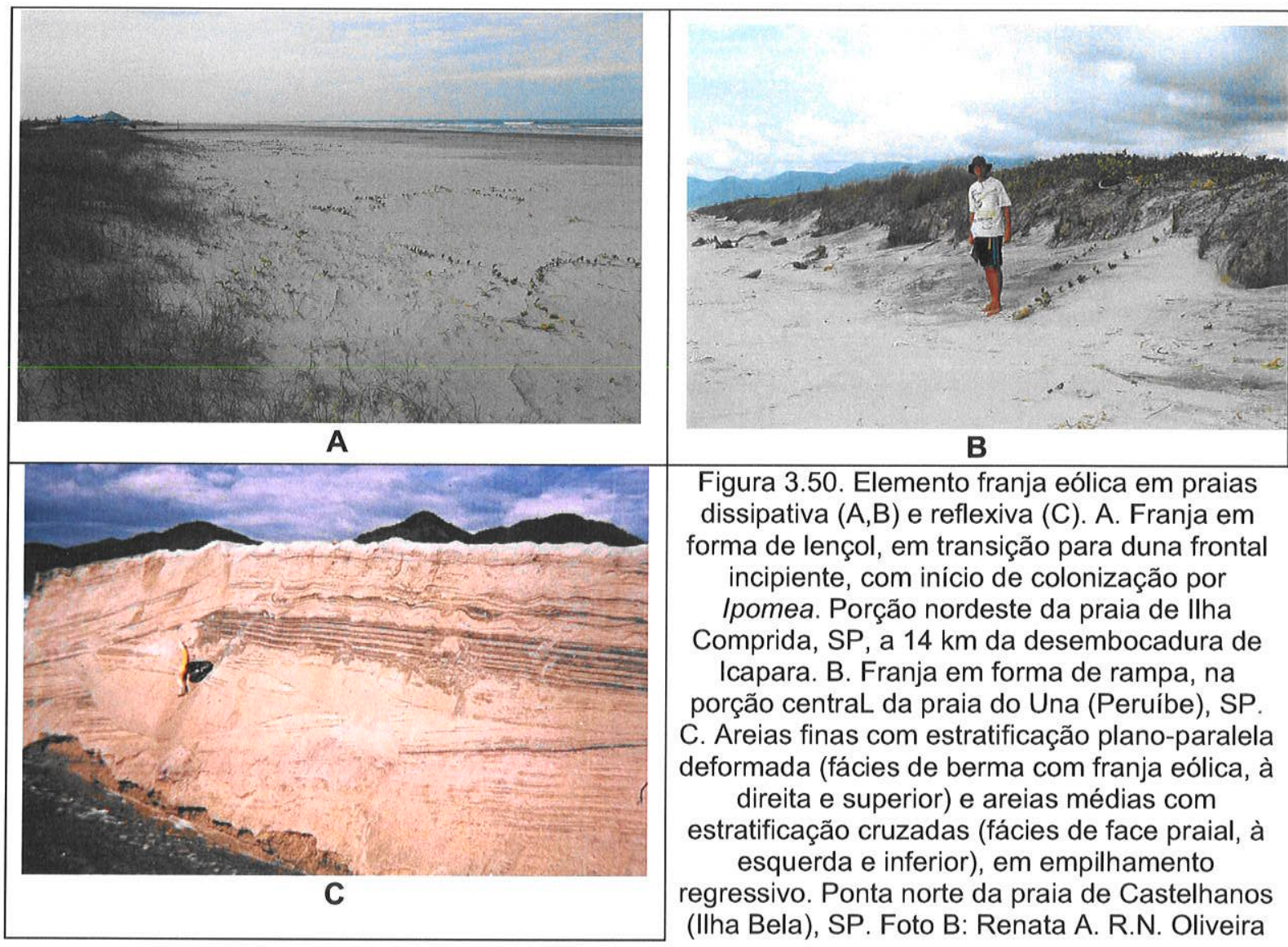

Figura 3.50. Elemento franja eólica em praias dissipativa $(A, B)$ e reflexiva (C). A. Franja em forma de lençol, em transição para duna frontal incipiente, com início de colonização por Ipomea. Porção nordeste da praia de llha Comprida, SP, a $14 \mathrm{~km}$ da desembocadura de Icapara. B. Franja em forma de rampa, na porção centraL da praia do Una (Peruíbe), SP. C. Areias finas com estratificação plano-paralela deformada (fácies de berma com franja eólica, à direita e superior) e areias médias com estratificação cruzadas (fácies de face praial, à esquerda e inferior), em empilhamento regressivo. Ponta norte da praia de Castelhanos (Ilha Bela), SP. Foto B: Renata A. R.N. Oliveira

Protodunas

Protodunas são formas de leito eólicas com até poucos metros de altura, sem face de avalancha ou slipface (Kocurek et al. 1992), de geometria dômica ou orientadas transversalmente ao vento efetivo. O termo guarda correspondências com as "ondulações espaçadas de 30 a $40 \mathrm{~cm}$ e sujeitas a crescimento posterior" observadas por Hunter (1977) sob ventos costeiros fortes (mais de $60 \mathrm{~km} / \mathrm{h}$ ). Equivale também às "megaondulações" (megaripples) de Taira \& Scholle (1979) e aos "montes" (heaps) de Kroy et al. (2002). Formam-se quando a desaceleração na frente da forma de leito dá-se apenas por aumento de espaçamento e desvio, sem separação, de linhas de fluxo (Kocurek et al. 1992, Kroy et al. 2002). São comumente marcadas por microondulações eólicas típicas (ôndulas de areia aplainadas de cristas bifurcadas e cordões de grânulos), com índice comprimento/altura (ripple index) maior na face barlavento que na sotavento. 
Podem ser especialmente bem desenvolvidas e atingir alturas métricas junto a lençóis de areia e/ou nas bordas de ergs (Schwan 1988, Lancaster 1995), onde, na presença de sedimentos grossos (até grânulos) transportados por rolamento, recebem a denominação de zibars. Cordões de grânulos e protodunas referem-se aparentemente a um mesmo gênero de formas de leito de granulação mista, em que os grãos mais grossos se concentram na crista, simétrica e ligeiramente sinuosa, por processos de rolamento, e os mais finos depositam-se em seguida na zona protegida a sotavento, por saltação, o que pode permitir à forma de leito maior altura e assimetria. Posteriormente, a crista da megaondulação pode ser truncada e retrabalhada por novo horizonte de cordões de grânulos, e assim sucessivamente. O resultado é a intercalação, em séries centimétricas a decimétricas, entre níveis residuais sub-horizontais de sedimentos relativamente grossos (até grânulos) e areias mais finas com estratificações cruzadas de ângulo baixo a médio (até $15^{\circ}$ ) realçadas por lâminas de sedimentos mais grossos.

Nos exemplos costeiros examinados no Brasil, observam-se protodunas achatadas de comprimento de onda decamétrico, as quais podem ser consideradas embriões de dunas transversais, associadas, juntamente com cordões de grânulos, a processos de carpete de tração eólico (Figuras 3.51).

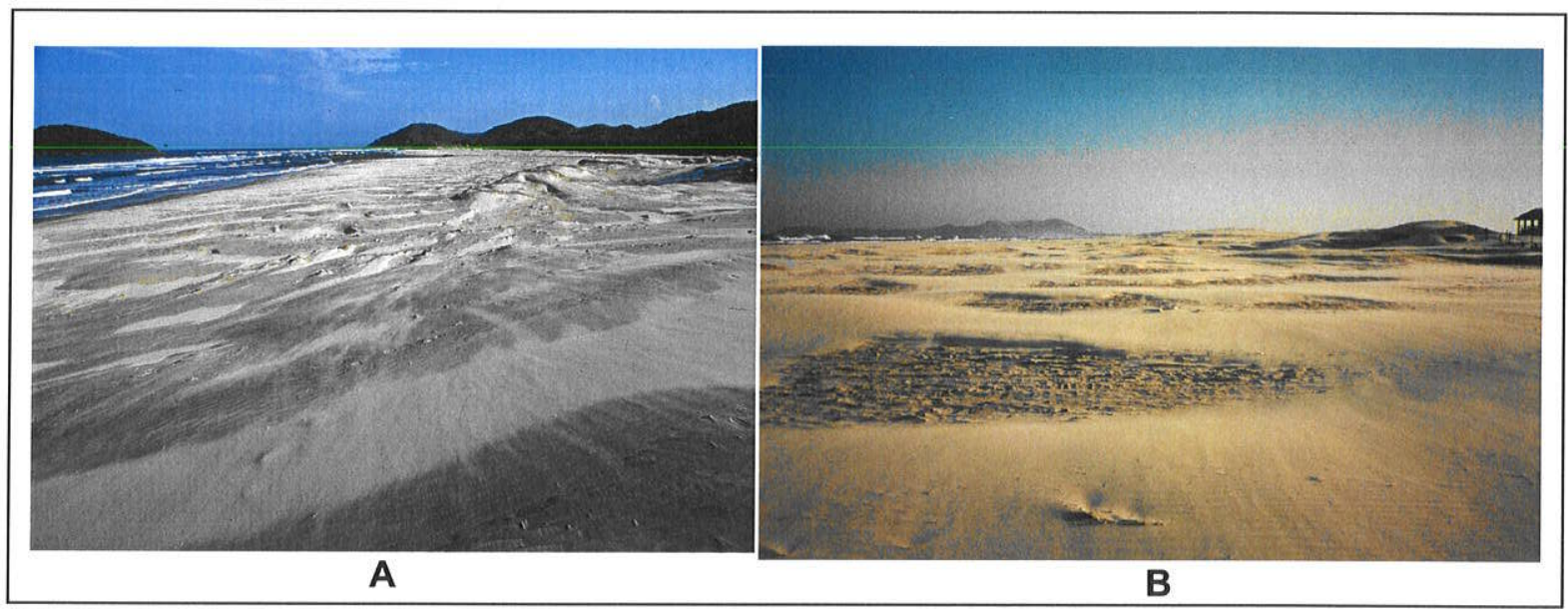

Figura 3.51. Protodunas transversais de comprimento de onda sub-métrico associadas a processo de carpete de tração eólico. Praias de Ibiraqüera, município de Imbituba (A), e da Galheta, município de Laguna (B), costa centro-sul de Santa Catarina.

\section{Dunas transversais}

Dunas transversais são megaformas de leito com crista linear aproximadamente retilínea, de orientação mais ou menos perpendicular ao vento efetivo, encontradas em campos de dunas livres paralelos ou ligeiramente oblíquos à linha de costa (Figura 3.52). Começam na antepraia superior e prosseguem por centenas de metros ao interior, onde podem passar, com o aumento de sinuosidade da crista, a cadeias barcanóides.

$\mathrm{Na}$ parte proximal do campo de dunas da praia Grande do Sul (Jaguaruna), SC, observa-se intercalação entre diferentes hierarquias de tamanho de dunas transversais (2 a $8 \mathrm{~m}$ ) ao longo do eixo de avanço. Rumo às porções mais distais, porém, a altura das dunas torna-se duas vezes maior e pouco variável (Martinho 2004). 

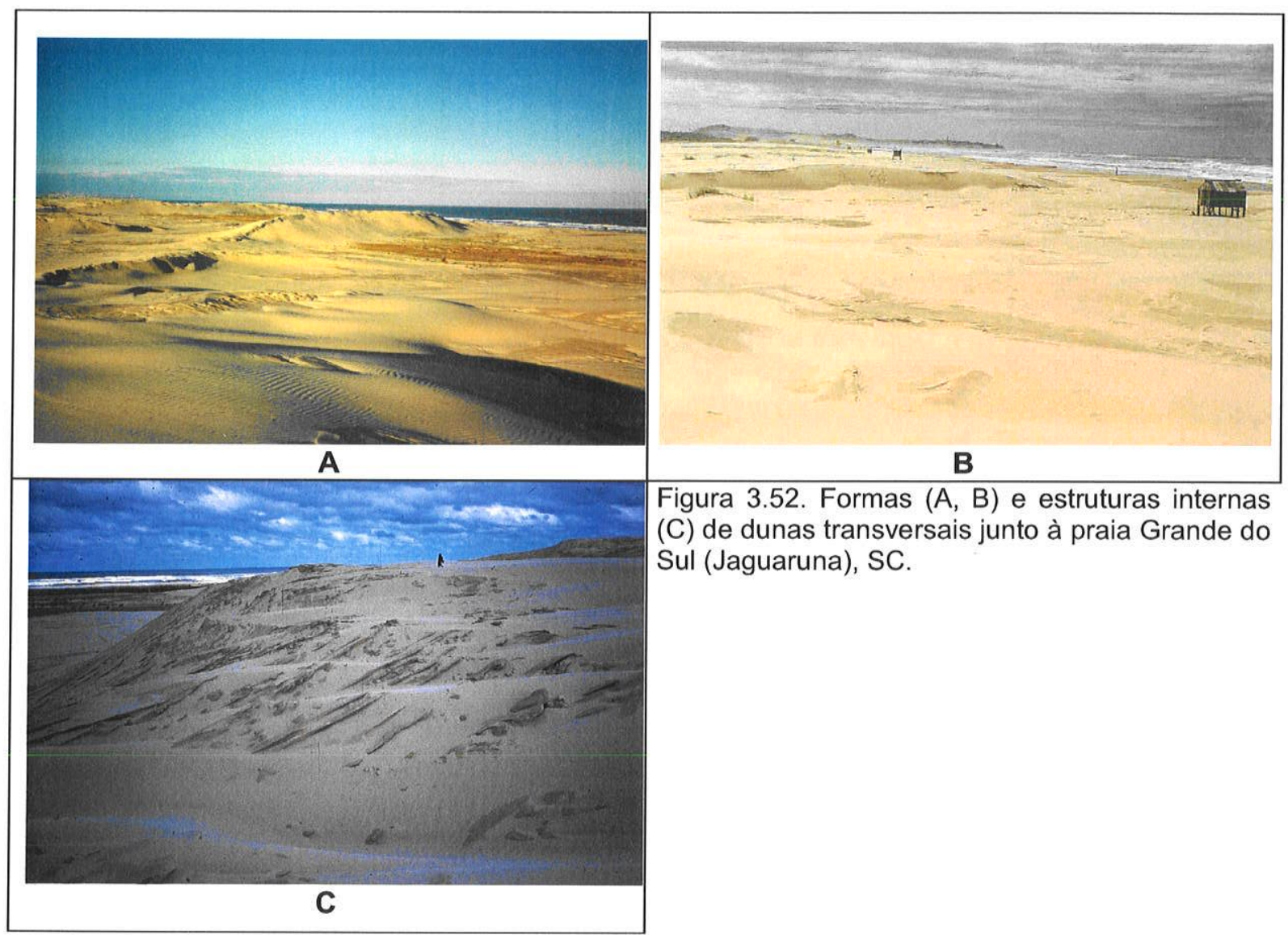

Figura 3.52. Formas (A, B) e estruturas internas (C) de dunas transversais junto à praia Grande do Sul (Jaguaruna), SC.

O elemento deposicional caracteriza-se por séries decimétricas a métricas de estratificações cruzadas planares, separadas por superfície de terceira ordem (Figura 3.52C), com atitudes pouco variáveis em relação à da face sotavento ativa. Estas séries de cruzadas repousam sobre areias com estratificações plano-paralelas de espraiamento de onda, com baixo mergulho para o mar, comumente realçadas por concentrações de minerais pesados escuros. Deposição de areias subaquosas sobre as eólicas também pode ocorrer, associado ao processo de abrasão marinha parcial da duna transversal durante eventos de tempestade (Figura 3.53). A relação processo-produto pode ser acompanhada em escarpas de altura métrica produzidas nesses eventos pela ação erosiva do fluxo pulsátil sobre a cauda externa da duna (Giannini 1993, Giannini \& Santos 1994). O processo de espraiamento de preamar por sobre depósitos eólicos remodelados pela corrente pulsátil (overtop) materializa-se na deposição de estratificações plano-paralelas, com rumo de mergulho variável, sobre estratificações cruzadas de dunas eólicas. Com a retomada da deposição eólica ao término da tempestade, a duna transversal reconstrói-se, o que se concretiza na recorrência da fácies deposicional eólica sobre a subaquosa. 


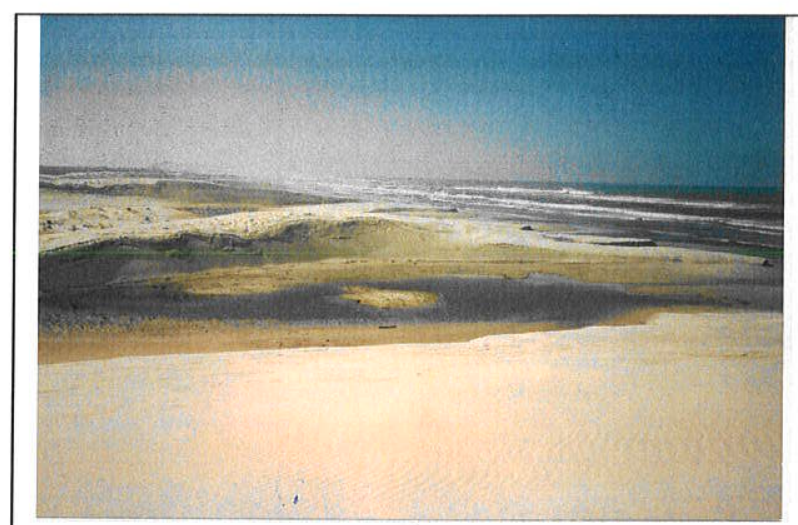

A

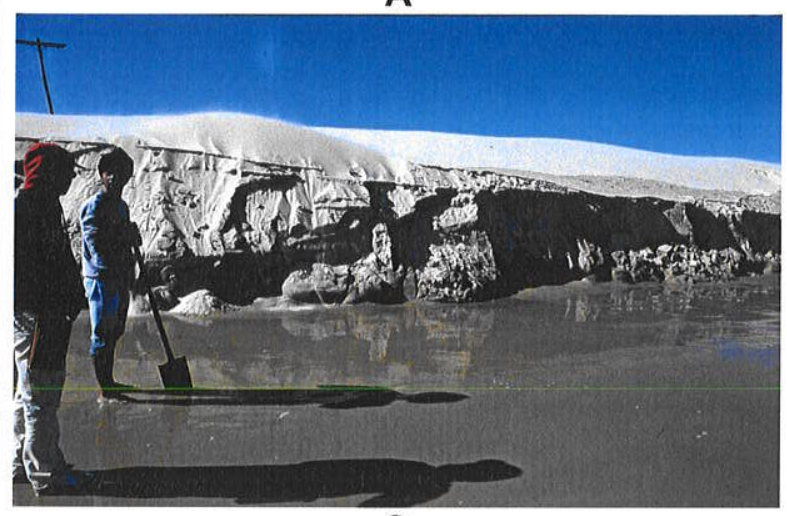

C

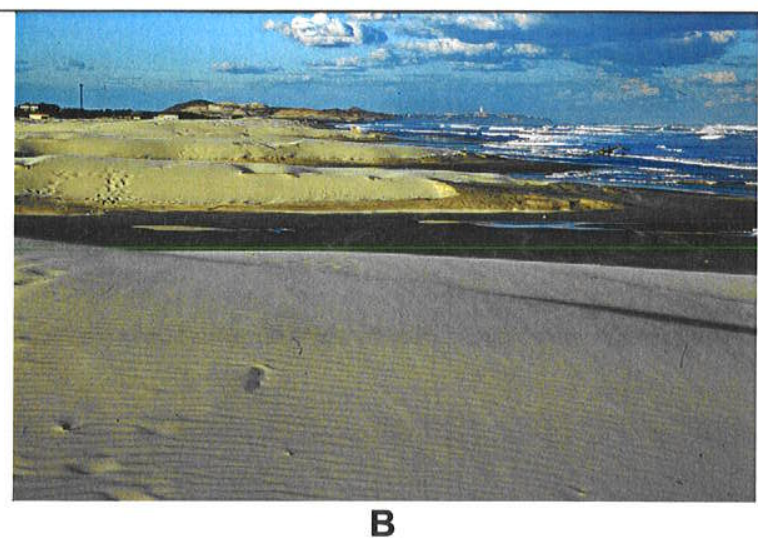

B

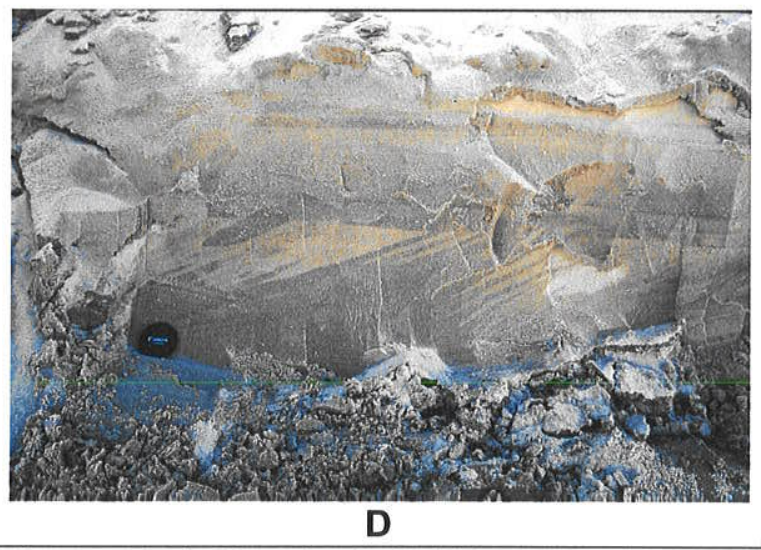

Figura 3.53. Dunas transversais alcançadas pelas ondas, na praia Grande do Sul (Jaguaruna), SC. A, B. Aspectos gerais. C. Falésia obliqua à crista. D. Estruturas sedimentares na falésia: estratificações cruzadas (fácies de duna transversal) intercaladas com estratificações plano-paralelas (fácies de overtop e espraiamento).

Cadeias barcanóides (barchanoid chains)

As cadeias barcanóides, com alturas até decamétricas, consistem de conjuntos de dunas barcanas (em meia-lua, com concavidade voltada para sotavento) lateralmente coalescidas, com crista sinuosa e orientação transversal ao vento efetivo (Figuras 3.54). Nos campos de dunas subparaleos à costa, podem constituir a continuação lateral de dunas transversais presentes na antepraia.

Nos sedimentos da face sotavento da costa catarinense, detecta-se leve piora de seleção no cume. A distribuição de freqüência de azimute do mergulho é bimodal, com dispersão de $60^{\circ}$, o que reflete a sinuosidade característica da forma de leito (Martinho 2004). Padrão similar é encontrado em trincheiras, onde são visíveis séries submétricas de estratificações cruzadas planares, truncadas entre si por superfícies de terceira ordem (Figura 3.55). A presença de moda secundária com mergulho para NE nos exemplos estudados em Santa Catarina está ligada provavelmente à preservação de faces barlavento ou a depósitos de ventos reversos. 


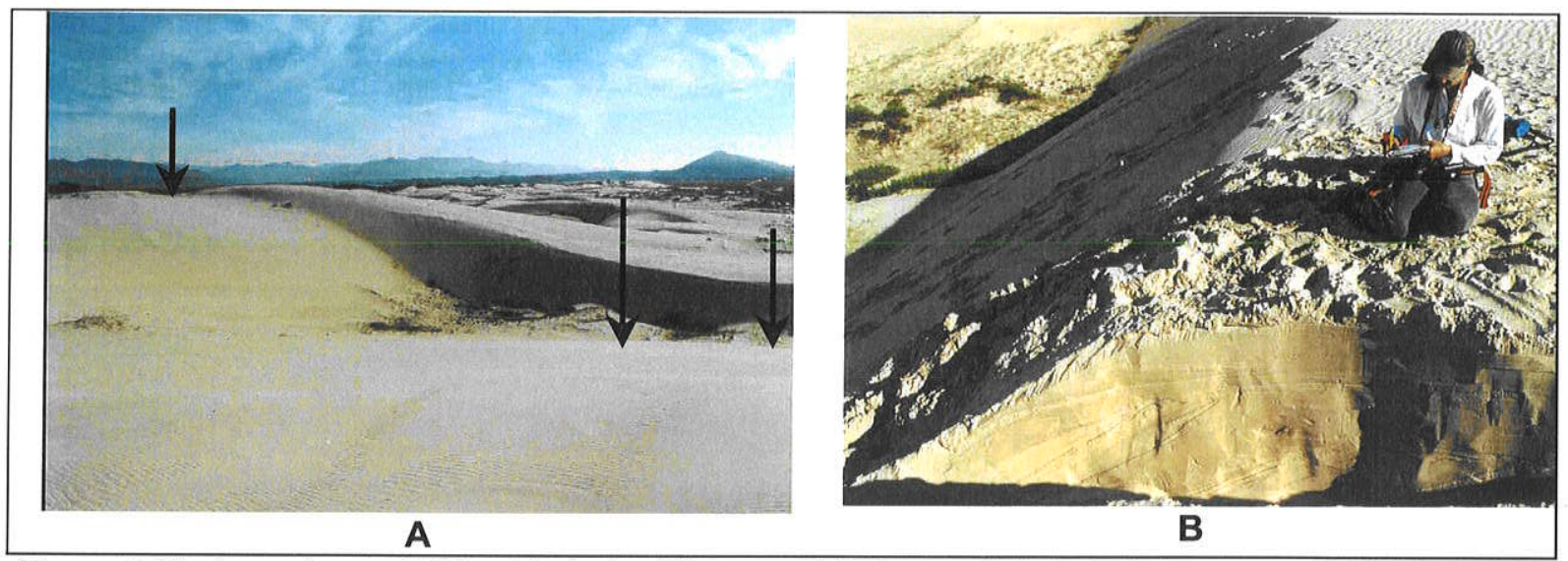

Figura 3.54. Aspecto geral (A) e trincheira (B) em cadeia barcanóide estudada no campo de dunas de Ibiraqüera (Imbituba), SC. As setas, em A, indicam três extensões lineares.

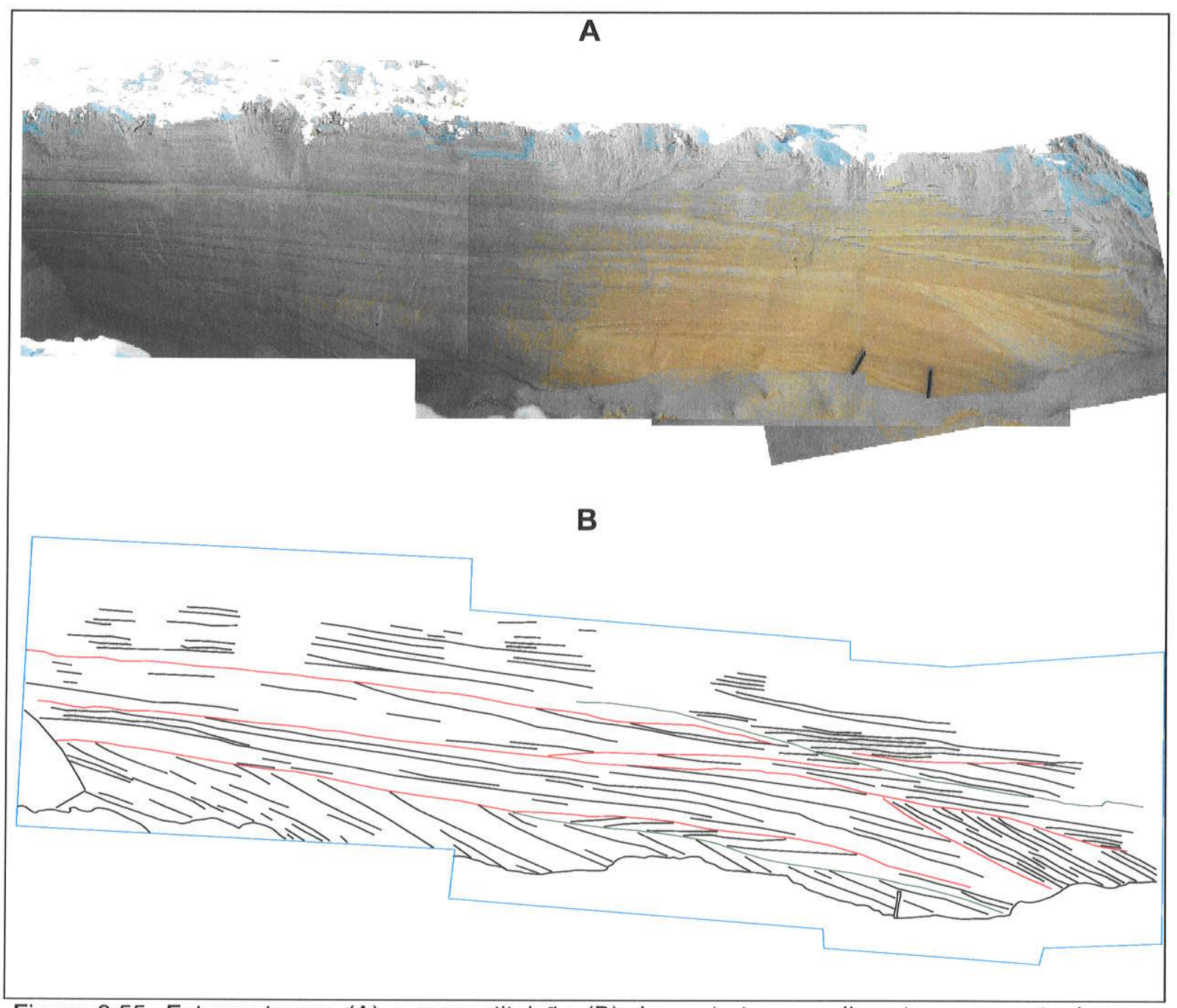

Figura 3.55. Fotomontagem (A) e reconstituição (B) das estruturas sedimentares encontradas em trincheira escavada em cadeia barcanóide, no campo de dunas de Ibiraqüera (Imbitiuba), SC. Pelo menos oito série de estratificação podem ser observadas. As linhas vermelhas equivalem a superfícies de terceira ordem e as linhas verdes são possiveis superficies de deflação geradas por ventos reversos. 
As extensões lineares são depósitos eólicos com crista linear, orientados subparalelamente ao vento efetivo, anexados à porção côncava e mais alta da cadeia barcanóide (Cooper 1958, Figura 3.56). Podem possuir vegetação esparsa e apresentar a crista retrabalhada por rupturas de deflação. As alturas são compatíveis com as das cadeias barcanóides com as quais se encontram associadas. Nos sedimentos superficiais, observase tendência de afinamento para o cume (Martinho 2004).

O elemento deposicional caracteriza-se por sucessivas séries de estratificações cruzadas planares, separadas por superfícies de terceira ordem e marcadas por intercalações entre lâminas lenticulares de areia média e lâminas tabulares de areia fina, que corresponderiam aos produtos de processos de fluxo de grãos e queda de grãos, respectivamente. Lâminas tabulares de concentração de minerais pesados também são abundantes e, localmente, aparecem deformadas, e interrompidas, à semelhança de falhas. As séries apresentam entre si diferença angular de azimute de aproximadamente $180^{\circ}$. As modas encontradas são discrepantes em até $90^{\circ}$ em relação ao vento efetivo na deposição eólica e na formação das cadeias barcanóides. Este padrão de distribuição de azimutes é semelhante ao encontrado em dunas lineares (seif) de ergs, cujas condições de fluxo aerodinâmico poderiam portanto ser tomadas como modelo para explicar a geração das extensões lineares. Assim, a construção da extensão linear seria devida à deposição associada a pequenos desvios (até $90^{\circ}$ ) do vento em relação ao rumo principal (ortogonal à cadeia barcanóide). Converge para esta hipótese o padrão entrelaçado das séries de cruzadas, com superfícies de truncamento em forma de letra z (Figura 3.57), que é parecido com o classicamente descrito como típico de dunas seif.

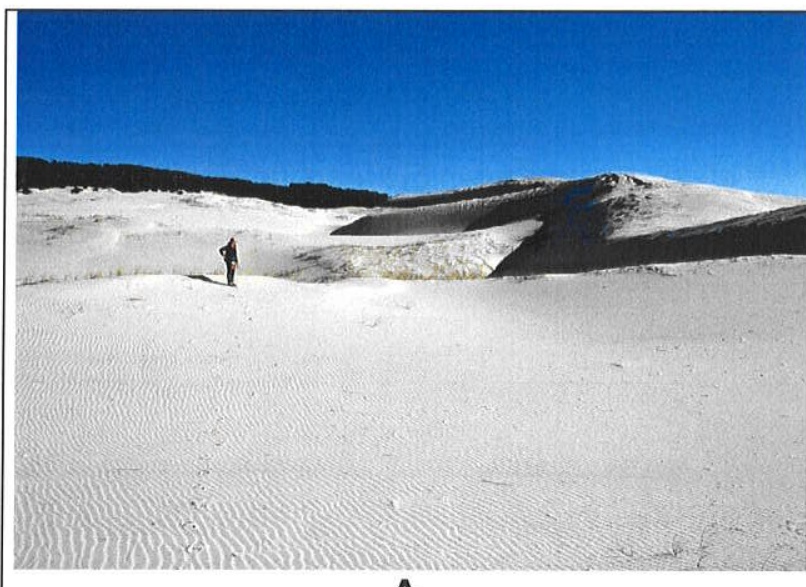

A

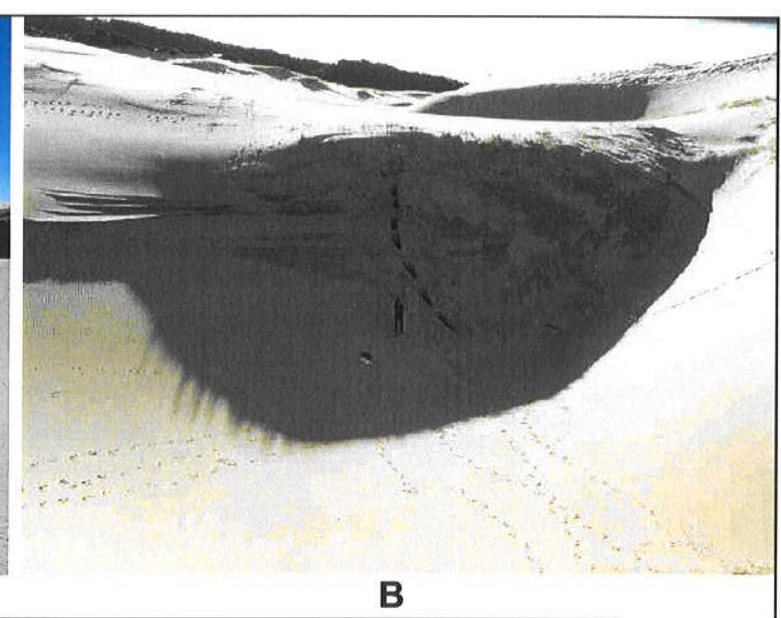

B

Figura 3.56. Elemento morfológico extensão linear, adjacente a parte central e mais alta da concavidade de cadeia barcanóide em Ibiraqüera (Imbituba), SC. Na foto de detalhe (B), vê-se uma série de trincheiras de estudo, abertas ao longo do declive externo da feição. 


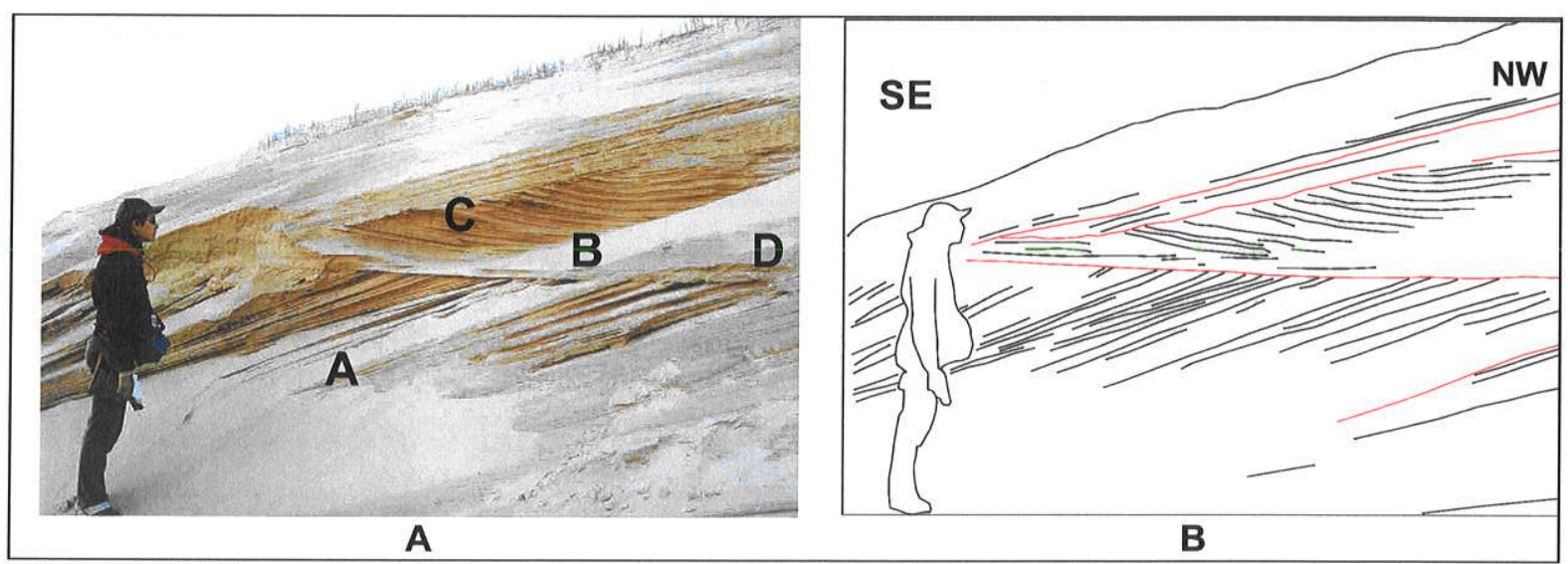

Figura 3.57. Fotografia (A) e reconstituição de afloramento natural (B) em extensão linear em Arroio Corrente (Jaguaruna), SC. Pelo menos quatro séries de estratificações planares a ligeiramente tangenciais podem ser observadas. As linhas vermelhas equivalem a superficies de terceira ordem, com arranjo em "Z" característico deste elemento deposicional.

\section{Depressões interdunas}

As depressões interdunas são zonas de perfil ligeiramente côncavo para cima situadas entre o costado de uma duna e a frente da duna à retaguarda, que o cavalga. Ocorrem tipicamente no meio do campo de dunas. Correspondem a planícies interdunas entulhadas por dunas (Figura 3.58A).

Os depósitos desta elemento são representados por camada centimétrica de areias finas bem selecionadas com atitude coincidente com a da superfície atual (Figura 3.58 B,C). Ocorrem discordantemente sobre fácies de areias ligeiramente mais grossas e menos selecionadas, caracterizadas por séries submétricas de estratificações cruzadas de atitude e geometria análogas às encontradas nas cadeias barcanóides adjacentes. A espessura reduzida dos depósitos de depressão interdunas e sua passagem transicional para os depósitos de frente de duna levam a interpretar difícil individualização de fácies no registro deposicional.

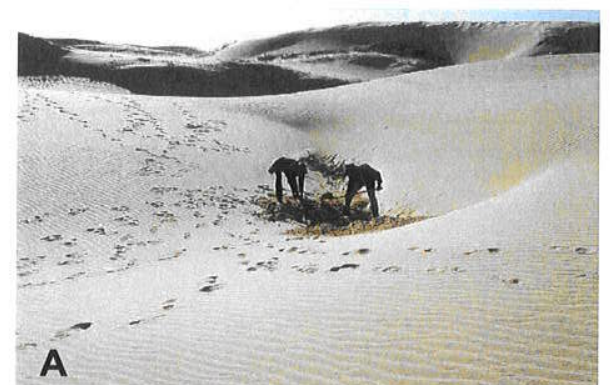

Figura 3.58. Morfologia (A) e depósitos $(B, C)$ de depressão interdunas em Ibiraqüera, SC. A fotografia $B$ e a reconstituição $C$ referem-se à trincheira de estudo $(\mathrm{m}$ abertura em A. Duas séries de estratificações planares podem ser vistas, separadas por superficie de terceira ordem (linha vermelha em C).

Apenas a série superior contém

B depósitos de depressão interdunas.
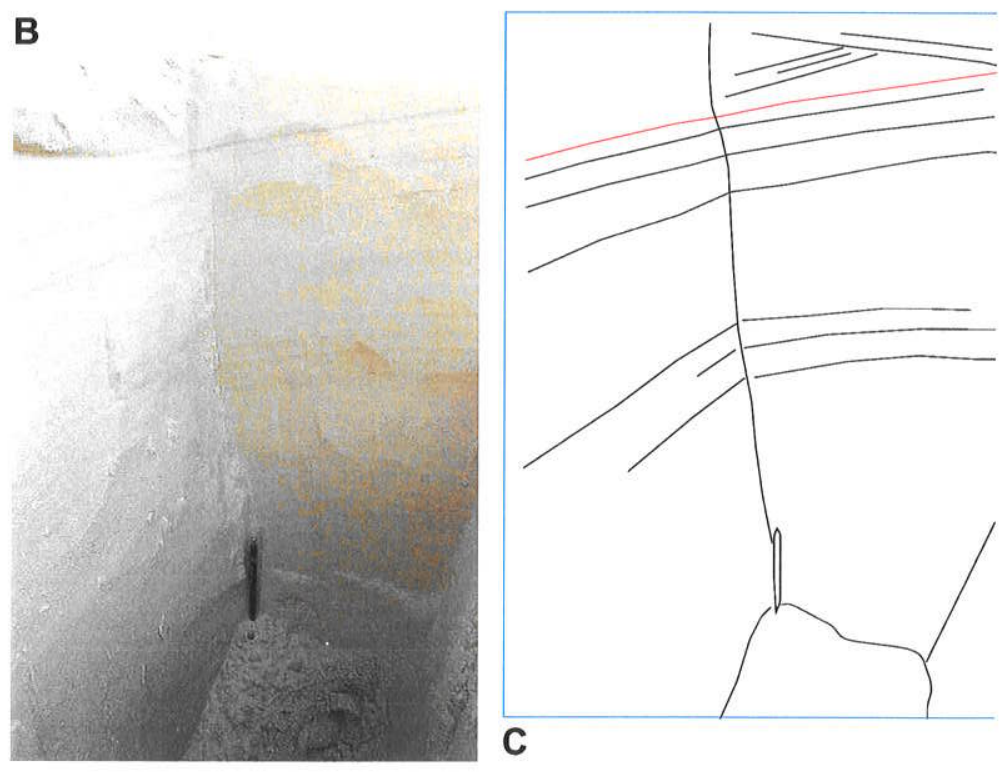
Os lobos deposicionais correspondem a frentes de avanço principais dos campos de dunas, com dezenas de metros a quilômetros de extensão. Possuem formato parabólico e migram, sobre terreno vegetado, no rumo do vento efetivo. Em exemplos deste elemento morfológico estudados na costa centro-sul de Santa Catarina, as dimensões variam de acordo com a morfologia geral do campo de dunas. Em campos de dunas com área deflacionar à retaguarda, como os de Ibiraqüera e Vila Nova - Roça Grande (Imbituba), a altura é de poucos $(<5)$ metros e a relação comprimento/largura é elevada $(>3: 1)$. Já no campo de dunas da praia Grande do Sul (Jaguaruna), sem área deflacionar, os lobos deposicionais possuem altura máxima de aproximadamente $24 \mathrm{~m}$ e baixa relação comprimento/largura (2:1).

Os sedimentos superficiais apresentam melhora ascendente da seleção (Martinho 2004). O rumo de mergulho das faces de avalancha varia em $120^{\circ}$ entre os dois flancos opostos do lobo deposicional, definindo assim sua geometria parabólica em planta. Nas partes laterais do lobo, a fácies deposicional é caracterizada por séries de estratificações cruzadas aproximadamente planares, parte delas com tangenciamento local no topo (Figura 3.59). $\mathrm{Na}$ base dos flancos, encontra-se fácies de convoluções atribuída à fluidificação da areia (Figura 3.60). Na parte frontal do lobo, a fácies deposicional caracteriza-se por estratificações cruzadas tangenciais no topo (possivelmente sigmóides) ou truncadas por superfícies de terceira ordem (Figura 3.61).

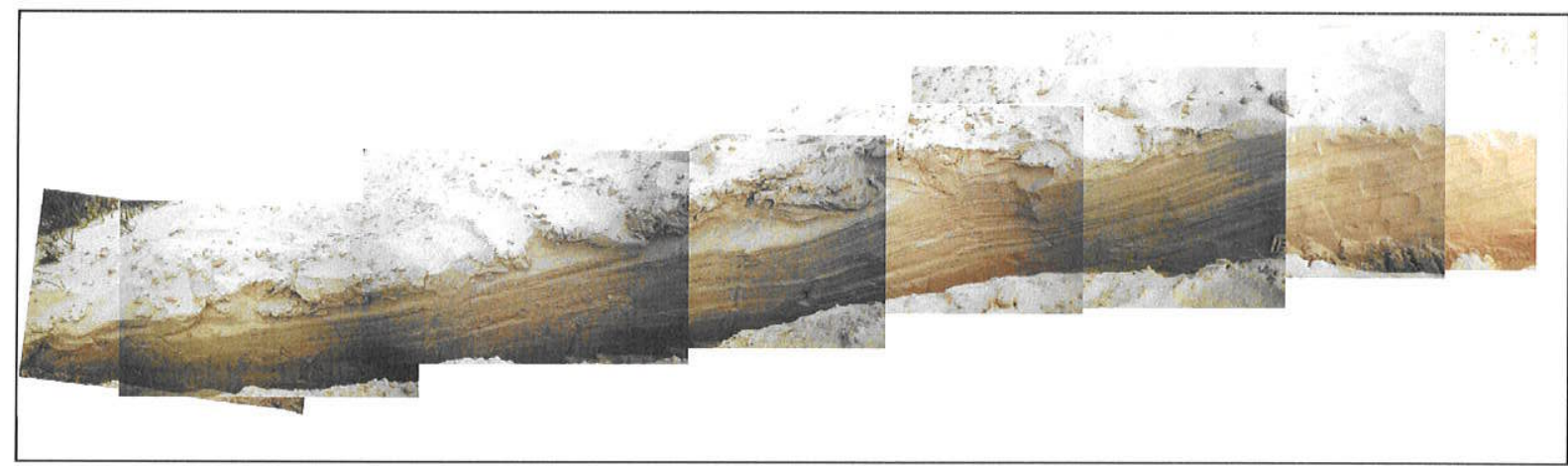

Figura 3.59. Fotomosaico das estruturas expostas em trincheira no flanco de lobo deposicional em Ibiraqüera (Imbituba), SC.

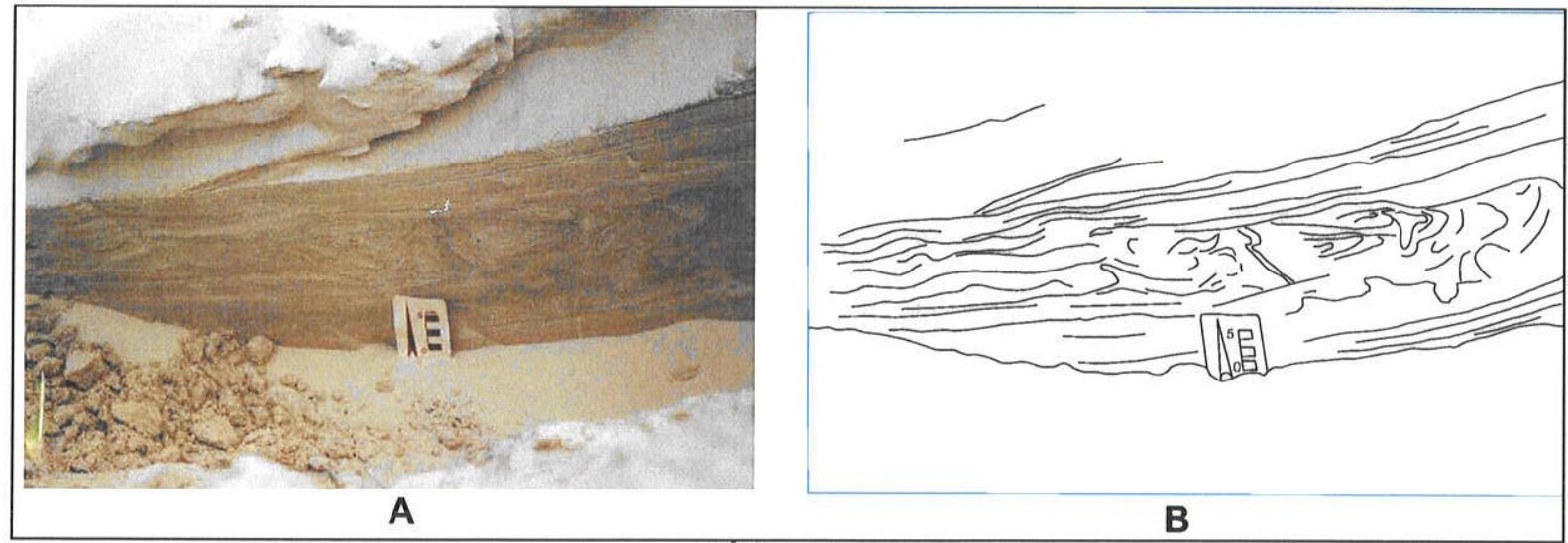

Figura 3.60. Fotografia $(A)$ e reconstituição $(B)$ das estruturas sedimentares, expostas em trincheira, na base do flanco esquerdo de lobo deposicional, em Ibiraqüera (Imbituba), SC. Notar abundância de convoluções, indicativas de areia em estado liquidificado. 


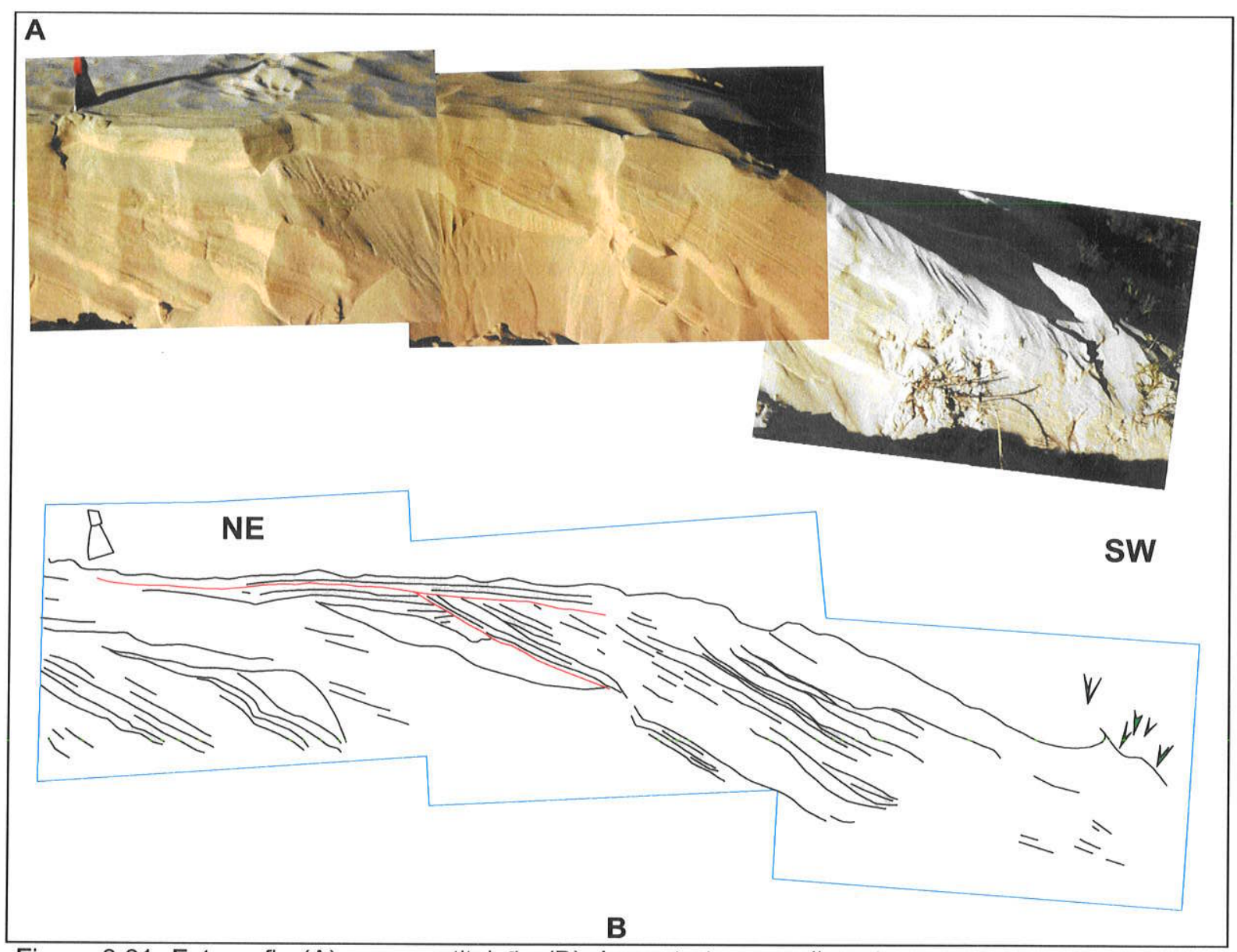

Figura 3.61. Fotografia $(A)$ e reconstituição $(B)$ das estruturas sedimentares expostas em trincheira na frente de lobo deposicional estudado em Ibiraqüera (Imbituba), SC.

\subsubsection{Arranjo espacial}

\subsubsection{Em campos de dunas}

Este subitem é uma tentativa de síntese sobre a distribuição espacial dos diferentes tipos de depósitos eólicos nos principais campos de dunas transgressivos brasileiros, a partir da compilação bibliográfica apresentada por Giannini et al. (2005).

No Ceará, Claudino Sales (2002) classificou as dunas costeiras ativas em "móveis e semi-fixas", designando assim respectivamente os depósitos sem e com participação essencial da vegetação na sedimentação. As "dunas móveis" incluem campos de barcanóides e barcanas, às quais podem associar-se "feições longitudinais" (rastros de deflação). Dominam, sobretudo, os segmentos mais externos das planícies litorâneas cearenses. Em Jericoacoara, Claudino Sales \& Peulvast (2002) relatam interações das formas de leito em movimento com a água das interdunas resultando na evolução destas feições longitudinais, bem como na intercalação de "cordões arenosos" (retrocordões) com pequenas lagoas em meia-lua. Este tipo de associação estende-se para oeste, ocorrendo por exemplo em Camocim (Figura 3.62A).

As "dunas semi-fixas" da classificação de Claudino Sales (2002) são representadas por dunas frontais, nebkhas e dunas parabólicas. As frontais, com 1 a $2 \mathrm{~m}$ de altura, dominam setores de praia protegidos, à retaguarda de cordões de rochas praiais, e faixas de praia em franca progradação. As parabólicas ocorrem no litoral central e ocidental do estado 
e evoluem a partir de blowouts. Suas partes centrais abrigam lagoas interdunas temporárias ou perenes, resultantes da interação entre deflação e oscilações do nível freático (Figura $3.62 \mathrm{~B})$.
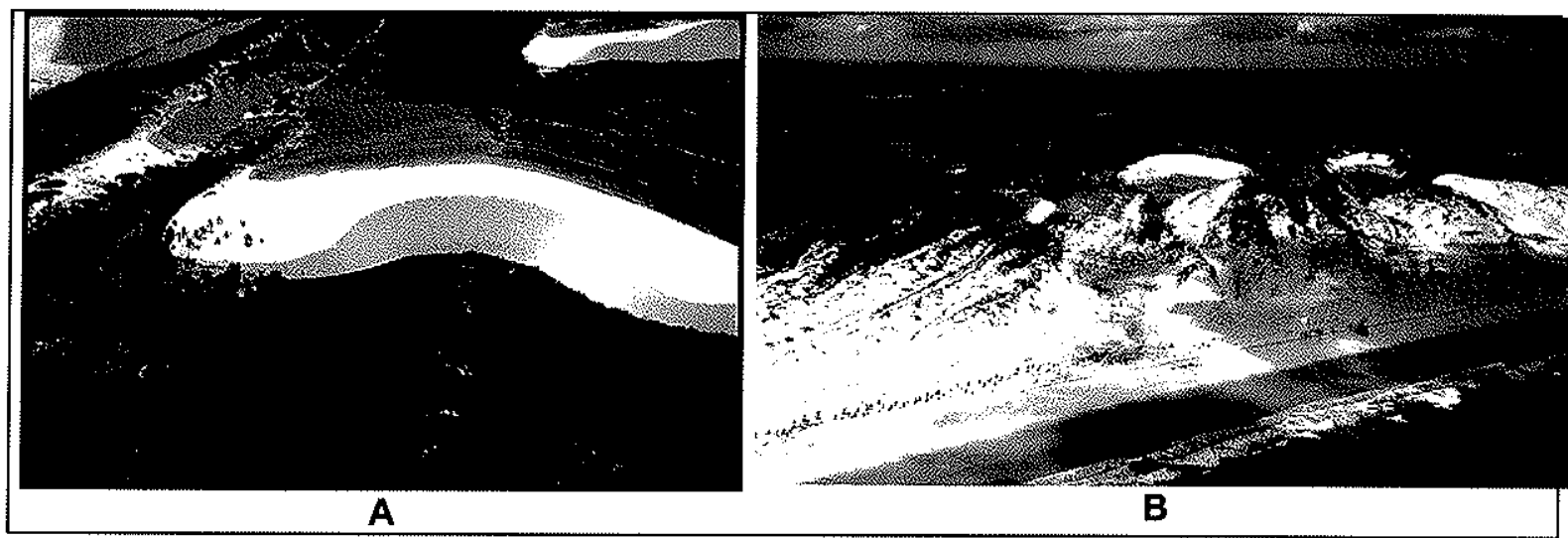

Figura 3.62. Dois exemplos de morfologias resultantes da interação entre dinâmica eólica e água na costa oeste cearense, segundo Claudino Sales (2002) e Claudino Sales \& Peulvast (2002). A. Dunas barcanas ("geração D2") colmatando laguna na região de Barrinha (Camocim). A presença de água na planicie interdunas reduz a deflação e o fornecimento de sedimentos e mantém, desse modo, a individualização das barcanas (Claudino Sales, 2002). B. Dunas "semi-fixas" parabólicas na planicie litorânea de Lagoinha (Paraipaba), formadas a partir da evolução de rupturas de deflação. As partes centrais abrigam lagoas interdunas formadas por deflação seguida de elevação do nível freático. Fotos: J-P Peulvast.

Entre a costa centro-oeste do Ceará e a região de Touros, RN, a morfologia predominante nos depósitos eólicos ativos é a de cadeias barcanóides, associadas ou não a frentes parabólicas transgressivas, separadas da linha de costa por zona deflacionar com vegetação e rastros lineares (Figura 3.63). A leste de Macau, RN, junto à planície flúviomarinha do rio Açu, dunas barcanas isoladas ocorrem a barlavento das cadeias barcanóides (Figura 3.63B; Giannini et al. 2005), passando, rumo à costa, a retrocordões.
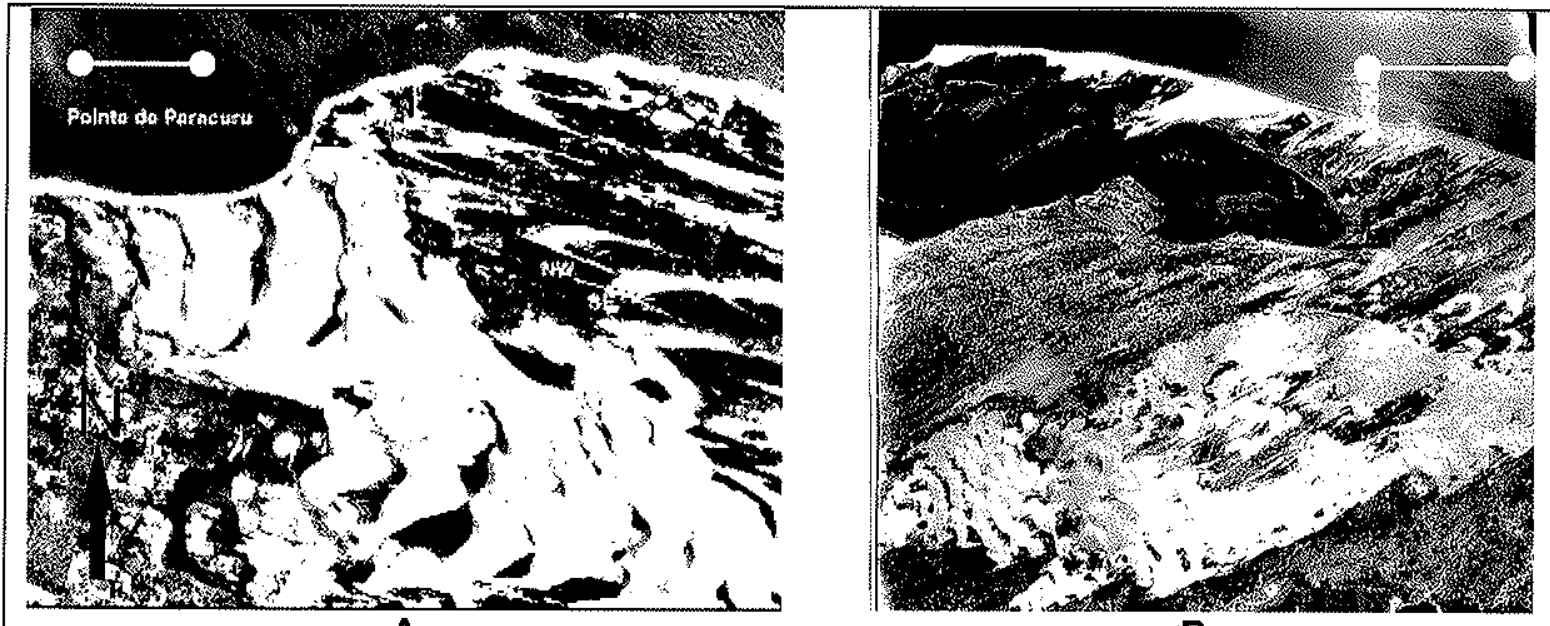

A

B

Figura 3.63. Exemplos de campos de dunas livres da Região Nordeste, formados por barcanas e/ou barcanóides. A. Em Paracuru (costa centro-oeste do Ceará), com dunas parabólicas e rastros lineares deixados no percurso de migraçäo. $\mathrm{B}$. Na reglão a leste de Macau, RN, com cadeias barcanóides agrupadas sob forma de frente parabólica. Notar também barcanas isoladas e retrocordões a barlavento. $O$ substrato é formado por paleodunas com morfologia pouco nítida. Fotografias aéreas verticais cedidas por V. Claudino Sales e A.M.F.Barreto. Escala gráfica indicada: cerca de $1 \mathrm{~km}$. 
Para os campos de dunas ativos situados entre a foz do rio São Francisco, na região fronteiriça de Alagoas com Sergipe, e Mangue Seco, no extremo norte do litoral baiano, Barbosa (1997) individualiza três "domínios": o externo ou de lençol de areia (LA), o intermediário, ou de dunas isoladas e interdunas (DII), e o interno, constituído por dunas compostas (DC) ou por "dunas" de precipitação (DP). Nas adjacências mais imediatas da foz do rio São Francisco (entre Pontal do Peba e Pontal de Japaratuba), os depósitos eólicos situados em margens opostas do rio diferenciam-se quanto a textura e morfologia (Figura 3.64).

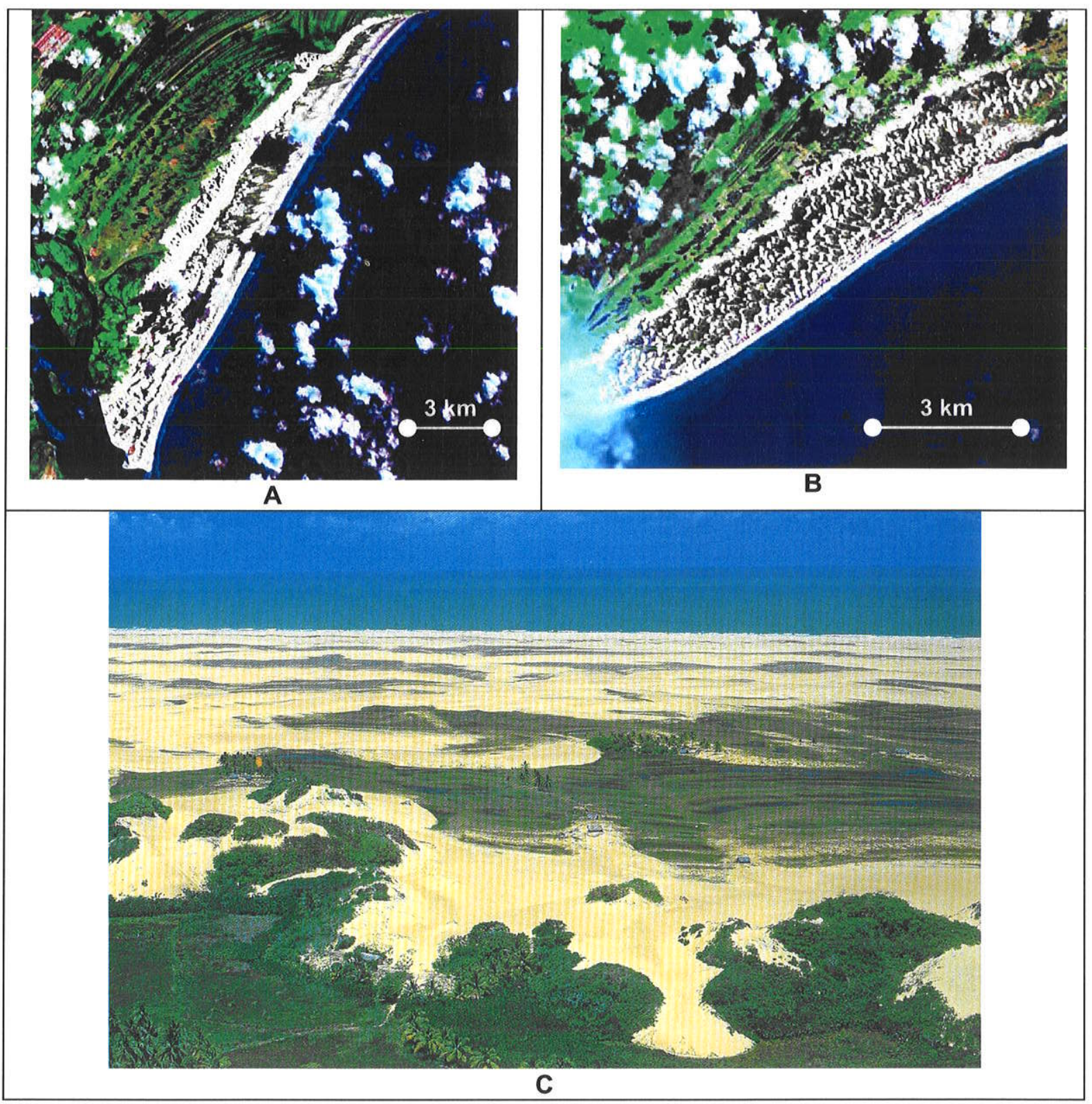

Figura 3.64. Campos de dunas costeiros junto à desembocadura do rio São Francisco, AL/SE. A. A NE da foz, com cordão de precipitação largo e lobos de precipitação coalescidos na parte distal. B, C. A SW da foz, com maior evidenciamento de planície de deflação, contendo retrocordões, e de cordão de precipitação na parte distal, este localmente interrompido por lobos deposicionais curtos (menos de $100 \mathrm{~m}$ ). Fotos A, B: Landsat 1990 in NASA 2007. Foto C: Silvestre Silva ("Reflexo") in AbSaber (2001). 
No trecho a NE da foz, a granulação da areia varia entre fina e muito fina. As feições deposicionais incluem dunas barcanas com altura variável de poucos centímetros a $5 \mathrm{~m}$, no domínio intermediário (DII), e "megaforma de leito ou duna composta, com cristas transversais superimpostas" de 18 a $33 \mathrm{~m}$ de altura, no domínio interno (DC). No período seco, cristas transversais e pequenas barcanas formam-se na face barlavento dessa megaforma. O limite interno deste campo de dunas faz-se por numerosos lobos de precipitação com poucas centenas de metros de extensão, voltados para W (Figura 3.64 A).

No trecho a SW da foz do rio São Francisco, a granulometria dos sedimentos eólicos varia entre areia média e areia fina. Depósitos eólicos de cristas pouco marcadas com altura variável entre alguns centímetros e $5 \mathrm{~m}$ (LA), sem faces de deslizamento e "com braços voltados para barlavento", associam-se a dunas de sombra. Pelas características texturais e morfológicas, estes depósitos podem ser classificados como zibars. No domínio interno, identificam-se cordões de precipitação (DP), com $20 \mathrm{~m}$ de altura em média, associados a numerosos corredores de deflação (Barbosa 1987, Giannini et al. 2005), com retrocordões associados. A boa definição do cordão de precipitação aqui deve-se às menores quantidade e extensão dos lobos de precipitação (Figura 3.64 B, C).

As diferenças de morfologia entre os depósitos eólicos situados nas margens opostas da foz do rio São Francisco podem ser atribuídas a contrastes de granulação dos sedimentos na praia, com possível influência da mudança de orientação da linha de costa conforme a regra de Goldsmith (Barbosa 1997, Giannini et al. 2005). De acordo com essa hipótese, no setor situado a NE da desembocadura, a maior disponibilidade de areia fina a muito fina e a disposição da linha de costa perpendicular aos ventos favorecem o potencial de formação de dunas (no caso, barcanas e campo de barcanóides), com maior desenvolvimento de lobos de precipitação, em transição para lobos deposicionais. Do outro lado, a menor disponibilidade de sedimentos finos na praia e o menor ângulo entre vento e linha de costa determinam a formação de zibars e cordões de precipitação mais contínuos, separados entre si por feições deflacionares (blowouts e parabólicas) nítidas. A diferença de granulação relaciona-se à deriva litorânea regional de NE para $S W$, combinada ao efeito molhe da desembocadura fluvial. Desse modo, os sedimentos finos transportados pela deriva litorânea longitudinal são retidos no trecho a NE da foz, enquanto o trecho a SW é alimentado pelo aporte sedimentar fluvial, enriquecido em areia média.

De acordo com McKee \& Bigarella (1972), o campo de dunas de Cabo Frio caracterizase, a barlavento (NE), pela presença de dunas transversais pequenas (altura métrica) e cadeias barcanóides mal desenvolvidas. Passaria, rumo sotavento, para "dunas parabólicas" (lobos ou frentes deposicionais de campo de dunas, com geometria individual parabólica), maiores nas áreas com menos vegetação e próximas à praia. Castro et al. (2002) concebem os depósitos eólicos costeiros desta mesma região como dois sistemas, um paralelo à costa, descrito como um "sistema duplo de cordões eólicos", e outro de orientação NE-SW, formado por barcanas e barcanóides. Com base na descrição dos autores, estes dois sistemas podem ser correlacionados respectivamente a dunas frontais e campos de dunas livres. Separam-se entre si por uma zona deflacionar, mais desenvolvida na parte sul dos arcos praiais que atuam como área fonte.

O campo de dunas localizado entre as praias da Joaquina e do Campeche e a margem sul das lagunas do Canto da Lagoa e da Conceição, em Florianópolis (Figura 3.27 C,D), descrito por Bigarella (1975) sob a denominação de "campo de dunas da Lagoa", consiste, segundo este autor, de "grande massa de areia deflacionada" (blowouted sand mass), parcialmente rodeada e delimitada no lado continental por "cristas de areias eólicas estabilizadas". Dunas parabólicas são a feição deposicional principal da zona de deflação, enquanto dunas transversais lineares (a sinuosas, na dependência do grau de atuação de ventos reversos, de NE e N) se destacam na porção terminal (norte). Na terminologia aqui 
adotada, corresponde a um campo de dunas transgressivo, com excepcional desenvolvimento da zona deflacionar, devido à intensa deriva eólica para NW (conforme item 3.2.2.1.2). As "cristas de areia estabilizadas" referidas pelo autor seriam, portanto, cordões de precipitação ativos.

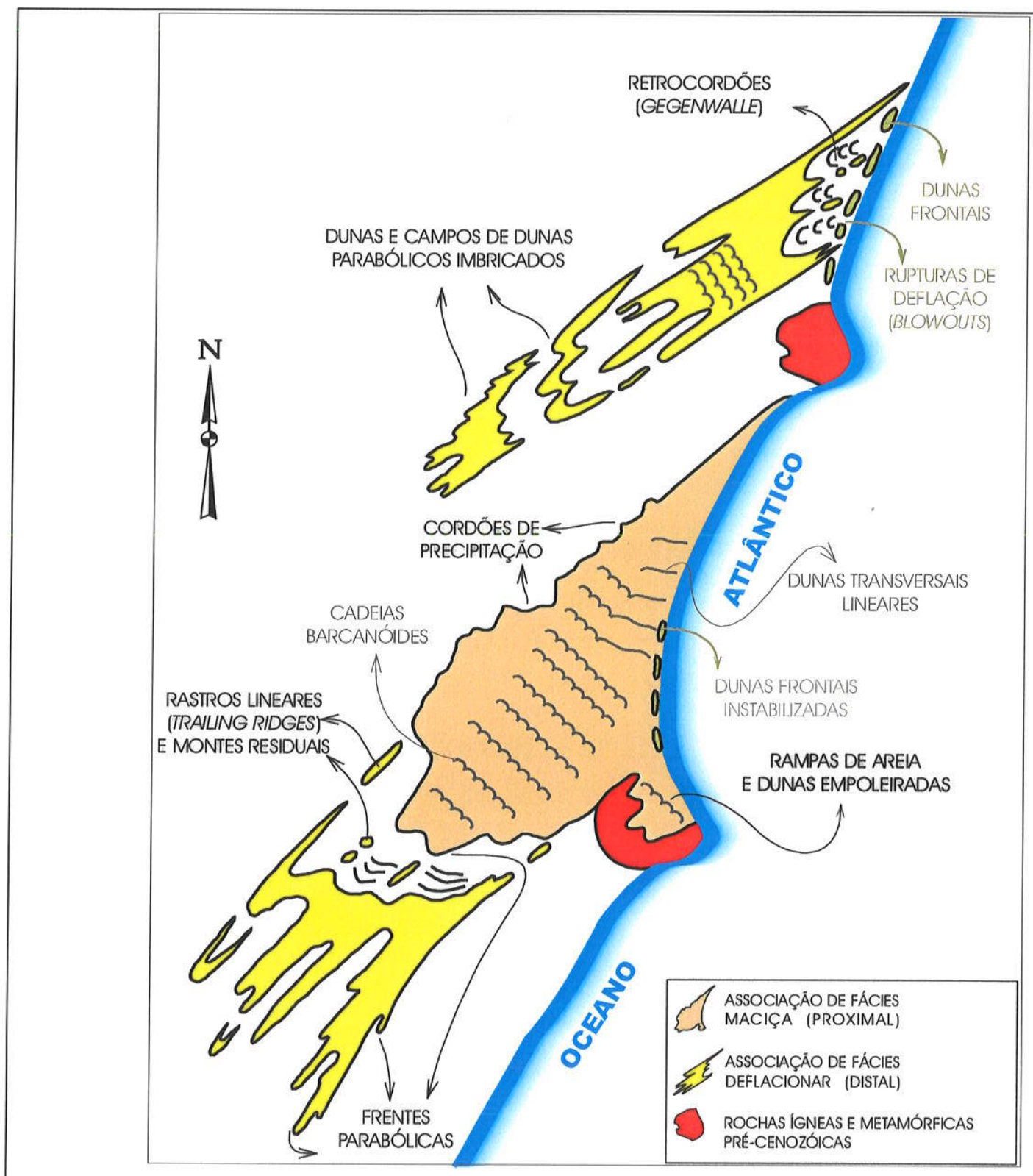

Figura 3.65. Mapa esquemático com os dois tipos de "associações de fácies" na costa centro-sul de Santa Catarina (modificado de Giannini 2002). Extensão dos campos de dunas é variável: poucos quilômetros a dezenas de quilômetros.

Na costa centro-sul de Santa Catarina, o exame da distribuição de "fácies eólicas" definidas pelo critério morfológico conduziu à distinção de duas "associações de fácies" (Giannini 1993, 1998, 2001, Giannini et al. 2001b,c, Martinho \& Giannini 2002, Martinho et al. 2007, Figura 3.65). A "associação de fácies" de posição proximal, com até dezenas de quilômetros de extensão, inicia-se por dunas frontais incipientes tipicamente instabilizadas, 
grada ao interior para dunas transversais lineares e barcanóides e termina, rumo SW, em frentes parabólicas. Estende-se por dezenas de quilômetros ao longo da costa, sem apresentar fácies deflacionares. Seria formada por "instabilização maciça de dunas frontais" (sensu Short 1988a), resultando no espalhamento contínuo de areias eólicas desde a orla praial até os lobos deposicionais, daí sua designação como "associação de fácies maciça" (Giannini 1998, 2002). A "associação de fácies" distal, com extensão inferior a 7 km, iniciase por rastros lineares, retrocordões, dunas parabólicas isoladas e cavas deflacionares inundadas, passa para cadeias barcanóides e termina por lobos deposicionais alongados. Com presença característica de planícies de deflação e fácies com vegetação entre o campo de dunas e a praia, é também denominada "associação de fácies deflacionar" (Giannini 1998, 2002). A margem lateral interna de ambas as associações apresenta frentes de avanço secundárias, contidas por vegetação (Giannini 1993), correspondentes a cordões de precipitação (Martinho et al. 2007).

O desenvolvimento completo da "associação de fácies proximal" ocorre preferencialmente sobre o sistema deposicional barra-barreira (barrier-bar sensu Fisher \& McGowen 1967 e Reinson 1979) existente a sul do cabo de Santa Marta, onde a costa adquire orientação NE, paralela ao vento efetivo, e a plataforma interna se torna mais larga. Em contraste, a "associação de fácies distal" predomina no sistema deposicional planície costeira de cordões (strandplain sensu Fisher \& McGowen 1967 e Fisher 1983) existente a norte de Laguna, onde a orientação da linha de costa é NNE (Giannini 2002, Giannini et al. 2005, Martinho et al. 2007).

De acordo com o modelo de distribuição espacial dos tipos de feições eólicas no litoral norte do Rio Grande do Sul, proposto por Tomazelli (1990, 1994), as dunas com vegetação (dunas frontais incipientes ou embrionárias, dunas frontais estabelecidas e nebkhas) ocorrem, em geral, mais próximas à linha de costa, enquanto as dunas livres, sem cobertura vegetal (barcanas, cadeias barcanóides e dunas transversais), se encontram mais interiorizadas. Outras feições eólicas (blowouts, dunas parabólicas e rastros lineares) associam-se a zonas com cobertura vegetal submetidas à deflação (Figura 3.66). De acordo com mesmo autor, a existência, em determinados locais, de faixas arenosas sem vegetação que se estendem diretamente a partir do sistema praia - duna frontal ou de rupturas deflacionares dele derivadas, permite ao campo de dunas livres continuar recebendo suprimento de areia nova proveniente da fonte praial. Estas faixas de areia desempenhariam, segundo Tomazelli (1990), o papel de "corredores de alimentação", capazes de evitar ou retardar o desaparecimento gradativo do campo de dunas livres que inevitavelmente passa a ocorrer quando a fonte sedimentar é cancelada. Com base na classificação destes depósitos quanto à posição e geometria, Tomazelli (1990) fez distinção morfológica entre dois tipos de feições eólicas transgressivas longitudinais ao vento, os "depósitos eólicos mantiformes" e os "lençóis arenosos parabólicos", conforme o inicio da faixa arenosa se dê na praia ou em zona deflacionar interior, respectivamente. Esta classificação e terminologia foi adaptada por Giannini (1993) para referir-se a tipos de campos de dunas ou "associações de fácies eólicas" encontrados na costa centro-sul catarinense. Para evitar confusão com a definição de lençol de areia, o uso destes termos foi substituído mais tarde pela distinção entre "associação" proximal ou maciça e distal ou deflacionar (Giannini 1998, 2002, Martinho et al. 2007). 


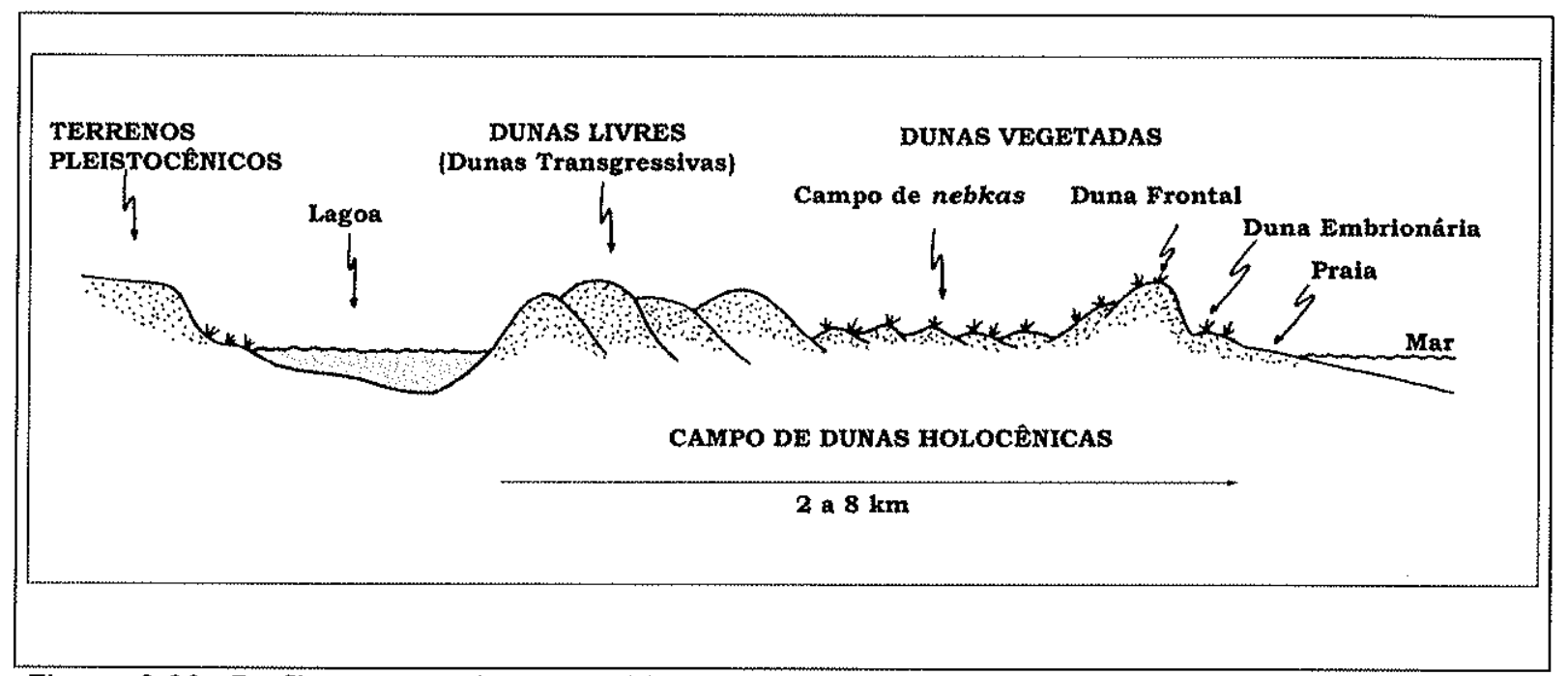

Figura 3.66. Perfil transversal esquemático da planície costeira do Rio Grande do Sul (segundo Tomazelli 1994).

\subsubsection{Ao longo de sistemas praia-duna}

Em setores costeiros dominados por campos de dunas livres

Descrições de campo do sistema praia-duna ao longo das praias mais extensas (maiores que $4 \mathrm{~km}$ ) da região entre Jaguaruna e Imbituba (Giannini 1993, Giannini \& Santos 1994) demonstram que a assimetria dos campos de dunas referida no item 3.2.2.1.3 manifesta-se em mudanças no tipo e/ou na morfologia e dimensões das dunas existentes junto à orla. A freqüente mudança gradual de dunas frontais para dunas transversais no rumo da deriva litorânea longitudinal predominante ao longo de mesmo setor praial obedeceria ao aumento de areia disponivel ao retrabalhamento eólico. A distribuição relativa e o tamanho dos dois tipos de dunas variam também de acordo com as condições climáticas e com o regime de ondas e marés (Giannini 1993, Giannini \& Santos 1994). Durante épocas de areia seca, a zona de domínio de dunas transversais amplia-se para barlamar. Inversamente, nos trechos de praia mais constantemente umedecidos por arroios e canais temporários de sobrelavagem, a redução de aporte de areia incoesa permitiria o crescimento de vegetação pioneira e a formação de dunas frontais e nebkhas. A associação no tempo e no espaço entre dunas com e sem vegetação nestas praias evidencia assim que dunas transversais formam-se às custas da destruição de dunas frontais em presença de excesso de areia incoesa e que estas podem resultar da colonização das transversais por vegetação. Os dois tipos de dunas estariam relacionados como os lados opostos de um balanço de equilibrio, controlado pela quantidade de areia disponivel ao retrabalhamento eólico.

$\mathrm{Na}$ mesma região, dispõe-se de informações mais detalhadas sobre a variação longitudinal do sistema praia-duna nas praias Grande do Sul, em Jaguaruna (Giannini 1993, Martinho 2004, Martinho et al. 2007), do Ji, em Laguna (Giannini 1993, Giannini \& Santos 1994, Hesp et al. 2007), e de Ibiraqüera, em Imbituba (Martinho \& Giannini 2001, Martinho 2004, Martinho et al. 2007), todas com evidências geomorfológicas e sedimentológicas de deriva litorânea longitudinal dirigida para NE ou NNE. Em todas elas, o campo de dunas inicia-se da ponta norte da praia e migra para SW, transgredindo o continente no Ji e em Ibiraqüera e correndo subparalelamente à costa na praia Grande do Sul.

Na praia Grande do Sul, os primeiros $6 \mathrm{~km}$ a SW, entre o vilarejo de Campo Bom e a desembocadura da laguna Arroio Corrente perfazem o único trecho com ocorrência de dunas frontais. Em Campo Bom, porção mais distal do campo de dunas, as dunas frontais 
constituem terraço contínuo e ondulado. Rumo NE, torna-se dominante a ocorrência de cordão de dunas frontais estabelecidas, com terraço de dunas frontais incipientes no sopé. Próximo à desembocadura da laguna Arroio Corrente, as dunas frontais tornam-se descontínuas. A NE desta desembocadura, elas dão lugar a dunas transversais de até $17 \mathrm{~m}$ de altura, que ocorrem de modo contínuo por distância de cerca de $15 \mathrm{~km}$. Suas planícies interdunas podem sofrer inundações periódicas, o que propicia o desenvolvimento de vegetação, com formação localizada de nebkhas. Nos últimos $3 \mathrm{~km}$ da parte nordeste da praia Grande do Sul, próximo à desembocadura lagunar do Camacho, dunas transversais de 4 a $8 \mathrm{~m}$ de altura intercalam-se com dunas mais baixas, de aproximadamente $2 \mathrm{~m}$ (Figura 3.67).

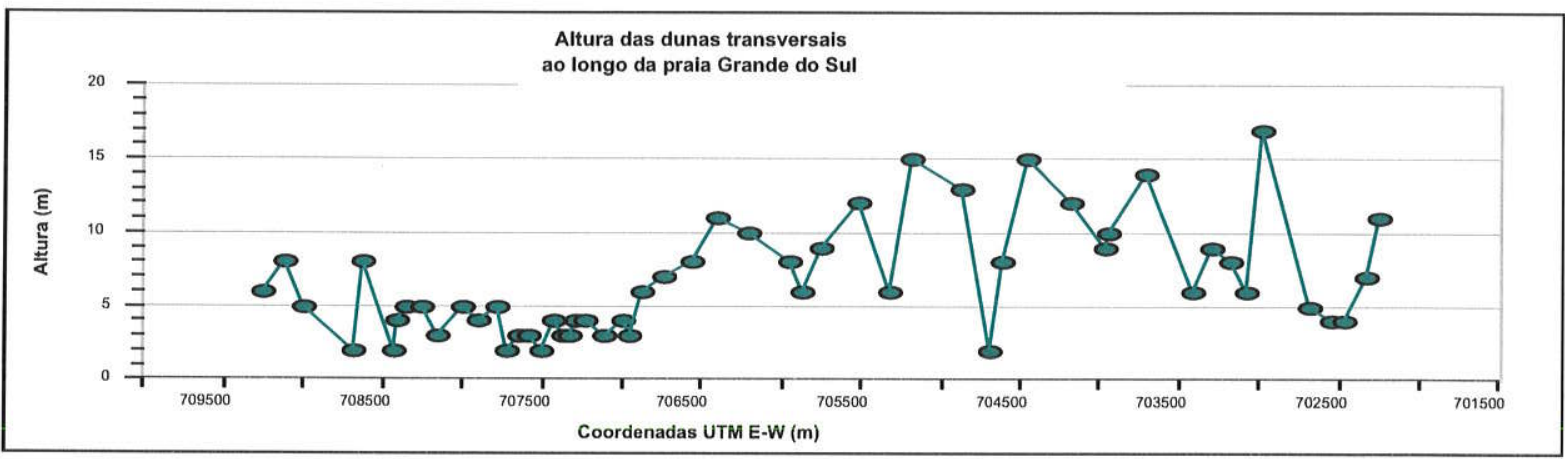

Figura 3.67. Variação da altura das dunas transversais em função da distância ao longo da praia Grande do Sul (Jaguaruna), SC, segundo dados de Martinho (2004).

A praia do Ji (Figura 3.68) possui arco praial suave, quase retilíneo, com $4,5 \mathrm{~km}$ de extensão. Tomando como referência de distância a ponta do Iró, na extremidade sudoeste e barlamar da praia, o trecho correspondente ao primeiro quilômetro e meio caracteriza-se por dunas frontais estabelecidas dômicas de até mais de $3 \mathrm{~m}$ de altura, correlacionáveis ao estágio 3 de Hesp (1988). No terço mediano da extensão longitudinal da praia, as dunas frontais passam a incipientes, com 0,5 a 2,5 m de altura, ladeadas, rumo ao mar, por franja de areia eólica de espessura centimétrica, onde a ação de transporte por carpete de tração torna-se evidente. No trecho nordeste da praia, até a ponta do Ji, as dunas frontais incipientes adquirem geometria de montículos com altura inferior a $1 \mathrm{~m}$. Paralelamente, a franja de areia eólica espessa-se rumo norte, dando lugar, de modo gradual, primeiro a protodunas de altura submétrica (Figura 3.69) e depois a dunas transversais métricas. Neste trecho, o fenômeno de carpete de tração é intenso. Apesar de a concavidade do arco praial ser suave, os pontos de mudança acentuada na morfologia das dunas, examinados nas fotografias aéreas, coincidem com inflexões ou mudanças tênues de direção da linha de costa. 


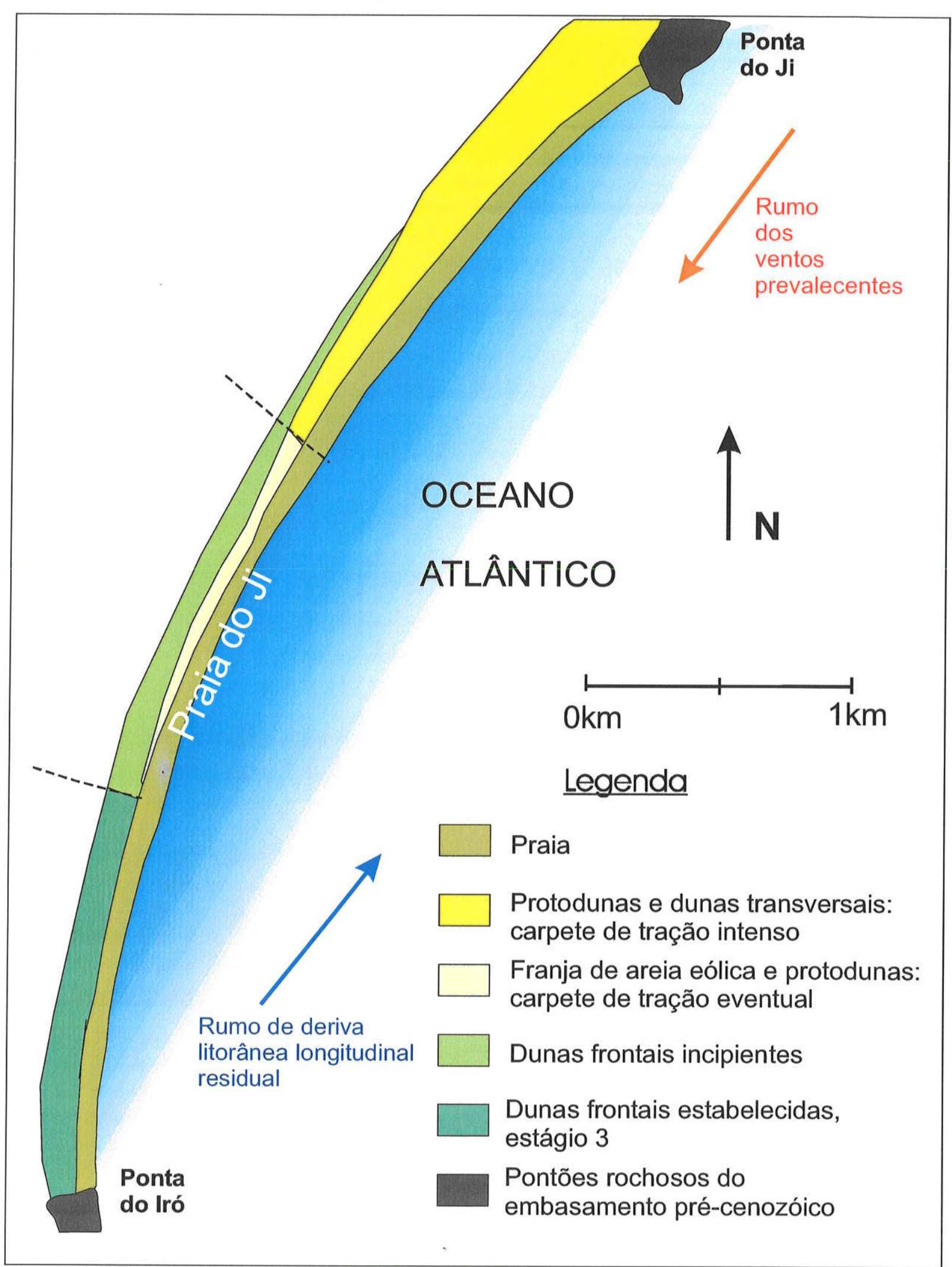

Figura 3.68. Variação de elementos morfológicos eólicos ao longo da praia do Ji, município de Laguna, SC. 


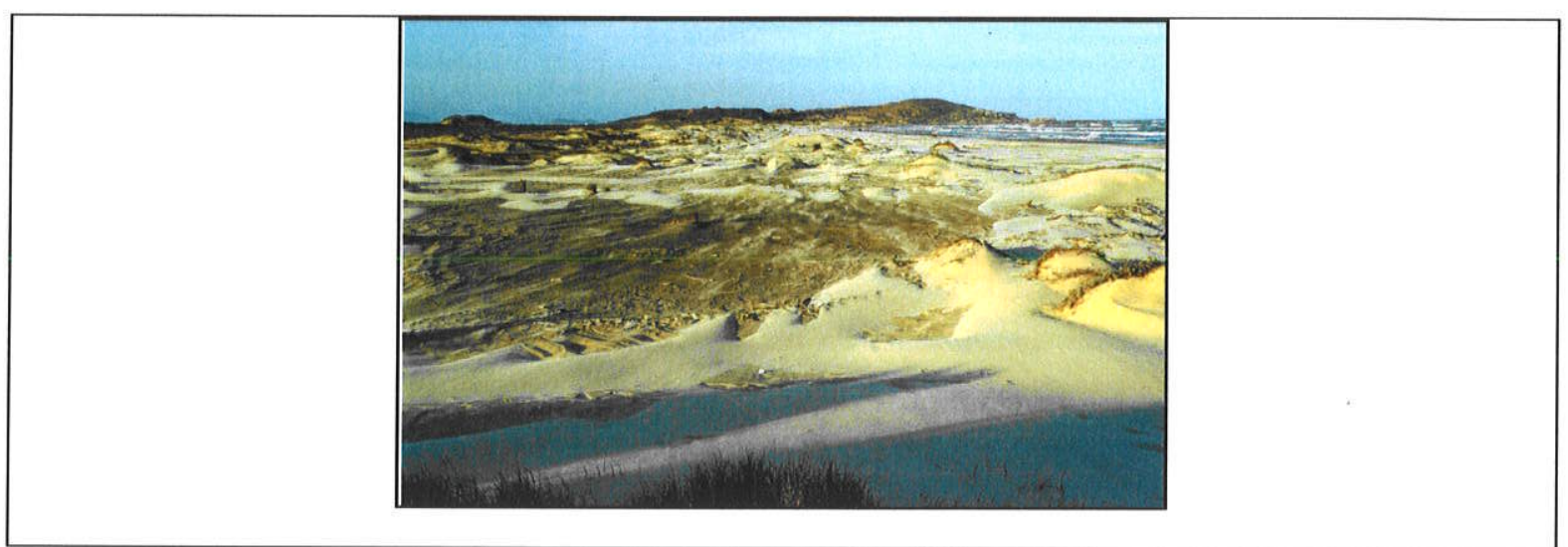

Figura 3.69. Campo de protodunas transversais e barcanóides, próximo à terminação nordeste da praia do Ji (Laguna), SC. A ponta do Ji, limite norte da praia, pode ser vista ao fundo.

Em Ibiraqüera (Figura 3.38A), a concavidade da praia é mais acentuada que no Ji, principalmente na terminação norte. A variação de morfologia dunar é similar. No limite sul da praia, a umidade e coesão das areias de antepraia impossibilita a formação de dunas frontais. Rumo NE, tem-se primeiramente terraço de dunas frontais estabelecidas, com $0,4 \mathrm{~m}$ de altura e, em seguida, já na porção média da praia, cordão de dunas frontais estabelecidas contínuo, de 3 a $4 \mathrm{~m}$ de altura, com dunas frontais incipientes em rampa, com altura de cerca de $0,5 \mathrm{~m}$, no sopé. No limite norte da praia, as dunas frontais encontram-se na forma de cordões incipientes descontínuos de até 2,2 $\mathrm{m}$ de altura. Entre a zona de espraiamento e as dunas frontais, observam-se protodunas e/ou pequenas dunas transversais de até $0,5 \mathrm{~m}$ de altura e 3,5 m de espaçamento, em que o carpete de tração se apresenta como um dos processos eólicos mais atuantes.

Aparentemente, as dunas frontais incipientes do extremo norte dessas praias tornamse instáveis devido ao soterramento por grande quantidade de sedimentos arenosos, o que dá lugar a protodunas e dunas transversais sem vegetação. Desse modo, a variação longitudinal de morfologia dunar, com aparecimento gradual de dunas sem vegetação de SW para NE, torna evidente o aumento de estoque sedimentar de areia eólica junto à praia, neste rumo. Segundo Martinho \& Giannini (2001) e Martinho et al. (2007), dois fatores principais podem estar condicionando este aumento. O primeiro relaciona-se à estocagem de sedimentos na terminação setentrional da praia pela corrente de deriva litorânea residual de rumo NE ou NNE, conforme o modelo de Giannini (1993) e Giannini \& Santos (1994). O segundo fator seria a concavidade do arco praial, e a conseqüente obliqüidade do vento em relação à linha de costa. Na parte norte das praias do $\mathrm{Ji}$ e lbiraqüera, onde a linha de costa possui direção paralela ao vento efetivo, vindo de NE, a areia eólica permanece junto à praia. A ausência de obstáculos ao longo da praia favorece a manutenção da velocidade de fluxo e a deposição sob forma de carpete de tração. Na parte sul destas praias, o vento passa a atuar obliquamente, rumo ao continente, fazendo com que parte da areia se disperse em meio à planície de deflação do campo de dunas. A menor retenção de areia eólica junto à praia desfavorece a manutenção das formas tipicamente sem vegetação, como dunas transversais e protodunas. Com isso, chega-se, na extremidade sudoeste, ao predomínio local de dunas frontais estabelecidas ou até mesmo à ausência de dunas eólicas. No caso da praia Grande do Sul, o quase perfeito paralelismo entre campo de dunas e linha de costa explicaria a maior extensão do trecho de dunas sem vegetação. Relacionado a este fato, o efluxo de areia eólica para o interior é drasticamente reduzido. Ao mesmo tempo, o espaço de acumulação eólica entre a área fonte praial e o limite interno do campo de dunas torna-se restrito. O aumento da relação entre aporte e espaço de 
acumulação propicia o entulhamento da antepraia por dunas sem vegetação e previne a formação de dunas frontais e de área deflacionar ao longo de maior parte da praia.

Os dois fatores evocados por Martinho \& Giannini (2001) e Martinho et al. (2007) relacionam-se entre si, pois a planimetria ligeiramente assimétrica da linha de costa, mais curva a barlamar (SW) que a sotamar, reflete o rumo da deriva litorânea residual. Conclui-se, portanto, que o exame minucioso da distribuição dos depósitos eólicos de orla praial faz por confirmar a influência exercida direta ou indiretamente pela deriva litorânea longitudinal.

\section{Em setores costeiros dominados por dunas frontais}

Estudos sobre a variação de morfologia e dimensões de dunas frontais ao longo das praias de Una, Juréia e Ilha Comprida, no litoral sul paulista (Ferreira et al. 2003, Ferreira 2003, Bentz 2004, Nascimento et al. 2005, Nascimento 2006, Giannini et al. 2007b), evidenciam forte relação entre o tipo de duna e o regime morfodinâmico ou erosivodeposicional da praia, este vinculado ao padrão inferido de células de deriva litorânea.

$\mathrm{Na}$ praia do Una, caracterizada por relativa estabilidade da linha de costa e por deriva litorânea residual dirigida para NE (Souza 1997, Bentz \& Giannini 2003), a morfodinâmica, em seus $15 \mathrm{~km}$ de extensão, apresenta três comportamentos distintos: dissipativo, no terço nordeste e no extremo sudoeste, intermediário-dissipativo, na porção central, e intermediário-reflexivo, na porção meio-sudoeste. Dunas frontais incipientes, com forma de cordão contínuo e retilíneo, constituem o elemento morfológico francamente predominante, exceto pela ocorrência de terraços de dunas frontais incipientes em montículos isolados próximo à desembocadura de rios e sangradouros. $\mathrm{O}$ aumento de altura das dunas frontais rumo NE (Figura 3.70) pode ser relacionado ao aporte sedimentar crescente, seja por efeito da deriva litorânea predominante seja pela chegada dos sedimentos do rio Una do Prelado. Representa, paralelamente, correlação positiva com o grau de dissipatividade da praia.

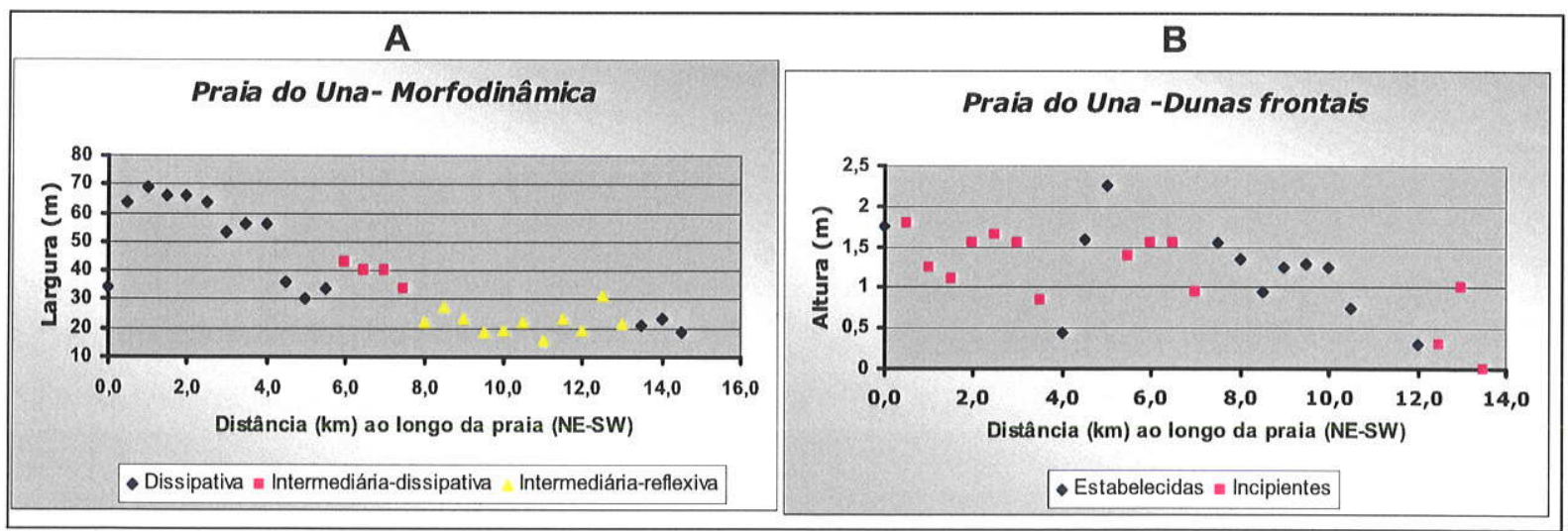

Figura 3.70. Variação de largura e morfodinâmica praial (A) e de altura e tipo de duna frontal (B) ao longo da praia do Una (Peruíbe), SP, de NE para SW. Notar aumento da largura da praia e da altura das dunas frontais no rumo da deriva litorânea residual (NE).

Já na praia da Juréia, caracterizada por células de deriva litorânea divergentes na porção meio-sul (Bentz \& Giannini 2003, Ferreira et al. 2003, Ferreira 2003; Figura 3.71A), com erosão associada da ordem de alguns metros por ano (Menezes 1994), o predomínio é de paleodunas cimentadas, com cobertura vegetal densa e diversificada, e de dunas frontais estabelecidas. Paleodunas com morfologia sugestiva de modificação por blowout, erodidas pelas ondas na forma de falésias, são comuns. A relativa escassez ou subdesenvolvimento de dunas frontais incipientes pode ser correlacionada à extensão e intensidade do processo 
erosivo. Dentro desse cenário geral, o campo de nebkhas existente no extremo sudoeste da praia representaria anomalia local, ligada ao aporte pela desembocadura do Ribeira de Iguape e à intensa deriva invertida a sotamar (SW) de sua desembocadura.

A análise da variação da altura de duna em função da distância ao longo da praia da Juréia, levando em consideração o tipo de duna (Figura 3.71B), evidencia que as maiores alturas, encontradas na porção central, estão associadas a paleodunas, enquanto as menores, concentradas no terço sudoeste da praia, associam-se a dunas frontais incipientes. Dentre as paleodunas, observa-se tendência de incremento de altura para NE, talvez associada ao aumento de aporte eólico (por sua vez ligado à paleoderiva litorânea) nesse rumo. Já as frontais estabelecidas aumentam rumo SW porque ocorrem restritas à porção da praia em que o suprimento sedimentar por deriva litorânea regional encontra-se localmente invertido pelo efeito molhe hidráulico do rio Ribeira de Iguape.

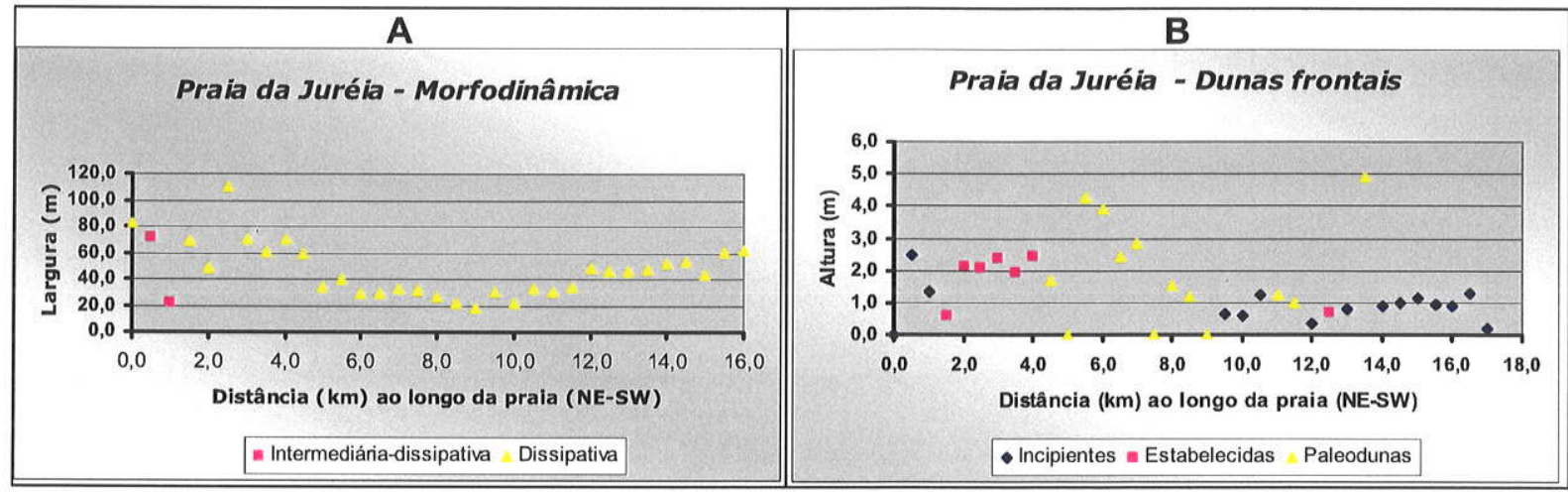

Figura 3.71. Variação de largura e morfodinâmica da praia $(A)$ e da altura e elemento morfológico eólico (B), ao longo da praia da Juréia (Iguape), SP. Em A, a porção mais estreita da praia coincide com o trecho onde se observa, em fotos aéreas, truncamento de cordões litorâneos pela linha de costa atual, e, no campo, presença de falésias vivas.

A morfodinâmica da praia da ilha Comprida é dominantemente dissipativa, com variações locais para intermediária-dissipativa (rhytmic bar and beach), na extremidade sudoeste, intermediária-reflexiva (transverse bar and rip) desde essa extremidade até $4 \mathrm{~km}$ de distância rumo NE, e dissipativa com cúspides (longshore bar trough), nos 12 km seguintes. Apresenta dois trechos de estreitamento, com largura inferior a $60 \mathrm{~m}$ (em relação a preamar de maré média), ligados a aumento do ângulo de mergulho da antepraia $(>0,8$ grau). O primeiro estreitamento compreende o setor de praia menos dissipativa, junto à terminação sudoeste. O segundo ocorre adjacente ao morro de Icapara, próximo à terminação nordeste (entre 58 e $62 \mathrm{~km}$ rumo NE) da ilha-barreira, e coincide com zona marcada por intensa erosão nas últimas quatro décadas. A partir da comparação de fotografias aéreas de 1962 e 2000, a erosão neste setor pode ser explicada pela destruição de uma projeção da linha de costa, formada entre 1938 e 1945 e preservada pelo menos até 1965 (Geobras 1966). Tal projeção relaciona-se provavelmente ao desvio temporário da terminação nordeste da barreira para $\mathrm{N}$ durante esse período, com decorrente mudança na configuração dos bancos de maré vazante e aprisionamento de areia a barlamar (SW) da antiga desembocadura lagunar de Icapara. Após 1965, com a migração progressiva da desembocadura para NE por meandramento, a projeção da linha de costa teria começado a erodir à medida que deixava a zona de sombra hidrodonâmica produzida peos bancos de vazante (Giannini et al. 2007b).

Os depósitos eólicos ativos da ilha Comprida podem ser classificados em quatro tipos: dunas frontais, rupturas de deflação, dunas parabólicas e cadeias barcanóides, este último encontrado exclusivamente em pequeno campo de dunas transgressivo $(2 \times 0.5 \mathrm{~km}) \mathrm{na}$ região de máximo estreitamento da ilha, próximo à vila de Icapara. 
Dunas frontais, incipientes e estabelecidas, são observadas ao longo de toda a praia, principalmente sob a forma de cordão, mas também em terraço e rampa (Figura 3.72). Os terraços de dunas frontais mais típicos são baixos (predominantemente menores que $1,0 \mathrm{~m}$ ) e ocorrem junto às duas desembocaduras lagunares que delimitam a ilha. Dunas frontais incipientes com geometria em rampa, ancoradas principalmente sobre paleodunas, predominam no trecho entre 10 e $26 \mathrm{~km}$ de distância da extremidade sudoeste. Em alguns casos, como no setor sob erosão no nordeste da praia, a forma aparente de cordão assimétrico resulta do soterramento de falésia de duna frontal estabelecida por rampa de duna frontal incipiente, evidência de reconstrução eólica recente. As alturas máximas medidas encontram-se em cordões da parte meio-sudoeste da praia: 3,6 m, nas dunas estabelecidas, e 2,9m nas incipientes. Observa-se correlação direta entre a altura das dunas frontais incipientes e a largura da praia (Figura 3.73). Esta correlação inverte-se nas terminações da ilha, onde o alargamento da praia relacionado à aproximação das desembocaduras lagunares de Cananéia e Icapara é acompanhado por formação de terraços baixos de dunas frontais incipientes.

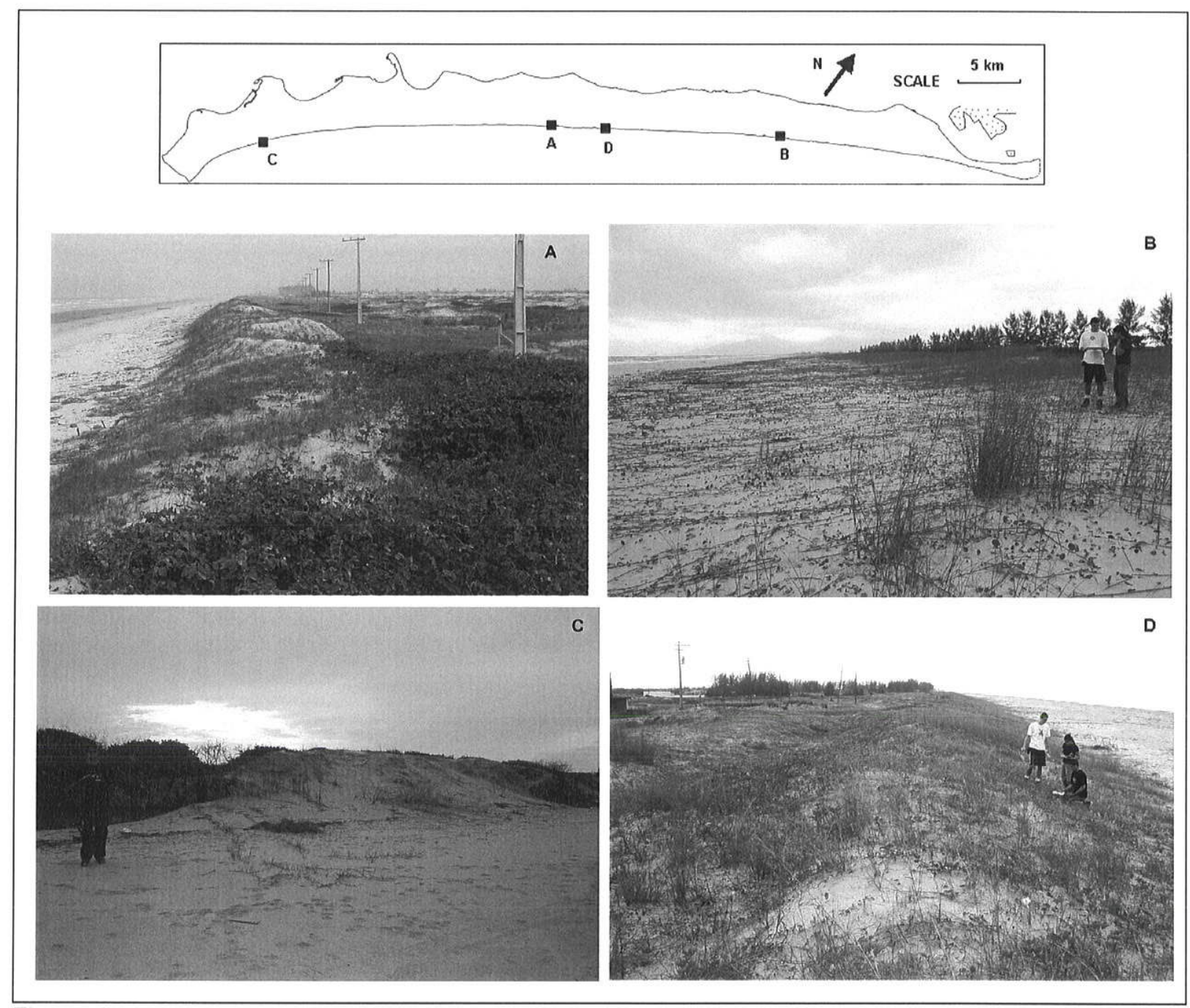

Figura 3.72. Tipos de feições eólicas ativas na praia de ilha Comprida, SP. A. Duna frontal incipiente em cordão, B. Duna frontal incipiente em terraço. C. Duna frontal incipiente em rampa, ancorada em falésia sobre duna frontal estabelecida. D. Dunas frontais estabelecida (à esquerda) e incipiente, em cordão. Localização dos pontos encontra-se indicada no mapa. 


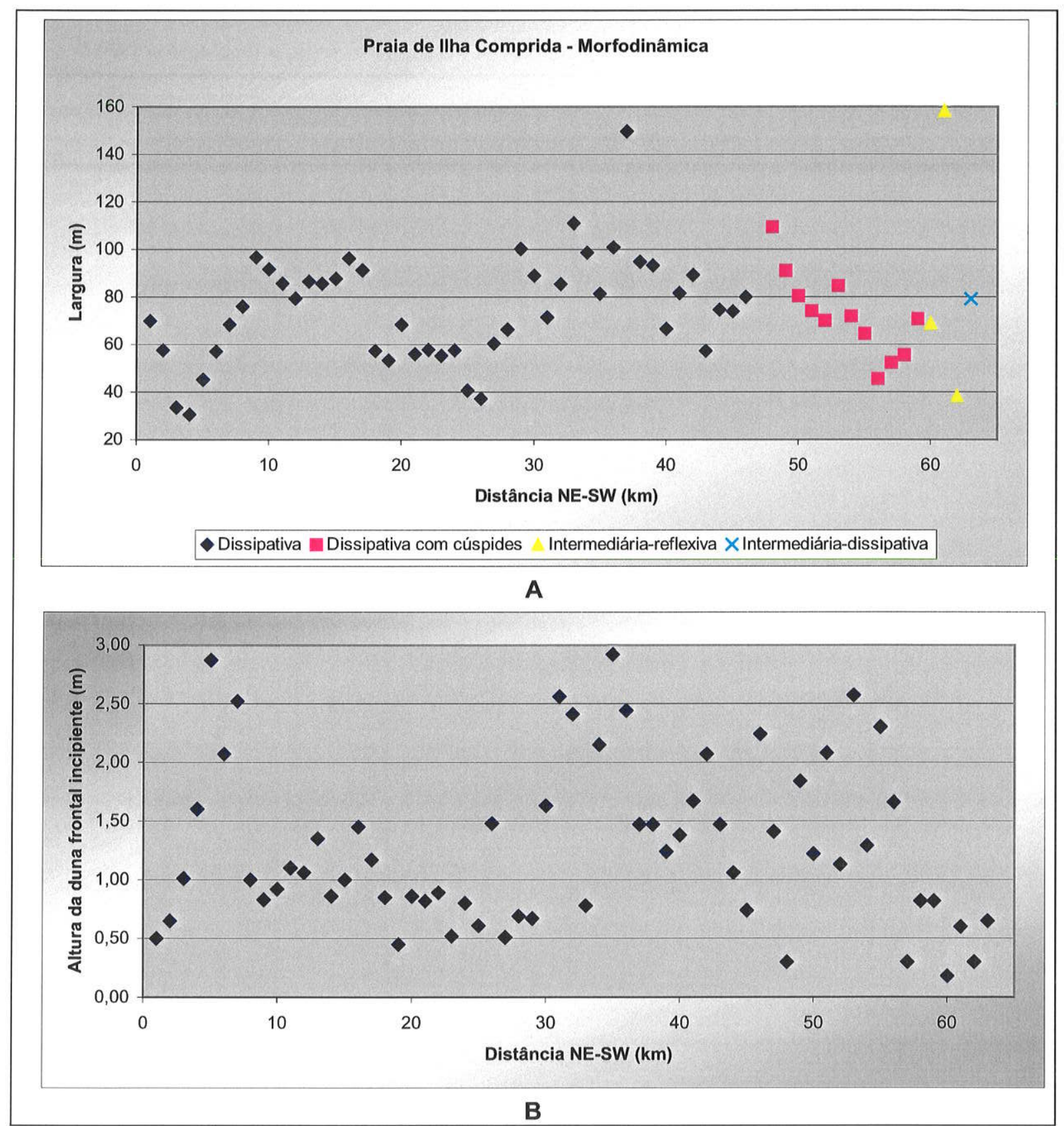

Figura 3.73. Variação da largura da praia (A) e da altura das dunas frontais incipientes (B) em função da distância ao longo da praia de llha Comprida, SP, de NE para SW.

As rupturas de deflação podem ocorrer atadas ou desligadas dos cordões de dunas frontais ativos, formando, em ambos os casos, lobos deposicionais preferencialmente orientados para NNW. As formas atadas são responsáveis pela sinuosidade freqüentemente observada na crista dos cordões de frontais. Já as independentes apresentam dois modos de ocorrência. Dentro do trecho entre 10 e $26 \mathrm{~km}$ de distância da desembocadura de Cananéia, em que as paleodunas se encontram mais próximas da praia, muitas vezes com sinais de erosão recente na forma de falésias de até $2 \mathrm{~m}$ de altura, as rupturas apresentam- 
se coalescidas e/ou superpostas. Seus lobos deposicionais, alongados por até dezenas de metros e tendendo a dunas parabólicas, precipitam sobre a cobertura arbórea de paleodunas e terraços marinhos (Figura 3.36). A segunda forma de ocorrência de rupturas de deflação desligadas de dunas frontais encontra-se no pequeno campo de dunas transgressivo de Icapara, onde eles evoluem ao interior para dunas parabólicas e raras cadeias barcanóides, de até $8 \mathrm{~m}$ de altura. Esta passagem de feições mais deflacionares para feições mais deposicionais pode ser relacionada ao aumento da razão de saldo sedimentar eólico (influxo/efluxo) rumo ao interior. A presença exclusiva de campo de dunas na parte nordeste da ilha, coincidente com sua zona mais estreita, pode ser explicada pela alta relação entre aporte eólico e área de acumulação. Além da redução local de área de acumulação, o suprimento de areia pode também ter sido localmente aumentado no final do século XIX e início do século $X X$, quando esta área se encontrava imediatamente a barlamar da desembocadura de Icapara, situação favorável a aprisionamento de areias costeiras (Giannini et al. 2007b).

Conclui-se que a sucessão de elementos morfológicos eólicos ao longo do sistema praia - duna frontal é determinada pela distribuição longitudinal de sedimentos. Esta, por sua vez, seria controlada principalmente pela área fonte continental imediata (falésias e rios) e pelo padrão de deriva litorânea longitudinal. Uma dedução lógica a partir desta hipótese é a de que a alternância e/ou passagem gradual entre feições eólicas de caráter deposicional e erosivo, encontrada nas praias do litoral sul paulista, pode ser correlacionada à existência de zonas de excesso ou déficit, respectivamente, de sedimentos no prisma praia-duna.

Em ordem de vocação deposicional eólica descrescente, os elementos morfológicos eólicos dos sistemas praia-duna estudados no litoral sul de São Paulo podem ser separados em seis categorias principais: 1. elementos de estocagem sedimentar imediata, representados pelas dunas frontais incipientes em terraço ou cordão (Figuras 3.74 a 3.76); 2. elementos de estocagem sedimentar imediata retomada, correspondente a dunas frontais incipientes em rampa (Figura 3.77); 3. elementos relacionados a estocagem sedimentar interrompida, abrangendo as dunas frontais incipientes com falésias vivas (Figura 3.78); 4. elementos de manutenção de estoque mediato, correspondentes às dunas frontais estabelecidas (Figura 3.79A); 5 . elementos de erosão temporária, representados por dunas estabelecidas ativas com falésias (Figura 3.79B); e 6. elementos com erosão duradoura, equivalentes a paleodunas com falésias (Figura 3.79C), categoria encontrada nas praias da Juréia e de liha Comprida. Diferentes elementos podem ocorrer combinados no mesmo ponto da praia, em disposição espacial que permite reconstituir a sucessão de eventos recentes. Por exemplo, falésia de paleoduna (6) coberta por duna estabelecida com falésia (5), esta por sua vez ancorando duna frontal incipiente com falésia viva (3), é uma sucessão característica de aumento da relação deposição/erosão. Os elementos descritos podem também variar espacialmente, ao longo da mesma praia, permitindo interpretar a distribuição de zonas preferenciais de erosão e deposição.

Os resultados de distribuição das seis categorias genéticas de elementos morfológicos eólicos ao longo das praias da Juréia e Una indicam que as feições consideradas como de caráter mais erosivo associam-se preferencialmente a zonas interpretadas de acordo com o modelo de rumo de deriva litorânea adotado como de barlamar, enquanto os elementos de caráter mais construtivo associam-se a zonas de sotamar. 


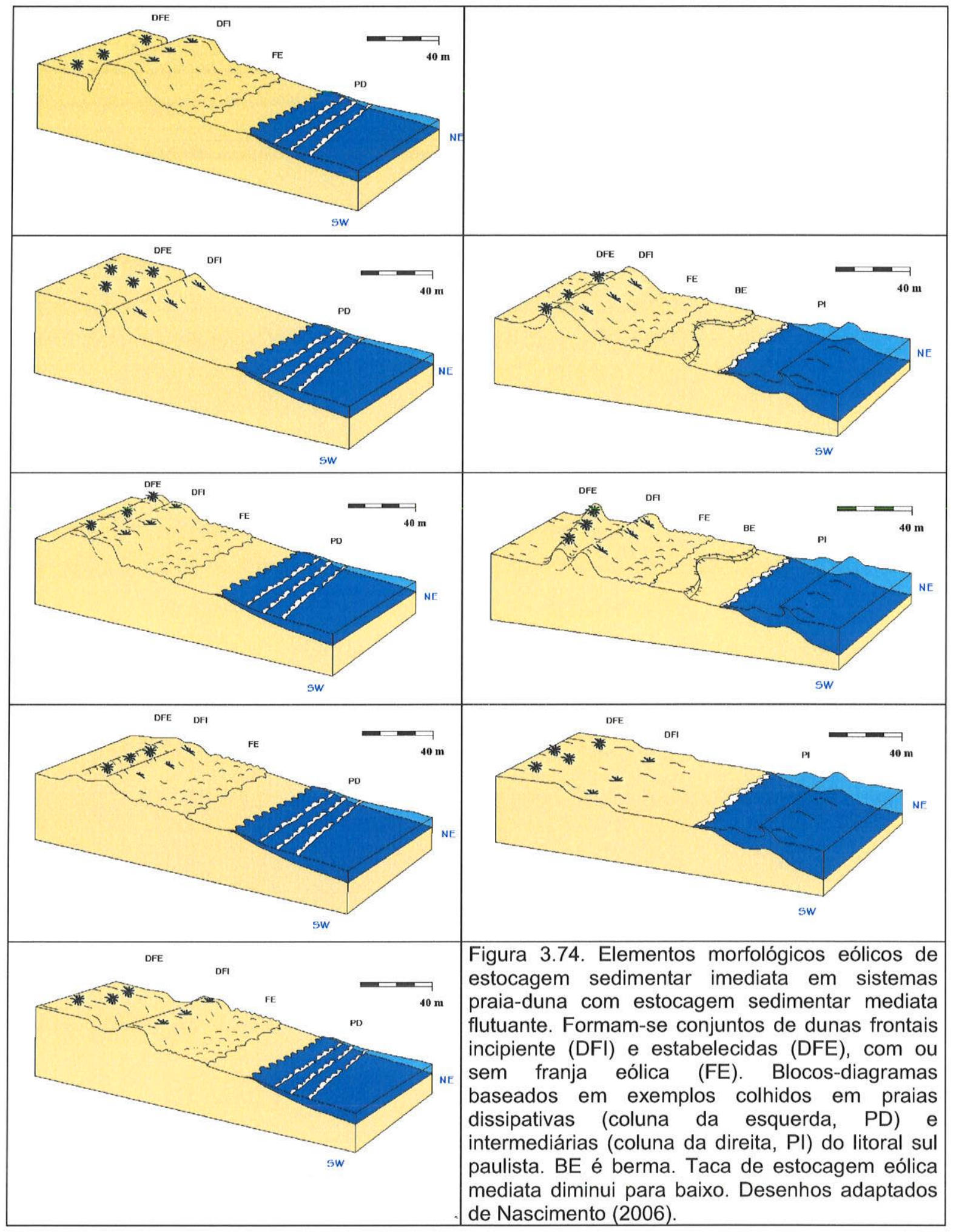




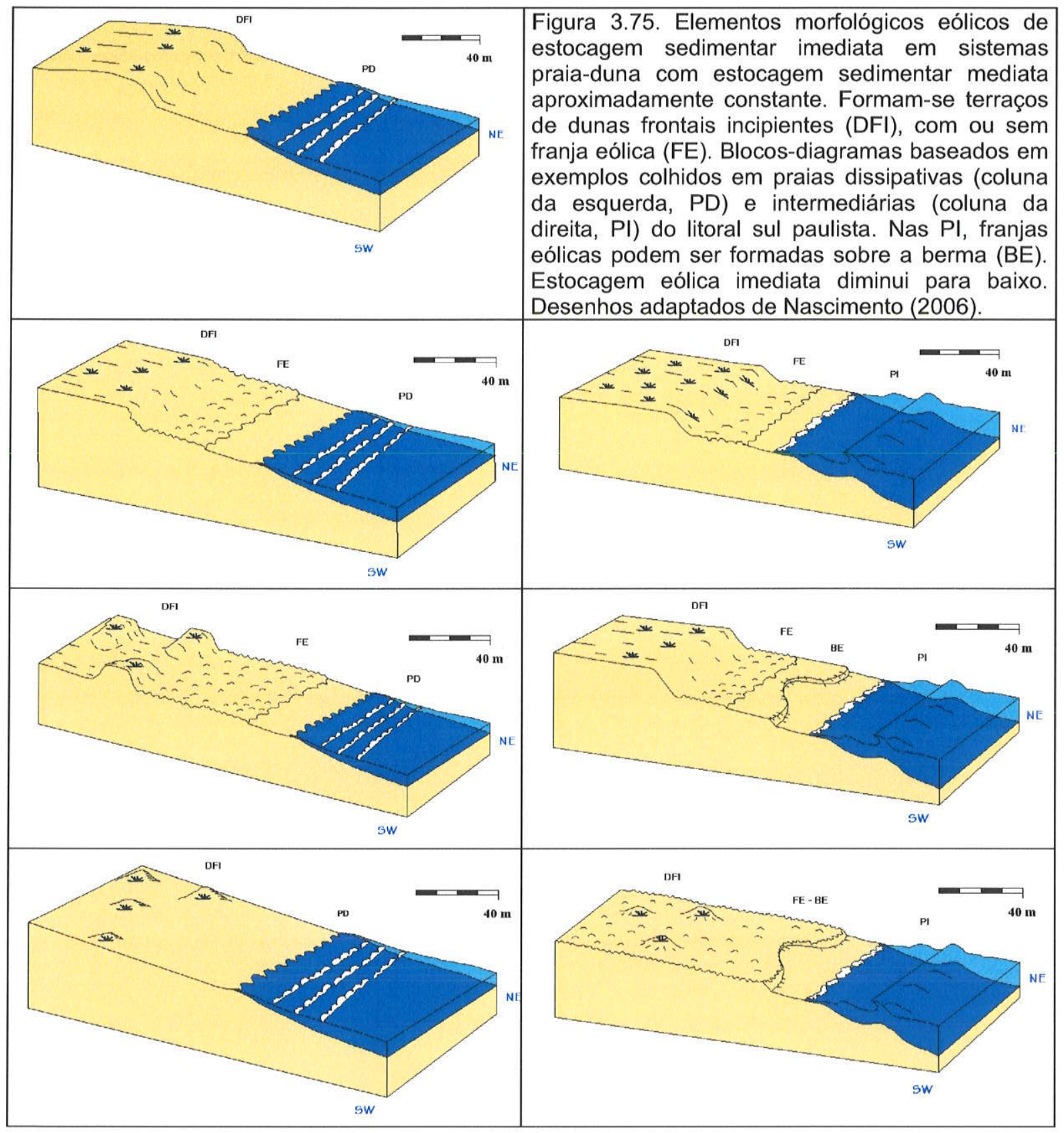




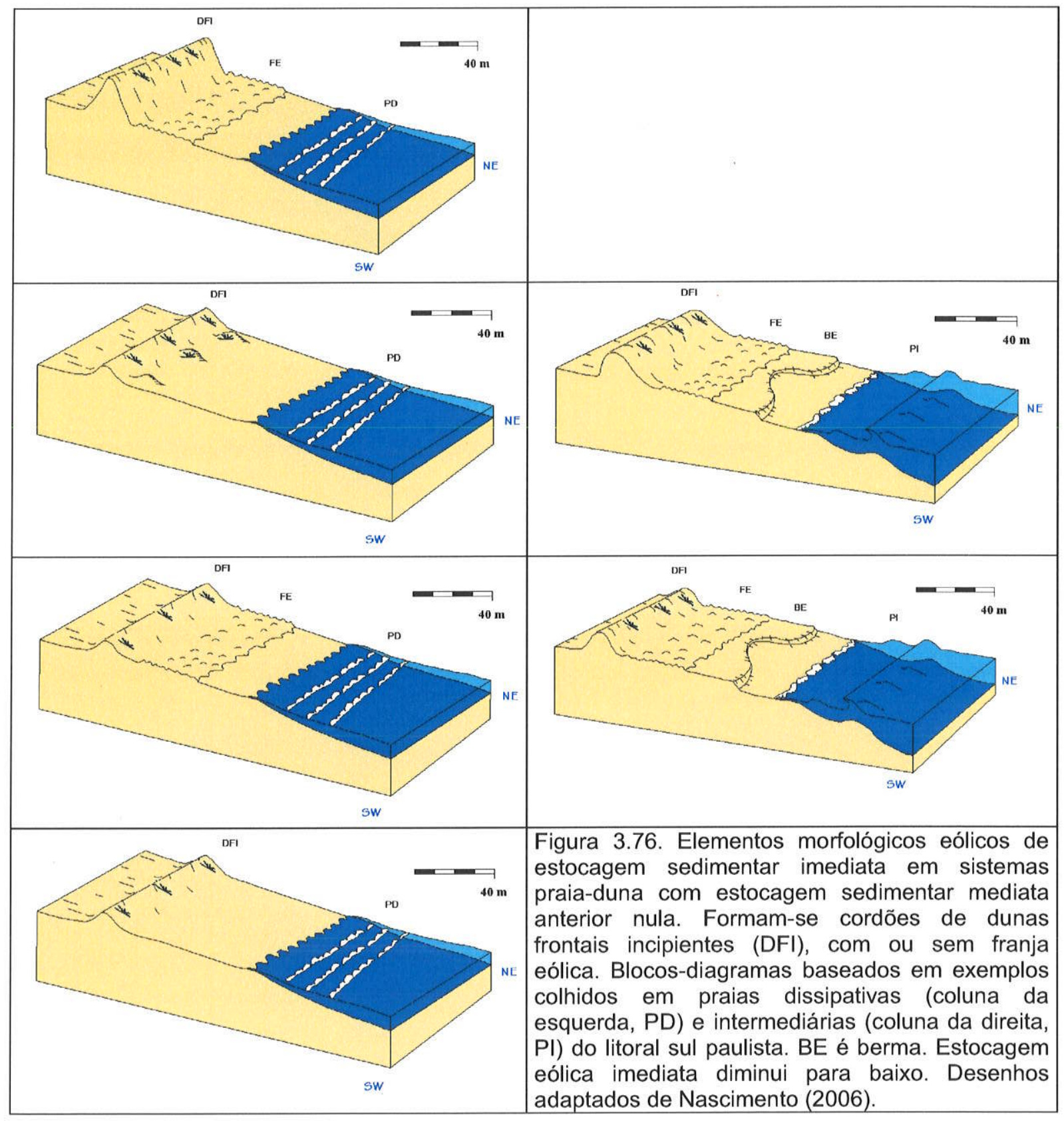




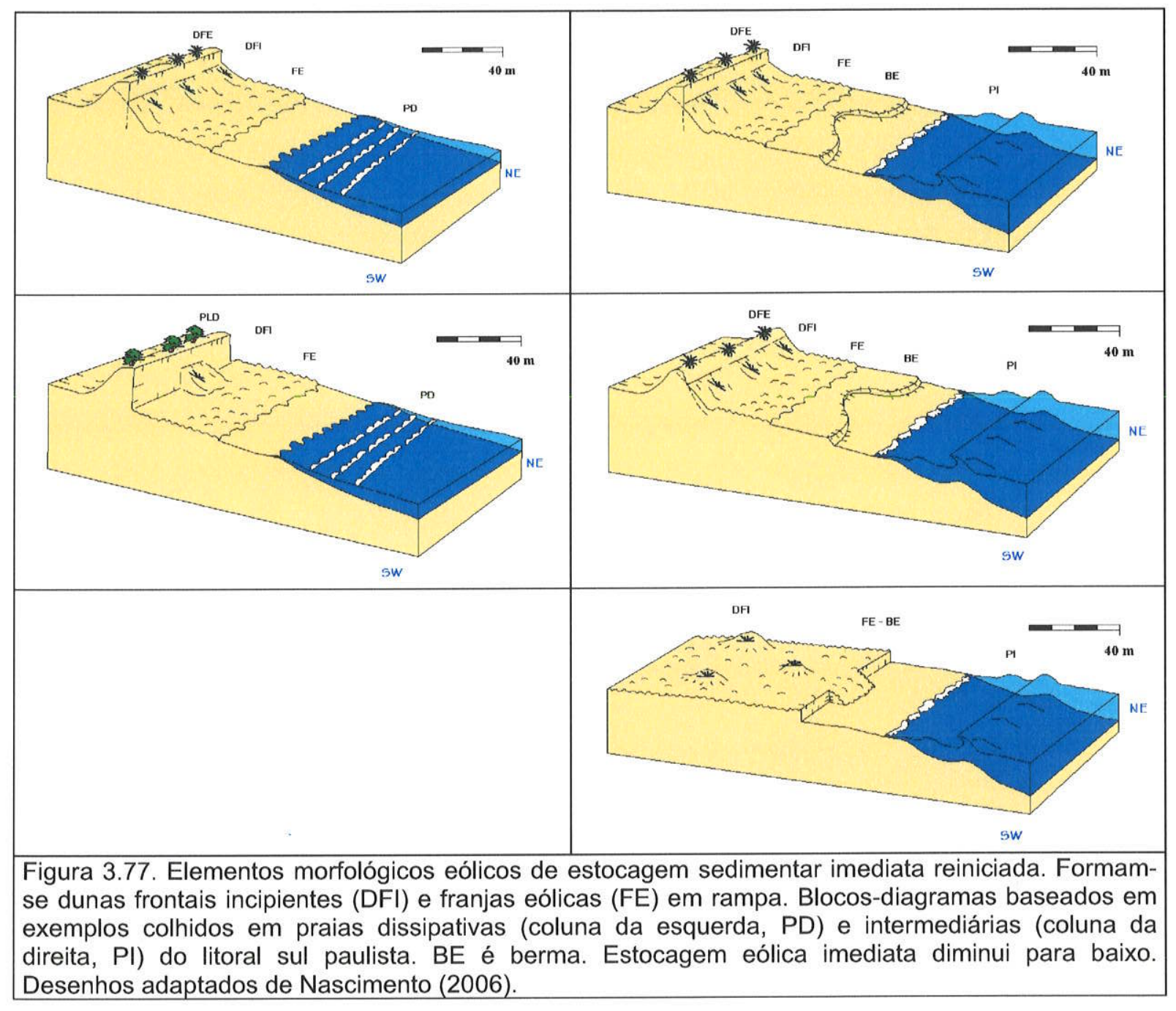




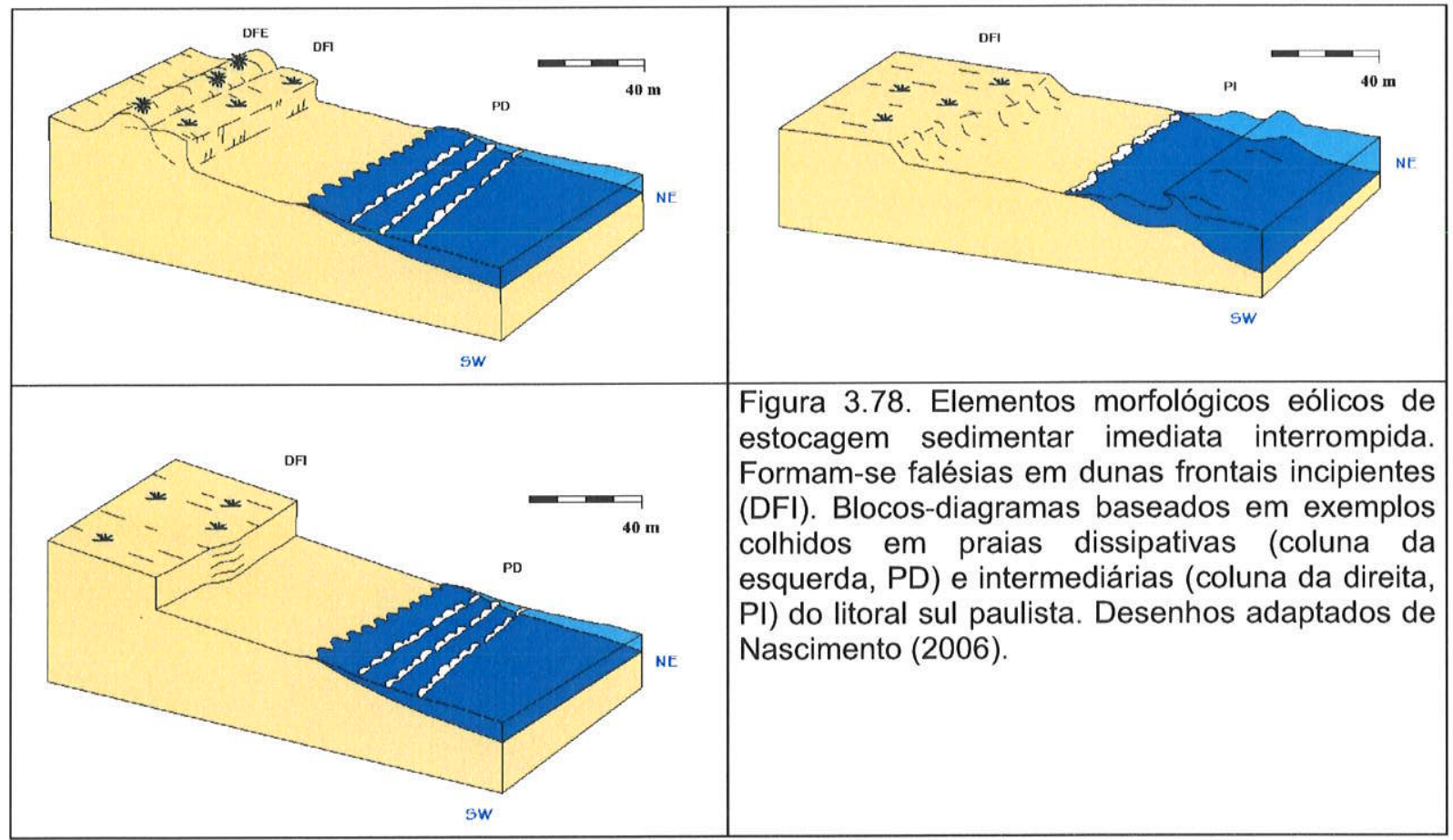




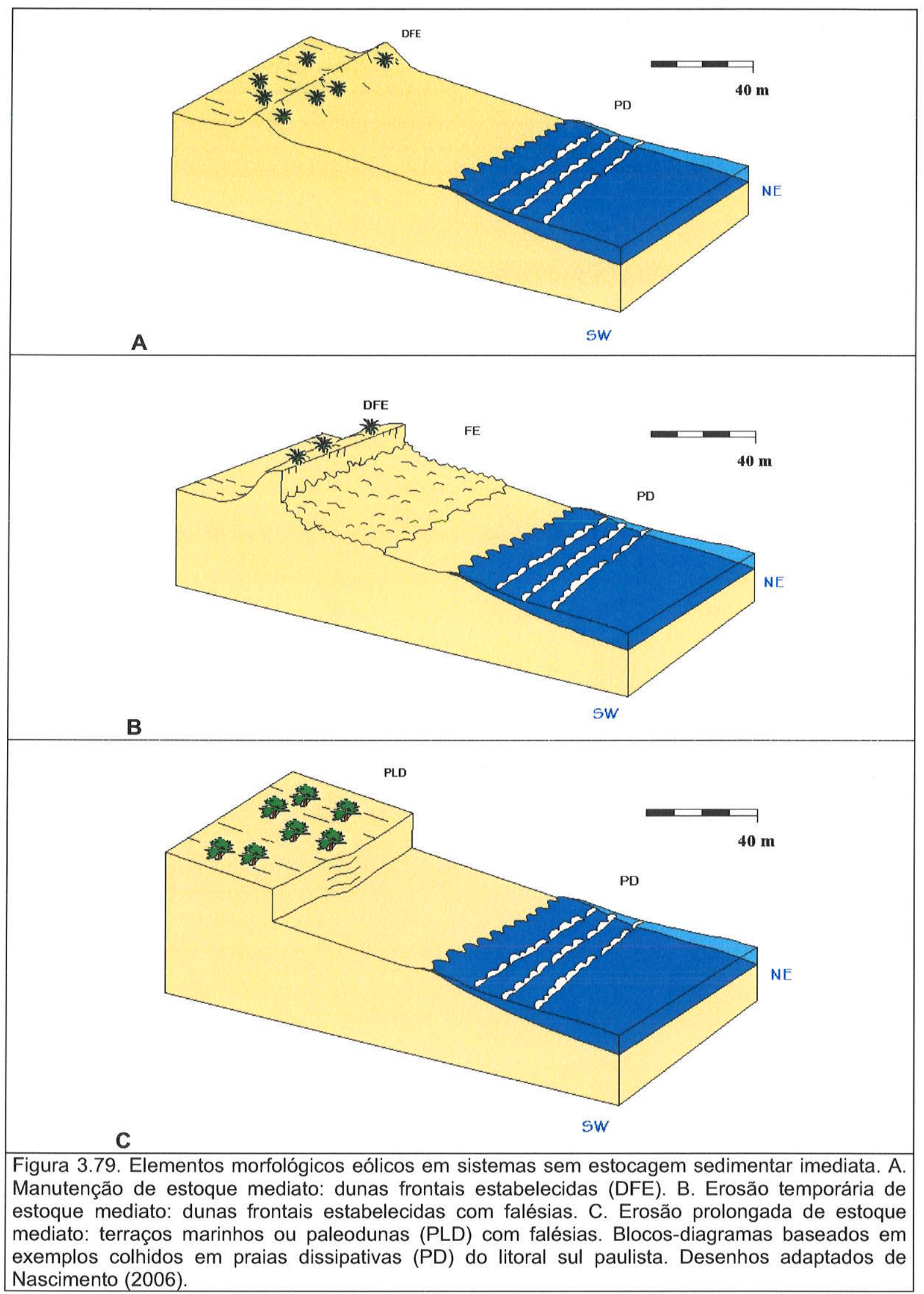


Em relação aos aspectos da morfodinâmica praial, as zonas de barlamar e os elementos eólicos típicos de baixo estoque sedimentar sempre coincidem com áreas de estreitamento. Nas praia do Una e de llha Comprida, coincidem também com trechos mais reflexivos. Levando-se em consideração, conforme Wright et al. (1979), que a morfodinâmica reflexiva representa excesso de sedimentos na antepraia rasa e falta de sedimentos na antepraia profunda e face litorânea, a presença de morfodinâmica mais refletiva nos trechos de barlamar indica que a saída de sedimentos destas zonas, por deriva litorânea, dá-se predominantemente no prisma submerso da praia e não na antepraia rasa. Por outro lado, tem sido reconhecida na literatura uma associação preferencial ou correlação direta entre aporte eólico e dissipatividade da praia (Short 1988, Giannini 1993, Giannini \& Santos 1994), pelo menos no caso de campos de dunas transgressivos. Os resultados obtidos até o momento, especialmente na praia do Una, indicam que esta relação pode ser estendida ao caso de dunas frontais, uma vez que os regimes eólicos mais deposicionais (construção de dunas incipientes) ocorrem nos trechos atualmente mais dissipativos. Parece existir correlação direta, portanto, entre o estoque de sedimentos no prisma submerso do sistema praia-duna (antepraia profunda e face litorânea) e o estoque de sedimentos eólicos.

\subsubsection{Morfodinâmica}

Do ponto de vista genético, a classificação dos elementos ou associações de fácies em com versus sem vegetação não é eficiente, pois feições com vegetação, como dunas parabólicas e rastros lineares, associam-se, com freqüência, a zonas de deflação a barlavento de campos de dunas livres. Além disso, é possivel a passagem, no tempo e no espaço, de um tipo vegetado para um livre, na dependência de variações no equilibrio entre a taxa de suprimento eólico e a taxa de crescimento de vegetação (Giannini \& Santos 1994; Giannini et al. 2005). Desse modo, os dois tipos maiores de elementos morfológicos eólicos aqui reconhecidos não são completamente independentes. Este fato torna conveniente adotar uma classificação de associações faciológicas que leve em consideração a distribuição e interação entre estes diferentes tipos de elementos, como função do efluxo e do influxo, o que é uma das metas finais desta Tese.

Um primeiro passo na construção dessa classificação foi dado em relação aos campos de dunas livres ativos da costa centro-sul de Santa Catarina onde as duas associações de fácies eólicas reconhecidas com base em critérios morfológicos (maciça versus deflacionar) e, ao mesmo tempo, de posição relativa no sistema deposicional (proximal versus distal, respectivamente) possuem também significado genético quanto a aporte e morfodinâmica. $A$ associação de fácies maciça seria formada sob razão influxo/efluxo mais elevada, ou DEE menor, que a associação deflacionar (Giannini 1993, 1998, 2001, Giannini et al. 2001b, Martinho \& Giannini 2002, Martinho 2004, Martinho et al. 2007), como evidenciado pela escassez de feições de deflação e maior volume de areia.

A distribuição geográfica da associação de fácies proximal pode estar ligada ao excesso de areia em desequilibrio na face litorânea e costa afora, favorecido pela redução do gradiente da plataforma interna a sul de Santa Marta, Laguna, SC (Giannini, 1993, 1998, 2002; Giannini \& Santos, 1994; Giannini et al., 2001b,c). Mas pode relacionar-se também à orientação do vento efetivo em relação à linha de costa (Martinho \& Giannini 2002, Matinho et al. 2004). Sob esse aspecto, é importante destacar que o campo de dunas transgressivo entre Santa Marta e Campo Bom é um dos poucos no Brasil com orientação essencialmente paralela à costa.

$\mathrm{Na}$ proposta original das duas associações de fácies de Santa Catarina, importância fundamental foi creditada à "fácies" de dunas frontais, encarada como estoque primário de areia eólica costeira. Esta "fácies" seria exclusiva da associação proximal. As dunas frontais, quando instáveis, de ocorrência restrita e/ou temporária, constituiriam a fonte 
imediata de areia para a associação de fácies proximal. Quando estáveis, sob a forma de cordões contínuos e perenes favorecidos pela baixa DEE, seriam a "fácies" única da mesma associação abortada, isto é, não desenvolvida completamente por falta de areia. De acordo com esse modelo, a segunda associação situa-se sempre a sotavento da primeira, seja esta abortada ou não, dela se separando por uma área deflacionar, onde se encontram suas fácies mais proximais (Giannini 1993, 1998).

Nas áreas de aporte eólico mais efetivo, a deposição de areia eólica junto à praia ocorre em taxa maior que a velocidade de crescimento de vegetação pioneira, o que dificulta o desenvolvimento perene de dunas frontais. Este estado de desequilibrio favorece a instabilização maciça destas dunas, dando vez ao desenvolvimento de extensos campos de dunas transgressivos que se iniciam na orla praial e só terminam nas frentes parabólicas interiores, distantes por até dezenas de quilômetros. No caso de campos de dunas paralelos à costa, a proximidade da área fonte praial ao longo de toda a extensão do campo de dunas também favorece o aporte eólico e a instabilização de dunas frontais. Nas áreas costeiras de aporte eólico menor, as dunas frontais não se instabilizam, mas sofrem deflação gradual pelo ventos prevalecentes, formando dunas parabólicas de migração lenta, as quais se coalescem em maior ou menor grau na forma de lençóis de areia e campos de dunas transgressivos, de geometria geral parabólica, sempre menos extensos que os depósitos maciços proximais. O grau de instabilização das dunas frontais, processo fundamental na distinção entre os dois tipos de associações de fácies, aumenta, ao longo de dado setor praial, no rumo de deriva litorânea longitudinal (Giannini 1993, Giannini \& Santos 1994).

A classificação em dois tipos de associações de fácies maiores pode ser estendida aos sistemas eólicos costeiros de outras regiões do Brasil. Assim, a presença da associação proximal pode ser reconhecida por exemplo em parte dos campos de dunas do Maranhão, como Lençóis, Ponta das Gaivotas e Tutóia, nas "dunas móveis do segmento externo" reconhecidas por Claudino-Sales (2002) na costa cearense, principalmente em sua porção noroeste (por exemplo, entre a Ponta Aguda e a foz do rio Curu), em parte da unidade LA referida por Barbosa (1997) no litoral adjacente à foz do rio São Francisco e na costa sulriograndense entre Quintão e Mostardas (Tomazelli 1990). Já a associação de fácies distal predominaria na maioria das demais áreas com campos de dunas transgressivos. Apesar dessa sua ampla aplicabilidade, trata-se de uma classificação excessivamente abrangente, e que não dá conta das importantes diferenças morfológicas e sedimentológicas entre associações de mesmo tipo nas diferentes áreas costeiras do país. 


\section{Modelo genético para o sistema eólico costeiro do Brasil}

\subsection{Funções de elementos}

Um modelo genético para o sistema eólico costeiro pressupõe sua abordagem como domínio do espaço (espaço de acumulação), cujo volume sedimentar é controlado por entradas e saídas (influxo e efluxo eólicos) dependentes das variáveis do meio. Este é o princípio geral da descrição externa de sistemas, referido no item 3.2.1. Levar este princípio a cabo no âmbito da descrição externa do sistema deposicional significa focar a descrição do seu funcionamento em termos de variáveis do espaço de acumulação (altura e distância de equilíbrio) e do saldo entre influxo e efluxo. O primeiro passo é portanto entender e classificar a função de cada fácies ou associação de fácies (elemento morfológico e deposicional) no controle desse saldo e no preenchimento daquele espaço.

Para facilidade de análise, será inicialmente admitida a premissa de que o sistema eólico se encontra em equilíbrio dinâmico, isto é, com influxo igual a efluxo, ou em desequilibrios próximos deste equilíbrio. $\mathrm{Na}$ situação mais típica, após aumento da relação influxo/efluxo eólico, o sistema deve atravessar uma fase de crescimento e configuração morfológica (com influxo maior que efluxo, rumo a condição de equilíbrio), seguida de fase de manutenção ativa ou equilíbrio estacionário (balanço entre influxo e efluxo, com constância de forma e redução da dinâmica a processos de migração do sistema). Admitida esta premissa de situações de desequilíbrio restritas às proximidades do equilibrio, as reações do sistema a pequenas flutuações das variáveis de estado (relação influxo/efluxo) serão de retroalimentação negativa, incluindo adaptações na altura e distância de equilíbrio. Também para facilidade de análise, serão inicialmente (até o item 4.4) consideradas fixas outras variáveis além do saldo sedimentar, como, por exemplo, o espaço de acumulação.

\subsubsection{Elementos de suprimento inicial}

Considerando que a posição relativa dos elementos morfológicos reflete suas funções e que as funções aqui referem-se a fluxo de sedimentos, o exame das funções de cada elemento deve partir das posições mais proximais em relação à área fonte sedimentar, a praia, para as mais distais. Os elementos que se situam imediatamente junto à praia, e que portanto materializam a entrada inicial dos sedimentos costeiros no sistema eólico, são os de dunas frontais (estabelecidas e incipientes), franjas de areia, protodunas e dunas sem vegetação de orientação transversal ao vento (com respectivas planícies interdunas e nebkhas ou retrocordões associados). Maior parte da areia incorporada nestes elementos provém diretamente da praia. Eles podem portanto ser classificados como elementos de estoque (ou suprimento ou entrada) inicial, cujas funções são armazenar e fornecer areia para as demais fácies do sistema eólico (Giannini 1993). Correspondem a feições deposicionais tipicamente primárias, no sentido de Davies (1980), modificado por Short (1988), isto é, depósitos eólicos derivados diretamente das areias de praia, sem estocagem intermediária (segundo Short 1988, campos de dunas primários resultam da "instabilização maciça de dunas frontais" e "transporte direto praia - duna frontal - duna interior", enquanto que os secundários seriam formados pela "coalescência de blow-outs ou parabólicas"). A idéia das dunas frontais e feições relacionadas como geradoras das outras formas eólicas é antiga. Solger (1910 apud Cooper 1958) já afirmava que "...em toda a diversidade (de feições eólicas) deve-se atentar firmemente ao fato de que cada duna costeira veio originalmente de uma duna frontal vegetada".

A existência de elementos de estoque inicial é condição sine qua non para o desenvolvimento e manutenção em atividade do sistema eólico costeiro, independentemente das caracteristicas texturais e morfológicas desse sistema. Eles constituem, desse modo, a 
única categoria funcional de elemento morfológico que possui existência universal. Por outro lado, os elementos morfológicos de estoque inicial só serão os únicos do sistema quando, sozinhos, forem suficientes para satisfazer a condição de equilibrio (influxo igual a efluxo), seguida ou não de desequilibrio erosivo (efluxo maior que influxo). $\mathrm{Na}$ outra hipótese, condição de desequilíbrio construtivo neste conjunto de elementos (influxo maior que efluxo), o excesso de areia tende a ser consumido na formação e alimentação de outros tipos de fácies eólicas. Surge assim a necessidade de existência de associações de fácies ou elementos mais interiores. Esta parece ser uma situação típica ou muito comum quando os elementos de estoque inicial não possuem vegetação. No caso de dunas frontais incipientes, o eventual excesso de areia pode tanto ser consumido na geração de outros tipos de elementos, por exemplo, rupturas de deflação e/ou dunas parabólicas, como também na formação de elementos similares, isto é, dunas frontais estabelecidas. As dunas estabelecidas possuem relação influxo/efluxo tipicamente de equilibrio, visto que representam apenas trânsito (by-pass) de sedimentos. Isto significa que, se os elementos de estoque inicial compreenderem apenas dunas estabelecidas, não existe reabastecimento do sistema eólico. Assim, a manutenção de dunas frontais estabelecidas, sem erosão, como elemento inicial único (Figura 3.79A), é uma situação instável e improvável. Ou elas são acompanhadas por dunas incipientes, por pequenas que sejam (Figura 3.74), ou submetemse à erosão pelas ondas, na forma de falésias vivas, o que caracteriza sistema eólico em condição de desequilibrio destrutivo, com efluxo maior que influxo (Figura 3.79B). A alternância entre estas duas situações pode ser o mecanismo a mais longo prazo pelo qual o sistema eólico costeiro se mantenha numa situação de saldo próximo de zero.

Para dada orientação do vento e da linha de costa, a altura e a distância de equilibrio do sistema eólico aumentam em função direta do incremento na relação influxo/efluxo dos elementos de estoque inicial. Assim, ao longo de uma praia em que exista variação no tipo de elemento eólico de estoque primário, o campo de dunas tende a ser melhor desenvolvido em altura e extensão nos trechos de dunas sem vegetação, como transversais e protodunas, que nos trechos de dunas frontais.

\subsubsection{Elementos de deflação}

Seguindo rumo às partes mais afastadas da área fonte praial, o sistema eólico pode apresentar um grupo de elementos tipicamente secundários, derivados da deflação atuante sobre depósitos eólicos preexistentes (mais comumente dunas primárias ativas). Este grupo inclui rupturas de deflação, rastros lineares residuais, retrocordões, dunas parabólicas e parte dos montes residuais. Se modificados pela própria deflação superimposta, alguns destes elementos podem ser de difícil distinção entre si, reconhecendo-se então apenas mares de nebkhas. Traços comuns a estes elementos são o caráter vegetado e a elevada capacidade de reciclagem dos próprios sedimentos. Esta capacidade está ligada ao papel desta associação de fácies perante a operação geral do sistema eólico costeiro, que é o de separar duas acumulações principais (estoque inicial e estoque final) segundo a distância de equilibrio. A capacidade de transferência de sedimentos aumenta das rupturas de deflação para as dunas parabólicas isoladas, das parabólicas isoladas para as parabólicas com rastros lineares e retrocordões a barlavento, e destas para os retrocordões e rastros a barlavento de barcanas e barcanóides. Desse modo, a distância e a altura de equilibrio do sistema eólico costeiro aumentam à medida que a zona de deflação passe a incluir esses elementos, na ordem mencionada. 


\subsubsection{Elementos de superposição e cavalgamento e elementos de avanço}

Quando o saldo sedimentar criado nos elementos de estoque inicial for baixo, a simples existência dos elementos de deflação pode ser suficiente para consumir todo o excesso de areia. Caso contrário, rumo ao interior, seguem-se mais um ou dois grupos de elementos possiveis. O mais proximal deles, estável apenas sob elevado saldo positivo de areia eólica, é formado por dunas barcanas e, tipicamente, cadeias barcanóides (incluindo extensões lineares), com respectivas depressões interdunas. Estes elementos podem tanto derivar-se a partir de elementos de deflação e possuir assim caráter secundário, como conectar-se diretamente a elementos de estoque inicial (protodunas e dunas transversais) e, por extensão, à praia, sendo nesse caso primários. A existência de elementos de estoque final primários relaciona-se a distância de equilibrio certamente (ainda) não atingida e, portanto, à elevado saturação sedimentar no sistema. Barcanas são relativamente raras nos campos de dunas brasileiros, onde representam aparentemente a transição entre retrocordões e cadeias barcanóides. São portanto, via de regra, secundárias, ainda que às vezes à pequena distância da praia.

O papel desta associação de elementos face à operação geral do sistema eólico costeiro é o de elevar a acumulação até sua altura de equilibrio, através da superposição sobre megaforma de hierarquia maior, representada pelo campo de dunas livre, e, ao mesmo tempo, através do cavalgamento (climbing) das formas de leito (as próprias barcanóides) de mesma hierarquia. Desse modo, trata-se de elementos de superposição e cavalgamento, dois efeitos possíveis somente se o saldo influxo-efluxo local for positivo (e, portanto, se os elementos de suprimento inicial e/ou deflação já não tiverem alcançado a altura de equilibrio do sistema). Uma vez aicançada a altura de equilibrio do sistema, porém, o elemento de cadeias barcanóides passa a representar o ponto mais alto do campo de dunas livres e seu saldo influxo-efluxo torna-se nulo. O campo de dunas pára de crescer na vertical, restando-lhe porém a possibilidade de estender-se até a distância de equilibrio, e, em seguida, de migrar.

A função de estender o campo de dunas, lateral e longitudinalmente, até sua distância de equilibrio é desempenhada pelos dois elementos mais distais do sistema, cordões de precipitação e lobos deposicionais, que podem portanto ser classificados como elementos de avanço. Na ausência de elementos de superposição, devido à razão influxo/efluxo insuficiente, os elementos de avanço assumem também a função de alcançar a altura de equilíbrio. Em analogia com os elementos de superposição, os de avanço apresentam influxo maior que efluxo enquanto, mantida a taxa de entrada de sedimentos no sistema, a distância de equilibrio não tiver sido atingida. Uma vez alcançada esta distância, o saldo influxo-efluxo nas fácies de avanço também se torna zero. A partir deste ponto, a evolução do sistema varia, conforme seu saldo influxo-efluxo como todo mantenha-se positivo ou torne-se nulo (Figura 4.1).

Se o balanço influxo-efluxo no sistema como todo permanece positivo, o sistema mantém-se através da subdivisão em duas porções, separadas por planície de deflação, de modo que a porção mais proximal passe a atuar como fonte para a distal. Com isso, a distância entre os elementos de avanço de cada porção e suas respectivas fontes sedimentares mantém-se dentro do limite de equilibrio. Trata-se de um típico exemplo de retroalimentação negativa. Pode tanto representar a transformação de um campo de dunas primário em secundário, com re-estocagem de areia eólica, na forma de um novo campo de dunas primário em iniciação, como a "duplicação" de um campo de dunas secundário. Em ambos os casos, o reaparecimento de saldo sedimentar positivo em parte do sistema serve para alimentar e manter ativa a parte restante. 


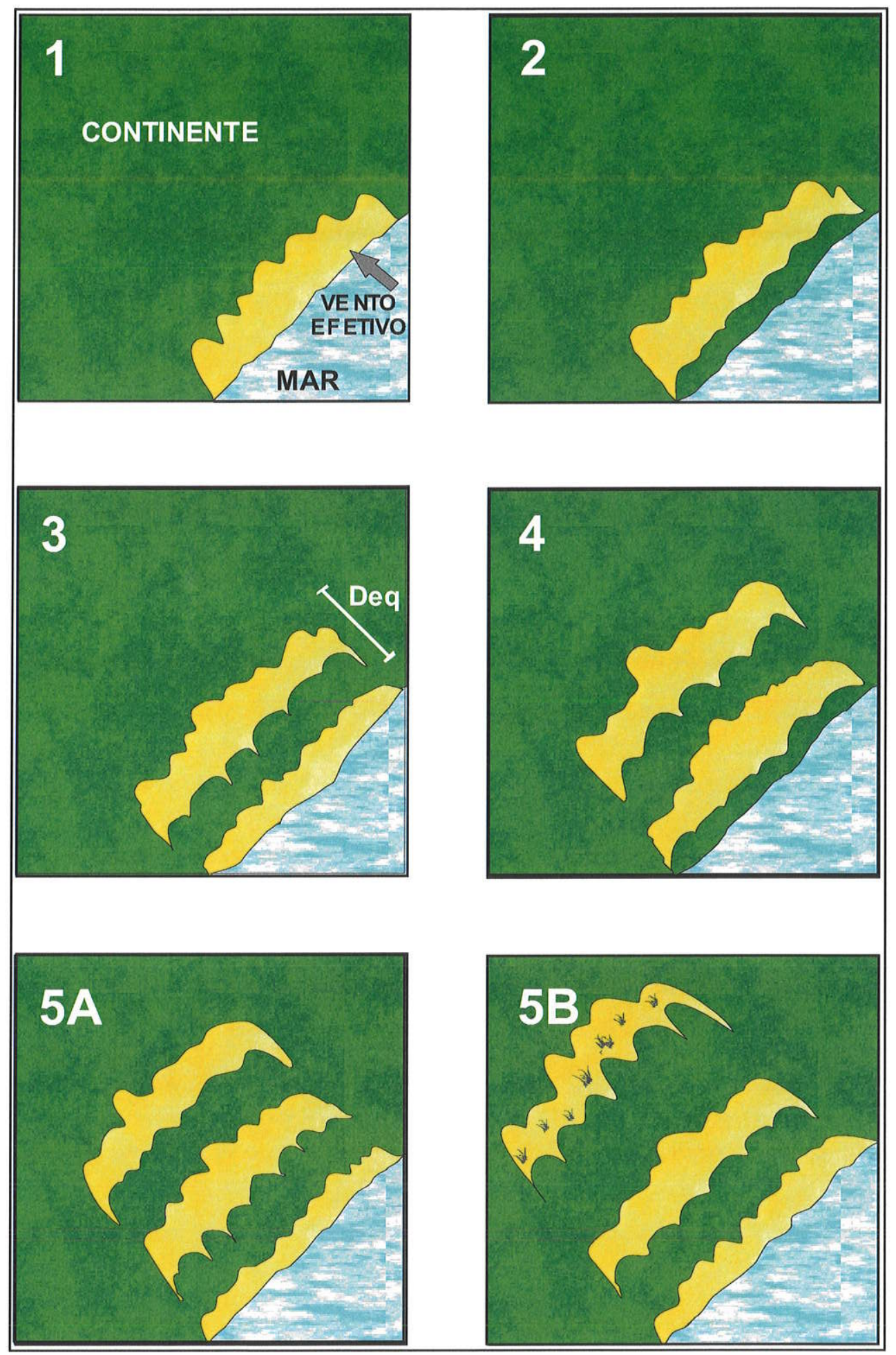

Figura 4.1. Modelo para evolução e replicação de campo de dunas adjacente a linha de costa estável. Os quadros 1 a 4 representam estágios sucessivos sob saldo sedimentar eólico positivo (influxo maior que efluxo). Os quadros $5 \mathrm{~A}$ e $5 \mathrm{~B}$ representam configurações alternativas para o estágio seguinte, sob saldo eólico positivo e nulo, respectivamente. $\mathrm{D}_{\mathrm{eq}}$ é a distância de equilíbrio. 
Este fenômeno explica a ocorrência atual ou histórica de "campos de dunas duplos", em regiões especificas da costa brasileira, por exemplo, na costa do Ceará com orientação W-E, na praia do Forte, em Cabo Frio, RJ (Figura 3.25), e em Laguna (Figura 3.27A e B), SC. A distância entre estes campos de dunas, em cada região, é característica, embora possa variar ao longo da praia na proporção direta do aporte, por exemplo, via deriva litorânea longitudinal. Em tese, a subdivisão ou multiplicação de campos de dunas pode ocorrer tantas vezes quantas a distância de equilíbrio regional for alcançada sob condição de influxo do sistema maior que efluxo. Esta distância desempenha, em escala maior, o mesmo papel que o comprimento de onda de equilíbrio em ondulações ou dunas eólicas. Sua existência indica que os campos de dunas múltiplos não representam precisamente gerações de dunas, como interpretado por Claudino-Sales 2002 (ainda que a multiplicação demande tempo e tenha portanto, de fato, um significado cronológico), mas sim trens de megaformas de mesma geração, em hierarquia superior a de duna.

Em contrapartida, se a distância de equilibrio é atingida e o saldo influxo-efluxo no sistema torna-se nulo, as fácies de avanço passam simplesmente a migrar. Esta migração leva ao distanciamento do campo de dunas, em relação à área fonte, além da distância de equilibrio e, a médio prazo, à sua estabilização. Ao mesmo tempo, um novo campo de dunas ativo tende a surgir junto à praia. Este fenômeno, por sua vez, pode ajudar a explicar a alternância entre paleodunas frontais e paleocampos de dunas (item 3.1.1.3), como os encontrados a sul da foz do São Francisco (SE), na enseada da Pinheira (SC) e na costa gaúcha entre Sarita e Albardão.

\subsection{Associações de elementos e suas combinações internas possíveis}

Definidas as funções dos elementos, resta deduzir suas associações enquanto domínios do espaço. Os elementos de estoque inicial afinam-se entre si não somente quanto à função, mas também quanto à posição dentro do sistema, pois todos situam-se na interface praia-duna. Constituem, portanto, no sentido aqui adotado, verdadeiras associações de fácies (conjuntos de fácies vizinhas que formem arranjos preferenciais e que tenham posições relativas preferenciais dentro do sistema) maiores. Analogamente, os elementos de deflação reúnem-se num segundo domínio fundamental do sistema eólico costeiro, a planície deflacionar. Os elementos de cavalgamento e de avanço, isolados ou associados, definem e delimitam uma terceira associação faciológica, o campo de dunas livres. Desse modo, dentro do modelo genético de sistema eólico costeiro aqui concebido, campos de dunas livres podem ser redefinidos como associações onde elementos de superposição e/ou de avanço estão presentes. Podem avizinhar-se, em sua margem de barlavento, tanto à associação de fácies de planície de deflação quanto à associação de fácies de interface praia-duna. No primeiro caso, o conjunto campo de dunas mais planície de deflação corresponde ao que em trabalhos anteriores (Giannini 1993, 2002, Martinho et al. 2007) convencionou-se denominar associação deflacionar ou distal, enquanto as dunas frontais compõem a associação maciça ou proximal "abortada" por falta de aporte (item 3.3.3). No segundo caso, o conjunto campo de dunas mais interface praia-duna constitui a associação maciça ou proximal plenamente desenvolvida ("não abortada").

Uma vez definidas as associações de fácies maiores, o passo seguinte consiste em verificar as diferentes possibilidades de combinações de elementos dentro de cada associação. Considerando a universalidade da associação de fácies de interface praia-duna, e que a origem do fluxo de matéria e energia aí reside, a tipologia desta associação adquire caráter fundamental. $\mathrm{Na}$ ordem de razão influxo/efluxo crescente, as seguintes possibilidades de associações de estoque inicial ou praia-duna (referidas pelo símbolo A) podem ser reconhecidas com base em exemplos brasileiros: A1. paleodunas ou dunas frontais estabelecidas com falésia viva; A2. paleodunas ou dunas frontais estabelecidas com 
falésias e dunas frontais incipientes em rampa; A3. paleodunas ou dunas estabelecidas ativas com falésias e dunas frontais incipientes em rampa, transformada em cordão assimétrico; A4. dunas frontais incipientes em cordão ou terraço; A5. dunas frontais incipientes em cordão ou terraço, com franja eólica acentuada e/ou zibars; A6. protodunas; A7. dunas de orientação transversal ao vento (transversais sensu stricto, barcanas e barcanóides) com nebkhas e/ou retrocordões (regularmente inundáveis) associados; A8. dunas de orientação transversal. Os cordões e terraços de dunas frontais incipientes (elementos $\mathrm{A} 3, \mathrm{~A} 4$ e A5) podem ser considerados os elementos de suprimento inicial típicos, todavia passiveis de instabilização seja por falta de areia (elementos A1 e A2) seja por excesso (elementos $A 6, A 7$ e $A 8$ ).

Na segunda categoria de associação de elementos, a planície deflacionar (símbolo B), as principais possibilidades podem ser assim enumeradas: B1. rupturas de deflação atadas a dunas frontais; B2. rupturas de deflação independentes, isoladas; B3. rupturas de deflação amalgamadas e/ou cavalgantes entre si; B4. rupturas de deflação, rastros lineares, e dunas parabólicas; B5. rupturas de deflação, rastros lineares e dunas parabólicas, com retrocordões e/ou montes residuais; B6. falhas isoladas de cobertura arenosa (pocket bushes). A difícil individualização dos elementos morfológicos nas associações dos tipos B3, B4 e B5, pode dar origem ao que se tem denominado de "mares de nebkhas".

$\mathrm{Na}$ associação de elementos de campo de dunas livres (símbolo $\mathrm{C}$ ), as possibilidades são basicamente três: $\mathrm{C} 1$. cordões de precipitação; $\mathrm{C} 2$. barcanóides e cordões de precipitação; C3. barcanóides, cordões de precipitação e lobos deposicionais (campo de dunas livres "completo"). Os casos brasileiros de cordões de precipitação isolados (C1) parecem relacionar-se a coalescência, tanto lateral como frontal, de dunas parabólicas.

\subsection{Combinações entre associações de elementos: os tipos de sistema}

O último passo da elaboração do modelo genético consiste em analisar os tipos de relações entre as associações de elementos quanto ao fluxo de matéria e energia, de modo a comportar uma classificação abrangente dos sistemas eólicos costeiros brasileiros. Como resultado desta análise, as relações entre as associações faciológicas podem ser resumidas em quatro categorias conforme o equilibrio entre matéria e energia (distância e altura de equilibrio) seja atingido na associação praia-duna (A), na relação entre associação praiaduna e a associação planície de deflação $(A-B)$, na relação entre as associações praia-duna, planície de deflação e campo de dunas livres (A-B-C) ou na relação direta entre as associações praia-duna e campo de dunas livres (A-C). Este último caso representa distância de equilibrio e, portanto, equilibrio entre influxo e efluxo, seguramente ainda não atingidos. A partir destas relações entre associações de elementos, os seguintes tipos de sistemas em equilibrio podem ser enumerados, mais uma vez em ordem de relação influxo/efluxo inicial (de iniciação do sistema) crescente: 1. Tipo A: dunas frontais; 2. Tipo A$\mathrm{BI}$ : dunas frontais com rupturas de deflação atadas; 3 . Tipo A-BII: dunas frontais e rupturas de deflação independentes; 4 . Tipo A-BIII: dunas frontais e dunas parabólicas; 5 . Tipo A-B$\mathrm{Cl}$ : dunas frontais, planície de deflação e cordão de precipitação; 6. Tipo A-B-Cll: dunas frontais, planície de deflação e barcanóides; 7. Tipo A-B-Cll!: dunas frontais, planície de deflação e campos de dunas livres completos; 8. Tipo A-C: protodunas/dunas transversais (sensu lato) e campos de dunas livres completos.

A geometria típica destes oito tipos de sistemas em regiões com vento efetivo transversal e sub-paralelo à costa encontra-se esquematizada nas figuras 4.2 e 4.3 , respectivamente. 


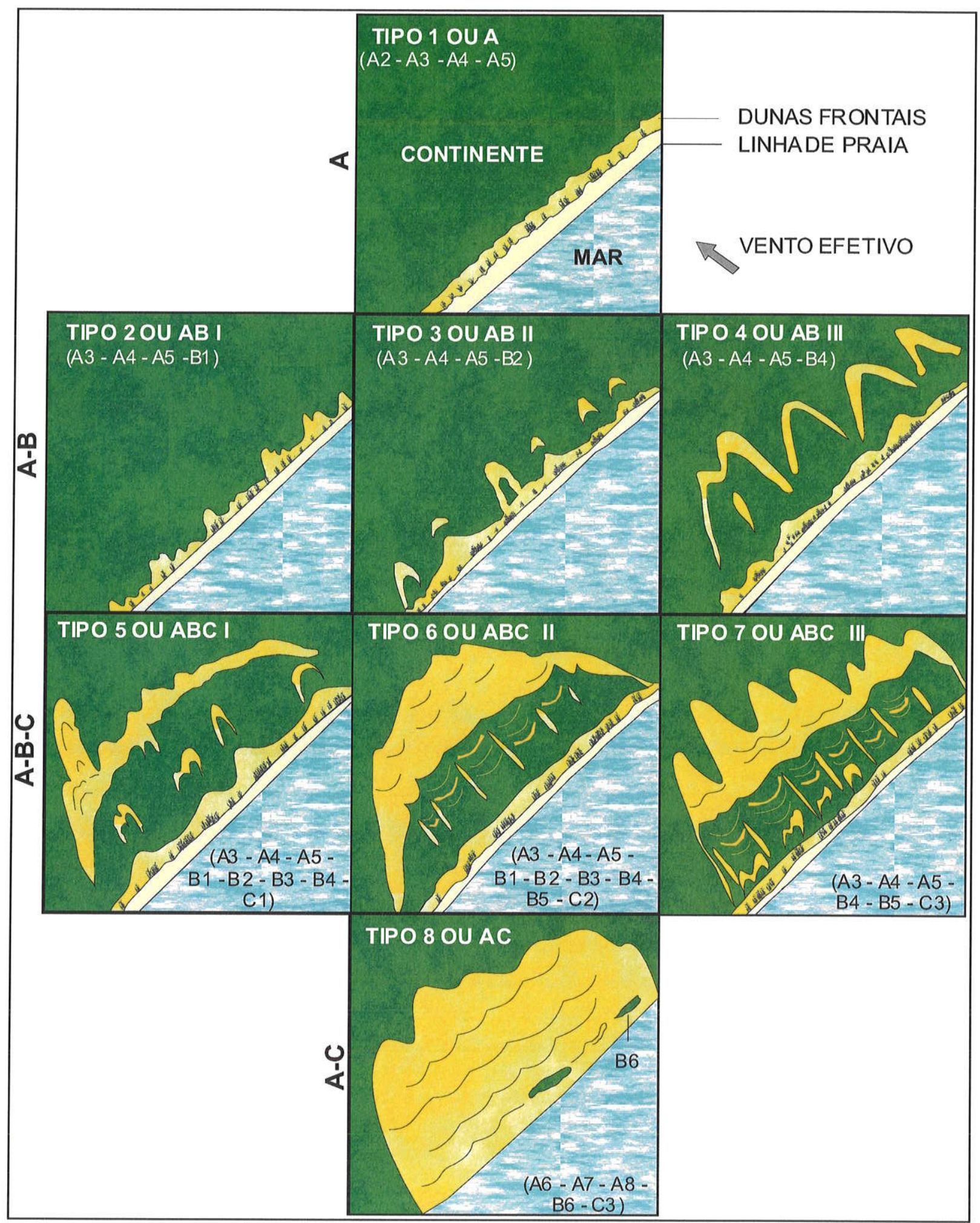

Figura 4.2. Tipos de sistemas eólicos costeiros do Brasil, sob condição de vento efetivo transversal à linha de costa. 


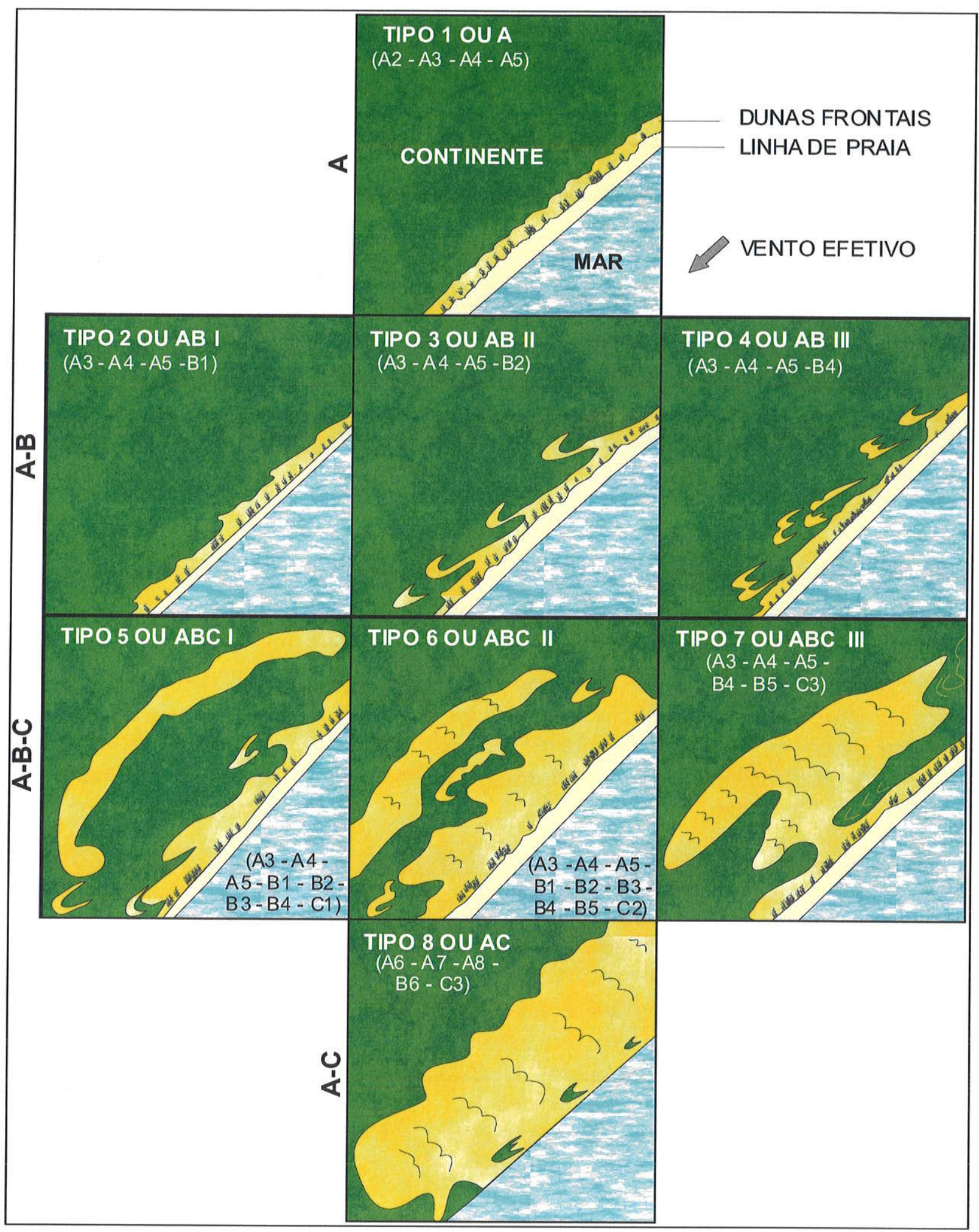

Figura 4.3. Tipos de sistemas eólicos costeiros do Brasil, sob condição de vento efetivo sub-paralelo à linha de costa. 


\subsection{Exemplos brasileiros de tipos de sistema}

A seguir, apresenta-se a descrição resumida da sucessão de elementos em cada tipo de sistema e das principais ocorrências ao longo da costa brasileira. Características comuns a várias ocorrências de cada tipo são eventualmente destacadas apenas a título de levantamento de possíveis variáveis ou condições ambientais favoráveis.

\section{Sistema eólico costeiro tipo A}

O sistema tipo A pode ser formado pelos diferentes elementos de dunas frontais $(A 2$, A3, A4 e A5), combinados ou isolados. Predomina atualmente na costa do Paraná e dos estados da Região Sudeste, bem como na porção da Região Nordeste situada a sul de Barra do Camaratuba (PB). As principais peculariaridades geomorfológico-geológicas destas duas faixas de ocorrência são a presença da serra do Mar, na faixa sul, e das falésias da Formação Barreiras, na norte. Do ponto de vista climático, estas regiões têm em comum o clima sempre úmido. Na costa sul-sudeste, este tipo de clima é encontrado também em regiões com outros tipos de sistema eólico, como o sul de Santa Catarina e o Rio Grande do Sul, aí porém sob condições de verão menos ameno.

\section{Sistema eólico costeiro tipo A-BI}

O sistema tipo A-BI é formado por elementos de dunas frontais (A3, A4 e A5) com cristas sinuosas devidas à superimposição de elementos de rupturas de deflação (B1), sem chegar a gerar formas de deflação independentes (Figura 4.4). Encontra-se este tipo de sistema principalmente em trechos específicos das costas sudeste e nordeste, com destaque para a porção central da ilha Comprida, SP, a metade oeste da Restinga de Massambaba, RJ, e a costa norte baiana e sul sergipana. Em todos os exemplos, o vento efetivo na formação das rupturas de deflação é sub-perpendicular à linha de costa. A extensão do sistema ao interior varia de poucos a dezenas de metros e o clima preferencial é o sempre úmido. 


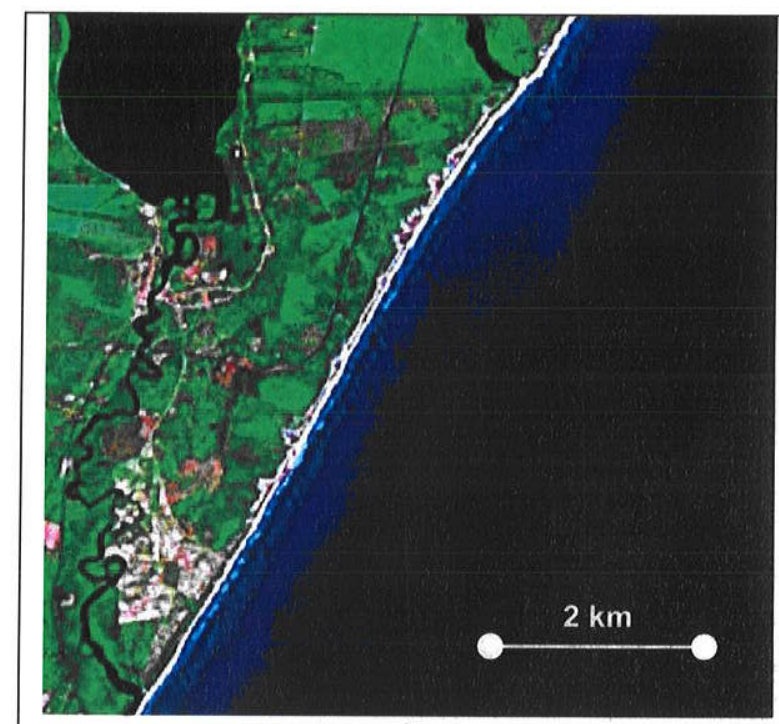

A

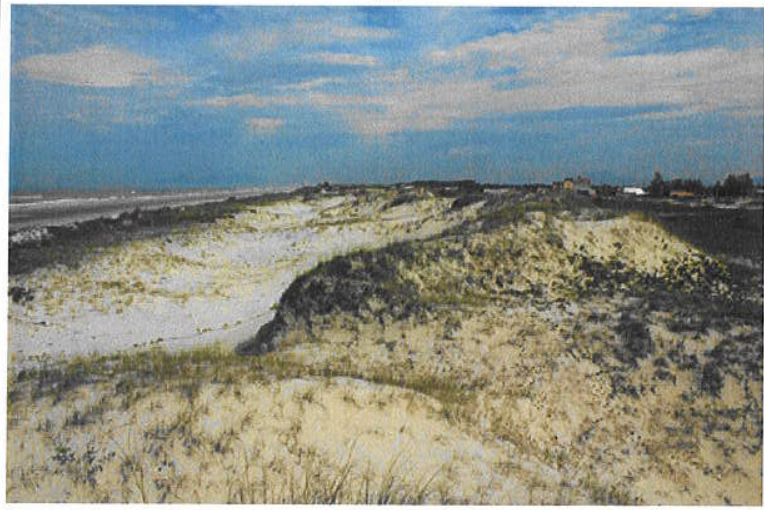

C

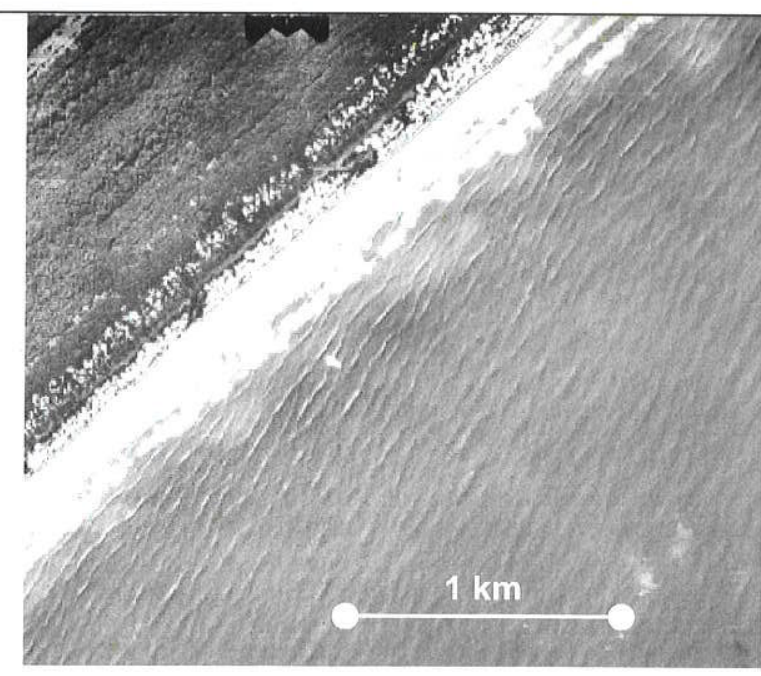

B

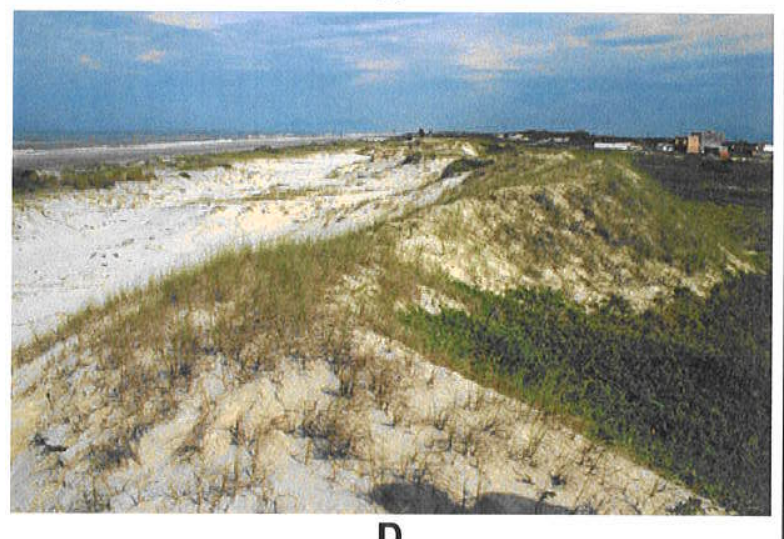

D

Figura 4.4. Exemplos de sistemas eólicos costeiros do tipo 2 ou A-BI. A. Praia da Barra do Jequiá (São Miguel dos Campos), AL. B, C, D. Praia de llha Comprida, SP, cerca de $22 \mathrm{~km}$ a NE da desembocadura de Cananéia. 


\section{Sistema eólico costeiro tipo A-BII}

O sistema A-BII constitui-se de elementos de dunas frontais (A3, A4 e A5), com rupturas de deflação independentes ao interior (elementos B2). Ocorre localmente nas mesmas praias em que se encontra o tipo 2 (Figura 4.5). É exemplificado na porção meiosudoeste da ilha Comprida, especialmente entre as distâncias 16 e $23 \mathrm{~km}$ a partir da ponta sudoeste, onde as rupturas de deflação chegam a avançar mais de uma centena de metros ao interior.

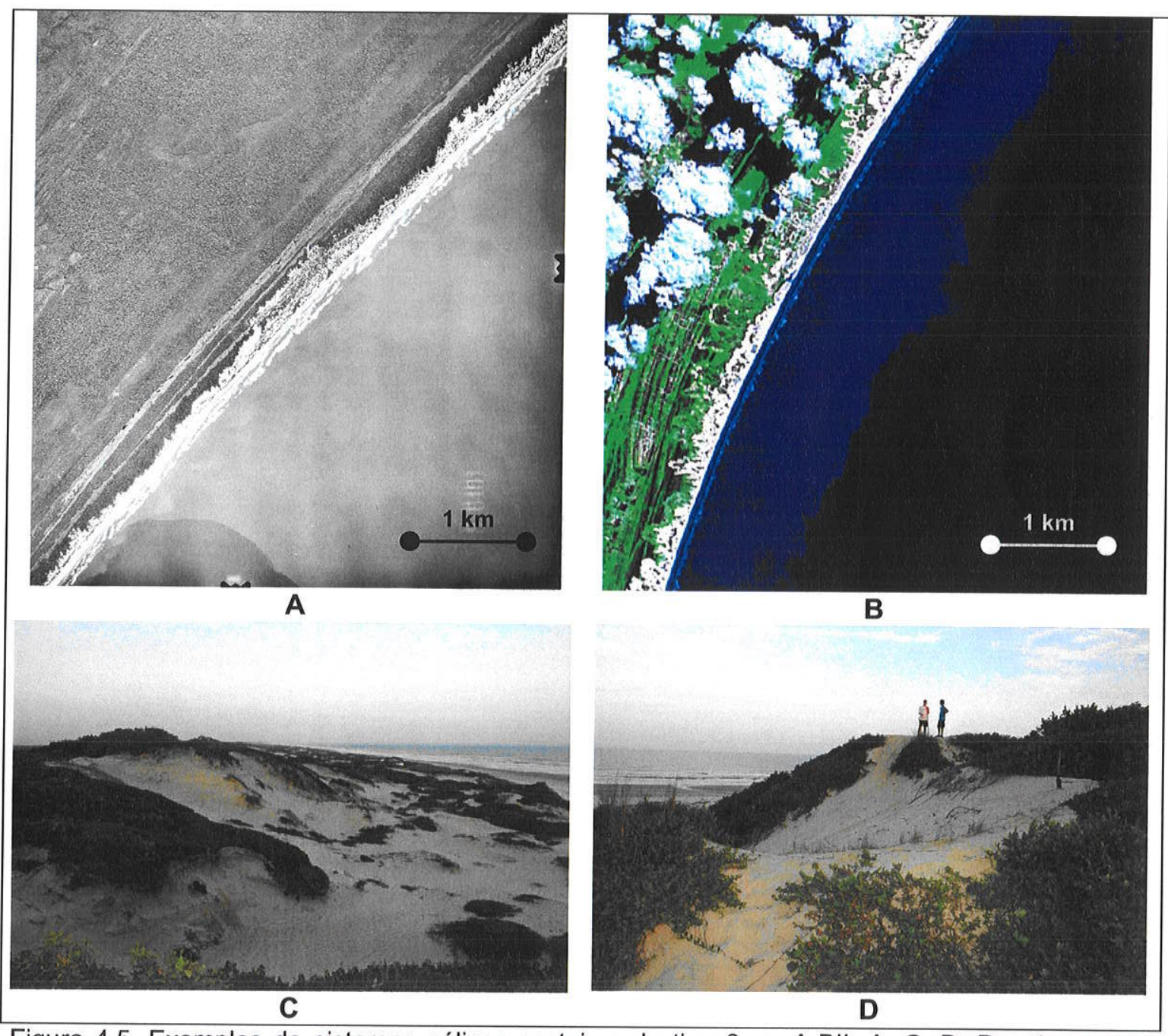

Figura 4.5. Exemplos de sistemas eólicos costeiros do tipo 3 ou A-BII. A, C, D. Porção centrosudoeste da praia de llha Comprida, SP, entre 15 e $18 \mathrm{~km}$ a NE da desembocadura de Cananéia. B. Praia do Saco (Estância), SE.

\section{Sistema eólico costeiro tipo A-BIII}

No tipo A-BIII, as dunas frontais são ladeadas ao interior por dunas parabólicas (Figura 4.6). Este tipo encontra-se melhor representado no trecho da costa nordestina entre Barra de Camaratuba, no norte da Paraíba, e Natal, no centro-sul da costa potiguar (Figura 4.6C), mas ocorre também, mais localmente, nas proximidades de Sarita, RS (Figura 4.6A), 
na parte centro-leste da Restinga de Massambaba RJ (Figura 4.6B), na costa do Sergipe e no trecho de direção NW da costa do Ceará (Figura 4.6D). Estas regiões possuem em comum o vento efetivo oblíquo, em ângulo de aproximadamente $45^{\circ} \mathrm{com}$ a linha de costa. $\mathrm{O}$ comprimento máximo do sistema nestas regiões, na direção do vento efetivo, é de pouco mais de $1 \mathrm{~km}$.

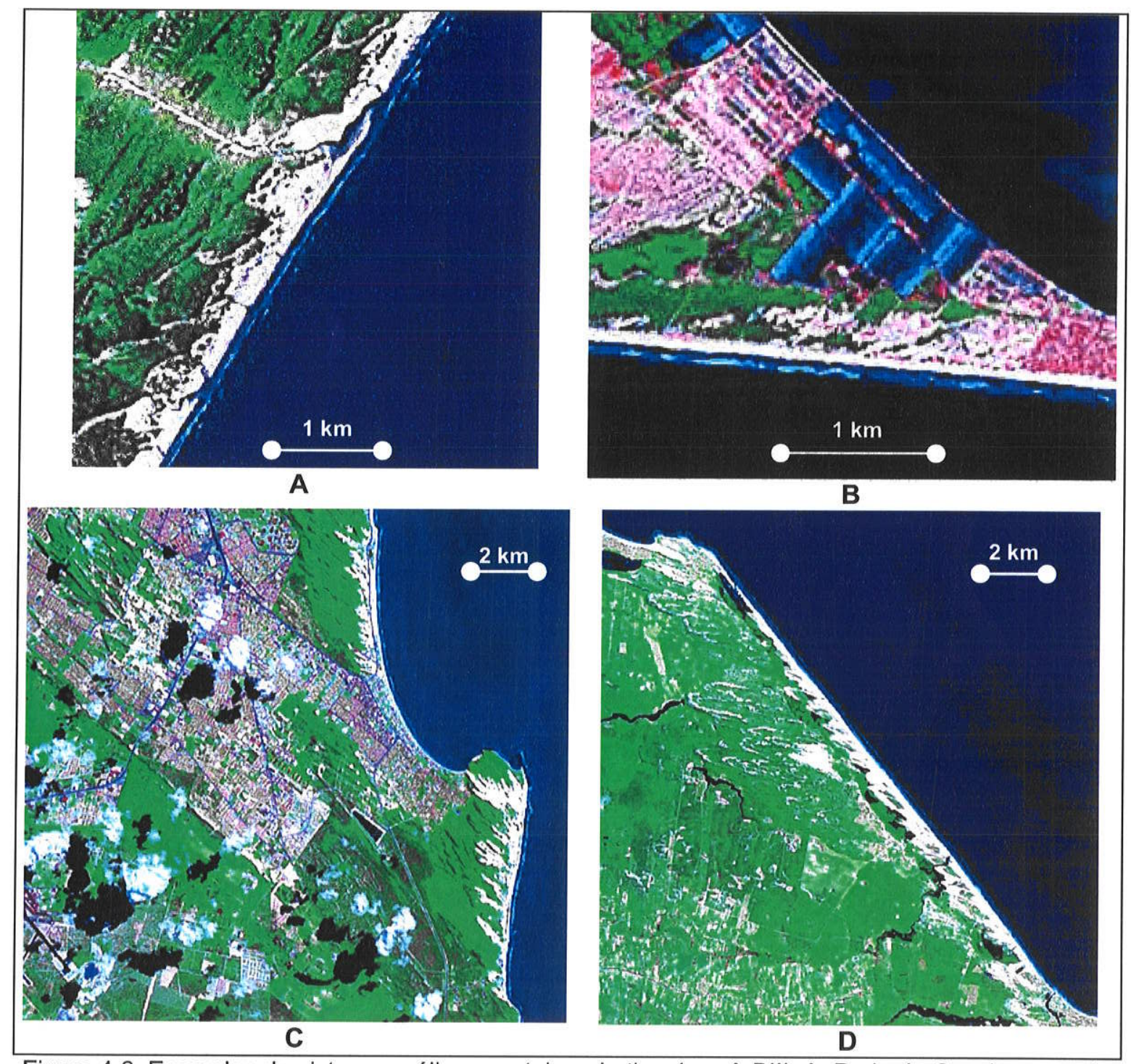

Figura 4.6. Exemplos de sistemas eólicos costeiros do tipo 4 ou A-BIII. A. Praia do Cassino, a norte de Sarita (Cassino), RS. B. Parte meio-leste da praia de Massambaba, junto a Figueira (Arraial do Cabo), RJ. C. Praia de Pium, a sul de Ponta Negra (Natal), RN. D. Praias de Balbino (entre rios, a $\mathrm{SE}$ ) e Baloque (municípios de Cascavel e Aquiraz), CE.

\section{Sistema eólico costeiro tipo A-B-Cl}

O sistema tipo A-B-Cl possui elementos de estoque inicial na forma de dunas frontais (A3, A4, A5), elementos de planície deflacionar na forma de rupturas (B1, B2, B3) e/ou dunas parabólicas (B4), e elementos de campo de dunas, representadas exclusivamente por cordões de precipitação (C1), via de regra formados por dunas parabólicas coalescidas. 
Encontram-se exemplos deste tipo de sistema entre Vergas e Cassino, RS (Figura 4.7A), no litoral sul de Santa Catarina, na porção leste da restinga de Massambaba, RJ, na planície costeira junto à foz do rio São Francisco (Figuras 4.7B,C), e em parte das praias da costa norte potiguar entre Natal e Touros, como Redinha, Maxaranguape e Pititinga (Figura 4.7D), onde se associa ao tipo 4. Na planície costeira da foz do São Francisco, a porção norte, com maior disponibilidade de areia fina e muito fina (Barbosa 1997), apresenta feições transicionais para o tipo 6, como maior entulhamento da zona deflacionar, maior largura do cordão de precipitação, presença sazonal de barcanóides e lobos de precipitação relativamente alongados.

As dimensões encontradas em campos de dunas desta categoria são muito variáveis. Característica comum às ocorrências identificadas é o ângulo oblíquo (até $70^{\circ}$ ) do vento efetivo em relação à linha de costa.

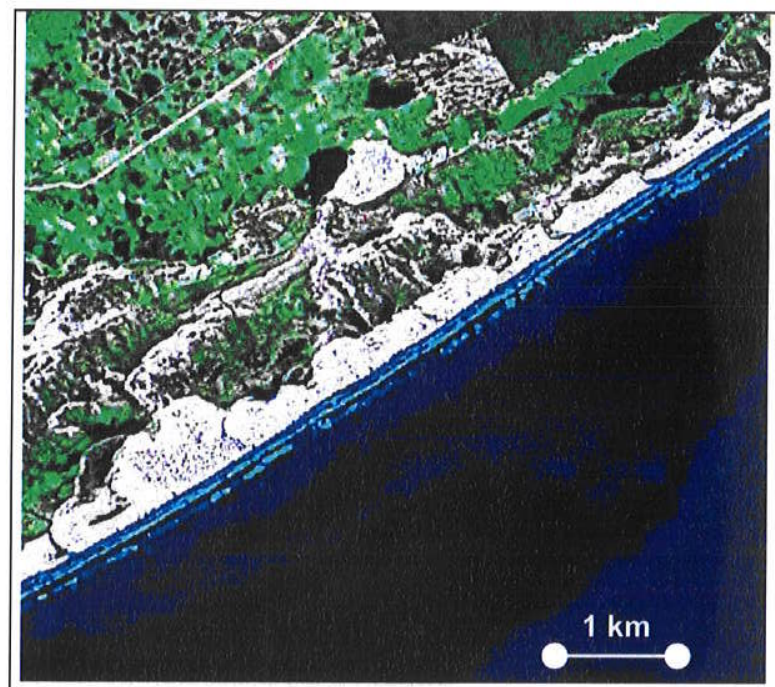

A

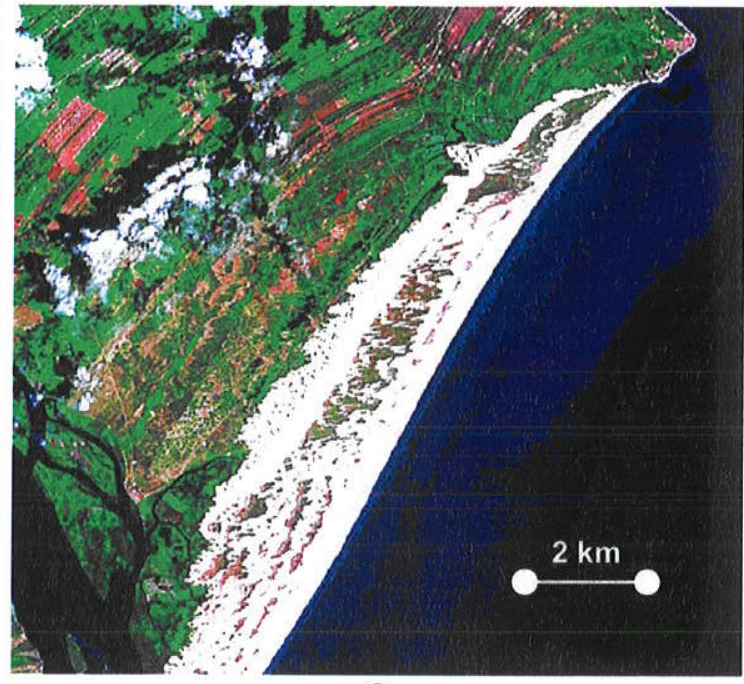

C

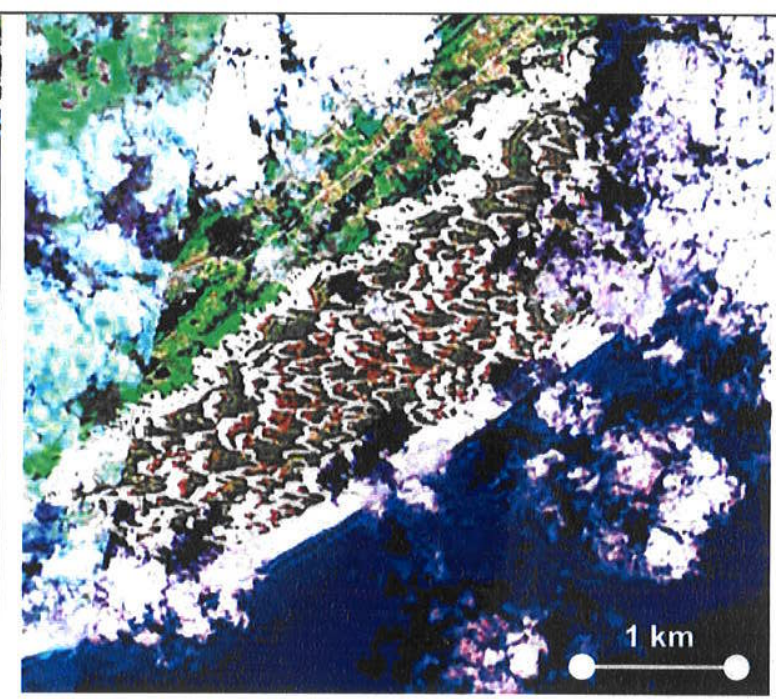

B

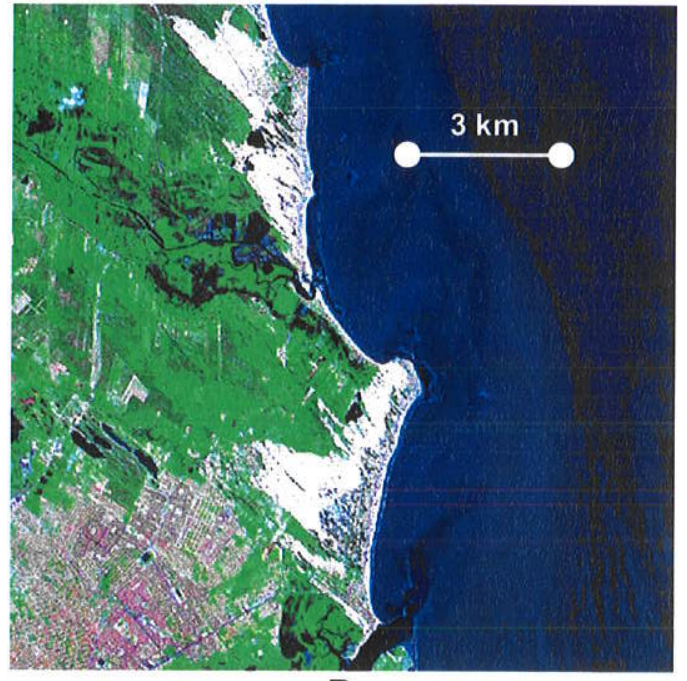

D

Figura 4.7. Exemplos de sistemas eólicos costeiros do tipo 5 ou A-B-Cl. A. Região a norte de Estreito (Rio Grande), RS. B. Praia de Pirambu, a SW da foz do rio São Francisco, SE. C. Praia da Peba, a NE da foz do rio São Francisco (Piaçabuçu), AL, em transição para tipo 6. D. Praias de Redinha - Santa Rita e Genipabu-Graçandu, a norte da foz do rio Potenji (Extremoz), RN. 


\section{Sistema eólico costeiro tipo A-B-CII}

O sistema tipo A-B-Cll compreende elementos de dunas frontais (A3, A4, A5), rupturas de deflação (B1, B2, B3) e/ou dunas parabólicas (B4), com ou sem retrocordões (B5), e campo de dunas incompleto, formado por barcanóides e cordões de precipitação (C2). Encontra-se, por exemplo, no trecho convexo da costa gaúcha, entre Chuí e Albardão (Figura 4.8A), na ilha de Santa Catarina (SC), no trecho de orientação leste-oeste da costa potiguar (Figura 4.8B, C), na costa sudeste do Ceará (Figura 4.8D) e no litoral do Piauí. A partir deste tipo, começam a tornar-se possíveis extensões de mais de uma dezena de quilômetros no rumo do vento efetivo. Característica comum às diversas ocorrências na costa brasileira é o caráter simétrico ou sub-simétrico do campo de dunas.

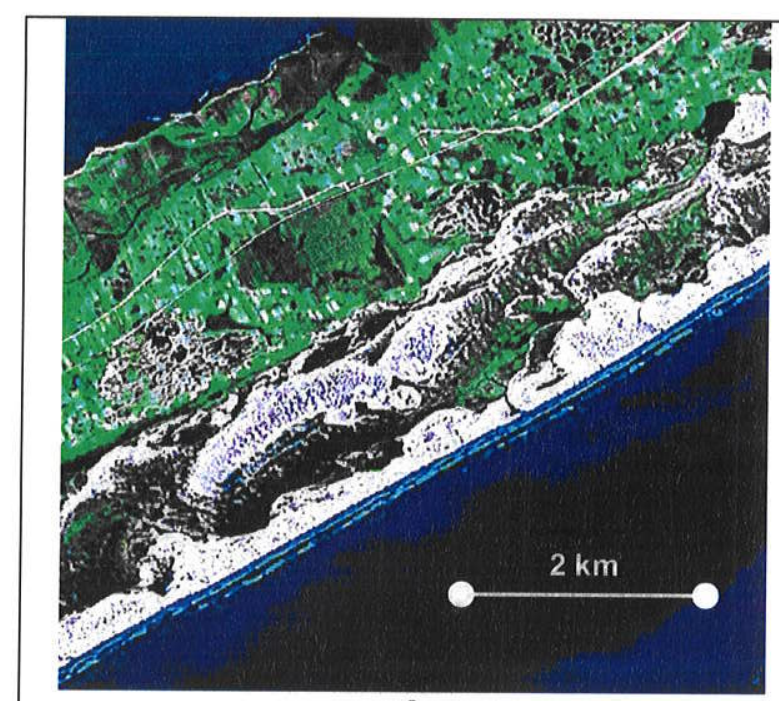

A

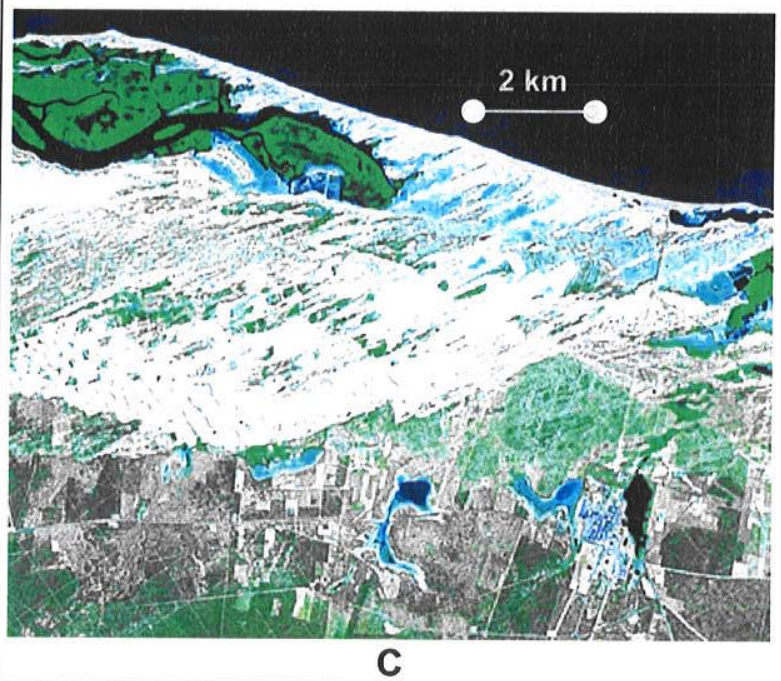

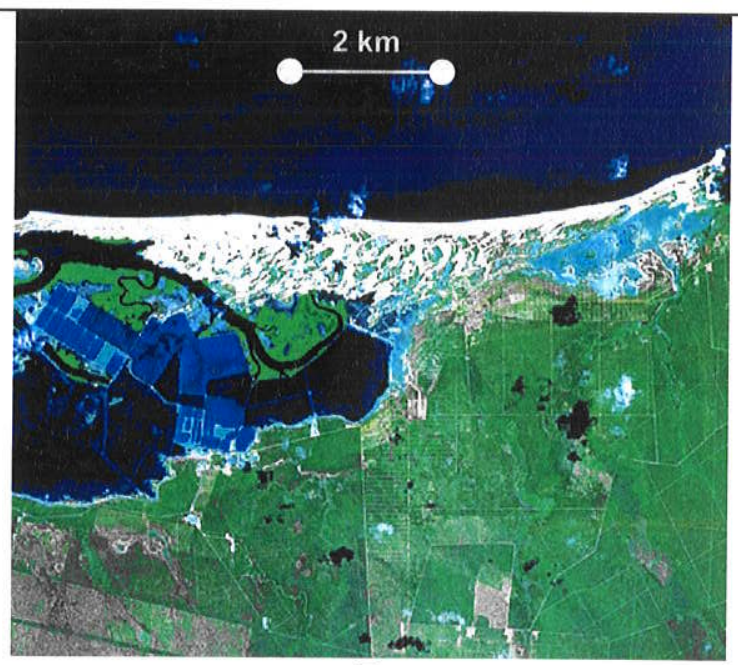

B

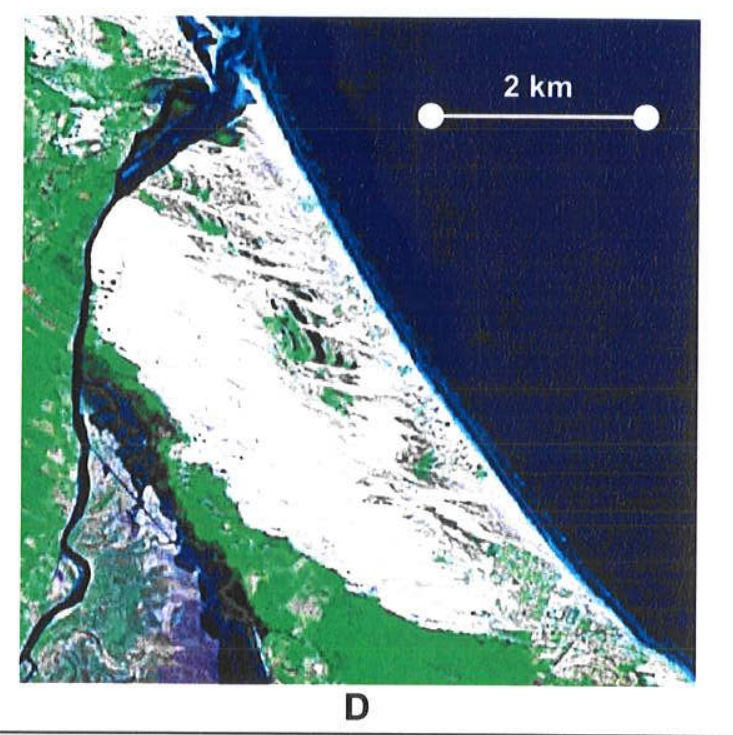

Figura 4.8. Exemplos de sistemas eólicos costeiros do tipo 6 ou A-B-CII. A. Região de Estreito (Rio Grande), RS. B. Praia dos Galos (Galinhos), RN. C. Praia do Minhoto (Guamaré), RN. D. Praia do Morro Branco (Beberibe), CE. 


\section{Sistema eólico costeiro tipo A-B-CIII}

O sistema tipo A-B-CIII é formado por elementos de dunas frontais (A3, A4, A5), planície de deflação com dunas parabólicas e rastros lineares, freqüentemente com retrocordões (B4, B5), e campo de dunas livres completo (C3), com lobos deposicionais proeminentes. Ocorre entre Quintão e Tramandaí, RS (Figura 4.9A), na costa catarinense entre Campo Bom e Arroio Corrente (Figura 4.9B) e entre Laguna e Garopaba, nas praias do Foguete e Peró, em Cabo Frio (RJ), em várias praias da costa noroeste do Ceará (Figuras 4.9C,D) e em parte dos Pequenos Lençóis Maranhenses. Neste conjunto de ocorrências, os ângulos entre vento efetivo e linha de costa são menores que $60^{\circ}$, a extensão no rumo do vento é nunca inferior a $3 \mathrm{~km}$, e a forma da linha de costa é predominantemente côncava.

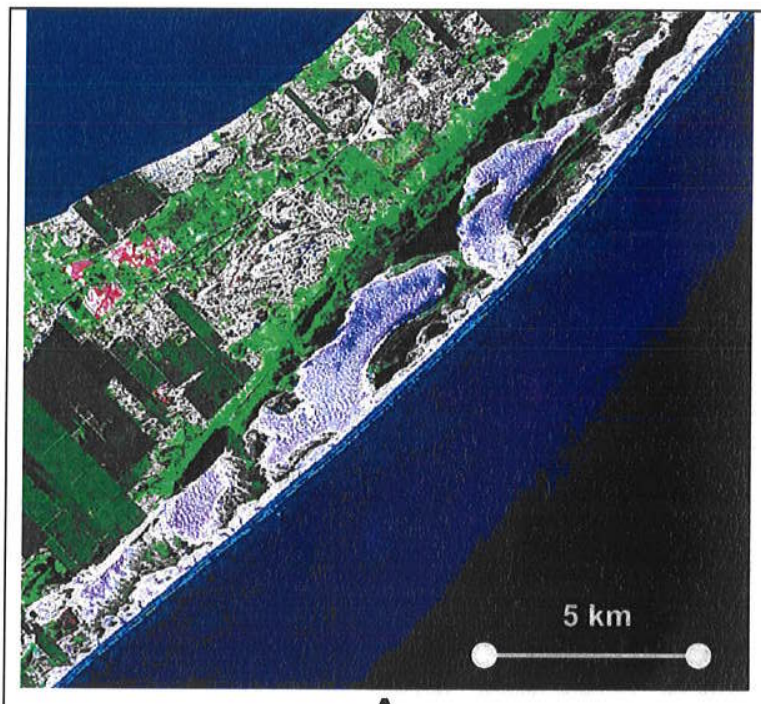

A

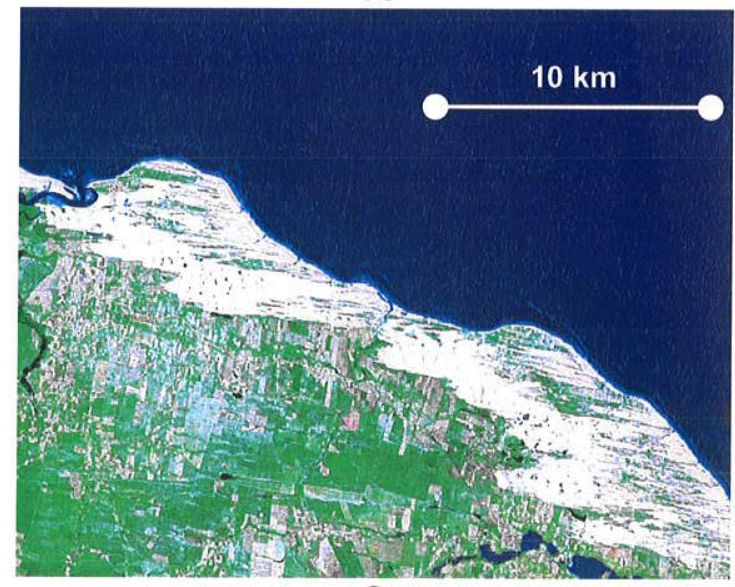

C

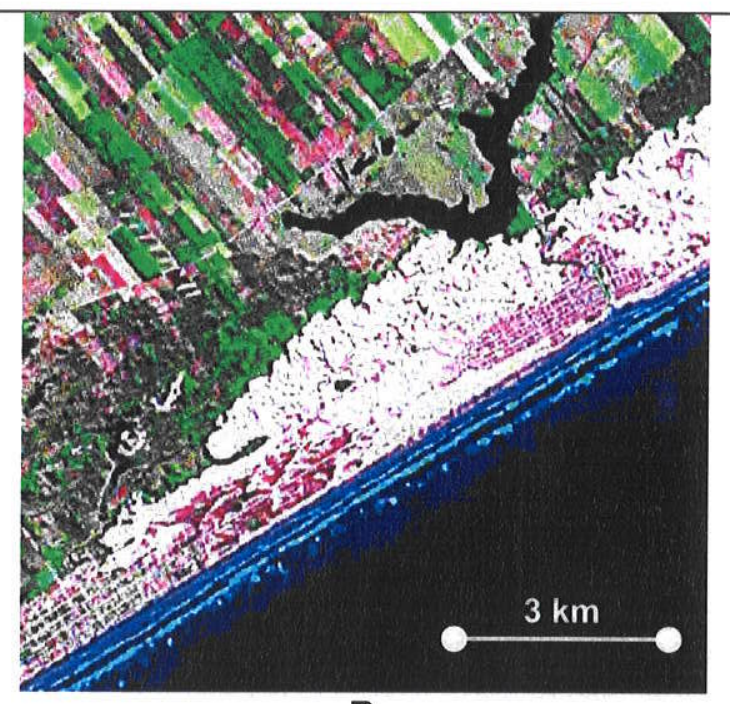

B

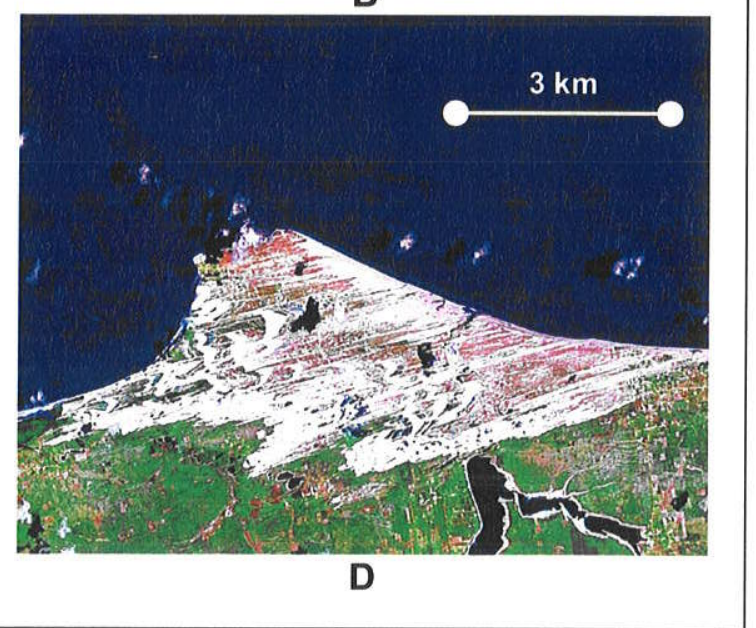

Figura 4.9. Exemplos de sistemas eólicos costeiros do tipo 7 ou A-B-CIII. A. Região de Bojuru, RS. B. Praia Grande do Sul, entre Campo Bom e Arroio Corrente, Jaguaruna, SC. C. Praias de Fleixeiras, Imboaca e Mundaú (Trairi), CE. D. Praia de Jericoacoara, CE.

\section{Sistema eólico costeiro tipo A-C}

O sistema tipo A-C caracteriza-se pela passagem direta da associação de elementos de praia-duna, representada por protodunas ou dunas sem vegetação transversais ao vento, 
com ou sem retrocordões e/ou nebkhas associados (A6, A7, A8), para associação de elementos de campo de dunas (C3). Os elementos de deflação são tipicamente ausentes, ainda que falhas localizadas de cobertura arenosa (B6) possam ocorrer (Figura 4.10). Os principais exemplos seriam o trecho convexo da costa do Rio Grande do Sul entre as lagoas Retovado e Charqueada (Figura 4.10A), a costa sul catarinense entre Arroio Corrente e Santa Marta, a praia entre Ribeirão e Guarda do Embaú (SC) e os Lençóis Maranhenses (Figura 4.10D). Em outros dois exemplos da costa do Maranhão, as praias de Tutóia e Ponta das Gaivotas (Figura 4.10C), a associação de elementos de campo de dunas encontra-se incompleta (sem cordão de precipitação e lobos deposicionais), porém não por questão de aporte insuficiente, mas por falta de espaço para acomodação destes elementos (existência de canal de maré ao interior). Situação similar ocorre ainda na parte oeste da praia de Galos (Galinhos), RN, e na praia de Aranaú (Acaraú), CE (Figura 4.10B).

Os exemplos de sistema eólico tipo A-C apresentam como características os ângulos baixos $\left(<45^{\circ}\right)$, e freqüentemente sub-paralelos, entre vento efetivo e linha de costa, as elevadas dimensões (comprimento e largura mínimos de 10 e $7,5 \mathrm{~km}$, respectivamente), o caráter simétrico do campo de dunas e a plataforma continental larga ( $>100 \mathrm{~km}$ ). A praia entre Ribeirão e Guarda do Embaú constitui exceção no que se refere à largura da plataforma, enquanto Lençóis Maranhenses é grande exceção tanto quanto à inclinação à linha de costa como quanto à simetria.

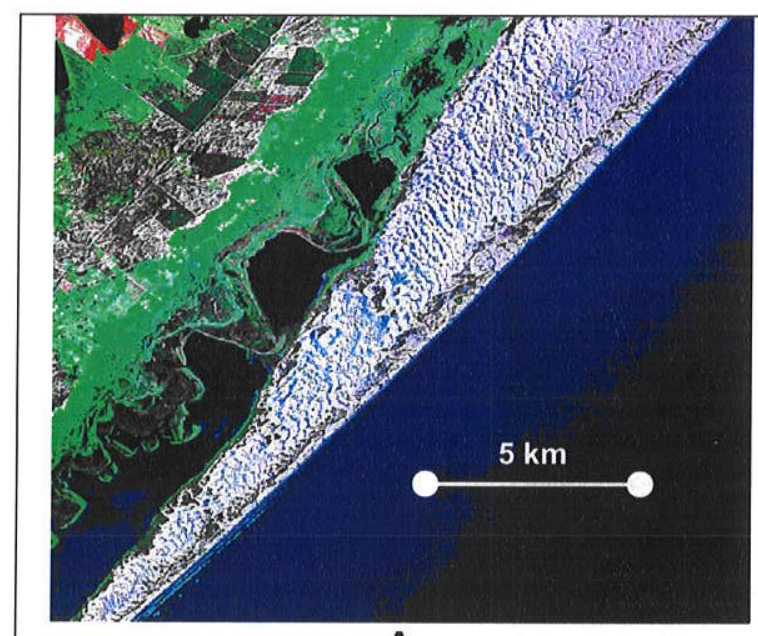

A

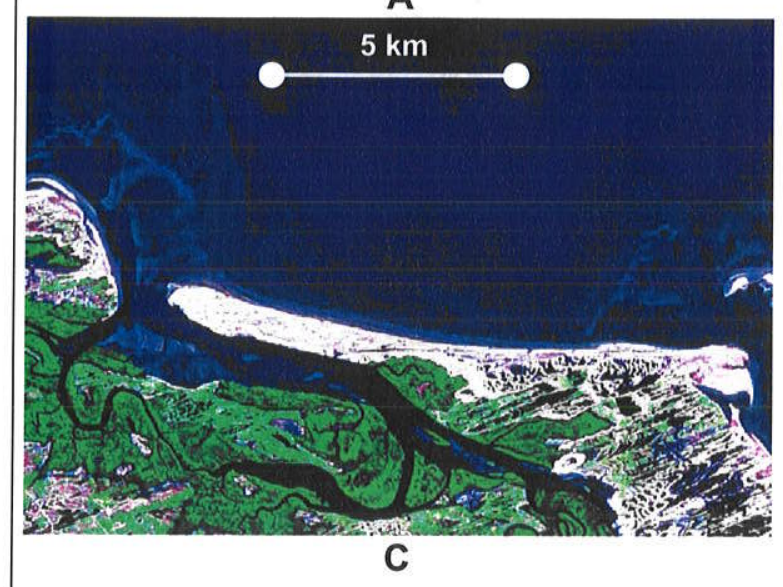

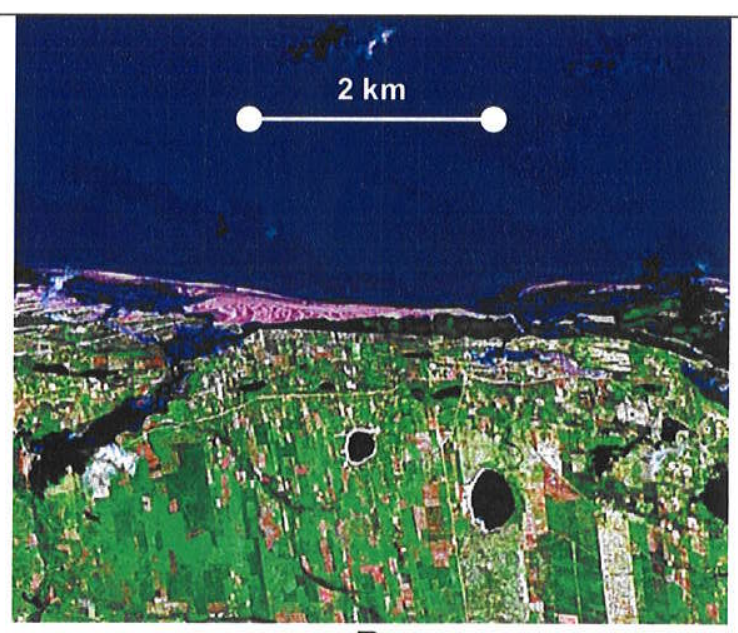

B

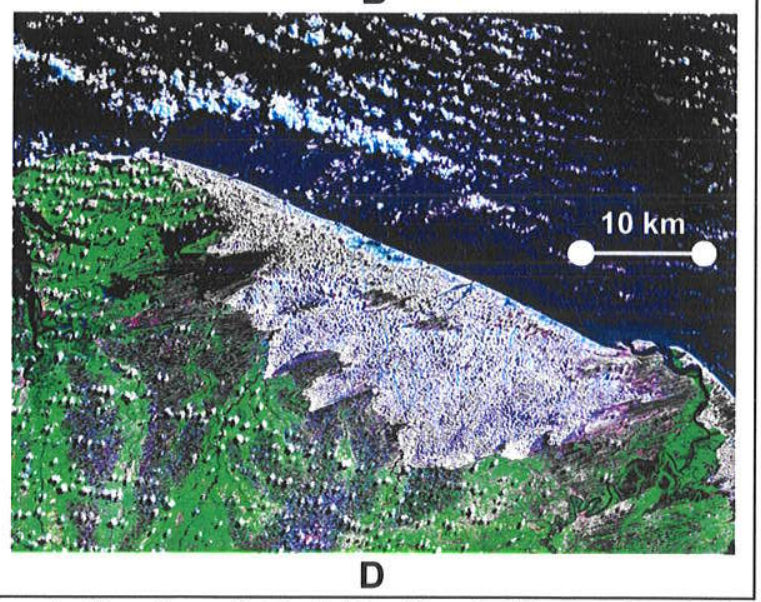

Figura 4.10. Exemplos de sistemas eólicos costeiros do tipo 8 ou A-C. A.Região de Mostardas, RS. B. Praia de Aranaú (Acaraú), CE. C. Ponta das Gaivotas (Tutóia), MA. D. Lençóis Maranhenses, MA. 


\subsection{Influxo/efluxo vs. espaço de acumulação}

A comparação entre as características dos oito tipos de sistemas deposicionais eólicos aqui deduzidos para a costa brasileira evidencia tendências gerais com o grau crescente de desenvolvimento do sistema, compatíveis com as previsões apresentadas no modelo conceitual. Por exemplo, a tendência para maior desenvolvimento nas zonas de plataforma mais larga. Mas evidencia também importantes exceções nessas tendências gerais, o que vem confirmar o princípio sistêmico da não causalidade ou não linearidade de relações entre variáveis: não existe um só fator, como orientação do vento ou largura da plataforma que, sozinho, consiga explicar todas as tendências de variação observadas, na prática, do estágio de desenvolvimento 1 ao 8 . Até mesmo as tendências morfométricas mais imediata e diretamente ligadas ao grau de desenvolvimento do sistema, por exemplo, o crescimento das dimensões comprimento e largura e da distância de equilíbrio, guardam exceções importantes. Chama particularmente a atenção a grande amplitude de variação de tamanho dos sistemas, especialmente nas categorias supostas como de alto grau de desenvolvimento.

A existência destas exceções torna claro, ao mesmo tempo, que não se pode relacionar o grau de desenvolvimento do sistema eólico costeiro simplesmente à relação influxo/efluxo, ou pelo menos não em termos absolutos. Aceitar o contrário seria acreditar que todos os exemplos de grau 8 possuem saldo sedimentar de mesma ordem de grandeza absoluta. A razão para isto é o efeito de escala ou tamanho relativo na tipologia de sistemas eólicos em foco. Um sistema eólico restrito a arco praial relativamente pequeno, como o de Ribeirão - Guarda do Embaú (SC), requer saldo positivo de sedimentos eólicos muito menor, em número absolutos, que o mesmo tipo de sistema encontrado ao longo de trechos mais extensos de costa, como Arroio Corrente - Laguna (SC), Retovado-Charqueada (RS), e, chegando ao outro extremo de tamanho, Lençóis Maranhenses. O comprimento do arco praial e a largura da planície até a zona periserrana ou lagunar, disponivel para livre atuação do vento e para migração dunar, desempenham, na determinação da tipologia do sistema eólico, papel similar ao exercido pelo espaço de acomodação na determinação do padrão de preenchimento de bacias subaquosas. Em resumo, a tipologia de sistemas eólicos aqui apresentada não se relaciona simplesmente ao balanço influxo-efluxo (Qi-Qe), e às inúmeras variáveis locais e regionais que interagem para determinar este balanço, mas também ao espaço disponivel para acumulação e avanço normal do sistema. Em outras palavras, relaciona-se ao saldo influxo-efluxo relativo a esse espaço.

Se o espaço de acumulação diminui, sob saldo influxo-efluxo positivo e constante, o saldo eólico relativo aumenta. É o que ocorre, por exemplo, quando encostas e/ou corpos de água posicionados ao interior do sistema eólico costeiro afetam sua dinâmica. No caso de encostas e escarpas, a desaceleração da velocidade de avanço horizontal apressa progressivamente $o$ entulhamento do sistema, das partes mais distais para as mais proximais. A influência de corpos de água lacustres ou lagunares situados a sotavento do campo de dunas pode ser dividida em três momentos. Num primeiro momento, a aceleração do vento nas vizinhanças do corpo de água reduz a altura de equilíbrio e aumenta a velocidade de migração do sistema eólico. Isto gera o avanço preferencial do sistema no rumo do corpo de água. Num segundo momento, a chegada de areia sobre a zona deprimida, úmida e às vezes vegetada da margem do corpo de água, reduz bruscamente esta migração. Num terceiro momento, desde que haja estoque suficiente na associação de fornecimento inicial, o sistema é progressivamente entulhado das partes distais para as proximais. É interessante reexaminar a distribuição dos campos de dunas transgressivos do Rio Grande do Sul e do sul catarinense sob essa perspectiva. Os campos "mais bem desenvolvidos", compativeis com os tipos de mais alta razão influxo/efluxo na classificação aqui apresentada, ocorrem coincidentemente nos trechos de costa onde o sistema lagunar 
se encontra mais próximo da linha de costa, em pleno assoreamento pelo sistema eólico. Isto torna claro que se trata aqui de relação influxo/efluxo específica ou relativa. Exemplos análogos em menor escala encontram-se na ilha Comprida, SP, no campo de dunas associado à foz do rio São Francisco, $\mathrm{AL}$, e ao longo do trecho da costa cearense com orientação SE-NW. Na praia da Ilha Comprida, o único trecho com ocorrência de campo de dunas livres (Figura 4.11A) coincide justamente com a zona de maior estreitamento da ilhabarreira (Giannini et al. 2007). No campo de dunas da praia do Pontal do Peba, os dois principais lobos deposicionais encontram-se sobre lagos intercordões (Figura 4.11B). Na região de Beberibe, onde lagos e rias estuarinas, de geometrias respectivamente subcircular e alongada transversal à costa, ocupam não mais que $10 \%$ da área da planície, 60 a $70 \%$ dos lobos deposicionais desenvolvem-se justamente a barlavento destes corpos de água (Figura 4.11C).

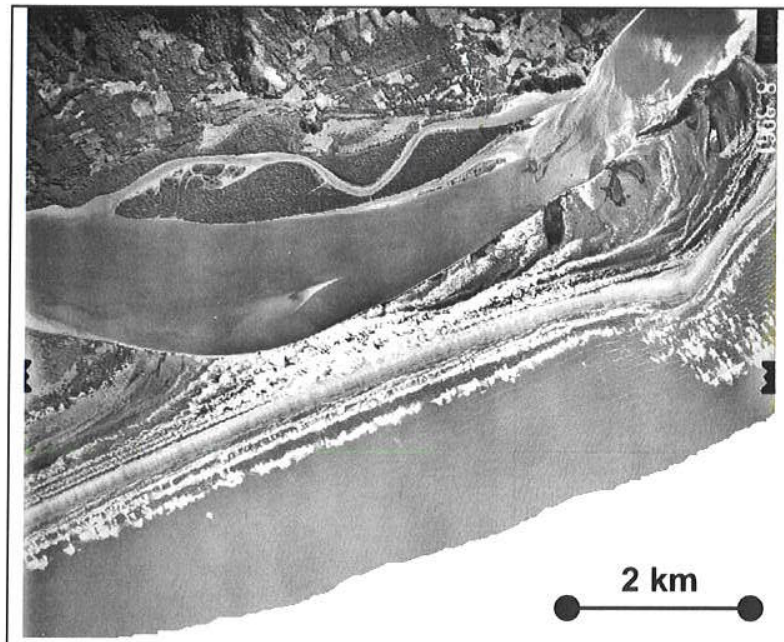

A

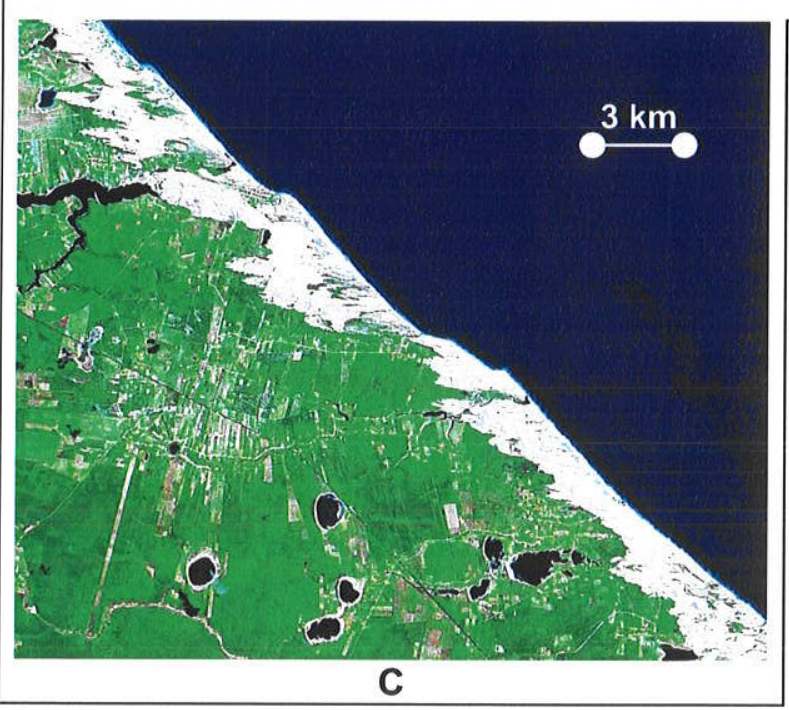

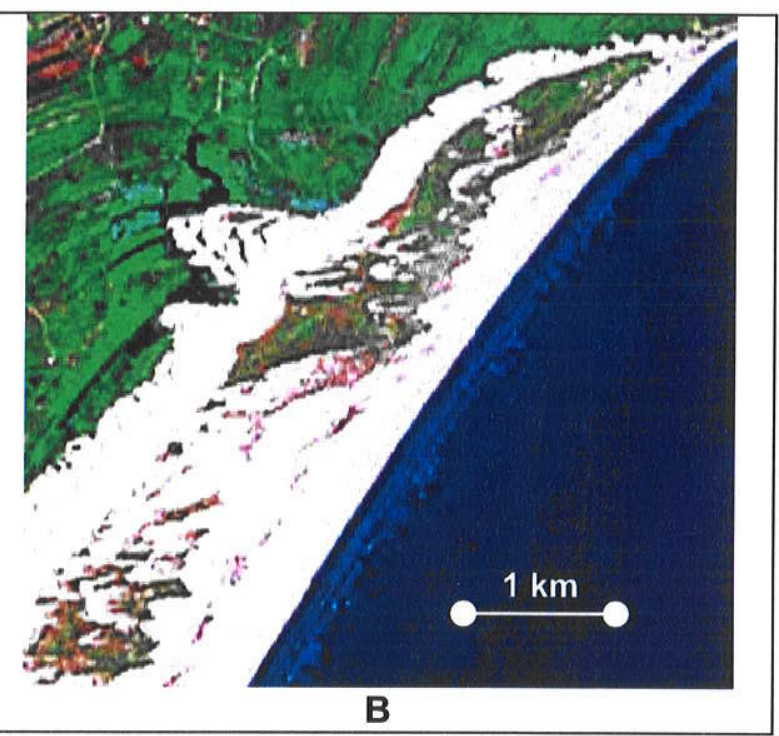

Figura 4.11. Evidências de formação ou crescimento preferencial de campos de dunas livres onde a pista do vento encontra lagunas, lagos ou estuários. A. Praia de llha Comprida, SP. B. Praia do Pontal do Peba (Piaçabuçu), AL. C. Praias de Barra de Sucatinga, Uruaú e Diogo (Bebeberibe), CE.

Várias tendências de variação observadas com o aumento da relação influxo/efluxo vs. espaço confirmam previsões construídas a partir do modelo de saldo sedimentar relativo. A redução do ângulo entre vento efetivo e linha de costa nos tipos de sistemas de número mais alto, por exemplo, pode ser relacionada à elevada taxa de manutenção da areia eólica dentro de faixa costeira extremamente restrita. O resultado é um sistema extenso ao longo 
da costa, bem desenvolvido e com bom potencial de superação de obstáculos (pontões cristalinos, por exemplo) nessa direção, porém tipicamente pouco afastado da praia. Uma segunda tendência, o aumento da simetria dos campos de dunas com a elevação da relação influxo/efluxo, guarda certamente correlação direta com a tendência anterior, pois ângulos baixos entre transporte eólico e linha de costa favorecem o espalhamento homogêneo da areia ao longo daquela estreita faixa costeira.

No extremo oposto, os sistemas de dunas frontais, supostamente gerados sob baixo saldo entre influxo e efluxo, apresentam duas de suas áreas de ocorrência mais importantes, - litoral norte paulista e sul fluminense e o litoral sul nordestino, coincidentes com áreas de espaço de acumulação reduzido pela máxima aproximação à costa das encostas da serra do Mar e das falésias da Formação Barreiras, respectivamente. Aqui, são provavelmente outros fatores, controladores do próprio aporte, como as características morfodinâmicas das praias, freqüentemente de tombo, e a constituição dos sedimentos, rica em areia média e grossa e em minerais pesados, que inibem o desenvolvimento do sistema eólico. Apesar do espaço a ser preenchido ser pequeno, o próprio transporte e acumulação eólicos encontram-se desfavorecidos.

\subsection{Análise de estabilidade do sistema}

\subsubsection{Estabilidade de tipo}

Conclui-se que os oito tipos ou graus de desenvolvimento de sistemas eólicos costeiros aqui identificados com base em exemplos brasileiros representam estágios morfodinâmicos determinados pela relação, crescente de 1 a 8 , entre saldo sedimentar eólico envolvido na iniciação do sistema e taxa de criação de espaço de acumulação. Alcançada a relação de equilíbrio entre influxo e efluxo dentro do sistema, e suposta nula a criação de espaço (através, por exemplo, de estabilidade da linha de costa), cada um desses tipos prossegue ativo e estável, enquanto essas condições permanecerem. Nessa situação, a resposta do sistema é de permanente reconstrução no caso de elementos de dunas frontais e de simples migração no rumo do vento, no caso de demais elementos. Desse modo, nos tipos 1 e 2 , a associação de elementos praia-duna mantém-se na mesma posição ao longo do tempo, sem perder suas características morfológicas. Analogamente, nos tipos 3 a 8, as associações de elementos de deflação e de campo de dunas podem migrar e se replicar, mas o aparecimento de novo campo de dunas junto à praia é acompanhado da estabilização do anterior. Mudam as posições dos elementos, sem alteração substancial de morfologia. Significa que a evolução no tempo destes tipos, sob balanço influxo-efluxo equilibrado, é a formação de sistemas múltiplos paralelos de diferentes idades.

Se a relação influxo/efluxo se modifica, criando desequilibrio próximo do equilibrio, o sistema reage mais uma vez por auto-regulação ou retroalimentação negativa, sem modificar suas características morfológicas essenciais. Um exemplo é a redução do influxo devido ao aumento de coesão das areias de praia por chuvas temporárias prolongadas. A resposta do sistema pode ser apenas o ligeiro aumento dos elementos com vegetação, além do incremento de coesão de suas próprias areias, o que reduz o efluxo e, desse modo, desloca o equilíbrio no sentido oposto ao imposto pelas perturbação, de modo a manter suas características morfológicas. O comportamento da linha de costa, como variável do espaço de acumulação, não é suficiente para determinar o tipo e a dinâmica do sistema eólico, mas também influi na morfodinâmica eólica através desse principio de auto-regulação. Se a linha de costa sofre regressão temporária, o espaço de acumulação aumenta, reduzindo teoricamente o influxo por área de deposição, mas esta perda de influxo especifico é compensada porque parte da areia que antes se encontrava submersa torna-se disponível 
ao vento. Se a costa possui comportamento transgressivo, a perda imediata de espaço de acumulação é compensada pela saída de areias eólicas por erosão subaquosa.

Se a relação influxo/efluxo ou o espaço de acumulação se modificam de modo drástico, criando desequilíbrio muito distante do equilibrio, o sistema reage por autoorganização ou retroalimentação positiva. Trata-se do tipo de transformação que leva de um estágio morfodinâmico a outro, em poucas anos a séculos, portanto em processo instantâneo na escala de tempo geológica. Este tipo de processo requer alteração brusca nos fatores de controle do estoque inicial. O sistema é colocado numa situação inteiramente nova, muito distante de seu equilibrio anterior, o que requer dissipação concentrada de energia, no caso, eólica. Sob condição de específico decrescente (queda absoluta do saldo influxo-efluxo e/ou aumento absoluto de espaço), a reação consiste em deslocar o sistema para um novo equilíbrio dinâmico, em que a retenção de areia seja menor, portanto para estágio morfodinâmico de número (geralmente seguinte) inferior. Sob condição de influxo específico crescente, o sistema desloca-se para estágio de numero mais alto, compativel com situação de maior retenção de areia eólica. O comportamento da linha de costa mais uma vez não é suficiente para determinar o tipo e a dinâmica do sistema eólico, mas influi na morfodinâmica eólica através do princípio de auto-organização. Se a linha de costa regride irreversivelmente, parte da areia que antes se encontrava em circulação no sistema praiaduna passa a ser consumida para a construção dos elementos subaquosos progradantes, 0 que diminui a disponibilidade de areia para o sistema eólico, ao mesmo tempo em que amplia o espaço de acumulação; a reação do sistema é portanto de deslocar o equilíbrio para estágio compativel com menor consumo de areia eólica. Se a costa possui comportamento transgressivo, depósitos subaquosos preexistentes, erodidos e recolocados em circulação, elevam a probabilidade de alimentação do sistema eólico, ao mesmo tempo em que podem reduzir o espaço de acumulação. A retroalimentação positiva do sistema atua neste caso no sentido de aumentar a saturação de areias eólicas. Sob comportamento regressivo persistente, a sucessão de regimes de saldo eólico cada vez menor pode conduzir por exemplo à transformação de campos de dunas livres em feixes de cordões dunares. Já sob comportamentos transgressivos persistentes, cordões de dunas frontais podem sofrer deflação crescente e permitir o estabelecimento gradual de campos de dunas livres.

O exemplo mais extremo de auto-organização no modelo aqui proposto seria a transformação de uma planície monótona de cordões dunares progradantes, típicos do estágio 1, em campos de dunas móveis característicos dos estágios 5 a 8 , ao final de uma elevação rápida do NRM. Com esta elevação, a grande quantidade de areia antes emersa, colocada em circulação no recém-instalado sistema praia-duna, pode representar enorme estoque potencial para o transporte eólico. Este é o tipo de processo aqui evocado para explicar a formação das duas seqüências de depósitos eólicos, deduzidas em grande parte dos setores costeiros brasileiros com vocação atual ou recente para formação de campos de dunas. Dentro da seqüência mais nova, os depósitos representativos de três gerações eólicas (2, 3 e 4 ), também identificados em vários setores da costa brasileira, teriam se diferenciado no contexto de retroalimentações negativas posteriores à máxima inundação marinho-lagunar do Holoceno (Giannini 1993). Haja visto o caráter pós-transgressivo das duas gerações mais novas em todos esses setores, parece evidente que um fator determinante do hiato entre estas gerações e a geração 2 tenha sido a redução do suprimento eólico, por ocasião da máxima inundação, em virtude da escassez de áreas emersas e/ou do lençol freático elevado e, conseqüentemente, da pouco volume de areia incoesa disponivel para o transporte eólico. $O$ atraso da resposta do sistema à perturbação representada pelo afogamento transgressivo implica a possibilidade de este hiato ser materializado numa super-superfície ainda em formação. Isto ajudaria a explicar a sua pequena representatividade regional, e o contato ora gradual ora abrupto entre os depósitos 
das gerações 2 e 3/4, conforme observado em Santa Catarina (Giannini 1993, Giannini et al. 2001 b,c, 2007c). A redução do suprimento eólico pela máxima inundação explica também a menor extensão em área das gerações 3 e 4 em comparação com a geração 2.

Por outro lado, a geração 4 é aparentemente mais importante em área e volume de areia que a geração 3 , o que pode em alguma medida ser atribuído a uma questão de escala, o "paradoxo da taxa de sedimentação" (item 2.3.3; Quadro 2.3). Mas este fato poderia ser explicado também pela relação pelo menos em parte autocíclica e transicional entre estas duas gerações. Por outro lado, o aparente hiato entre suas respectivas idades (item 3.1.1.3), caso confirmado, permitiria interpretar que a geração 4 represente uma retomada ou intensificação da sedimentação eólica ligada a aumento de aporte. Muitos fatores, isolados ou combinados, poderiam ter interagido para determinar este aumento, mas dois deles devam talvez merecer especial atenção em estudos futuros. O primeiro deles é o climático, com indícios de águas mais frias na plataforma sul-sudeste e de climas mais secos em parte do pais, no final do Holoceno (item 3.1.2.4). O outro é o NRM, com suspeitas de ascensão nas últimas décadas ou séculos (Villwock \& Tomazelli 1989, Angulo \& Giannini 1996, Tomazelli et al. 1998, Harari et al. 2004).

\subsubsection{Estabilidade de posição e a arquitetura deposicional}

Transformações na razão entre o saldo influxo-efluxo e o espaço de acumulação eólica refletem-se em mudanças não somente no tipo de sistema, conforme discutido no item anterior, mas também na definição do seu sentido de movimento (avanço, recuo, expansão ou contração), ao longo do tempo, e da velocidade com que este movimento ocorre.

O espaço de acumulação do sistema é́lico costeiro é controlado essencialmente pela taxa de variação do volume de sedimentos eólicos e pela posição da linha da costa. Taxas de crescimento de aporte nulas ou negativas levam à estabilização do sistema, a menos que o espaço de acumulação reduza-se na mesma proporção, através de transgressão da linha de costa. Analogamente, linhas de costa francamente regressivas diluem o aporte eólico por ampla área e condenam o sistema à estabilização. Com base nestas premissas, três casos de dinâmica de sistema eólico costeiro e, por conseqüência, de arquitetura deposicional, podem ser reconhecidos, conforme a linha de costa esteja estável, variável segundo pulsos regressivos ou transgressiva (Sawakuchi 2006). Variações dentro dos dois primeiros tipos devem-se à taxa de crescimento do aporte eólico, se baixa (linear) ou elevada (exponencial).

No primeiro caso, linha de costa estável, o campo de dunas amplia gradualmente sua área de acumulação, de tal modo que as superficies de tempo encobrem-se sucessivamente na totalidade. Se o aporte sedimentar eólico cresce em razão linear, o aumento da área de acumulação dá-se em taxa declinante com o tempo e o campo de dunas desloca-se para o interior em padrão clino-ascendente ou cavalgante (Sawakuchi 2006; Figura 4.12A). O resultado, em termos de sucessão estratigráfica, é a deposição de fácies proximais sobre fácies distais, por exemplo, associações de deflação sobre associações de cavalgamento e superposição, e estas sobre associações de avanço. Se o aporte sedimentar eólico aumenta em função exponencial, o aumento da área de acumulação dá-se em taxa constante (Sawakuchi 2006) e as associações de fácies de superposição e cavalgamento avançam não somente sobre suas associações vizinhas mais distais, de avanço, como sobre as mais proximais, de deflação e suprimento inicial (Figura 4.12B).

O segundo caso, linha de costa alternando fases de estabilidade e pulsos regressivos, também pode gerar padrões estratigráficos distintos dependendo da taxa de aumento do aporte eólico. Se essa taxa é linear, campos de dunas desencadeados durante fases de estabilidade da costa podem ser sucessivamente abandonados, na fase subseqüente de regressão, devido ao isolamento ou distanciamento de sua área fonte 
primária. Cada campo de dunas é apenas parcialmente coberto, em suas fácies mais proximais, pelo campos de dunas gerado na fácies de estabilidade subseqüente (Figura 4.12C). O empilhamento seria portanto de fácies distais sobre proximais. Se a taxa de crescimento do aporte eólico é exponencial, o campo de dunas da nova fase de estabilidade da costa pode avançar sobre a superfície do campo de dunas antigo (Figura 4.12D) e gerar amalgamação de depósitos de superposição formados em diferentes linhas de tempo (Sawakuchi 2006).

No terceiro e último caso, linha de costa transgressiva sob NRM ascendente, as fácies proximais são sucessivamente inundadas, enquanto as fácies distais podem tanto sofrer inundação por eventual sistema estuarino-lagunar (Figura 4.12E), como restrição por obstáculos. A redução da área de acumulação favorece a concentração do aporte eólico e o desaparecimento ou entulhamento das zonas de deflação.

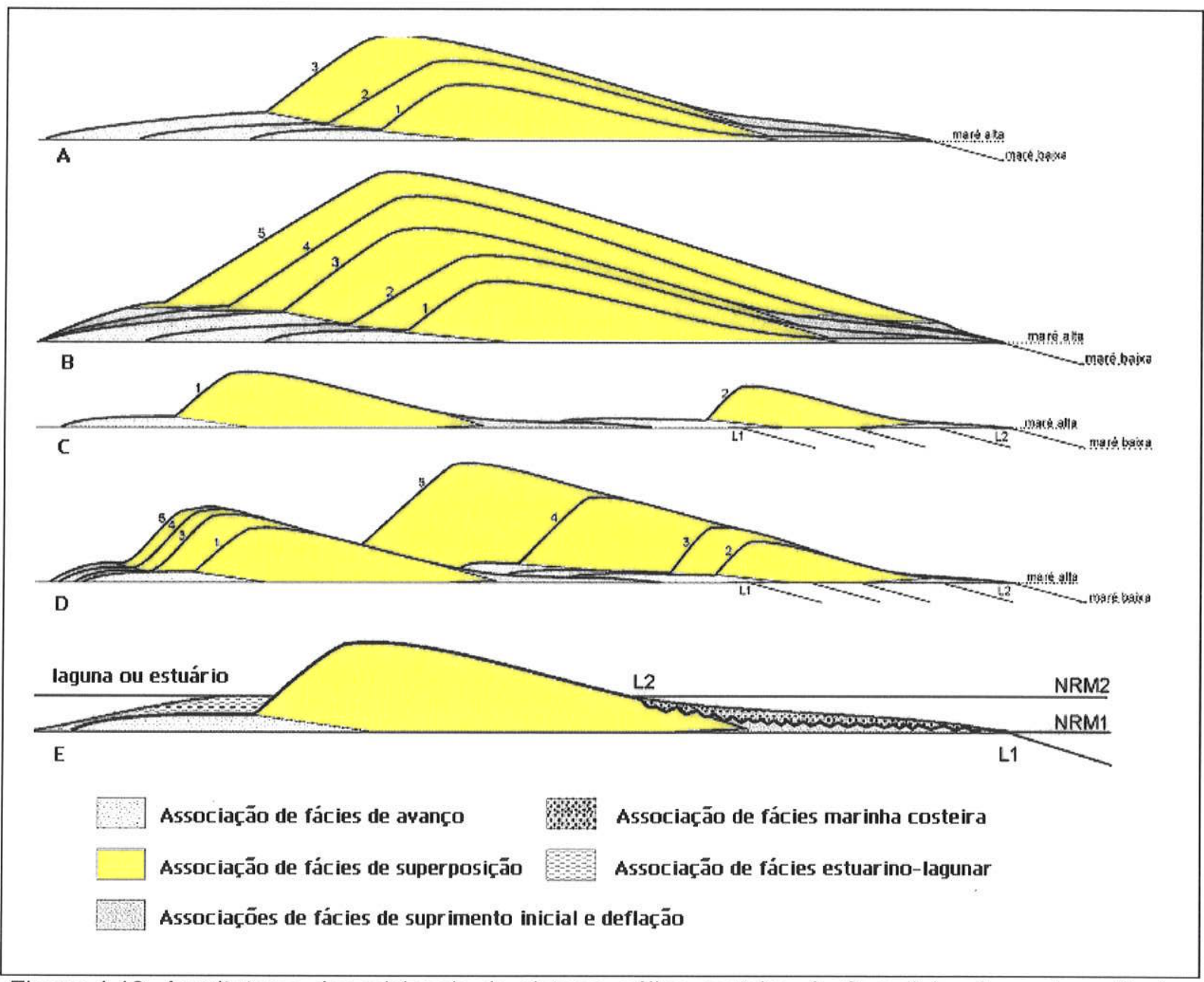

Figura 4.12. Arquiteturas deposicionais do sistema eólico costeiro. A. Com linha de costa estável e aporte eólico crescente em taxa linear. B. Com linha de costa estável e aporte eólico crescente em taxa exponencial. C. Com linha de costa regressiva em pulsos e aporte eólico crescente em taxa linear. D. Com linha de costa regressiva em pulsos e aporte eólico crescente em taxa exponencial. E. Com linha de costa transgressiva e NRM ascendente. L1 e L2 representam linhas de tempo ou de costa sucessivas. Adaptado de Sawakuchi (2006). 


\section{Conclusões}

As seguintes conclusões podem ser enumeradas:

1. A dinâmica de um sistema deposicional eólico é controlada pelo seu saldo sedimentar e pelo espaço para estocagem deste saldo. O saldo refere-se à diferença entre entradas e saídas de sedimentos eólicos, ou influxo (deriva eólica efetiva) e efluxo, respectivamente. $O$ espaço de estocagem é determinado pela posição do nivel freático relativa à superfície deposicional, controlada basicamente pelo clima e pela taxa de subsidência, os quais, nos casos costeiros, agem combinadamente através do nível relativo do mar (NRM).

2. A estocagem eólica desdobra-se em dois conceitos, o de acumulação, mecanismo pelo qual os sedimentos depositados pelo vento ao longo do tempo constituem um corpo tridimensional de estratos, e o de preservação, que é a incorporação desta acumulação ao registro estratigráfico.

3. Em sistemas eólicos costeiros, o espaço de acumulação é delimitado pela extensão da área fonte (praia), e pelas dimensões de equilibrio, isto é, distância no rumo do vento e altura dentro das quais o saldo influxo menos efluxo no sistema permaneça positivo.

4. A distância e a altura de equilibrio refletem-se nas dimensões do sistema eólico costeiro e representam atratores no seu desenvolvimento em direção ao equilibrio estacionário (influxo igual a efluxo).

5. Em escala macroambiental, o saldo sedimentar eólico depende do aporte primário, isto é, da disponibilidade de sedimentos no sistema costeiro que atua como fonte, controlado por variáveis imediatas (locais e de curto prazo) e variáveis mediatas (regionais e de longo prazo).

6. Entre as variáveis imediatas que controlam o aporte primário de modo favorável à formação de sistemas eólicos, destacam-se o transporte e acúmulo por deriva litorânea longitudinal, o grau de dissipatividade da praia, a escassez de vegetação e o suprimento fluvial.

7. As variáveis mediatas que controlam o aporte primário e seu potencial de transferência para o sistema eólico costeiro quaternário são as condições climáticas (ventos, precipitação e tempestuosidade), o NRM e a fisiografia da margem da bacia (plataforma continental).

8. A formação e preservação de sistemas eólicos costeiros são favorecidas em tratos de sistema de mar alto e em plataformas de baixo declive (menor que $0,8^{\circ}$, aproximadamente) desde que acima do ângulo mínimo (em torno de $0,1^{\circ}$ ) necessário para o transporte eficiente de areia pelas ondas rumo à zona intermarés.

9. Com base em critérios geomorfológicos e tectono-estruturais, a margem continental brasileira pode ser dividida em seis setores, de sul para norte: 1. Chui-Laguna, 2. LagunaJoinville, 3. Joinville - Angra dos Reis, 4. Angra dos Reis - Cabo Frio, 5. Cabo Frio - Touros e 6. Touros - Oiapoque. A maior concentração e porte de campos de dunas livres encontrase nos setores 1 e 6 , e a menor no setor 3 . Esta distribuição pode ser explicada por uma convergência de fatores fisiográficos e climáticos.

10. Do ponto de vista fisiográfico, os setores com maior desenvolvimento de campos de dunas possuem como caracteristicas em comum a plataforma continental relativamente larga e de baixo mergulho e o predomínio de arcos praiais extensos (mais longos que 12 $\mathrm{km}$ ). Já no setor com menor desenvolvimento de campos de dunas, a característica geomorfológica mais singular é a presença da serra do Mar. 
11. Do ponto de vista climático, o setor 1 , Chuí-Laguna, destaca-se pelo verão quente e distribuição homogênea das chuvas ao longo do ano $(1400$ a $1900 \mathrm{~mm})$, enquanto o setor 6 , Touros-Oiapoque, coincide com a zona megatérmica de verão seco. Em contraste, o setor 3 , Joinville - Angra dos Reis, concentra os maiores índices pluviométricos do país, relacionados às chuvas orográficas da serra do Mar e à sua coincidência com a posição média da ZCAS.

12. A influência do clima, através do regime de ventos, no rumo de avanço de campos de dunas, é perceptivel principalmente em escala regional. Nessa escala, é possivel dividir a costa brasileira quanto ao regime eólico em três setores maiores. O setor norte, abrangendo a costa nordestina, é influenciado pelos ventos alísios de E, NE e SE. O intermediário, entre o litoral fluminense e a ilha de Santa Catarina, reflete a influência da precipitação sazonal que caracteriza a ZCAS. O transporte eólico é aí dominado pelos ventos mais fortes de sul, efetivos preferencialmente no inverno, estação mais seca e de frentes frias mais intensas. No setor sul, a distribuição de umidade é antes controlada pelo avanço da massa de ar polar que pela sazonalidade. Assim, os ventos mais fracos, porém mais secos e persistentes, oriundos de NE, prevalecem sobre os intensos ventos de sul no transporte eólico.

13. A influência da orientação da linha de costa sobre a direção e rumo de avanço dos campos de dunas diminui gradualmente de norte para sul. Assim, no setor norte, variações sub-regionais no rumo de avanço são determinadas principalmente pela transversalidade entre direção de vento e linha de costa. Em Cabo Frio, no setor intermediário, campos de dunas com rumos opostos ocorrem em praias vizinhas de distintas orientações. Já no setor sul, reversões nos campos de dunas ocorrem apenas em caráter local e/ou temporário e campos de dunas sub-paralelos à costa tornam-se mais comuns.

14. A redução, de norte para sul, da influência da orientação da costa sobre o rumo de avanço dos campos de dunas pode ser mais um indício de influência do clima, em escala regional (regimes de ventos com menor variabilidade direcional a sul). Mas reflete também a redução da amplitude de maré para sul. A regra de Goldsmith, de maior potencial de formação de dunas com aumento do ângulo entre costa e vento, baseia-se na premissa implícita de redução de efluxo para os sistemas subaquosos vizinhos, com o aumento desse ângulo. No entanto, este efluxo pode ser reduzido também por outros fatores, com destaque para a diminuição da retirada de sedimentos pela maré.

15. Em escala mais local e imediata, a orientação da linha de costa e das frentes de onda, e portanto, o rumo residual de deriva litorânea longitudinal, possuem evidente influência na posição dos campos de dunas, em relação ao arco praial, e na sua assimetria. Como regra, os campos de dunas iniciam-se e são melhor desenvolvidos, com maiores distância e altura de equilíbrio, no pólo deposicional da deriva longitudinal. Esta regra é válida pelo menos em arcos praiais restritos (até dezenas de quilômetros), sem trânsito (by-pass) eólico ou litorâneo significativo, onde a capacidade de transporte por deriva litorânea longitudinal seja compatível com o aporte continental através de rios e desembocaduras estuarino-lagunares. Esta é a condição dominante entre o cabo de Santa Marta e a costa do Piauí.

16. A sul do cabo de Santa Marta, a quase ausência de rios ou promontórios, por distâncias de dezenas de quilômetros ao longo da costa, a existência de irregularidades suaves na plataforma continental interna adjacente e o ângulo baixo de declive desta plataforma (em torno do "valor mínimo" de $0,1^{\circ}$, citado na conclusão 7) fazem com que o balanço de sedimentos nos sistemas costeiros fique a mercê das convergências e divergências de refração de ondas criadas pela topografia de fundo. Desse modo, a influência da fisiografia da plataforma continental interna sobre a energia e a trajetória das ondas é realçada, com concentração de estoque sedimentar e de campos de dunas nas zonas salientes, caracterizadas por convergência de fluxo sedimentar por ondas e aumento de declive. 
17. A assimetria dos campos de dunas de Pequenos Lençóis e Lençóis Maranhenses, MA, mais desenvolvidos em sua parte leste, de barlamar de deriva litorânea longitudinal, relaciona-se a volume de sedimentos costeiros introduzido por rios maior que a capacidade de dispersão pela deriva longitudinal. Em escala mais abrangente, porém, a reciclagem sucessiva de sedimentos eólicos de um campo de dunas para outro, desde Tutóia até Lençóis Maranhenses, através desses rios, e a interrupção da deriva longitudinal regional pela baía de São José, reflete-se no aumento progressivo de tamanho dos campos de dunas rumo $W$.

18. Os elementos morfológicos possíveis em sistemas eólicos costeiros podem ser divididos, quanto à sua função, em quatro grupos: estoque ou suprimento inicial, deflação, cavalgamento ou superposição, avanço.

19. Elementos de estoque ou suprimento inicial possuem as funções de armazenar e fornecer areia para as demais fácies do sistema eólico. Correspondem assim ao que tem sido denominado de sistema praia-duna. Incluem dunas frontais (estabelecidas e incipientes), franjas de areia, protodunas e dunas sem vegetação de orientação transversal ao vento (com respectivas planicies interdunas e nebkhas ou retrocordões associados). Constituem a única categoria funcional de elemento morfológico que possui existência universal. Sob condição de desequilíbrio construtivo neste conjunto de elementos (influxo maior que efluxo), o excesso de areia tende a ser consumido na formação e alimentação de outros grupos funcionais de elementos, mais interiores.

20. A sucessão de elementos morfológicos eólicos ao longo do sistema praia - duna é determinada pela distribuição longitudinal de sedimentos. Esta, por sua vez, seria controlada principalmente pela área fonte continental imediata (falésias e rios) e pelo padrão de deriva litorânea longitudinal. A alternância e/ou passagem gradual entre feições eólicas de caráter deposicional e erosivo pode ser correlacionada à existência de zonas de excesso ou déficit, respectivamente, de sedimentos no prisma praia-duna.

21. Nas praias adjacentes a campos de dunas, a associação no tempo e no espaço entre dunas com e sem vegetação evidencia que dunas livres formam-se às custas da destruição de dunas frontais em presença de excesso de areia incoesa e que estas podem resultar da colonização de dunas livres por vegetação. Os dois tipos de dunas estariam relacionados como os lados opostos de um balanço de equilíbrio, controlado pela quantidade de areia disponivel ao retrabalhamento eólico.

22. Em ordem de vocação deposicional eólica decrescente, os elementos morfológicos eólicos de sistemas praia - duna frontal podem ser separados em seis categorias principais: 1. elementos de estocagem sedimentar imediata, representados pelas dunas frontais incipientes em terraço ou cordão; 2 . elementos de estocagem sedimentar imediata retomada, correspondente a dunas frontais incipientes em rampa; 3. elementos relacionados a estocagem sedimentar interrompida, abrangendo as dunas frontais incipientes com falésias vivas; 4 . elementos de manutenção de estoque mediato, correspondentes às dunas frontais estabelecidas; 5 . elementos de erosão temporária, representados por dunas estabelecidas ativas com falésias; e 6 . elementos com erosão duradoura, equivalentes a paleodunas com falésias.

23. Para dada orientação do vento e da linha de costa, a altura e a distância de equilíbrio do sistema eólico aumentam em função direta do incremento na relação influxo/efluxo dos elementos de estoque inicial. Ao longo de uma praia em que exista variação no tipo de elemento eólico de estoque primário, o campo de dunas tende a ser melhor desenvolvido em altura e extensão nos trechos de dunas sem vegetação, como transversais e protodunas, que nos trechos de dunas frontais. 
24. O grupo dos elementos de deflação possui a função de separar duas acumulações principais (estoque inicial e estoque final) segundo a distância de equilibrio. Inclui rupturas de deflação, rastros lineares residuais, retrocordões, dunas parabólicas e parte dos montes residuais. Características comuns a estes elementos são o caráter vegetado e a elevada capacidade de reciclagem dos próprios sedimentos.

25. Quando o saldo sedimentar criado nos elementos de estoque inicial é baixo, a simples existência dos elementos de deflação é suficiente para consumir o excesso de areia do sistema. Caso contrário, rumo ao interior, seguem-se mais um ou dois grupos de elementos morfológicos: os de cavalgamento ou superposição e os de avanço.

26. Elementos de superposição ou cavalgamento incluem dunas barcanas e, tipicamente, cadeias barcanóides, com respectivas depressões interdunas e projeções lineares. Seu papel è o de elevar a acumulação até a altura de equilíbrio, através da superposição sobre megaforma de hierarquia maior, representada pelo campo de dunas livre, e, ao mesmo tempo, através do cavalgamento das formas de leito de mesma hierarquia.

27. Elementos de avanço, representados por cordões de precipitação e lobos deposicionais, possuem a função de estender o campo de dunas, lateral e longitudinalmente, até sua distância de equilibrio. Na ausência de elementos de superposição, devido à razão influxo/efluxo insuficiente, assumem também a função de alcançar a altura de equilíbrio.

28. Em analogia com demais grupos funcionais de elementos, os de avanço apresentam influxo maior que efluxo enquanto, mantida a taxa de entrada de sedimentos no sistema, a distância de equilibrio não tiver sido atingida. Uma vez alcançada esta distância, o saldo entre influxo e efluxo nas fácies de avanço também se torna nulo. A partir deste ponto, a evolução do sistema varia, conforme seu balanço influxo-efluxo como todo torne-se nula ou mantenha-se positiva.

29. Se a distância de equilibrio é atingida e o saldo influxo-efluxo no sistema é nulo, as fácies de avanço passam simplesmente a migrar. Esta migração leva ao distanciamento entre campo de dunas e área fonte além da distância de equilibrio e, a médio prazo, à estabilização do campo de dunas. Ao mesmo tempo, um novo campo de dunas tende a surgir junto à praia.

30. Se o saldo influxo-efluxo no sistema como todo permanece positivo, o sistema mantémse através de retroalimentação negativa, com a subdivisão em duas porções, separadas por planicie de deflação, de modo que a porção mais proximal passe a atuar como fonte para a distal. Ocorre assim a "duplicação" de campos de dunas ativos.

31. A replicação de campos de dunas pode ocorrer tantas vezes quantas a distância de equilibrio regional for alcançada sob condição de influxo do sistema maior que efluxo.

32. Os grupos de elementos morfológicos classificados quanto à função constituem domínios do espaço dentro do sistema e, por extensão, verdadeiras associações de fácies. Assim, os elementos de estoque inicial compõem a associação praia-duna (A). Os elementos de deflação reúnem-se na associação planície deflacionar $(B)$. $E$ os elementos de cavalgamento e de avanço, isolados ou associados, definem uma terceira associação faciológica, o campo de dunas livres $(\mathrm{C})$.

33. As relações entre as associações faciológicas podem ser resumidas em quatro categorias conforme o equilibrio entre matéria e energia (e entre influxo e efluxo) seja atingido na associação praia-duna (A), na relação entre associação praia-duna e a associação planície de deflação $(A-B)$ ou na relação entre as associações praia-duna, planície de deflação e campo de dunas livres (A-B-C). Relação direta entre as associações 
praia-duna e campo de dunas livres (A-C) representa equilibrio entre influxo e efluxo seguramente ainda não atingido.

34. A partir das quatro espécies de relações entre associações de elementos, oito tipos de sistemas em equilibrio podem ser enumerados, na ordem de entulhamento sedimentar crescente: 1. Tipo A: dunas frontais; 2 . Tipo A-Bl: dunas frontais com rupturas de deflação atadas; 3. Tipo A-BII: dunas frontais e rupturas de deflação independentes; 4. Tipo A-BIII: dunas frontais e dunas parabólicas; 5 . Tipo A-B-Cl: dunas frontais, planície de deflação e cordão de precipitação; 6 . Tipo A-B-Cll: dunas frontais, planície de deflação e barcanóides; 7. Tipo A-B-CIII: dunas frontais, planície de deflação e campos de dunas livres completos; 8. Tipo A-C: protodunas/dunas transversais (sensu lato) e campos de dunas livres completos.

35. A tipologia de sistemas eólicos de 1 a 8 relaciona-se à relação influxo-efluxo crescente, relativa ao espaço de acumulação.

36. A redução do ângulo entre vento efetivo e linha de costa em vários exemplos de tipos de sistemas de número mais alto da costa brasileira pode ser relacionada à elevada taxa de manutenção da areia eólica dentro de faixa costeira restrita.

37. Os sistemas eólicos limitados à associação praia-duna, supostamente gerados sob baixo saldo entre influxo e efluxo, apresentam duas de suas áreas de ocorrência mais importantes, o litoral norte paulista e sul fluminense e o litoral sul nordestino, coincidentes com áreas de espaço de acumulação reduzido pela máxima aproximação à costa das encostas da serra do Mar e das falésias da Formação Barreiras, respectivamente. Aqui, são provavelmente outros fatores, controladores do próprio aporte, como as características morfodinâmicas das praias, de tombo, e a constituição dos sedimentos, que inibem o desenvolvimento do sistema eólico.

38. Alcançada a relação de equilibrio entre influxo e efluxo dentro do sistema, e suposta nula a criação de espaço (através, por exemplo, de estabilidade da linha de costa), cada um dos oito tipos prossegue ativo e estável, enquanto essas condições permanecerem. Nessa situação, a resposta do sistema é de permanente reconstrução, no caso de elementos de dunas frontais, e de simples migração no rumo do vento, no caso de demais elementos. Desse modo, nos tipos 1 e 2, a associação de elementos praia-duna mantém-se na mesma posição ao longo do tempo, sem perder suas caracteristicas morfológicas. Analogamente, nos tipos 3 a 8 , as associações de elementos de deflação e de campo de dunas, replicadas ou não, mudam de posição, sem alteração substancial de morfologia.

39. Se a relação influxo/efluxo ou o espaço de acumulação (linha de costa, por exemplo) se modificam, criando desequilíbrio próximo do equilíbrio, o sistema reage por auto-regulação ou retroalimentação negativa, sem modificar suas características morfológicas essenciais.

40. Se a relação influxo/efluxo ou o espaço de acumulação se modificam de modo drástico, criando desequilibrio muito distante do equilibrio, o sistema reage por auto-organização ou retroalimentação positiva. Passa-se de um estágio morfodinâmico a outro, em processo instantâneo na escala de tempo geológica ("evolução espontânea").

41. Sob condição de influxo especifico decrescente (queda absoluta de razão influxo/efluxo e/ou aumento absoluto de espaço), a evolução espontânea consiste em deslocar o sistema para um novo equilibrio dinâmico, em que a retenção de areia seja menor, portanto para estágio morfodinâmico de número inferior; e vice-versa.

42. O comportamento da linha de costa não é suficiente para determinar o tipo e a dinâmica do sistema eólico, mas influi na morfodinâmica eólica através do princípio de autoorganização. Por exemplo, se a linha de costa regride irreversivelmente, parte da areia que antes se encontrava em circulação no sistema praia-duna passa a ser consumida para a construção dos elementos subaquosos progradantes, o que diminui a disponibilidade de 
areia para o sistema eólico, ao mesmo tempo em que amplia o espaço de acumulação; a reação do sistema é portanto de deslocar o equilíbrio para estágio compatível com menor consumo de areia eólica.

43. No caso oposto, costa com comportamento transgressivo, depósitos subaquosos preexistentes, erodidos e recolocados em circulação, elevam a probabilidade de alimentação do sistema eólico, ao mesmo tempo em que podem reduzir o espaço de acumulação. A retroalimentação positiva do sistema atua neste caso no sentido de aumentar a saturação de areias eólicas.

44. Sob comportamento regressivo persistente, a sucessão de regimes de saldo eólico cada vez menor pode conduzir, por exemplo, à transformação de campos de dunas livres em feixes de cordões dunares. Já sob comportamentos transgressivos, cordões de dunas frontais podem sofrer deflação crescente e permitir o estabelecimento gradual de campos de dunas livres.

45. Este é o tipo de processo aqui evocado para explicar a formação das duas seqüências de depósitos eólicos, deduzidas em Santa Catarina, mas extensivel a grande parte dos setores costeiros brasileiros com vocação atual ou recente para formação de campos de dunas livres.

46. A seqüência eólica mais antiga (A) relaciona-se ao NRM alto do último interglacial, enquanto a seqüência mais nova (B) associa-se ao NRM alto do Holoceno.

47. A ligação entre mudanças de NRM e iniciação de campos de dunas pode ser usada para integrar os sistemas eólicos costeiros ao modelo da estratigrafia de seqüencias. A fase principal de acumulação eólica ocorreria no final do trato de sistema transgressivo e no trato de mar alto. Nas partes marginais do sistema, sedimentos eólicos depositados durante tratos de mar alto apresentam maior potencial de preservação em virtude da menor probabilidade de erosão costeira.

48. No contexto da estratigrafia de seqüências, as sucessões A e B correspondem a seqüências deposicionais de quarta ordem (relacionadas a ciclos com 10 a $100 \mathrm{ka}$ de magnitude).

49. Dado o caráter global das mudanças de NRM, na escala de centenas de milhares de anos, as seqüências $A$ e $B$ podem ser correlacionadas com depósitos eólicos ao longo de outros setores da costa brasileira.

50. Quatro gerações de depósitos eólicos quaternários são reconhecidos com base em critérios morfoestratigráficos ou de datação absoluta, em diferentes áreas costeiras do Brasil com campos de dunas livres (Ceará, Rio Grande do Norte, Sergipe e norte da Bahia e Santa Catarina). Eles são correlacionáveis entre si e possuem idades aparentemente compativeis com o modelo de iniciação de campos de dunas em tratos de mar alto.

51. Os depósitos representativos de três gerações eólicas mais novas (2, 3 e 4), integrantes da seqüência $B$, teriam se diferenciado no contexto de retroalimentações negativas posteriores à máxima inundação marinho-lagunar do Holoceno.

52. Transformações na razão entre o saldo influxo-efluxo e o espaço de acumulação eólica refletem-se também no sentido de movimento do sistema (avanço, recuo, expansão ou contração), ao longo do tempo, na velocidade com que este movimento ocorre, e conseqüentemente, na maneira como os elementos deposicionais se distribuem e se empilham (arquitetura deposicional).

53. Linha de costa estável e aporte sedimentar eólico crescente em razão linear geram padrão clino-ascendente de migração de campo de dunas, com deposição de fácies 
proximais sobre fácies distais. Linha de costa estável e aporte sedimentar eólico crescente em função exponencial induz avanço de fácies de superposição e cavalgamento por sobre associações vizinhas.

54. Linha de costa com pulsos regressivos e aporte sedimentar eólico crescente em razão linear gera campos de dunas separados, com empilhamento de fácies distais de avanço sobre fácies de suprimento inicial e deflação. Mesma condição, mas com taxa exponencial de crescimento do aporte eólico gera amalgamação de depósitos de superposição formados em diferentes linhas de tempo.

55. Linha de costa transgressiva sob NRM ascendente favorece inundação das fácies mais proximais e redução da área de acumulação, com concentração do aporte eólico e aumento da saturação sedimentar. A tendência é o crescimento ascendente da representatividade de fácies de cavalgamento, principalmente em relação a fácies de deflação, e a deposição de fácies subaquosas sobre fácies de deflação e avanço. 


\section{Referências bibliográficas}

AB'SABER, A.N. 2001. Litoral do Brasil. Brazilian Coast. São Paulo, Metavídeo SP Produção e Comunicação Ltda., 287p.

ALLEN, J.R.L. 1983. Studies in fluviatile sedimentation: bars, bar complexes, and sansdtone sheets (low sinuosity braided streams) in the Brownstones (L. Devonian), Welsh border. Sedimentary Geology, 33: 237-293.

ALMEIDA, F.F.M. 1953. Contribuição à geomorfologia da região oriental de Santa Catarina. In: ASSEMBLÉIA GERAL ORDINÁRIA DA ASSOCIAÇÃO DOS GEÓGRAFOS DO BRASIL, 4, Goiânia, GO, 1948. Anais da Associação de Geógrafos do Brasil, 3(1): 1037.

ALMEIDA, F.F.M. 1964. Os fundamentos geológicos do relevo paulista. Boletim do Instituto Geográfico e Geológico, 41: 169-263.

ALMEIDA, F.F.M. 1975. The system of continental rifts bordering of Santos basin, Brazil. In: INTERNATIONAL SYMPOSIUM ON CONTINENTAL MARGINS OF ATLANTIC TYPE, São Paulo, SP, 1975. Anais da Academia Brasileira de Ciências, 48(supl.): 15-26.

ALMEIDA, F.F.M. 1991. O alinhamento magmático de Cabo Frio. In: SIMPÓSIO DE GEOLOGIA DO SUDESTE, 2, São Paulo, SP. Atas... São Paulo, SBG/SP-RJ, p.423437.

AMARAL, P.G.C.; LEDRU, M.P.; RICARDI-BRANCO, F.; GIANNINI, P.C.F. 2006 Late Holocene development of a mangrove ecosystem in southeastern Brazil (Itanhaém, state of São Paulo). Palaeogeography, Palaeoclimatology, Palaeoecology, 241: 608620 .

ANDERTON, R. 1985. Clastic facies models and facies analysis. In: BRENCHLEY, P.J. \& WILLIAMS, B.P.J. eds. Recent Developments and Applied Aspects. Oxford, The Geological Society - Blackwell Scientific Publ., p.31-47.

ANGULO, R.J. 1992. Geologia da Planície Costeira do Estado do Paraná. São Paulo, SP, Instituto de Geociências da Universidade de S.Paulo. Tese de Doutoramento (inéd.). $334 p$.

ANGULO, R.J. 1993a. Indicadores biológicos de paleoníveis marinhos quaternários na costa paranaense. Boletim Paranaense de Geociências, 41:1-34.

ANGULO, R.J. 1993b. A ocupação urbana do litoral paranaense e as variações da linha de costa. Boletim Paranaense de Geociências, 41: 73-81.

ANGULO, R.J. 1993c. Variações na configuração da linha de costa no Paraná nas últimas quatro décadas. Boletim Paranaense de Geociências, 41: 52-72.

ANGULO, R.J. \& GIANNINI, P.C.F. 1996. Variações do nivel relativo do mar nos últimos dois mil anos na Região Sul do Brasil: uma discussão. Boletim Paranaense de Geociências, 44: 67-76.

ANGULO, R.J. \& LESSA, G.C. 1997. The Brazilian sea-level curves: a critical review with emphasis on the curves from the Paranaguá and Cananéia regions. Marine Geology, 140(1997): 141-166.

ANGULO, R.J. \& SUGUIO, K. 1994. Problems in the interpretation of quaternary beach ridges: the example from the coastal plain of Paraná (Brazil). Anais da Academia Brasileira de Ciências, 66: 347-358. 
ANGULO, R.J.; GIANNINI, P.C.F.; KOGUT, J.S.; PRAZERES FILHO, H.J.; SOUZA, M.C. 1994. Variation of sedimentological parameters with deposition age across a succession of beach-ridges in the Holocene of Mel Island, Paraná, Brazil. In: INTERNATIONAL SEDIMENTOLOGICAL CONGRESS, 14. Recife, PE, 1994. Abstracts... Recife, IAS, p.D1-D3.

ANGULO, R.J.; GIANNINI, P.C.F.; KOGUT, J.S.; PRAZERES FILHO, H.J.; SOUZA, M.C. 1996. Variação das características sedimentológicas através de uma sucessão de cordões holocênicos, como função da idade deposicional, na ilha do Mel (PR). Boletim Paranaense de Geociências, 44: 77-86.

ANGULO, R.J.; GIANNINI, P.C.F.; SUGUIO, K.; PESSENDA, L.C.R. 1999. Relative sea level changes during the last 5500 years in the Laguna-Imbituba region (Santa Catarina, Brazil), based on vermetid radiocarbon ages. Marine Geology, 159(1999): 323-339.

ANGULO, R.J; LESSA, G.C; SOUZA, M.C. 2006. A critical review of mid- to late-Holocene sea-level fluctuations on the eastern Brazilian coastline. Quaternary Science Reviews, 25: 486-506.

ARENS, S.M. \& WIERMA, J. 1994. The Dutch foredunes: inventory and classification. Journal of Coastal Research, 10: 189-202.

ARZ, H.W.; PATZOLD, J.; WEFER, G. 1998. Correlated millenial-scale changes in surface hydrography and terrigenous sediment yield inferred from Last-Glacial Marine deposits off Northeastern Brazil. Quaternary Research, 50: 157-166.

ARZ, H.W.; PATZOLD, J.; WEFER, G. 1999. The deglacial history of the western tropical Atlantic as inferred from high resolution stable isotope records off northeastern Brazil. Earth and Planetary Science Letters, 167: 105-117.

ASMUS, H.E. 1978. Hipóteses sobre a origem dos sistemas de zonas de fraturas oceânicas /alinhamentos continentais que ocorrem nas regiões sudeste e sul do Brasil. In: PETROBRAS. Aspectos Estruturais da Margem Continental Leste e Sudeste do Brasil. Rio de Janeiro, p.39-73. (Série Projeto Remac, 4).

ASMUS, H.E. 1981. Relacionamento genético de feições geológicas da margem continental sudeste brasileira e da área continental emersa adjacente. In: SIMPÓSIO REGIONAL DE GEOLOGIA, 3, Curitiba, PR. Atas... São Paulo, SBG. v.1, p.262-273.

ASMUS, H.E. 1983. A Bacia de Pelotas no esquema evolutivo da margem continental brasileira. In: SIMPÓSIO SUL-BRASILEIRO DE GEOLOGIA, 1, Porto Alegre. Atas... Porto Alegre, SBG, p.245-251.

ASMUS, H.E. \& CARVALHO, J.C. 1978. Condicionamento tectônico da sedimentação nas bacias marginais do Nordeste do Brasil (Sergipe/Alagoas e Pernambuco/Paraíba). In: PETROBRAS. Aspectos Estruturais da Margem Continental Leste e Sudeste do Brasil. Rio de Janeiro, p.7-24. (Série Projeto Remac, 4).

ATLAN, H. 1979. Entre le Cristal et la Fummée. Essai sur L'órganisation du Vivant. Paris, Editions du Seuil, 1986. Rio de Janeiro, Jorge Zahar Editor, Tradução autorizada (Entre o Cristal e a Fumaça), 1992, 168 p.

BAGNOLD, R.A. 1941. The Physics of Blown Sand and Desert Dunes. Methuen \& Co. Ltd., London, $265 \mathrm{p}$.

BAK, P. 1997. How Nature Works - The Science of Self-Organized Criticality. Oxford, Oxford University Press, $212 \mathrm{p}$.

BAK, P.; TANG, C.; WIESENFELD, K. 1987. Self-organized criticality, an explanation of $1 / f$ 
noise. Physical Review Letters, 59: 381.

BARBERI, M.; SALGADO-LABOURIAU, M.L.; SUGUIO, K. 2000. Paleovegetation and paleoclimate of "Vereda de Águas Emendadas", central Brazil. Journal of South American Earth Sciences, 13: 241-254.

BARBOSA, L.M. 1997. Campos de dunas costeiras associados à desembocadura do Rio São Francisco (SE/AL). Salvador, Instituto de Geociências da Universidade Federal da Bahia, Tese de Doutoramento (inéd.), $202 \mathrm{p}$.

BARBOSA, L.M.; BITTENCOURT, A.C.S.P.; DOMINGUEZ,J.M.L.; MARTIN, L. 1986. Mapa Geológico do Quaternário Costeiro do Estado de Alagoas (integrado ao Mapa Geológico do Estado de Alagoas, escala 1:250.000), Recife, DGM/DPM, 2: 73-76. (Série Mapas e Cartas de Sintese, Seção Geológica).

BARCELOS, J.H. 1975. Sedimentação e Subambientes Deposicionais da Ilha Comprida, São Paulo. São Paulo, Instituto de Geociências da Universidade de S.Paulo. Dissertação de Mestrado (inéd.), 155p.

BARCELOS, J.H.; SUGUIO, K.; COIMBRA, A.M. 1976. Sedimentação e subambientes deposicionais da liha Comprida, São Paulo. In: CONGRESSO BRASILEIRO DE GEOLOGIA, 29, Camboriú, SC. Anais... Florianópolis, SBG, v.2, p. 107-135.

BARRETO, A. M. F. 1996. Interpretação Paleoambiental do Sistema de Dunas Fixadas do Médio Rio São Francisco, Bahia. São Paulo, Instituto de Geociências da Universidade de São Paulo, Tese de Doutoramento (inéd.), $174 \mathrm{p}$.

BARRETO, A.M.F.; TATUMI, S.H.; SUGUIO, K.; OLIVEIRA, P.E.; AYATA, W.; WATANABE, S. 1999. As dunas costeiras inativas do Rio Grande do Norte datadas por termoluminescência e implicações paleoambientais. In: CONGRESSO DA ASSOCIAÇÃO BRASILEIRA DE ESTUDOS DO QUATERNÁRIO (ABEQUA), 7, Porto Seguro, BA. Anais... meio digital (cd), Salvador, Abequa.

BARRETO, A.M.F; SUGUIO, K.; BEZERRA, F.H.R.; TATUMI, S.H.; GIANNINI, P.C.F. 2001a. Geologia e geomorfologia do Quaternário costeiro do Estado do Rio Grande do Norte. In: CONGRESSO DA ASSOCIAÇÃO BRASILEIRA DE ESTUDOS DO QUATERNÁRIO (ABEQUA), 8, Imbé, RS. Boletim de Resumos...Porto Alegre, Abequa, p.177-178.

BARRETO, A.M.F.; SUGUIO, K.; TATUMI, S.H.; YEE, M.; GIANNINI, P.C.F.; BEZERRA, F.H.R. 2001b. Dunas inativas do Rio Grande do Norte: idades, áreas-fonte e possíveis correspondências com o nivel relativo do mar no Quaternário. In: SIMPÓSIO REGIONAL DE GEOLOGIA DO NORDESTE. Boletim de Resumos... Recife, SBG

BARRETO, A.M.F.; BEZERRA, F.H.R.; SUGUIO, K.; TATUMI, S.H.; YEE, M.; PAIVA, R.P.; MUNITA, C.S. 2002a. Late Pleistocene marine terrace deposits in Northeastern Brazil: sea-level change and tectonic implications. Palaeogeography, Palaoclimatology, Palaecology, 179: 57-69.

BARRETO, A.M.F.; SUGUIO, K.; BEZERRA, F.H.R.; TATUMI, S.H.; YEE, M.; OLIVEIRA, P.E. 2002b. Datação de dunas costeiras inativas do Estado da Paraíba por métodos de luminescência. In: CONGRESSO BRASILEIRO DE GEOLOGIA, 41, João Pessoa, PB, Anais... João Pessoa, SBG, p. 351.

BARRETO, A.M.F.; SUGUIO, K.; DE OLIVEIRA, P.E.; TATUMI, S.H. 2002c. O campo de dunas inativas do médio rio São Francisco, Bahia, Brasil. In: SCHOBBENHAUS, C.; CAMPOS, D.A.; QUEIROZ, E.T.; WINGE, M.; BERBERT-BORN, M. eds. Sitios Geológicos e Paleontológicos do Brasil. Brasília, DNPM. Também disponível no sítio: http/l:www:unb.br/ig/sigep $n^{\circ} 56$. 
BARRETO, A.M.F; SUGUIO, K.; BEZERRA, F.H.R.; TATUMI, S.H.; YEE, M.; GIANNINI, P.C.F. 2004. Geologia e geomorfologia do Quaternário costeiro do Estado do Rio Grande do Norte. São Paulo, Geologia-USP, 4(2): 1-12.

BEHLING, H. 1995a. A high resolution Holocene pollen record from Lago do Pires, SE Brazil: vegetation, climate and fire history. Journal of Paleolimnology, 14(3): 253-268.

BEHLING, H. 1995b. Investigations into the Late Pleistocene and Holocene history of vegetation and climate in Santa Catarina (S Brazil). Vegetation History and Archaeobotany, 4(3): 127-152, 1995b.

BEHLING, H. 1997a. Late Quaternary vegetation, climate and fire history from the tropical mountain region of Morro de Itapeva, SE Brazil. Palaeogeography, Palaeoclimatology, Palaeoecology, 129: 407-422.

BEHLING, H. 1997b. Late Quaternary vegetation, climate and fire history of the Araucaria forest and campos region from Serra Campos Gerais, Paraná State (South Brazil). Review of Palaeobotany and Palynology, 97: 109-121.

BEHLING, H. 1998. Late Quaternary vegetational and climatic changes in Brazil. Review of Palaobotany and Palinology, 99:143-156.

BEHLING, H. 2002. South and Southeast Brazilian grasslands during Late Quaternary times: a synthesis. Palaeogeography, Palaeoclimatology, Palaeoecology, 177: 19-27.

BEHLING, H. \& NEGRELLE, R.R.B. 2001. Tropical rain forest and climate dymamics of the Atlantic lowland, Southern Brazil, during the Late quaternary. Quaternary Research, 56: 383-389.

BEHLING, H.; COHEN, M.C.L.; LARA, R.J. 2001. studies on Holocene mangrove ecosystems dynamics of the Bragança Peninsula in north-eastern Pará, Brazil. 2001. Palaeogeography, Palaeoclimatology, Palaeoecology, 167: 225-242.

BEHLING, H.; LICHTE, M.; MIKLÓS, A.W. 1998. Evidence of a forest free landscape under dry and cold climatic conditions during the last glacial maximum in the Botucatu region (São Paulo State), Southeastern Brazil. Quaternary of South America and Antarctic Peninsula, 11: 99-110.

BENTZ, D. 2004. Os Cordões Litorâneos da Planície de Una-Juréia, Municípios de Peruibe e Iguape, SP. São Paulo, Instituto de Geociências da Universidade de São Paulo, Dissertação de Mestrado (inéd.). 108p, 4 anexos.

BENTZ, D. \& GIANNINI, P.C.F. 2003. Interpretação aerofotogeomorfológica da planície costeira de Una-Juréia, municipios de Peruibe-lguape, SP: modelo evolutivo e origem da erosão na praia da Juréia. In: CONGRESSO DA ASSOCIAÇÃO BRASILEIRA DE ESTUDOS DO QUATERNÁRIO (ABEQUA), 9, Recife, PE. Anais... meio digital (cd). Recife, ABEQUA.

BERNAT, M.; MARTIN, L.; BITTENCOURT, A.C.S.P.; VILAS-BOAS, G.S. 1983. Datation Io/U du plus haut niveau marin interglaciaire sur la côte du Brésil: utilisation du 229Th comme traceur. Comptes Rendus de l'Ácademie de Sciences de Paris, 296: 197-200.

BERTALANFFY, L.V. 1928. Lo legado de Cusanus. In: Perspectivas en la Teoria General de Sistemas. Madrid, Alianza Universidad Ed., 1 ed. cast., 1979. p.49 61.

BERTALANFFY, L.V. 1937. La concepción organísmica. In: Perspectivas en la Teoria General de Sistemas. Madrid, Alianza Universidad Ed., 1 ed. cast., 1979. p.89-93. 
BERTALANFFY, L.V. 1950. Sistemas abiertos en física y biologia. In: Perspectivas en la Teoria General de Sistemas. Madrid, Alianza Universidad Ed., 1 ed. cast., 1979. p.115124.

BERTALANFFY, L.V. 1960. Nuevos patrones en el pensamiento biológico y médico. In: Perspectivas en la Teoría General de Sistemas. Madrid, Alianza Universidad Ed., 1 ed. cast., 1979. p.37-48.

BERTALANFFY, L.V. 1965. Modelos teóricos en biología. In: Perspectivas en la Teoria General de Sistemas. Madrid, Alianza Universidad Ed., 1 ed.cast., 1979. p.94-103.

BERTALANFFY, L.V. 1968. Teoria Geral de Sistemas. Petrópolis, Ed. Vozes Ltda. 2 ed. portug., 1975. 351p.

BERTALANFFY, L.V. 1972a. Historia y desarollo de la teoría general de sistemas. In: Perspectivas en la Teoria General de Sistemas. Madrid, Alianza Universidad Ed., 1 ed.cast., 1979. p.137-156.

BERTALANFFY, L.V. 1972b. Introducción. In: Perspectivas en la Teoría General de Sistemas. Madrid, Alianza Universidad Ed., 1 ed.cast., 1979. p.27-31.

BEZERRA, F.H.R.; BARRETO, A.M.F.; SUGUIO, K. 2003. Holocene sea-level history on the Rio Grande do Norte State coast, Brazil. Marine Geology, 196(2003): 73-89.

BIGARELLA, J.J. 1946. Contribuição ao Estudo da Planície Litorânea do Estado do Paraná. Curitiba, Instituto de Biologia e Pesquisas Tecnológicas, 111p, 44 estampas (Arquivos de Biologia e Tecnologia, 1, artigo 7).

BIGARELLA, J.J. 1970/1971. Wind pattern deduced from dune morphology and internal structures. Boletim Paranaense de Geociências., 28/29: 74-114.

BIGARELLA, J.J. 1972. Eolian environments: their characteristics, recognition, and importance. In: RIGBY, J.K. \& HAMBLIN, W.K. eds. Recognition of Ancient Sedimentary Environments, p.12-62. Society of Economic Paleontologists Mineralogists (Special Publication, 16).

BIGARELLA, J.J. 1975. Lagoa dune field (State of Santa Catarina, Brazil), a model of eolian and pluvial activity. In: INTERNATIONAL SYMPOSIUM ON THE QUATERNARY, Curitiba, PR. Special Contributions... Boletim Paranaense de Geociências, 33: 133-167

BIGARELLA, J.J. \& BECKER, R.D. 1975a. Correlative deposits. In: INTERNATIONAL SYMPOSIUM ON THE QUATERNARY, Curitiba, PR. Topics for Discussion, X... Boletim Paranaense de Geociências, 33: 225-230.

BIGARELLA, J.J. \& BECKER, R.D. 1975b. Sea level changes. In: INTERNATIONAL SYMPOSIUM ON THE QUATERNARY, Curitiba, PR. Topics for Discussion, XIII... Boletim Paranaense de Geociências, 33: 245-251.

BIGARELLLA, J.J. \& FREIRE, S.S. 1960. Nota sobre a ocorrência do cascalheiro marinho no litoral do Paraná. Boletim da Universidade do Paraná, Geologia, 3: 1-22.

BIGARELLA, J.J. \& MOUSINHO, M.R. 1965. Contribuição ao estudo da Formação Pariqüera-Açu, Estado de São Paulo. Boletim Paranaense de Geografia, 16/17: 1741.

BIGARELLA, J.J.; BECKER, R.D.; DUARTE, G.M. 1969. Coastal dune structures from Paraná, Brazil. Marine Geology, 7: 5-55.

BIGARELLA, J.J.; DUARTE, G.M.; BECKER, R.D. 1970/1971. Structural characteristics of the dune, foredune, interdune, beach, beach-dune, ridge and sand ridge deposits. Boletim Paranaense de Geociências, 28/29: 9-72, 32 fig. 
BITTENCOURT, A.C.S.P; MARTIN, L.; VILAS-BOAS, G.S.; FLEXOR, J.M. 1979. The marine formations of the coast of the State of Bahia, Brazil. In: INTERNATIONAL SYMPOSIUM ON COASTAL EVOLUTION IN THE QUATERNARY, São Paulo, SP. Proceedings... São Paulo, IGCP, p.232-253.

BITTENCOURT, A.C.S.P.; MARTIN, L.; DOMINGUEZ, J.M.L.; FERREIRA,Y.A. 1982. Dados preliminares sobre a evolução paleogeográfica do Rio São Francisco - SE/AL, durante o Quaternário: influência das variações do nivel do mar. In: SIMPÓSIO DO QUATERNÁRIO NO BRASIL, 4, Rio de Janeiro, RJ, 1981. Atas... Rio de Janeiro. p. 49 $-68$.

BITTENCOURT, A.C.S.P.; MARTIN, L.; DOMINGUEZ, J.M.L. 1983a. Evolução paleogeográfica quaternária da costa do Estado de Sergipe e costa sul do Estado de Alagoas. Revista Brasileira de Geociências, 13(2): 93 - 97.

BITTENCOURT, A.C.S.P.; MARTIN, L.; DOMINGUEZ, J.M.L. 1983b. Mapa Geológico do Quaternário Costeiro do Estado de Sergipe. In: BRUNI, M.A.L. \& SILVA, H.P. eds. Mapa Geológico do Estado de Sergipe, Escala 1:250.000. Min. das Minas e Energia / DNPM e Governo do Estado de Sergipe (Secretaria da Indústria, Comércio e Turismo).

BOYD, D.R. \& DYER, B.F. 1964. Frio barrier system of South Texas. Trans. Gulf Coast Assoc. Docs., 14: 309-322.

BRANDÃO, J.A.S.L. \& FEIJÓ, F.J. 1994. Bacia da Foz do Amazonas. Boletim de Geociências da Petrobrás, 8: 117-125.

BREED, C.S. \& GROW, T. 1979. Morphology and distribution of dunes in sand seas observed by remote sensing. In: McKEE, E.D. 1979. ed. A Study of Global Sand Seas, p. 253-302. Washington, U.S. Geological Survey (Professional Papers, 1052).

BROECKER, W.S. \& VAN DONK, J. 1970. Insolation Changes, Ice Volumes, and $\mathrm{O}^{18}$ Record in Deep-Sea Cores. Reviews of Geophysics and Space Physics, 8(1):169-198.

BROOKFIELD, M.E. 1977. The origin of bounding surfaces in ancient aeolian sandstones. Sedimentology, 24(3): 303 - 332.

BROOKFIELD, M.E. 1992. Eolian Systems. In: WALKER, R. G. \& JAMES, N.P. eds. 1992. Facies Models - Response to Sea Level Change. Stittsville, Geological Association of Canada, p.143-156.

BRUUN, P. 1962. Sea level rise as a cause of shore erosion. American Society of Civil Engrs. Proceedings, Journal of Waterways and Harbor Division, 88: 117-130.

BUSH, M.; PIPERNO, D.R.; COLINVAUX, P.; DE OLIVEIRA, P.E.; KRISSEK, L.; MILLER, M.C.; ROWE, W.E. 1992. A 14,300-yr paleoecological profile of a lowload lake in Panamá. Ecological Monographs, 62: 251-275.

BUSH M.; STUTE M.; LEDRU M.P.; BEHLING H.; COLINVAUX P.; DE OLIVEIRA P.E.; GRIMM E.; HABERLE S.; HOOGHIEMSTRA H.; LEYDEN B.; SALGADO-LABOURIAU M.L.; WEBB, R. 2001. Paleotemperatures estimates for the lowland Americas between $30 \mathrm{~S}$ and $30 \mathrm{~N}$ at the last glacial maximum. In: MARKGRAF, V. ed. Present and Past Inter-Hemispheric Climate Linkages in the Americas and their Societal Effects. London, Academic Press, p. 293-306

CAETANO-CHANG, M.R. 1997. A Formação Pirambóia no Centro-Leste do Estado de São Paulo. Rio Claro, SP, Instituto de Geociências e Ciências Exatas, Unesp. Tese de Livre-Docência (inèd.). 196 p. 
CARNEIRO FILHO, A.; SCHWARTZ, D.; TATUMI, S.H.; ROSIQUE, T. 2002. Amazonian paleodunes provide evidence for drier climate phases during the Late PleistoceneHolocene. Quaternary Research 58(2): 205-209.

CARTER, R.W.G. 1988. Coastal Environments. London, Academic Press, 617 p.

CARTER, R.W.G. 1990. The geomorphology of coastal dunes in Ireland. Catena Suppl. 18: $31-40$.

CARTER, R.W.G. \& CHANCE, S. 1997. Integrated management of coastal dunes in Ireland: Assessment and example. In: NOVO, F.G.; CRAWFORD, R.M.M.; BARRADAS, M.C.D. eds. The Ecology and Conservation of European Dunes. Sevilla, Universidad de Sevilla, Secretariado de Publicaciones, p.301-314.

CARTER, R.W.G.; NORDSTROM, K.F. \& PSUTY, N.P. 1990. The study of coastal dunes. In: NORDSTROM, K.F.; PSUTY, N.P \& CARTER, R.W.G. eds. 1990. Coastal Dunes Form and Process. Chichester, John Wiley \& Sons, p.1-11.

CARUSO, F., Jr. 1995. Mapa Geológico e de Recursos Minerais do Sudeste de Santa Catarina. Brasilia, DNPM, 52p., mapa. (Programas Cartas de Síntese e Estudos de Interpretação Geológica, 1).

CARVALHO, A.M. 2002. Dinâmica Costeira e a Atividade Eólica entre Cumbuco e MatõesCosta NW do Estado do Ceará. Salvador, Universidade Federal da Bahia, Tese de Doutorado (inéd.), 194p.

CARVALHO, A.M., COUTINHO, P.N.; MORAIS, J.O. 1994. Caracterização geoambiental e dinâmica costeira da região de Aquiraz na costa leste do Ceará. Revista Geologia UFC, 7: 55-68.

CARVALHO, C.H.G. \& GIANNINI, P.C.F. 1998a. Morfodinamica de draas costeiros e superfícies de truncamento na região de Imbituba-Jaguaruna, SC. In: CONGRESSO BRASILEIRO DE GEOLOGIA, 40, Belo Horizonte, MG. Anais... Belo Horizonte, SBG. p.258.

CARVALHO, C.H.G. \& GIANNINI, P.C.F. 1998b. Morfodinâmica de draas costeiros e superfícies de truncamento no Quaternário da região de Imbituba-Jaguaruna, SC. In: SIMP. DE INICIAÇÃO CIENTÍFICA DA UNIVERSIDADE DE SÃO PAULO, 6, São Carlos, SP. Resumos... meio digital (cd), São Carlos, USP.

CARVALHO, J.C. \& FRANCISCONI, O. 1981. Análise de depocentros e suas associações com a geomorfologia e a estrutura da margem continental brasileira. In: PETROBRAS, DNPM, CPRM. Estruturas e Tectonismo da Margem Continental Brasileira, e Suas Implicações nos Processos Sedimentares e na Avaliação do Potencial de Recursos Minerais. Rio de Janeiro, p.173-186. (Série Projeto Remac, 9).

CARVER, R.E. 1971. Heavy mineral separation. In: CARVER, R.E. ed. Procedures in Sedimentary Petrology. New York, Wiley - Interscience, p.427-452.

CASTELÃO, R.M.; CAMPOS, E.J.D.; MILLER, J.L. 2004. A modelling study of coastal upwelling driven by wind and meanders of the Brazil Current. Journal of Coastal Research, 20(3): 662-671.

CASTRO, J.W.A.; ÁVILA, C.A.; GONÇALVES, R.J. 2002. O sistema de dunas obliquas do litoral norte de Cabo Frio, Estado do Rio de Janeiro. $\mathrm{m}$ : SIMPÓSIO NACIONAL DE GEOMORFOLOFIA, 4, São Luís, MA. Anais... São Luís, UGB, p.23.

CHRISTIANSEN, C. \& BOWMAN, D., 1986. Sea-level changes, coastal dune building and sand drift, North-Western Jutland, Denmark. Geografisk Tidsskrift, 86: 28-31. 
CHRISTIANSEN C.; DALSGAARD, K.; MOLLER, J.T.; BOWMAN, D., 1990. Coastal dunes in Denmark. Chronology in relation to sea-level. Catena Suppl. 18: 61-70.

CHORLEY, R.J. \& KENNEDY, B.A. 1971. Physical Geography: A Systems Approach. London, Prentice-Hall.

CLAUDINO-SALES, V. 2002. Les littoraux du Ceará: Evolution Géomorfophologique de la Zone Côtière de l'Etat du Ceará, du Long Terme au Court Terme. Paris, Université Paris-Sorbonne, Thèse de Doctorat (inéd.), 523p.

CLAUDINO-SALES, V. \& PEULVAST, J.P. 2001. Geomorfologia dos campos de dunas do Estado do Ceará. In: CONGRESSO DA ASSOCIAÇÃO BRASILEIRA DE ESTUDOS DO QUATERNÁRIO (ABEQUA), 8, Imbé, RS. Anais... Porto Alegre, Abequa, p. 273276.

CLAUDINO-SALES, V. \& PEULVAST, J.P. 2002. Dunes generations and ponds on the coast of Ceará, North-East Brazil. In: ALLISON, R. ed. Applied Geomorphology. London, John Wiley \& Sons, p. 421-440.

COE, A.L. \& CHURCH, K.D. 2003. Sequence stratigraphy and sea-level change. In: COE, A.L. ed. The Sedimentary Record of Sea-Level Change. The Open University, Cambridge University Press, Cambridge, p. 57-98.

COLLINSON, J.D. \& THOMPSON, D.B. 1982. Sedimentary Structures. London, George Allen \& Unwin. $187 p$.

COOPER, W.S. 1958. The coastal sand dunes of Oregon and Washington. 169p. Tulsa, Okla, Geological Society America (Memoir, 72).

CORREAA, I.C.S. 1996. Les variations du niveau de la mer durant les derniers 17.500 ans PB: l'exemple de la plate-forme continentale du Rio Grande do Sul - Brésil. Marine Geology, 130(1996): 163-178.

CORREAA, I.C.S. \& TOLDO JR., E.E. 2001. Estabilizações do nivel do mar desde a última glaciação inferidas pela morfologia na plataforma continental sul e sudeste brasileira. In: CONGRESSO DO QUATERNARIO DE PAÍSES DE LÍNGUAS IBÉRICAS, 1, Actas... Lisboa, Portugal. Sociedade Geol. de Portugal, Grupo de Trabalho Português para o Estudo do Quaternário e Assoc. Espagn. para Estudio del Quaternário, Lisboa, p.190-193.

COWELL, P.J. \& THOM, B.G. 1994. Morphodynamics of coastal evoltion. In: CARTER, R.W.G. \& WOODROFFE, C.D. eds. Coastal Evolution, Late Quaternary Shoreline Morphodynamics. Cambridge, Cambridge University Press, p.33-86.

CRISTALLI, P. 2006. Macrofitofósseis em Tufos Calcários Quaternários do Norte da Bahia como Indicadores Paleoclimáticos. São Paulo, Instituto de Geociências da Universidade de São Paulo, Tese de Doutoramento (inéd.), 195p.

CRUZ, F.W., Jr. 2003. Estudo Paleoclimático e Paleoambiental a Partir de Registros Geoquímicos Quaternários em Espeleotemas das Regiões de lporanga (SP) e Botuverá (SC). São Paulo, Instituto de Geociências da Universidade de São Paulo, Tese de Doutoramento (inéd.), 134 p., 1 anexo.

CURTIS, J. \& HODELL, D.A. 1993. An isotopic and trace elements study of ostracods from lake Miragoane, Haiti: a 10,500 year record of paleosalinity and paleotemperature changes in the Caribbean. Climate change in continental isotopic records. Geophysical Monograph, 78: 135-152.

DAVIES, J.L.,1980. Geographical Variation in Coastal Development. London, Longmans, 2 ed, $212 \mathrm{p}$. 
DAVIS, J.C. 1986. Statistics and Data Analysis in Geology. New York. John Wiley \& Sons, $646 \mathrm{p}$.

DEAN, R.G. 1987. Additional sediment input to the nearshore region. Shore \& Beach, 55(3/4): 76-81.

DEBLASIS, P.; KNEIP, A.; SCHEEL-YBERT, R.; GIANNINI, P. C. F.; GASPAR, M. D. 2007. Sambaquis e paisagem: dinâmica natural e arqueologia regional no litoral do Sul do Brasil. Cidade do México, Revista de Arqueologia Americana, no prelo.

DELATTRE, P. 1981. Teoria dos Sistemas e Epistemologia. Lisboa, A Regra do Jogo. 107p. (Cadernos de Filosofia, 2).

DELLA FAVERA, J.C. 1990. Tempestitos na Bacia do Parnaiba. Porto Alegre, Universidade Federal do Rio Grande do Sul. Tese de Doutoramento (inéd.). 2v., 280p.

DE MIO, E. \& GIANNINI, P.C.F. 1997. Variação de minerais pesados transversal à planicie litorânea de Peruibe-ltanhaém, SP. In: CONGRESSO DA ASSOCIAÇÃO BRASILILEIRA DE ESTUDOS DO QUATERNÁRIO (ABEQUA), 6, Curitiba, PR. Resumos Expandidos... Curitiba, Abequa, p.109-114.

DE OLIVEIRA, P.E.; BARRETO, A.M.F.; SUGUIO, K. 1999. Late Pleistocene/Holocene climatic and vegetational history of the Brazilian caatinga: the fossil dunes of the middle São Francisco River. Palaeogeography, Palaeoclimatology, Palaeoecology, 152: 319337.

DESJARDINS, T.; CARNEIRO-FILHO, A.; MARIOTTI, A.; CHAUVEL, A.; GIRARDIN, C. 1996. Changes of the forest-savanna boundary in Brazilian Amazonia during the Holocene as revealed by soil organic carbon isotope ratios. Oecologia, 108: 749-756.

DILLENBURG, S.R.; ROY, P.S.; COWELL, P.J.; TOMAZELLI, L.J. 2000. Influence of antecedent topography on coastal evolution as tested by shoreface translation - barrier model (STM). Journal of Coastal Research, 16(1): 71-81.

DILLENBURG, S.R.; TOMAZELLI, L.J.; CLEROT, L.C.P. 2003. Gradientes de energia de onda: o principal fator controlador da evolução costeira no Rio Grande do Sul durante o Holoceno superior. In: CONGRESSO DA ASSOCIAÇÃO BRASILILEIRA DE ESTUDOS DO QUATERNÁRIO (ABEQUA), 9, Recife, PE. Anais..., meio digital (cd), Recife, Abequa, trabalho 142.

DOMINGUES, A. J. P. 1948. Contribuição a geologia do sudeste da Bahia. Revista Brasileira de Geografia, 10: 255-289

DOMINGUEZ, J.M.L.; MARTIN, L.; BITTENCOURT, A.C.S.P. 1987. Sea-level history and Quaternary evolution of rivermouth associated beach-ridges plains along the ESE Brazilian coast: a summary. In: NUMMENDAL, D.; PILKEY, O.H. \& HOWARD, J.D. eds. Sea-level Fluctuation and Coastal Evolution. p. 115-127. Tulsa, Okla., Society Economic Geologists Mineralogists (Special Publication, 41).

DOMINGUEZ, J.M.L.; LEÃO, Z.M.A.N.; LYRIO, R.S. 1996. Litoral norte do Estado da Bahia: roteiro da excursão E4. In: CONGRESSO BRASILEIRO DE GEOLOGIA, 37, Salvador, BA. Salvador, SBG, 32p.

DOOGE, J.C.I. 1968. The hydrologic cycle as a closed system. Bull. Association Scientific Hidrol., 13(1): 58-68.

DUBOIS, R.N. 1992. A re-evaluation of Bruun's rule and supporting evidence. Journal of Coastal Research, 8(3): 618-628. 
ESTEVES, L.S.; TOLDO, E.F., JR; ALMEIDA, L.E.S.B.; NICOLODI, J.L. 2001. Erosão na costa do Rio Grande do Sul entre 1975-2000. In: CONGRESSO DA ABEQUA, 8, Imbé, RS. Boletim de Resumos... Porto Alegre, Abequa, p.511-513.

ETHERIDGE, M.A.; SYMONDS, P.A.; LISTER G.S. 1990. Application of the detachment model to reconstruction of conjugate passive margins. In: TANKARD, A.J., AND BALKWILL, H.R. eds. Extensional Tectonics and Stratigraphy of the North Atlantic Margins, p.23-40. Tulsa, Okla., America Association Petroleum Geologists (Memoir, 46).

FERRAZ-VICENTINI, K.R. 1993. Análise Palinológica de uma Vereda em Cromínia, GO. Brasilia, Departamento de Ecologia, Universidade de Brasília. Dissertação de Mestrado (inéd.), 87p.

FERRAZ-VICENTINI, K.R. \& SALGADO-LABOURIAU, M.L. 1996. Palynological analysis of a palm swamp in Central Brazil. Journal of South American Earth Sciences, 9: 207-219.

FERREIRA, A.C.M. 2003. O Sistema Praia-Duna na Planície de Una-Juréia, Municípios de Peruibe e Iguape, SP. São Paulo, Instituto de Geociências da Universidade de São Paulo. Monografia de Trabalho de Formatura (inéd.), 41 p., 3 anexos.

FERREIRA, A.C.M.; GIANNINI, P.C.F.; BENTZ, D. 2003. Os cordões litorâneos da Planície do Una-Juréia, municípios de Peruíbe e Iguape, SP. In: SIMPÓSIO INTERNACIONAL DE INICIAÇÃO CIENTíFICA DA USP, 11. São Carlos, SP. Resumos... meio digital (cd), São Paulo, USP.

FERREIRA, F.J.F.; MORAES, R.A.V.; FERRARI, M.P.; VIANA, R.B. 1981. Contribuição ao estudo do alinhamento estrutural de Guapiara. In: SIMPÓSIO REGIONAL DE GEOLOGIA, 3, Curitiba, PR, 1981. Atas.... São Paulo, SBG/SP, p.226-240.

FICHTER, L.S. 1988. Process-response modeling and the scientific process. Journal of Geological Education, 36: 72-78.

FISHER, W.L. 1983. Facies Analysis in Reservoir Geology. Ouro Preto, Universidade Federal de Ouro Preto. Apostila de Curso (inéd.). 66p.

FISHER, W.L. \& BROWN, JR., L.F. 1972. Clastic Depositional Systems: a Genetic Approach to Facies Analysis. Austin, University of Texas, Bureau Economic Geology, 211p.

FISHER, W.L. \& McGOWEN, J.H. 1967. Depositional systems in Wilcox Group (Eocene) of Texas and their relation to occurrence of oil and gas. Bulletin America Association Petroleum Geologists, 53(1): 30-54, 1969.

FISHER, W.L.; BROWN, L.F.,Jr.; SCOTT, A.J.; MCGOWEN, J.H. 1969. Delta Systems in the Exploration of Oil and Gas. Austin, Bureau Economic Geololgy, University of Texas, $212 p$.

FLENLEY, J.R. 1998. Tropical forests under the climates of the last 30,000 years. Climatic Change, 39: 177-197.

FRANÇA, A.M.C. 1979. Brasil. Margem Continental Leste. Mapa Fisiográfico. Rio de Janeiro, Petrobras/Cenpes/Dintep. (Série Projeto Remac).

FREITAS, H.A.; PESSENDA, L.C.R.; ARAVENA, R.; GOUVEIA, S.E.M.; RIBEIRO, A.S.; BOULET, R. 2001. Late Quaternary vegetation dynamics in the Southern Amazon Basin inferred from carbon isotopes in soil organic matter. Quaternary Research, 55: 39-46.

FREITAS, R.O. 1951a. Areias recentes da Praia Grande, São Paulo. Anais da Academia Brasileira de Ciências, 23(2): 163-175. 
FREITAS, R.O. 1951b. Areias recentes do Guarujá, São Paulo. Anais da Academia Brasileira de Ciências, 23 (2): 177-186.

FRYBERGER, S.G. 1979. Dune forms and wind regime. In: McKEE, E.D. ed. A Study of Global Sand Seas, p.83-154. Washington, U.S. Geological Survey (Professional Papers, 1052).

FRYBERGER, S.G. \& SCHENK, C. 1988. Pin stripe lamination: a distinctive feature of modern and ancient eolian sediments. Sedimentary Geology, 55(1/2): 1-15.

FÚlFARO, V.J.; SUGUIO, K.; PONÇANO, W.L. 1974. A gênese das planícies costeiras paulistas. In CONGRESSO BRASILEIRO DE GEOLOGIA, 28, Porto Alegre. Anais... Porto Alegre, SBG, v.3, p.37-42.

GALLOWAY, W.E. 1979. I. Introduction: the concept of natural systems. In: GALLOWAY, W.E.; KREITLER, C.W.; McGOWEN, J.H. eds. Depositional and Ground Water Flow Sistems in the Exploration for Uranium. Austin, Bureau of Economic Geology, University of Texas, p.1-2.

GALLOWAY, W.E. \& HOBDAY, D.K. 1983. Terrigenous Clastic Depositional Systems. New York, Springer-Verlag, $423 \mathrm{p}$.

GARCIA, M.J.; DE OLIVEIRA, P.E.; SIQUEIRA, E.; FERNANDES, R.S. 2004. A Holocene vegetational and climatic Record from the Atlantic rainforest belt of coastal State of São Paulo, SE Brazil. Review of Palaeobotany and Palynology, 131: 181-199.

GARDNER, D.E. 1955. Beach-sand heavy-mineral deposits of Eastern Austrália. BMR Bulletin, 28, 103 p.

GEOBRÁS, S./A. Engenharia e Fundações. 1966. Complexo Valo Grande, Mar Pequeno e rio Ribeira de Iguape. São Paulo, Geobrás, Serviço do Vale do Ribeira do Departamento de Águas e Energia Elétrica / SP. Relatório Técnico (inéd.), 2 volumes.

GIANNINI, P.C.F. 1985. Diferenciação Geológica entre os Setores Sudoeste e Nordeste do Litoral Paulista: Evolução do Conhecimento e dos Modelos Explicativos. São Paulo, Instituto de Geociências da Universidade de S.Paulo. Exame de Qualificação de Mestrado (inéd.), Tema Fundamental II, p. 57-81.

GIANNINI, P.C.F. 1987. Sedimentação Quaternária na Planície Costeira de PeruíbeItanhaém (SP). São Paulo, Instituto de Geociências da Universidade de S.Paulo. Dissertação de Mestrado (inéd.). 2 v., 3 mapas, 234 p.

GIANNINI, P.C.F. 1989. Evolução quaternária da planície costeira de Peruibe-Itanhaém (SP) segundo resultados granulométricos: um confronto de métodos de tratamento estatístico. Boletim Paranaense de Geociências, 38: 1-50.

GIANNINI, P.C.F. 1993. Sistemas Deposicionais no Quaternário Costeiro entre Jaguaruna e Imbituba, SC. São Paulo, Instituto de Geociências da Universidade de S.Paulo. Tese de Doutoramento (inéd.) 2v, 2 mapas, 439p.

GIANNINI, P.C.F. 1998. Associações de fácies eólicas ativas na costa centro-sul de Santa Catarina. Anais da Academia Brasileira de Ciências, 70(3): 696.

GIANNINI, P.C.F. 2002. Complexo lagunar centro-sul catarinense - valioso patrimônio sedimentológico, arqueológico e histórico. In: SCHOBBENHAUS, C.; CAMPOS, D.A.; QUEIROZ, E.T.; WINGE, M.; BERBERT-BORN, M. eds. Sítios Geológicos e Paleontológicos do Brasil. Brasília, DNPM, p.213-222. 
GIANNINI, P.C.F. \& SANTOS, E.R. 1994. Padrões de variação espacial e temporal na morfologia de dunas de orla costeira no centro-sul catarinense. Boletim Paranaense de Geociências, 42: 73-96.

GIANNINI, P.C.F. \& SUGUIO, K. 1994. Diferenciação entre gerações de depósitos eólicos quaternários na costa centro-sul de Santa Catarina. In: CONGRESSO BRASILEIRO DE GEOLOGIA, 38, Balneário Camboriú, SC. Resumos Expandidos... Balneário Camboriú, SBG. p.402-403.

GIANNINI, P.C.F.; LESSA, G.C.; KOGUT, J.S.; ANGULO, R.J. 1997a. Variação nas assembléias de minerais pesados de testemunhos rasos na planície costeira de Paranaguá (PR). In: CONGRESSO DA ASSOCIAÇÃO BRASILEIRA DE ESTUDOS DO QUATERNÁRIO (ABEQUA), 6, Curitiba. Resumos Expandidos... Curitiba, Abequa, p.58-62.

GIANNINI, P.C.F.; SUGUIO, K.; SANTOS-GIANNINI, E.R.; KOGUT, J.S. 1997b. Gerações de areias eólicas na escarpa de Guaiúba, Imbituba, SC. In: CONGRESSO DA ASSOCIAÇÃO BRASILEIRA DE ESTUDOS DO QUATERNÁRIO (ABEQUA), 6 , Curitiba. Resumos Expandidos... Curitiba, Abequa, p.63-67.

GIANNINI, P.C.F.; DONATTI, L.M.; FERNANDES, L.A.; FONSECA, P. L..; SAWAKUCHI, A. O.; RODRIGUES, S.O.; MORI, E. K. 1999. Confronto entre o sistema eólico da costa sul-catarinense e as formações Pirambóia e Botucatu: correlações processo-produto do Quaternário no estudo de rochas mesozóicas. In: CONGRESSO DA ASSOCIAÇÃO BRASILEIRA DE ESTUDOS DO QUATERNÁRIO (ABEQUA), 7, Porto Seguro, BA. Anais...meio digital (cd), Salvador, Abequa. 3p.

GIANNINI P.C.F.; BARRETO, A.M.F.; SUGUIO, K.; TATUMI, S.H. 2001a. Idade TL e propriedades sedimentológicas na planície costeira do Rio Grande do Norte. In: CONGRESSO DA ASSOCIAÇÃO BRASILEIRA DE ESTUDOS DO QUATERNÁRIO (ABEQUA), 8, Imbé, RS. Boletim de Resumos... Porto Alegre, ABEQUA. p

GIANNINI, P.C.F.; SAWAKUCHI, A.O.; MARTINHO, C.T. 2001b. A estratigrafia de seqüências na evolução das dunas costeiras de Santa Catarina, Sul do Brasil. In: CONGRESSO DO QUATERNÁRIO DOS PAISES DE LÍNGUA IBÉRICA, 1, Lisboa. Actas... Lisboa, Sociedade Geol. de Portugal, Grupo de Trabalho Português para o Estudo do Quaternário e Assoc. Espagn. para Estudio del Quaternário, p. 117-120.

GIANNINI, P.C.F.; SAWAKUCHI, A.O.; MARTINHO, C.T. 2001c. O nivel do mar e as dunas eólicas no litoral centro-sul catarinense: um modelo de estratigrafia de seqüências no Quaternário. In: CONGRESSO DA ASSOCIAÇÃO BRASILEIRA DE ESTUDOS DO QUATERNÁRIO (ABEQUA), 8, Imbé, RS. Boletim de Resumos... Porto Alegre, Abequa, p. 45-46.

GIANNINI, P.C.F.; GUEDES, C.C.F.; ANGULO, R.J.; ASSINE, M.L.; SOUZA M.C.; MORI, E.K.; PESSENDA, L.C.R. 2003a. Geometria de cordões litorâneos e espaço de acomodação sedimentar na ilha Comprida, litoral sul paulista: modelo baseado em aerofotointerpretação. In: CONGRESSO DA ASSOCIAÇÃO BRASILEIRA DE ESTUDOS DO QUATERNÁRIO (ABEQUA), 9, Recife, PE. Anais... meio digital (cd), Recife, Abequa.

GIANNINI, P.C.F.; GUEDES, C.C.F.; ASSINE, M.L.; ANGULO, R.J.; SOUZA M.C.; PESSENDA, L.C.R.; TATUMI, S.H. 2003b. Variação transversal e longitudinal de propriedades sedimentológicas nos cordões litorâneos da itha Comprida, litoral sul paulista. In: CONGRESSO DA ASSOCIAÇÃO BRASILEIRA DE ESTUDOS DO QUATERNÁRIO (ABEQUA), 9, Recife, PE. Anais... meio digital (cd), Recife, Abequa. 
GIANNINI, P.C.F.; ANGULO, R.J.; SOUZA, M.C.; KOGUT, J.S.; DELAI, M.S. 2004a. A erosão na costa leste da ilha do Mel, baía de Paranaguá, Estado do Paraná: modelo baseado na distribuição espacial de formas deposicionais e propriedades sedimentológicas. Revista Brasileira de Geociências, 34(2): 231-242.

GIANNINI, P.C.F.; SAWAKUCHI, A.O.; FERNANDES, L.A.; DONATTI, L.M. 2004 b. Paleoventos e paleocorrentes subaquosas do Sistema Deposicional Pirambóia nos estados de São Paulo e Paraná, Bacia do Paraná: estudo baseado em análise estatística de dados azimutais. São Paulo, Revista Brasileira de Geociências, $34(2)$ : 282-292.

GIANNINI, P.C.F.; ASSINE, M.L.; BARBOSA, L.; BARRETO, A.M.F.; CARVALHO, A.M.; CLAUDINO-SALES, V.; MAIA, L.P.; MARTINHO, C.T.; PEULVAST, J.P.; SAWAKUCHI, A.O.; TOMAZELLI, L.J. 2005. Dunas eólicas costeiras e interiores. In: SOUZA, C.R.G.; SUGUIO, K.; OLIVEIRA, P.E.; OLIVEIRA. A.M. ed. Quaternário do Brasil. Abequa, ANP, FAPESP, IG, UnG. Ribeirão Preto, SP, Holos Editora, cap.11, p.235-257.

GIANNINI, P.C.F.; ASSINE, M.L.; SAWAKUCHI, A.O. 2007a. Ambiente eólico. In: PEDREIRA, A. ed. Ambientes de Sedimentação do Brasil. Rio de Janeiro, Petrobras (no prelo). 40p. ISBN 85-85227-76-1.

GIANNINI, P.C.F.; GUEDES, C.C.F.; NASCIMENTO FILHO, D.R.; TANAKA, A.P.B.; ANGULO, R.J.; ASSINE, M.L.; SOUZA, M.C. 2007b. Morphology and sedimentology of Ilha Comprida sand barrier, southern São Paulo coast. In: DILLENBURG, S.R. \& HESP, P. Geology of Brazilian Coastal Barriers, Springer-Verlag. No prelo.

GIANNINI, P.C.F.; SAWAKUCHI, A.O.; MARTINHO, C.T.; TATUMI, S.H. 2007c. Eolian depositional episodes controlled by Late Quaternary relative sea level changes on the Imbituba-Laguna coastal zone (southern Brazil). Marine Geology, 237(2007): 143-168.

GLASSFORD, D.K. \& SEMENIUK, V. 1990. Stratificacion and desconformities in yellow sands of the Bassendean and Spearwood Dunes, Swan Coastal Plain, South-Western Australia. Journal Royal Society Western Australia, 72(3): 75-92.

GLENNIE, K.W. 1970. Sedimentary Enviroments. Amsterdam, Elsevier. 222p. (Developments in Sedimentology, 14).

GOLDSMITH, V. 1973. Internal geometry and origin of vegetated coastal sand dunes. Journal of Sedimentary Petrology, 43(4):1128-1142.

GOLDSMITH, V. 1978. Coastal dunes. In: DAVIES Jr., R.A. Coastal Sedimentary Enviroments. Amsterdam, Springer Verlag, p.171-235.

GOMEZ, B.; PAGE, M.; BAK, P.; TRUSTUM, N. 2002. Self-organized criticality in layered, lacustrine sediments formed by landsliding. Geology, 30(6): 519-522.

GONÇALVES, R.A. 1995. Aspectos gerais da erosão, transporte e sedimentação costeira na região de Barreirinhas e Rio Novo - Lençóis Maranhenses, MA, Brasil. In: CONGRESSO DA ASSOCIAÇÃO BRASILEIRA DE ESTUDOS DO QUATERNÁRIO (ABEQUA), 5, Niterói, RJ. Anais...Niterói, Abequa, p.88-91.

GONÇALVES, R.A.; LEHEUGER, L.G.; CASTRO, J.W.A. 2002. Evolução das dunas costeiras e seu registro geológico: o modelo Lençóis Maranhenses, Maranhão, Brasil. In: SIMPÓSIO NACIONAL DE GEOMORFOLOGIA, 4, Anais... São Luis, UGB, p.45.

GOUVEIA, S.E.M. 2001. Isótopos do Carbono na Avaliação do Remonte Biológico de Latossolos e Podzólicos e de Eventos Paleoclimáticos em Distintas Localidades do Brasil. Piracicaba, Centro de Energia Nuclear na Agricultura, Universidade de São Paulo. Tese de Doutorado (inéd.), 116p. 
GOUVEIA, S.E.M.; PESSENDA, L.C.R.; ARAVENA, R.; BOULET, R.; ROVERATTI, R.; GOMES, B.M. 1997. Dinâmica das vegetações durante o Quaternário Recente no sul do Amazonas indicada pelos isótopos do carbono $\left({ }^{12} \mathrm{C},{ }^{13} \mathrm{C},{ }^{14} \mathrm{C}\right)$ do solo. Geochimica Brasiliensis, 11(3): 355-367.

GOUVEIA, S.E.M.; PESSENDA, L.C.R.; BOULET, R.; ARAVENA, R.; SCHEEL-YBERT, R. 1999. Isótopos do carbono dos carvões e da matéria orgânica do solo em estudos de mudança de vegetação e clima no Quaternário e da taxa de formação de solos do Estado de São Paulo. Anais da Academia Brasileira de Ciências, 71(4): 969-980.

GREGORY, K.J. 1985. A Natureza da Geografia Física. Rio de Janeiro, Bertrand Brasil, 1992. 367p.

GUAZELLI, W. \& CARVALHO, J.C. 1981. Estruturas da margem continental leste brasileira e das áreas oceânicas e continentais, adjacentes. In PETROBRAS. Estruturas e Tectonismo da Margem Continental Brasileira, e Suas Implicações nos Processos Sedimentares e na Avaliação do Potencial de Recursos Minerais. Rio de Janeiro, p.117-143. (Série Projeto Remac, 9).

GUEDES, C.C.F. 2003. Os Cordões Litorâneos e as Dunas Eólicas da llha Comprida, Estado de São Paulo. São Paulo, Instituto de Geociências da Universidade de São Paulo. Monografia de Trabalho de Formatura (inéd.), 53 p., 2 mapas.

GUERRA, A.T. 1950. Contribuição ao estudo da geomorfologia e do Quaternário do litoral de Laguna (Santa Catarina). Revista Brasileira de Geografia, 12(4): 535-564.

GUIA QUATRO RODAS PRAIAS. 1997. São Paulo, Editora Abril. 221p.

GUIA QUATRO RODAS PRAIAS. 2000. São Paulo, Editora Abril. 226p.

GUILCHER, A. 1958. Coastal ans Submarine Morphology. London, Methuen, 274p.

HANSEN, V.L.; GOODGE, J.W.; KEEP, M.; OLIVER, D.H. 1993. Asymmetric rift interpretation of the western North American margin. Geology, 21: 1067-1070.

HANSON, J.D. 2001. Coastal sensitivity to environmental change: a view from beach. Catena 42: $291-305$

HARARI, J.; FRANÇA, C.A.S.; CAMARGO, R. 2004. Variabilidade de longo termo de componentes de marés e do nivel médio do mar na costa brasileira. Afro-America Gloss News, 8(1).

HAVHOLM, K.G. \& KOCUREK, G. 1994. Factors controlling aeolian sequence stratigraphy: clues from super bounding surface features in the Middle Jurassic Page Sandstone. Sedimentology, 41(5): 913-934.

HAVHOLM, K.G.; BLAKEY, R.C.; CAPPS, M.; JONES, L.S.; KING, D.D.; KOCUREK, G. 1993. Eolian genetic stratigraphy: an example from the Middle Jurassic Page Sandstone, Colorado Plateau. In: PYE, K. \& LANCASTER, N. eds. Aeolian Sediments: Ancient and Modern, p.87-107. International Association of Sedimentologists (Special Publication, 16).

HAYES, M.O. \& SCOTT, A.J. 1964. Environmental complexes, South Texas coast. Trans. Gulf Coast Assoc. Geol. Soc., 14: 237-240.

HESP, P.A. 1981. The formation of shadow dunes. Journal of Sedimentary Petrology, 51(1): $101-112$.

HESP, P.A. 1983. Morphodynamics of incipient foredunes in New South Wales, Austrália. In: BROOKFIELD, M.E. \& AHLBRANDT, T.S. eds. Eolian Sediments and Processes. Amsterdam, Elsevier, p. 325-342 (Developments in Sedimentology, 38). 
HESP, P.A. 1988. Morphofology, dynamics and internal stratification of some established foredunes in Southeast Austrália. Sedimentary Geology, 55(1/2): 17-41.

HESP, P.A. 1989. A review of biological and geomorphological processes involved in the initiation and development of incipient foredunes. Proceedings of the Royal Society of Edinburgh, 96B: 181-201.

HESP, P.A. 1999. The beach backshore and beyond. In: SHORT, A.D. ed. Handbook of Beach and Shoreface Morphodynamics. Chichester, John Wiley \& Sons Ltd., p. 145270.

HESP, P.A. 2000. Coastal Sand Dunes. Form and Function. Massey, Massey University, 28 p. (CDNV Technical Bulletin, 4).

HESP, P.A. \& SHORT, A.D. 1999. Barrier Morphodynamics. In: SHORT, A.D. ed. Handbook of Beach and Shoreface Morphodynamics. Chichester, John Wiley \& Sons Ltd., p. 307333.

HESP, P.A. \& THOM, B.G. 1990. Geomorphology and evolution of active transgressive dunefields. In: NORDSTROM, K.F.; PSUTY, N.P.; CARTER, R.W.G. eds. Coastal Dunes: Form and Process. Chichester, John Wiley \& Sons Ltd.

HESP, P.A.; ILLENBERGER, W.; RUST, I.; MCLACHLAN, A.; HYDE, R. 1989. Some aspects of transgressive dunefield and transverse dune geomorphology and dynamics, south coast, South Africa. Z.Geomorph. N.F. Suppl..Bd 73: 111-123.

HESP, P.A.; MARTINHO, C.T.; GIANNINI, P.C.F.; MYOT DA SILVA, G.; ASP, P. 2007. The Holocene barrier systems of the central and southern Santa Catarina coast, southern Brazil. In: DILLENBURG, S.R. \& HESP, P.A. Geology of Brazilian Coastal Barriers. Springer-Verlag. No prelo.

HODELL, D.A.; CURTIS, J.H.; JONES, G.A.; HIGUERA-GUINDY, A.; BRENNER, M.; BINDFORD, M.W.; DORSEY, K.T. 1991. Reconstruction of Caribbean climate change over the past 10,500 years. Nature, 352: 790-793.

HODELL, D.A.; CURTIS, J.H.; BRENNER, M. 1995. Possible role of climate in the collapse of Classic Maya civilization. Nature, 375: 391-394.

HORN, N.O. 1988. Geologia das Folhas de Torres, Três Cachoeiras, Arroio Teixeira e Maquiné, Nordeste do Rio Grande do Sul. Porto Alegre, Universidade Federal do Rio Grande do Sul. Dissertação de Mestrado (inéd.). 241p.

HOWARD, A.D.; MORTON, J.B.; GAD-EL-HAK, M.; PIERCE, D.B. 1978. Sand transport model of barchan dune equilibrium. Sedimentology, 25: 307-338.

HOWELL, J.W. 1960. Glossary of Geology and Related Sciences. Washington, Amer. Geol. Inst. 325p.

HUBERT, J.F. 1962. A zircon-tourmaline-rutile maturity index and the dependence of the composition of heavy mineral assemblages with the gross composition and texture of sandstones. Journal of Sedimentary Petrology, 32(3): 440-450.

HUECK, K. 1955. Plantas e Formação Organogênica das Dunas no Litoral Paulista. Parte I. Secretaria da Agricultura do Estado de São Paulo, Instituto Botânico. São Paulo, 130 p.

HUGGET, R.J. 1985. Earth Surface Systems. New York, Springer-Verlag, 270p.

HUNTER, R.E. 1981. Stratification styles in eolian sandstones: some Pennsylvanian to Jurassic examples from the western interior U.S.A.. In: ETHRIDGE, F.G. \& FLORES, R.M. eds. Recent and Ancient Nonmarine Depositional Environments: 
Models for Exploration, p. 315-329. Society of Economic Palaeontologists and Mineralogists (Special Publication, 31).

IVANOV, S. 1996. Variability of sedimentary sequences: numerical modeling of the deposition-erosion process. Geol. Rundsch, 85:12-18.

JACKSON, R.G. 1975. Hierarchical attributes and a unifying model of bedforms, composed of cohesionless material and produced by shearing flow. Bulletin Geological Society of America, 86(11): 1523-1533.

JENNINGS, J.N. 1957. On the orientation of parabolic or U-dunes. Geological Journal, 123(4): 474-480.

JENNINGS, J.N. 1967. Cliff-top dunes. Australian Geographic Studies, 5: 40-49.

JIMENEZ, J.A.; MAIA, L.P.; SERRA, J.; MORAIS, J.O. 1999. Aeolian dune migration along the Ceará coast, North-Eastern Brazil. Sedimentology, 46: 689-701

JOLY, F. 1997. Glossaire de Géomorphologie. Base de Données Sémiologiques pour la Cartographie. Paris Ed. Armand Colin, $325 \mathrm{p}$.

KARPETA, W.P. 1990. The morphology of Permian palaeodunes - a reinterpretation of the Bridgnorth Sandstone around Bridgnorth, England, in the light of modern dune studies. Sedimentary Geology, 69(1/4): 59-75.

KING, L.C. 1956. A geomorfologia do Brasil Oriental. Revista Brasileira de Geografia, 18(2): 147-265.

KOCUREK, G. 1981. Significance of interdune deposits and bounding surfaces in eolian dune sands. Sedimentology, 28(6): 753-780.

KOCUREK, G. 1988. First-order and super bounding surfaces in eolian sequences Bounding surfaces revisited. Sedimentary Geology, 56(1/4): 193-206.

KOCUREK, G. \& DOTT, R.H., Jr. 1981. Distinction and uses of stratification types in the interpretation of eolian sand. Journal of Sedimentary Petrology, 51(2): 579-595.

KOCUREK, G. \& HAVHOLM, K.G. 1993. Eolian Sequence Stratigraphy - A Conceptual Framework. In: Siliciclastic Sequence Stratigraphy, p.393-409. America Association Petroleum Geologists (Memoir, 58).

KOCUREK, G. \& NIELSON, J. 1986. Conditions fovourable for the formation of warm climate aeolian sand sheets. Sedimentology, 33(6):795-816.

KORVIN, G. 1992. Fractal models in the earth sciences. Amsterdam, Elsevier, $396 \mathrm{p}$.

KOWSMANN, R.O. \& COSTA, M.P.A. 1979. Sedimentação Quaternária da Margem Continental Brasileira e das Áreas Oceânicas Adjacentes. Rio de Janeiro, Petrobrás/Cenpes/Dintep. 55p, 3 mapas (Série Projeto Remac, 8).

KOWSMANN, R.O.; COSTA, M.P.A.; VICALVI, M.A.; COUTINHO, M.G.N.; GAMBOA, L.A.P. 1977. Modelo da sedimentação holocênica na plataforma continental sul brasileira. In: PETROBRÁS. Evolução Sedimentar Holocênica da Plataforma Continental e do Talude do Sul do Brasil. Rio de Janeiro, Petrobrás/Cenpes/Dintep, p.7-26. (Série Projeto Remac, 2).

KROON, A. \& HOEKSTRA, P. 1990. Eolian sediment transport on a natural beach. Journal of Coastal Research, 6: 367-379.

KROY, K.; SAUERMANN, G.; HARRMANN, H.J. 2002. Minimal model for aeolian sand dunes. Physical Review, E66, 031302:1-18. 
KRUMBEIN, W.C. \& GRAYBILL, F.A. 1965. An Introduction to Statistical Models in Geology. New York, McGraw Hill.

LANCASTER, N. 1988. The development of large aeolian bedforms. Sedimentary Geology, 55(1/2): 69-89.

LANCASTER, N. 1995. The Geomorphology of Desert Dunes. London, Routledge, $312 \mathrm{p}$.

LANGFORD, R.P. 1989. Fluvial-aeolian interactions. Part I, modern systems. Sedimentology, 36(6): 1023-1036.

LASZLO, E. 1974. Prologos. In: Perspectivas en la Teoría General de Sistemas. Madrid, Alianza Universidad Ed., 1 ed.cast., 1979. p.12-16.

LEDRU, M.-P. 1993. Late Quaternary and climatic changes in Central Brazil. Quaternary Research, 39: 90-98.

LEDRU, M.-P.; BRAGA, P.I.S.; SOUBIÈS, F.; FOURNIER, M.; MARTIN, L.; SUGUIO, K.; TURCQ, B. 1996. The last 50,000 years in the Neotropics (Southern Brazil): evolution of vegetation and climate. Palaeogeography, Palaeoclimatology, Palaeoecology, 123: 239-257.

LEDRU, M.-P.; BERTAUX, J.; SIFFEDINE, A.; SUGUIO, K. 1998a. Absence of last glacial maximum records in lowland tropical forests. Quaternary Research, 49: 233-237.

LEDRU, M.-P.; SALGADO-LABOURIAU, M.L.; LORSCHEITTER, M.L. 1998b. Vegetation dynamics in southern and central Brazil during the last 10,000 yr BP. Review of Palaeobotany and Palynology, 99: 131-142.

LEDRU, M.-P.; CORDEIRO, R.C.; DOMINGUEZ, J.M.L.; MARTIN, L.; MOURGUIART, P.; SIFEDDINE, A.; TURCQ, B. 2001. Late-glacial cooling in Amazonia inferred from pollen at Lagoa do Caçó, Northern Brazil. Quaternary Research, 55: 47-56.

LEDRU M.-P.; MOURGUIART P.; CECCANTINI G.; TURCQ B.; SIFFEDINE A. 2002. Tropical climates in the game of two hemispheres revealed by abrupt climatic changes. Geology, 30(3): 275-278.

LEEDER, M. 1999. Sedimentology and Sedimentary Basins - From Turbulence to Tectonics. London, Blackwell Science, $592 \mathrm{p}$.

LEES, B. 2006. Timing and formation of coastal dunes in northern and eastern Australia. Journal of Coastal Research, 22(1): 78-89.

LEHUGEUR, L.G.O. 1995. Aspectos da geologia costeira do Estado do Piauí. In: SIMPÓSIO SOBRE PROCESSOS SEDIMENTARES E PROBLEMAS AMBIENTAIS DA ZONA COSTEIRA NORDESTE DO BRASIL, 1, Recife, PE. Anais...Recife, CNPq / Petrobras / ORSTOM / CPRM / SCTMA / Facepe. p. 142-143.

LEINZ, V. 1949. Contribuição à geologia dos derrames basálticos do Sul do Brasil. Boletim da Faculdade de Filosofia, Ciências e Letras da Universidade de S.Paulo, Bol. Geologia, 91(5): 61p.

LESSA, G.C.; ANGULO, R.J.; GIANNINI, P.C.F; ARAÚJO, A.D. 2000. Stratigraphy and Holocene evolution of a regressive barrier in South Brazil. Marine Geology, 165(2000): 87-108.

LISTER G.S.; ETHERIDGE, M.A.; SYMONDS, P.A. 1986. Detachment faulting and the evolution of passive continental margins. Geology, 14(3): 246-250.

LISTER G.S.; ETHERIDGE, M.A.; SYMONDS, P.A. 1991. Detachment models for the formation of passive continental margins. Tectonics, 10: 1038-1064 
LOOPE, W.L. \& ARBOGAST, A.F. 2000. Dominance of an 150 -year cycle of sand-supply change in Late Holocene dune-building along the eastern shore of Lake Michigan. Quaternary Research, 54: 414-422.

LORSCHEITTER, M.L. \& MATTOZO, I.J. 1995. Reconstituição paleoambiental da região dos Campos Gerais, Paraná, através da palinologia de sedimentos da Lagoa Dourada. In: CONGRESSO DA ASSOCIAÇÃO BRASILEIRA DE ESTUDOS DO QUATERNARIO (ABEQUA), 5, Niterói, RJ, 1995. Anais... Niterói, Abequa.

MACEDO, J.M. 1987. Evolução estrutural da Bacia de Santos e áreas continentais adjacentes. In: SIMPÓSIO SUL-BRASILEIRO DE GEOLOGIA, 3, Curitiba, PR. Atas... Curitiba, SBG, v.2, p.875-895.

MACEDO, J.M.; BACOCCOLI, G.; GAMBOA, L.A.P. 1991. O tectonismo mesocenozóico da Região Sudeste. In: SIMPÓSIO DE GEOLOGIA DO SUDESTE, 2, São Paulo. Atas... São Paulo, SBG/SP-RJ, p.429-433.

MAIA, L.P. 1998. Procesos Costeros y Balance Sedimentario al Largo de Fortaleza (NEBrasil): Implicaciones para una Gestión Adecuada de la Zona Litoral. Barcelona, Universitat de Barcelona, Facultat de Geologia, Departement d'Estratigrafia i Paleontologia. Tesis Doctoral (inéd.), 269p.

MAIA, L.P.; RODRIGUES, A.C.B.; CASCON, H.M.; BARRETO, A.M.F.; CASTRO, I.B.; TATUMI, H.S.; COSTA, A.A. 1999. Correlação estratigráfica em poços de subsuperfície e datação de dunas costeiras inativas da região do Cauípe/Pecém - Costa Oeste do Ceará. In: CONGRESSO DA ASSOCIAÇÄO BRASILEIRA DE ESTUDOS DO QUATERNÁRIO (ABEQUA), 7, Porto Seguro, BA. Anais...meio digital (cd), Salvador, Abequa. p. 65-68.

MAINGUET, M. \& CHEMIN, M.C. 1983. Sand seas of the Sahara and Sahel: an explanation of their thickness and sand dune type by the sand budget principle. In: BROOKFIELD, M.E. \& AHLBRANDT, T.S. eds. 1983. Eolian Sediments and Processes. Elsevier, Amsterdam, $660 \mathrm{p}$.

MARTIN, L. \& SUGUIO, K. 1975. The State of São Paulo coastal marine Quaternary geology - the ancient strandlines. Anais da Academia Brasileira de Ciências, 47: 249-263.

MARTIN, L. \& SUGUIO, K. 1976. O Quaternário marinho de Estado de São Paulo. In: CONGRESSO BRASILEIRO DE GEOLOGIA, 26, Ouro Preto. Anais... Ouro Preto, SBG, v.1, p.281-294.

MARTIN, L. \& SUGUIO, K. 1978. Ilha Comprida: um exemplo de ilha barreira ligada às flutuações do nivel marinho durante o Quaternário. In: CONGRESSO BRASILEIRO DE GEOLOGIA, 27, Recife. Anais... Recife, SBG, v.2, p. 905-912.

MARTIN, L.; FLEXOR, J.M.; VILAS-BOAS, G.S.; BITTENCOURT, A.C.S.P.; GUIMARÃES, M.M.M. 1979. Courbe de variation du niveau relatif de la mer au cours des 7000 derniéres années sur um secteur homogéne do littoral brésilien (nord de Salvador Bahia). In: SUGUIO, K.; FAIRCHILD, T.R.; MARTIN, L.; FLEXOR, J.M. ed. INTERNATIONAL SYMPOSIUM ON COASTAL EVOLUTION IN THE QUATERNARY, São Paulo, SP. Proceedings... p. 264-295.

MARTIN, L.; BITTENCOURT, A.C.S.P.; VILAS-BOAS, G.S.; FLEXOR, J.M. 1980. Mapa Geológico do Quaternário Costeiro do Estado da Bahia. Escala 1:250.000. Texto. Salvador, COM/SME, $57 \mathrm{p}$.

MARTIN, L.; BITTENCOURT, A.C.S.P.; VILAS-BOAS, G.S. 1982. Primeira ocorrência de corais pleistocênicos da costa brasileira: data do máximo da Penúltima Transgressão. Ciências da Terra, 1: 16-17. 
MARTIN, L.; BITTENCOURT, A.C.S.P.; FLEXOR, J.M.; VILLAS-BOAS, G.S. 1984. Evidências de um tectonismo quaternário nas costas do Estado da Bahia. In: CONGRESSO BRASILEIRO DE GEOLOGIA, 33, Rio de Janeiro. Rio de Janeiro, SBG, Anais... v.1, p.19-35.

MARTIN, L.; FLEXOR, J.L.; BLITZKOW, D.; SUGUIO, K. 1985. Geoid changes indication along the Brazilian coast. In: INTERNATIONAL CORAL REEF CONGRESS, 5. Proceedings...v.3, p.85-90.

MARTIN, L.; SUGUIO, K.; FLEXOR, J.M. 1988a. Hauts niveaux marins pleistocenes du litoral bresilien. Palaeogeography, Palaeoclimatology, Palaecololgy, 68(3): 231-239.

MARTIN, L.; SUGUIO, K.; FLEXOR, J.M.; AZEVEDO, A.E.G. 1988b. Mapa Geológico do Quaternário Costeiro dos Estados do Paraná e Santa Catarina. Brasília, DNPM, 40p., 2 mapas (Série Geologia 28, Seção Geologia Básica 18).

MARTIN, L.; BERTAUX, J.; CORREGE, T.; LEDRU, M.P.; MOURGUIART, P.; SIFEDDINE, A.; SOUBIES, F.; WIRRMANN, D.; SUGUIO, K.; TURCQ, B. 1997a. Astronomical forcing of contrasting rainfall changes in tropical South America between 12,400 and 8,800 cal yr B.P.. Quaternary Research, 47: 117-122.

MARTIN, L.; SUGUIO, K.; DOMINGUEZ, J.M.L.; FLEXOR. J.M. 1997b. Geologia do Quaternário Costeiro do Litoral Norte do Rio de Janeiro e do Espírito Santo. Belo Horizonte, CPRM, FAPESP. 112p. 2 mapas.

MARTINHO, C.T. 2001. Morfodinâmica de Draas Costeiros e Gerações de Depósitos Eólicos no Quaternário da Região de Imbituba-Laguna, SC. São Paulo, Instituto de Geociências da Universidade de S. Paulo, Monografia de Trabalho de Formatura (inéd.), $62 \mathrm{p}$.

MARTINHO, C.T. 2004. Morfodinâmica e Sedimentologia de Campos de Dunas Transgressivos da Região de Jaguaruna-Imbituba, Santa Catarina. São Paulo, Instituto de Geociências da Universidade de São Paulo. Dissertação de Mestrado (inéd.), 108 p.

MARTINHO, C.T. \& GIANNINI, P.C.F. 2001a. Diferenças texturais entre os cimentos das paleodunas eólicas de Imbituba-Laguna, SC. In: CONGRESSO DA ASSOCIAÇÃO BRASILEIRA DE ESTUDOS DO QUATERNÁRIO (ABEQUA), 8, Imbé, RS. Boletim de Resumos..., Porto Alegre, Abequa, p. 136-138.

MARTINHO, C.T. \& GIANNINI, P.C.F. 2001b. Petrografia e microscopia eletrônica de varredura de diferentes gerações de paleodunas eólicas quaternárias do morro de Santa Marta, município de Laguna, SC. Pesquisas, 28(2): 53-66.

MARTINHO, C.T. \& GIANNINI, P.C.F. 2002. Geomorphology of the lbiraqüera dunefield, Santa Catarina coast. Anais da Academia Brasileira de Ciências, 74(3): 545.

MARTINHO, C.T.; GIANNINI, P.C.F.; SAWAKUCHI, A.O. 2003. Fácies morfológicas e fácies deposicionais de campos de dunas transgressivos ativos da região de JaguarunaImbituba, SC. In: CONGRESSO DA ASSOCIAÇÃO BRASILEIRA DE ESTUDOS DO QUATERNÁRIO (ABEQUA), 9, Recife, PE. Anais... meio digital (cd), Recife, Abequa.

MARTINHO, C.T.; GIANNINI, P.C.F.; SAWAKUCHI, A.O. 2004. Morphological and depositional facies of transgressive dunefields of the Imbituba-Jaguaruna region, Santa Catarina State, Southern Brazil. In: ICS2004 - INTERNATIONAL COASTAL SYMPOSIUM, 8, Itapema, SC, Abstracts... ICS, Itajaí.

MARTINHO, C.T.; GIANNINI, P.C.F.; SAWAKUCHI, A.O. 2005. Morfologia e sedimentologia do sistema praia-duna frontal de Ibiraqüera, SC. In: CONGRESSO DA ASSOCIAÇÃO 
BRASILEIRA DE ESTUDOS DO QUATERNÁRIO (ABEQUA), 10, Guarapari, ES. Anais... meio digital (cd), Guarapari, Abequa.

MARTINHO, C.T., GIANNINI, P.C.F., SAWAKUCHI, A.O.; HESP, P.A. 2007. Morphological and depositional facies of transgressive dunefields in the Imbituba-Jaguaruna region, Santa Catarina State, Southern Brazil. Journal of Coastal Research, Special Issue 139, no prelo.

MCINTIRE, A. \& MOLFINO, B. 1997. Forcing of atlantic equatorial and subpolar millenial cycles by precession. Science, 274: 1867-1872.

McKEE, E.D. (ed.) 1979. A Study of Global Sand Seas. Washington, U.S. Geological Survey, 423p. (Professional Paper, 1052).

McKEE, E.D. \& BIGARELLA, J.J. 1972. Deformational structures in Brazilian coastal dunes. Journal of Sedimentary Petrology, 42(3): 670-681.

McKEE, E.D. \& WEIR, G.W. 1953. Terminology for stratification and cross stratification in sedimentary rocks. Bulletin Geological Society of America, 63(4): 381-390.

MCLAREN, P. 1981. An interpretation of trends in grain-size measures. Journal of Sedimentary Petrology, 51(2): 611-624.

MCLAREN, P. \& BOWLES, D. 1985. The effects of sediment transport on grain-size distributions. Journal of Sedimentary Petrology, 55(4): 457-470.

MELO, M.S.; GIANNINI, P.C.F.; PESSENDA, L.C.R.; BRANDT NETO, M. 2003. Holocene paleoclimatic evidence in the Lagoa Dourada deposits, Paraná State, South of Brazil. Geologica Acta, 1(3): 289-302.

MELTON, F.A. 1940. A tentative classification of sand dunes its application to dune history in the Southern High Plains. Journal of Geology, 48(2):113-145.

MENEZES, M. P. 1994. A Influência da Ação Antrópica na Dinâmica Sedimentar. São Paulo, Programa de Pós-Graduação em Ciência Ambiental da Universidade de S.Paulo. Dissertação de Mestrado (inéd.), 2 v., 3 mapas, 297 p.

MESOLELLA, K.J.; MATTHEWS, R.K.; BROECKER, W.S.; THURBER, D.L. 1969. The astronomical theory of climate change: Barbados data. Journal of Geology, 77.

MIALL, E.D. 1985. Architectural-element analysis: a new method of facies analysis applied to fluvial deposits. Earth Science Review, 22: 261-308.

MIALL, E.D. 1988. Reservoir heterogeneities in fluvial sandstones: lessons from outcrops studies. America Association of Petroleum Geologists Bulletin, 72: 682-697.

MIALL, E.D. 1994. Sequence stratigraphy and chronoestratigraphy: problems of definition and precision in correlation, and their implications for global eustasy. Geoscience Canada, 21: 1-26.

MIALL, E.D. 1996. The Geology of Fluvial Deposits: Sedimentary Facies, Basin Analysis and Petroleum Geology. Berlin, Springer-Verlag, $582 \mathrm{p}$.

MIALL, E.D. 1999. Principles of Sedimentary Basin Analysis. New York, Springer-Verlag, $668 p$.

MIALL, A.D. \& TYLER N. 1991. The three-dimensional facies architecture of terrigenous clastic sediments and its implications for hydrocarbon discovery and recovery. SEPM, Concepts in Sedimentology and Paleontology, 3: 6-12.

MILLIMAN, J.D. \& BARRETO, H.T. 1975. Relict magnesian calcite oolite and subsidence of the Amazon shelf. Sedimentology, 22: 137-145. 
MONTEIRO, C.A.F. 1973. A Dinâmica Climática e as Chuvas no Estado de São Paulo. São Paulo, Instituto de Geografia da USP, 129p.

MORAES REGO, L. F. 1926. Reconhecimento geológico da parte occidental do Estado da Bahia. Boletim do Serviço Geológico e Mineralógico, 17: 33-54.

MOREIRA, M.E.S.A. 1988. Seasonal processes of the beach-dune system on the Western Coast of Portugal. Journal of Coastal Research, Special /ssue 3: 47-51.

MORTON, A.C. 1984. Stability of detrital heavy minerals in Tertiary sandstones from the North Sea Basin. Clays and Clay Minerals, 19: 287-308.

NAMIKAS, S.L. 2003. Field measurement and numerical modelling of aeolian mass flux distributions on a sandy beach. Sedimentology, 50: 303-326.

NASCIMENTO, D.R., Jr. 2006. Morfologia e Sedimentologia ao Longo do Sistema Praia Duna Frontal de Iha Comprida, SP. São Paulo, Instituto de Geociências da Universidade de S.Paulo. Dissertação de Mestrado (inéd.), 97p, 3 anexos.

NASCIMENTO, D.R., Jr.; TANAKA, A.P.; GIANNINI, P.C.F.; GUEDES, C.C.F. 2005. Morfologia e granulometria ao longo do sistema praia - duna frontal de llha Comprida, SP. In: CONGRESSO DA ASSOCIAÇÃO BRASILEIRA DE ESTUDOS DO QUATERNÁRIO (ABEQUA), 10, Guarapari, ES. Anais... meio digital (cd), Guarapari, Abequa.

NEVES, P.C.P. \& LORSCHEITTER, M.L. 1995. Upper Quaternary palaeoenvironments in the northern coastal plain of Rio Grande do Sul, Brazil. Quaternary of South America and Antarctic Peninsula, 9: 39-67.

NIMER, E. 1966. Circulação atmosférica do Brasil. Revista Brasileira de Geografia, 28(3): 232-250.

NIMER, E. 1979. Climatologia do Brasil. Rio de Janeiro, IBGE. 2 ed., 1989, 421 p.

NOGUÉS-PAEGLE, J. \& MO, K.C. 2000. Alternating wet and dry conditions over South America during summer. Monthly Weather Review, 125: 279-291.

NORDSTROM, K.F. \& McCLUSKEY, J.M. 1985. The effects of houses and sand fences on the eolian sediment budget at Fire Island, New York. Journal of Coastal Research, 1: 39-46.

PAIVA, G. 1933. Geologia do município de Lages, Santa Catarina. Boletim do Serviço Mineral, 69: 1-14.

PALMA, J.J.C. 1979. Brasil. Margem Continental Norte. Mapa Fisiográfico. Rio de Janeiro, Petrobras/Cenpes/Dintep. (Série Projeto Remac).

PAUL, K. 1944. Morphologie und vegetation der Kurische Nehrung. Acta Nova Leopoldina Carol., NF13: 217-318.

PEREIRA, M.J. \& MACEDO, J.M. 1990. A Bacia de Santos: perspectivas de uma nova província petrolifera na plataforma continental sudeste brasileira. Boletim de Geociências da Petrobrás, 4(1): 3-11.

PESSENDA, L.C.R. \& CAMARGO, P.B. 1991. Datação radiocarbônica de amostras de interesse arqueológico e geológico por espectrometria de cintilação líquida de baixa radiação de fundo. Química Nova, 14(2): 98-103.

PESSENDA, L.C.R.; ARAVENA, R.; MELFI, A.J.; BOULET, R. 1996a. The use of carbon isotopes $(C-13, C-14)$ in soil to evaluate vegetation changes during the Holocene in central Brazil. Radiocarbon, 38(2): 191-201. 
PESSENDA, L.C.R.; VALENCIA, E.P.E.; MARTINELLI, L.A.; CERRI, C.C. 1996 B. ${ }^{14} \mathrm{C}$ mensurements in tropical soil developed on basic rocks. Radiocarbon, 38(2): 203-208.

PESSENDA, L.C.R.; VALENCIA, E.P.E.; ARAVENA, R.; TELLES, E.C.C.; BOULET, R. 1998a. Paleoclimate studies in Brazil using carbon isotopes in soils. In: WASSERMAN, J.C.; SILVA-FILHO, E.; VILLAS-BOAS, R. eds. Environmental Geochemistry in the Tropics. Berlin, Springer-Verlag, p.7-16.

PESSENDA, L.C.R.; GOMES, B.M.; ARAVENA, R.; RIBEIRO, A.S.; BOULET, R.; GOUVEIA, S.E.M. 1998b. The carbon isotope record in soils along a forest-cerrado ecosystem transect: implications for vegetation changes in the Rondonia state, southwestern Brazilian Amazon region. The Holocene, 8(5): 631-635.

PESSENDA, L.C.R.; GOUVEIA, S.E.M.; ARAVENA, R.; GOMES, B.M.; BOULET, R.; RIBEIRO, A.S. $1998 \mathrm{c} .{ }^{14} \mathrm{C}$ dating and stable carbon isotopes of soil organic matter in forest-savanna boundary areas in the southern Brazilian Amazon region. Radiocarbon, 40(2): 1013-1022.

PESSENDA, L.C.R.; BOULET, R.; ARAVENA, R.; ROSOLEN, V.;GOUVEIA, S.E.M.; RIBEIRO, A.S.; LAMOTTE, M. 2001a. Origin and dynaimcs of soil organic matter and vegetation changes during the Holocene in a forest-savanna transition zone, Brazilian Amazon region. The Holocene, 11(2): 250-254.

PESSENDA, L.C.R.; RIBEIRO, A.S.; GOUVEIA, S.E.M.; BENDASSOLLI, J.A.; BOULET, R.; PELLEGRINOTTI, T.C.; SILVA, V.F. 2001b Dinâmica do ecótono cerrado-floresta desde o Pleistoceno tardio na região de Barreirinhas, Estado do Maranhão, empregando os isótopos do carbono do solo. In: CONGRESSO DA ASSOCIAÇÃO BRASILEIRA DE ESTUDOS DO QUATERNÁRIO (ABEQUA), 8, Imbé, RS. Boletim de Resumos... Porto Alegre, Abequa.

PIMIENTA, J. 1958. A Faixa Costeira Meridional de Santa Catarina. Rio de Janeiro, DNPM/DGM, 104p. (Boletim 176).

POSAMENTIER, H.W. \& ALLEN, G.P. 1994. Siliciclastic Sequence Stratigraphy. Concepts and Applications. Tulsa, Okla., AAPG Short Course, $89 \mathrm{p}$.

POSAMENTIER, H.W. \& JAMES, D.P. 1993. An overview of sequence-stratigraphic concepts: uses and abuses. Special Publication I.A.S., 18: 3-18.

POSAMENTIER, H.W. \& VAIL, P.R. 1988. Eustatic controls on clastic deposition II sequences and systems tract models. In: WILGUS, C.K.; HASTINGS, B.S.; KENDALL, C.G.S.C.; POSAMENTIER, H.W.; ROSS, C.A.; VAN WAGONER, J.C. eds. Sea Level Change - An Integrated Approach, p. 125-154. Tulsa, Okla., Society Economic Paleontologists Mineralogists (Special Publication, 42).

POSAMENTIER, H.W.; JERVEY, M.T.; VAIL, P.R. 1988. Eustatic controls on clastic deposition I - conceptual framework. In: WILGUS, C.K.; HASTINGS, B.S.; KENDALL, C.G.S.C.; POSAMENTIER, H.W.; ROSS, C.A.; VAN WAGONER, J.C. eds. Sea Level Change - An Integrated Approach. P. 110-124. Tulsa, Okla., Society Economic Paleontologists Mineralogists (Special Publication, 42).

PRIGOGINE, I. \& STENGERS, I. 1988. Entre le Temps et l'Éternité. São Paulo, Companhia das Letras, Tradução (Entre o Tempo e a Eternidade), 1992, 226p.

PSUTY, N.P. 1988. Sediment budget and dune/beach interaction. Journal of Coastal Research, 3: 1-4. 
PYE, K. 1982. Morphological development of coastal dunes in a humid tropical environment, Cape Bedford and Cape Flattery, North Queensland. Geografiska Annaler, 64A(3-4): 213-227.

PYE, K. 1983a. Early post-deposicional modification of eolian dune sands. In: BROOKFIELD, M.E. \& AHLBRANDT, T. S. eds. Eolian Sediments and Processes. Amsterdam, Elsevier. p.197-221. (Developments in Sedimentology, 38).

PYE, K. 1983b. Formation and history of Queensland coastal dunes. Z. Geomorphol., supplbd.45: $175-204$.

PYE, K. \& BOWMAN, G.M. 1984. The Holocene Marine Transgression as a Forcing Function on Episodic Dune Activity on The Eastern Australian Coast. In: THOM, B.G. (ed.), Coastal Geomorphology in Australia. Sydney, Academic Press, p. 115-127.

PYE, K. \& TSOAR, H. 1990. Aeolian Sand and Sand Dunes. London, Unwin, 396p.

ROTH, L. \& LORSCHEITTER, M.L. 1993. Palynology of a bog in Parque Nacional de Aparados da Serra, East Plateau of Rio Grande do Sul, Brazil. Quaternary of South America and Antarctic Peninsula, 8: 39-69.

ROTHMAN, D,H,; GROTZINGER, J.P.; FLEMINGS, P. 1994. Scaling in turbidite deposition. Journal of Sedimentary Research, A64(1): 59-67.

ROY, P.S.; COWELL, P.J.; FERLAND, M.A.; THOM, B.G., 1994. Wave-dominated coasts. In: CARTER, R.W.G. \& WOODROFFE, C.D. eds., Coastal Evolution, Late Quaternary Shoreline Morphodynamics. Cambridge, Cambridge University Press, p.121-186.

SADLER, P.M. 1981. Sediment accumulation rates and the completeness of stratigraphic sections. Journal of Geology, 89: 569-584.

SALLENGER, A.H., Jr. 1979. Inverse grading and hydraulic equivalence in grain-flow deposits. Journal of Sedimentary Petrology, 42(2): 553-562.

SANTOS, J.O.S.; NELSON, B.W.; GIOVANINNI, C.A.1993. Dunas gigantes e campos de areia. Ciência Hoje (Paleoclimas da Amazônia): 22-25.

SARRE, R.D. 1988. Evaluation of aeolian sand transport equations using intertidal zone measurements, Sauton Sands, England. Sedimentology, 35: 671-679.

SATYAMURTI, P.; NOBRE, C.; DIAS, P.L.S. 1998. South America. In: KAROLY, D.J. \& VICENT, D.J. eds. Meteorology of the Southern Hemisphere. Boston, American Meteorological Society, p.119-139.

SAUERMANN, G.; KROY. K.; HERRMAN, H.J. 2001. Continuum saltation model for sand dunes. Physical Review, E64, 031305, Issue 3: 10p.

SAWAKUCHI, A.O. 2000. Dinâmica e Contexto Paleogeográfico do Sistema Deposicional Eólico Pirambóia no Estado de São Paulo. São Paulo, Instituto de Geociências da Universidade de S.Paulo. Monografia de Trabalho de Formatura (inéd.), 38p., 11 anexos, 14 fotos.

SAWAKUCHI, A.O. 2003. Sistemas Deposicionais Eólicos na Costa Centro-Sul Catarinense: Relações com o Nivel do Mar. São Paulo, Instituto de Geociências da Universidade de S.Paulo. Dissertação de Mestrado (inéd.), 86 p.

SAWAKUCHI, A.O. \& GIANNINI, P.C.F. 2006. Complexidade em sistemas deposicionais. Revista Brasileira de Geociências (no prelo).

SAWAKUCHI, A.O.; GIANNINI, P.C.F.; MARTINHO, C.T. 2003. Episódios de deposição eólica quaternária no litoral centro-sul de Santa Catarina: correlação com variações do 
nível relativo do mar baseada em idades TL e LOE. In: CONGRESSO DA ASSOCIAÇÃO BRASILEIRA DE ESTUDOS DO QUATERNÁRIO, 9, Recife, PE. Anais... meio digital (cd), Recife, Abequa.

SAYELES, R.W. 1931. Bermuda during the Ice Age. Proceedings of the American Academy of Arts and Sciences, 66: 381-468.

SCHOFIELD, J.C. 1975. Sea level fluctuations cause periodic post-glacial progradation, South Kaipara barrier, North Island, New Zealand. N.Z. Journal of Geology and Geophysics, 18: 295-316.

SCHUMM, S.A. 1991. To Interpret the Earth - Ten Ways to be Wrong. Cambridge University Press, Cambridge, $133 \mathrm{p}$.

SEMENIUK, V.; CRESWELL, I.D.; WURM, P.A.S. 1989. The Quindalup Dunes: the regional system, physical framework and vegetation habitats. Journal of Royal Society Western Austrália, 71(2/3): 23-47.

SHACKLETON, N.J. 1987. Oxygen isotopes, ice volume and sea level. Quaternary Science Reviews, 6: 183-190.

SHORT, A.D. 1988a. Holocene coastal dune formation in Southern Austrália: a case study. Sedimentary Geology, 55(1/2): 121-142.

SHORT, A.D. 1988b. Wave, beach, foredune, and mobile dune interactions in the Southern Australia. Journal of Coastal Research, Special Issue 3: 05-09.

SHORT, A.D. \& HESP, P.A. 1982. Wave, beach and dune interactions in South-eastern Austrália. Marine Geology, 48(4): 259-284.

SHORT, A.D.; MENGEL, G.; CROWLEY, T.J.; HYDE, W.T.; NORTH, G.R. 1991. Filtering of Milankovitch cycles by earth's geography. Quaternary Research, 35: 157-173.

SIFEDDINE, A.; FROHLICH, F.; FOURNIER, M.; MARTIN, L.; SERVANT, M.; SOUBIĖS, F.; SUGUIO, K.; RIBEIRO, C.V. 1994a. La sédimentation lacustre indicateur de changements des paléoenvironments au cour des 30.000 derniérs annés (Carajás, Amazonie, Brésil). Géociences de Surface, 645-1652.

SIFEDDINE, A.; BERTRAND, P.; FOURNIER, M.; MARTIN, L.; SERVANT, M.; SOUBIĖS, F.; SUGUIO, K.; TURCQ, B. 1994b. La sédimentation organique lacustre en milieu tropical humide (Carajás, Amazonie orientale, Brésil): relation avec les changements climatiques au cours des 60000 dernières années. Bull. Soc. Géol. Franc., 165(6): 613-621.

SOARES, P.C. 1992. Tectônica Sinsedimentar Cíclica na Bacia do Paraná - Controles. Curitiba, Departamento de Geologia da Universidade Federal do Paraná. Tese de Professor Titular (inéd.).131p.

SOUZA, C.R.G. 1997. As Células de Deriva Litorânea e a Erosão nas Praias do Estado de São Paulo. São Paulo, Instituto de Geociências da Universidade de São Paulo. Tese de Doutorado (inéd.), 2 v, 359 p.

STEVAUX, J.C. 1994. The Upper Paraná River (Brazil): geomorphology, sedimentology and paleoclimatology. Quaternary International, 21: 143-161.

STEVAUX, J.C. 2000. Climatic events during the Late Pleistocene and Holocene in the Upper Parana River: Correlation with NE Argentina and South-Central Brazil. Quaternary international, 72: 73-85. 
STOKES, S.; KOCUREK, G.; PYE, K.; WINSPEAR, N.R. 1997. New evidence for the timing of aeolian sand supply to the Algodones dunefield and East Mesa area, southeastern California, USA. Palaeogeography, Palaeoclimatology, Palaeoecology, 128: 63-75.

STOKES, W.L. 1968. Multiple parallel - truncation bedding planes a feature of wind deposited sandstone formations. Journal of Sedimentary Petrology, 38(2): 510-515.

STRAHLER, A.N. 1977. Geografia Física. Barcelona, Omega. 767p.

STRAHLER, A.N. 1980. Systems theory in physical geography. Physical Geography, 1(1): 127.

SUGUIO, K. \& MARTIN, L. 1978a. Formações quaternárias marinhas do litoral paulista e sul fluminense. In: INTERNATIONAL SYMPOSIUM ON COASTAL EVOLUTION IN THE QUATERNARY, São Paulo, SP. Special Publication (1)... São Paulo, IGCB/IGUSPI SBG, 55p.

SUGUIO, K. \& MARTIN, L. 1978b. Mapas Geológicos da Planície Costeira do Estado de São Paulo e Sul do Rio de Janeiro (1:100.000). São Paulo, DAEE / Secr. de Obras e Meio Ambiente. Governo do Estado de São Paulo.

SUGUIO, K. \& MARTIN, L. 1994. Geologia do Quaternário. In: FALCONI, F.F. \& NIGRO, A. Jr. 1994. eds. Solos do Litoral de São Paulo. São Paulo, Mesa Redonda ABMS/ASSECOB, p. 69-97.

SUGUIO, K. \& PETRI, S. 1973a. Stratigraphy of the Iguape-Cananéia Lagoonal Region Sedimentary Deposits, São Paulo State, Brazil. Part I Field observations and grain size analysis. Boletim IG-USP, 4: 1-20.

SUGUIO, K. \& PETRI, S. 1973b. Stratigraphy of the Iguape-Cananéia Lagoonal Region Sedimentary Deposits, São Paulo State, Brazil. Part II: Heavy minerals studies, ventories and stratigraphical interpretations. Boletim IG-USP, 4: 21-40.

SUGUIO, K.; COIMBRA, A.M.; GUARDADO, L.R. 1974. Correlação sedimentológica de arenitos da Bacia do Paraná. Boletim IG-USP, 5: 85-116.

SUGUIO, K.; MARTIN, L.; BITTENCOURT, A.C.S.P.; DOMINGUEZ, J.M.L.; FLEXOR, J.M. \& AZEVEDO, A.E.G. 1985. Flutuações do nível relativo do mar durante o Quaternário Superior a longo do litoral brasileiro e suas implicações na sedimentação costeira. Revista Brasileira de Geociências, 15(4): 273-286.

SUGUIO, K.; TATUMI, S.H.; KOWATA, E.A. 1999a. As cristas de dunas inativas e os seus possiveis significados na evolução holocênica da llha Comprida, Sul do litoral paulista. In: CONGRESSO DA ASSOCIAÇÃO BRASILEIRA DE ESTUDOS DO QUATERNÁRIO (ABEQUA), 7, Porto Seguro, BA. Anais... meio digital (cd). Salvador, Abequa. $3 p$.

SUGUIO, K.; TATUMI, S.H.; KOWATA, E.A. 1999b. The Comprida Island inactive dune ridges and their possible significance for the island evolution during the Holocene, State of São Paulo, Brazil. Anais da Academia Brasileira de Ciências, 71(4-1): 623-630.

SUGUIO, K.; BARRETO, A.M.F.; BEZERRA. F.H.R. 2001. Formações Barra de Tabatinga e Touros: evidências de paleoniveis do mar pleistocênicos da costa norte-riograndense. In: CONGRESSO DA ASSOCIAÇÃO BRASILEIRA DE ESTUDOS DO QUATERNÁRIO (ABEQUA), 8, Imbé, RS. Boletim de Resumos..., Porto Alegre, Abequa, p.108-110.

SUGUIO, K.; ANGULO, R.J.; CARVALHO, A.M.; CORREAA, I.C.S.; TOMAZELLI, L.J.; VILLWOCK, J.A.; VITAL, H. 2005. Paleoniveis do mar e paleolinhas de costa. In: SOUZA, C.R.G.; SUGUIO, K.; OLIVEIRA, P.E.; OLIVEIRA. A.M. ed. Quaternário do 
Brasil. Abequa, ANP, FAPESP, IG, UnG. Ribeirão Preto, SP, Holos Editora, cap.6, p.114-129.

TABAJARA, L.L.; MARTINS, L.R.; FERREIRA, E.R. 2000. Efetividade de métodos estruturais na construção de dunas frontais. Pesquisas, 27(1): 97-110.

TALBOT, M.R. 1985. Major bounding surfaces in aeolian sandstones - a climatic model. Sedimentology, 32: 257-265.

TATUMI, S.H. 2002. A datação por luminescência aplicada à geocronologia do Quaternário. In: CONGRESSO BRASILEIRO DE GEOLOGIA, 46, João Pessoa, PB. Anais..., João Pessoa, SBG, p. 369.

TATUMI, S.H.; NAGATOMO, T.; SENGUPTA, D.; WATANABE, S.; BARRETO, A.M.F.; SUGUIO, K. 1998a. Thermoluminescence dating of eolian sediments from São Francisco river, state of Bahia, Brazil. Radiation Effects \& Defects in Solids, 146: 285295.

TATUMI, S.H.; NAGATOMO, T.; SENGUPTA, D.; WATANABE, S.; BARRETO, A.M.F.; SUGUIO, K. 1998b. Thermoluminescence studies on quartz grains from eolian sediments in Brazil. Radiative Physics and Chemistry, 51(4-6): 719-720.

TATUMI, S.H.; YEE, M.; CARNEIRO FILHO, A.; SCHWARTZ, D. 2000. Datação luminescente de paleodunas, localizadas na bacia do Rio Negro, Amazonas. in: CONGRESSO BRASILEIRO DE GEOLOGIA, 46, João Pessoa, PB. Anais..., João Pessoa, SBG, p.370.

TENBERG, A.G. 1994. Nebkhas - their spatial distribution, morphometry, composition and age - in the Side Bouzid area, central Tunisia. Z.Geomorph., 38(3): 311-325.

TERJUNG, W.B. 1976. Climatology for geographers. Ann. Assoc. American Geographers, 66: $199-222$.

THOM, R. 1972. Structural Stability and Morphogenesis. Massachussets, W.A. Benjamin, Reading, 1976, 348p.

THOMAS, D.S.G. \& SHAW, P.A. 1991 "Relict" desert systems: interpretations and problems. Journal of Arid Environments, 20:1-14.

TESSLER, M.G. 1982. Sedimentação Atual na Região Lagunar de Cananéia - Iguape, Estado de São Paulo. São Paulo, Instituto de Geociências da Universidade de S.Paulo. Dissertação de Mestrado (inéd.), 2v., 8 mapas, 110p.

TESSLER, M.G. 1988. Dinâmica Sedimentar Quaternária no Litoral Sul Paulista. São Paulo, Instituto de Geociências da Universidade de S.Paulo. Tese de Doutoramento (inéd.), 1 mapa, 276p..

TESSLER, M.G. \& FURTADO, V.V. 1983. Dinâmica das feições de assoreamento da região lagunar Cananéia-Iguape, Estado de São Paulo. Boletim do Instituto Oceanográfico, 32 (2): $117-124$.

TOMAZELLI, L.J. 1990. Contribuição ao Estudo dos Sistemas Deposicionais Holocênicos do Nordeste da Província Costeira do Rio Grande do Sul, com Ênfase no Sistema Eólico. Porto Alegre, Universidade Federal Rio Grande do Sul. Tese de Doutoramento (inéd). $270 p$.

TOMAZELLI, L.J. 1993. O regime de ventos e a taxa de migração das dunas eólicas costeiras do Rio Grande do Sul, Brasil. Pesquisas, 20(1): 18-26.

TOMAZELLI, L.J. 1994. Morfologia, organização e evolução do campo eólico costeiro do litoral norte do Rio Grande do Sul, Brasil. Pesquisas, 21(1): 64-71. 
TOMAZELLLI, L.J. \& VILLWOCK, J.A. 1996. Quaternary geological evolution of Rio Grande do Sul Coastal Plain, Southern Brazil. Anais da Academia Brasileira de Ciências, 68: 373382.

TOMAZELLI, L.J. \& VILLWOCK, J.A. 2000. O Cenozóico no Rio Grande do Sul: geologia da planície costeira. In: HOLZ, M. \& DE ROS, L.F. eds. Geologia do Rio Grande do Sul. Porto Alegre, ClGO/UFRGS, p.375-406.

TOMAZELLI, L.J.; VILLWOCK, J.A.; DILLENBURG, S.R.; BACHI, P.A.; DEHNHARDT, B.A. 1998. Significance of present-day coastal erosion and marine transgression, Rio Grande do Sul, southern Brazil. Anais da Academia Brasileira de Ciências, 70: 221 229.

TONNELAT, J. 1978. Thermodynamique et Biologie. Paris, Maloine. 2v.

TRENHAILE, A.S., 1997. Sand Dunes. In: Coastal Dynamics and Landforms. Oxford, Clarendon Press, p.144-169.

ULBRICH, H.H.G.J. \& GOMES, C.B. 1981. Alkaline rocks from continental Brazil. Earth Science Review, 17: 135-154.

VAIL, P.R.; MITCHUM, R.M., Jr.; THOMPSON, S. 1977. Seismic stratigraphy and global changes of sea level from coastal onlap. In: PAYTON, C.E. ed. Seismic Stratigraphy Applications to Hydrocarbon Exploration. p. 63-81. Tulsa, Okla., American Association of Petroleum Geologists (Memoir, 26).

VAN DER WAL, D. 2004. Beach-dune interactions in nourishment areas along the Dutch coast. Journal of Coastal Research, 20(1): 317-325.

VAN WAGONER, J.C., POSAMENTIER, H.W., MITCHUM, R.M., Jr. 1988. An overview of the fundamentals of sequence stratigraphy and key definitions. In: WILGUS, C.K.; HASTINGS, B.S.; KENDALL, C.G.S.C.; POSAMENTIER, H.W.; ROSS, C.A.; VAN WAGONER, J.C. eds. Sea-level Changes - An Integrated Approach. p. 39-45. Tulsa, Okla., Society Economic Paleontologists Mineralogists (Special Publication, 42).

VAN WAGONER, J.C.; MITCHUM, R.M.; CAMPION, K.M.; RAHMANIAN, V.D. 1990. Siliclastic Sequence Stratigraphy in Well Logs, Cores and Outcrops. Tulsa, America Association Petroleum Geologists, 55p. (Methods in Exploration Series, 5).

VILLWOCK, J.A. 1984. Geology of the coastal province of Rio Grande do Sul, Southern Brazil. A Synthesis. Pesquisas, 16: 5-49.

VILLWOCK, J.A. \& TOMAZELLI, L.J. 1989. Sea-level changes and Holocene evolution in Rio Grande do Sul coastal plain, Brazil. In: INTERNATIONAL SYMPOSIUM ON GLOBAL CHANGES IN SOUTH AMERICA DURING THE QUATERNARY: PAST-PRESENTFUTURE, São Paulo, SP. INQUA-ABEQUA, São Paulo. Special Publication 1... p.192196.

VILLWOCK, J.A.; TOMAZELLI, L.J.; LOSS, E.L.; DEHNHARDT, E.A.; HORN, N.O. FILHO; BACHI, F.A.; DEHNHARDT, B.A. 1986. Geology of the Rio Grande do Sul Coastal Province. I $n$ : INTERNATIONAL SYMPOSIUM ON SEA LEVEL CHANGES AND QUATERNARY SHORELINES, São Paulo, SP. Quaternary South America Antarctic Peninsula, 4: 79-97.

WALKER, R.G. 1976. Facies and facies models. General introduction. In: WALKER,R.G. ed. Facies Models. Toronto, Geosc. Canada,1979, p.17. (Reprint Series, 1).

WALKER, R.G. 1992. Facies, facies models and modern stratigraphic concepts. In: WALKER, R.G. \& JAMES, N.P. eds. Facies Models: Response to Sea Level Change. Geological Association of Canada, St John's, Newfoundland, p. 1-14. 
WALKER, R. G. \& JAMES, N.P. eds. 1992. Facies Mode/s - Response to Sea Level Change. Geological Association of Canada, Stittsville, 454 p..

WALKER, R.G. \& MIDDLETON, G.V. 1977. Eolian sands. In: WALKER, R.G. ed. Facies Models. Toronto, Geosc. Canada, 1979, p.33-41. (Reprint Series,1).

WASSON, R.J. \& HYDE, R. 1983. Factors determining desert dune type. Nature, 304: 337339.

WATANABE, E.A.; TATUMI, S.H.; SUGUIO, K.; MUNITA, C.S.; PAIVA, R.P. 2003. Luminescence dating of dunes from São Paulo State, Brazil and the Pleistocene relative sea-levels. Journal of Coastal Research, Special Issue 35: 284-292.

WEAVER, C.E. 1989. Clays, Muds, and Shales. Amsterdam, Elsevier. 819 p. (Developments in Sedimentology, 44).

WERNICKE, B. 1981. Low-angle normal faults in the Basin and Range province: nappe tectonics in an extending orogen. Nature, 291: 645-648.

WERNICKE, B. 1985. Uniform-sense normal simple shear of the continental lithosphere. Canadian Journal of Earth Sciences, 22: 108-125.

WERNICKE, B. \& TILKE, P.G. 1990. Extensional tectonic framework of the U.S. Central Atlantic paassive margin. In: TANKARD, A.J. \& BALKWILL, H.R. eds. Extensional Tectonics and Stratigraphy of the North Atlantic Margins, p.7-21. Tulsa, Okla., America Association Petroleum Geologists (Memoir, 46).

WEFER, G. \& BERGER, W.H. 1991. Isotope paleontology: growth and composition of extant calcareous species. Marine Geology, 100(1991): 207-248.

WELTON, J.E. 1984. SEM Petrology Atlas. Tulsa, Oklahoma, America Association Petroleum Geologists, 237 p. (Methods in Exploration Series).

WHITE, B.R. 1979. Soil transport by winds on Mars. Journal of Geophysical Research, 84: 4643-51.

WILSON, I.G., 1972. Aeolian bedforms - Their development and origins. Sedimentology, 19: 173-210.

WRIGHT, L.D. \& THOM, B.G. 1977. Coastal depositional landforms: a morphodynamics approach. Progress in Physical Geography, 1: 412-459.

YBERT, J.-P.; BISSA, W.M.; CATHARINO, E.L.M.; KUTNER, M. 2003. Environmental and sea-level variations on the southeastern Brazilian coast during the Late Holocene with comments on prehistoric human occupation. Palaeogeography, Palaeoclimatology, Palaeoecology, 189: 11-24.

YEE, M.; TATUMI, S.H.; GOZZI, G.; BRITO, S.L.M.; BARRETO, A.M.F.; SUGUIO, K.; BEZERRA, F.H.R. 2002. Datação de sedimentos retirados de dunas eólicas costeiras do Estado do Rio Grande do Norte pelo método da termoluminescência (TL). In: CONGRESSO BRASILEIRO DE GEOLOGIA, 46, João Pessoa, PB. Anais... João Pessoa, SBG, p. 372.

YOCKEY, J.F. org. 1993. Meditações com Nicholas de Cusa. Tradução para o português de B.T. Lambert. São Paulo, Editora Gente, 155p.

ZEMBRUSCKI, S.G. 1979. Brasil. Margem Continental Sul. Mapa Fisiográfico. Rio de Janeiro, Petrobras/Cenpes/Dintep. (Série Projeto Remac). 
Sítios da rede eletrônica internacional

GUIA INTERNET BRAZIL.1999. Clima. guianet@guianet.com.br. (consultado em julho de 2004).

NASA. 2007. Geocover. www.zulu.ssc.nasa.gov/mrsid (consultado em janeiro e fevereiro de 2007).

SCP-RS. 2007. Atlas Socioeconômico Rio Grande do Sul. www.scp.rs.gov.br/ATLAS. (consultado em fevereiro de 2007). 